\author{
UNIVERSIDADE DE SÃO PAULO \\ MUSEU DE ARQUEOLOGIA E ETNOLOGIA \\ PROGRAMA DE PÓS-GRADUAÇÃO EM ARQUEOLOGIA
}

\title{
A fase Bacabal e seus correlatos arqueológicos na Amazônia
}

Carlos Augusto Zimpel Neto

São Paulo, 2018 
Carlos Augusto Zimpel Neto

\section{A fase Bacabal e seus correlatos arqueológicos na Amazônia}

Tese apresentada ao Programa de PósGraduação em Arqueologia do Museu de Arqueologia e Etnologia da Universidade de São Paulo para a obtenção de título de Doutor em Arqueologia.

Orientador: Prof. Dr. Eduardo Góes Neves

Área de Concentração: Arqueologia

Linha de Pesquisa: Espaço, Sociedade e Processos de Formação do Registro Arqueológico

São Paulo, 2018 
Para Francisco de Freitas Zimpel 


\section{Resumo}

Neste trabalho tratamos sobre a fase cerâmica Bacabal, que foi criada por Eurico Miller no começo dos anos 90 para classificar os vestígios cerâmicos encontrados em nas áreas inundáveis do médio rio Guaporé, estado de Rondônia. A cronologia de sua ocorrência recua até o Holoceno médio, desde ca. 2000 a.C. até 800 d.C. Buscamos nesta tese descrever os vestígios cerâmicos desta fase e discutir as hipóteses previamente estabelecidas sobre as suas correlações com outras fases encontradas na Amazônia e afora. 


\begin{abstract}
In this work we investigate the Bacabal phase, created by Eurico Miller in the early 90's to classify ceramics found in the flooded areas of the middle Guaporé river, state of Rondônia, Brazil. The chronology for this archaeological culture reach the middle Holocene, ranging from ca. 2000 a.C. until 800 AD. We aimed to describe the vestiges and discuss hypotheses previously established about their correlations with other stylistic horizons found in the Amazon and beyond. We also propose that there may be a relationship between this pottery and other archaeological cultures found in the Amazonian southwest and surrounding areas.
\end{abstract}




\section{Agradecimentos}

Primeiramente, agradeço ao CNPq pela bolsa concedida durante grande parte da pesquisa.

Ao prof. Dr. Ari Ott, magnífico reitor da Fundação Universidade Federal de Rondônia, pela liberação para o afastamento requerido para o cumprimento desta pesquisa.

Aos bravos colegas do Departamento de Arqueologia: Elisangela Oliveira, Eduardo Bespalez, Valéria Silva, Silvana Zuse, Juliana Santi por seguraram a barra da arqueologia durante o meu afastamento, e pelo empenho e luta demonstrado nestes anos.

Agradeço o grande Tijolo (Carlos Augusto da Silva) pelo exemplo de dedicação que nos traz. Aos colegas de Arqueotrop, um verdadeiro time solidário e competente que colaboraram de maneira fundamental nas pesquisas de campo em meio aos tantos riscos e apertos sempre encontrados no pantanal do Guaporé: Gabriela Prestes Carneiro, Guilherme Mongeló, Jennifer Watling, Laura Furquim, Myrtle Schock, Robson Ravani, Thiago Hermenegildo. irmãos.

Agradeço a Santa Maria, que brotou da terra para nos confortar e ensinar a ser

Agradeço ao professor Eduardo Neves, reconhecido como professor no melhor entendimento da palavra, comandante de uma competente equipe. Obrigado por ter me convencido a estudar a arqueologia de Rondônia no ano de 2004, sem isso eu nunca teria conhecido o Guaporé. A tua orientação transpassa a esfera da academia colonizada e é vanguarda.

Ao Francisco Pugliese, que foi o único loco suficiente para realocar o colosso do banhado, e pela força de vontade de sempre cumprir com excelência os objetivos da pesquisa e da vida.

Um agradecimento especial para Ana Izabela Bertolo, que ao acompanhar me apoiando em toda a trajetória acadêmica e pessoal, me trouxe um porto seguro que eu não imaginava que poderia ter, mas acima de tudo, me deu uma oportunidade de ser melhor. A admiração que tenho por ti é fonte de energia. Você alimentou minha barriga e minha alma, me trouxe calma quando eu mais precisei, entendeu as minhas ausências, e é a minha companheira para o que der e vier.

Agradeço também ao meu guri, Francisco de Freitas Zimpel, pois a tua simples 
presença traz uma vibração de positividade imensurável. Tu teve atitude e soube entender a minha a ausência, compartilhou o computador comigo, privando-se dos teus games. Também agradeço por ser um gigante e compreender a consequência que um fim de um doutorado impõe. Obrigado por me manter na linha, fazendo com que eu hoje possa reconhecer novamente os valores da lucidez e da sobriedade.

Aos meus pais, Zoé e Clovis, que sempre me deram o norte para tudo, pela liberdade de poder escolher fazer o quis para viver, pelo apoio incondicional para que este momento chegasse. Obrigado pela oportunidade, vocês são exemplos de paixão pela vida que me fazem persistir. 


\section{Índice}

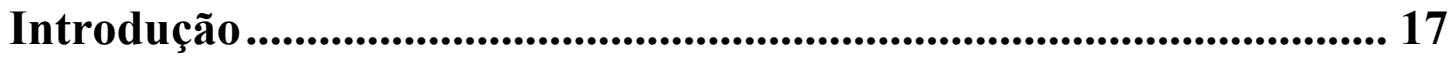

Capítulo 1 - Arqueologia em Rondônia............................................. 22

Arqueologia no rio Guaporé - Contexto e antecedentes ....................................................... 26

Capítulo 2 - A fase Bacabal e e sua relação com outros contextos.... 31

A fase Bacabal e os sambaquis na Amazônia .............................................................31

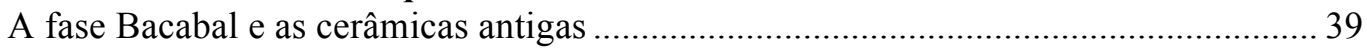

Hipóteses de Miller $(1992,2009,2013)$ sobre a difusão de estilos cerâmicos no Guaporé e as relações com a cultura Valdívia (Equador) ....................................................................... 41

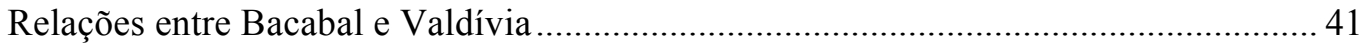

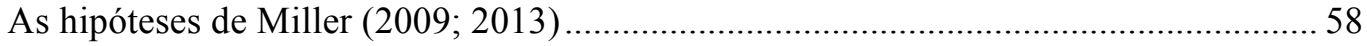

Hipótese de Zimpel e Pugliese sobre a relação com contexto boliviano ......................... 64

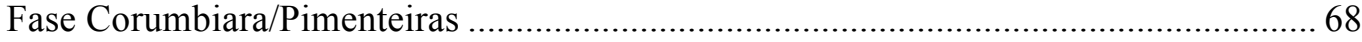

Capítulo 3 - Sitio Monte Castelo e a fase Bacabal .................................. 87

Descrição da área de pesquisa .................................................................................................... 87

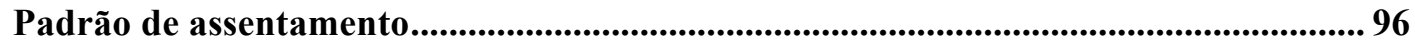

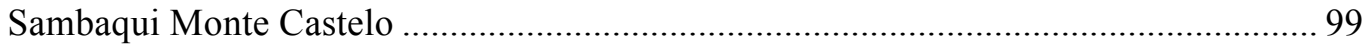

Procedimentos de análise da cerâmica .............................................................................. 114

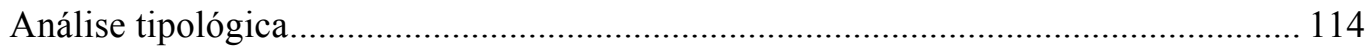

Capítulo 4 - Descrição da fase Bacabal ................................................... 133

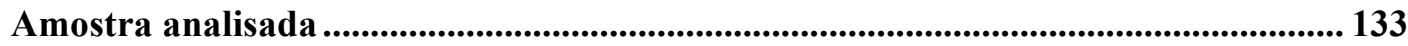

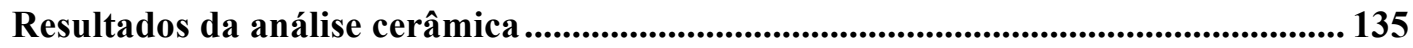

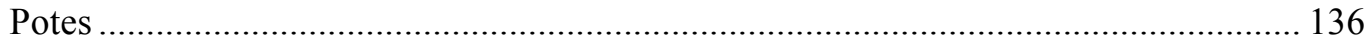

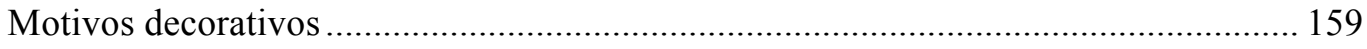

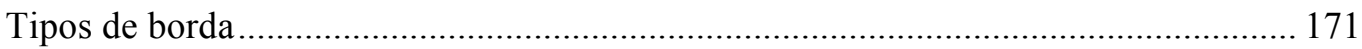

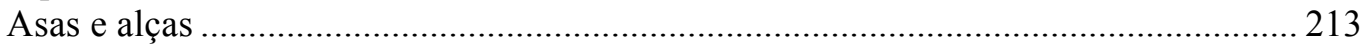

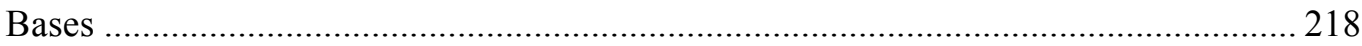

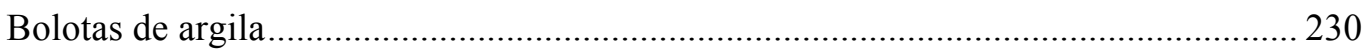

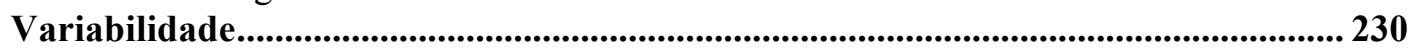

Análises arqueobotânicas em fragmentos ................................................................... 237



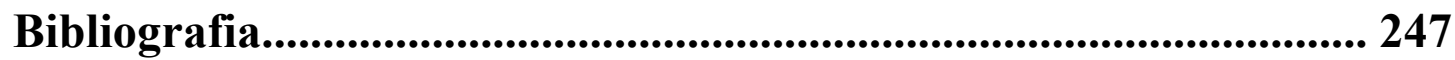




\section{Índice de imagens}

Imagem 1: Rio Guaporé, divisa ente Rondônia, Mato Grosso e fronteira com a Bolivia. Pontos em vermelho são sítios das fases Pimenteiras/Corumbiara. Em laranjas são sítios do tipo geoglifo.................................. 18 Imagem 2: de migração proposta por Miller (2013, p. 361)............................................................... 20 Imagem 3: áreas arqueológicas de Rondônia com evidências de ocupação durante o Holoceno médio. 1) alto rio Madeira; 2) Rio Machado, Ji-paraná; 3) médio rio Guaporé, .............................................................. 22 Imagem 4: camadas da fase Girau e Massangana, sítio Teotônio (Mongeló 2017) .................................... 24 Imagem 5: cerâmicas corrugadas do sítio Encontro........................................................................ 25 Imagem 6: sítio arqueológicos do médio rio Guaporé e áreas de pesquisa adjacentes. Em vermelho estão os sítio levantado por Miller (1983) e em laranja estão geoglifos (Trindade 2010) Imagem 7:Datações radiocarbônicas calibradas para os sítios do alto (AG) e médio (MG) rio Guaporé encontradas em Zimpel e Pugliese (2016). Abaixo a tabela completa com as informações sobre a cronologia da

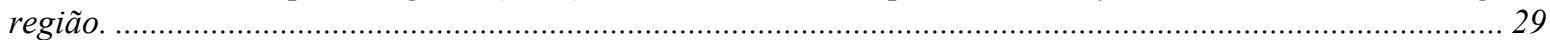
Imagem 8: localização dos sambaquis na Amazônia (Pugliese et al. 2017)................................................. 32 Imagem 9: : Comparação entre Bacabal e Valdivia proposta por Miller (2013b, p. 364) ........................... 42 Imagem 10: Comparação entre motivos da Fase Bacabal e Cultura Valdivia proposta por Miller (2013).... 43 Imagem 11: Distribuição dos sítios Valdivia por periodo, apud Staller (2003)............................................ 47 Imagem 12: Localização de sítios citados na tese, apud Staller (2003), ....................................................... 48 Imagem 13: Morfologia e aspectos decorativos dos potes em Valdivia I e II, Damp e Vargas, (1995) .......... 50 Imagem 14: Tipos e formas da fase I-II (Hill, 1971). .................................................................................. 51 Imagem 15: Vasos acastelados acima e abaixo tetrápodes, encontrados em Meggers et al (1965) prancha $n$. 103.

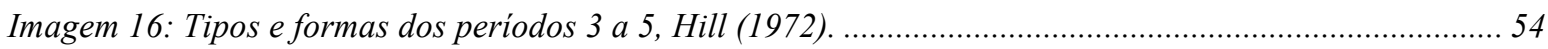
Imagem 17: morfologia das fases VII e VIII, apud Staller (2008) ............................................................... 56 Imagem 18: Formas diagnósticas das fases, a esquerda 6-8, e a direita 4-6, apud Staller (2003). ................ 57 Imagem 19: comparação da cronologia de Valdivia e Machallila, apud Staller (2003)................................ 58 Imagem 20: Tipo Inciso Línea Fina, Meggers, et. al. 1965, Prancha 10 ...................................................... 59 Imagem 21: tipo Ayangue Inciso, cerâmica Machallila, Meggers, et al. (1965)...........................................60 Imagem 22: Motivos das fases 3 e 4 comparados a motivos das fases 1 e 2. Hill (1972)............................... 61 Imagem 23: a) Valdivia; b) Machallila; c) Bacabal.............................................................................. 61 Imagem 24: Formas e tipos decorados da cultura Valdivia, fases 1 e 2, (Megger, et al. 1965, prancha 103). 62 Imagem 25: Quadro resumo de imagens recorrentes geradas por alucinógenos........................................ 63 Imagem 26: Fase Aguapé, os grifos são relacionados a motivos que foram utilizados na comparação. Os grifos são nossos e a imagem é cortesia de Eurico Miller..... 65 Imagem 27: Comparação de cerâmicas Bacabal, Valdivia, Machallina e a fase Aguapé, do alto rio Guaporé

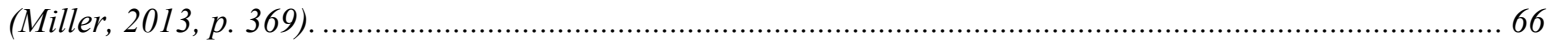
Imagem 28: Cerâmicas típicas das fases Corumbiara e Pimenteiras (Zimpel e Pugliese, 2016, apud Betancourt, 2013) 2-Pote encontrado no sítio Pedras Negras 3 - Acervo do Museu do Estado de Rondonia, provenientes do médio Guaporé, cortesia de Zuse, com. Pessoal. a) .................................................................................... 72

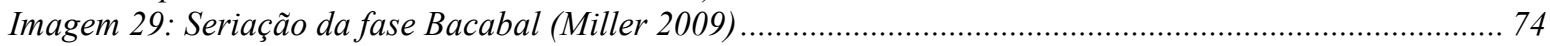
Imagem 30: Seriação da fase Corumbiara e Pimenteiras, Miller (1983, p.371). ....................................... 75 Imagem 31: Elementos comuns a Bacabal e Corumbiara/Pimenteiras. ...................................................... 76 Imagem 32: Mapa da localização de sítios arqueológicos no médio rio Guaporé, Rondônia, Brasil. Cerâmicas da fase Bacabal: Monte Castelo (1) Ilha do Antelmo (2) Bom Futuro (3) e outras encontradas em na região: Sítio Jasiasquiri (5: Betancourt, 2014) Sítio Aliança. ........................................................................... 78 Imagem 33:Ocorrência do motivo decorativo recorrente na fase Bacabal-Bacabal inciso e Bacabal excisoinciso-hachurado - e suas idiossincrasias nas fases Corumbiara e Pimenteiras - Sítio aliança (a,b,c) ; Bolívia. Sítio Loma Mendoza (d); Sítio Jasiaquiri (f-h); Pantanal do Mato-Grosso, tradição Descalvados (e). Com exceção da figura (e), que tem o motivo representado em pintura vermelha sobre engobo branco, as demais são representadas a partir da técnica de decoração plástica. Figura elaborada a partir de imagens de publicações de Miller (1983); Betancourt (2014); Prümmers (2014) e Migliacio (2006). (Fonte: Zimpel e Pugliese, 2016).81 Imagem 34: Motivos encontrados nas cerâmicas no Guaporé do lado boliviano, de Dougherty e Calandra (1985).

Imagem 35: modelo de elevação digital da região de estudo (Pugliese 2017) ............................................ 88

Imagem 36: Areias e lentes de argila da formação Guaporé (Adamy 2010). ..............................................89

Imagem 37: vista aérea do rio Branco e adjacências.................................................................................. 90

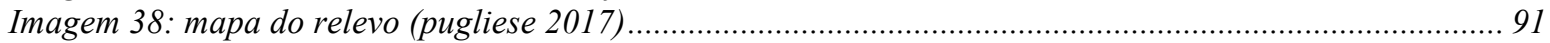

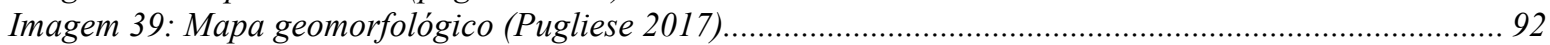

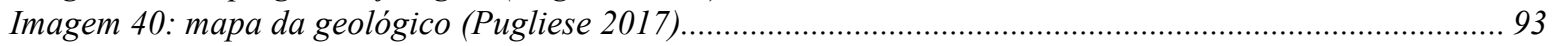




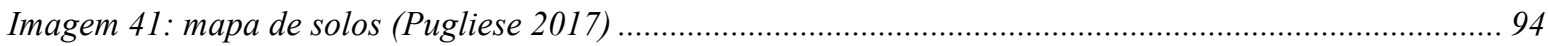

Imagem 42: Mapa de vegetação da área (Pugliese 2017).................................................................... 95

Imagem 43: ilhas de terra firme em meio ao Pantanal do Guaporé. ............................................................. 97

Imagem 44: Sítio Ilha Fazenda Pau d'Óleo e Ilha do Antelmo ..................................................................... 98

Imagem 45: cerâmicas da fase Bacabal do sítio Ilha do Antelmo, abaixo, à esquerda, um cachimbo tubular. 98 Imagem 46: a esquerda, foto do sítio no momento do mapeamento (estação seca), e a direita a chegada ao sítio no momento da segunda etapa de campo, durante o período de cheia. ......................................................... 100

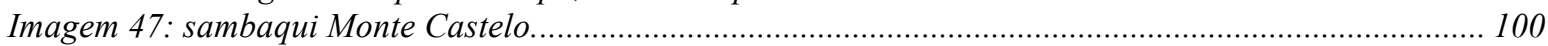

Imagem 20: mapa topográfico do sítio Monte Castelo (Pugliese 2017). ............................................... 101

Imagem 49: artefatos com formas variadas da fase Cupim (Pugliese 2017). ....................................... 103

Imagem 50: A esquerda o resultado da escavação de 2014, onde aparecem camadas relacionadas as fases Sinimbu e Bacabal. A direita a escavação realizada na década de 80 por Eurico Miller (Miller 2009)...... 104 Imagem 51: O denominado "corte 4" escavado por Miller após a reabertura e remoção das camadas perturbadas (Foto: Eduardo Neves) ......................................................................................... 105 Imagem 52: As unidades marcadas em cinza indicam a localização do Corte 4. O marrom indica as áreas escavadas em fevereiro de 2014 e que apresentavam diferentes graus de preservação das estruturas arqueológicas. Valores vermelhos indicam as cotas topográficas iniciais da escavação (Pugliese 2017).... 106 Imagem 53: Registro do contexto de escavação com a Estação Total (Foto: Eduardo Neves).................... 107 Imagem 54: escavações da segunda etapa de campo já bem desenvolvidas. Na foto já se percebe o perfil de Miller acessado e dois membros da equipe do ArqueTrop escavando dois sepultamentos distintos.............. 107 Imagem 55: Cerâmicas típicas da fase Bacabal recuparadas no ano de 2014...................................... 108 Imagem 56: Perfil norte - resultados parciais da escavação. Etapa de 2014 (460cm), Etapa $2016(630$ (Pugliese

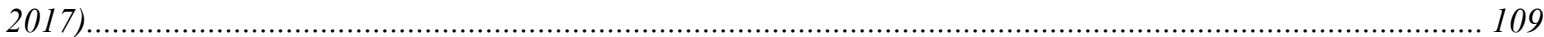

Imagem 57: detalhe do perfil norte, camadas A-G.(Pugliese 2017) ......................................................... 111

Imagem 58: Sepultamento 2 (Foto: Eduardo Neves)...................................................................... 113

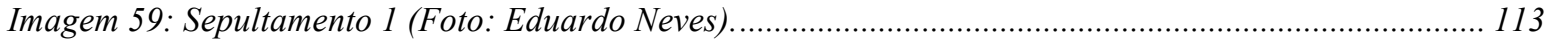

Imagem 60: tipos de aspecto da areia. ......................................................................................... 118

Imagem 61: 1) $5 \%, 0,5-1 \mathrm{~mm}$; 2) $5 \%, 0,5-2 \mathrm{~mm}$; 3) $5 \%, 0,5-3 \mathrm{~mm}$; 4) $10 \%, 0,5-1 \mathrm{~mm}$; 5) $10 \%, 0,5-2 \mathrm{~mm}$; 6) $10 \%$, 0,5-3mm; 7) $20 \%, 0,5-1 \mathrm{~mm}$;8) $20 \%, 0,5-2 \mathrm{~mm}$; 9) $20 \%, 0,5-3 \mathrm{~mm}$; 10) $30 \%, 0,5-1 \mathrm{~mm}$; 11) $30 \%, 0,5-2 \mathrm{~mm}$; 12)

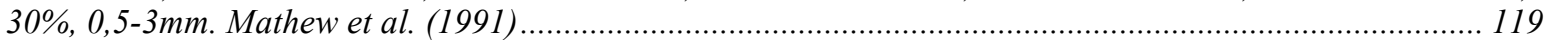

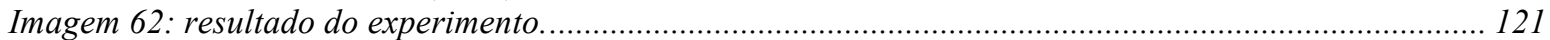

Imagem 63: resultado do experimento ..................................................................................................... 122

Imagem 64: detalhe do resultado do experimento com o sabugo, sem os grãos...................................... 122

Imagem 65: detalhe do experimento feito com a espiga de milho mole ................................................. 123

Imagem 66: a esquerda detalhe do milho mole, e à direita detalhe do resultado do experimento. ................ 123

Imagem 67: fragmento com tratamento de esgrafiado, que envolve técnicas de excisão, incisão, aplicação de

engobo, e controle da temperatura de queima e resfriamento da peça......

Imagem 68: a esquerda tipos morfológicos e de espessamento de borda (Barreto et al. 2016). A direita a mesma borda e suas possíveis diferentes inclinações. De cima para baixo: restrita, direta, irrestrita e irrestrita inclinada..... 130

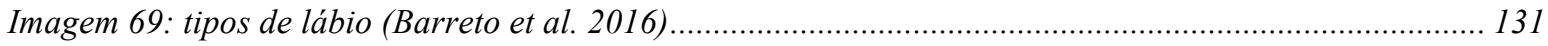

Imagem 70: exemplo de coleta de informação da inclinação de uma base ................................................. 131

Imagem 71: tipos de base (Barreto et al. 2016)......................................................................................... 132

Imagem 72: perfil de fragmentos cerâmicos onde é percebido as partículas brancas (calcário) e os vazios irregulares e agrupados, escala em milimetros.

Imagem 73: vazios agrupados registrados a partir de microscopia eletrônica, do SEM, onde a topografia e o arranjo dos minerais são registrados e os agrupamentos de vazios podem ser visualizados. Da esquerda para a direita: Camada D3, camada D2, camada C. Fonte: Pugliese (2017).

Imagem 74:a-b) inciso fino; $c$-d) inciso largo fundo; e-f) inciso largo raso; $g$-h) escovado espiga; $i$ ) impressão de cestaria; j) impressão de tecido; $k$-l) escovado sabugo; $m$-n) exciso; $n$-p) engobo vermelho; $q$-s) banho vermelho; $t$-u) polido; v) brunido; $n-q)$ esgrafiado 157 Imagem 75: Motivos decorativos identificados: a) bacabal; b) bacabal espelhado; c) bacabal 2; d) bacabal repetido; e) bacabal inciso paralelo; f) inciso losangular; g) inciso cruzado; h) inciso não cruzado; i) escovado sabugo; j) escovado espiga); k) impressão de de tecido; l) impressão de cestaria; m) quadriculado; n) representação zoomorfa; $n$-o) representação antropomorfa n) rosto; o) vulva. Imagem 76: a-j) motivo Bacabal, excisos, associado a Bacabal paralelo, com tratamento tipo esgrafiado; $k$-l) motivo Bacabal associado a Bacabal paralelo e engobo vermelho m,n,q,s) polidos; o,r,s) com barbotina; $p$ ) em superficie simples; $t$ ) Bacabal em serrilhado. 
Imagem 77: a-h) Bacabal espelhado, excisos - esgrafiado(e,f); banho vermelho (a.c.d); engobo vermelho (b,c); engobo vermelho e polimento $(g, h)$ i-l) Bacabal 2 - inciso fino, superficie com barbotina; $m$-r) Bacabal repetido - barbotina (m,p,q,r); exciso, polido e engobo vermelho (n); inciso polido e engobo vermelho (o).164 Imagem 78: motivo Bacabal paralelo.

Imagem 79: a-c) Escovados indefinidos; $d$-q) escovados sabugo; r) escovado sabugo com barbotina erodindo.

Imagem 80: a-b) Escovado sabugo com polimento e banho vermelho; c) escovado sabugo; d-f) escovado espiga; g-i) impressão de tecido; j-r) impressão de cestaria; $s$-z) impressão de tecido.

Imagem 81:motivos decorativos, a-b) representação zoomorfa; $c$-d) representação antropomorfa, face (a); vulva(b); e)inciso cruzado; f) inciso losangular; g) inciso não cruzado ................................................. 168

Imagem 82: fragmentos de bordas com alça (acima) e asa (abaixo) ponteadas. ......................................... 169

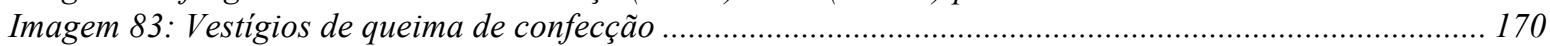

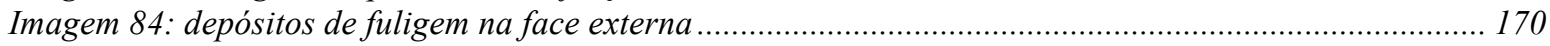

Imagem 85: Borda direta com furo posterior a queima .................................................................. 170

Imagem 86: Fragmentos de potes com alterações em serrilhado. ..................................................... 171

Imagem 87: Morfologia direta, inclinação irrestrita inclinada. ............................................................... 182

Imagem 88: Morfologia Direta, inclinação Irrestrita. ......................................................................... 183

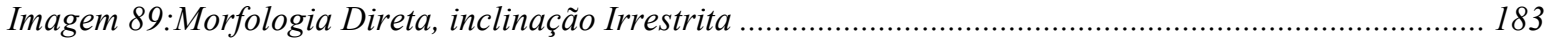

Imagem 90: Morfologia Direta, inclinação Irrestrita ................................................................................ 184

Imagem 91: Morfologia Direta, inclinação Irrestrita. ............................................................................ 185

Imagem 92: Morfologia Direta, inclinação Irrestrita. ................................................................. 186

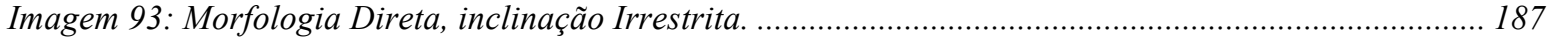

Imagem 94: Morfologia Direta, inclinação Direta..................................................................................... 188

Imagem 95: Morfologia Direta, inclinação Direta ....................................................................................... 189

Imagem 96: Morfologia Direta, inclinação Direta............................................................................ 190

Imagem 97: Morfologia Direta, inclinação Direta ...................................................................................... 192

Imagem 98: Morfologia Direta, inclinação Direta ..................................................................................... 193

Imagem 99: Morfologia Direta, inclinação Direta.................................................................................... 194

Imagem 100: Morfologia Direta, inclinação retrita ............................................................................. 195

Imagem 101: Introvertidas irrestritas inclinadas ................................................................................ 202

Imagem 102: Introvertidas irrestritas inclinadas .................................................................................. 203

Imagem 103: Introvertidas diretas..................................................................................................... 204

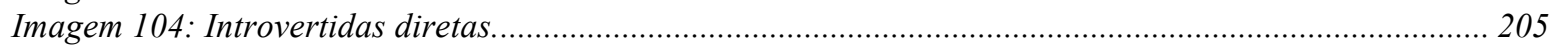

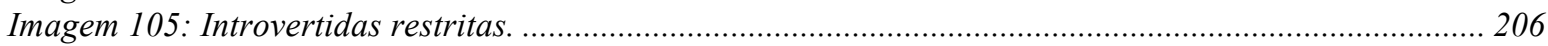

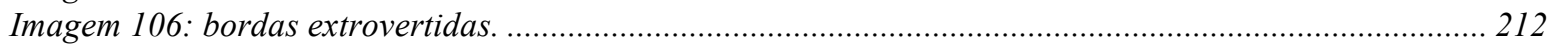

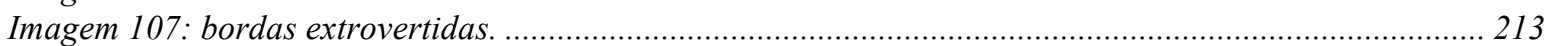

Imagem 108: acima asas ponteadas e incisas, ao centro asa antropomorfa, abaixo asa ponteada.............. 214

Imagem 109: acima asa inciso e ponteada, abaixo asas incisas e ponteadas............................................... 215

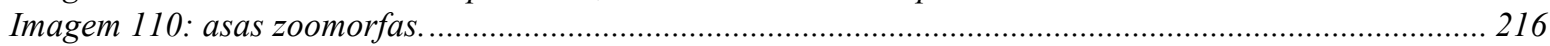

Imagem 111: reconstituição do perfil de potes com asas. ........................................................................... 217

Imagem 112: procedimento para a coleta do ângulo de saida da parede na bases.................................. 219

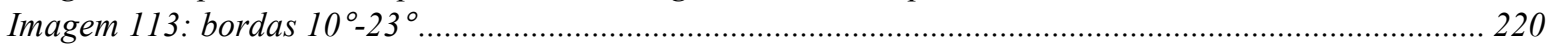

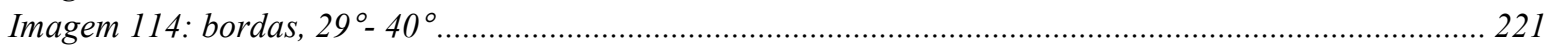

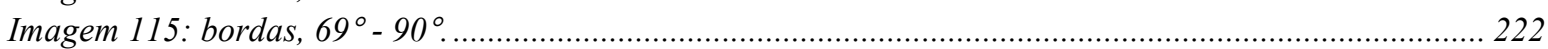

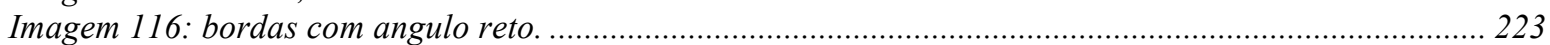

Imagem 117: Sequência seriada dos tipos morfológicos inspirados nas bordas divididas por tipo e inclinação,

distribuidas pelo diâmetro de boca. As séries hachuradas indicam que ocorrem tipos decorados............... 224

Imagem 118: Panelas grandes para cozer bebidas fermentadas registradas entre Enawenenawe (Gerard,s.d.),

a direita, entre indígenas falantes de língua do troco Pano na fronteira do Brasil com o Acre (Erikson, 1993).

Em ambos os casos os potes estão escorados por trempes.................................................................... 225

Imagem 119: trempes bem fragmentadas ...................................................................................... 226

Imagem 120: acima trempe decorada com motivo Bacabal Losangular, ao centro com superficie alisada e

abaixo polida. Nota-se a queima identificada como incompleta nestes exemplares...................................... 227

Imagem 121: acima trempe decorada com o motivo Inciso não-cruzado, ao centro e abaixo trempes com a

queima reduzida completa, percebe-se que estes exemplos tem seu interior oco.......................................228

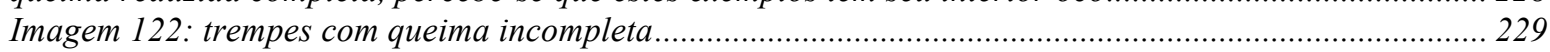

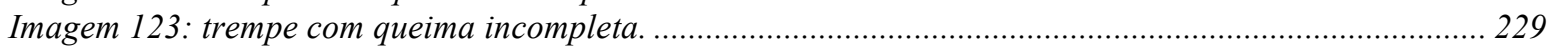

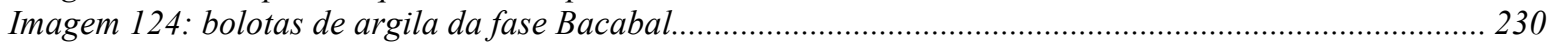

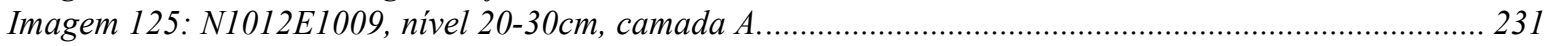

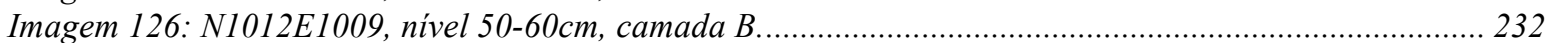


Imagem 127: grãos de amido encontrados a) milho moído, b) milho não danificado, c) milho moído e tostado, d) batata doce, e) abóbora, f) Dioscorea trifida (g), Dioscorea sp., H) amido de tubérculo não identificado (MC 8), i) amido gelatinizado por aquecimento, j) um dos grupos de amido irregular de MC7. 239 Imagem 128: 1- Cerâmica da fase Bacabal: (a) Bacabal inciso (b) Bacabal exciso-inciso-hachurado (c, d) Inciso (e) Representação antropomorfa (f) Representação zoomorfa. Desenhos de Ubirajara Mello, 2 Morfologia dos potes segundo Miller (2009b) (Zimpel e Pugliese. 


\section{Lista de Tabelas}

Tabela 1: datações radiocarbônicas para a fase Bacabal.

Tabela 2: datações por termoluminiscência feitas com cerâmicas da fase Bacabal.

Tabela 3: atributos para classificação de base

Tabela 4: Resultado da triagem de materiais cerâmicos da etapa de $2014 \_134$

Tabela 5: Resultado da triagem do material cerâmico de $2016 \_135$

Tabela 6: tipos de artefatos identificados _ـ 136

Tabela 7: partes identificados dos potes _ 137

Tabela 8: espessura mínima e máxima dos fragmentos__ 139

Tabela 9: Tipos de antiplástico e agrupamentos ___ 141

Tabela 10: quantidade e porcentagem dos tipos de tamanho de partículas de areia entre os grupos de antiplástico. _ـ 144

Tabela 11: quantidade e porcentagem do grau de incidência de antiplástico por tipo de pasta. 1) 5\%, 0,5$1 \mathrm{~mm}$; 2) $5 \%, 0,5-2 \mathrm{~mm}$; 3) $5 \%, 0,5-3 \mathrm{~mm}$; 4) $10 \%, 0,5-1 \mathrm{~mm}$; 5) $10 \%, 0,5-2 \mathrm{~mm}$; 6) $10 \%, 0,5-3 \mathrm{~mm}$; 7) $20 \%, 0,5-$ $1 \mathrm{~mm}$; 8) $20 \%, 0,5-2 \mathrm{~mm}$; 9) $20 \%, 0,5-3 \mathrm{~mm}$; 10) $30 \%, 0,5-1 \mathrm{~mm}$; 11) $30 \%$,12) $30 \%, 0,5-3 \mathrm{~mm}$.

Tabela 12: quantidade e porcentagem dos tipos de tamanho das partículas de areia entre os tipos de frequência de antiplásticos dos grupos 1, 2 e 3.

Tabela 13: quantidade e porcentagem dos fragmentos separados pelo tipo cor. 149

Tabela 14: quantidade e porcentagem de fragmentos com a técnica de manufatura identificada___ 150

Tabela 15: quantidade e proporção na amostra do tipo de tratamento de superfície aplicado a face externa dos fragmentos $(n=1318)$

Tabela 16: quantidade e proporção dos tipos de tratamento dado a face externa dos fragmentos___ 154

Tabela 17: quantidade e proporção do tratamento dado a face externa dos tipos alisados___ 154

Tabela 18: quantidade e porcentagem dos tipos com aplicação de pigmentação na face externa___ 155

Tabela 19: Tipo de tratamento $x$ tratamento dado a superfície da face externa $(n=649) \ldots 158$

Tabela 20: quantidade e proporção dos motivos identificados $(n=649) \_160$

Tabela 21: quantidade e proporção dos tipos com marcas de uso.___ 170

Tabela 22: Quantidade e proporção dos tipos de morfologia de borda em relação aos tipos de inclinação. 172

Tabela 23: quantidade e proporção dos tipos de inclinação entre os tipos de espessamento das bordas diretas.

Tabela 24:quantidade e frequência dos tipos de lábios entre os tipos de espessasmento de bordas diretas e suas inclinações $(n=146) \ldots 174$

Tabela 25: quantidade de fragmentos e proporção entre os tipos de espessura máxima e mínima. ___ 175

Tabela 26: quantidade e frequência dos tipos de inclinação das bordas diretas entre os tipos de diâmetro. 178

Tabela 27: quantidade e porcentagem das bordas diretas entre os diametros de abertura de boca. ___ 181

Tabela 28: quantidade e frequência dos tipos de lábios entre os tipos de espessasmento de bordas introvertidas e suas inclinações 197

Tabela 29: quantidade e proporção dos tipos de espessura dos fragmentos das bordas introvertidas __ 198

Tabela 30: quantidade e percentual dos dos tipos de inclinação das bordas introvertidas entre os valores de diâmetro de abertura de boca.

Tabela 31: quantidade e porcentagem dos tipos de borda introvertidas alisadas e decoradas entre os diâmetros de abertura de boca identificados.

Tabela 32: : quantidade e percentual dos tipos de inclinação das bordas extrovertidas entre os tipos de espessamento.

Tabela 33: quantidade e porcentagem dos tipos de espessura das bordas extrovertidas.

Tabela 34: : quantidade e porcentagem dos tipos de inclinação das bordas extrovertidas entre os diâmetros

diagnosticados.

Tabela 35: quantidade e porcentagem dos tipos de inclinação das bordas extrovertidas alisadas e decoradas

entre os tipos de diâmetro reconhecidos _ 211

Tabela 36: tipos de tratamento de superfície das bases. 218

Tabela 37: tipo de queima entre as bordas e as paredes com impressão __ 219

Tabela 38: quantidade e porcentagem de fragmentos cerâmicos por camada. _ـ 233

Tabela 39: quantidade e porcentagem dos tipos de antiplástico por camada.

Tabela 40: quantidade e porcentagem dos tipos de areia na pasta por camada.

Tabela 41: : quantidade e porcentagem dos motivos reconhecidos entre as camadas_ 236

Tabela 42: quantidade e porcentagem dos tipos de borda entre as camadas arqueológicas. ___ 237

Tabela 43: amostras analisadas. _ـ 238 
Tabela 44: Tabela mostrando frequências e identificações taxonômicas de grãos de amido encontrados nas cerâmicas de Monte Castelo. $X^{*}=$ encontrado na amostra de raspagem; $X=$ encontrado na amostra de pincel molhado; $(X)$ = caso em que a espécie é uma tentativa. 


\section{Lista de Gráficos}

Gráfico 1: tipos de artefatos identificados

Gráfico 2: partes identificados dos potes

Gráfico 3: Espessura dos fragmentos

Gráfico 4: Espessura mínima e máxima dos fragmentos

Gráfico 5: quantidade de fragmentos por tipo de antiplástico

Gráfico 6: sequencia seriada do tamanho da partícula de areia entre os grupos de tipo de antiplástico. 144 Gráfico 7: Sequencia seriada do grau de incidência de antiplástico por tipo de pasta. 1) 5\%, 0,5-1mm; 2) 5\%, 0,5-2mm; 3) $5 \%, 0,5-3 \mathrm{~mm}$; 4) $10 \%, 0,5-1 \mathrm{~mm}$; 5) $10 \%, 0,5-2 \mathrm{~mm}$; 6) $10 \%, 0,5-3 \mathrm{~mm}$; 7) $20 \%, 0,5-1 \mathrm{~mm}$; 8) $20 \%$, $0,5-2 \mathrm{~mm}$; 9) $20 \%, 0,5-3 \mathrm{~mm}$; 10) $30 \%, 0,5-1 \mathrm{~mm}$; 11) $30 \%, 0,5-2 \mathrm{~mm}$; 12) $30 \%, 0,5-3 \mathrm{~mm}$.

Gráfico 8: sequencia seriada dos tipos de tamanho das partículas de areia entre os tipos $\overline{\text { de frequência de }}$ antiplásticos dos grupos 1, 2 e 3.

Gráfico 9: quantidade de fragmentos por cor

Gráfico 10: quantidade de fragmentos com a técnica de manufatura identificada. 149

Gráfico 11: tipo de tratamento dado a face externa dos fragmentos $(n=1318) \ldots 153$

Gráfico 12: tratamento dado a face externa dos fragmentos _ـ_ 153

Gráfico 13: tratamento dado a face externa dos tipos alisados__ 154

Gráfico 14: cor na face externa___ 155

Gráfico 15: quantidade de tipos de estrias de alisamento em tipos alisados $n=630 \_155$

Gráfico 16: quantidade e proporção de tipos de estrias de alisamento em tipos alisados $n=630 \_156$

Gráfico 17: sequencia seriada da frequência do tipo de tratamento e o tratamento dado a superfície da face externa $(n=649$

Gráfico 18: motivos reconhecidos na fase Bacabal___ 160

Gráfico 19: sequência seriada dos tipos de tratamento de superficie entre os motivos decorativos reconhecidos na fase Bacabal $\quad 162$

Gráfico 20: marcas de uso.__las 169

Gráfico 21: sequência seriada dos tipos de morfologia de borda entre os tipos de inclinação ___ 172

Gráfico 22: sequência seriada dos tipos de inclinação entre os tipos de espessamento das bordas diretas. 173

Gráfico 23:sequência seriada da frequência dos tipos de lábios entre os tipos de espessamento de bordas

diretas e suas inclinações $(n=146)$

Gráfico 24:previsão linear das medidas de espessura máxima e mínima entre as bordas diretas. ___ 175

Gráfico 25: espessura do fragmentos - bordas diretas (n=149) ___ _ _ 175

Gráfico 26: previsão linear entre as medidas de espessura e diâmetro de boca __ 176

Gráfico 27: sequência seriada dos tipos de inclinação da bordas diretas entre os tipos de diâmetro de abertura de boca.

Gráfico 28: sequencia seriada das bordas diretas simples e decoradas entre os diâmetros de boca. __ 180 Gráfico 29: sequência seriada dos tipos de inclinação entre os tipos de espessamento de bordas introvertidas $(n=46)$.

Gráfico 30: quantidade e proporção dos tipos de inclinação entre os tipos de espessamento de bordas introvertidas $(n=46)$

Gráfico 31: sequência seriada dos tipos de lábios entre os tipos de espessamento de bordas introvertidas e suas inclinações

Gráfico 32: previsão linear da espessura mínima e máxima das bordas introvertidas.___ 198

Gráfico 33: espessura dos fragmentos das bordas introvertidas. ___ 198

Gráfico 34: previsão linear entre a espessura máxima e o diâmetro de boca das bordas introvertidas. 199

Gráfico 35: sequência seriada dos tipos de inclinação das bordas introvertidas entre os valores de diâmetro de abertura de boca.

Gráfico 36: sequência seriada do tipos de borda introvertidas alisadas e decoradas entre os diametros de abertura de boca identificados.

Gráfico 37: sequência seriada dos tipos de inclinação das bordas extrovertidas entre os tipos de espessamento.

Gráfico 38: previsão linear da espessura mínima e máxima das bordas extrovertidas. 207

Gráfico 39: distribuição das bordas extrovertidas entre as espessuras mais frequentes 208

Gráfico 40: sequência seriada dos tipos de inclinação das bordas extrovertidas entre os diâmetros

diagnosticados.

Gráfico 41: sequência seriada dos tipos de inclinação das bordas extrovertidas alisadas (em preto) $e$

decoradas (em vermelho) entre os tipos de diâmetro reconhecidos.

Gráfico 42: espessura mínima e máxima de bordas e paredes com impressões

Gráfico 43: quantidade de fragmentos por camada. 
Gráfico 44: tipo de antiplástico por camada.

Gráfico 45: sequência seriada dos tipos de areia na pasta por camada.

Gráfico 46: sequencia seriada dos motivos reconhecidos entre as camadas.

236

Gráfico 47: sequência seriada dos tipos de borda entre as camadas arqueológicas.

237

Gráfico 48: diagrama de frequência de fitólitos. 


\section{Introdução}

Nesta tese vamos tratar sobre a classificação e a interpretação de vestígios cerâmicos da fase Bacabal (Miller 1992, 2009, 2013) que é encontrada no médio curso do rio Guaporé, sudoeste da região amazônica, estado de Rondônia. A fase foi proposta a partir de pesquisa feita na década de 80 em uma área de banhado adjacente ao rio Guaporé, e tem sua área de ocorrência delimitada pelos afluentes rio Bacabalzinho e rio Branco.

O rio Guaporé que está localizado na porção sudoeste da Amazônia e demarca grande parte a fronteira entre o Brasil e a Bolívia. Também conhecido como Iteñez no país vizinho, e é usualmente considerado como o limite leste da região arqueológica conhecida como Llanos de Mojos (Denevan 1966; Erickson 1995). Os principais rios que formam o Guaporé estão localizados próximas à cidade de Vila Bela da Santíssima Trindade, no estado do Mato Grosso, de onde percorre mais de $1100 \mathrm{~km}$ em direção norte, até sua confluência com o rio Mamoré, na porção norte da fronteira do estado de Rondônia com o território boliviano (Imagem 1). 


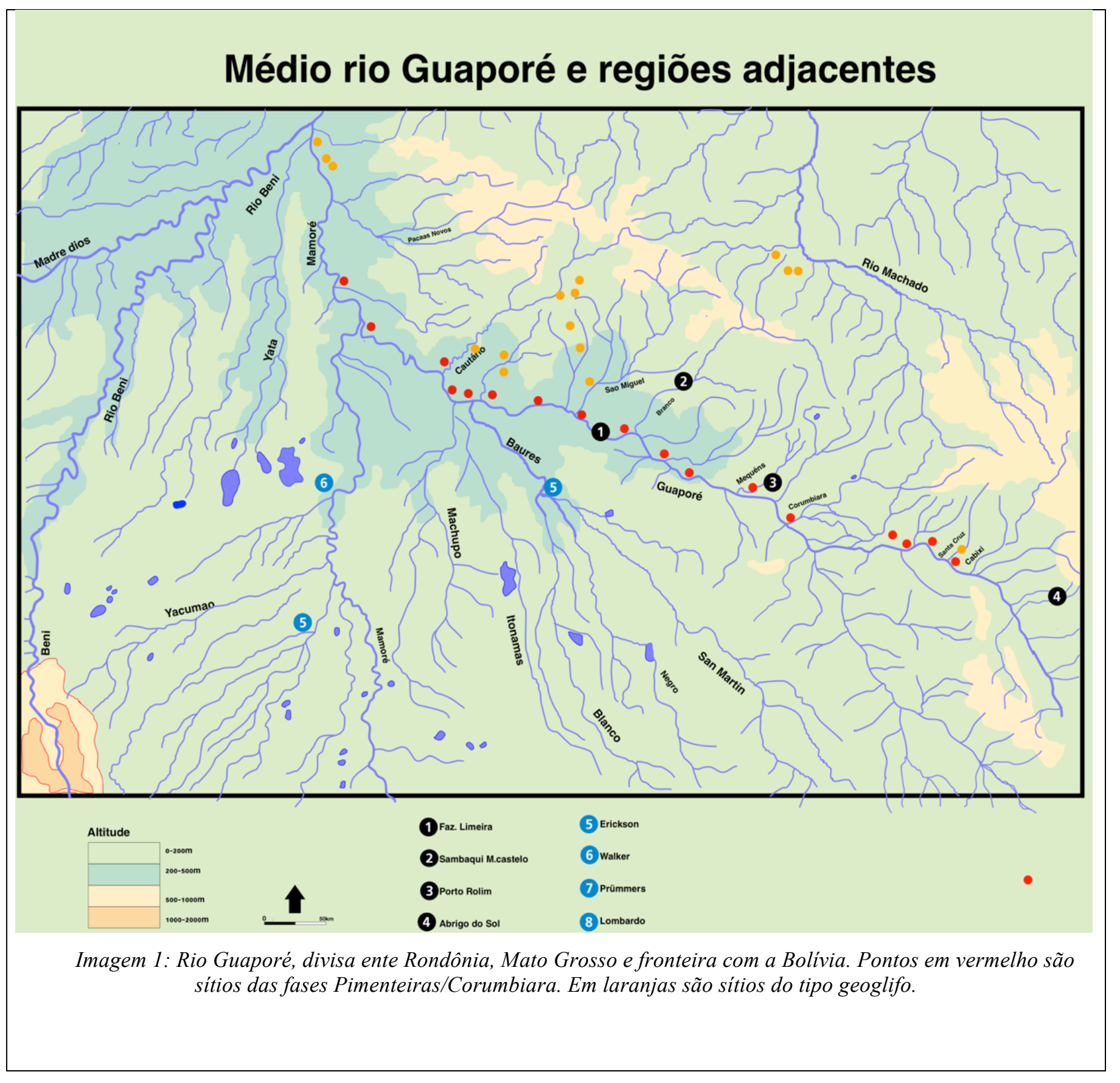

A bacia do rio Guaporé tem vegetação composta pela característica floresta tropical que é intercalada por extensas planícies inundáveis cobertas por gramíneas, foi um lugar onde mais de 50 línguas diferentes foram registradas. Essas línguas representam uma ampla diversidade de famílias linguísticas, além de grupos isolados e línguas não classificadas, sendo um dos pontos de maior divergência linguística da América do Sul. Arawak, Chapacura, Jabuti, Nambikwara, Pano e Tupi são as famílias registradas até o momento, além de outras 11 línguas isoladas. Para a linguística histórica, essa complexidade 
encontrada no presente pode ser resultado de diversas ondas populacionais que chegaram à região e foram convivendo durante milênios (Crevels e van der Voort, 2009).

As primeiras notícias sobre a arqueologia da região estão publicadas em Nordenskiöld (1912) e Becker-Donner (1956). Dados mais recentes foram produzidos pelas pesquisas coordenadas naquela região pelo arqueólogo Eurico Miller, que apresentou um significativo volume de informações (Miller, 1977,1983,1992a, 1992b, 2009b, 2013) resultante de pesquisas desenvolvidas no âmbito do PRONAPABA (Simões, 1977,1983; Simões e Lopes, 1987). Do lado boliviano, Dougherty e Calandra (1984-85 e 1985) e, mais recentemente, Betancourt $(2011,2014)$, divulgaram informações mais detalhadas sobre coleções cerâmicas de diferentes pontos do rio Guaporé e de regiões bolivianas ligadas à margem esquerda daquele rio.

Além da presença de sambaquis, no lado brasileiro da bacia têm sido registrados diversos sítios que possuem como características em comum a presença de Terra Preta de Índio (TPI) - frequentemente acompanhada de construções em terra, como valas circulares ou em arco - com camadas culturais que raramente ultrapassam $50 \mathrm{~cm}$ de espessura e enterramentos em urnas cerâmicas.

Para o sambaqui Monte Castelo, as ilhas de terra firme e os demais sítios espalhados pelo banhado, a cerâmica foi classificada como pertencente à fase Bacabal (Miller 1992b, 2009b), enquanto que para os sítios próximos à margem do médio rio Guaporé, as cerâmicas foram classificadas segundo as fases Pimenteiras e Corumbiara (Miller, 1983).

Até hoje não existem pesquisas na arqueologia que fizessem um debate sobre o conhecimento produzido para uma região onde atualmente tem se visto um crescimento no volume de informações produzidas - visto a produção sobre os Llanos de Mojos, Rondônia e sobre o Mato Grosso, por exemplo.

Buscou-se então elaborar uma proposta a partir da discussão de hipóteses centrais a interpretação do registro arqueológico da fase Bacabal e seus possíveis desdobramentos, testando as proposições a partir de estudos de caso de sítios arqueológicos localizados no médio rio Guaporé.

Até o ano de 2009 a cerâmica da fase Bacabal era praticamente desconhecida, sem imagens publicadas e seu conhecimento se resumia em poucos parágrafos de descrição feitas por Miller (1992). Em Miller (2009, 2013) publica de maneira mais completa os resultados de suas pesquisas da década de 80 , além de uma série de intepretações hipóteses pouco ortodoxas sobre o contexto arqueológico como a da origem cerâmica Bacabal tendo 
relação direta com migrantes da cultura Valdívia (Meggers et al. 1965) vindos da costa do Equador e se instalando no pantanal do rio Guaporé (Imagem 2).

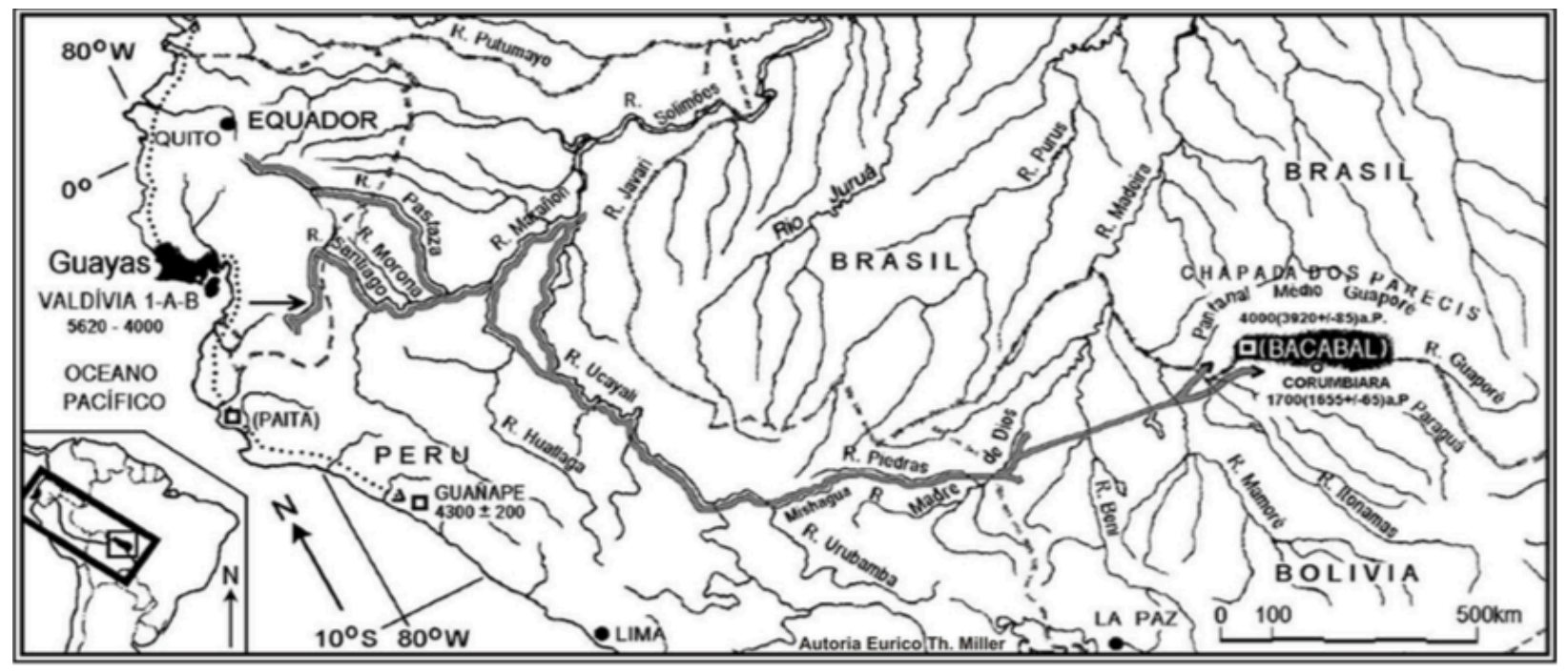

Imagem 2: de migração proposta por Miller (2013, p. 361).

Este assunto pouco foi debatido na arqueologia e confiamos que é possível uma nova avaliação, assim como o teste de conjecturas alternativas pois tanto Valdívia como Bacabal possuem distintas interpretações do que aquelas levadas em consideração por Miller para a elaboração do modelo original publicado. Buscamos neste trabalho desenvolver ideias relacionadas as recentes interpretações buscando repetir a pergunta de Miller quando propõe a hipótese corrente, se existem ou não relações entre Bacabal e Valdívia.

O arqueólogo também estabelece relações entre a fase Bacabal e outras culturas arqueológicas do noroeste do estado do Mato Grasso (Miller 2013), e sendo assim nesta tese procuramos dialogar com as demais culturas arqueológicas regionais (Betancourt 2009, 2011)

No capítulo 1 vamos apresentar a arqueologia do Estado Rondônia, dando ênfase as pesquisas executadas no rio Guaporé, e significância do registro arqueológico para o entendimento da história dos povos nativos do Estado.

No capítulo 2 vamos debater as hipóteses sobre os desdobramentos que possam ter relação ao modelo de dispersão da fase Bacabal regionalmente, tratar da hipótese da correlação entre a fase Bacabal e a cultura Valdívia, além dos contextos de ocorrência de sambaquis na Amazônia.

No capítulo 3 apresentamos a fase Bacabal com mais detalhes, trazendo dados sobre o padrão de assentamento e descrevendo a técnica de nossas pesquisas durantes estes 
últimos quatro anos, além de demonstrar o método empregado na análise das cerâmicas arqueológicas.

Já no capítulo 4 apresentamos os resultados da nossa análise cerâmica onde exploramos a variabilidade formal e artefactual (Schiffer e Skibo 1997; Silva 2007) da fase Bacabal e são discutidos os resultados.

O Capítulo 5 é de caráter conclusivo, e nele apresentar-se-á uma síntese final dos resultados refletindo sobre a importância da região para o entendimento do contexto arqueológico amazônico. 


\section{Capítulo 1 - Arqueologia em Rondônia}

Há muito tempo que a arqueologia de Rondônia vem sendo marcada pela precocidade e diversidade de eventos que se tornariam comuns na Amazônia como um todo. A retomada das pesquisas no estado nas duas últimas décadas vem demonstrando uma riqueza de informações arqueológicas relacionadas a diferentes temáticas como o surgimento das primeiras terras pretas de Índio (TPI) e de diferentes culturas cerâmicas que aparecem durante o Holoceno médio (Miller et al 1992, Zimpel 2009; Mongeló 2015; Pugliese 2017).

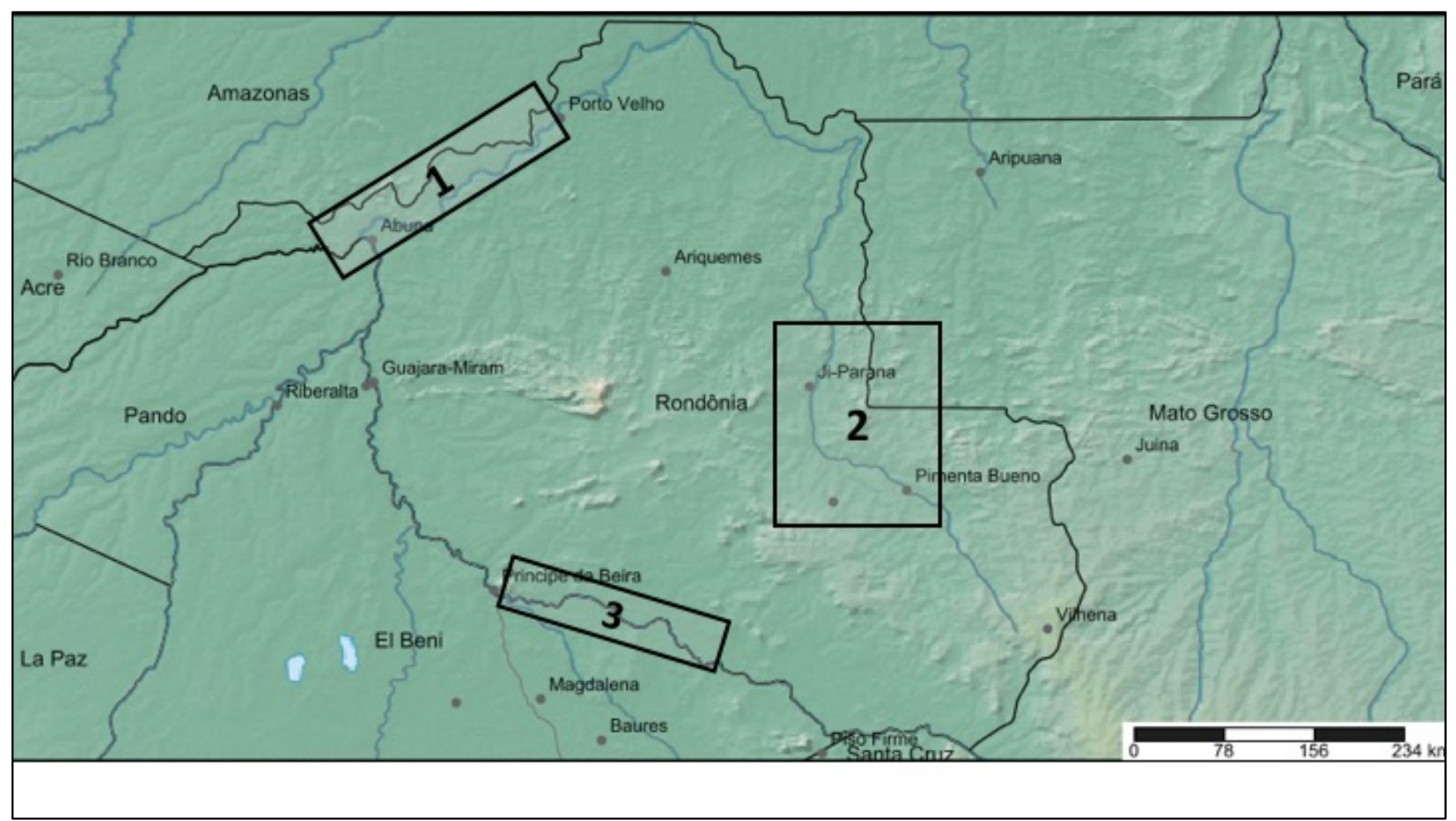

Imagem 3: áreas arqueológicas de Rondônia com evidências de ocupação durante o Holoceno médio. 1) alto rio Madeira; 2) Rio Machado, Ji-paraná; 3) médio rio Guaporé,

No alto rio Madeira os dados apontam vestígios de populações há cerca de 9000 anos atrás, e que perdura até a conquista europeia com poucos hiatos Miller (1987, 1992, 2009; Almeida 2013; Mongeló 2015; Zuse 2016). Entre o início do Holoceno e seu período médio tem-se testemunhos de ocupação em diferentes pontos do estado, como a região centro-leste do rio Machado (Ji-paraná) e o médio rio Guaporé.

A datação mais antiga que remete a ocupação para o estado de Rondônia é encontrada na publicação de Miller e Meggers (2003) que citam a uma datação de 13500 
anos AP para um sítio pré-cerâmico localizado no rio Machado.

Outros sítios com datas mais recuadas cronologicamente e relacionados ao início do Holoceno são encontrados no rio Jamari. Este rio tem sua nascente no sudoeste da Serra dos Pacaás Novos, de onde corre, no sentido norte, desembocando na margem direita do rio Madeira. A região faz parte de uma extensa planície com poucas elevações. Ao longo de seu médio e baixo curso, datações indicam a presença humana há pelo menos 8000 anos. Tais ocupações antigas foram classificadas em três fases, e se estendem até o Holoceno médio (Miller et al. 1992).

No sítio RO-PV-48 é possível encontrar estas três fases. O assentamento ocorre sobre um barranco alto na terra firme, adjacente ao rio Massangana, muito próximo a sua foz no rio Jamari. Lá foi identificada A fase lítica Itapipoca (cal. $8320 \pm 100-6970 \pm 60$ ) enterrada entre $510-600 \mathrm{~cm}$ de profundidade e que tem em seu inventário tecnológico lascas, percutores, raspadores laterais e terminais, percutores com evidências de uso e núcleos esgotados produzidos em calcedônia, quartzo, rochas cristalinas e basalto.

Subsequentemente ocorre no sítio a Fase Pacatuba (cal. 6090 \pm 10 - 5210 \pm 70 ) que em sua indústria lítica encontram-se lascas, percutores em seixos, em quartzito e sílex, pedras-bigorna, núcleos, e no final da sequência, polidores, lâminas de machado lascadas, e microlascas em quartzo.

Em seguida tem-se a fase Massangana (cal 4780 $\pm 90-2640 \pm 60$ ) Miller et al. (1992). É nesta fase que ocorrem as terras pretas de índio até o momento mais antigas da Amazônia. Os artefatos líticos da fase correspondem a microlascas principalmente de quartzo, algumas com evidências de uso, raros raspadores pequenos, pedras- bigorna, pequenos pilões e pequenas mãos de pilão. Núcleos, percutores, moedores impregnados de corante e pedras corantes (hematita) são encontramos juntamente com lâminas-demachado picotadas, lascadas e pequenas. As matérias primas escolhidas foram principalmente rochas cristalinas, com menor frequência de calcedônia, quartzo e laterita. Tal cultura arqueológica não se restringe sua ocorrência ao sítio no rio Jamari e é também encontrada durante o Holoceno médio no sítio Teotônio, rio Madeira (Mongeló 2015). 


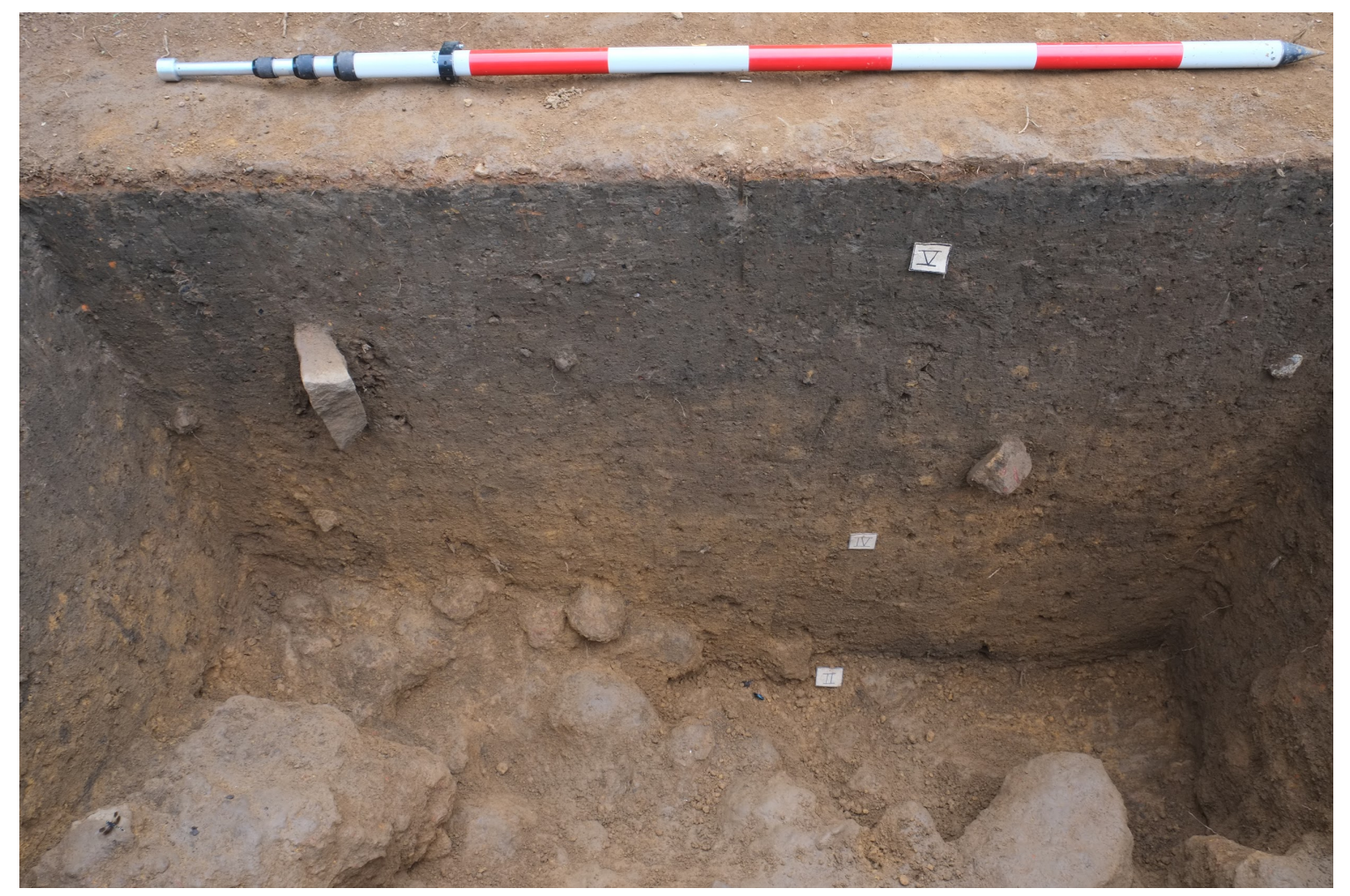

Imagem 4: camadas da fase Girau e Massangana, sitio Teotônio (Mongeló 2017)

No alto rio Madeira, entre entre 3000 e 500 anos atrás surgem uma série de diferentes cerâmicas com estilos variados que muitas se sobrepõem em um mesmo sítio, como é o caso do Teotônio, Santa Paula e Ilha do Dionísio (Zuse 2016). Para Almeida (2013), a marcante variabilidade no registro arqueológico regional pode remeter a possibilidade de ter havido um padrão multiétnico de ocupação no Alto Madeira, em que a cachoeira do Teotônio teria um papel importante para a configuração de tal cenário.

$\mathrm{Na}$ região centro-oeste do estado, próximo a cidade de Ji-paraná, existem informações sobre uma ocupação que chegaria a mais de 13000 anos (Miller e Meggers 2003), porém são parcamente divulgadas e não se tem ideia sobre o tipo de sítio e da cultura arqueológica que fora datada. Entretanto, existem descrições sobre outras fases lítica que ocorrem na região, como a fase Vilhena, que compreende uma indústria com raspadores circulares e laterais, lascas simples e com evidências de modificação e uso, núcleos e seixos com retirada, em arenito e sílex. Para a fase tem-se notícia de três datações radiocarbônicas a colocam num horizonte cronológico semelhante a fase

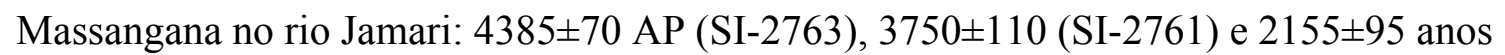


AP (SI-2762). Entretanto, nesta fase não ocorre a TPI (Miller 1978; 1987)

Também são encontradas informações de que em Ji-paraná ocorrerem as fases Itajuba e Itapema, onde em ambas são encontradas lascas simples, percutores e núcleos. A diferença nas fases seria na Itapema que conta com talhadores presentes no registro arqueológico (Miller, 1987a, 1987b)

Todavia o que mais chama atenção dentro deste contexto regional é a precocidade da aparição de evidências cerâmicas. Entre 5000-4500 anos AP, em diferentes pontos aparecem indícios de uma tecnologia cerâmica que perduraria durante milênios na área, relacionada a tradição Tupiguarani (Miller 2009b, Zimpel 2009; Cruz 2009) (imagem $5)$.
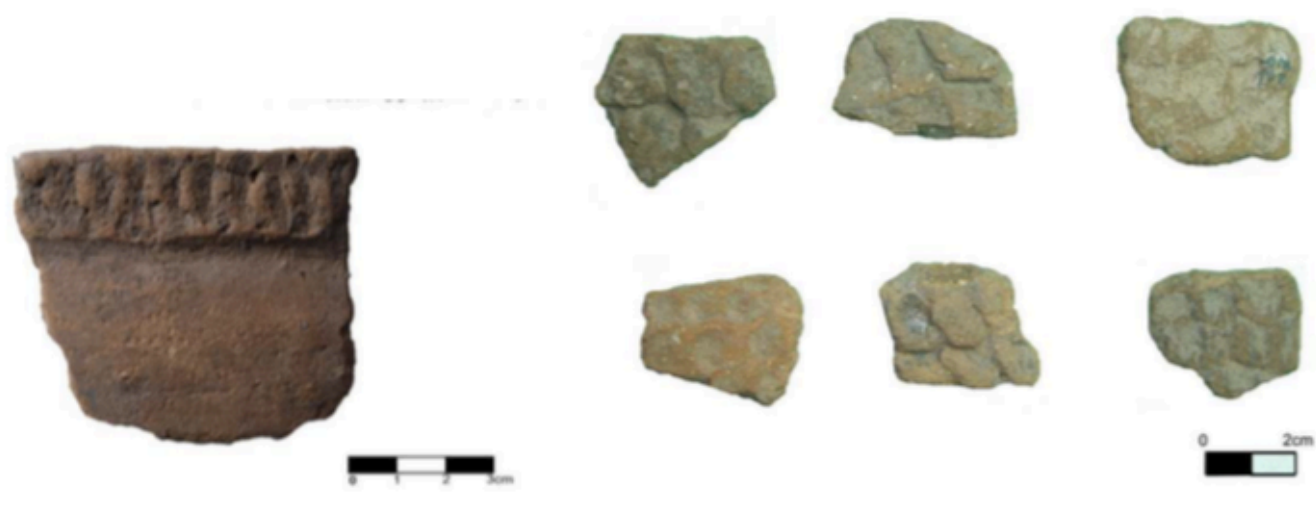

Imagem 5: cerâmicas corrugadas do sítio Encontro.

Um exemplo é o sítio arqueológico Encontro (cal. 4.520 a 4.150 anos AP) que está inserido na serrania da Providência, adjacente a porção de planície de inundação do rio Machado, local reconhecido pela quantidade e variabilidade de registro rupestres e pela precocidade de sítios relacionados a tradição Tupiguarani (Miller 2009, Zimpel 2009, Coimbra 2010). Trata-se de um sítio de pequenas dimensões considerando os padrões amazônicos. Em sua área encontram-se duas concentrações de TPI com feições circulares medindo $20 \mathrm{~m}$ de diâmetro, e sendo a TPI caracterizada pela baixa fertilidade quando comparada com as encontradas na fase Massangana, mas comparável a outras que ocorrem no rio Caquetá (Colômbia), no sudeste do Pará e em alguns pontos do oeste do estado do Amazonas (Kern et al. 2017). A cerâmica tem como antiplástico a areia média a grossa, e entre os cacos decorados há uma predominância dos tipos corrugado, inciso, roletado e ungulado (Zimpel 2009). Tais cerâmicas Tupiguarani persistem regionalmente 
e suas evidência são concentradas principalmente no oeste do estado, chegando até o noroeste de Mato Grosso, no município de Aripuanã (Scientia 2009, 2010)

Portanto, percebe-se que o contexto arqueológico já aparece bem diversificado durante o início do Holoceno médio, momento de aparecimento da fase Bacabal, assunto central desta tese. Talvez o registro arqueológico feito nestas regiões, somados àqueles relacionados ao rio Guaporé poderiam ajudar a resolver questões pertinentes na arqueologia da Amazônia atual, como a história da domesticação de cultivares, que ainda é um evento pouco entendido pela arqueologia. Tal falta de informação poderia ser compreendida dado que há poucas regiões na Amazônia onde as evidências encontradas recuassem cronologicamente ao Holoceno médio, momento propício para tal investigação (Neves 2011).

\section{Arqueologia no rio Guaporé - Contexto e antecedentes}

A bacia do rio Guaporé foi um lugar onde tradicionalmente mais de 50 línguas diferentes foram registradas. Essas línguas representam uma ampla diversidade de famílias linguísticas, além de grupos isolados e línguas não classificadas, sendo um dos pontos de maior divergência linguística da América do Sul. Arawak, Chapacura, Jabuti, Nambikwara, Pano, Tupi são famílias registradas, além de outras 11 isoladas. Para a linguística histórica, essa complexidade encontrada no presente pode ser resultado de diversas ondas de populações que chegaram a área durante milênios (Crevels e van der Voort 2009).

Hoje em dia, poucos indígenas espalham-se no médio rio Guaporé. As comunidades remanescentes de quilombos possuem a maior densidade populacional da região.

Apesar de longa data, a arqueologia deste importante tributário amazônico ainda foi pouco explorada. Entretanto, com as informações disponíveis já é possível registrar informações que a ocupação deste rio remonta a, pelo menos, 10000 anos nas suas cabeceiras (Miller 1977, 1987) e a 8000 anos AP (Miller 1992a, 2009) na bacia do médio Guaporé.

As primeiras pesquisas na região foram realizadas por Erland Nordenskiöld, que, após percorrer os afluentes do lado boliviano do rio Guaporé - entre eles, o rio Beni coletou informações sobre os sítios arqueológicos no rio Mequéns, afluente do Guaporé em terras brasileiras. Na década de 50, Becker-Donner (1956) também atuou na área e, de certa maneira, ambos os pesquisadores apontaram em seus relatos para uma 
uniformidade dos achados cerâmicos nos sítios do médio curso daquele rio, por meio do registro de recorrências nos motivos decorativos e na morfologia de alguns potes.

Após um período sem a realização de pesquisas arqueológicas, a retomada nos trabalhos na região ocorre praticamente de maneira concomitante no lado brasileiro e no lado boliviano - no estado de Rondônia e no departamento do Beni -, em áreas localizadas na porção média da bacia do rio Guaporé. Na Bolívia, Dougherty e Calandra (1984-85, 1985) realizaram escavações em diferentes sítios arqueológicos, criando cinco fases cerâmicas ${ }^{2}$. Trata-se de sítios com a presença de TPI, em camadas de até $40 \mathrm{~cm}$ de espessura, e que possuem construções em terra, compostas por valas circulares que chegam a $5 \mathrm{~m}$ de profundidade e $10 \mathrm{~m}$ de largura. Segundo os autores, a cerâmica dessas fases apresenta a pasta temperada com cauixi e com chamote. A decoração predominantemente foi feita por incisões, por vezes muito finas, ocorrendo poucos adornos e poucos tipos pintados. Foi registrado um enterramento em urna.

Esse cenário é muito semelhante ao que ocorre no Brasil, nos sítios onde foram descritas as fases Corumbiara e Pimenteiras (Miller 1983), com características muito próximas às das fases de Dougherty e Calandra (1984-85, 1985) (imagem 6). 


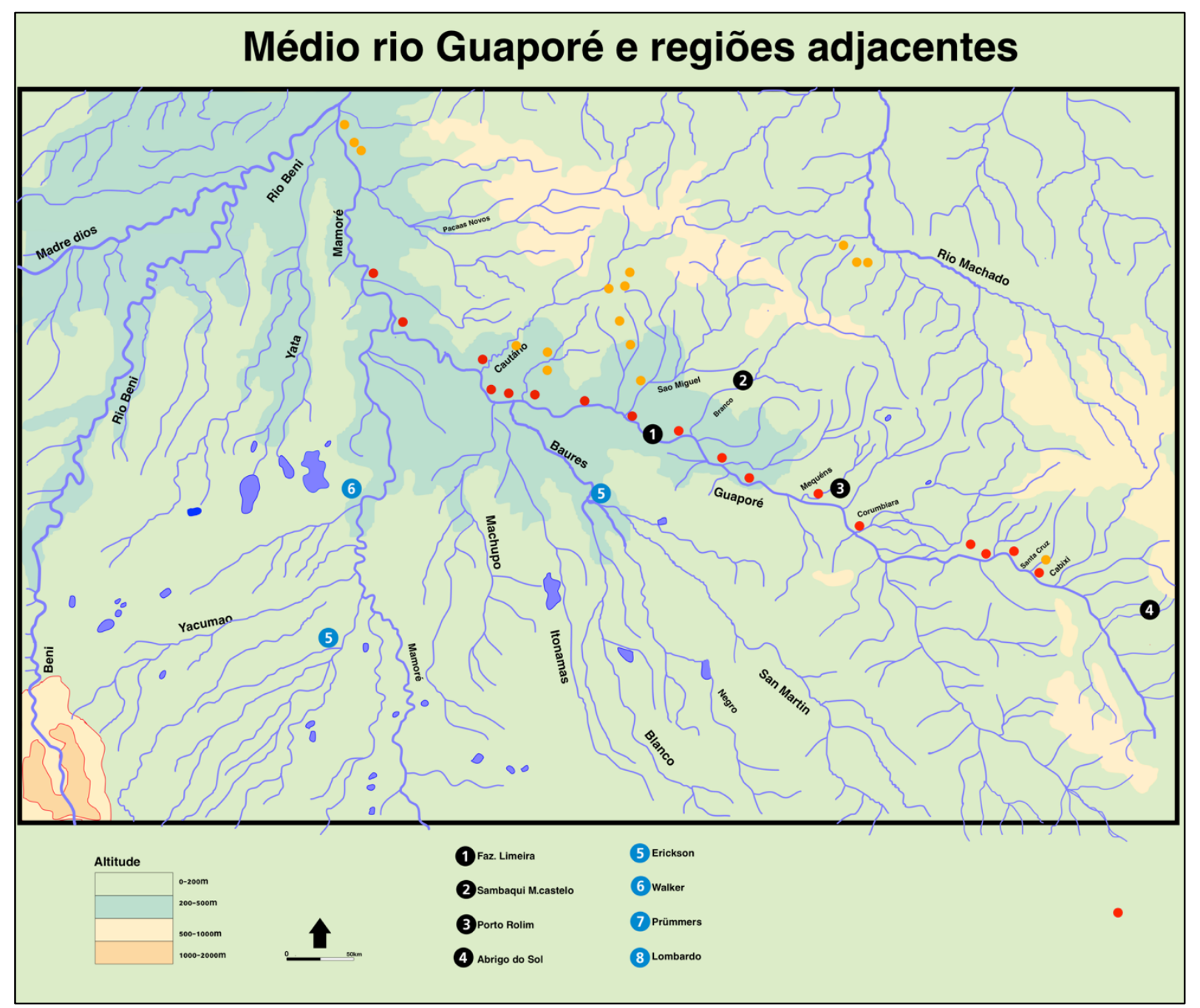

Imagem 6: sítio arqueológicos do médio rio Guaporé e áreas de pesquisa adjacentes. Em vermelho estão os sítios levantados por Miller (1983) e em laranja estão geoglifos (Trindade 2010)

Dentre os sítios arqueológicos conhecidos do lado brasileiro, existem alguns pontos diferenciados em meio ao contexto homogêneo identificado na maioria deles, devido à antiguidade e à persistência dos testemunhos de ocupação. O Abrigo do Sol (Miller, 1977, 1987) e o sambaqui Monte Castelo (Miller, 1992b, 2009b) - localizados, respectivamente, no alto e no médio curso do rio Guaporé - remontam a uma jornada de pelo menos 10.000 anos de história. No Abrigo do Sol ocorrem conjuntos líticos compostos principalmente por seixos lascados e lascas brutas, mas também foram encontradas lâminas lascadas e polidas. Datas publicadas por Miller situam cronologicamente as ocupações mais antigas daquele sítio entre 8700 e 4500 a. C. Já o Sambaqui Monte Castelo é testemunho de ocupações cujas datações calibradas recuam cerca de 9500 anos. A partir das camadas superiores do sambaqui $(>-2,3 \mathrm{~m})$ são encontrados os vestígios cerâmicos atribuídos à Fase Bacabal. Esta fase cerâmica possui datações calibradas entre 2576 anos a.C. e 1350 d.C. (Tabela 1 e Imagem 7). 


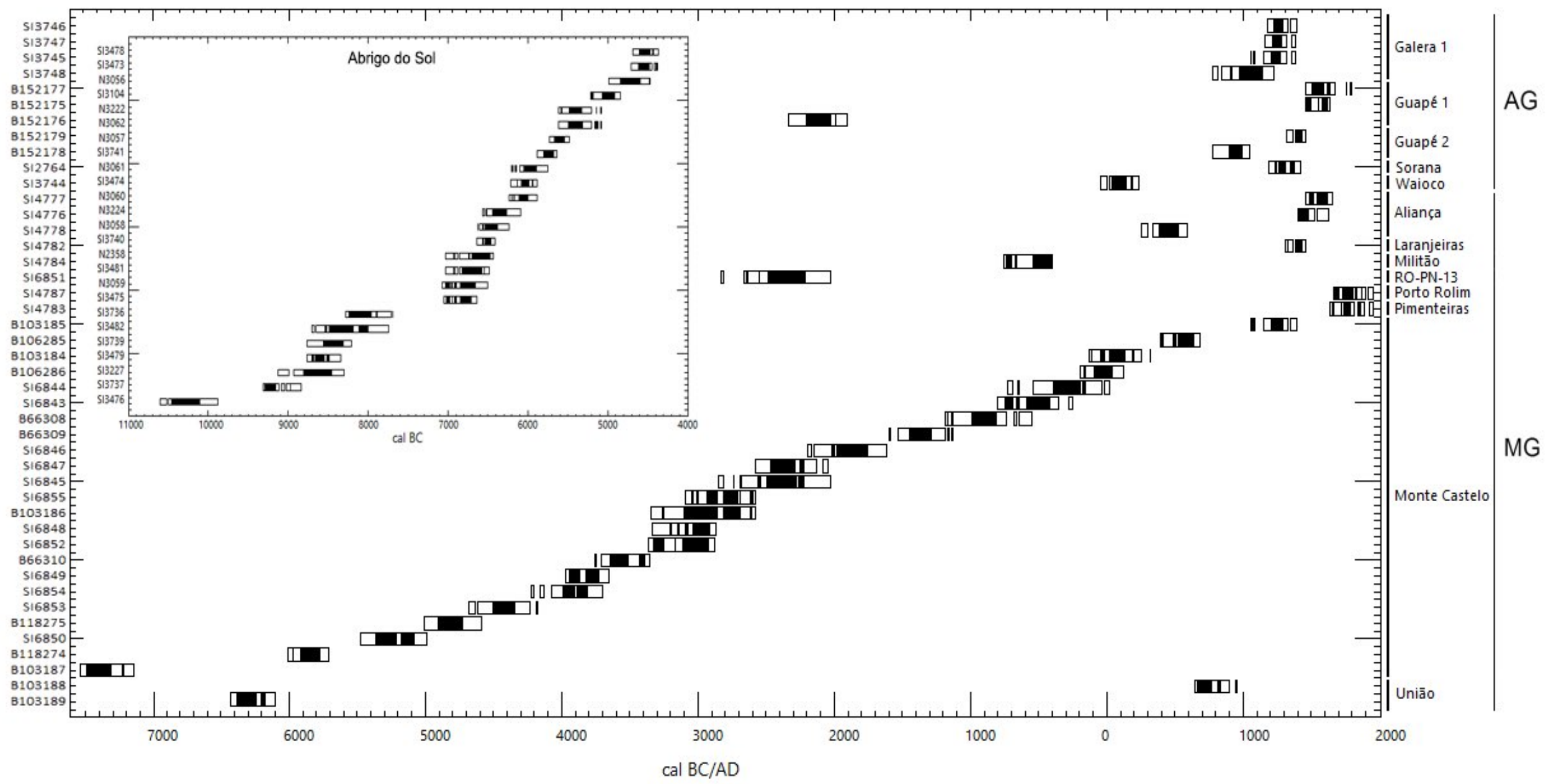

Imagem 7:Datações radiocarbônicas calibradas para os sitios do alto (AG) e médio (MG) rio Guaporé encontradas em Zimpel e Pugliese (2016). Abaixo a tabela completa com as informações sobre a cronologia da região. 


\begin{tabular}{|c|c|c|c|c|c|c|}
\hline Sítio & Sigla & ${ }^{14} \mathrm{C}$ & 1 - Sigma & 2 -Sigma & Fase & Fonte \\
\hline Abrigo do Sol & S13476 & $10405 \pm 100$ & cal BC $10502-9875 \mathrm{p}=0,9420$ & cal BC 10602 - $10516 \mathrm{p}=0,0579$ & Complexo Dourado & Miller (1977. 1987) \\
\hline Abrigo do Sol & 513737 & $9775 \pm 70$ & cal BC 9317 - $9113 \mathrm{p}=0,7395$ & cal BC $9023-8839 \mathrm{p}=0,2367$ & Complexo Dourado & Miller (1987) \\
\hline Abrigo do Sol & S13227 & $9410 \pm 120$ & cal BC $8925-8300 \mathrm{p}=0,911$ & cal BC $9126-8996 \mathrm{p}=0,0889$ & Complexo Dourado & Miller (1987) \\
\hline Abrigo do Sol & 513479 & $9370 \pm 70$ & cal BC $8760-8339 p=1$ & & Complexo Dourado & Miller (1977, 1987) \\
\hline Abrigo do Sol & 513739 & $9245 \pm 120$ & cal BC $8768-8211 p=1$ & & Complexo Dourado & Miller (1987) \\
\hline Abrigo do Sol & $\mathrm{S} 13482$ & $9115 \pm 160$ & cal BC $8653-7747 p=0,9906$ & cal BC $8703-8673 p=0,0093$ & Complexo Dourado & Miller (1977, 1987) \\
\hline Abrigo do Sol & S13736 & $8930+100$ & cal BC $8282-7712 \mathrm{p}=0,9970$ & cal BC 7691- $7686 \mathrm{p}=0,0029$ & Complexo Dourado & Miller (1987) \\
\hline Monte Castelo & B103187 & $8350 \pm 70$ & cal BC $7528-7141 \mathrm{p}=1$ & & Cupim & Miller (2009b) \\
\hline Abrigo do Sol & SI3475 & $7970 \pm 75$ & cal BC $7050-6642 p=1$ & & Complexo Dourado & Miller (1977, 1987) \\
\hline Abrigo do Sol & N3059 & $7950 \pm 115$ & $\mathrm{cal} B C 7076-6499 \mathrm{p}=1$ & & Complexo Dourado & Miller (1977 1987) \\
\hline Abrigo do Sol & $\mathrm{SI} 3481$ & $7875 \pm 85$ & cal BC $6859-6481 \mathrm{p}=0,8364$ & cal BC $7028-6930 p=0,1080$ & Complexo Dourado & Miller (1977 1987) \\
\hline Abrigo do Sol & N2358 & $7810 \pm 110$ & cal BC $6850-6429 p=0,9$ & cal BC 7028 - $6931 \mathrm{p}=0,06502$ & Complexo Dourado & Miller (1977) 1987$)$ \\
\hline Abrigo do Sol & SI3740 & $7695 \pm 65$ & cal BC $6636-6413 p=1$ & & Complexo Dourado & Miller $(1977,1987)$ \\
\hline Abrigo do Sol & N3058 & $7630 \pm 95$ & cal BC $6612-6240 p=0,9967$ & cal BC $6628-6623 p=0,0038$ & Complexo Dourado & Miller (1987) \\
\hline Abrigo do Sol & N3224 & $7530 \pm 105$ & cal BC $6510-6088 p=0,9914$ & cal BC $6561-6548 p=0,0064$ & Complexo Dourado & Miller (1987) \\
\hline União & B103189 & $7460 \pm 70$ & cal BC $6174-6100 p=0,094$ & cal BC $6430-6202 p=0,889481$ & Cupim & Miller (2009b) \\
\hline Abrigo do Sol & N3060 & $7220 \pm 85$ & cal BC 6231 - $5886 p=1$ & & Complexo Dourado & Miller (1987) \\
\hline Abrigo do Sol & S13474 & $7190 \pm 70$ & cal BC $6130-5888 p=0,8962$ & cal BC $6211-6131 p=0,1037$ & Complexo Dourado & Miller (1977) \\
\hline Abrigo do Sol & N3061 & $7130 \pm 85$ & cal BC $6102-5745 p=0,9912$ & cal BC $6201-6194 p=0,0036$ & Complexo Dourado & Miller (1987) \\
\hline Monte Castelo & B118274 & $7010 \pm 80$ & cal BC $6008-5712 \mathrm{p}=1$ & & Cupim & Miller (2009b) \\
\hline Abrigo do Sol & SI3741 & $6900 \pm 65$ & cal BC $5886-5634 p=1$ & & Complexo Dourado & Miller (1987) \\
\hline Abrigo do Sol & N3057 & $6730 \pm 85$ & cal BC $5730-5480 p=1$ & & Complexo Dourado & Miller (1987) \\
\hline Abrigo do Sol & N3062 & $6470 \pm 110$ & cal BC $5620-5206 \mathrm{p}=0,9863$ & Cal BC 5094- $5081 \mathrm{p}=0,0051$ & Complexo Dourado & Miller (1987) \\
\hline Abrizo do Sol & N3222 & $6460 \pm 100$ & cal BC $5570-5207 \mathrm{p}=0,9801$ & cal BC 5614- $5585 \mathrm{p}=0,0147$ & Complexo Dourado & Miller (1987) \\
\hline Monte Castelo & 516850 & $6316 \pm 105$ & cal BC $5474-4987 \mathrm{p}=1$ & & Sinimbu & Miller (2009b) \\
\hline Monte Castelo & B118275 & $5970+80$ & cal BC 5011- $4588 \mathrm{p}=1$ & & Sinimbu & Miller (2009b) \\
\hline Abrigo do Sol & N3056 & $5900+105$ & cal BC $4983-4484 \mathrm{p}=0.9932$ & cal BC $4478-4465 p=0.0067$ & Complexo Dourado & Miller (1977) \\
\hline Abrico do Sol & $\mathrm{s} \mid 3473$ & $5750+60$ & cal BC $4710-4444 \mathrm{p}=0.9660$ & cal BC $4421-4396 \mathrm{p}=0.024$ & Complexo Dourado & Miller (1987) \\
\hline Abrigo do Sol & $\$ 13478$ & $5730+60$ & cal BC 4688 - $4438 \mathrm{p}=0.9116$ & cal BC $4426-4370 \mathrm{p}=0.0883$ & Complexo Dourado & Miller (1977) \\
\hline Monte Castelo & 516853 & $5605 \pm 95$ & cal BC $4680-4635 \mathrm{p}=0,0193$ & $\mathrm{ccl}$ BC $4620-4232 \mathrm{p}=0,9774$ & Sinimbu & Miller (2009b) \\
\hline Monte Castelo & 516854 & $5165+80$ & cal BC $4072-3705 p=0,9703$ & cal BC $4162-4130 \mathrm{p}=0.0191$ & Sinimbu & Miller (2009b) \\
\hline Monte Castelo & S16849 & $5065 \pm 85$ & cal BC $3972-3650 p=1$ & & Sinimbu & Miller (2009b) \\
\hline Monte Castelo & B66310 & $4810 \pm 90$ & cal BC $3713-3354 \mathrm{p}=\mathrm{p}=0,9963$ & Cal BC 3749 - 3744 $p=p=0.0020$ & Sinimbu & Miller (2009b) \\
\hline Monte Castelo & S16852 & $4455 \pm 100$ & cal BC $3369-2877 p=1$ & & Sinimbu & Miller (2009b) \\
\hline Monte Castelo & $\$$ & $4395 \pm 70$ & cal BC $3139-2872 p=0,8481$ & cal BC $3193-3151 p=0,027$ & Sinimbu & Miller (2009b) \\
\hline Monte Castelo & B103186 & $4350+130$ & cal BC $3346-2616 \mathrm{p}=0,9817$ & $\mathrm{cal} \mathrm{BC} 2611-2581 \mathrm{p}=0,0182$ & Sinimbu & Miller (20009) \\
\hline Monte Castelo & S16855 & $\begin{array}{l}4350150 \\
4300 \pm 80\end{array}$ & cal BC 3038- $2617 \mathrm{p}=0,9499$ & $\mathrm{cal} \mathrm{BC} 3090-3043 \mathrm{p}=0,0356$ & Sinimbu & Miller (2009b) \\
\hline Monte Castelo & SI6845 & $3945 \pm 110$ & cal BC $2679-2033 p=0,9844$ & cal BC $2692-2689 p=0,0006$ & Bacabal & Miller (2009b) \\
\hline RO-PN-13 & S16851 & $3935 \pm 105$ & cal BC $2638-2033 p=0,9875$ & cal BC $2663-2646 p=0,0061$ & Bacabal & Miller (2009b) \\
\hline Monte Castelo & S16847 & $3920 \pm 85$ & cal BC $2576-2129 \mathrm{p}=0,9786$ & cal BC $2087-2048 p=0,0213$ & Bacabal & Miller (2009b) \\
\hline Guapé I & B152176 & $3760 \pm 70$ & cal BC $2341-1907 p=1$ & & Não definido & Wüst (2001) \\
\hline Monte Castelo & S16846 & $3580 \pm 105$ & cal BC $2146-1615 p=0,9885$ & cal BC $2196-2171 p=0,0114$ & Bacabal & Miller (2009b) \\
\hline Monte Castelo & B66309 & $3160 \pm 70$ & cal BC $1532-1192 p=0,9856$ & cal BC $1143-1131 p=0,0064$ & Bacabal & Miller (2009b) \\
\hline Monte Castelo & B66308 & $2760 \pm 100$ & cal BC $1131-745 p=0,9356$ & cal BC $644-551 p=0,0383$ & Bacabal & Miller (2009b) \\
\hline Monte Castelo & 516843 & $2475 \pm 105$ & cal BC $806-356 p=0,9888$ & cal BC $283-257 \mathrm{p}=0,0111$ & Bacabal & Miller (2009b) \\
\hline Militão & SI4784 & $2465 \pm 55$ & cal BC $672-400 \mathrm{p}=0,7865$ & cal BC $757-679 \mathrm{p}=0,2134$ & Corumbiara & Miller (1983) \\
\hline Monte Castelo & SI6844 & $2270 \pm 105$ & cal BC $543-42 p=0,97$ & cal BC 20 - AD $18 \mathrm{p}=0,0142$ & Bacabal & Miller (2009b) \\
\hline Monte Castelo & B106286 & $2060 \pm 60$ & cal BC 163 - AD $116 \mathrm{p}=0,9717$ & Cal BC $198-174 \mathrm{p}=0,0282$ & Bacabal & Miller (2009b) \\
\hline Monte Castelo & B103184 & $1970+80$ & cal BC 115 - AD $249 \mathrm{p}=0.9896$ & cal BC $135-118 \mathrm{p}=0.009$ & Bacabal & Miller (2009b) \\
\hline Waioco & $\begin{array}{l}513744 \\
\end{array}$ & $1945+55$ & cal AD $14-232 \mathrm{p}=0.9303$ & cal BC 46- $4 \mathrm{p}=0.0696$ & Apuaáé & Miller (1977) \\
\hline Alianca & S14778 & $1655+65$ & cal AD $330-590 \mathrm{p}=0.9412$ & cal AD $251-299 \mathrm{p}=0,0587$ & Corumbiara & Miller (1983) \\
\hline Monte Castelo & B106285 & $1540+80$ & cal AD 405- $675 \mathrm{p}=0.9924$ & cal AD $390-400 \mathrm{p}=0,0075$ & Bacabal & Miller (2009b) \\
\hline Monte Castelo & B103188 & $1330+70$ & cal AD 638 - AD $893 \mathrm{p}=0.9923$ & cal AD 939 - AD $950 \mathrm{p}=0.007633$ & Bacabal & Miller (2009b) \\
\hline Guapé II & B152178 & $1140 \pm 60$ & cal AD $772-1040 p=1$ & & Não definido & Wüst (2001) \\
\hline Galera 1 & S13748 & $1060 \pm 100$ & cal AD 839 - $1221 p=0,97401$ & cal AD $776-814 p=0,02598$ & Galera & Miller (1977) \\
\hline Galera 1 & $\$ 13745$ & $825+60$ & $\mathrm{cal} A \mathrm{AD} 1148-1316 \mathrm{p}=0,9613$ & cal AD $1355-1382 \mathrm{p}=0,0330$ & Galera & Miller (1977) \\
\hline Monte Castelo & B103185 & $810 \pm 70$ & cal AD $1147-1326 \mathrm{p}=0,8930$ & cal AD $1341-1390 \mathrm{p}=0,0936$ & Bacabal & Miller (2009b) \\
\hline Galera 1 & S13747 & $\begin{array}{l}810 \pm 60 \\
810+6\end{array}$ & cal AD $1156-1317 \mathrm{p}=0,9403$ & cal AD $1354-1383 \mathrm{p}=0,0596$ & $\begin{array}{l}\text { Galera } \\
\text { Gater }\end{array}$ & Miller (1977) \\
\hline Galera 1 & SI3746 & $\begin{array}{l}010000 \\
790060\end{array}$ & cal AD $1177-1323 \mathrm{p}=0,8752$ & cal AD $1346-1388 \mathrm{p}=0,1247$ & Galera & Miller (1977) \\
\hline Sorana & SI2764 & $744 \pm 85$ & cal AD $1178-1413 p=1$ & & Caju & Miller (1977) \\
\hline Laranjeiras & SI 14782 & $585 \pm 55$ & cal AD $1376-1451 \quad p=0,6821$ & cal AD $1303-1363 p=0,3178$ & Pimenteiras & Miller (1983) \\
\hline Guapé II & B152179 & $570 \pm 50$ & cal AD $1381-1455 p=0,8106$ & cal AD $1315-1357 \mathrm{p}=0,1893$ & Não definido & Wüst (2001) \\
\hline Aliança & S14776 & $490 \pm 60$ & cal AD 1393 - 1516 p=0,8232 & cal AD $1540-1625 \mathrm{p}=0,1767$ & Corumbiara & Miller (1983) \\
\hline Guapé I & B152175 & $400 \pm 50$ & cal AD $1450-1633 p=1$ & & Não definido & Wüst (2001) \\
\hline Aliança & S14777 & $380 \pm 60$ & cal AD $1450-1649 p=1$ & & Corumbiara & Miller (1983) \\
\hline Guapél & B152177 & $350 \pm 60$ & cal AD $1451-1669 p=0,9907$ & cal AD $1785-1794 p=0,0085$ & Não definido & Wüst (2001) \\
\hline Pimenteiras & SI4783 & $240 \pm 40$ & cal AD $1719-1813 p=0,5947$ & cal AD $1629-1711 p=0,3383$ & Pimenteiras & Miller (1983) \\
\hline Rolim de Moura & S14787 & $195 \pm 45$ & cal AD $1656-1818 p=0,6711$ & cal AD $1827-1894 p=0,2138$ & Corumbiara & Miller (1983) \\
\hline
\end{tabular}




\section{Capítulo 2 - A fase Bacabal e e sua relação com outros contextos}

\section{A fase Bacabal e os sambaquis na Amazônia}

Cronologicamente é possível estabelecer relações entre a cerâmica da fase Bacabal e os seus precedentes (fase Cupim e Sinimbu), no contexto de aparecimento das primeiras culturas ceramistas na América do Sul.

Podemos associar o surgimento destas evidências na região amazônica recuando até o oitavo milênio antes do presente e sendo encontrado em três contextos diferentes: 1) baixo Amazonas: os sambaquis fluviais Taperinha, no rio Tapajós, e os do Guará, na volta grande do rio Xingu. 2) Estuário e Áreas Costeiras: onde ocorrem dezenas de sítios conhecidos situados em ambientes lacustres atlânticos e nos baixos cursos dos rios que desembocam no litoral da Amazônia atlântica, nos estados do Pará e Maranhão e na Guiana, relacionados à Tradição Mina e à Fase Alaka. 3) Sudoeste Amazônico: onde no Pantanal do Guaporé e nos Llanos de Mojos são encontrados uma série de sítios construídos que vão desde o sítio Monte Castelo, no lado brasileiro da região, até outros sambaquis localizados em áreas ao sul e ao centro-norte do pampa boliviano (Pugliese et al. 2017). 


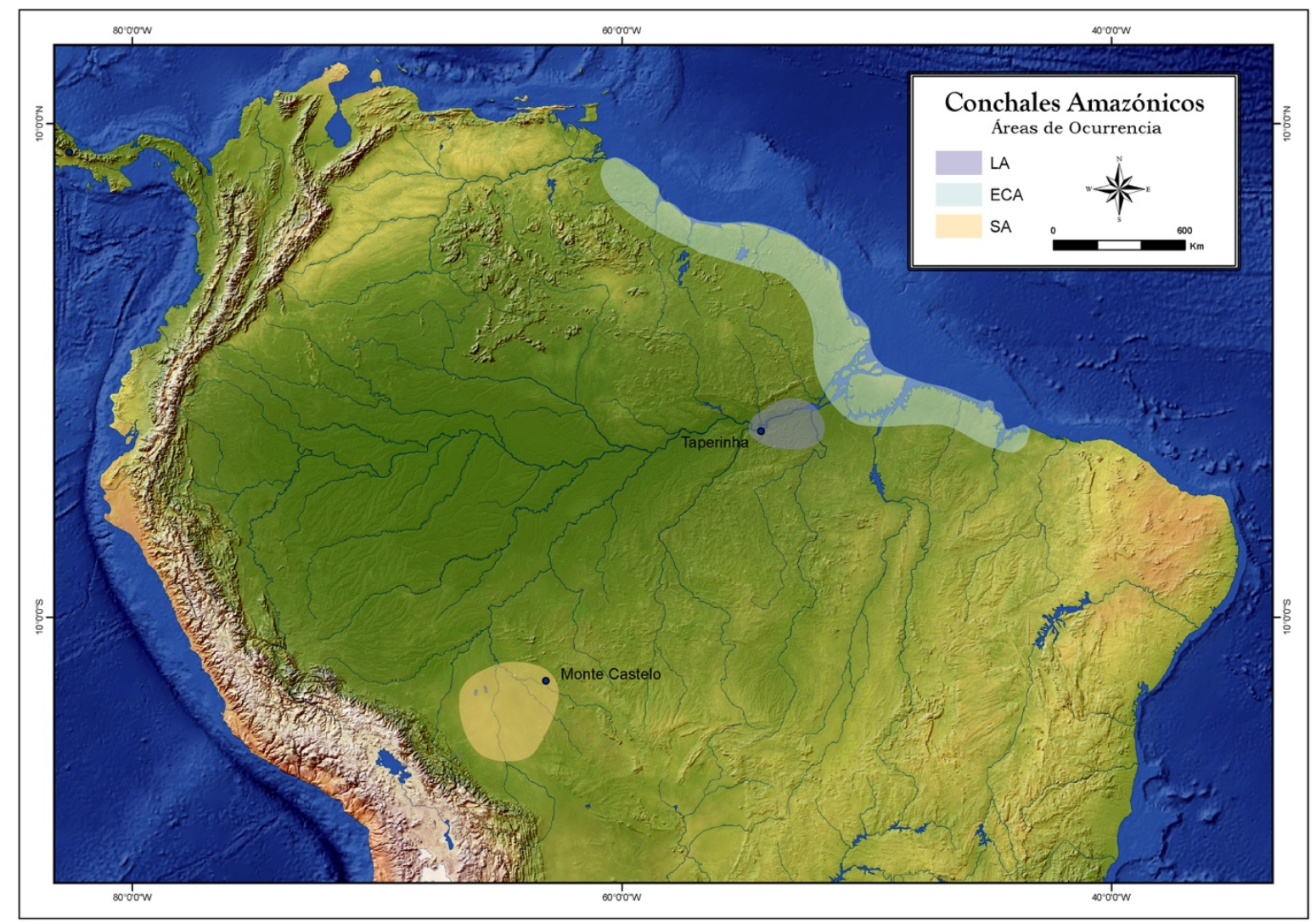

Imagem 8: localização dos sambaquis na Amazônia (Pugliese et al. 2017).

Portanto, em seu padrão de assentamento podemos encontrar elementos que podem ser considerando semelhantes com os primeiros complexos cerâmicos conhecidos, com sítios construídos de tipo sambaqui vinculado à exploração de recursos aquáticos descritos tanto para a fase Mina (Bandeira 2012), quanto para o baixo Xingu (Perota e Botelho 1993) e para o sítio Taperinha (Roosevelt 1991). Em todos esses locais, a tecnologia cerâmica apresenta um início repentino e um desaparecimento brusco, apresentando pouca ou nenhuma relação de continuidade com as culturas arqueológicas subsequentes encontradas naquelas regiões. A distância entre essas ocorrências de sambaquis na Amazônia é considerável, tendo um intervalo sem ocorrência conhecida entre os sítios do baixo amazonas e os sítios do sudoeste da bacia. Sendo assim, poderia ser esperado que esses sítios representassem processos de ocupação distintos, onde pouca, ou talvez nenhuma, correlação cultural pudesse ser estabelecida entre eles. Entretanto, as características compartilhadas pelos sítios, notadamente em relação à cronologia, aos padrões de assentamento e às inovações e persistências nos conjuntos artefactuais, estão se tornando cada vez mais evidentes (Pugliese et al. 2017; Pugliese 2017). 
Cerâmicas antigas da América do Sul encontradas em sambaqui são registradas na Amazônia e já bem estudadas (Evans e Meggers, 1960; Simões, 1981; Williams, 1981; Meggers, 1987; Roosevelt et al, 1991; Roosevelt, 1992; Hoopes, 1994; Meggers, 1997; Roosevelt, 1997; Williams, 1997). Entretanto, para Pugliese et al. (2017) o fato de que em todos os sambaquis já registrados na Amazônia são encontradas cerâmicas e que nesses sítios há este tipo de tecnologia desde as suas camadas mais profundas vem se tornando evidente quando se é feito uma análise regional mais ampla. A cerâmica que ocorre nos níveis iniciais sempre aparece ser produzida a partir de uma tecnologia simples, onde por volta do Holoceno médio incorpora inovações (Pugliese 2017). Isso pode ter ocorrido no Taperinha, no Monte Castelo, d nos sítios do Xingu e da costa do Pará e das Guianas, mas também ocorre nas cerâmicas antigas do litoral da Colômbia e do Equador (Meggers et al. 1965; Reichel-Dolmatoff 1985; Hoopes 1994; Oyuela-Caycedo 1996).

Se observarmos nestes sítios, para as camadas mais recentes, na grande maioria deles, existem variações na maneira de ocupação e aparecem de maneira concomitante tecnologias cerâmicas diferentes daquelas registradas em camadas subsequentes assim como diferentes maneiras de construir o aterro (Pugliese et al 2017). Algumas ocupações situadas no Holoceno tardio podem ter se estendido até o período da conquista, e outras atingem os dias atuais. Sob este ponto de vista, os sambaquis, assim como as cachoeiras, são lugares significativos (Zedeño e Bowser, 2009) onde a ocupação humana acontece por milênios.

$\mathrm{Na}$ cachoeira do Teotônio, no alto rio Madeira, por exemplo, é reportado o testemunho de ocupações que recuam ao Holoceno médio, tendo uma sequencia arqueológica bem diversificada (Almeida 2013; Almeida e Kater 2017), chamando a atenção a precocidade do aparecimento da TPI (Mongeló 2015) associadas a uma diversidade de plantas manejadas e cultivadas (Waitling et al. 2018). A diversidade e a abundância de informações arqueológicas encontradas seriam consequência de que estes lugares significativos também poderiam funcionar como entroncamentos para o encontro de diferentes populações indígenas que durante muito tempo utilizaram desta paisagem, seja para obtenção de recursos, seja para utilizar o local como moradia ou como local escolhido para o enterramento de seus parentes. (Almeida e Kater 2017). Diferentemente dos sambaquis, nas camadas mais antigas da cachoeira do Teotônio não são encontradas cerâmicas, mas um abundante registro arqueobotânicos associado a material lítico (Mongeló 2015) 
A primeira cerâmica associada a horizontes muito antigos foi encontrada no baixo Amazonas por Hartt (1885) em um braço rio Tapajós, próximo da cidade de Santarém-PA. Na década de 80 a arqueóloga Anna Roosevelt retoma as pesquisas legadas de Hartt e desenvolve pesquisas arqueológicas no sambaqui Taperinha, com o objetivo de testar a antiguidade dos vestígios cerâmicos lá encontrados pelo seu descobridor (Roosevelt 2009).

O Sítio está implantado sob uma porção de terra firme ao lado de uma planície inundável do rio Tapajós, cercada de lagos, baías e igapós. O sítio ocupa uma área de $50000 \mathrm{~m} 2$, e tem mais de 6 metros de altura (Roosevelt 1999). Os estratos onde Hartt havia indicado a possibilidade de uma cerâmica muito antiga foram datadas em 7000 anos AP, colocando em xeque as hipóteses difusionistas (Meggers 1986) sobre o início da produção cerâmica na Amazônia e na América do Sul (Roosevelt et. al. 1991; 1995; 1999; 2009).

A população que construiu o sambaqui Taperinha deve ter sido numerosa, e tinham a pesca e a coleta de mariscos uma atividade bastante exercida. A cerâmica de taperinha não é muito numerosa, 383 cacos foram identificados nos 48 estratos escavados, que continham também evidências de fauna, sementes, carvão, instrumentos feitos em osso e rocha (Roosevelt et al. 1991; 1999).

Nas camadas mais antigas, o antiplástico das cerâmicas é na maioria das vezes constituído de saibro (chamote?), mas também por areia e poucos fragmentos com conchas trituradas como antiplástico. (Roosevelt et al. 1991; 1999). As formas são de contorno simples e remetem às de tecomate, fechadas e abertas, com base arredondada e bordas apontadas, arredondadas e planas. Os poucos exemplares que possuem decoração apresentaram incisões, curvilíneas e retilíneas, possivelmente formando motivos que a autora a pesar da pouca representatividade da amostra obtida, remete ao horizonte zonados-hachurado (Roosevelt 1992; 1999). Nas escavações desses estratos foram encontrados instrumentos líticos na forma de percutores, lascas, moedores $e$ pedras para cozinhar. Ocorreram também artefatos como raspadores em osso de tartaruga e em conchas (Roosevelt et al. 1991).

Infelizmente, ademais da cerâmica, outras informações sobre o sítio arqueológico, como alguma inferência sobre o seu processo de formação são esparsas. Para Pugliese et al. (2017) as publicações sobre o sítio Taperinha (Roosevelt 1991; $1992 ; 1995 ; 1999 ; 2009)$ poderiam fornecer algumas destas informações, como o fato de que nas camadas mais antigas poderia se perceber o registro de um aterro inicial, 
anterior às atividades construtivas pelo acúmulo de conchas. $\mathrm{O}$ início da construção do sambaqui propriamente dito marca o momento em que um novo tipo de assentamento se instalou e onde passam a ser identificados contextos mais complexos, tanto habitacionais quanto fúnebres.

A autora também aponta que a ocupação do sítio persistiu por um longo período, após a formação das camadas onde foram encontradas as cerâmicas mais antigas. Sobreposta àquela ocupação, foi encontrada uma camada substancial de conchas relacionada ao Holoceno médio e, ainda, uma ocupação posterior, da Fase Santarém, cuja matriz é composta por terra preta de índio.

Mais ao sul, na região do baixo rio Xingu também são encontrados sambaquis (Perota e Botelho 1992). São poucas as informações sobre os sítios Guará I e II, que teriam sido erguidos há 3000 anos AP, e lá seria encontrada a cerâmica da fase Mina.

Há alguma informação sobre a presença da tradição Polícroma, fase Independência, ocorrendo nas camadas de TPI que recobririam estes sambaquis, a partir de cerca de 1000 AP (idem)

No litoral paraense, no final da década de 1960, Mário Ferreira Simões dá início ao Projeto Salgado, que pouco tempo depois já teria cadastrado dezenas de sambaquis e sítios a céu aberto com a presença desse material. A cerâmica encontrada foi denominada como Mina, e dividida nas fases: Mina, Uruá, Areão, Castália e Macapá. Estas fases não possuem uma diferença muito grande em relação ao fazer cerâmico, estão divididas principalmente pela localização e pelo tipo de sítio em que estão assentadas (Simões, 1981; Oliveira \& Silveira, 2016).

Os sítios da tradição Mina ocorrem em áreas estuarinas, em margens de rios e nos interiores de baías e ilhas, em muitos casos circundados por mangues. As dimensões variam, o sítio Porto da Mina possui dimensões de 40×30m tendo 4m de altura, enquanto o sítio Ponta das Pedras possui dimensões de 145x70m e 9m de altura. Mais para o interior ocorrem locais de cerâmica Mina onda não há sambaquis, como é o caso do sítio Jabuti, onde a cerâmica foi encontrada em meio a TPI.

A pasta da cerâmica Mina contém areia e concha triturada como antiplástico e a maioria dos fragmentos é alisado. O engobo vermelho é utilizado de maneira frequente, e a queima parece não atingir altas temperaturas. As formas são de contorno simples, com bases planas ou levemente arredondadas, lábio plano ou arredondado. Entre os tipos decorados ocorrem os escovados, os roletados e as incisões (Simões, 1981; Bandeira, 2008). 
Para o sambaqui do Bacanga, Maranhão, os dados indicam que a tradição Mina pode ser encontrada no local antes mesmo do início da construção do sambaqui, entre 6600 anos AP até 5800 anos AP, quando se percebe o início da antropização da área em que posteriormente iria se erguer o aterro. Tal evento é visto pela presença de vestígios relacionados a combustão compostas por blocos de laterita colocados de maneira circular e onde a presença de carvão, restos alimentares e cerâmica. Contudo, estes fragmento pré-sambaqui possuem uma diferença em relação a aquele encontrados nas camadas subsequentes. Estes não possuem o característico antiplástico de concha triturada, e apresentam paredes finas e bem queimadas, portanto, compartilhando poucos atributos tecnológicos e morfológicos que ocorrem na tradição Mina (Bandeira, 2011). A princípio parece que para este momento o testemunho deixado pelas pessoas indica uma população pouco dependente de recursos aquáticos e a presença do material cerâmico é menos densa comparado as camadas construídas subsequentes (Bandeira, 2009).

Posteriormente àquele período, as camadas datadas entre 4.800 até 1.830 anos AP do sambaqui do Bacanga atestam uma mudança tecnológica significativa, marcada pelo início da construção do sambaqui e pela ampliação da atividade produção de recursos aquáticos e da produção de artefatos em cerâmica. Além da cerâmica, vestígios ósseos de vertebrados terrestres e aquáticos, carvão, blocos de laterita, artefatos em rocha, osso, concha e adornos (Bandeira, 2011; 2015).

Nos sambaquis da tradição Mina ocorrem também enterramentos, onde os indivíduos são acompanhados frequentemente por material funerário, como conchas e adornos. São encontradas diversas estruturas de combustão e evidências de buracos de estaca (Simões, 1981; Bandeira, 2011).

A Tradição Mina é possui uma profundidade temporal expressiva (c. 5500-2000 anos AP) e correlatos muito similares ocorrem na Guiana (fase Alaka) e a fase Guará na volta grande do Xingu. Portanto, a cerâmica Mina não seria somente um evento longo que ocorre por milênios na costa do Pará e Maranhão, mas também um evento amplo, que atinge diferentes locais do Amazônia e do litoral (Simões, 1981; Williams, 1981; Hoopes, 1994; Bandeira, 2011).

Como nos casos anteriores, as camadas mais recentes dos sítios da tradição Mina também são sobrepostos em sua fase final por culturas provavelmente distintas daquelas que construíram os aterros. Em casos do Pará foram registradas cerâmicas relacionadas as nações afro-brasileiras (Simões 1981) e no Maranhão a presença de 
cerâmica Tupinambá, que persiste até o século XVIII quando sucumbidos pela conquista europeia.

Já no sudoeste da Amazônia temos duas áreas de ocorrência de sambaqui, o sambaqui Monte Castelo no Pantanal do Guaporé (Miller 2009, Pugliese et al. 2017), e os Llanos de Mojos na Bolívia (Lombardo et al. 2013).

O sambaqui Monte Castelo que possui 120 metros em seu eixo maior e cerca de 6,5 metros de altura. Trata-se de um sítio inserido na paisagem regional que vem sendo formado desde o Holoceno inicial, cuja estratigrafia contém registros relativamente contínuos da ocupação humana divididos em três períodos culturais - fase Cupim, Sinimbu e Bacabal (Miller 1983; 2009; Pugliese et al. 2017; Pugliese 2017).

A cerâmica ocorre desde as primeiras camadas até os últimos pacotes arqueológicos expostos na superfície atual. As primeiras amostras dessa tecnologia, da fase Cupim, são encontradas relacionadas a vestígios de fauna e carvão, em camadas onde não ocorria o acúmulo de conchas como material construtivo. Ocorre um volume considerável de pequenos blocos e placas de argila queimadas, encontrado principalmente na forma de fragmentos de uma espécie de artefatos, que não exclusivamente recipientes cerâmicos, talvez comparáveis às clayballs encontradas em sítios da cultura Maia na América Central e no final período arcaico final nos EUA. Raros exemplares demonstram características de paredes e bordas e estariam relacionados a produção de potes. $\mathrm{O}$ antiplástico é predominantemente composto por grãos de quartzo, e uma frequência muito pequena de cauxí. Não existem indícios suficientes para afirmar sobre o uso destes utensílios (Pugliese 2017).

Nas camadas construídas sob este primeiro aterro (fase Sinimbu), entre as cerâmicas encontradas parecer haver um maior investimento na elaboração de potes. A própria matriz sedimentar muda. Na fase Cupim as camadas identificadas remetem mais a construção de um aterro, enquanto na fase Sinimbu registrou-se uma intensa atividade doméstica partir de fogueiras e outros vestígios da produção e consumo de alimentos. Tornou-se comum a utilização de cauxí como antiplástico e a queima dos artefatos tinha um maior controle que na fase Cupim. Além do tempero de cauixi e areia, algumas peças possuem concha triturada como antiplástico (idem).

Após 3000 anos de produção cerâmica nas camadas que recobrem a fase Sinimbu começam a aparecer as cerâmicas da fase Bacabal, com um grau de sofisticação e elaboração muito além das fases anterior encontradas no sítio. Junto a elas ocorre uma grande quantidade de vestígios zooarqueológicos como: gastrópodes, 
quelônios, cervídeos, roedores, répteis, diversas espécies de peixes e algumas conchas de moluscos bivalves. Há indícios tanto do consumo destes animais, quanto ao uso de partes de seus esqueletos para preparação de utensílios como adornos, agulhas e anzóis. Os sepultamentos ocorrem em covas que são demarcadas com contornos ou aglomerações de conchas e contam com artefactual funerário associado. A pasta da cerâmica Bacabal possui como antiplástico uma grande quantidade de cauixi, misturado a areia fina, e somente alguns fragmentos nas camadas mais antigas apresentam também concha moída. A queima era muito mais controlada e na maioria das vezes em ambiente redutor. Os potes acordelados por vezes possuíam apliques e alças, alguns deles zoomorfos. O exciso e o inciso foram os mais recorrentes tipos de técnica plástica utilizados para a composição de motivos e não ocorrem tipos com decoração por motivos pintados. A decorações plásticas são fartamente encontradas, com os tipos mais frequentes caracterizados pela presença de motivos formados por excisões em ziguezague, criando áreas triangulares preenchidas por incisões finas paralelas - esse mesmo motivo também é encontrado em decorações elaboradas a partir de linhas incisas, onde as zonas formadas eram preenchidas por ponteados. As formas dos potes são simples, com bases planas a côncavas e bordas com contorno simples. O diâmetro das bordas e a espessura das paredes indicam que os potes teriam as mais variadas dimensões, desde pequenos potes para servir até grandes panelas de cozimento.

Em território boliviano, os sambaquis ocorrem em meio a ilhas de terra firme. Existem três sítios próximos a cidade de Trinidad cuja a locação, a matriz estratigráfica e as evidências que ocorrem remetem muito ao caso do Monte Castelo. São sítios menores que podem atingir $2 \mathrm{~m}$ de altura, e se destacam na paisagem em meio à pampa. Por volta de 10000 anos AP é que se inicia a construção do sambaqui (Lombardo, et al, 2013). Como bem observado em Pugliese et al. (2017) desde o médio Holoceno, percebe-se um maior investimento na construção e no acumulo de conchas, assim como ocorrem novas tecnológicas, como artefatos em cerâmica. Além disso, as cerâmicas de lá foram encontradas a partir de 5000 anos AP e são muito semelhantes com aquelas da fase Cupim e Sinimbu.

Contudo, o testemunho do período construtivo do sítio se encerra por volta 4000 anos AP, e diferentemente de outros sambaquis da Amazônia, ocorre um hiato na informação arqueológica que volta a ocorrer 3000 anos depois, representada por vestígios associados a povos construtores de terra (Erickson 1995; Betancourt 2009) que ocupam a região posteriormente. 


\section{A fase Bacabal e as cerâmicas antigas}

A fase Bacabal é uma cultura arqueológica com datações radiocarbônicas que recuam até 4200 anos AP e se assemelha em alguns aspectos com os primeiros complexos cerâmicos conhecidos já conhecidos, mas estas comparações ficariam restritas em relação ao padrão de assentamento vinculado à exploração de recursos aquáticos descrito tanto para a fase Mina, quanto para o baixo Xingu e para o sítio Taperinha.

Entretanto as cerâmicas destes complexos iniciais apresentam notáveis diferenças que podem ser elencadas. Primeiro, nos três pontos em que ocorrem estas cerâmicas antigas o antiplástico utilizado para o fabrico das pastas foi diferente. Ao Norte, em Taperinha, temos areia e saibro, na tradição Mina e fase Alaka a concha triturada, e ao sul, em Monte Castelo tem-se areia fina e cauxí. Temos também diferenças nos tratamentos de superfície e nas decorações, praticamente ausentes na fase Mina e muito elaborados na fase Bacabal.

Tendo as culturas arqueológicas um horizonte cronológico semelhante, surgindo por volta do Holoceno médio, estas evidências poderiam apontar pelo menos duas tradições cerâmicas antigas distintas na Amazônia, uma mais local, duradoura e com pouca mudança tecnológica durante o tempo, que é representada pelos sambaquis e sítios da tradição Mina, e outra, mais decorada, que compartilha elementos com os complexos cerâmicas iniciais da América do Sul (Meggers 1997). Estas diferenças poderiam ajudar a explicar a ocorrência de cerâmicas antigas tão distintas no baixo amazonas, como as da fase Mina e as dos sítios do horizonte Zonado-Hachurado, como a fase Ananatuba, que tem datas que recuam a 3500 anos AP (Simões 1969; Meggers e Danon 1988).

O sambaqui do Jauari (Hilbert 1968) não possui datas, mas sua cerâmica foi interpretada. Lá tem-se dois tipos distintos de tecnologia, uma com tempero composto por areia e concha triturada e com formas simples (Fase Castália) que poderia ser comparado a tradição Mina, enquanto a fase Jauarí possui tempero de cauxí e padrões decorativos na cerâmica que remetem ao horizonte Zonado-Hachurado.

A interpretação feita por Miller $(2009,2013)$ sobre a fase Bacabal também a remete ao horizonte Zonado-Hachurado, pois esta teria relação a um processo de 
difusão cultural a partir dos sítios da fase Valdívia, no Equador, hipótese defendida por Meggers (1997).

O horizonte Zonado-Hachurado é bastante diversificado, ocorre em diferentes locais no norte da América do Sul, e em diferentes épocas. Possui variações regionais, contudo determinadas características podem ser elencadas. A pasta é composta de cauxí e areia, em alguns casos ocorrem de maneira concomitante o chamote e/ou a concha triturada. A maioria das vasilhas possuem bordas com o contorno simples, mas ocorrem formas complexas, além de estatuetas, cachimbos e assadores. A decoração é feita com padrões geométricos a partir de incisões e excisões na parede e junto as bordas. Ocorrem alças e asas inciso-modeladas com motivos zoomórficos e também engobo vermelho e branco.

Se a partir de nossos dados fossemos aproximar a fase Bacabal entre as cerâmicas mais antigas da Amazônia poderíamos afirmar que ela tem mais semelhanças com o horizonte Zonado-Hachurado do que com a cerâmica da tradição Mina e em Taperinha. Assim como no sambaqui do Jauarí (Hilbert 1968), em Monte Castelo também são encontrados dois contextos cerâmicos bem distintos, um mais simplificado sobreposto por outro com com cerâmica elaborada e com farta decoração. Entretanto, no caso do baixo amazonas, a mudança no componente cerâmico é datada, e não é possível saber se esta mudança ocorre de maneira abrupta, como caso do o Guaporé onde tem-se uma continuidade cronológica entre as cerâmicas mais antigas e aquelas mais elaboradas que ocorrem na fase Bacabal, o se há um hiato, como ocorre no caso dos Llanos de Mojos, descritos por Lombardo et al. (2013).

Nesse sentido, nossos dados apontam para uma situação distinta aos cenários descritos para o baixo Amazonas, onde os conjuntos cerâmicos antigos não têm relação com a cerâmica que ocorre na área posteriormente.

Além de não haver uma diferença cronológica significativa entre as camadas onde predominam fragmentos cerâmicos mais simples tecnologicamente e as camadas com aqueles mais elaborados, há a hipótese de que existe uma relação histórica entre a fase Bacabal e outras culturas arqueológicas que vêm a ocorrer nas porções de terra firme de ambas as margens durante toda extensão do rio Guaporé e em rios que compõem a sua bacia localizados nos Llanos de Mojos (Zimpel e Pugliese 2016).

É interessante perceber que, além de haver sítios de significativa antiguidade localizados no alto e médio curso do rio Guaporé, em Rondônia está sendo construída uma sequência arqueológica onde em dois locais diferente, porém próximos 
geograficamente, é encontrada a produção de artefatos cerâmicos há mais de 4000 anos. Além da fase Bacabal, outro conjunto cerâmico, situado em Rondônia e Mato Grosso - mais especificamente entre os rios Machado e o Aripuanã - apresenta as datações mais antigas conhecidas para a cerâmica da tradição Tupiguarani. São dois conjuntos distintos que possuem datas que recuam mais de cinco milênios e que apresentam significativa continuidade e estabilidade na sequência de ocupação registrada arqueologicamente (Zimpel, 2009; Miller 2009b). Nestas cerâmicas até hoje não foram encontrados motivos decorativos semelhantes a aqueles que são utilizados para a aproximação histórica das fases que são subsequentes a Bacabal.

\section{Hipóteses de Miller (1992, 2009, 2013) sobre a difusão de estilos cerâmicos no Guaporé e as relações com a cultura Valdívia (Equador)}

\section{Relações entre Bacabal e Valdívia}

A hipótese sobre a relação entre a cultura Valdívia e a fase Bacabal sustentada por Miller é encontrada de maneira breve em 1992 e melhor explicada em (2009b), sendo complementada em Miller (2013). Para o autor, por ser a cultura ceramista mais antiga do sudoeste da Amazônia e esta não ter ligação a outro complexo cerâmico próximo a cerâmica Bacabal provavelmente teria origens na Cultura Valdívia pois dois aspectos relacionado a tipos cerâmicos decorados, relacionados aos tipos Bacabal Inciso e Monte Exciso assemelham-se aos de Valdívia Inciso Línea Fina, motivos 3-6 e Valdívia Inciso Línea Larga, motivo 4. As similaridades incluem bandas em ziguezague definindo áreas triangulares preenchidas com linhas cruzadas finas (substituídas por incisões paralelas na cerâmica Bacabal), incisões retas paralelas sobre toda a superfície e bandas e zonas preenchidas com linhas incisas cruzadas (Imagem 9 e 10).

$$
\begin{aligned}
& \text { "O único complexo cerâmico sul-americano que é mais } \\
& \text { antigo que Bacabal e tem em comum algumas das } \\
& \text { mesmas decorações é a fase Valdívia na costa do } \\
& \text { Equador” (Miller, 2009, p.114) }
\end{aligned}
$$

Na classificação de Meggers, et. al. (1965), estes motivos estariam ligados ao período inicial da cultura Valdívia, entre 5.600 e 4.300 a.P. 


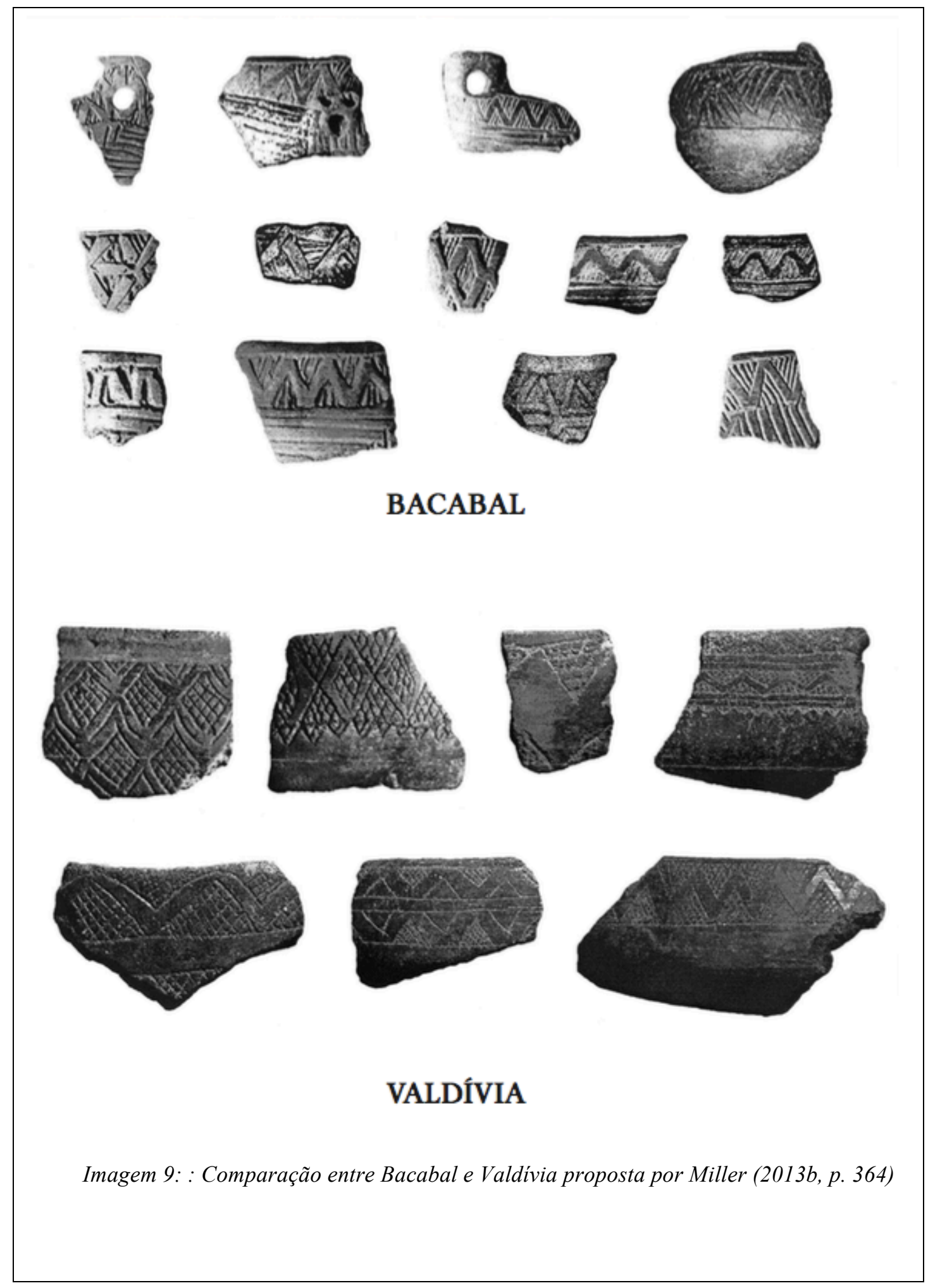




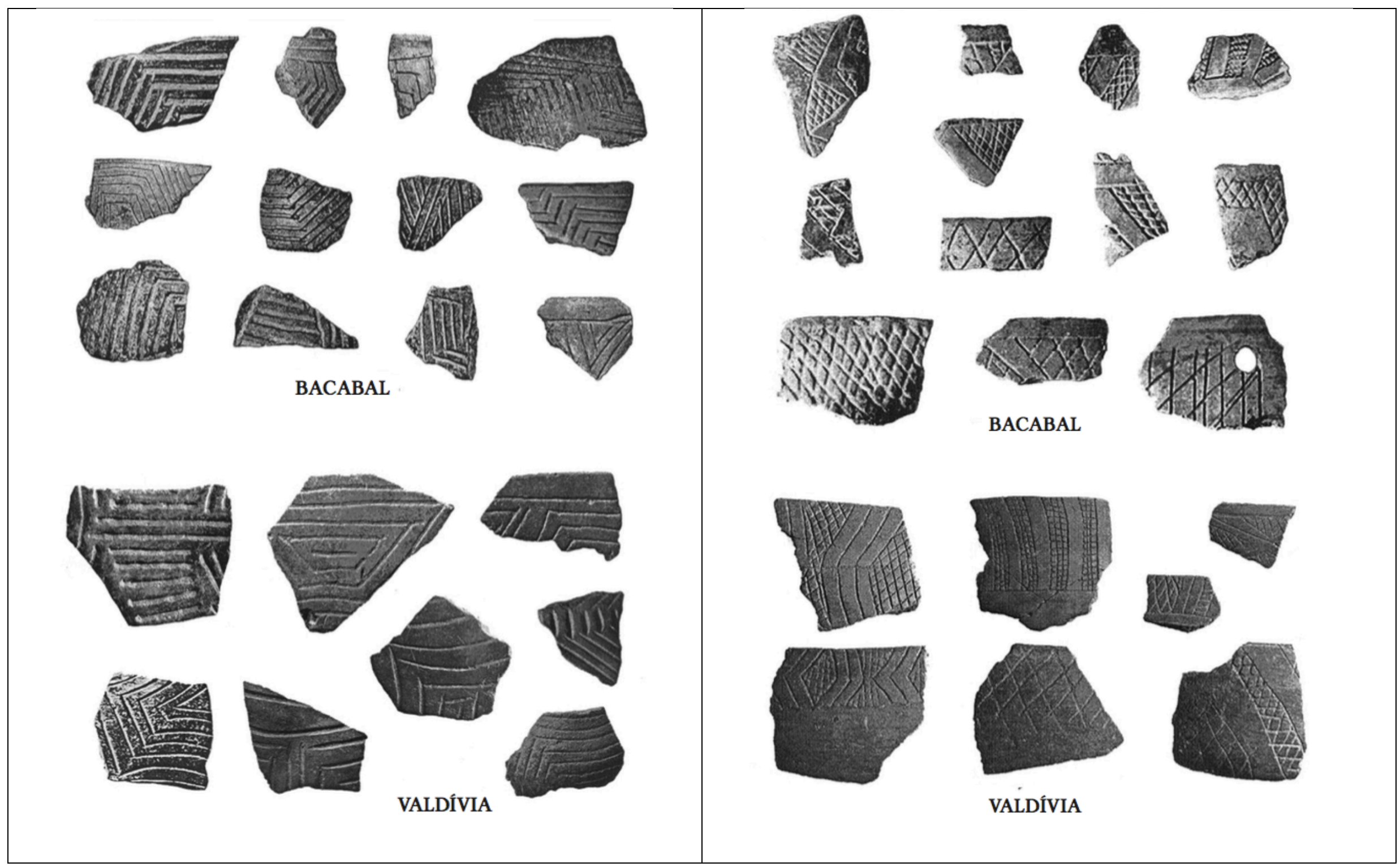

Imagem 10: Comparação entre motivos da Fase Bacabal e Cultura Valdivia proposta por Miller (2013) 
Essa hipótese não gerou muita discussão entre a comunidade, talvez pela falta de fundamentação empírica, sobre como tal processo possa ter sido efetivado.

\section{(...)É esperado para o meio ambiente intermediário entre} as fases Valdivia e Bacabal, num futuro incremento de pesquisas de campo, o encontro de outra(s) fase(s) associada(s) com datas intermediárias. (...)Embora as similaridades entre Bacabal e Valdivia A impliquem em um parentesco, por ora, ao longo do espaço intermediário (> $3.000 \mathrm{~km})$, em nenhum dos poucos sítios conhecidos foi encontrado decoração similar e antiga. Antecedentes da decoração Bacabal Inciso e Ponteado, que também aparece plenamente desenvolvida no periodo A de Bacabal, tampouco foram encontrados até agora em lugar algum da América do Sul. (...)

Talvez tal fragilidade no modelo arqueológico pouco ortodoxo possa ter gerado a discreta presença da cerâmica Bacabal na literatura nos últimos anos onde a fase continua de fora das discussões sobre as cerâmicas iniciais na Amazônia e na América.

$\mathrm{Na}$ busca de compreender mais a fundo e testar hipótese sobre a possibilidade de relação entre Valdívia e Bacabal, torna-se necessário remete-se ao conhecimento disponível sobre a cultura Valdívia. A argumentação feita por Miller é feita a partir de argumentos centrais da interpretação de Meggers et. al. (1965). Como veremos adiante, o conhecimento acerca a cultura Valdívia é vasto e diversificado, e estão disponíveis outras hipóteses e informações que se tornaram vigentes e que nos ajudam a testar as hipóteses.

\section{Cultura Valdivia}

Sítios arqueológicos da cultura Valdívia podem ser localizados em locais das áreas baixas do oeste e no litoral do Equador, durante o denominado período formativo inicial. É elencada como uma cultura arqueológica que representa uma das primeiras evidências de modo de vida sedentário nas américas (4400-1450 cal AP) (Zeidler, 2008)

Foi definida por Estrada $(1956,1958)$ e estudada subsequentemente por Meggers, Evans e Estrada (1965), onde são propostas as primeiras tentativas de periodização da longa sequência cronológica encontradas nos sítios. 
Meggers, et al (1985) descreve abundante cerâmica, lascas, artefatos líticos lascados, material zooarqueológico de fauna terrestre e marinha, em um local de estratigrafia complexa onde não seria possível identificar camadas com uma divisão muita clara. A partir de datações radiocarbônicas a cultura Valdívia foi separada em quatro períodos cerâmicos (A-D) criados a partir de determinadas mudanças que ocorrem com a cerâmica no tempo.

No momento de sua publicação, a fase A da cultura Valdívia era considerada a cerâmica mais antiga da América, e dada sua considerável sofisticação, tal evidência gera debate e acaba gerando hipóteses que até hoje são controversas. Talvez a mais controversa de todas as ideias seria a proposta da origem da cerâmica Valdívia como fruto de uma migração transpacífica, sendo resultado da difusão da tradição Jomón, representada por população do período médio (ca. 5500-4500 AP) da região de Kyushu no Japão, Meggers (1997).

Tal argumento, baseado na similaridade encontrada na cerâmica, foi questionado quando no início dos anos 70, Hill (1971) propõe uma cronologia alternativa ao modelo de Meggers, e que atualmente ainda é a mais aceita para a explicação sobre a cronologia da cultura cerâmica.

A sequência de oito fases cerâmicas feitas por Hill $(1972 ; 1974)$ a partir da comparação de atributos estilísticos, morfológicos, tecnológicos e sobre os padrões decorativos, que abre um novo momento em relação ao que sabemos sobre Valdívia, e ainda hoje é utilizada como parâmetro comparativo (Imagem 10, 11. A utilização e o teste do modelo de Hill fez com que novas premissas pudessem ser avaliadas em relação ao padrão de assentamento regional, a organização dos espaços intra-sítio e as diferenças entres as fases cerâmicas (Marcos 1988; 2003; 2005; Marcos et al. 1998; Zeidler 1984; 1991). 


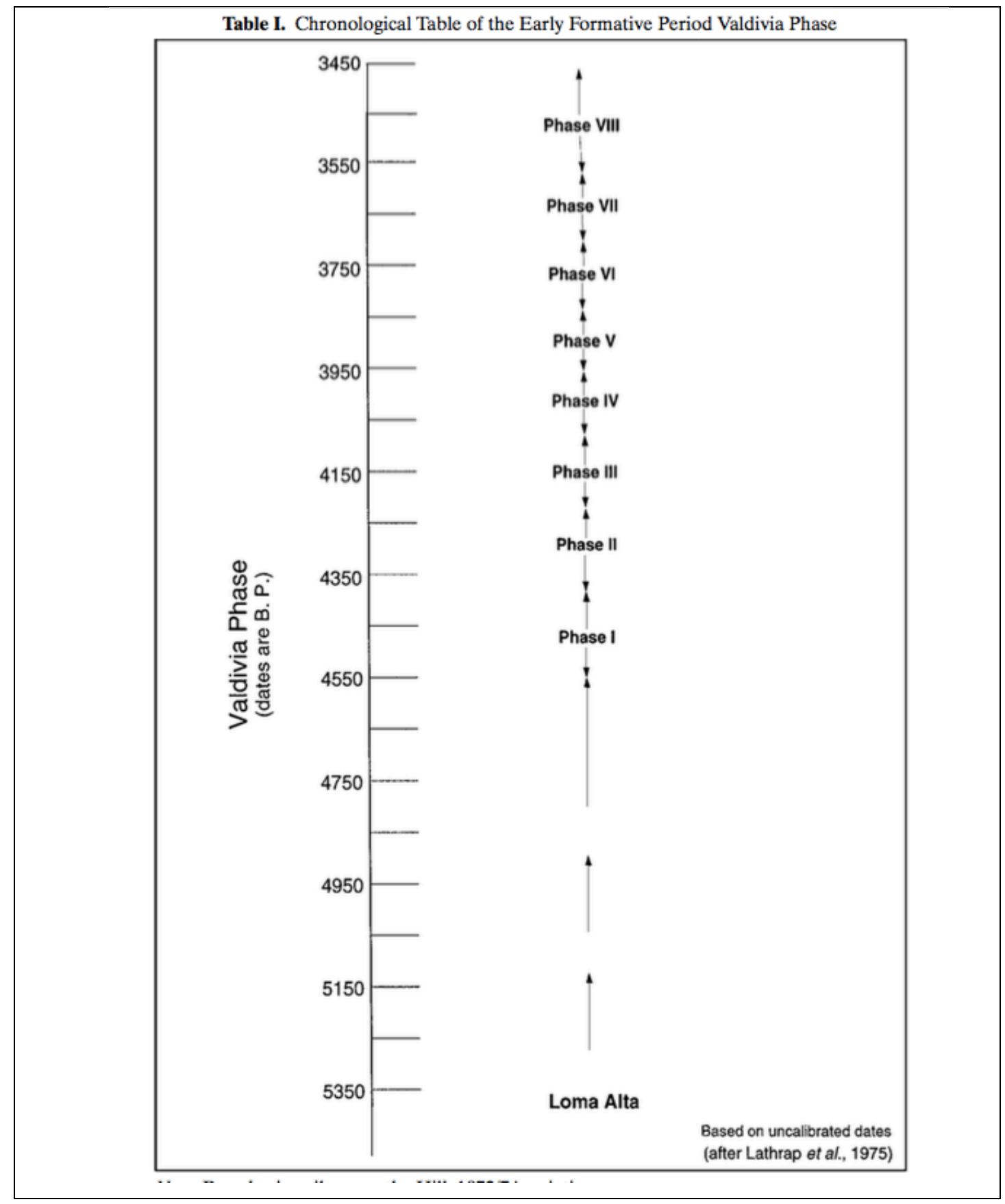




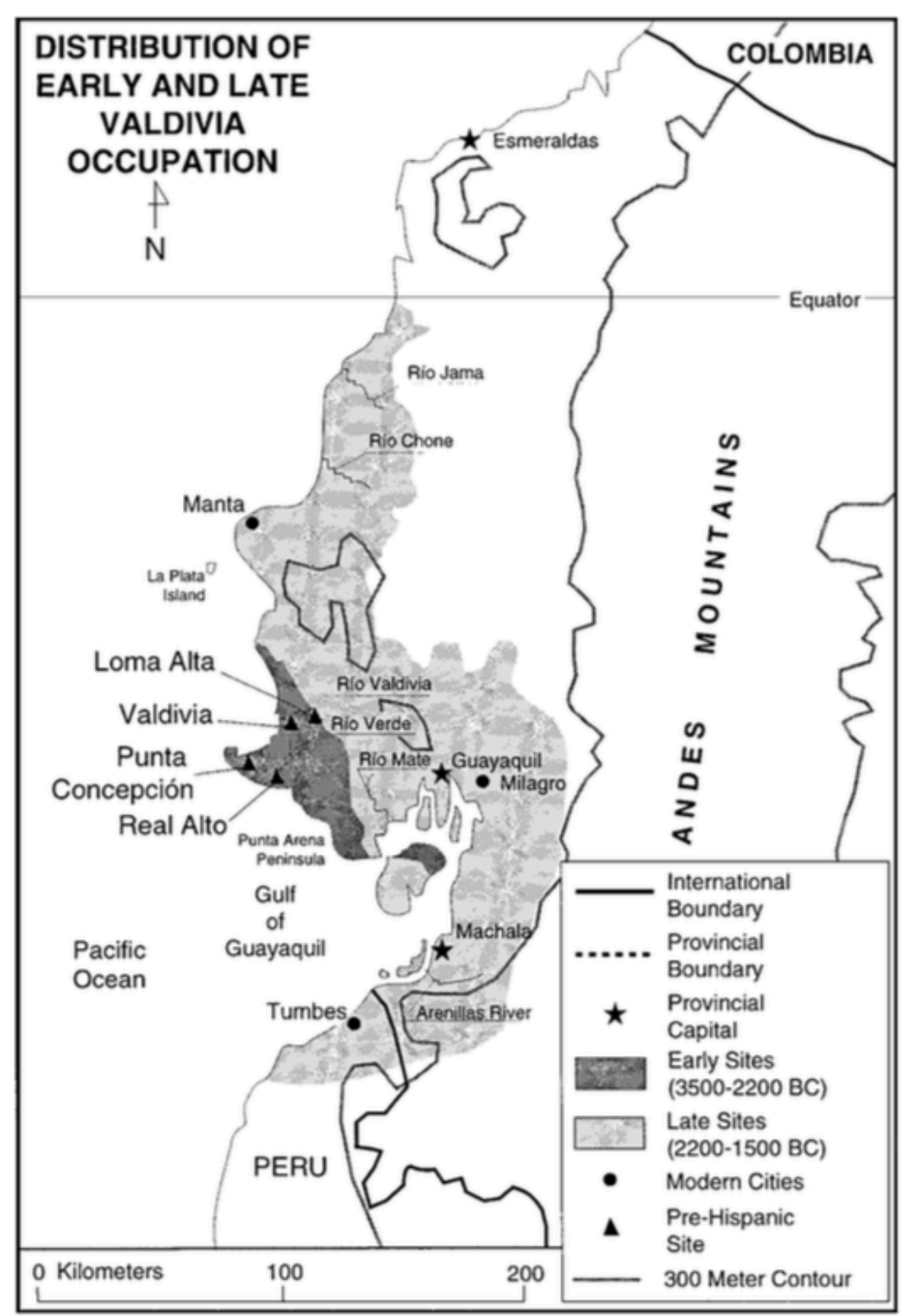

Imagem 11: Distribuição dos sítios Valdivia por período, apud Staller (2003)

Para Zeidler (2003) atualmente a fase 1 está datada em 6400-5300 AP e esta estaria ligada ao final do período inicial da cerâmica Jomón (7300-5500 AP), e não ao período médio como a proposta encontrada em Meggers et al (1965). Na avaliação do autor, a localização de um dos sítios centrais na interpretação de Meggers (Sítio G-3), e sua óbvia vinculação a exploração de recursos marítimos levaram os autores a propor que Valdívia representaria uma cultura marítima semi-sedentária, com pescadorescoletores vivendo de maneira igualitária, tendo a agricultura como atividade secundária. 
Com o decorrer dos anos novos sítios foram pesquisados como San Pablo, Real Alto e Salando (Litoral) e Loma Alta, Colimes, San Lorenzo del Mate (terra firme), que faz com que se leve a discutir a interpretação anteriormente estabelecida em relação aos vestígios ligados a cultura Valdívia, incluindo o seu padrão de subsistência e organização social (imagem 12).

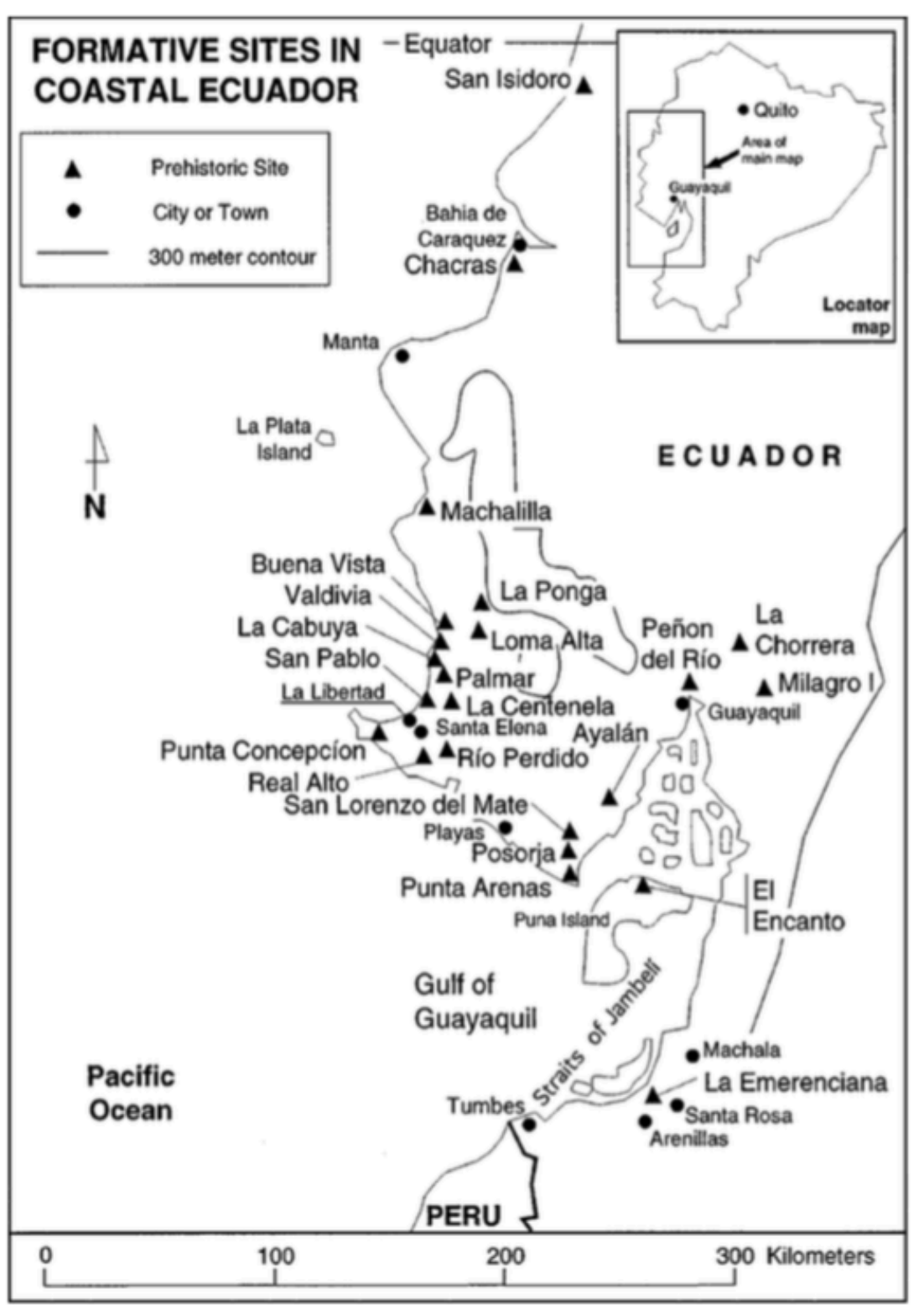

Imagem 12: Localização de sítios citados na tese, apud Staller (2003),

Para Lathrap (1970 [2010], p.101) a cultura Valdívia é uma cultura onde estão presente elementos de floresta tropical, e seus assentamentos localizados no interior com características agrícolas, e já na década de 70, previa evidencias para a presença, do milho, por exemplo, que naquela época só era identificado no final da sequencia. 
A subsistência relacionada a cultura Valdívia pode indicar desde a sequencia inicial, uma economia mista, que incluía a caça de animais, a coleta de plantas e recursos marinhos junto a uma gama variada de cultivares como milho, feijão, mandioca, algodão, pimenta e abóbora. Hoje sabe-se que a maioria destes cultivares têm a Amazônia como provável centro de origem (McMichel et al. 2016; Clement et al. 2016; Watling et al. 2018). O milho está presente em sítios desta cultura desde o seu período inicial e no sítio Real Alto foram escavadas evidências de milho duro e milho mole que remontam 6000 anos AP (Pearsall, 2003; Perry et al. 2007)

Atualmente a cerâmica Valdívia é uma das mais precoces ocorrências de cerâmica da América, e o debate contemporâneo ainda persiste, e uma série de argumentos são defendidos sobre a origem da cerâmica, se é possível relacionar esta com outros conjuntos, sobre o padrão de subsistência, agricultura e domesticação de cultivares (Estrada 1956; Meggers et al. 1965; Hill 1972; Lathrap 1970, 1971; Zeidler 2003; Meggers 1987; Roosevelt 1991; Damp e Vargas, 1995)

Zeidler (2006) define a cultura Valdívia como resultado da história de uma sociedade dinâmica, sedentária de horticultores caracterizada por progressivo crescimento populacional e por aumentar com o tempo as desigualdades sociais e consequentemente diferenças de status entre segmentos.

As cerâmicas consideradas iniciais na cultura Valdívia são as fases I e II 53004300 AP. Na Fase I encontrada nos sítios Real Alto e Loma alta, ocorrem fragmentos de cerâmica com paredes simples, engobo vermelho, tigelas e vasos em sua maior com formatos introvertido, e extrovertido, combinado com incisões em motivos geométricos (Imagem 13 e 14). 


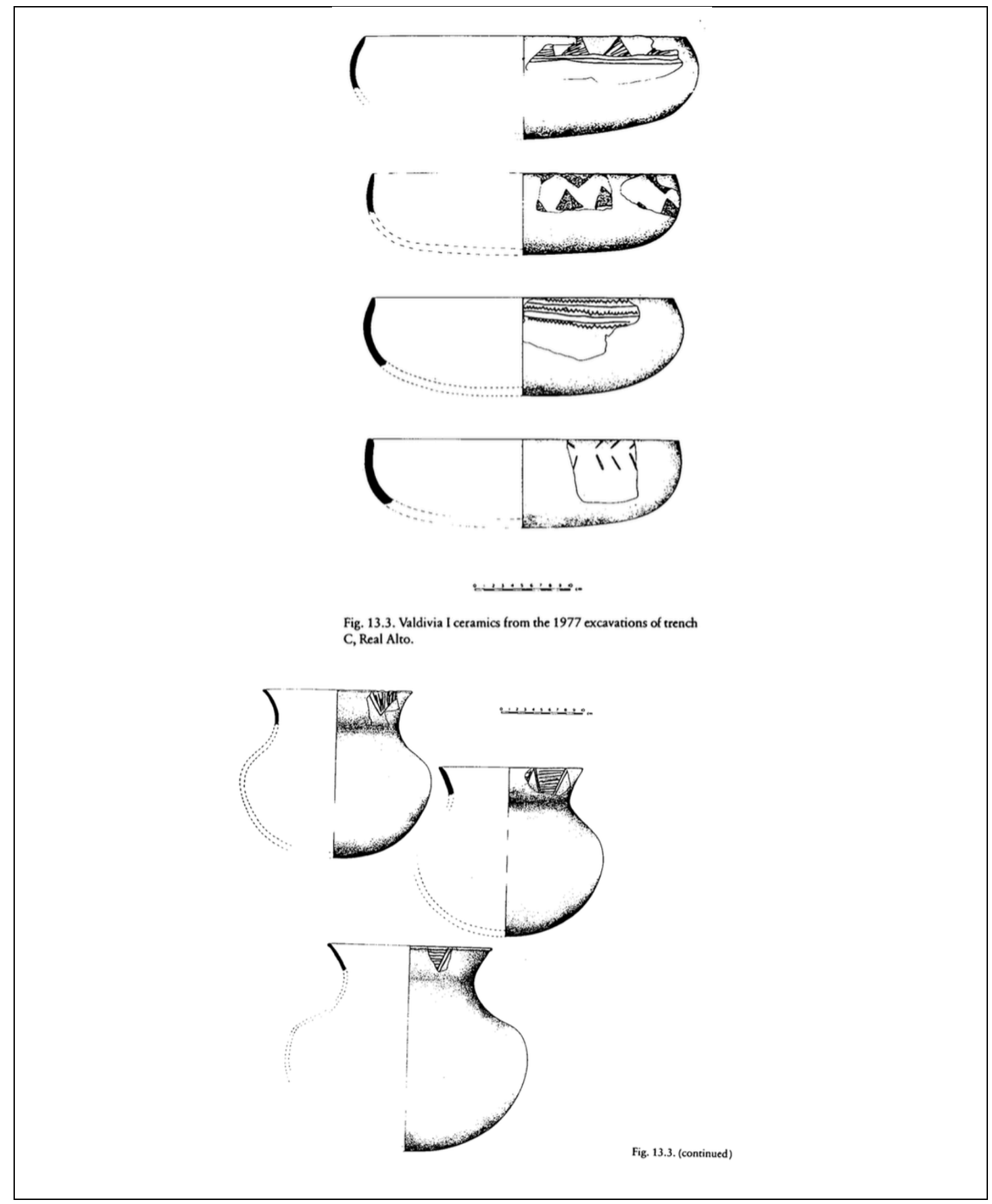

Imagem 13: Morfologia e aspectos decorativos dos potes em Valdivia I e II, Damp e Vargas, (1995) 


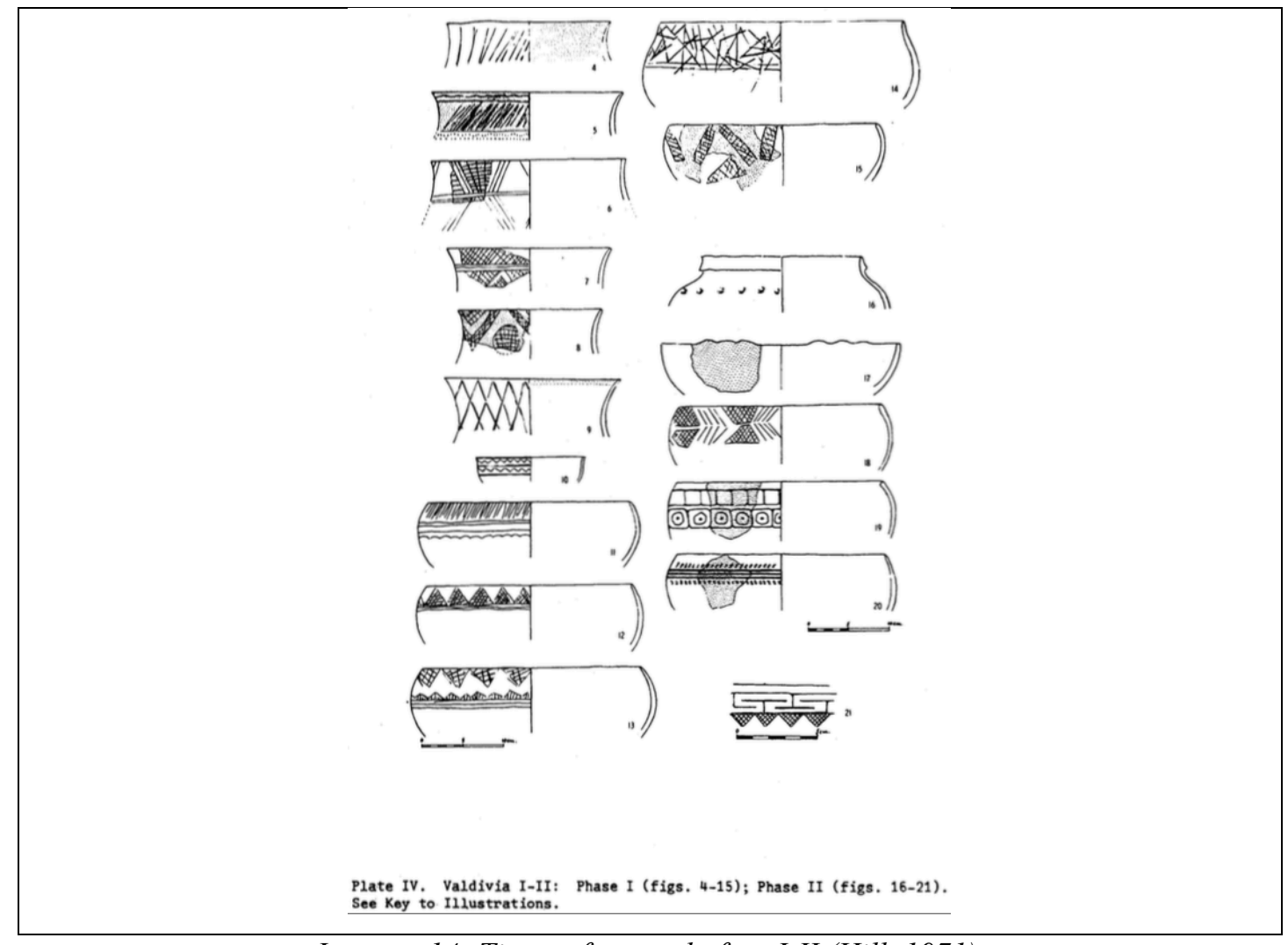

Imagem 14: Tipos e formas da fase I-II (Hill, 1971).

A Fase II é caracterizada pela persistência de motivos da Fase I e pelo início da ocorrência de tipos morfológicos mais elaborados, como grandes potes para cozinhar, em formatos introvertidos e decorados com incisões largas, além também do início do aparecimento de potes tetrápodes e com bordas acastelados (imagem 15). 


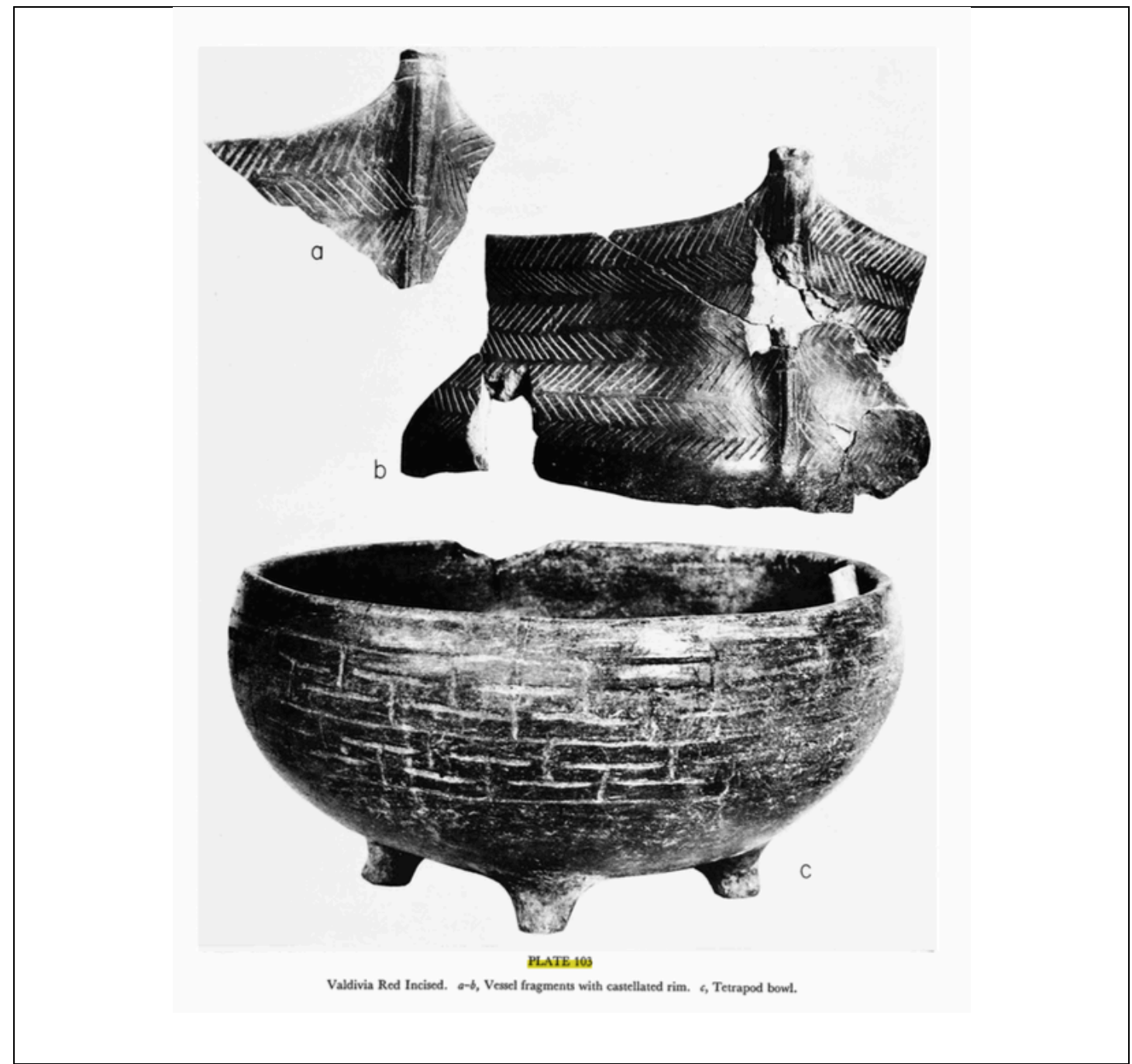

Imagem 15: Vasos acastelados acima e abaixo tetrápodes, encontrados em Meggers et al (1965) prancha $n .103$.

As fases I e II compreendem mil anos e aparentemente ocorrem mais na porção sudoeste da baia de Guyas, constituem perto da metade da sequência cronológica de Valdívia. Muitos traços diagnósticos vão ser presentes no decorrer da sequência das fases cerâmicas. (Staller 1996)

Localizado na região sudoeste da província de Guyas, Real Alto é um sítio significativo para o estudo da cultura Valdívia e diversos pesquisadores abordaram o assentamento em suas pesquisas (Damp 1984, 1988; Lathrap et al. 1977; Marcos 1988; Pearsall 1988; Zeidler 1984).

De uma maneira geral, a interpretação leva os pesquisadores a crer que a cultura Valdívia, para os períodos iniciais, seriam povoados que com o tempo sofrem mudanças no sentido de tornar-se maiores, com um provável aumento na população e um aumento na dependência de plantas cultivadas. Esses fatores em meio a série de mudanças que ocorrem na cultura material poderiam sugerir aspectos relacionado as relações sociais 
também poderiam estar mudando. A sequência Valdívia encontrada em Real Alto pode ser datada em Valdívia 1 e 2 (inicial), 4500-2900 a.C., Valdívia 3 2900-2600 a.C.; Valdívia 4 -7 2600-2100 a.C. Valdívia 8 2100-2000 a.C. (Zeidler 1991; 2006).

Em Pearsall, encontramos a informação que no período inicial da cerâmica Valdívia, Real Alto poderia ser uma pequena aldeia (ca. de 1 hectare em Valdívia 1 e 2,25 hectares em Valdívia 2). Para a pesquisadora, a cultura Valdívia seria uma sociedade agrícola desde os primeiros períodos. Com exceção do feijão, todas outras culturas que se tornam populares precocemente no litoral como: milho, mandioca, pimenta, abóbora, amendoim, algodão. A autora sustenta que a diferença entre a importância de alimentos cultivados vs. manejados, ainda não pode ser afirmada a partir de vestígios botânicos, mas ao mesmo tempo concorda que nos períodos iniciais na cultura Valdívia seriam encontrados diferentes elementos de uma sociedade agrária, como a localização dos sítios (topograficamente favoráveis ao plantio); os tipos de colheita (ligados a carboidratos); e evidências de estocagem. No decorrer da sequência o plantio deve ter se tornado mais significativo, e alguns cultivares poderiam se tornar mais importantes em relações aos demais, caso que ainda deve ser testado e que aparentemente aconteceu com o milho, que ocorreria a partir da fase Valdívia 3, quando o Real Alto alcança seu tamanho máximo, com 12 hectares de área (Pearsall et al 2004).

A partir de Valdívia 3 Real Alto já um grande assentamento com a presença de locais que são interpretados como cerimoniais e em pelo menos duas construções monticulares, sua cerâmica sofre grandes mudanças, como o aparecimento das figuras antropomorfas e uma amplitude variada na maneira de construir os artefatos e de como modelar as suas formas. Neste período a cerâmica é caracterizada por uma maior elaboração de motivos estilísticas e um aumento significativo na variabilidade das morfologias dos vasilhames. A partir destas mudanças, e da mesma maneira como Valdívia 1 e 2 são agrupadas e relacionadas como iniciais, a partir de Valdívia 3 e até Valdívia 5, tem-se o período médio da sequencia histórica desta cultura (Hill 1972; Marcos 1988; imagem 16). 


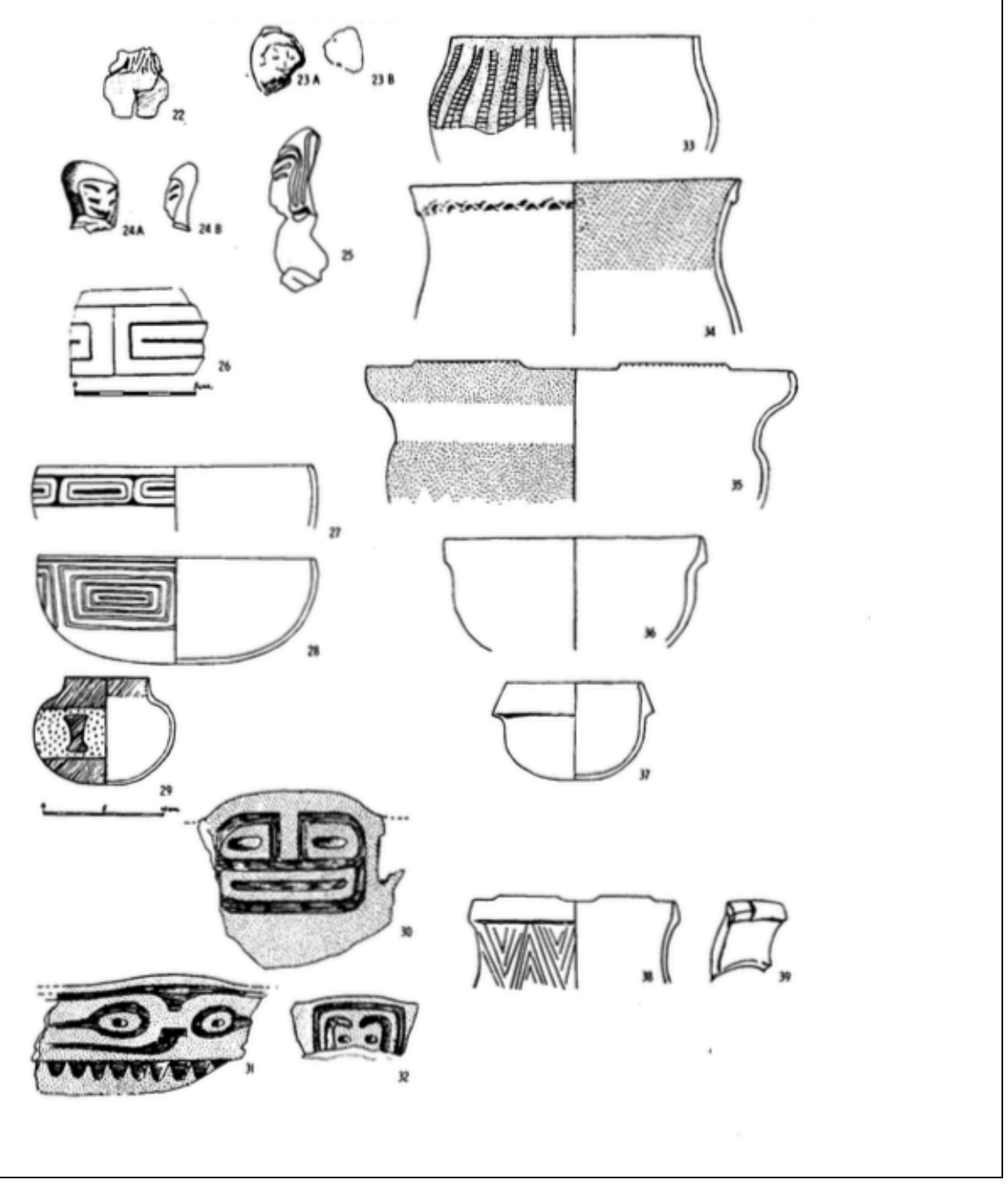

Imagem 16: Tipos e formas dos periodos 3 a 5, Hill (1972).

A porção média da sequência de cerâmica Valdívia (fases 3-5) foi definida com base em diagnósticos recorrentes na região costeira do sudoeste do Equador. Nesta parte da sequência histórica há uma proliferação de assentamentos Valdívia em direção ao interior do território, além da expansão para outras partes, como o sul da província de Manabi, no Golfo de Guayaquil, e El Oro.

Especialistas no período formativo do Equador reconhecem que houveram mudanças marcantes na cerâmica Valdívia a partir da fase 3, com o aumento na variabilidade do formato das formas dos vasos, além da diversificação de atributos decorativos (Lathrap et al., 1977; Staller, 1994; Zeidler, 1984)

A produção agrícola em todo este período histórico é diversificada, tanto com milho, bem como uma série de tubérculos, e do início da ocorrência de pimenta, que 
são presentes em diversos contextos (Pearsall et al. 2004).

A partir da fase 6 ocorrem mudanças na técnica de manufatura dos utensílios cerâmicos, quando o acordelado que fora uma técnica predominante, passa a ocorrer entre outras técnicas, como o modelado e moldado, e que podem ser encontradas em diferentes pontos da costa do Equador (Staller, 2001).

É neste momento que segundo a literatura a cultura Valdívia inicia o seu colapso. Na porção sudoeste da costa do Equador, ao sul de Manabi, escavações indicam que as fases 6 a 8 poderiam ter sítios menores que as ocupações anteriores. (Damp 1984; Estrada 1956; Lathrap et al. 1977; Raymond 1996)

Traços diagnósticos das Fases 6 a 8 (Imagem 17 e 18) também incluem um aumento na variação formal e estilística de atributos na cerâmica, e para momento há a proposta de uma maior ocorrência de sítio que indicariam concentrações variações subregionais, que tiveram o surgimento com explicações relacionadas a diferenças ambientais, derivas culturais e processos de migração e difusão (Meggers et al. 1965; Lathrap 1970; Staller 1994). 


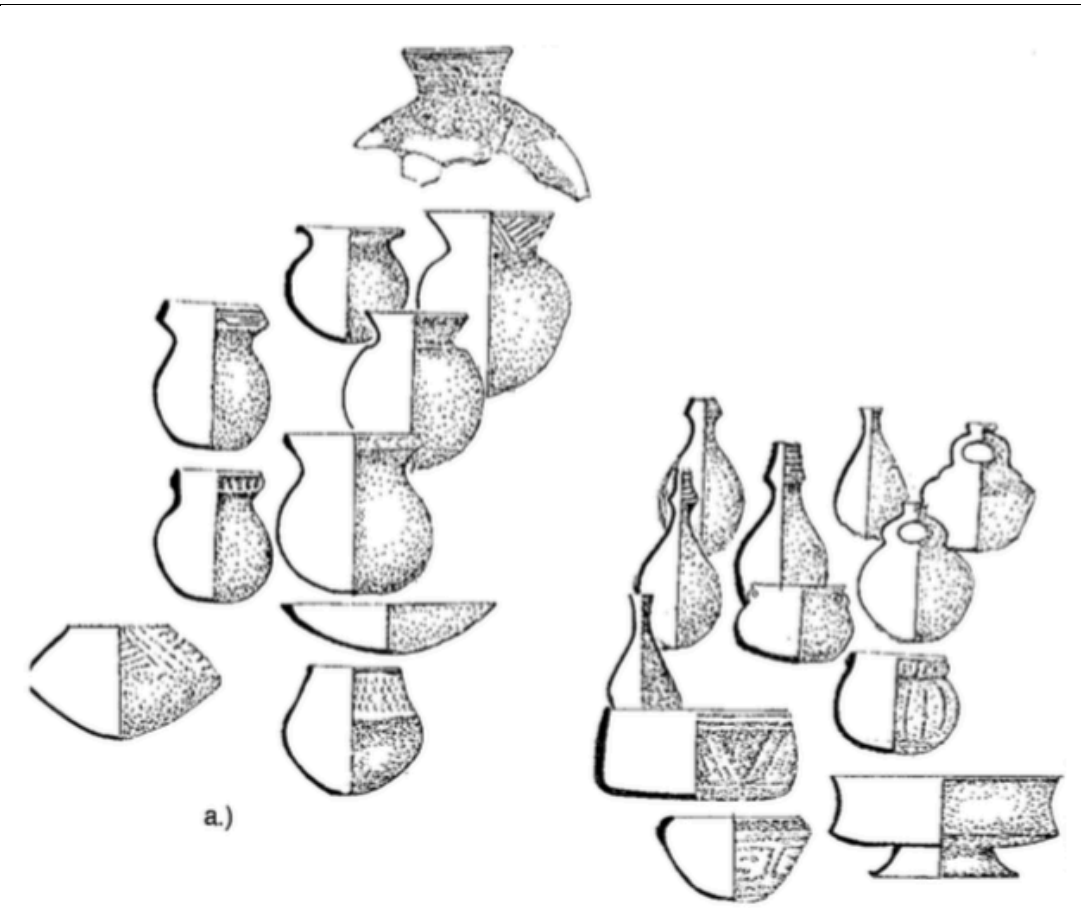

b.)

Fig. 7. Diagnostic vessel forms of the Valdivia VII-VIII Jelí Phase complex identified at La Emerenciana.

The Formative of Coastal Ecuador

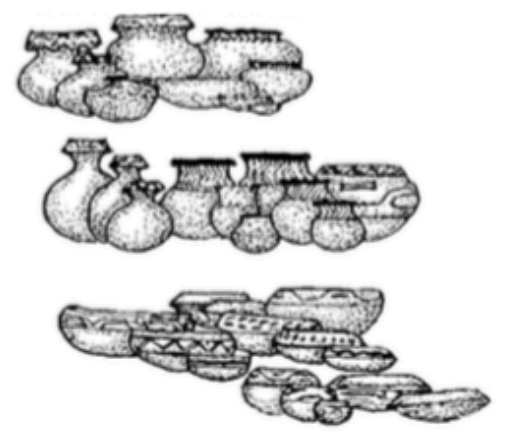

a)

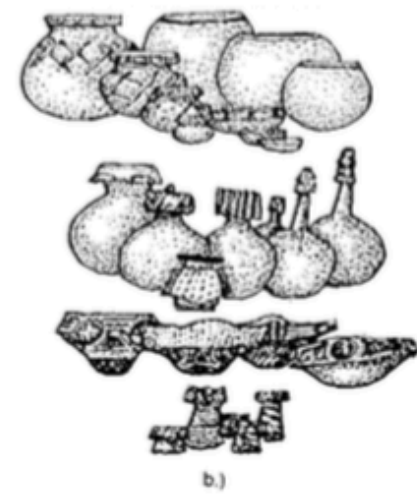

b.)

Fig. 8. Diagnostic vessel forms from the Valdivia VII-VIII component at San Lorenzo del Mate located in the Río Mate Valley, within the Gulf of Guayaquil subregion and the Phase VII component from Real Alto located along the Río Verde in SW coastal Ecuador. (a) Phase VII diagnostics (b) Phase VIII diagnostics (after Marcos et al., 1999, Fig. 4).

Imagem 17: morfologia das fases VII e VIII, apud Staller (2008). 


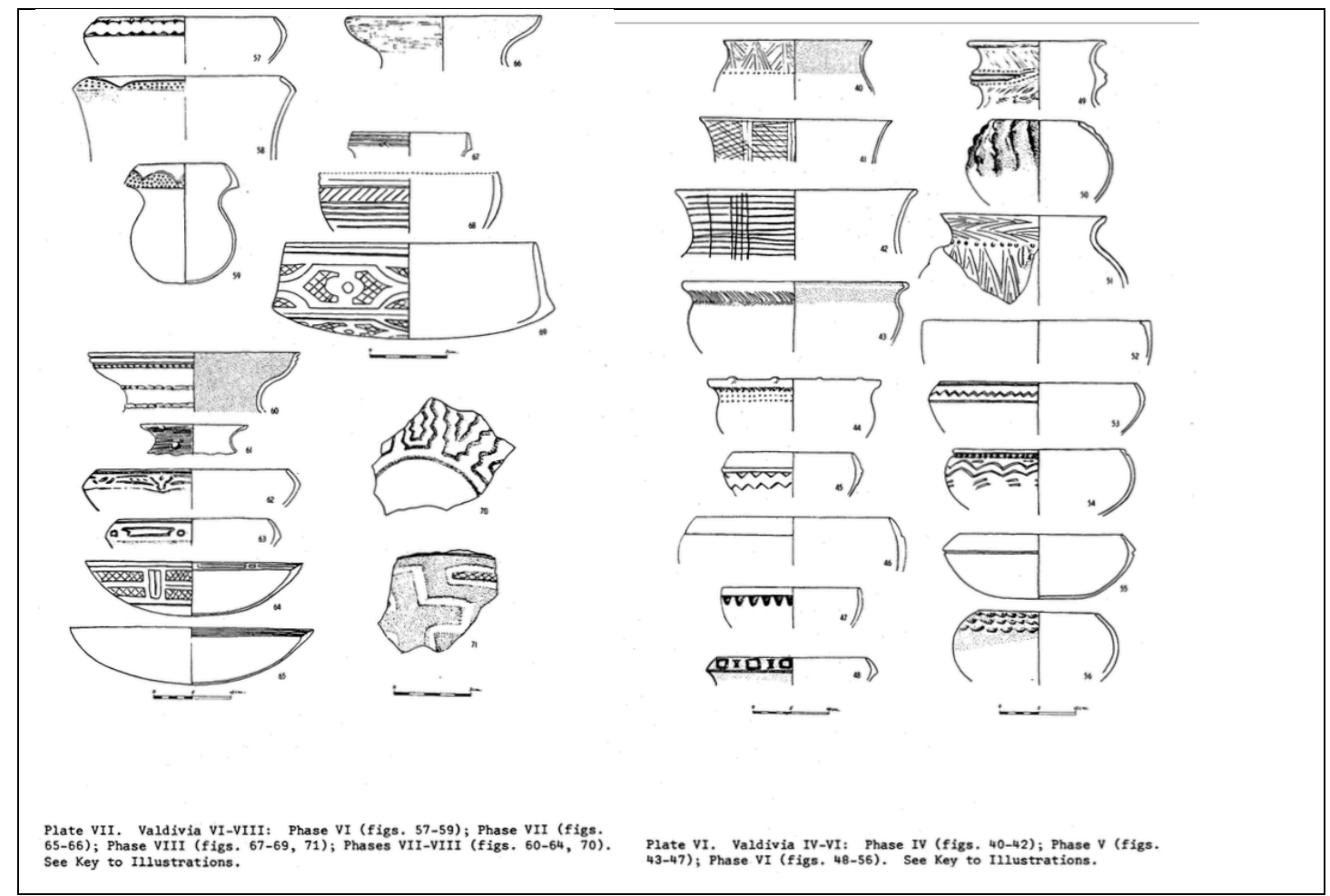

Imagem 18: Formas diagnósticas das fases, a esquerda 6-8, e a direita 4-6, apud Staller (2003).

As sequencia cultural encontrada em Hill (1972) tem datas de cal em 28701940 AP. para a fase 7, e a mais recente, relacionada ao período 8, está situada entre 1890-1620 AP. O que ocorre após o fim da sequência Valdívia ainda é um debate em aberto. Alguns arqueólogos argumentam que culturas como Machallila seriam posteriores cronologicamente e teriam se desenvolvido de maneira independente de Valdívia (Lathrap 1971; Lathrap et al., 1975). Para outros, poderia haver uma relação entre as culturas arqueológicas por volta de $3450 \pm 200$ AP., com o final da sequência Machallila ocorrendo por volta de 2950 AP. (Meggers et al 1965; Meggers, 1987; Willey, 1971) e (imagem 19). 


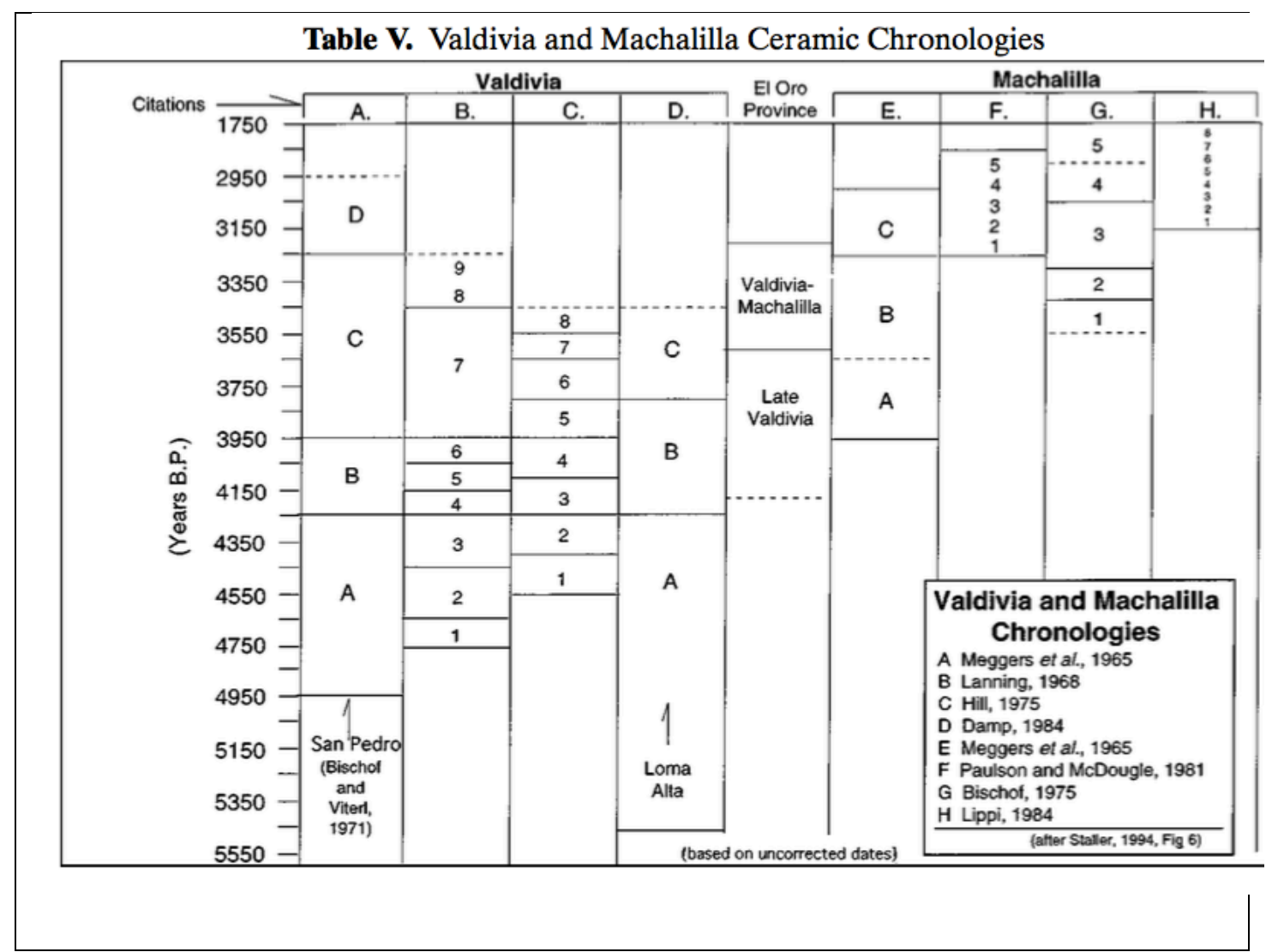

Imagem 19: comparação da cronologia de Valdívia e Machallila, apud Staller (2003).

Como se percebe, as informações sobre Real Alto e Loma Alta, e a cultura Valdívia em geral são mais bem definidas na proposta de Hill (1972) de que em Meggers, et al. (1965), e a hipótese da pesquisadora norte americana fora utilizada por Eurico Miller para explicar o seu modelo.

As hipóteses de Miller (2009; 2013)

Na proposta de Miller (2009; 2013) os tipos Bacabal Exciso e Inciso foram comparados com os motivos encontrados no tipo inciso línea fina (Imagem 20). Além de possuírem características similares na composição do motivo, outros aspectos também poderiam ser avaliados. 


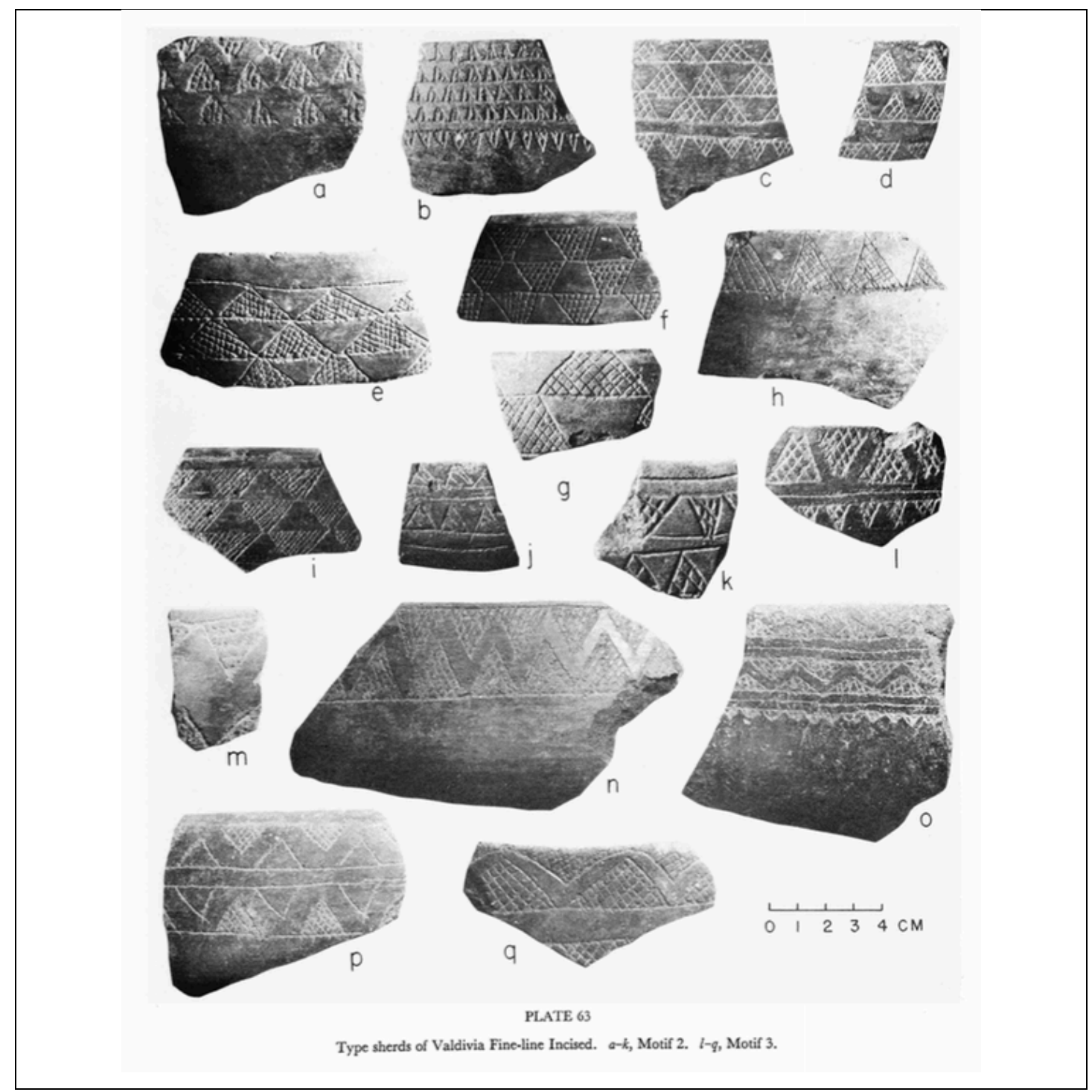

Imagem 20: Tipo Inciso Línea Fina, Meggers, et. al. 1965, Prancha 10.

Na descrição de Meggers et al. (1965) e depois em Hill (1971) encontramos a ocorrência deste motivo normalmente associadas a fragmentos de potes que teriam a pasta com antiplástico fino a médio, queima controlada e com paredes bem alisadas, com presença de engobo vermelho na parte externa e interna, por vezes alternado pelo polimento. Meggers compara Valdívia com outras cerâmicas precoces da América do Sul e a relaciona com Machallila. Mesmo não havendo consenso sobre esta relação, é interessante observar o tipo Ayangue Inciso, que seria semelhante a tipos encontradas em Valdívia, e também é vinculado a uma classe de fragmentos com um tratamento diferenciado, com tempero de areia fina, exterior muito bem alisado ou polido, as vezes alternado por engobo vermelho, as superfícies internas normalmente eram polidas (Imagem 21) 


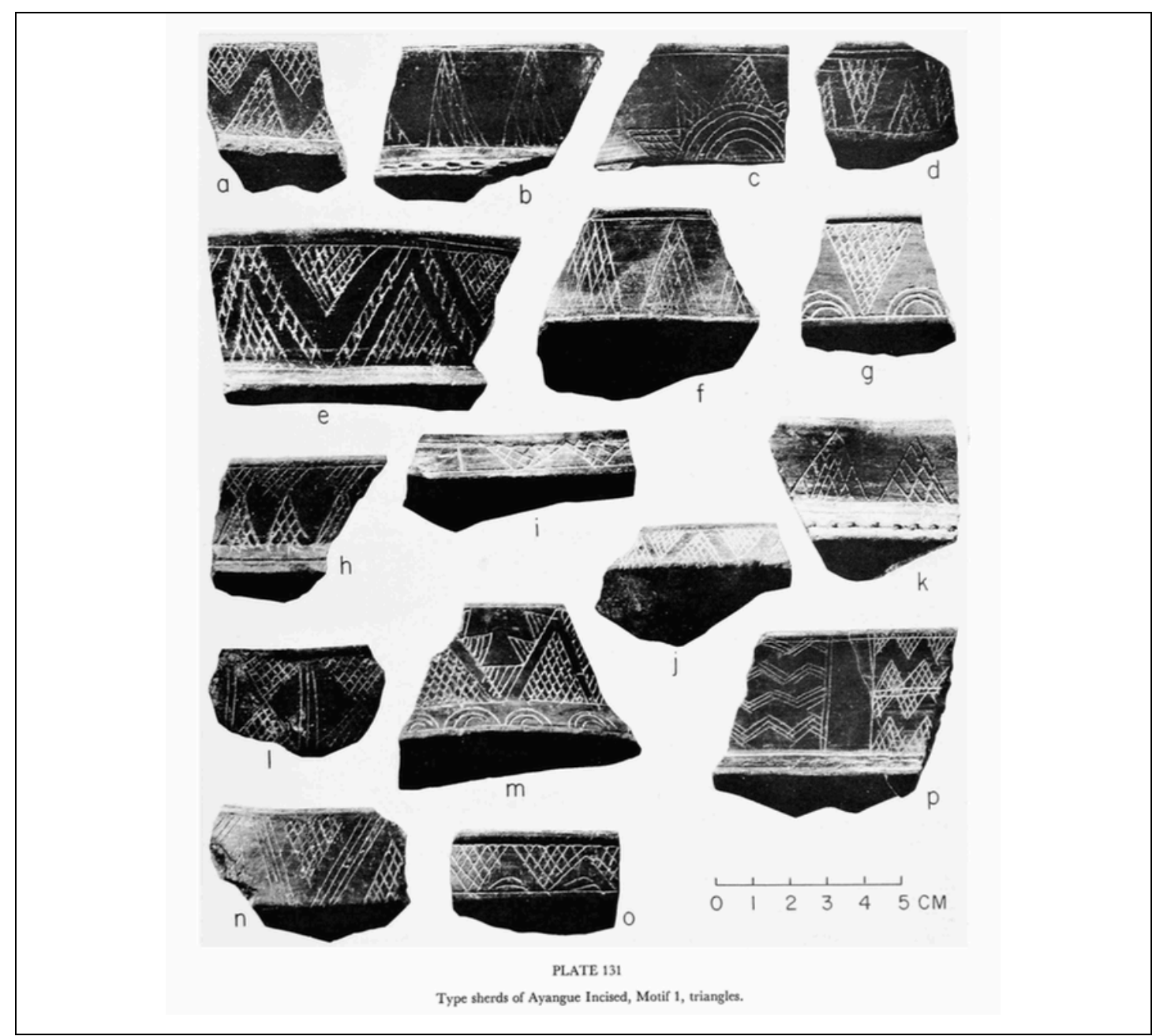

Imagem 21: tipo Ayangue Inciso, cerâmica Machallila, Meggers, et al. (1965).

Tanto em Valdívia quanto em Machallila percebe-se um tratamento diferenciado das superfícies internas e externas dos tipos com a presença do motivo em comparação. Este é justamente este um dos tipos decorativos utilizados por Miller (2009; 2013) para a comparação entre Valdívia e Bacabal, porém o autor não avalia outros aspectos que estes tipos decorativos poderiam ter. Além da semelhança da aparência iconográfica destes tipos decorados ocorrem aspectos tecnológicos de acabamento das superfícies e retoque semelhantes entre as culturas. Este esmero diferenciado aplicado a superfície em relação a outros tipos iconográficos ocorre tanto em Bacabal, quanto em Valdívia.

Cronologicamente o motivo em ziguezague ocorre em Bacabal e adjacências em um período de aproximadamente 3200 anos. A cerâmica Valdívia tem alta variação a partir da fase 3, mas aparentemente o motivo em ziguezague, ou a sua ideia persistem. 
O tipo pode ser encontrado nas fases 1 e 2 e no período 3 e 4 (Imagem 22), e poderia se estender cronologicamente ainda mais, se considerarmos a hipótese de uma relação histórica entre a cultura Valdívia e a cultura Machallila (Meggers et al. 1965; Meggers 1997) e por consequência teríamos uma persistência do motivo por 3200 anos AP.

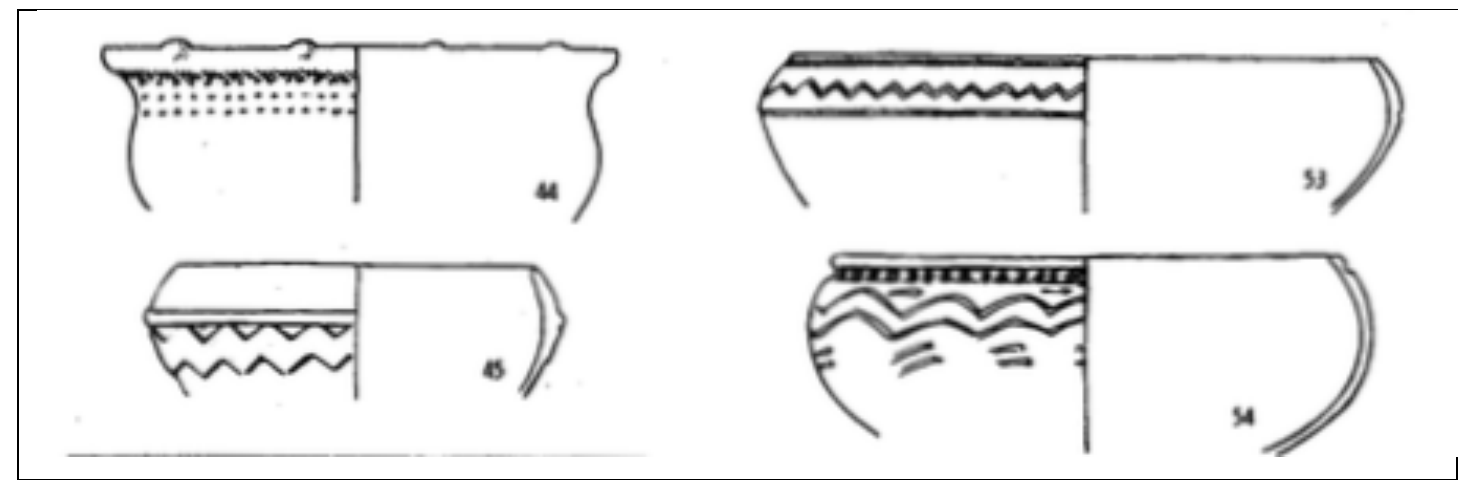

Imagem 22: Motivos das fases 3 e 4 comparados a motivos das fases 1 e 2. Hill (1972).

Essas informações podem remeter que o motivo seja persistente tanto em Valdívia quanto em Bacabal e este cuidado tido no passado pelas artesãs possa não ser obra do acaso. Entretanto, se olharmos com detalhe no gesto feito para criar os motivos nas diferentes culturas, apesar de semelhança nas incisões, excisões e no acabamento, percebe-se que o formato na criação do ziguezague em Bacabal cria-se um ângulo obtuso, diferente de Valdívia e Machallila, que formam um ângulo agudo (Imagem 23)
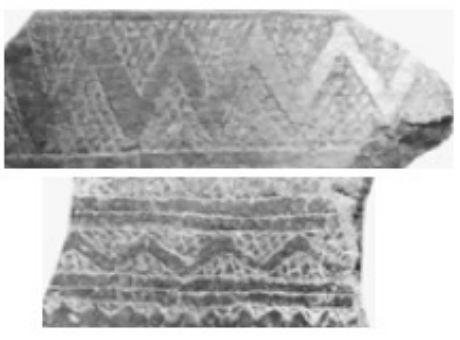

a)

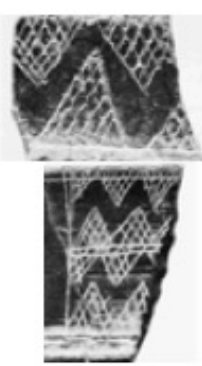

b)
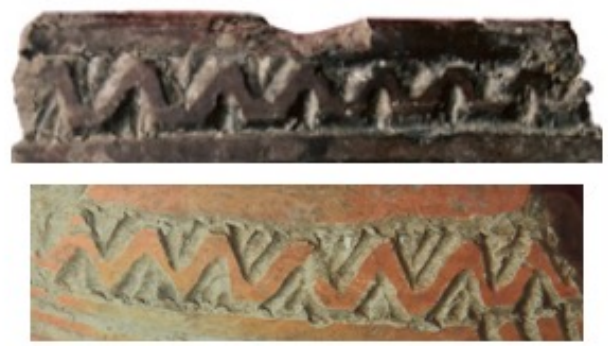

c)

Imagem 23: a) Valdivia; b) Machallila; c) Bacabal 
Este é um dos aspectos que as diferem, e além disso, em Bacabal ocorrem diferentes idiossincrasias do motivo, o que não ocorre na cultura Valdívia.

Existem outros pontos que são comparáveis como a morfologia dos potes que pode ter semelhanças entre o período inicial da cultura Valdívia e Bacabal. A maioria dos potes possui contorno simples e o motivo em ziguezague que sempre aparece junto a borda (imagem 24).

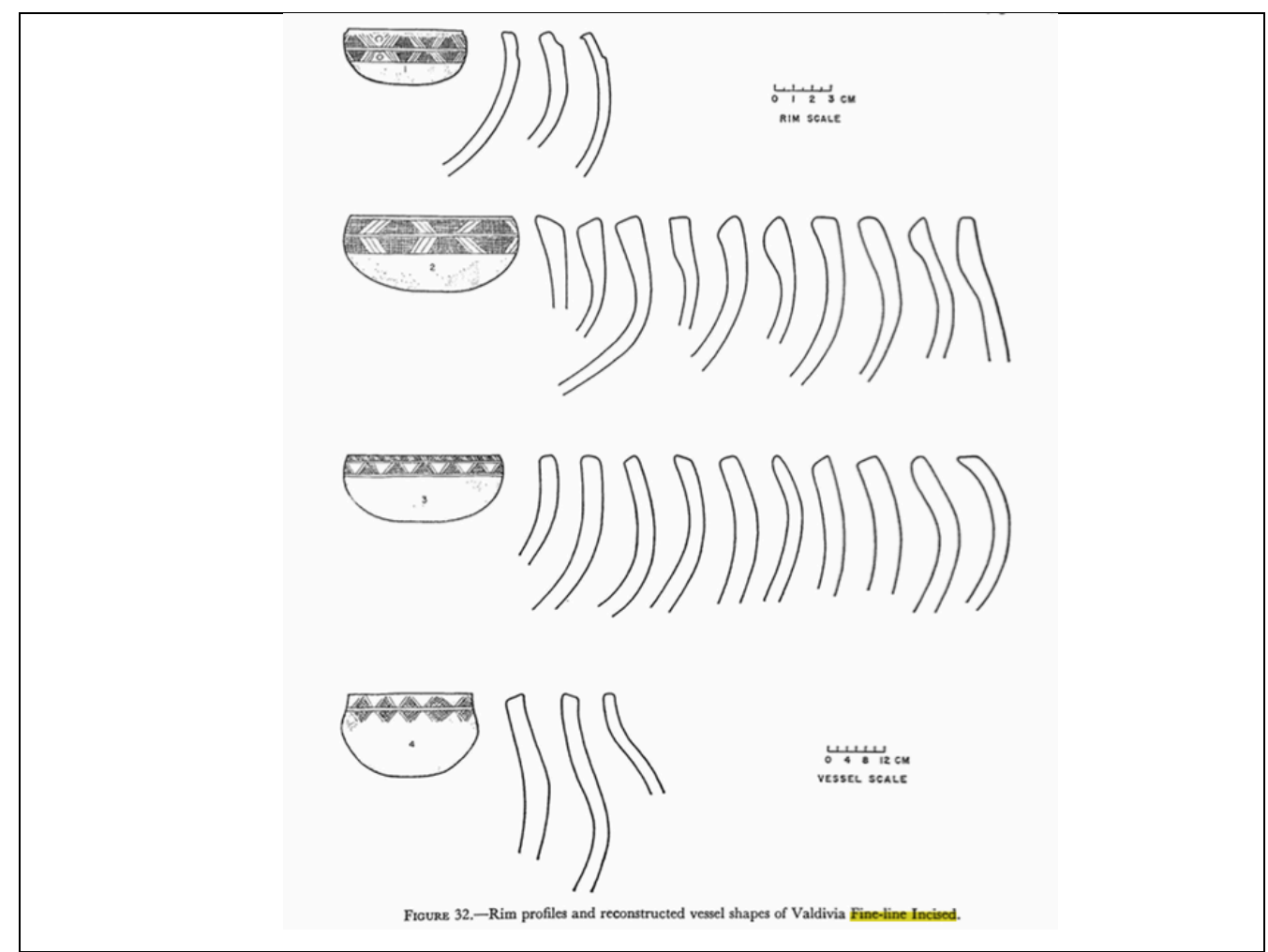

Imagem 24: Formas e tipos decorados da cultura Valdivia, fases 1 e 2, (Meggers, et al. 1965, prancha 103)

O contato entre as culturas do litoral do Equador e da floresta tropical é uma hipótese há muito tempo assuntada (Zeidler 1984; Lathrap 1970), e dados recentes demonstram a sustentabilidade de tal ideia já que importantes cultivares de origem amazônica são encontrados precocemente em sítios arqueológicos da cultura Valdívia (Pearsall et al 2004).

Stahl (1985) argumenta que no período inicial aspectos de uma interação entre povos da cultura Valdívia e os habitantes da floresta Amazônica podem ser percebidas tendo como base a leitura dos motivos iconográficos expressos na cerâmica Valdívia. Para o autor, no litoral do Equador poderiam ser encontrados no registro arqueológico certos correlatos materiais relacionados a alucinação ritual - um padrão comportamental de importância particular na vida das nações na floreta amazônica. Argumenta que a 
gênese de pelo menos parte da iconografia encontrada na cerâmica de Valdívia, desde sua primeira aparição na costa do Equador, pode ser encontrada dentro da imagem eidética consistente e repetida associada à alucinação.

A abrangência da iconografia dos potes de consumo encontrados em Valdívia poderiam ser melhor compreendidos comparando-a a imagens alucinatórias recorrentes e registradas na etnologia.

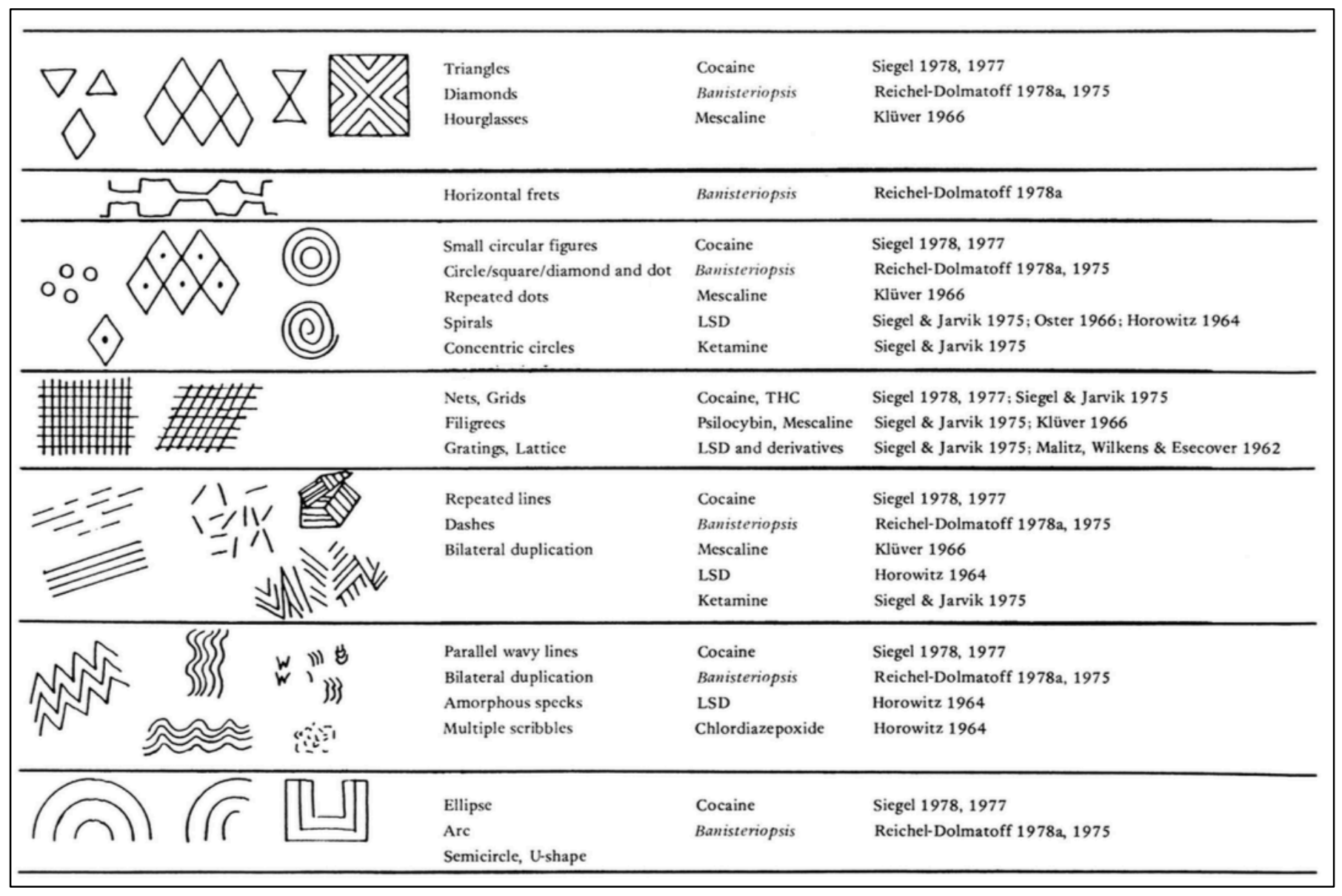

Imagem 25: Quadro resumo de imagens recorrentes geradas por alucinógenos.

Para Stahl (1986) os tipos ziguezague e losangular encontrados na cerâmica Valdívia e poderiam ser remetidos a utilização de Banisteriopsis caapi amplamente difundida na floresta Amazônica. Além disso, o retoque de cor vermelha, muito comum nestes tipos decorados, pode ser relacionado com a força das imagens alucinógenas, hipótese sustentada a partir de registro de contextos etnográficos. Para a antropologia a cor vermelha em diferentes contextos amazônicos é reconhecida por ter profundo significado nas relações cosmológicas entre o mundo observado e o mundo secular. Consequentemente, se os potes de cerâmica fossem usados no contexto de ritual, não 
seria coincidência descobrir uma associação consistente entre recipientes cerimoniais, de cor vermelha forte e as respectivas imagens causadas pela alucinação Stahl (1986)

Existem ainda outros pontos a especular, como o padrão de assentamento com a presença de sítios no entorno de monumentos erguidos a partir de conchas, ou até uma similaridade possível entre as culturas que as precedem - a cultura Las Vegas no Equador possui no seu inventário artefactual pequenas lascas em quartzo e bolotas de argila, algo semelhante a fase Cupim.

Existem referências de que Valdívia foi uma sociedade extremamente móvel, com contatos marítimos e terrestre observado a partir do comércio de obsidiana (Marcos et al. 1998; Zeidler e Pearsall 1994).

Contudo, mesmo havendo elementos que possam estreitar a similitude e a correlação entre Valdívia e Bacabal acreditamos que ainda é cedo afirma sua validade e mais, a especulação sobre a hipótese nos leva a pensar que somente com os dados arqueológicos não conseguimos explicar e nem validar a hipótese. Uma lição que fica é que afinal, quem procura acha, pois conseguimos ampliar o número de características em comum sobre a cerâmica Bacabal e Valdívia em relação ao que foi elencado por Miller (2009). Dada a complexidade do tema, seriam necessários muito mais argumentos, para além da arqueologia, de mais áreas do conhecimento, como a genética, a osteologia, por exemplo, para que esta história possa ser melhor explicada.

\section{Hipótese de Zimpel e Pugliese sobre a relação com contexto boliviano}

Para o arqueólogo Eurico Miller a fase Bacabal teria descendência direta com a cerâmica Valdívia no Equador. Isso dado a similaridade de diferentes motivos decorativos encontrados na cerâmica. Em em processo similar o autor sustenta que a cerâmica Bacabal, por sua vez, teria difundido ideias que seriam encontradas em fases cerâmicas localizadas no alto rio Guaporé.

Das fases arqueológicas conhecidas naquela região, as que possuem descrições e datações radiocarbônicas divulgadas são a Poaia, a Aguapé (Imagem 26) e Galera. No alto rio Guaporé, são as cerâmicas mais próximas cronologicamente àquelas das ocupações da Fase Bacabal. A pasta das fases Poaia e Aguapé é composta de antiplástico de cariapé, associado a outros elementos não descritos. São apresentados vasos globulares e tigelas rasas, com alisamento e decoração incisa, motivos com linhas paralelas, curvas e em ziguezague. As datas calibradas para as fases as situam entre 300 a.C. e o século II, 
sendo que a fase Aguapé é estratigraficamente superior à fase Poaia. Com características muito semelhantes às fases Poaia e Aguapé, Wüst (2001) descreve, também para o alto rio Guaporé, um conjunto cerâmico denominado Guapé, que possui motivos de linhas cruzadas na borda, por vezes ocorrendo concomitantemente a motivos zoomorfos, que podem estar relacionados a representações estilizadas de rãs. As datações ficam em torno dos séculos XIV e XVII.

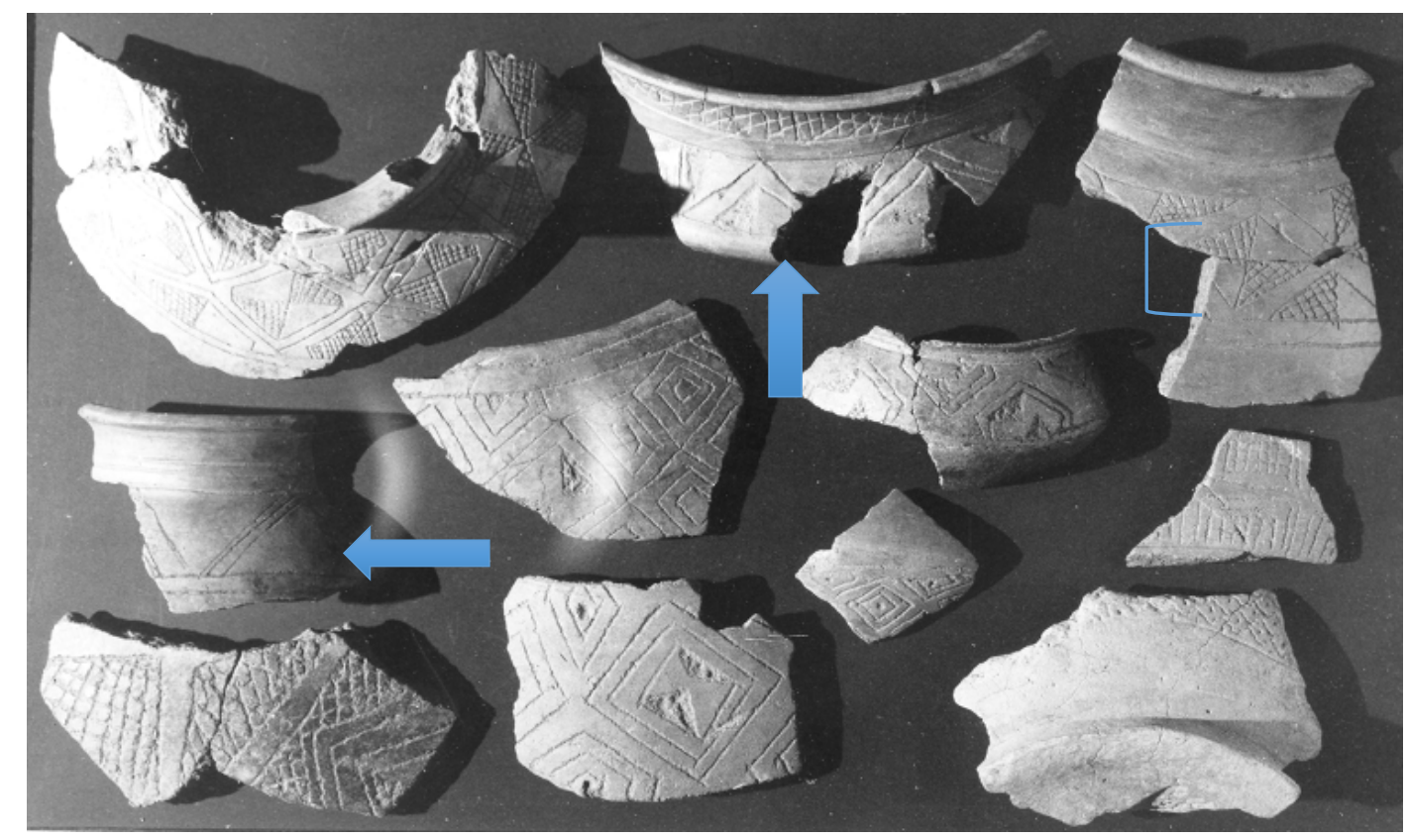

Imagem 26: Fase Aguapé, os grifos são relacionados a motivos que foram utilizados na comparação. Os grifos são nossos e a imagem é cortesia de Eurico Miller. 


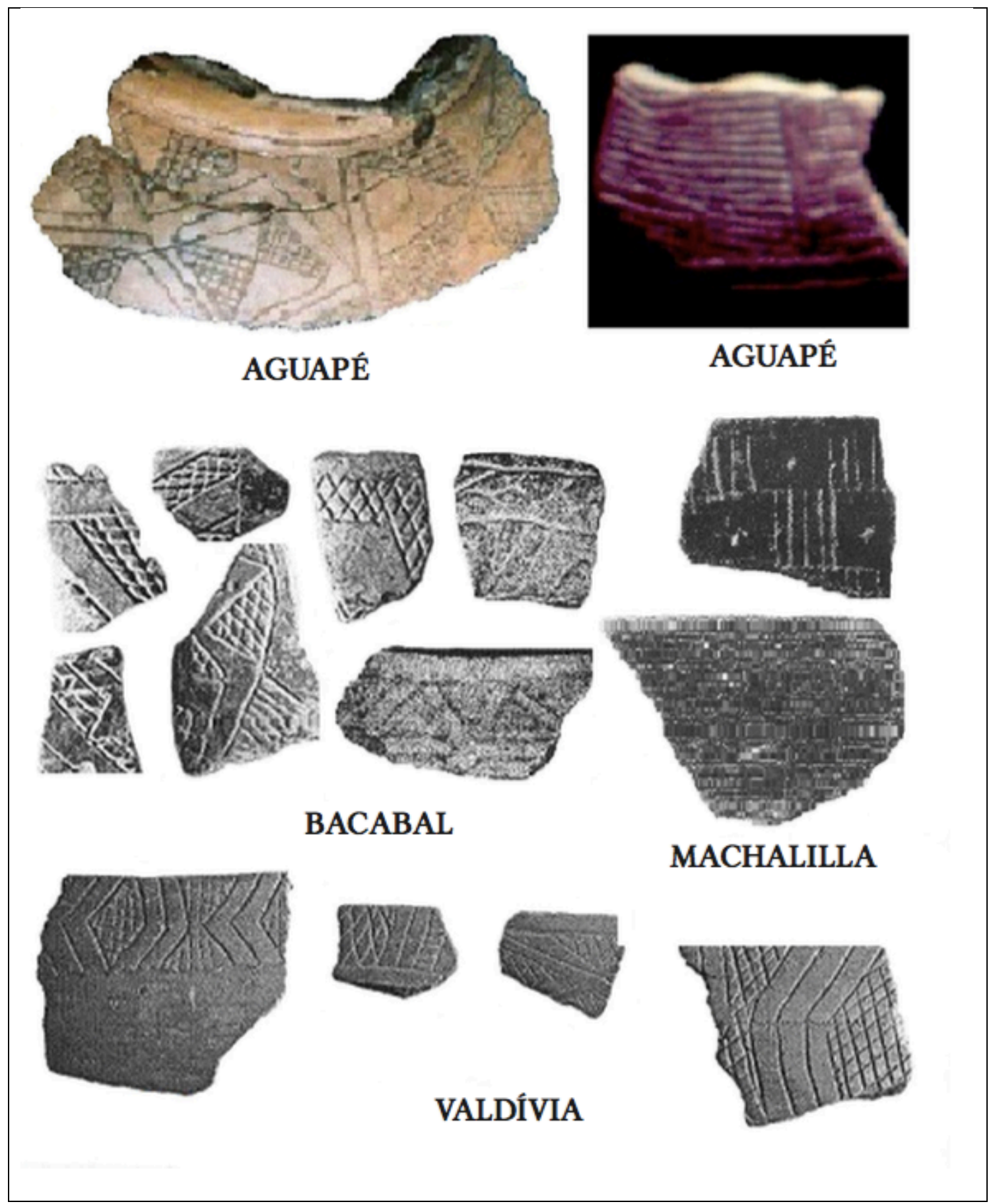

Imagem 27: Comparação de cerâmicas Bacabal, Valdivia, Machallila e a fase Aguapé, do alto rio Guaporé (Miller, 2013, p. 369).

Em relação à cerâmica da fase Galera, seu registro ocorre em sítios a céu aberto com a presença de enterramentos em urna e em abrigo-sob-rocha, na encosta da Chapada dos Parecis, ao longo do rio Galera. Situada cronologicamente entre os séculos IX e XIV, o padrão de assentamento é associado à presença de TPI, mas infelizmente ainda são inéditas as informações sobre a profundidade, a extensão ou a morfologia dos sítios arqueológicos. A decoração da cerâmica apresenta incisões em linhas finas, com motivos 
horizontais e verticais em linhas retas; linhas inclinadas escalonadas; combinação de linhas retas e escalonadas em conjuntos espaçados entre si com gravados zoomórficos; losangos e meio-losangos alternados e contínuos com uma cruz puntiforme no centro; cruzeta simples e complexa; destaca-se o retoque branco sobre o inciso e os emblemas; ocorrem vasos antropomorfos, pesos-de-fuso e pendentes (Miller 2013, p. 359).

A aproximação entre a fase Bacabal e as outras fases cerâmicas descritas para o alto Guaporé foi feita a partir da avaliação e da comparação dos dados sobre o tratamento de superfície e sobre os tipos decorados e seus motivos (Miller 2013b, p. 353). Sua hipótese seria indicada pela a quantidade de analogias que poderiam ser feitas entre os tipos decorados da cerâmica Valdívia e a a fase Bacabal, onde a fase Aguapé compartilharia traços daquela tecnologia cerâmica que teria vindo de tão longe.

Entretanto, estas comparações ficam restritas às fases do alto rio Guaporé, e sobre o médio curso, local onde Miller desenvolve uma dissertação de mestrado (Miller 1984) a interpretação é sucinta:

"Os ceramistas das fases Pimenteiras e Corumbiara
teriam ocupado as barrancas de terra firme do rio
Guaporé e posteriormente as ilhas de terra firme
onde ocupavam os ceramistas Bacabal, que são
absorvidos com o tempo." (Miller 2009b, p. 113)

$\mathrm{Na}$ explicação, Miller não aponta diretamente como teria ocorrido essa “absorção" e não aponta nenhuma direção para a relação entre Bacabal a cultura que a sobrepõe geograficamente no decorrer do tempo. Não fica muito claro o porque pois, nas fases Corumbiara/Pimenteiras, existem características que parecem ser indícios de relações entre as fases, e além disso, hipóteses apresentadas por Zimpel e Pugliese (2016) apontam para a possibilidade haverem traços compartilhados entre a fase Bacabal e outras cerâmicas além do rio Guaporé, encontradas no Mato Grosso (Brasil) e nos Llanos de Mojos (Bolívia) (Zimpel e Pugliese 2016). 


\section{Fase Corumbiara/Pimenteiras}

No médio rio Guaporé, área de ocorrência das fases Pimenteiras e Corumbiara, o maior volume de informações vem dos dados dos trabalhos de Miller (1977,1983,1992a, 1992b) e dos informes do PRONAPABA (Simões, 1977,1983) e Simões e Lopes (1987). Nessas publicações são divulgadas diversas fases cerâmicas, mas somente as fases Pimenteiras e Corumbiara possuem uma descrição mais precisa, assim como datações absolutas divulgadas.

\begin{tabular}{|c|c|c|c|c|c|c|}
\hline \multicolumn{7}{|c|}{$\begin{array}{l}\text { Sítios arqueológicos cadastrados na área do médio e baixo Guaporé A partir de Miller }(1977,1983) \text {, Simões } \\
\qquad(1977,1983) \text { e Simões e Lopes (1987). }\end{array}$} \\
\hline Sigla & eixo maior $(m)$ & eixo menor $(m)$ & Profundidade $(\mathrm{cm})$ & Tipo & Valas & Fase \\
\hline RO-PB-01 & 800 & 150 & 35 & cerâmico & $\mathrm{X}$ & Limeira \\
\hline RO-PB-02 & 500 & 200 & 30 & $\begin{array}{l}\text { cerâmico com } \\
\text { enterramentos }\end{array}$ & $\mathrm{X}$ & Limeira \\
\hline RO-PB-03 & 280 & 140 & 30 & cerâmico & $\mathrm{X}$ & Machupo \\
\hline RO-PB-04 & 900 & 700 & 40 & cerâmico & $\checkmark$ & Machupo \\
\hline RO-PB-05 & 1800 & 540 & 50 & cerâmico & $\checkmark$ & Machupo \\
\hline RO-PB-06 & 400 & 250 & 30 & cerâmico & $\mathrm{X}$ & Machupo \\
\hline RO-PB-07 & 200 & 100 & 15 & cerâmico & $\mathrm{X}$ & Não definida \\
\hline RO-PB-08 & 500 & 400 & 30 & cerâmico & $\mathrm{X}$ & Machupo \\
\hline RO-PB-09 & 300 & 180 & 35 & cerâmico & $\mathrm{X}$ & Machupo \\
\hline RO-PB-10 & 750 & 200 & 40 & cerâmico & $\mathrm{X}$ & Machupo \\
\hline RO-PB-11 & 200 & 150 & 30 & cerâmico & $\checkmark$ & Machupo \\
\hline RO-PB-12 & 400 & 250 & 30 & cerâmico & $\mathrm{X}$ & Machupo \\
\hline RO-PB-13 & 900 & 200 & 35 & cerâmico & $\mathrm{X}$ & Machupo \\
\hline RO-PB-14 & 350 & 200 & 30 & cerâmico & $\checkmark$ & Machupo \\
\hline RO-PN-01 & 1000 & 500 & 40 & $\begin{array}{l}\text { cerâmico com } \\
\text { enterramentos }\end{array}$ & $v$ & Pirizal \\
\hline RO-PN-02 & 700 & 230 & 45 & $\begin{array}{l}\text { cerâmico com } \\
\text { enterramentos }\end{array}$ & $v$ & Corumbiara \\
\hline RO-PN-03 & 400 & 200 & 90 & $\begin{array}{l}\text { cerâmico com } \\
\text { enterramentos }\end{array}$ & $\checkmark$ & Corumbiara \\
\hline RO-PN-04 & 370 & 180 & 45 & $\begin{array}{l}\text { cerâmico com } \\
\text { enterramentos }\end{array}$ & $\checkmark$ & Corumbiara \\
\hline RO-PN-05 & 300 & 240 & 40 & $\begin{array}{l}\text { cerâmico com } \\
\text { enterramentos }\end{array}$ & $\checkmark$ & Não definida \\
\hline RO-PN-06 & 500 & 250 & 40 & $\begin{array}{l}\text { cerâmico com } \\
\text { enterramentos }\end{array}$ & $v$ & Mateguá \\
\hline
\end{tabular}




\begin{tabular}{|c|c|c|c|c|c|c|}
\hline RO-PN-07 & 200 & 450 & 35 & $\begin{array}{l}\text { cerâmico com } \\
\text { enterramentos }\end{array}$ & $\mathrm{X}$ & Mateguá \\
\hline RO-PN-08 & 100 & 100 & 800 & sambaqui & $\mathrm{X}$ & Bacabal \\
\hline RO-CO-01 & 400 & 150 & 30 & $\begin{array}{l}\text { cerâmico com } \\
\text { enterramentos }\end{array}$ & $\boldsymbol{V}$ & Pimenteiras \\
\hline RO-CO-02 & 200 & 80 & 20 & $\begin{array}{l}\text { cerâmico com } \\
\text { enterramentos }\end{array}$ & $\boldsymbol{V}$ & Pimenteiras \\
\hline RO-CO-03 & 600 & 200 & 40 & $\begin{array}{l}\text { cerâmico com } \\
\text { enterramentos }\end{array}$ & $\boldsymbol{V}$ & Pimenteiras \\
\hline RO-CO-04 & 250 & 120 & 80 & $\begin{array}{l}\text { cerâmico com } \\
\text { enterramentos }\end{array}$ & $\boldsymbol{V}$ & Pimenteiras \\
\hline RO-CO-05 & 600 & 200 & 35 & $\begin{array}{l}\text { cerâmico com } \\
\text { enterramentos }\end{array}$ & $\boldsymbol{V}$ & Pimenteiras \\
\hline RO-CO-06 & 900 & 200 & 40 & $\begin{array}{l}\text { cerâmico com } \\
\text { enterramentos }\end{array}$ & $\checkmark$ & Pimenteiras \\
\hline RO-CO-07 & 300 & 150 & 40 & cerâmico & $\boldsymbol{V}$ & Pimenteiras \\
\hline RO-PA-01 & 250 & 150 & 90 & cerâmico & $\mathrm{X}$ & Moré \\
\hline RO-PA-02 & 120 & 90 & 20 & cerâmico & $\checkmark$ & Moré \\
\hline RO-PA-03 & 800 & 200 & 35 & $\begin{array}{l}\text { cerâmico com } \\
\text { enterramentos }\end{array}$ & $\boldsymbol{V}$ & Moré \\
\hline RO-PA-04 & 150 & 80 & 35 & cerâmico & $\mathrm{X}$ & Poção \\
\hline RO-PA-05 & 250 & 150 & 35 & cerâmico & $\mathrm{X}$ & Poção \\
\hline RO-PA-06 & 320 & 240 & 30 & cerâmico & $\mathrm{X}$ & Poção \\
\hline RO-PA-07 & 260 & 180 & 30 & cerâmico & $\mathrm{X}$ & Poção \\
\hline
\end{tabular}




\section{Médio rio Guaporé e regiões adjacentes}

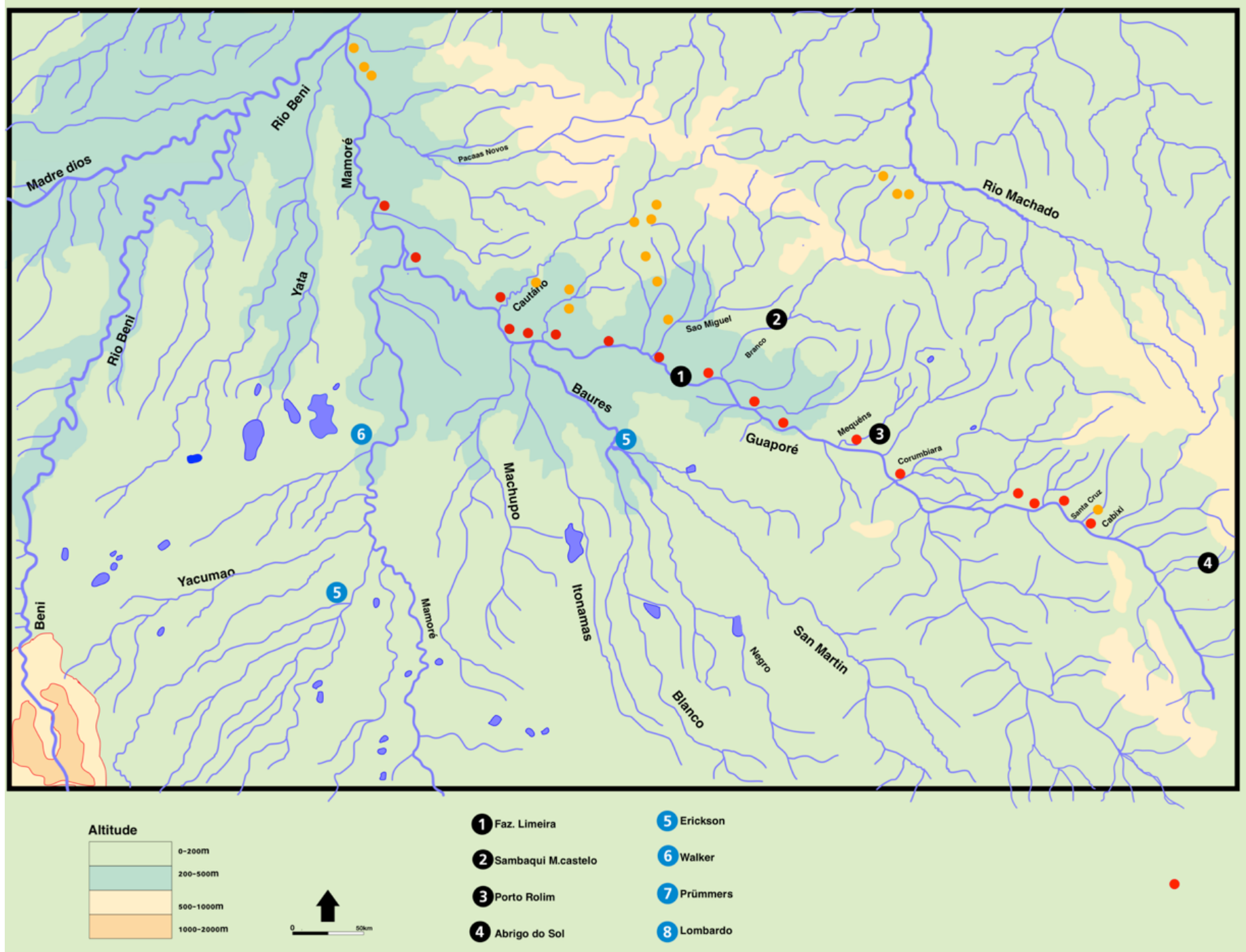

Os sítios classificados como pertencentes a essas duas fases (Corumbiara e Pimenteiras) possuem características em comum, que vão desde o padrão de assentamento até elementos da tecnologia e da iconografia expressa na cerâmica. A distinção entre as fases é feita a partir de diferenças na extensão dos assentamentos (onde os menores são encontrados nos sítios da fase Pimenteira), da maior variedade de tipos decorados na fase Corumbiara e da maior variedade morfológica dos tipos na fase Pimenteiras. Estas diferenças foram identificadas a partir dos resultados da sequência seriada dos tipos cerâmicos recuperados de diferentes sítios. A semelhança entre os dois conjuntos é apontada também por Bettancourt (2011), para a autora é possível pensar numa homogeneidade para a tecnologia cerâmica do médio rio Guaporé, pelo menos entre estas fases. 
A fase Corumbiara possui 12 sítios com a presença de TPI e de enterramentos e área de dispersão de evidências sempre paralela ao rio. Os sítios possuem dimensões que variam entre $300 \mathrm{~m}$ e $900 \mathrm{~m}$ de comprimento e $150 \mathrm{~m}$ e $230 \mathrm{~m}$ de largura e têm a distribuição estratigráfica dos vestígios com profundidade sempre alcançando de $40 \mathrm{~cm}$ a $90 \mathrm{~cm}$. Na fase Pimenteiras, as dimensões dos sítios variam entre $250 \mathrm{~m}$ e $600 \mathrm{~m}$ de comprimento e $80 \mathrm{~m}$ e $200 \mathrm{~m}$ de largura, com a profundidade variando entre $20 \mathrm{~cm}$ e $50 \mathrm{~cm}$. Nos sítios de ambas as fases são registradas valas escavadas, em sua maioria em forma de arco, geralmente ligando a área de ocorrência dos vestígios ao curso d'água mais próximo. Não são mencionados pelos pesquisadores maiores detalhes sobre essas construções que, por vezes, são encontradas em grande número, chegando a quatro estruturas em um só sítio (Miller 1983).

Para essas fases os artefatos cerâmicos seriam feitos com uma pasta de argila elaborada com cauixi e cariapé, que aparece de maneira isolada ou combinada. Os vasilhames são descritos como vasos, panelas e assadores, onde são encontrados, além dos tipos alisados, os tipos inciso, ponteado, filetes aplicados e modelados, ocorrendo isoladamente ou associados, e, por vezes, finalizados pela pintura branca. Os motivos descritos são paralelos, retilíneos e em ziguezague, algumas vezes complementados com estilos antropomorfos. (idem; Imagem 28)

A partir da relação entre datações absolutas, seriações e elementos históricos, Miller (1983) propõe que os sítios dessas fases se situam cronologicamente entre 900-1700 AD. 


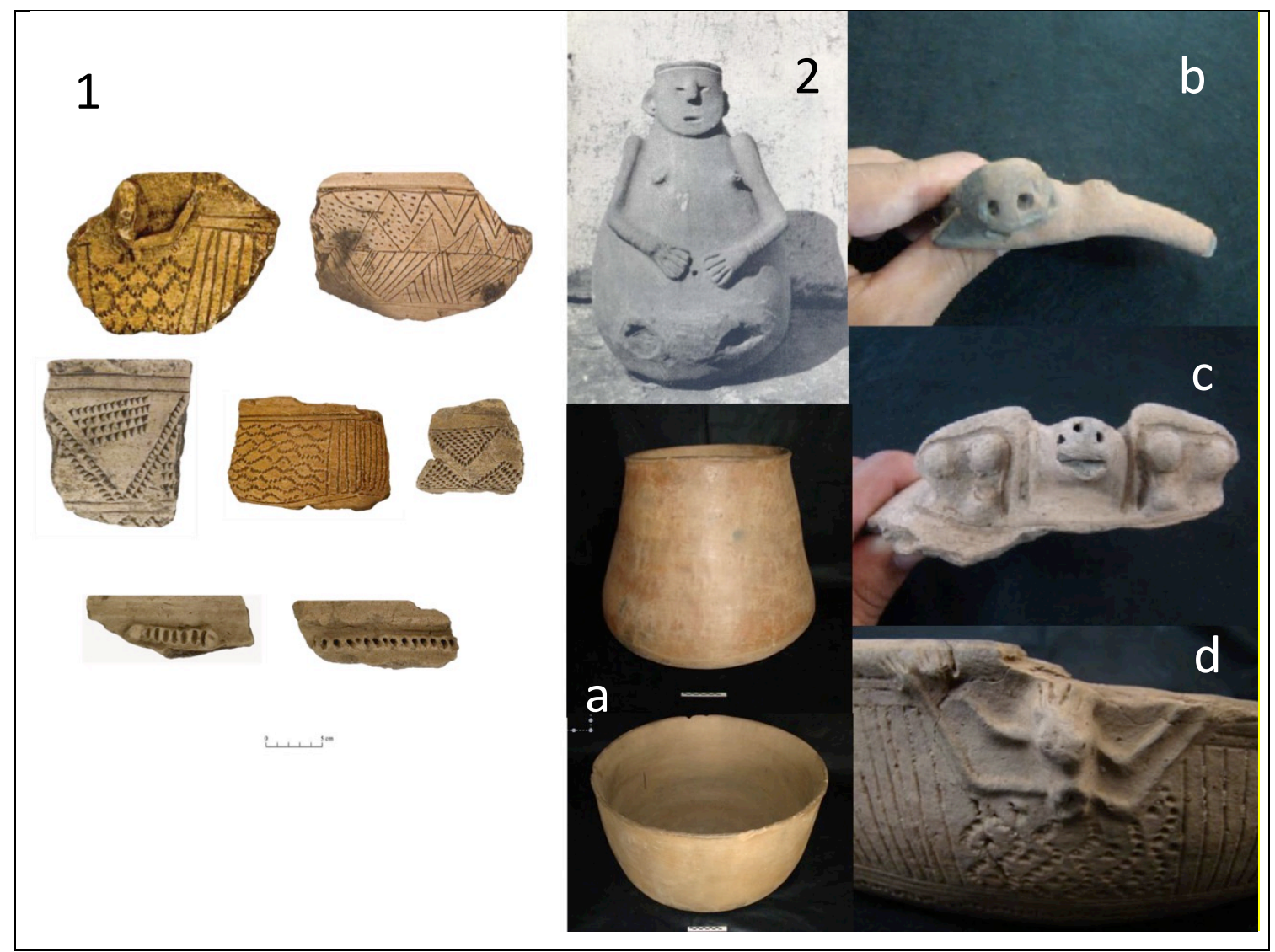

Imagem 28: Cerâmicas tipicas das fases Corumbiara e Pimenteiras (Zimpel e Pugliese, 2016, apud Betancourt, 2013) 2-Pote encontrado no sitio Pedras Negras 3 - Acervo do Museu do Estado de Rondônia, provenientes do médio Guaporé, cortesia de Zuse, com. Pessoal. a)

Se pensarmos nas informações cronológicas, podemos perceber que em algum momento por volta da porção média da sequencia diversos elementos encontrados na cerâmica bacabal estão presentes nas cerâmicas que começam a ocorrer em diferentes pontos do rio Guaporé (imagem 32).

\section{Interações entre Bacabal e Pimenteiras/Corumbiara}

As cerâmicas das fases Corumbiara e Pimenteiras possuem uma característica em sua pasta que pode ser determinante para evidenciarmos uma possível relação entre esses conjuntos e a fase Bacabal. Na sequência seriada dos tipos cerâmicos encontrados por Miller (1983, p.371-374), está presente, em todos os níveis escavados, alguma evidência de cerâmica com cariapé, o que na fase Bacabal é encontrado somente a partir de 2000 AP (Miller, 2009b). Essa data marca a concomitância entre as ocupações do sambaqui e dos sítios na beira do rio Guaporé. 
$\mathrm{Na}$ sequência seriada da fase Bacabal percebe-se ainda que, mesmo com o aparecimento do cariapé, os motivos decorativos continuam sem grandes mudanças para maiores detalhes consultar os gráficos das sequências seriadas em Miller (2009b, p. 108-110; imagens 29 e 30). 
LHA

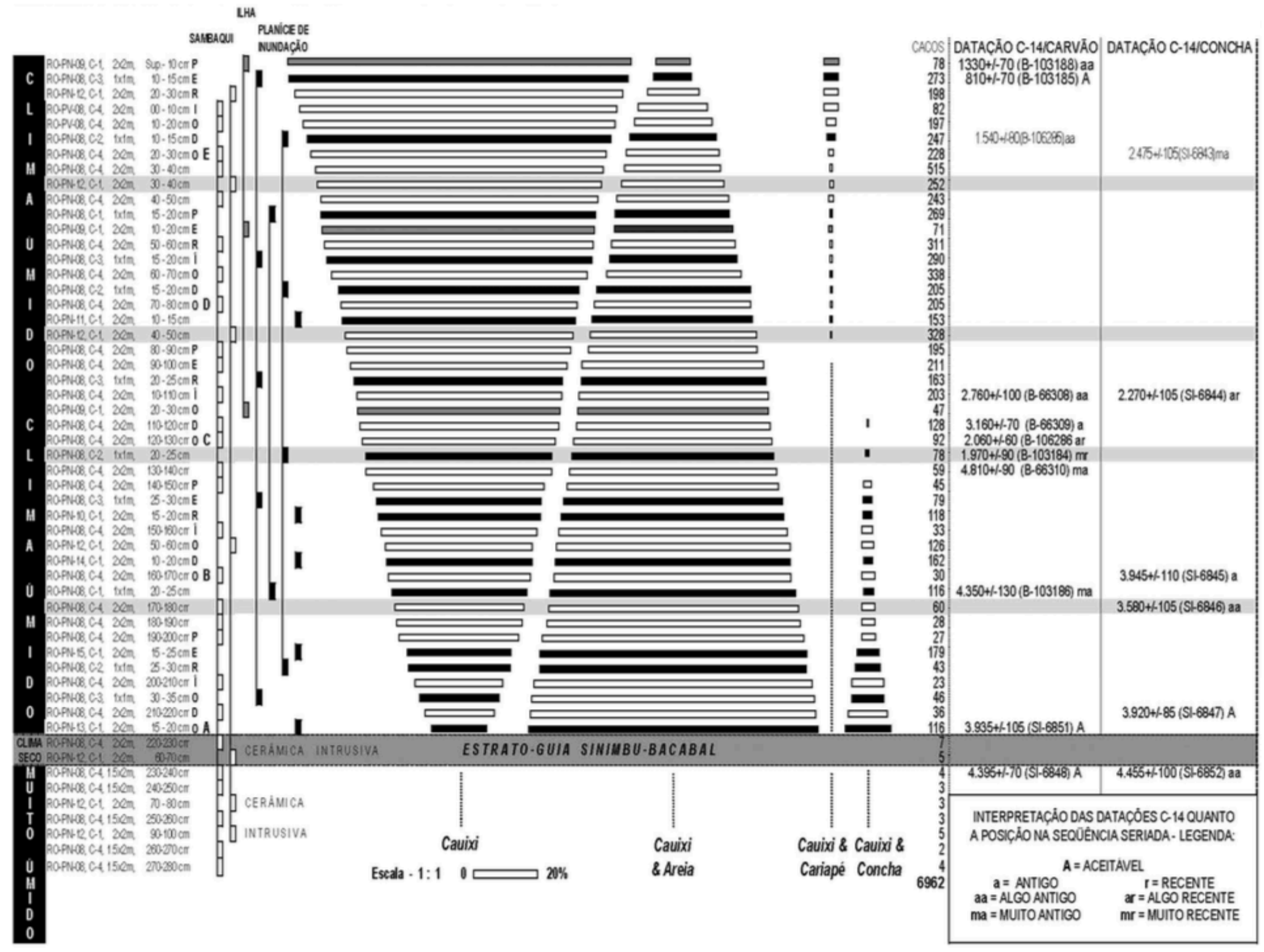

Imagem 29: Seriação da fase Bacabal (Miller 2009) 


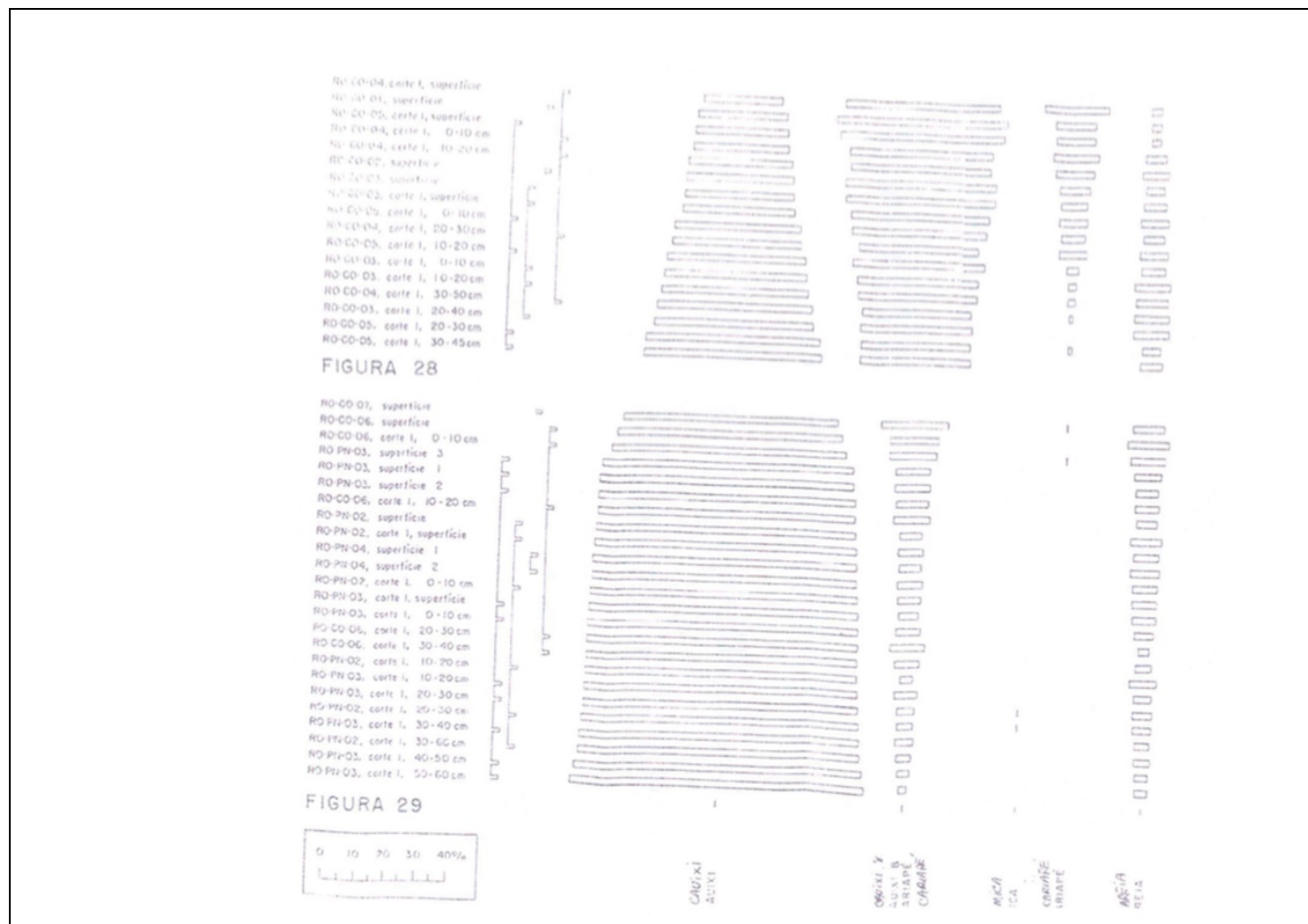

Miller (1983) fig. 28 e 29 - Tipos de pasta nas fases Corumbiara e Pimenteiras

Imagem 30: Seriação da fase Corumbiara e Pimenteiras, Miller (1983, p.371). 
Contudo, durante a analise dos vestígios recuperados de nossas escavações em Montes Castelo, não foram encontrados fragmentos cerâmicos recorrentes onde se era possível identificar o cariapé, tendo aparecido em somente um caso(n=1). Sendo assim, acreditamos que tal hipótese ainda deva ser testada.

Mesmo assim, é possível identificar elementos iconográficos característicos da fase Bacabal estão presentes nas fases Corumbiara/Pimenteiras (imagem 31).

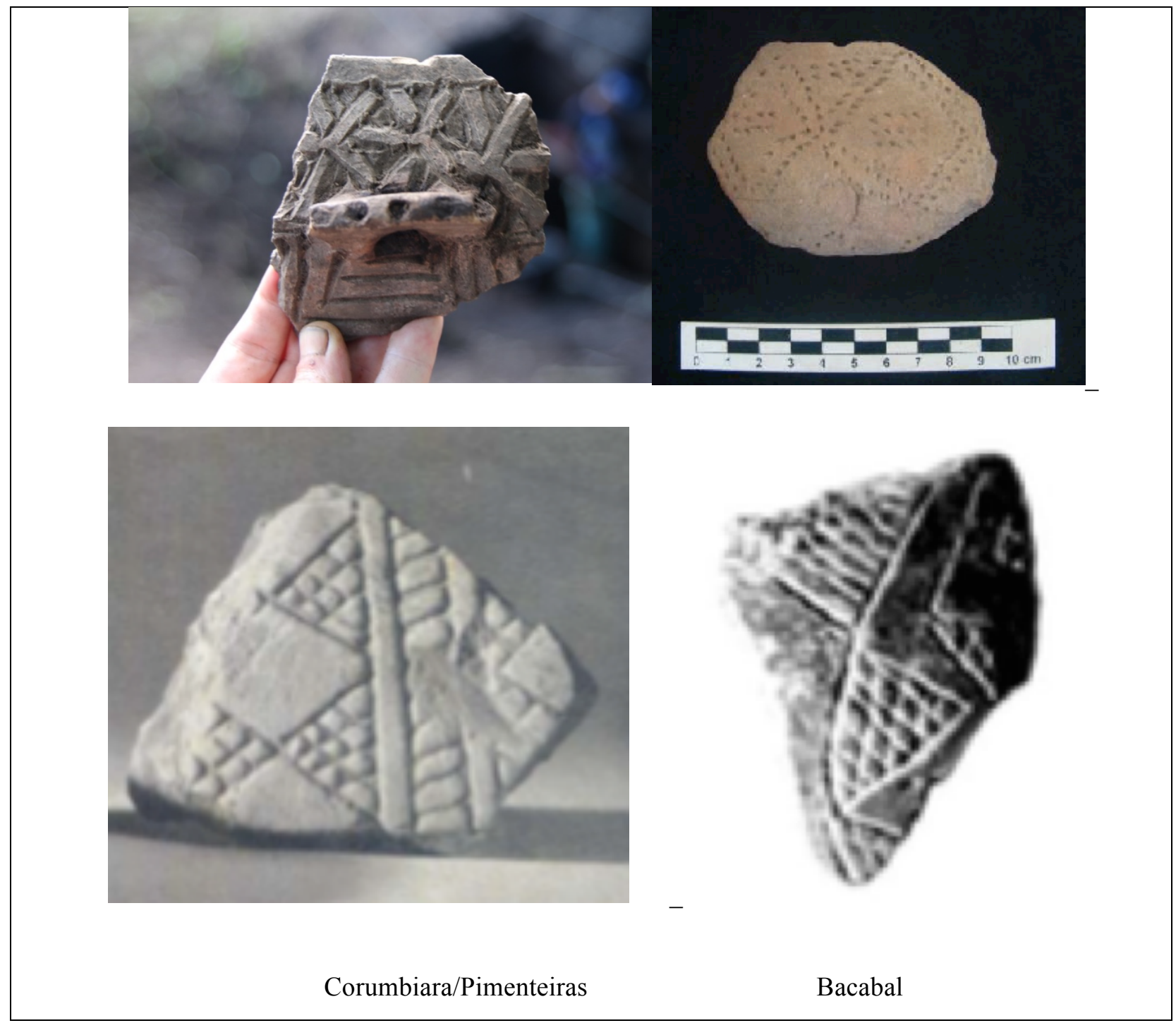

Imagem 31: Elementos comuns a Bacabal e Corumbiara/Pimenteiras.

Uma das datas apresentadas por Miller para o século III A.D. (Miller 1983, p.190) para a fase Pimenteiras (considerada pelo autor demasiada antiga para o conjunto) deve ser reavaliada em consideração ao compartilhamento de atributos entre as fases Bacabal e Corumbiara/Pimenteiras que pode ter ocorrido durante séculos de história compartilhada. 
Avaliar as fases Poaia e Aguapé e sobre suas ligações com as fases Corumbiara e Pimenteiras poderia ajudar a entender melhor a variabilidade presente nesses conjuntos. Essa hipótese é alimentada pelas características dos sítios que temos estudado, uma vez que no médio Guaporé há motivos iconográficos que recorrem há 4000 anos e que no alto Guaporé há a ocorrência do cariapé há pelo menos 2500 anos (durante as fases Aguapé, Poaia, Capão do Canga), fato este que até o momento é um milênio mais antigo que a ocorrência desse antiplástico no médio curso do rio, pelo menos.

Betancourt (2011) contribui significativamente no sentido de entender o espalhamento de determinados traços diagnósticos cerâmicos compartilhados, a partir da apresentação e descrição de cerâmicas arqueológicas dos Llanos de Mojos e Brasil (Betancourt, 2003, 2011), provindas de coleções reunida por Nordenskiöld no início do século XX (alguns locais de coleta foram os mesmo onde Miller escavou décadas depois), a pesquisadora consegue estabelecer comparações entre as cerâmicas dos lados esquerdo e direito da bacia do rio Guaporé. Para a arqueóloga, é pertinente pensar que houve o compartilhamento de atributos da iconografia cerâmica - poucos elementos são relacionados por comparações entre as morfologias e a composição das pastas - entre os sítios do lado boliviano e do lado brasileiro.

Ligações culturais entre as fases Corumbiara/Pimenteiras e o Llanos de Mojos já eram propostas por Miller (1983, p. 264), visto a recorrência de faces de jaguares nos motivos incisos das cerâmicas estudadas no alto-médio rio Guaporé, o que poderia remeter ao culto do jaguar, traço mítico característico encontrado nos Mojos (Métraux 1948). Contudo tal hipótese não é plenamente desenvolvida e permanece no plano especulativo. 

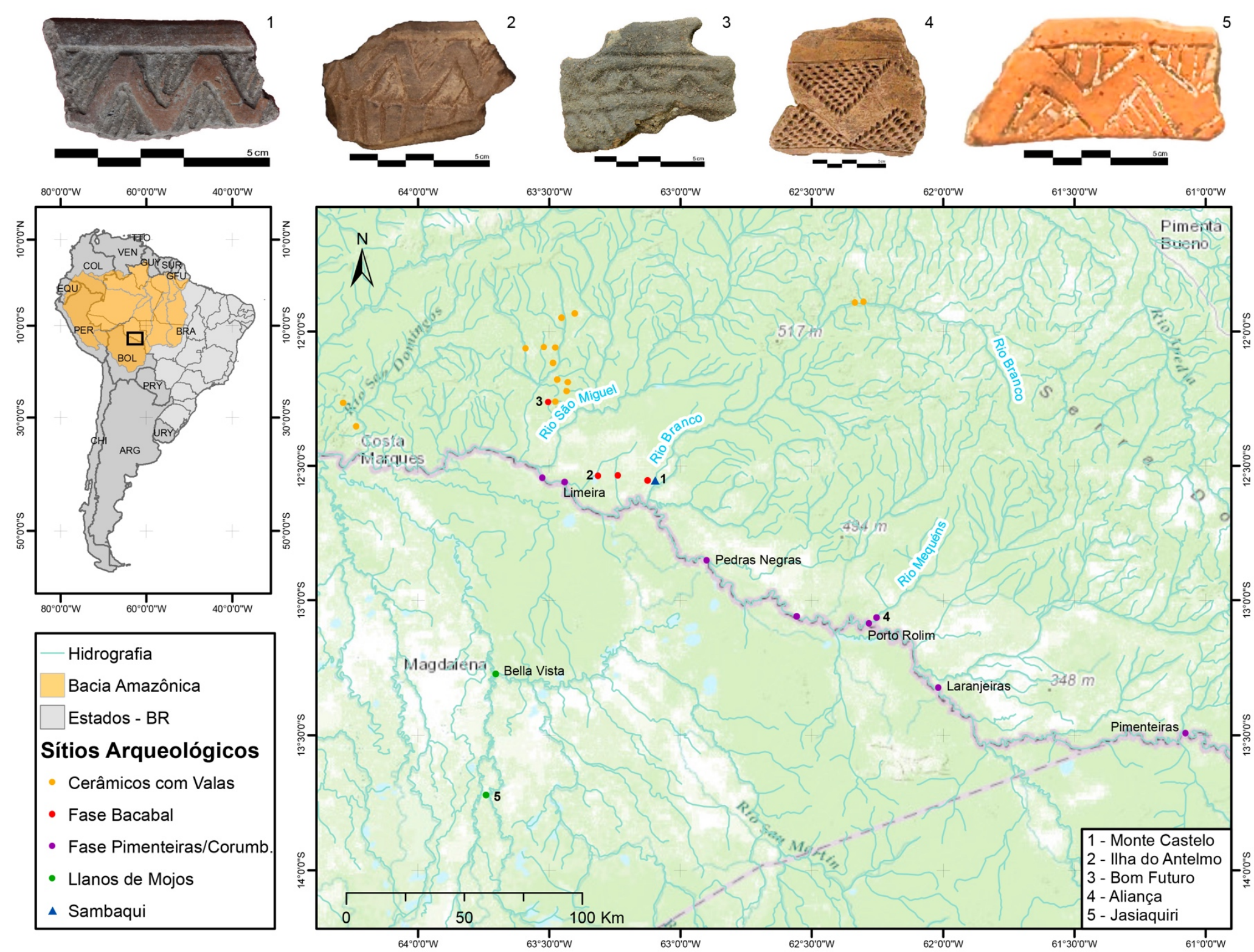

Imagem 32: Mapa da localização de sítios arqueológicos no médio rio Guaporé, Rondônia, Brasil. Cerâmicas da fase Bacabal: Monte Castelo (1) Ilha do Antelmo (2) Bom Futuro (3) e outras encontradas em na região: Sítio Jasiasquiri (5: Betancourt, 2014) Sítio Aliança. 
Não temos dados suficientes ainda para estabelecer se a diferença nos conjuntos cerâmicos deste contexto poderia ser resultado da variabilidade cultural no passado ou se estas diferenças resultam de diferenças cronológicas, A comparação dos traços em comum transpassa as comparações dos motivos estilísticos da cerâmica e estabelece uma relação de compartilhamento de traços culturais.

Os sítios do médio rio Guaporé e dos Llanos de Mojos orientais podem ter em comum elementos decorativos impressos na cerâmica, e de características relacionadas ao padrão de assentamento, com sítios normalmente rasos (os mais típicos são encontrados com a TPI apresentando cerca de $50 \mathrm{~cm}$ de espessura), com estruturas em terra de formas variadas e que aparecem tardiamente no contexto arqueológico regional, por volta do século $\mathrm{X}$.

Dentro das coleções dos sítios comparados por Betancourt (2011) é recorrente encontrarem-se fragmentos que saem do padrão decorativo mais comum no médio Guaporé, mas que podem ser comparados a cerâmicas de outras partes da bacia. No sítio Bella Vista, é apresentada informação sobre tipos decorativos de diferentes partes do Guaporé que são encontrados no conjunto cerâmico daquele assentamento. A partir da coexistência dessas cerâmicas em diversos sítios e das evidências arqueológicas que levam a interpretá-los como assentamentos unicomponenciais, a pesquisadora afirma que as diferenças nos complexos cerâmicos não seriam cronológicas e podem ser interpretadas como testemunhos de contatos, trocas e influências.

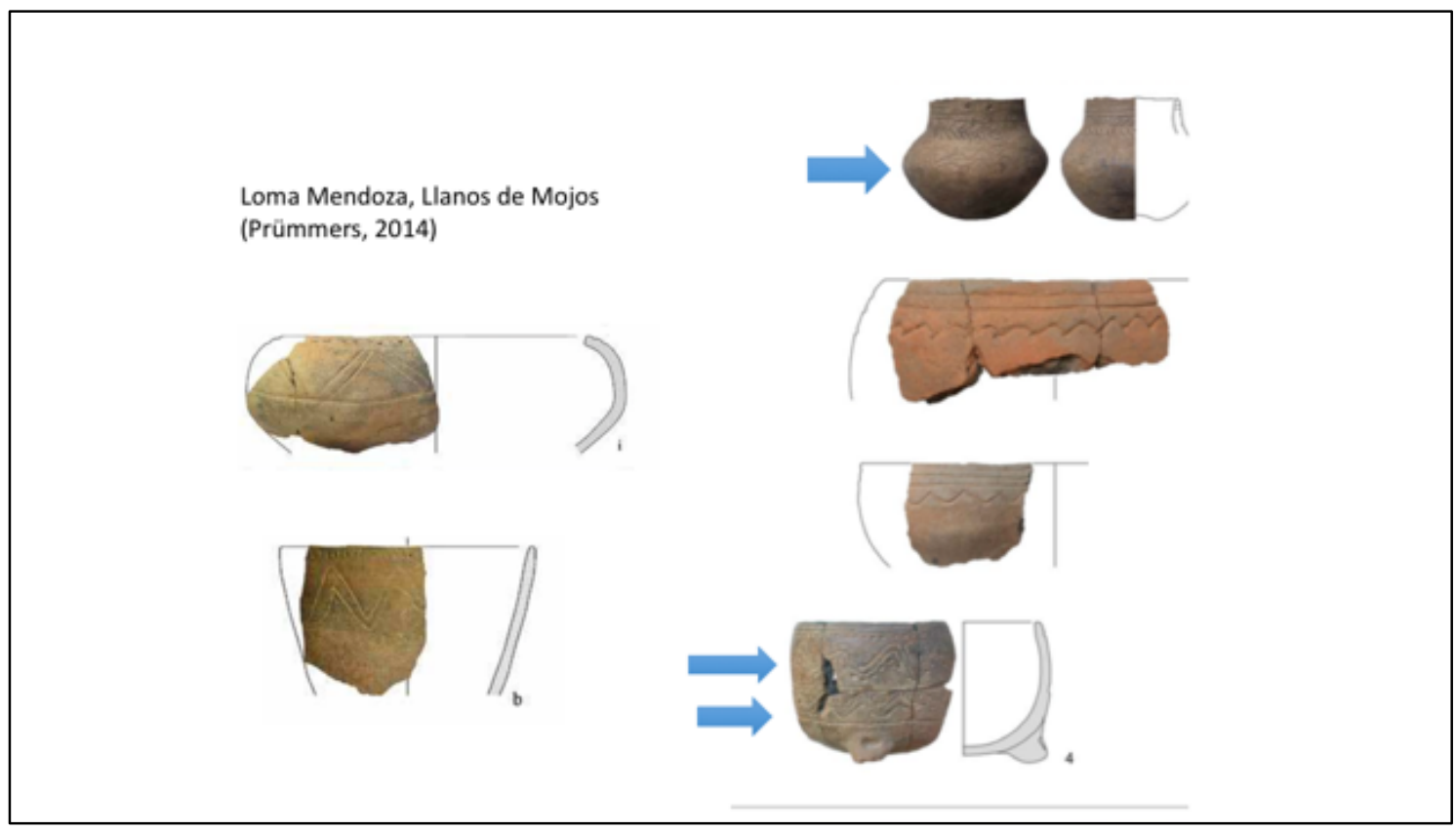



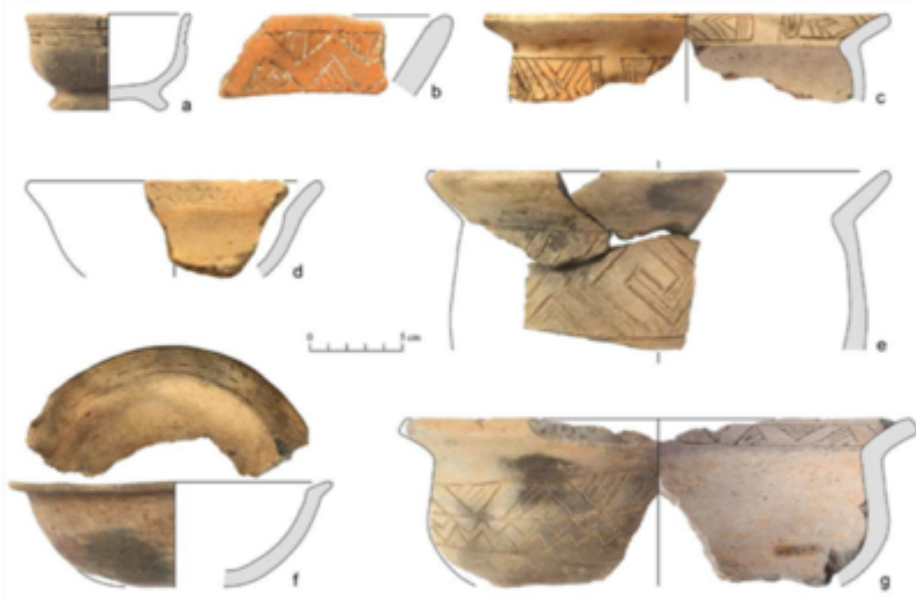

9

Sendo assim, para Betancourt $(2011,2014)$, o mosaico cultural encontrado nos Llanos orientais pode ser mais complexo que as diferenças encontradas nas construções em terra documentadas e a cerâmica pode ter um papel fundamental para decifrar este código. Segundo a autora, a construção das zanjas não foi somente um fenômeno tardio, mas também um fenômeno multicultural.

As pesquisas arqueológicas nos Llanos de Mojos demonstram que dentro da distribuição na paisagem podem existir diferenças nas construções, como a uma maior ocorrência de zanjas na área oriental, enquanto a área central tende a apresentar maior ocorrência de montículos habitacionais e aterros denominados canelones (Denevan 1963, 1980; Dougherty y Calandra 1984-5; Erickson 2000, 2006, 2008; Prümers et al. 2006). Essas construções em terra teriam capacidade de demonstrar evidências de diferenças culturais um pouco difusas no tempo e no espaço, a cerâmica desses diferentes locais poderia ajudar a fortalecer a hipótese de diversidade cultural vinculada ao fenômeno das construções. (Betancourt, 2011)

O motivo mais recorrente da fase Bacabal, classificado como Bacabal, aparece em diversos conjuntos descritos no lado brasileiro e nos Llanos de Mojos (imagem 32, n. $3)$.

O motivo Bacabal e suas variantes incisas ocorrem comumente em sítios da região, além de também ocorrerem como pintura nos Llanos de Mojos centrais e no Pantanal mato-grossense, mais especificamente na tradição Descalvados, onde há um padrão de assentamento muito semelhante ao verificado nas planícies encharcadas do Guaporé 
(Migliacio 2006). É fato que a utilização desse elemento estilístico teve uma distribuição muito ampla, que não foi restrita à bacia do rio Guaporé.

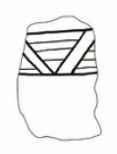

a

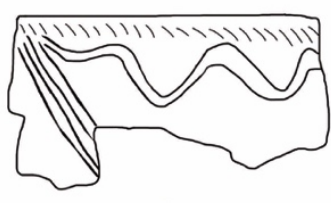

d

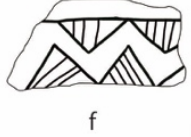

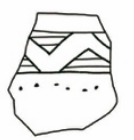

b
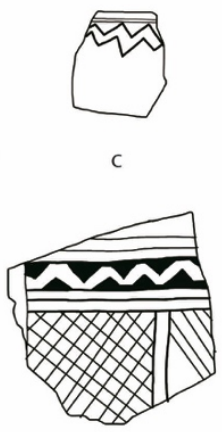

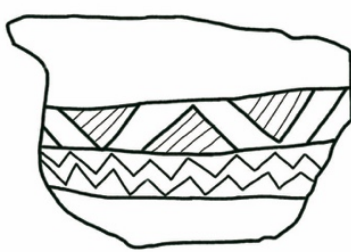

g

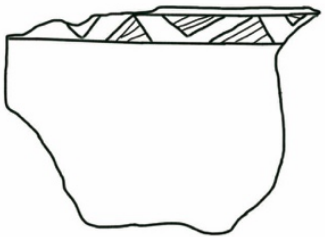

$\mathrm{h}$

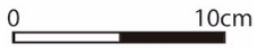

Imagem 33:Ocorrência do motivo decorativo recorrente na fase Bacabal-Bacabal inciso e Bacabal exciso-inciso-hachurado - e suas idiossincrasias nas fases Corumbiara e Pimenteiras Sítio aliança $(a, b, c)$; Bolivia: Sítio Loma Mendoza (d); Sítio Jasiaquiri (f-h); Pantanal do MatoGrosso, tradição Descalvados (e). Com exceção da figura (e), que tem o motivo representado em pintura vermelha sobre engobo branco, as demais são representadas a partir da técnica de decoração plástica. Figura elaborada a partir de imagens de publicações de Miller (1983); Betancourt (2014); Prümmers (2014) e Migliacio (2006). (Fonte: Zimpel e Pugliese, 2016).

Para as relações históricas entre as fases cerâmicas descritas acima, de maneira geral, existem duas hipóteses estabelecidas: 1) os sítios Bacabal apresentam correlações, a partir da comparação de atributos estilísticos na cerâmica, com sítios do alto rio Guaporé (Miller, 2013) e 2) os sítios do médio Guaporé apresentam correlações estilísticas com a cerâmica dos sítios localizados nos Llanos de Mojos orientais (Betancourt, 2011). Entretanto, uma pergunta permanece pouco explorada: entre o alto e o médio Guaporé existem elementos ou traços estilísticos que possibilitam o estabelecimento de correlações entre os sítios? Existe relação entre a cerâmica encontrada nas ilhas de terra firme adjacentes ao rio - fase Corumbiara e Pimenteiras e a fase Bacabal? 
As comparações feitas por Miller (2009a, 2013) são voltadas para a análise dos tipos decorados - a tecnologia cerâmica, a morfologia dos potes e o padrão de assentamento não foram relevantes para o autor naquele momento. Entretanto, se avaliarmos estes parâmetros, percebe-se que podem ter no ocorrido relações entre a fase Bacabal e as demais fases do médio e alto Guaporé e até mesmo em rincões mais distantes, já em solo boliviano. Essas interações dizem respeito - além dos motivos iconográficos encontrados - à tecnologia cerâmica e aos padrões de assentamento que vêm sendo investigados.

É significativo o fato de que um elemento muito comum na cerâmica Bacabal apresente essa vasta recorrência e que, além dos sítios das fases Galera, Poaia e Aguapé, também esteja presente nos contextos de sítios com estruturas construídas em terra. Porém, motivos iconográficos e padrão de assentamento assemelhados entre si não implicam, necessariamente, que os conjuntos arqueológicos onde inserem-se essas indústrias cerâmicas.

Por outro lado, há que se considerar que essa mudança tecnológica marcada na pasta das cerâmicas que ocorre no lado brasileiro do Guaporé parece não acontecer de maneira tão marcada no lado boliviano, pois nos sítios dos Llanos de Mojos os antiplásticos parecem ser compostos de elementos diferentes daqueles mais recorrentes na Amazônia brasileira, como o cariapé e o cauixi. Os indícios que temos na Bolívia foram apresentados por Dougherty e Calandra (1984-5) nas fases criadas para cerâmicas que ocorrem nas proximidades com o Brasil, mas são encontrados em pequena proporção em relação à amostra total e somente em fragmentos temperados com cauixi. E nestas cerâmicas também são descritos motivos e traços semelhantes ao encontrados em Bacabal (Imagem 34). 


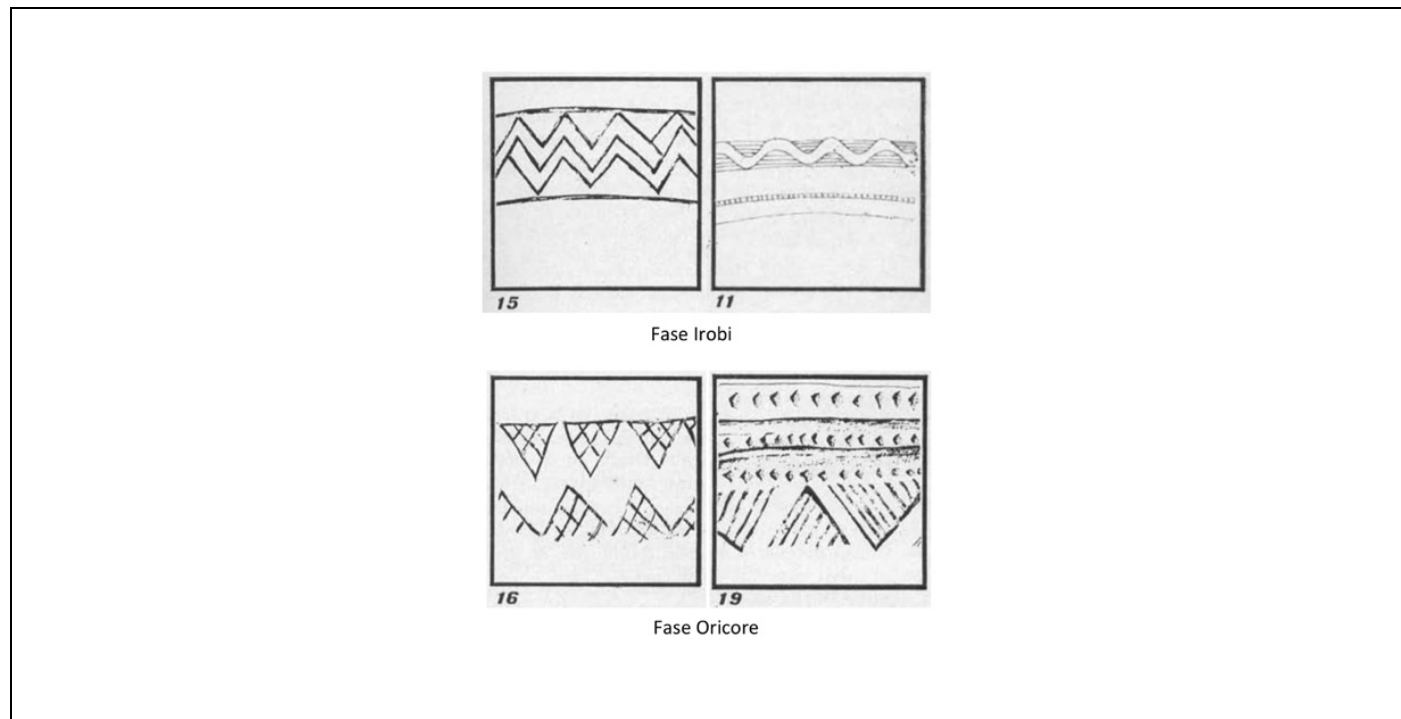

Imagem 34: Motivos encontrados nas cerâmicas no Guaporé do lado boliviano, de Dougherty e Calandra (1985).

Betancourt e Prümmers (2015) escavam na localidade de Jasiaquiri relatam que as camadas datadas entre os século IV-V, relacionadas a fase Jasiaquiri, poderiam muito provavelmente equivalentes ao que Dougherty e Calandra chamaram de fase Oricoré.

A cerâmica da fase Jasiaquiri possui uma característica em sua composição que é compartida com a fase Bacabal. O antiplástico da pasta é composto por areia e chamote, porém ocorre em concomitância a estes elementos “ poros y cavidades vacías dejadas por la combustión de algún material vegetal" que muito provavelmente remetem aqueles mesmos vazios reconhecidos na cerâmica estudada em Monte Castelo.

Outros elementos para se mencionar que nesta fase não são encontradas bases com de impressões (tecido, cestaria) e que são características em potes da fase Bella Vista, encontrada na mesma região, entre os séculos XIII e XVI (Prümers et al. 20061; Betancourt 2013). Essas impressões são frequentes na fase Bacabal e em outros sítios nos Llanos de Mojos, como as lomas Salvatierra e Casarabe (Betancourt 2010; 2013), tendo variação no suporte ou instrumento utilizado para a impressão. Outro fato é de que as datas mais antigas de Jasiaquiri são muito próximas as datas mais antigas que Miller descarta para as fases Corumbiara/Pimenteiras, podendo estas serem reconsideradas.

Ainda no lado boliviano, outras cerâmicas do rio Machupo e do sítio Granja do Padre possuem também o cauixi, mas não possuem descrição de motivos que se assemelhem a Bacabal.

Afora estes casos, nas cerâmicas onde o motivo Bacabal exciso e suas variantes incisas ocorreram, o antiplástico era composto prioritariamente de areia, chamote e, por 
vezes, conchas e caulim. Entretanto, mais ao norte, na cerâmica dos sítios com estruturas em terra de Riberalta descritos por Saunaluoma (2010), o cariapé parece ter sido utilizado mais amplamente, mas em contextos que não apresentam, a princípio, elementos iconográficos em comum com as cerâmicas do rio Guaporé.

É conveniente observar como ideias expressadas na iconografia da cerâmica podem ter percorrido mais de 300 quilômetros, diversificando-se por vários ambientes, sem que se alterassem significativamente aqueles aspectos mais rígidos do fazer cerâmico, como os componentes da pasta e a morfologia dos utensílios. Pensando nessas possibilidades, o estudo das variedades de pasta no tempo e no espaço nos fornece indícios que ajudam no entendimento da diversificação e da multiplicação dos sujeitos que construíram a paisagem do Guaporé e dos Llanos de Mojos e seus entrelaçamentos.

Curiosamente se percebe que não havendo uma fronteira clara para os padrões de assentamento, uma vez que há um contexto bem difundido de construções em terra por todo o sudoeste amazônico, podemos constatar certos limites para a ocorrência de diferentes tipos de antiplásticos presentes nas pastas das cerâmicas destes assentamentos. Os dados disponíveis indicam que o rio Guaporé demarca uma área de transição entre culturas cerâmicas que em sua pasta possuem antiplásticos com características amazônicas e outras com antiplásticos com características do Chaco e do alto Paraguai. Sítios com cariapé estão relacionados ao contexto do alto rio Madeira (Zuse, 2014; Almeida, 2014) e as fases cerâmicas dos geoglifos do Acre (Dias, 2006) e ocorrem em território boliviano somente mais ao norte, nos sítios de Riberalta (Saunaluoma, 2010).

A história da circulação e do compartilhamento de elementos iconográficos pode ajudar a entender os eventos que no passado estavam associados às construções em terra, fenômeno amplamente difundido em todo o sudoeste amazônico e sobre o qual inicia-se o entendimento sobre sua variabilidade cronológica e espacial.

Como vimos, determinados elementos que serviram para a comparação de Miller entre a fase Bacabal e as fases do alto Guaporé são encontrados tanto na cerâmica Corumbiara e Pimenteiras, quanto nas áreas bolivianas mais próximas ao Brasil.

Entender a relação entre as fases Pimenteiras e Corumbiara e a fase Bacabal pode ajudar a compreender a história das nações que modelaram a paisagem do sudoeste amazônico já que como vimos, para a cronologia disponível do lado direito do rio Guaporé, há uma sequência de ocupação que apresenta uma continuidade sem hiatos durante 8000 anos, e no lado esquerdo, na região do Llanos de Mojos, aparentemente contextos mais antigos também estão sendo descobertos (Lombardo et al 2013; Walker 2015) 
Hipóteses correntes sobre as construções em terra no sudoeste amazônico colocam a difusão do fenômeno em um período tardio na longa história de ocupação da região (ca. $400 \mathrm{AD}$ ), por outro temos no Brasil aterros que contém mais de 8000 anos de história e valas que podem ter começado a ser escavadas antes mesmo do século III.

Entre os primeiros resultados obtidos em nossas pesquisas na bacia do médio rio Guaporé, foi possível identificar um grande número de sítios típicos da fase Bacabal, significando uma ampliação considerável na área de ocorrência dos mesmos (antes restrita ao sambaqui e alguns sítios do entorno), que agora são encontrados em ilhas de terra firme um tanto distantes do sítio Monte Castelo, como o sítio Ilha do Antelmo, e em outros assentamentos em áreas mais elevadas do município de São Francisco do Guaporé (Imagem 32). Nos levantamentos realizados naquela área, têm sido encontradas cerâmicas que podem ser diretamente relacionadas às ocupações Bacabal do Pantanal do Guaporé. As decorações apresentam, além das típicas representações de quelônios por meio de apliques em vasilhames abertos (pratos), o zonado-hachurado com excisões e suas idiossincrasias que compõe o maior número de vestígios decorativos que são encontrados nas vasilhas da fase Bacabal.

Percebe-se que a área de ocorrência da fase Bacabal não está restrita ao sambaqui e aos sítios do seu entorno e que elementos decorativos diagnósticos relacionados à fase notadamente o Bacabal exciso e o Bacabal Inciso, que possuem datações que recuam a 3000 a.C. e relativa estabilidade testemunhada durante três milênios, ao menos, no sambaqui Monte Castelo - ocorrem também em diversos outros sítios da região do médio rio Guaporé e adjacências, como é caso dos sítios Jasiaquiri e Bella Vista na Bolívia e dos aterros da tradição Descalvados no estado do Mato Grosso. Por outro lado, apesar de apresentar elementos decorativos compartilhados nos vasilhames e características semelhantes no padrão de assentamento dos sítios arqueológicos, elementos mais rígidos da tecnologia cerâmica - como a escolha dos temperos da pasta e a morfologia dos potes - aparecem geograficamente bem demarcados naquele cenário da Amazônia antiga, sendo possível identificar duas tendências culturais diferentes: uma localizada no lado oriental do médio rio Guaporé, com suas pastas amazônicas temperadas com cauixi e cariapé, e outra encontrada do lado ocidental da bacia, cujas cerâmicas contam com a presença expressiva de chamote, um material antiplástico cuja incidência é muito mais representativa em conjuntos arqueológicos chaqueños e andinos.

A avaliação das informações arqueológicas disponíveis indica que a distribuição dos conjuntos cerâmicos estudados representa um caso em que as fronteiras entre culturas 
arqueológicas não são bem definidas, e não necessariamente resultado de situações de conflito no passado. Ao contrário, se por um lado as fronteiras bem demarcadas na tecnologia e na morfologia da cerâmica sustentam a possibilidade da presença de uma unidade cultural marcada na história antiga dos povos que habitaram o médio Guaporé, situações de interação social parecem ter ocorrido, como o caso das construções em terra, por exemplo, gerando os correlatos de intercâmbio cultural que são encontrados na forma de elementos em comum, presentes em sítios dispersos por ampla região arqueológica.

Nesse sentido, os dados apresentados em Zimpel e Pugliese (2016) e outros mencionados aqui vão na mesma direção que aqueles apresentados por Betancourt (2011, 2014), quando sugere que o processo de revolvimento de terra no sudoeste amazônico foi fruto de uma gênese multicultural. Entretanto, o período em que o fenômeno ocorre na região pode ser reavaliado, uma vez que há dados sobre ocupações mais antigas do que aquelas relacionadas à formação dos sítios nos dois últimos milênios. Considerando as datações produzidas no sambaqui Monte Castelo - que sugerem uma continuidade com as ocupações Corumbiara/Pimenteiras remontando uma história de pelo menos 4000 anos de revolvimentos de terra em uma região adjacente aos Mojos na Bolívia - o início da história de construções em terra e de interações culturais pode estar vinculado ao Holoceno médio, ou a um período de ocupação até mesmo mais antigo, ainda que o registro arqueológico dessas estruturas esteja, em sua maioria, em sítios cujas datações situam-se em um período relativamente bem mais recente ( $>300$ a.C.). Existem diferentes contextos que antecedem a formação dos sítios em relação ao horizonte inicial de construção aterros encontrados em outros pontos do sudoeste amazônico e áreas adjacentes, como o sambaqui Monte Castelo e outras "ilhas" antrópicas na Bolívia (Lombardo, 2013) e os aterros nos estados do Mato Grosso (Migliacio 2006) e do Mato Grosso do Sul (Schmitz et al. 1998). 


\section{Capítulo 3 - Sitio Monte Castelo e a fase Bacabal}

\section{Descrição da área de pesquisa}

Os vestígios arqueológicos classificados como fase Bacabal estão localizados na região conhecida como Pantanal do Guaporé, que está situada na região sudoeste da Amazônia, em uma área de transição entre a floresta e cerrado. Este rio possui mais de $1100 \mathrm{~km}$ entre a sua nascente, próxima a cidade de Vila Bela no Mato Grosso, e a foz, no distrito de Surpresa, Rondônia, quando se junta ao baixo curso do rio Mamoré, que dá início ao seu trecho encachoeirado que ajuda a formar o rio Madeira.

A navegação do rio Guaporé é tranquila, somente nos períodos extremos do verão (julho a outubro) é que surgem obstáculos, como bancos de areia e pedrais em dois locais, à montante na comunidade quilombola de Pedras Negras e à jusante, de fronte ao Forte Príncipe da Beira.

Durante o médio curso no Pantanal depara-se com uma predominância de ecossistemas aquáticos representados por pantanais e extensas planícies inundáveis por rios de água clara, além de lagos/lagoas marginais, canais, baías e igarapés (Brasil 1984). 


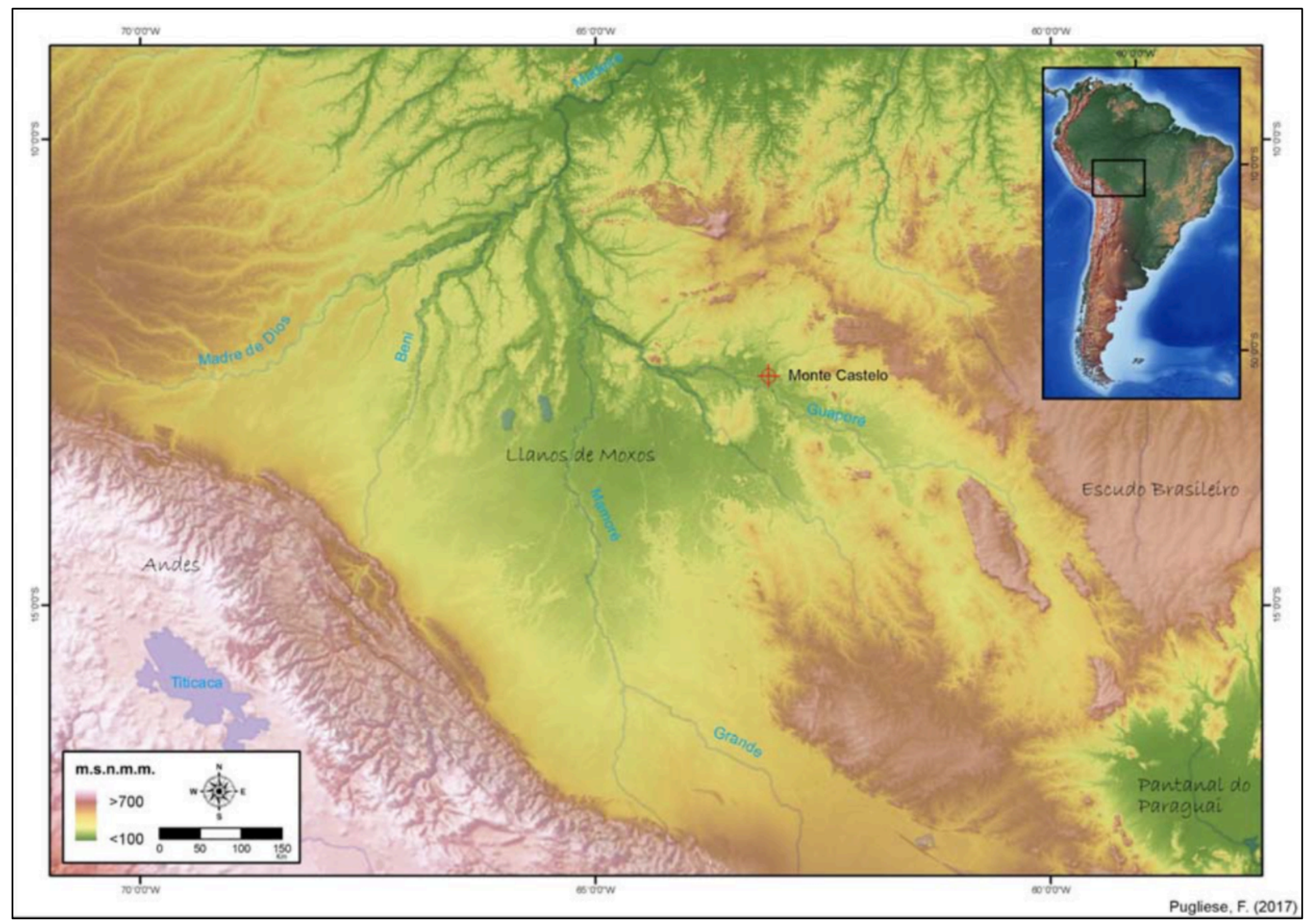

Imagem 35: modelo de elevação digital da região de estudo (Pugliese 2017)

Geomorfologicamente a área está situada sobre os sedimentos das unidades Depressão do Guaporé e Planícies e Pantanais do Médio e Alto Guaporé. Estas são caracterizadas por terem largas superfícies pediplanadas com altitudes variando sempre abaixo de 200m, com ocorrência de áreas de acumulação permanente de água e locais sujeitos a inundações periódicas, sob maior influência hidrográfica de rios afluentes como o rio Branco. As formas de relevo associadas a essa região são compostas pela predominância de planícies fluviais, além de terraços fluviais e ilhas de terra firme. As ilhas ocorrem em manchas de terrenos mais altos (acima de 160m) e são locais de abrigo perante as inundações, correspondentes a pequenas áreas da superfície de erosão pediplanadas, isoladas pela sedimentação atual (Brasil 1984).

Sob o ponto de vista da geologia esta área esta sobre formações recentes de acumulação, em coberturas cenozóicas, que compreendem depósitos sedimentáres 
inconsolidados do terciário e quaternário (areias, siltes e argilas da Formação Guaporé), de idade quaternária e de litologias aflorantes do Complexo Xingu (granitos e gnaisses), que ocorrem principalmente ao longo do sistema fluvial (Adamy, 2010).

A Formação Guaporé é encontrada na planície de inundação, é dividida em duas subunidades: uma de nível inferior, antigo e que não inunda, denominado Depósitos Arenosos, que é constituído por areias grossas a médias, frequentemente estratificadas, imaturas, com níveis de cascalho e lentes de argila. E um nível superior, mais recente, denominado Depósitos Pantanosos, correspondente à área da planície de inundação do rio Guaporé, sazonalmente inundável, composto por areia fina maciça, esbranquiçada, intercalada com silte e contendo lentes de argila.

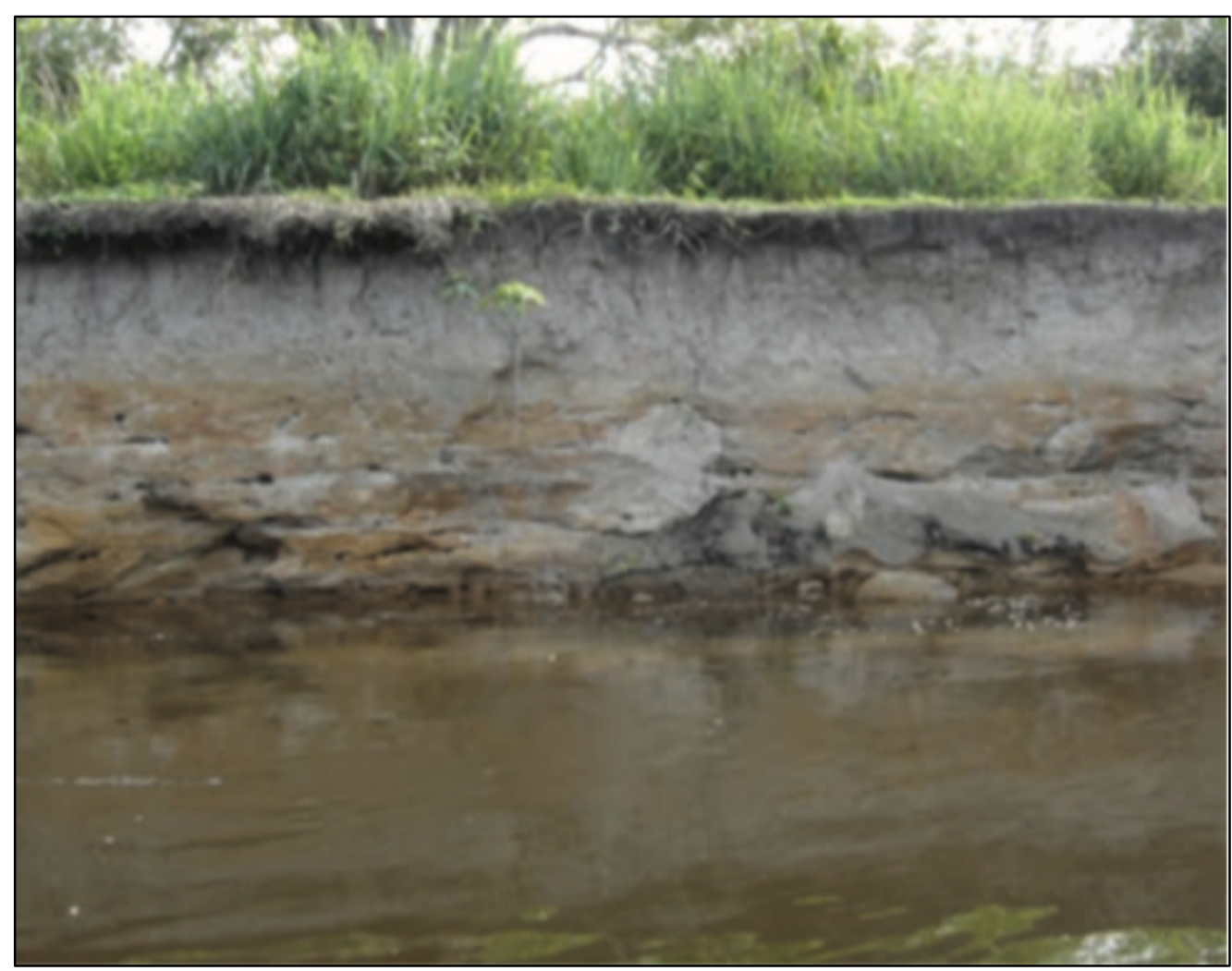

Imagem 36: Areias e lentes de argila da formação Guaporé (Adamy 2010).

$\mathrm{Na}$ área os tipos de solos encontrados são: Plintossolos, Cambissolos, Espodossolos, Gleissolos e, de maneira predominante o Latossolo. Além destes tipos, são encontrados de maneira esparsa trechos de Neossolos, que por sua vez são constituídos por material mineral, ou por material orgânico pouco espesso (Brasil 1984).

Os solos de áreas inundáveis (Gleisolos e Neossolos), não são próprios ao plantio de culturas perenes ou espécies de raízes profundas, as quais não permitem seu 
aproveitamento durante o período chuvoso. Os Plintossolos estão presentes em áreas de pouca drenagem. Durante o verão (seca), estes solos proporcionam boa potencialidade para culturas de ciclo curto. Outras áreas de solos mais arenosos, que apresentam pouca capacidade de fixar nutrientes (espodossolos) tem anualmente sua matéria orgânica renovadas por conta da sazonalidade do regime de cheia dos rios, conferindo assim uma maior fertilidade. (Adamy, 2010)

O pantanal é recoberto por imensos campos de gramíneas nativas, florestas de igapó e galeria que são sazonalmente inundadas, assim como amplos buritizais e matas de pindaíba. São formações pioneiras fluviais, arbustivas, graminóides e de buriti, que ocorrem predominantes entre zonas com Floresta Ombrófila Aberta, aluvial e submontana.

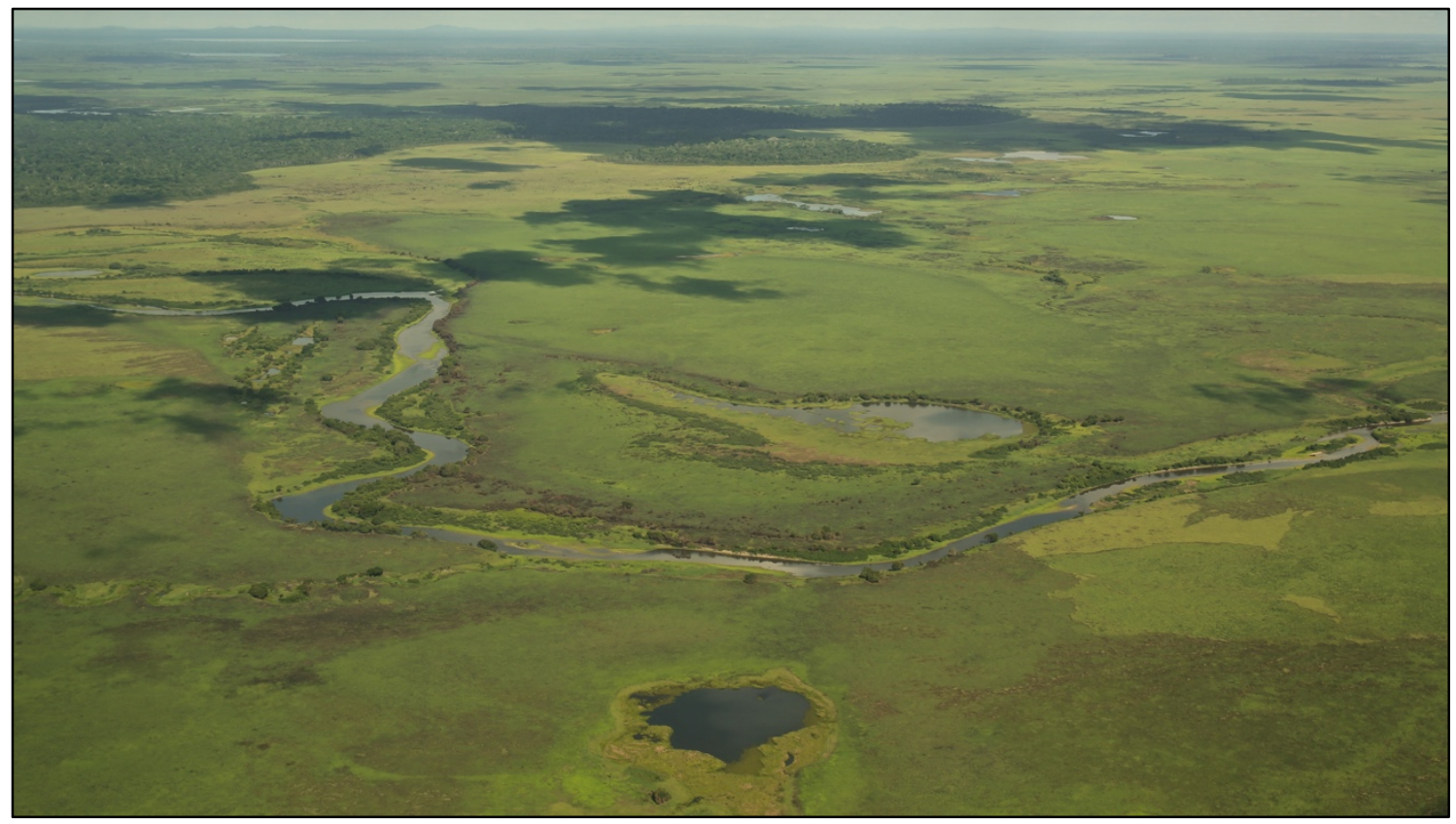

Imagem 37: vista aérea do rio Branco e adjacências. 


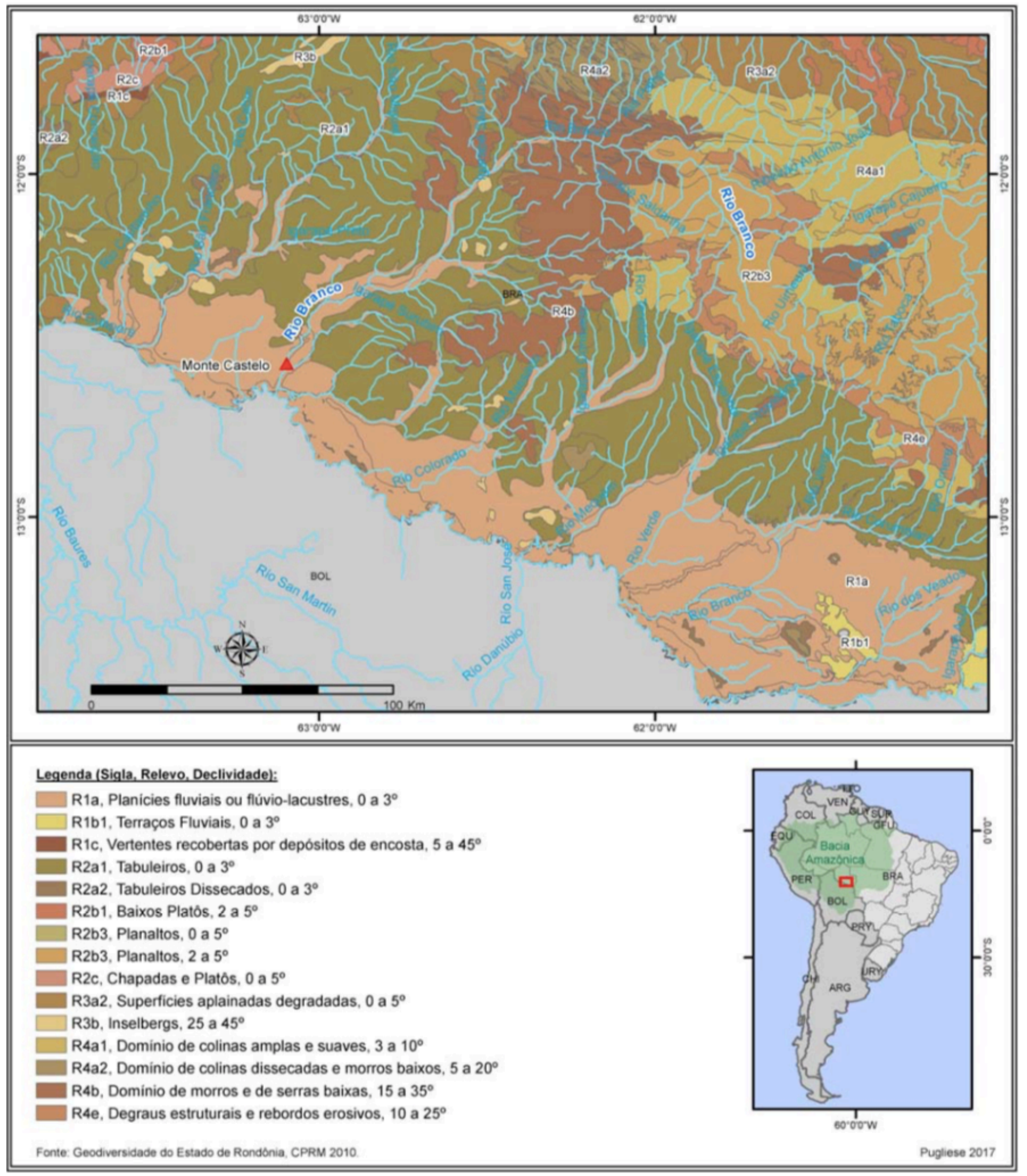

Imagem 38: mapa do relevo (pugliese 2017) 


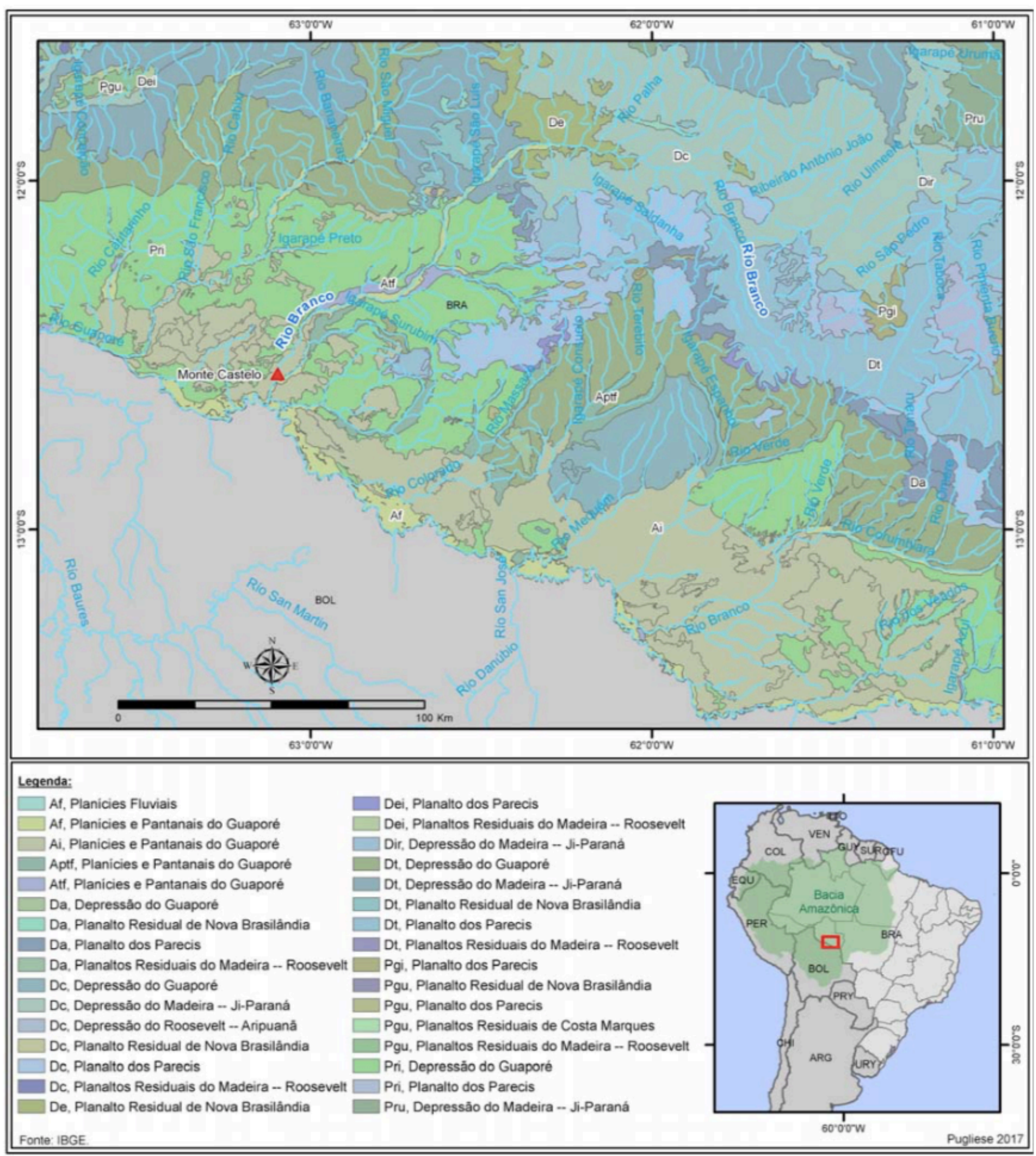

Imagem 39: Mapa geomorfológico (Pugliese 2017) 


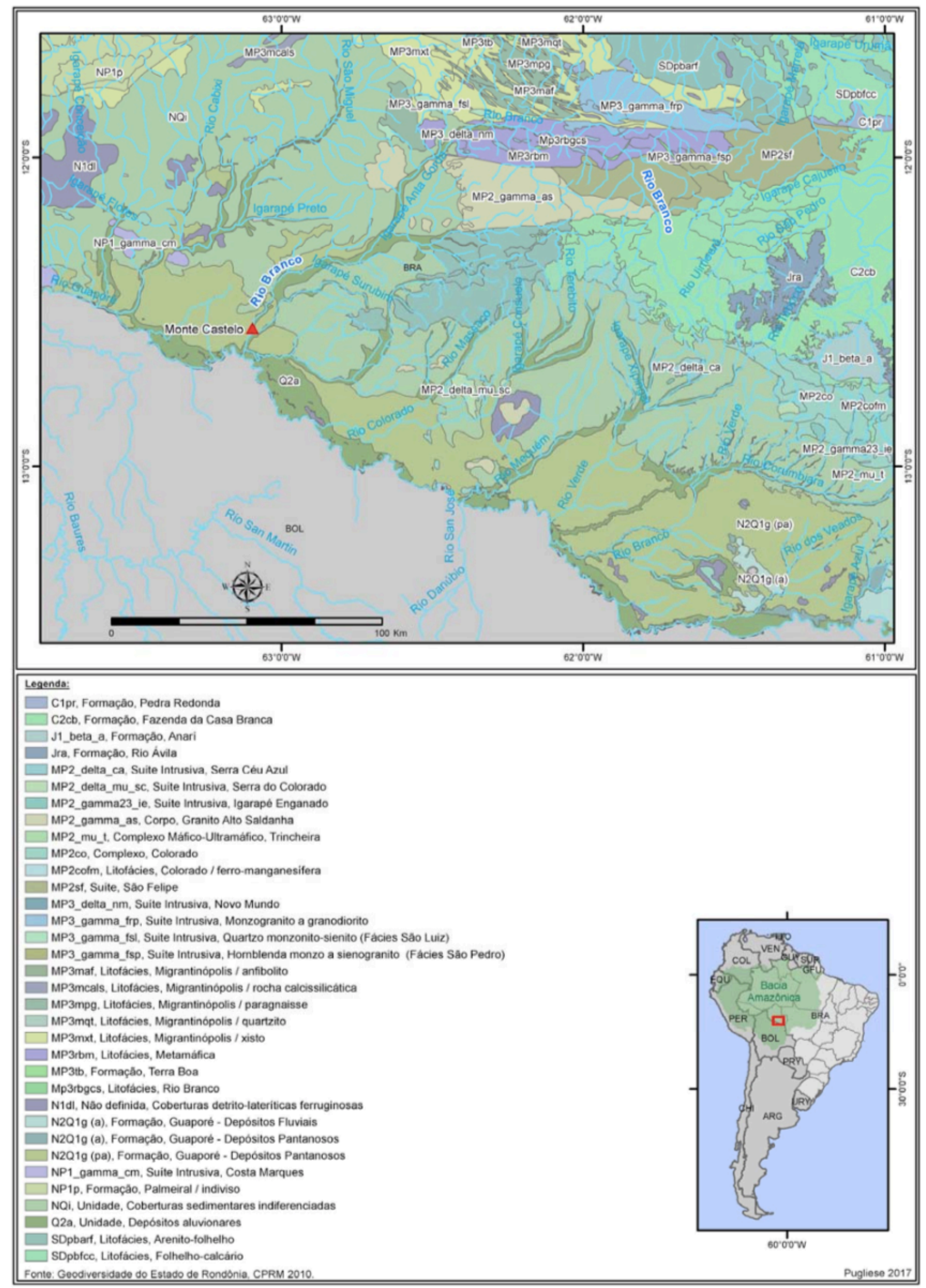

Imagem 40: mapa da geológico (Pugliese 2017) 


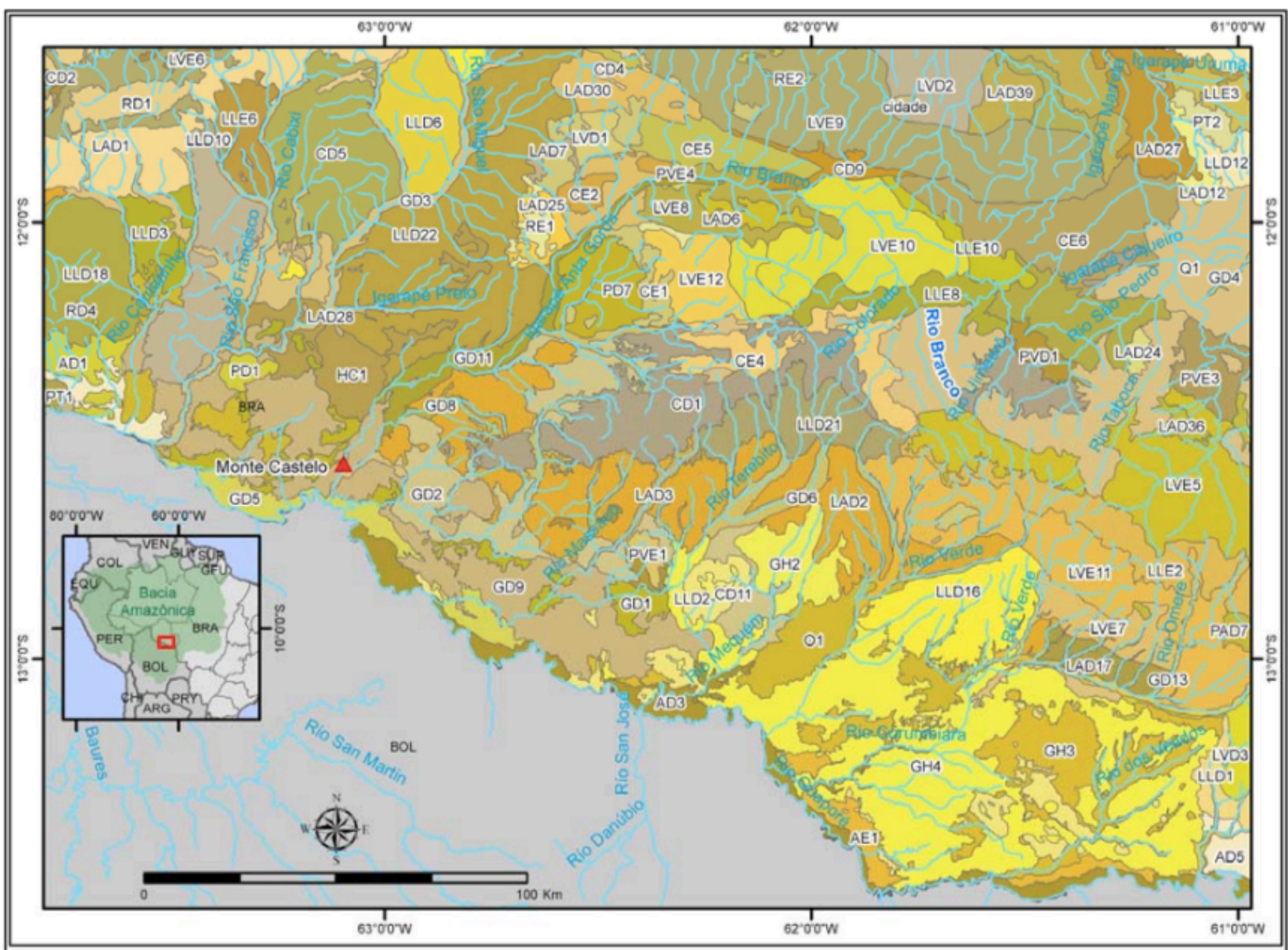

\begin{tabular}{|c|c|c|c|}
\hline \multicolumn{4}{|c|}{ Legenda: } \\
\hline & AD1, Solos Aluviais Distróficos & LAD1, Latossolos Amarelos Distróficos & LVD1, Latossolos Vermelho-Escuros Distróficos \\
\hline & AD3, Solos Aluviais Distróficos & LAD12, Latossolos Amarelos Distróficos & LVD2, Latossolos Vermelho-Escuros Distróficos \\
\hline & AD5, Solos Aluviais Distróficos & LAD17, Latossolos Amarelos Distróficos & LVD3, Latossolos Vermelho-Escuros Distróficos \\
\hline & AE1, Solos Aluviais Eutróficos & LAD2, Latossolos Amarelos Distróficos & LVE10, Latossolos Vermelho-Escuros Eutróficos \\
\hline & CD1, Cambissolos Distróficos & LAD24, Latossolos Amarelos Distróficos & LVE11, Latossolos Vermelho-Escuros Eutróficos \\
\hline & CD11, Cambissolos Distróficos & LAD25, Latossolos Amarelos Distróficos & LVE12, Latossolos Vermelho-Escuros Eutróficos \\
\hline & CD2, Cambissolos Distróficos & LAD27, Latossolos Amarelos Distróficos & LVE5, Latossolos Vermelho-Escuros Eutróficos \\
\hline & CD4, Cambissolos Distróficos & LAD28, Latossolos Amarelos Distróficos & LVE6, Latossolos Vermelho-Escuros Eutróficos \\
\hline & CD5, Cambissolos Distróficos & LAD3, Latossolos Amarelos Distróficos & LVE7, Latossolos Vermelho-Escuros Eutróficos \\
\hline & CD9, Cambissolos Distróficos & LAD30, Latossolos Amarelos Distróficos & LVE8, Latossolos Vermelho-Escuros Eutróficos \\
\hline & CE1, Cambissolos Eutróficos & LAD36, Latossolos Amarelos Distróficos & LVE9, Latossolos Vermelho-Escuros Eutróficos \\
\hline & CE2, Cambissolos Eutróficos & LAD39, Latossolos Amarelos Distróficos & O1, Solos Orgánicos \\
\hline & CE4, Cambissolos Eutróficos & LAD6, Latossolos Amarelos Distróficos & PAD7, Podzólicos Amarelos Distróficos \\
\hline & CE5, Cambissolos Eutróficos & LAD7, Latossolos Amarelos Distróficos & PD1, Podzólicos Vermelho-Amarelos Distróficos \\
\hline & CE6, Cambissolos Eutróficos & LLD1, Latossolos Vermelho-Amarelos Distróficos & PD7, Podzólicos Vermelho-Amarelos Distróficos \\
\hline & GD1, Solos Glei Distróficos & LLD10, Latossolos Vermelho-Amarelos Distróficos & PT1, Plintossolos \\
\hline & GD11, Solos Glei Distróficos & LLD12, Latossolos Vermelho-Amarelos Distróficos & PT2, Plintossolos \\
\hline & GD13, Solos Glei Distroficos & LLD16, Latossolos Vermelho-Amarelos Distroficos & PVD1, Podzolicos Vermelho-Escuros Distroficos \\
\hline & GD2, Solos Glei Distróficos & LLD18, Latossolos Vermelho-Amarelos Distróficos & PVE1, Podzólicos Vermelho-Escuros Eutróficos \\
\hline & GD3, Solos Glei Distróficos & LLD2, Latossolos Vermelho-Amarelos Distróficos & PVE3, Podzólicos Vermelho-Escuros Eutróficos \\
\hline & GD4, Solos Glei Distróficos & LLD21, Latossolos Vermelho-Amarelos Distróficos & PVE4, Podzólicos Vermelho-Escuros Eutróficos \\
\hline & GD5, Solos Glei Distróficos & LLD22, Latossolos Vermelho-Amarelos Distróficos & Q1, Areias Quartzosas \\
\hline & GD6, Solos Glei Distróficos & LLD3, Latossolos Vermelho-Amarelos Distróficos & RD1, Solos Litólicos Distróficos \\
\hline & GD8, Solos Glei Distróficos & LLD6, Latossolos Vermelho-Amarelos Distróficos & RD4, Solos Litólicos Distróficos \\
\hline & GD9, Solos Glei Distróficos & LLE10, Latossolos Vermelho-Amarelos Eutróficos & RE1, Solos Litólicos Eutróficos \\
\hline & GH2, Solos Glei Húmicos & LLE2, Latossolos Vermelho-Amarelos Eutróficos & RE2, Solos Litólicos Eutróficos \\
\hline & GH3, Solos Glei Húmicos & LLE3, Latossolos Vermelho-Amarelos Eutroficos & TRE1, Terras Roxas Eutróficas \\
\hline & GH4, Solos Glei Húmicos & LLE6, Latossolos Vermelho-Amarelos Eutróficos & cidade, Áreas Urbanas \\
\hline & HC1, Solos Hidromórficos & LLE8, Latossolos Vermelho-Amarelos Eutróficos & \\
\hline & Geodiversidade do Estado de Rondónia, CPR & & Pugliese 2017 \\
\hline
\end{tabular}

Imagem 41: mapa de solos (Pugliese 2017) 


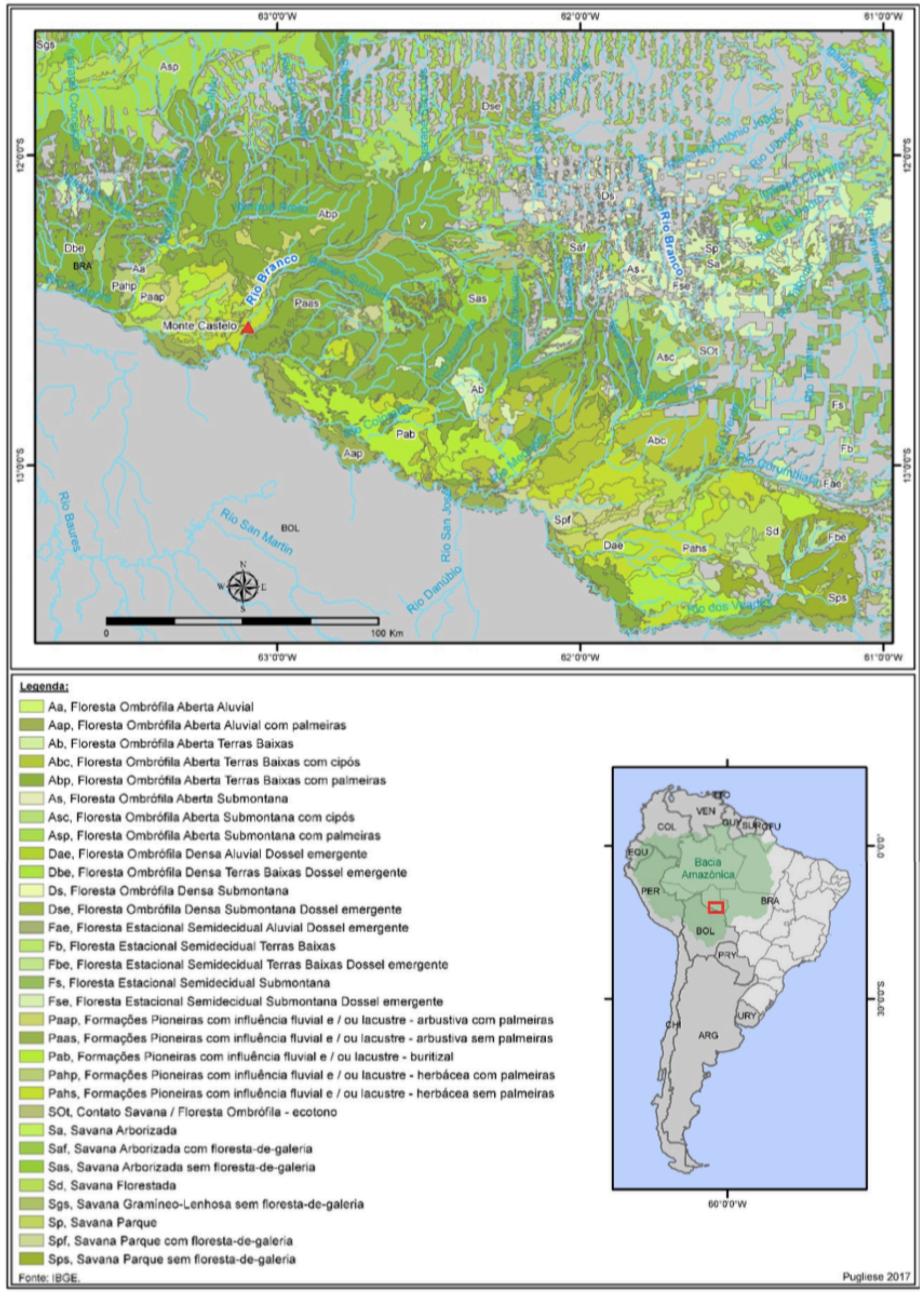

Imagem 42: Mapa de vegetação da área (Pugliese 2017). 


\section{Padrão de assentamento}

O levantamento que temos realizado na área ${ }^{1}$ do Pantanal do Guaporé têm confirmado o modelo de Miller (2009b) onde os sítios arqueológicos relacionados à fase Bacabal ocupam áreas mais elevadas das planícies alagáveis. Os sítios mais recorrentes são encontrados nas "ilhas" de terra firme - em sítios com Terra Preta de Índio (TPI) e em aterros antrópicos - como o sambaqui Monte Castelo. As evidências arqueológicas ocorrem também, mas com menos frequência, em áreas com topografia favorável à ocupação sazonal, como locais relativamente mais altos que são utilizáveis durante a estação seca e em cabeceiras de igarapés

O sítio Ilha União é um exemplo de ocupação em ilhas. Ele está localizado a $11 \mathrm{~km}$ do sambaqui Monte Castelo. Nas pesquisas ali realizadas foi descrita uma dispersão de evidências em uma área elíptica e os vestígios cerâmicos associados à fase Bacabal assim como no sambaqui Monte Castelo - estão situados estratigraficamente acima de evidências líticas atribuídas ao período de ocupação pré-cerâmica da fase Cupim. Ocorrem estruturas compostas por aglomerados de material malacológico junto à TPI e líticos como: mão-de-pilão, mó, almofariz, lascas, percutor e nódulo de ferro com propriedade corante (Miller 2009).

Áreas topograficamente elevadas apresentam ocupações assemelhadas àquelas encontradas nos aterros antrópicos e os vestígios cerâmicos encontrados nesses locais são comumente associados à concentrações de palmeiras, como o babaçu e o buriti, como é o caso da Ilha do Antelmo, outro típico sítio arqueológico associado à fase Bacabal (imagens 43-45).

Ilha do Antelmo está a $22 \mathrm{~km}$ em linha reta do Sambaqui e muito próximo da margem do rio Bacabalzinho. Logo na chegada já é percebido a presença de suaves aterros que circundam a ilha. Nestes aterros ocorrem cerâmicas em superfície, além de matacões e lascas líticas esparsas. As evidências arqueológicas ocorrem também no interior da ilha, onde é encontrada a TPI.

\footnotetext{
${ }^{1}$ Trabalhos realizados no âmbito do projeto de pesquisa: Geoglifos e Sambaquis na bacia do médio rio Guaporé: uma proposta de levantamento arqueológico no sudoeste amazônico. Portaria Iphan no 05/2014, coordenação de Eduardo Goes Neves e Francisco Pugliese.
} 
Também é conhecido o sítio Fazenda Pau d’Óleo, situado na ilha homônima, é caracterizado por uma extensa faixa de TPI associada a um urucurizal onde afloram da superfície fragmentos cerâmicos e líticos.

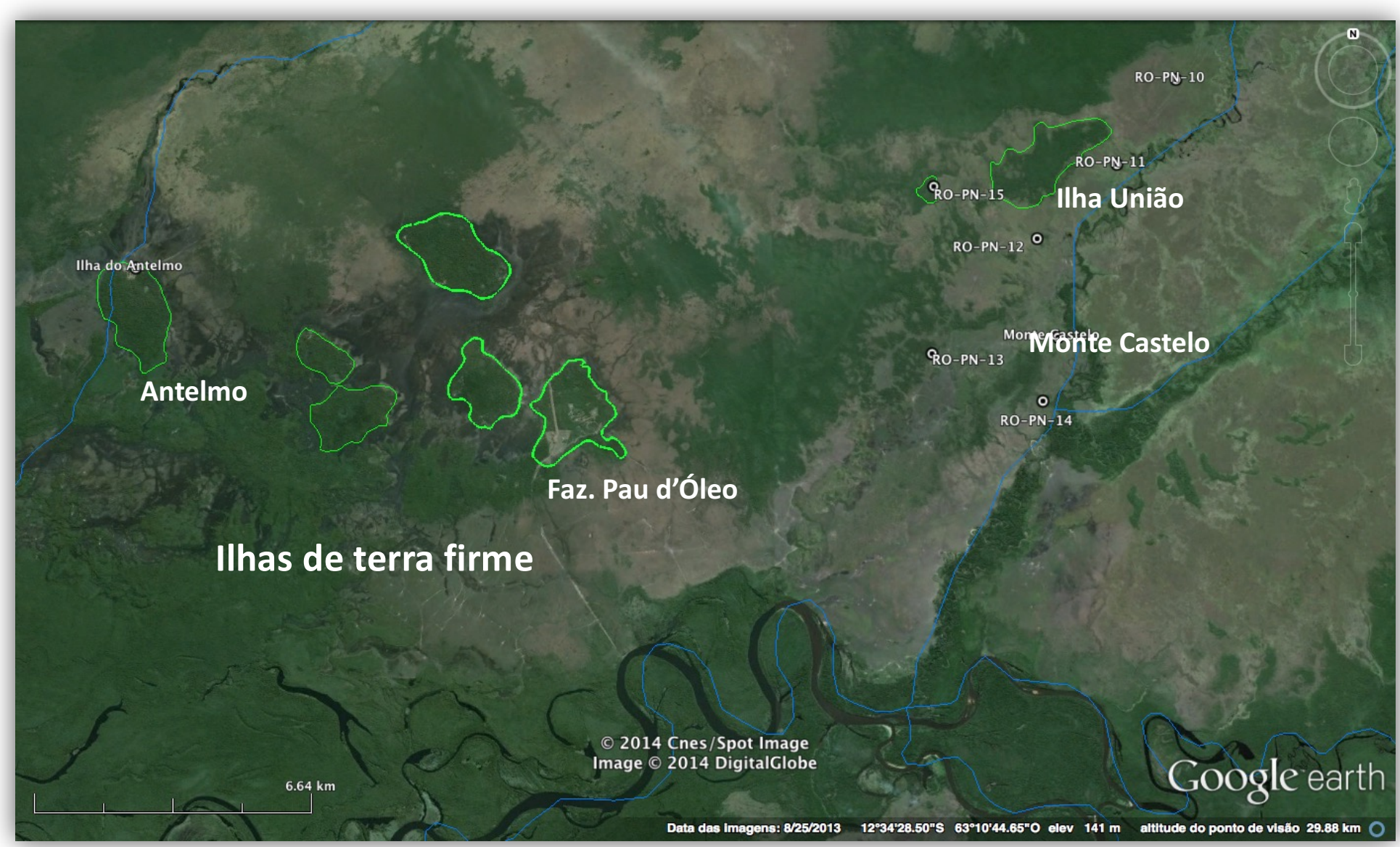

Imagem 43: ilhas de terra firme em meio ao Pantanal do Guaporé. 


\section{Ilhas de terra firme e aterros}

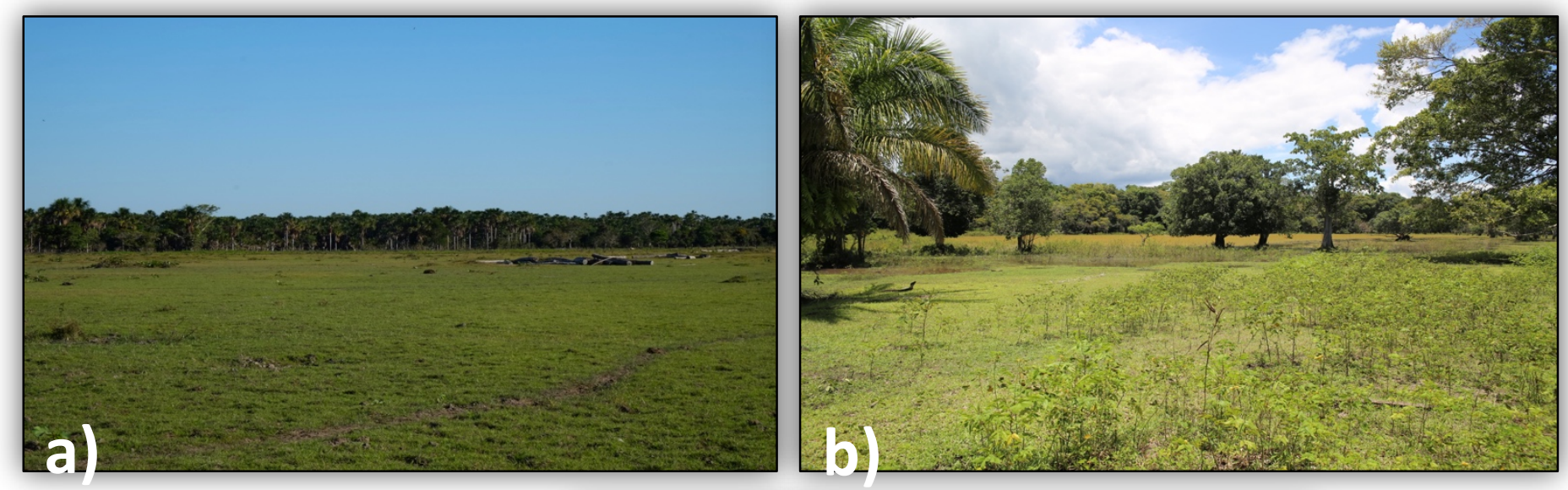

a) Ilha Fazenda Pau d'Óleo

b) Ilha do Antelmo

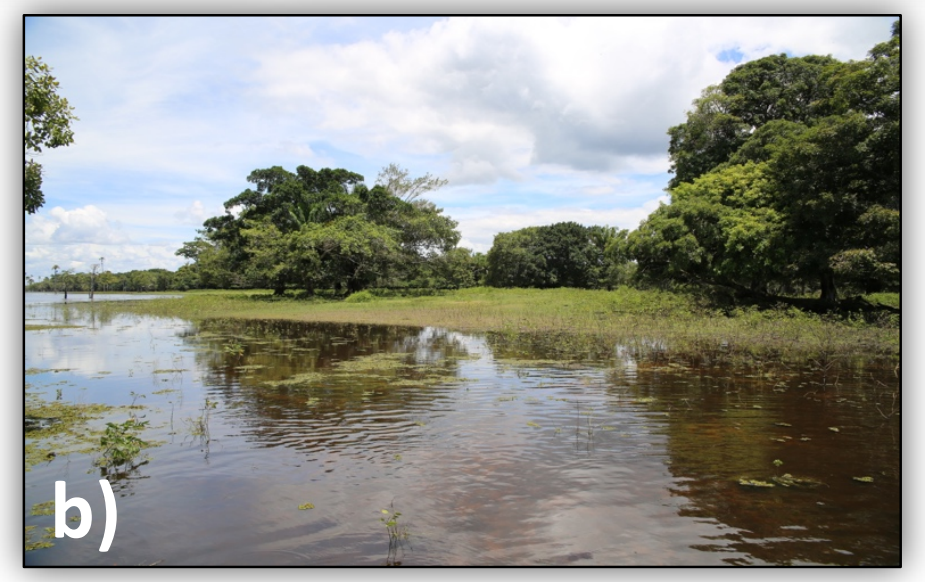

Imagem 44: Sítio Ilha Fazenda Pau d'Óleo e Ilha do Antelmo

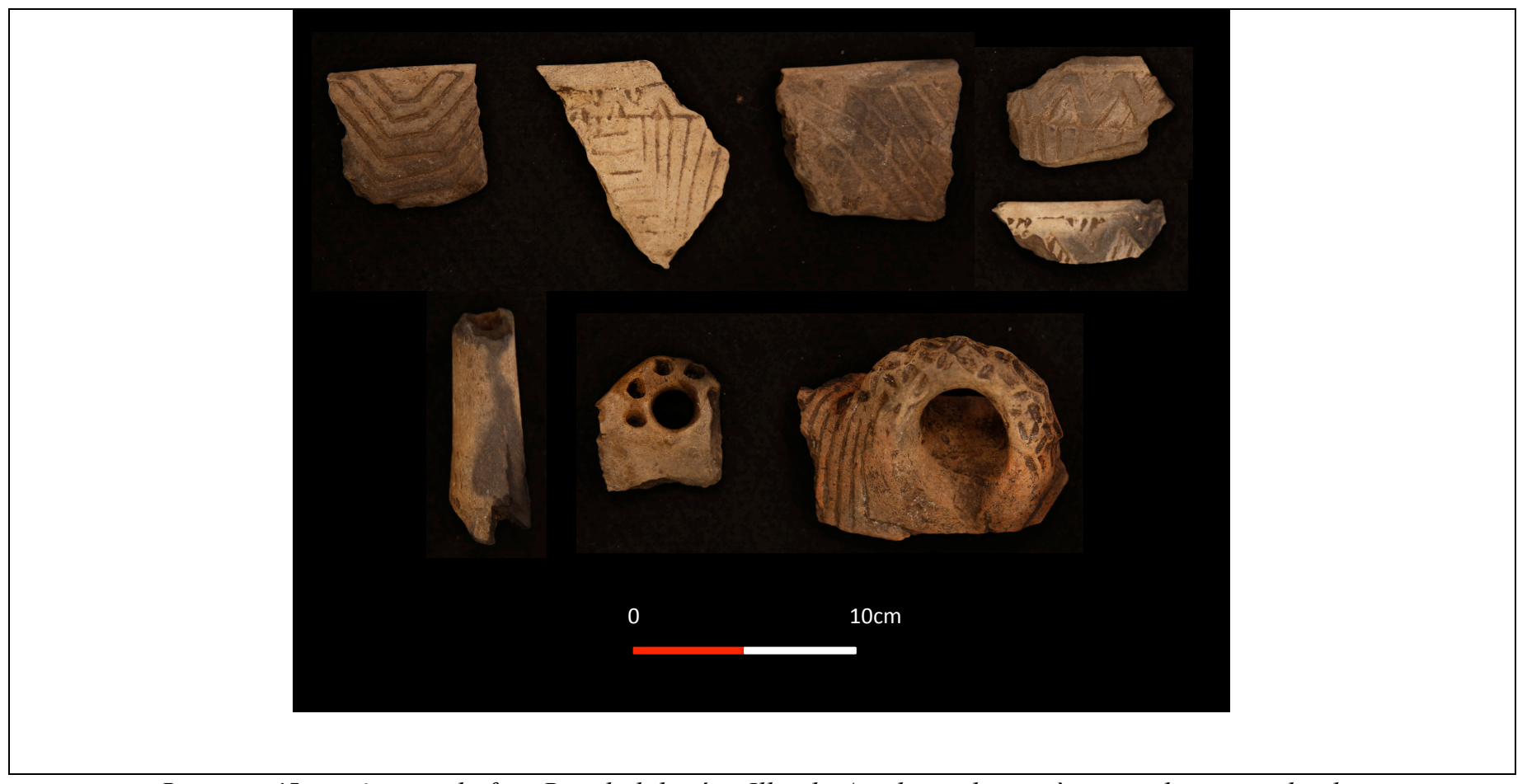

Imagem 45: cerâmicas da fase Bacabal do sítio Ilha do Antelmo, abaixo, à esquerda, um cachimbo tubular. 
Entretanto, até o momento o mais expressivo componente arqueológico que atesta a história dos povos que são responsáveis pela formação do registro associado à fase Bacabal é o sambaqui Monte Castelo, que é integrante de diferentes projetos em desenvolvimento (Neves 2015; Pugliese 2017; Carneiro 2017).

\section{Sambaqui Monte Castelo}

O sítio Monte Castelo é mencionado pela primeira vez na literatura arqueológica em meados dos anos 80, resultado de pesquisas arqueológicas feitas no âmbito do PRONAPABA. Até o ano de 1992, ficaria restrita a menção de sua localização e era divulgado somente um pequeno trecho onde se menciona a fase bacabal, que é descrita de uma maneira simples (Simões 1982; Miller 1992). Já no ano de 2009 são divulgados dados mais detalhados sobre o sítio Monte Castelo, sua localização e uma descrição mais ampla da cerâmica Bacabal (Miller 2009).

A partir de 2013 a equipe do Arqueotrop ${ }^{2}$ retoma as pesquisas no local, fazendo a localização e um mapeamento inicial do local. A partir daí novas etapas foram realizadas e diversos pesquisadores foram responsáveis pela coleta amostras zooarquelógicas, arqueobotânicas, geoarqueológicas, geológicas, osteológicas, além dos artefatos cerâmicos, líticos e em osso.

O Sambaqui Monte Castelo (imagem 46-47) está situado adjacente ao baixo curso do Rio Branco, tributário da margem direita do rio Guaporé foi identificado por Miller (1992, 2009). Foram realizadas três etapas de campo. A primeira teve como objetivo a localização e o mapeamento inicial do sítio arqueológico (Imagem 46, esquerda). A segunda etapa teve como objetivo alocar uma escavação próxima a unidade de escavação anteriormente feita por Miller, no intuito de acessar com mais eficiência informações estratigráficas que nos ajudaram a compor as estratégias para a terceira etapa de campo, onde aprofundou-se a escavação além de realizar uma escavação mais detalhada nas camadas mais recentes do sítio, relacionadas a fase Bacabal (Pugliese e Neves 2016; Pugliese 2017).

\footnotetext{
${ }^{2}$ Laboratório de Arqueologia do Trópicos, Museu de Arqueologia e Etnologia, Universidade de São Paulo, coordenado pelo prof. Dr. Eduardo Goes Neves.
} 


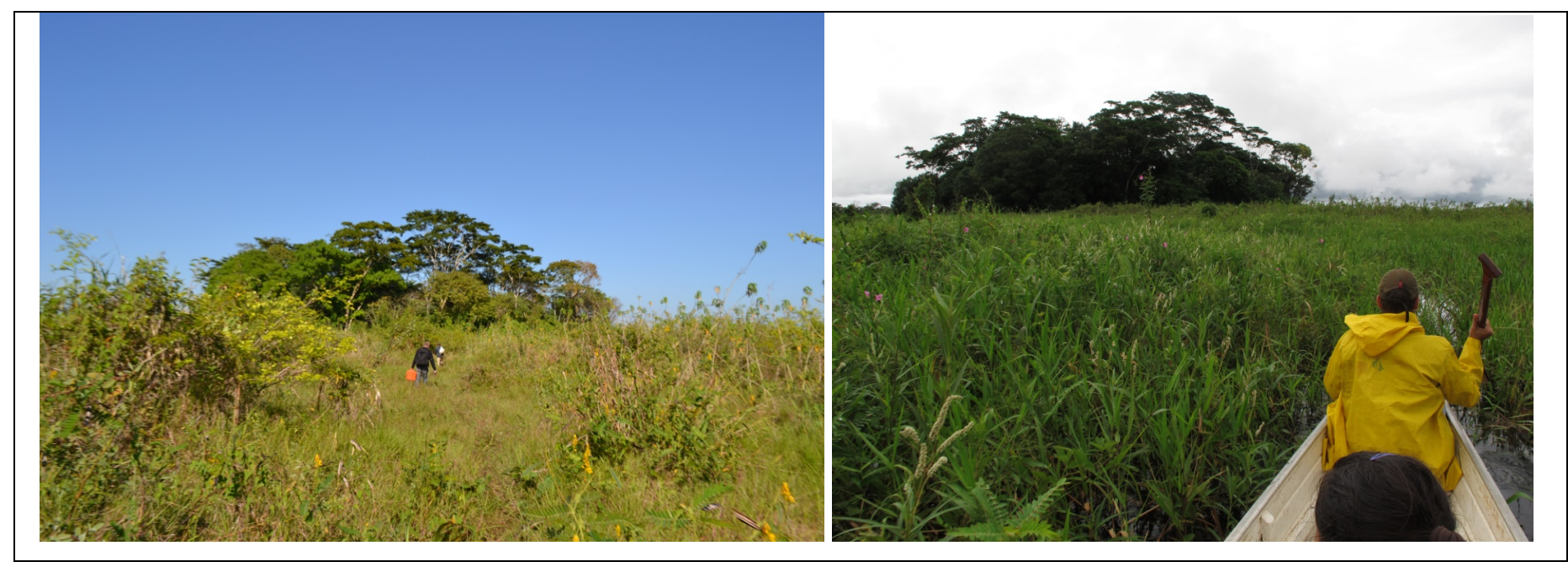

Imagem 46: a esquerda, foto do sítio no momento do mapeamento (estação seca), e a direita a chegada ao sítio no momento da segunda etapa de campo, durante o periodo de cheia.

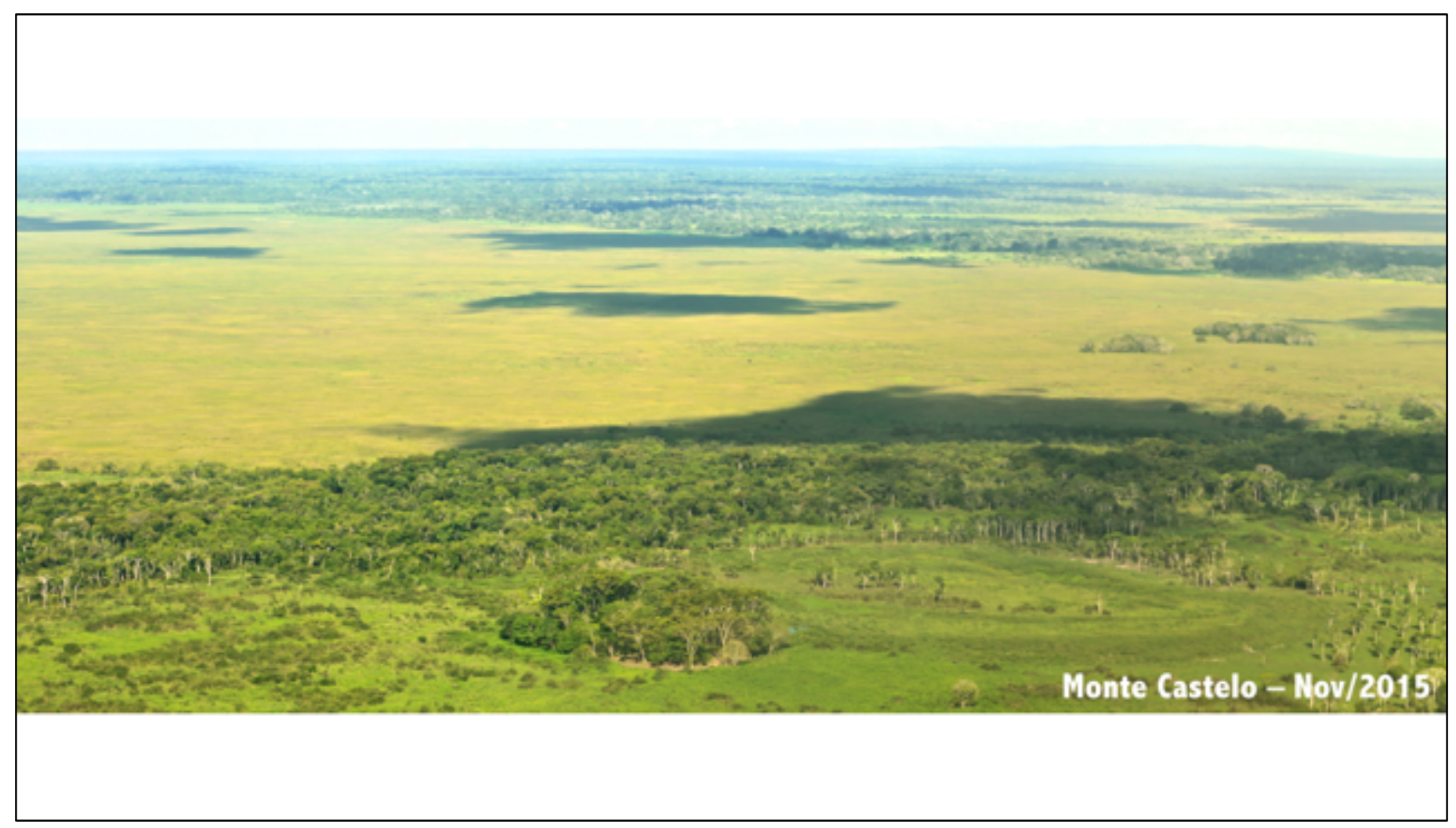

Imagem 47: sambaqui Monte Castelo.

Trata-se de um aterro que vem sendo construído há milênios e atualmente conta com dimensões aproximadas de 120 metros de diâmetro e 6,30 metros de altura, onde dezenas de sucessivas camadas arqueológicas atestam a história de eventos construtivos ao longo de mais de 9000 anos de ocupação. Há pacotes cuja matriz é composta primordialmente de solo antropogênico, enquanto em outros o que prevalece é uma quantidade muito significativa de conchas de gastrópodes inteiras ou pouco fragmentadas 
de outros vestígios zooarqueológicos (principalmente quelônios, cervídeos, roedores, diversas espécies de peixes, moluscos bivalves e alguns répteis).

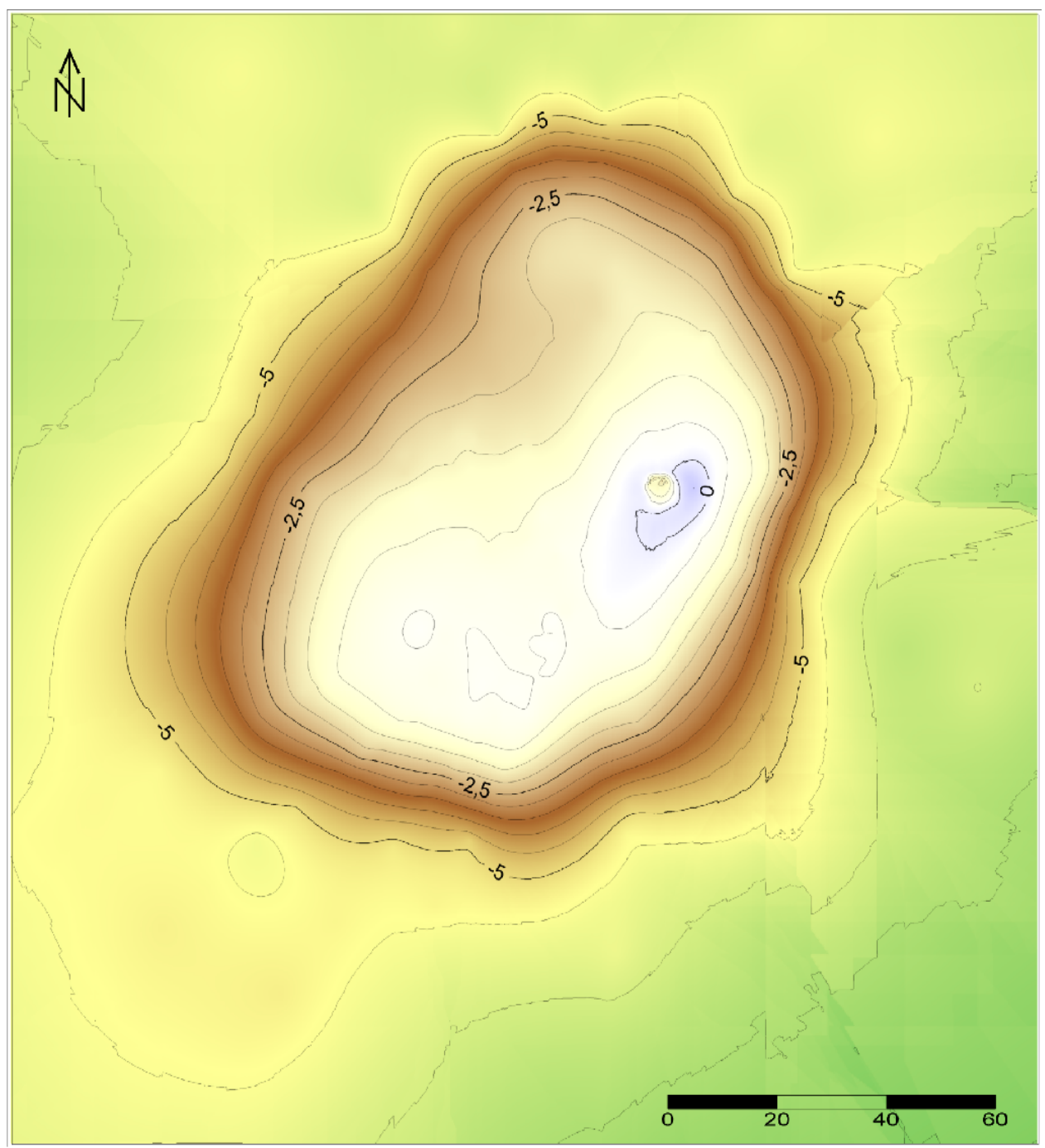

Imagem 48: mapa topográfico do sítio Monte Castelo (Pugliese 2017).

A identificação das camadas estratigráficas feita por Miller (2009) define para o sítio diferentes períodos culturais representados por três fases arqueológicas. O período mais recente seria a fase Bacabal que ocorre acima dos estratos da fase Sinimbu. Em nossas pesquisas confirmamos a presença nas camadas superiores $(>2,3 \mathrm{~m})$ de vestígios cerâmicos atribuídos à Fase Bacabal que possui datações calibradas entre 2576 a.C. e 1350 d.C. (Zimpel e Pugliese 2016; Pugliese 2017).

Estas camadas (A-D) apresentam alta densidade de evidências cerâmicas, muitas peças líticas e vários tipos de vestígios arqueobotânicos. Os sepultamentos são recorrentes; as covas são demarcadas com contornos ou aglomerações de conchas e contam com acompanhamentos funerários associados (Pugliese 2017). 
A cerâmica Bacabal está localizada acima de camadas associadas a fase Sinimbu (cal. 5800-5000 AP). Tratam-se de finas camadas sucessivas de solo e de concha com a presença de uma cerâmica muito simples, com queima a temperaturas muito baixas (600800 oC). O antiplástico predominante na pasta é a areia, com a presença de cauxí e conchas trituradas. Possivelmente seriam pequenos potes de contorno simples e não apresentam nenhum sinal de decoração. Dada a pequena amostra disponível é difícil afirmar a função de tais utensílios, se seria usado para cozinhar, por exemplo. Estas cerâmicas ocorrem em meio a vestígios de fauna resultado de consumo e de artefatos em osso, como agulhas e pontas de flecha (Pugliese 2017)

Os responsáveis pelo inicio da ocupação do sambaqui, e que também deixam vestígios em outros locais, como a ilha união por exemplo, estão relacionados a fase Cupim (7800 a 5800 cal AP), que são caracterizadas por evidências atribuídas a atividades como fogueiras, restos de fauna e a presença abundante de cerâmicas, com antiplástico de cauxí e areia. Estas compreendem pequenos blocos, bolotas e placas de argila queimadas, ocorrendo uma pequena amostra que apresenta fragmentos de possíveis potes, depositados em camadas de cerca de $10 \mathrm{~cm}$ de espessura que datadas em 7800 AP (idem) (imagem 21).

É interessante a percepção de Pugliese (2017) que considera que mesmo havendo um considerável intervalo de tempo entre as fases Cupim e Sinimbu, e cada uma das fases possuírem características próprias, alguns traços em comum podem ser notados, como ocorrência de um de artefato classificado como amorfo (cerâmicas queimadas que não corresponde a potes ou adornos), dada a característica variável da sua morfologia, e que permanecem no registro arqueológico por praticamente 3000 anos. 


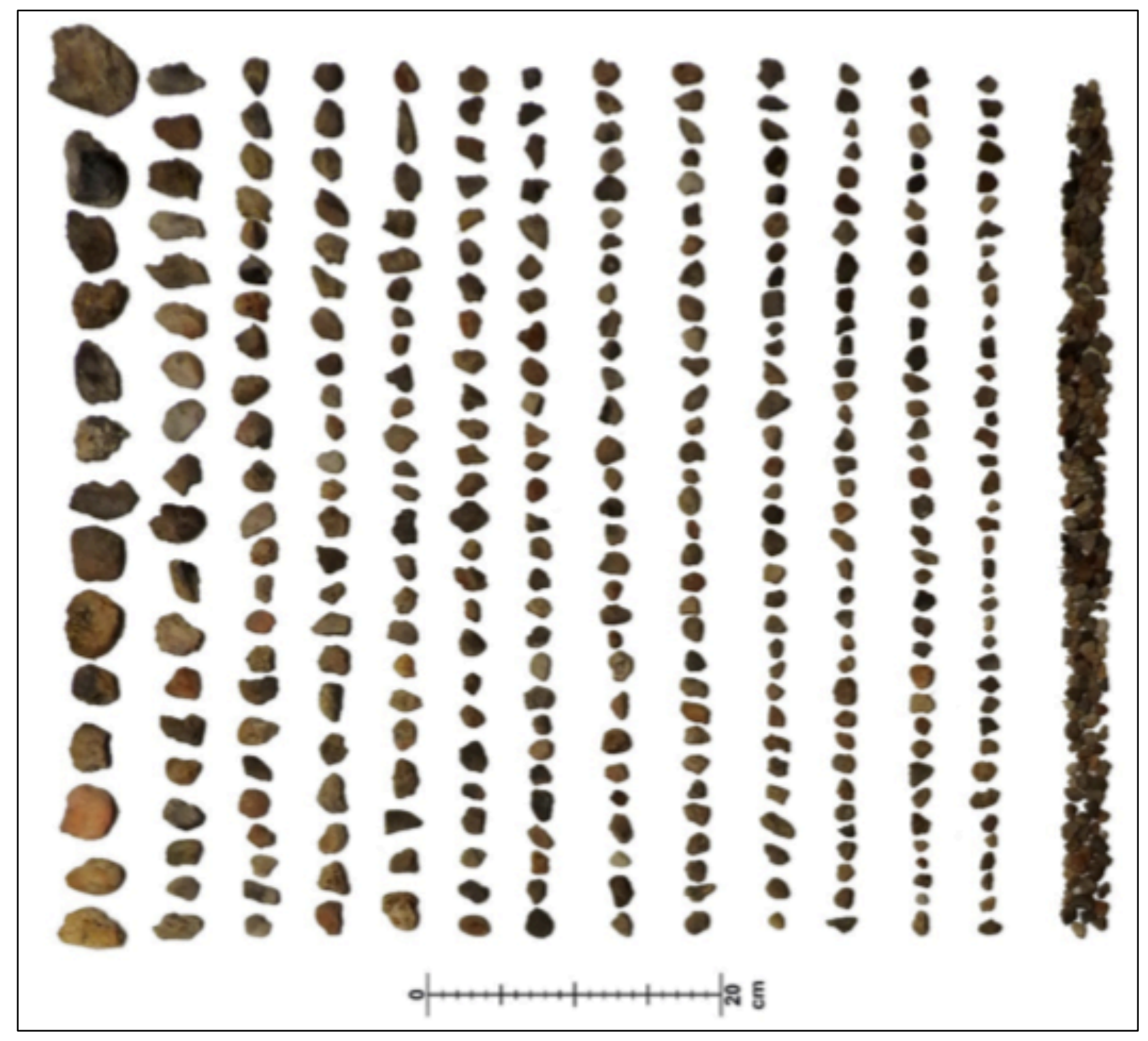

Imagem 49: artefatos com formas variadas da fase Cupim (Pugliese 2017). 


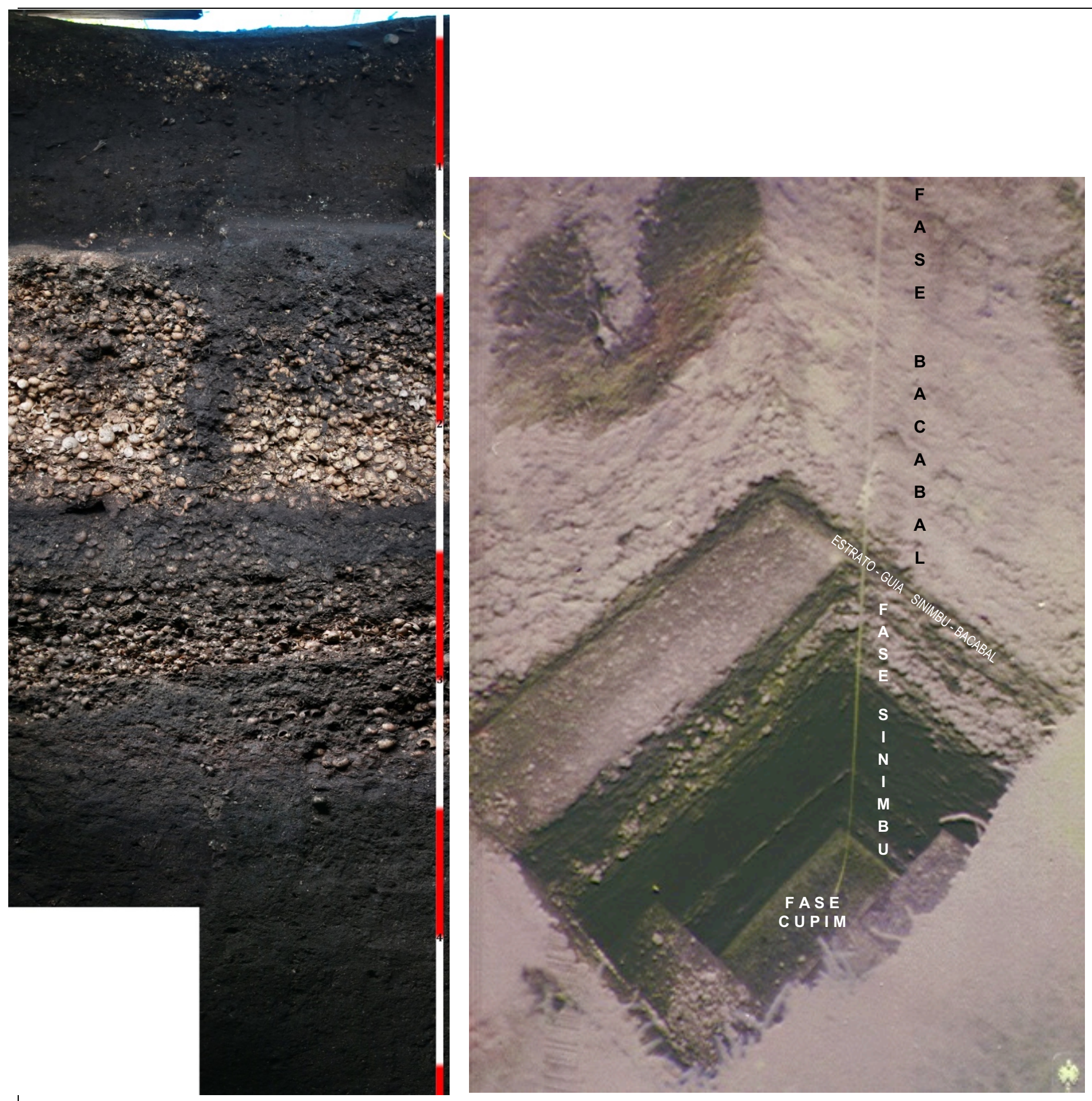

Imagem 50: A esquerda o resultado da escavação de 2014, onde aparecem camadas relacionadas as fases Sinimbu e Bacabal. A direita a escavação realizada na década de 80 por Eurico Miller (Miller 2009). 
Decidiu-se para a primeira intervenção feita em 2014 por proceder com técnicas de escavação e registro com o objetivo de acessar rapidamente a maior quantidade possível de informação estratigráfica do sítio. Ao invés de ser aberta uma nova área de escavação foi escolhido reabrir a escavação previamente realizada por Eurico Miller que está localizada na porção mais alta do sítio. Neste momento pode-se proceder de maneira mais incisiva em locais nitidamente perturbados - presença de material histórico, solos mosqueados, etc. - e agir de maneira precisa em áreas consideradas preservadas.

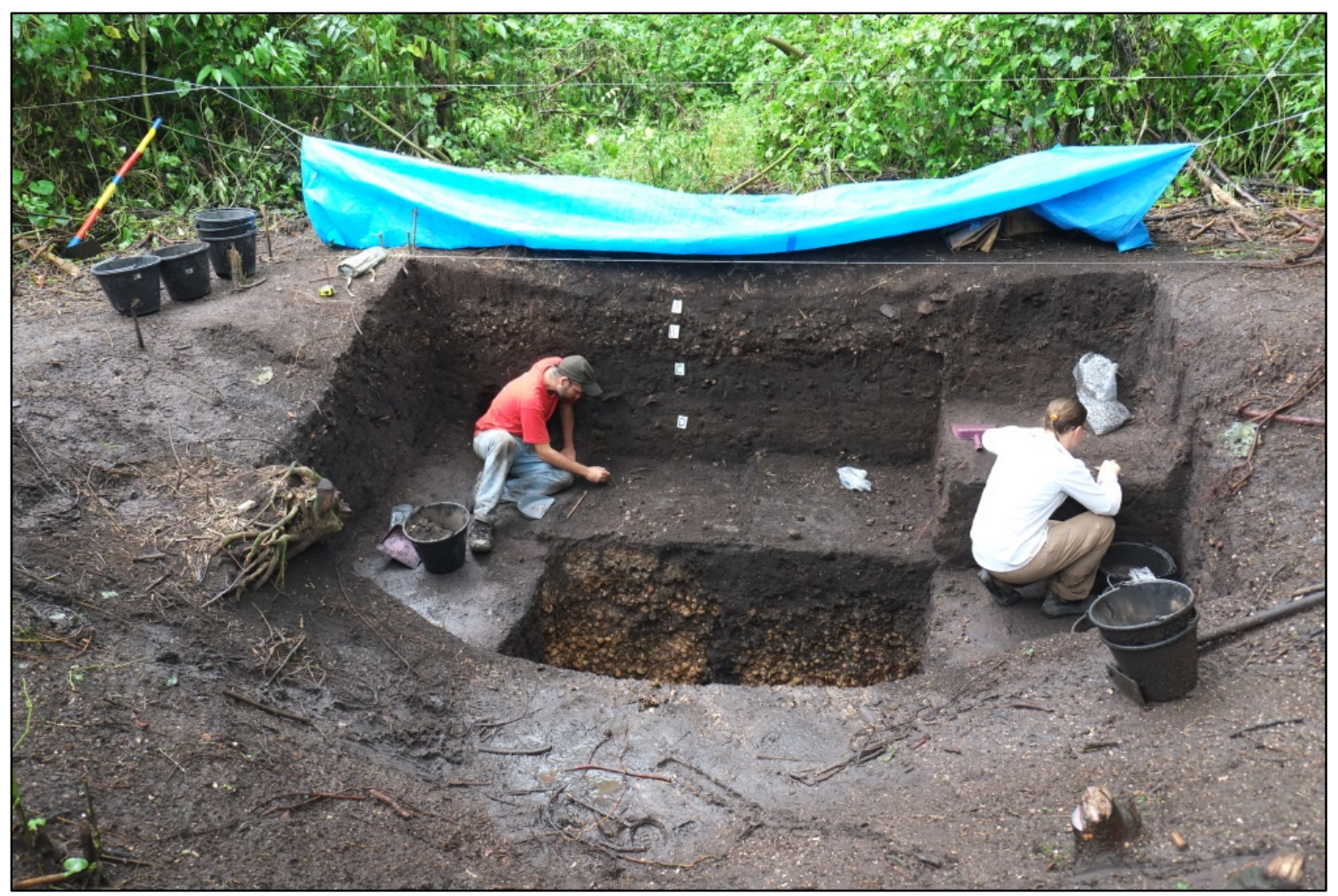

Imagem 51: O denominado "corte 4" escavado por Miller após a reabertura e remoção das camadas perturbadas (Foto: Eduardo Neves)

Nestes contextos perturbados, o sedimento foi retirado a partir de níveis arbitrários estipulados a partir da presença ou ausência de materiais não relacionados ao contexto arqueológico já estabelecido para o sambaqui. Nos contextos preservados, foram seguidos níveis artificiais de 10 centímetros, enquanto eram registradas as características dos estratos naturais das camadas. Nos casos em que poderiam ser notados, as interrupções, os contatos ou as transições entre camadas foram detalhados para orientar a escavação. O controle estratigráfico foi feito com uma estação total, a partir do zero e 
todo o material coletado foi registrado por meio de números de proveniência, acondicionado e enviado para o MAE/USP (imagem 52-53).

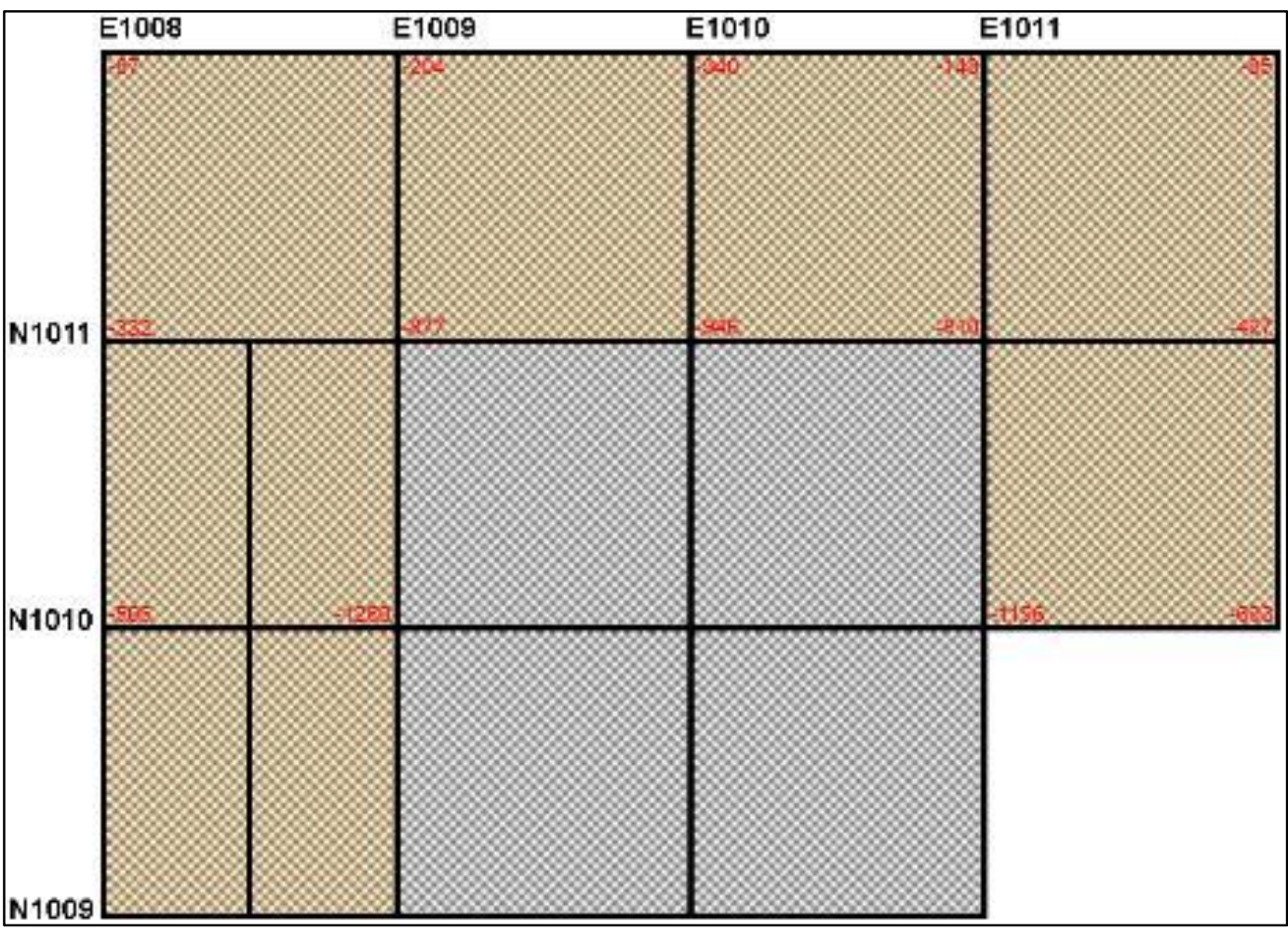

Imagem 52: As unidades marcadas em cinza indicam a localização do Corte 4. O marrom indica as áreas escavadas em fevereiro de 2014 e que apresentavam diferentes graus de preservação das estruturas arqueológicas. Valores vermelhos indicam as cotas topográficas iniciais da escavação (Pugliese 2017). 


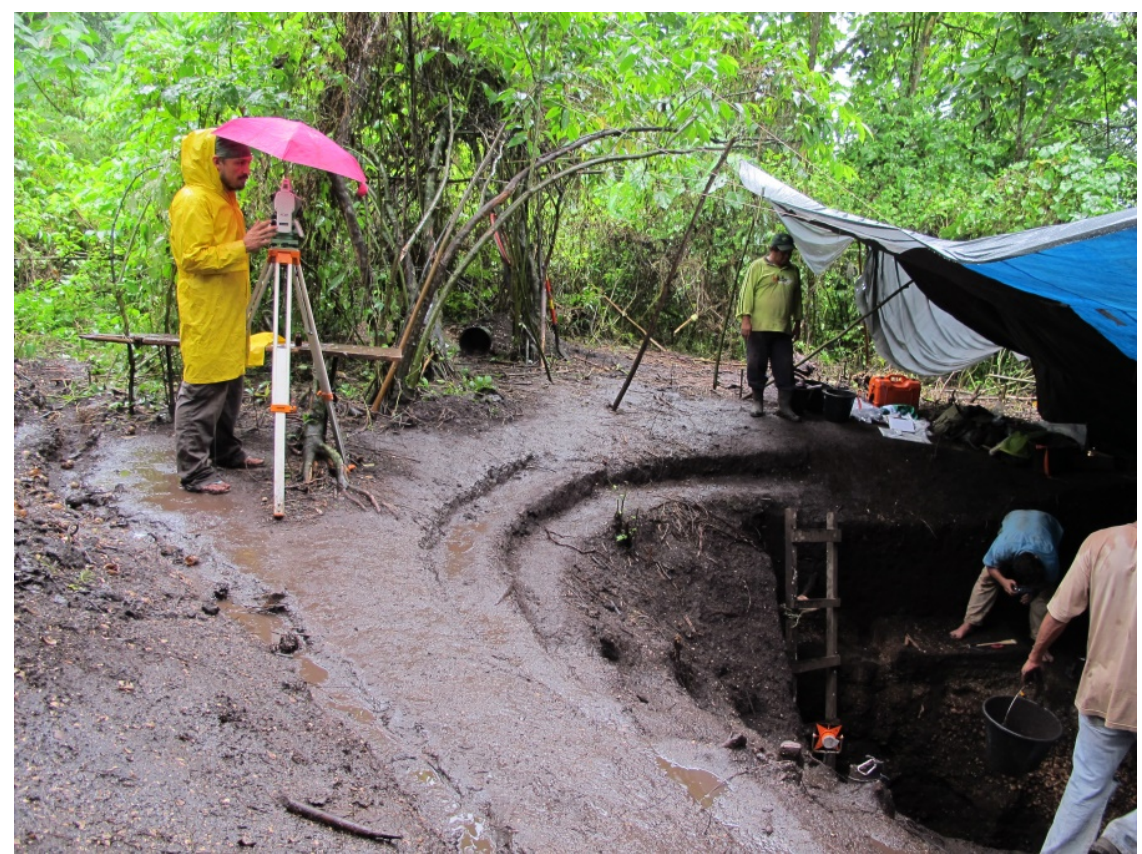

Imagem 53: Registro do contexto de escavação com a Estação Total (Foto: Eduardo Neves)

$\mathrm{Na}$ segunda etapa pode-se chegar a porções mais profundas do sítio, sendo possível realizar um registro detalhado das fases Sinimbu e Cupim, além de realizar uma amostragem ampla de vestígios associados as camadas onde ocorreram vestígios associados a fase Bacabal (imagem 54).

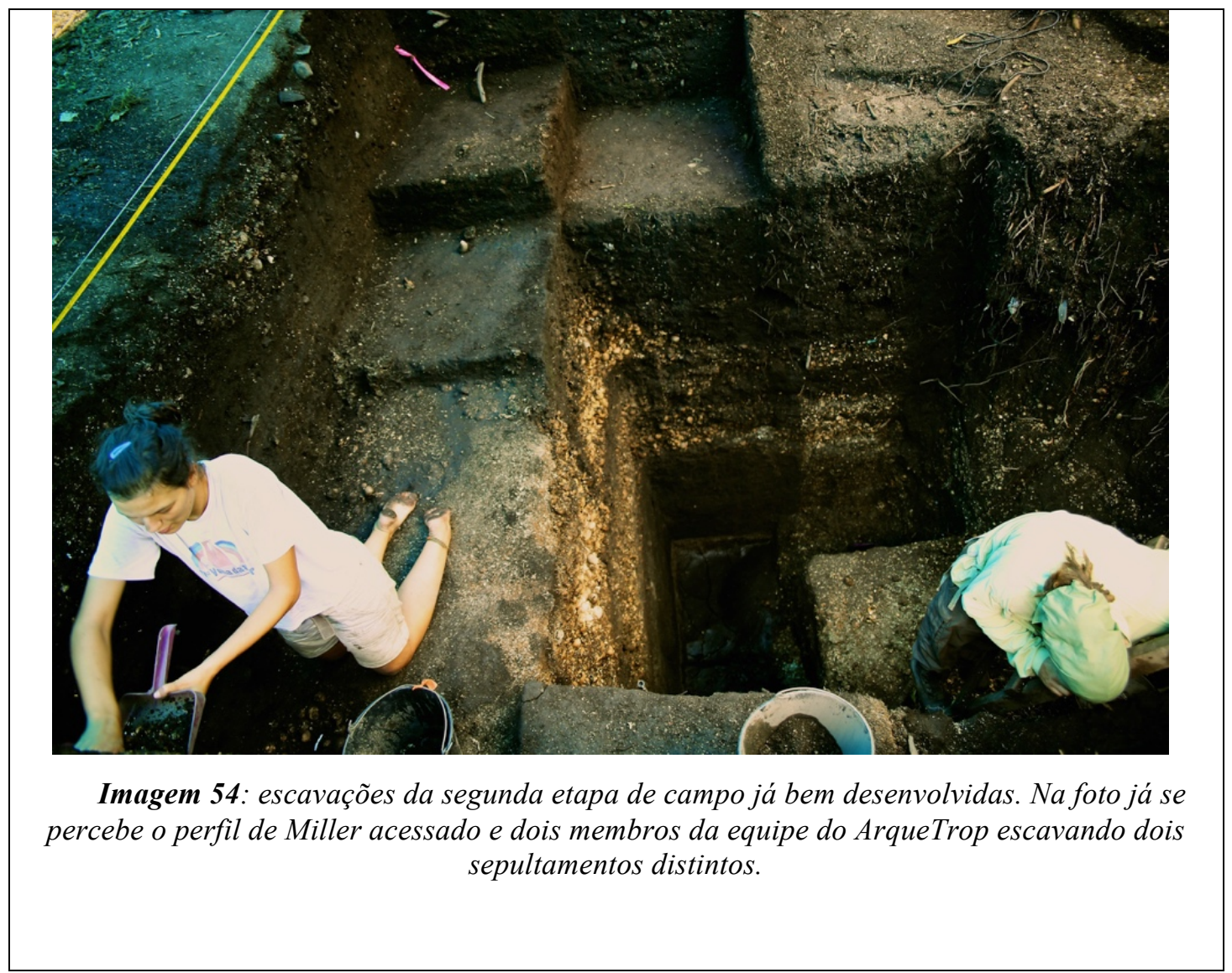




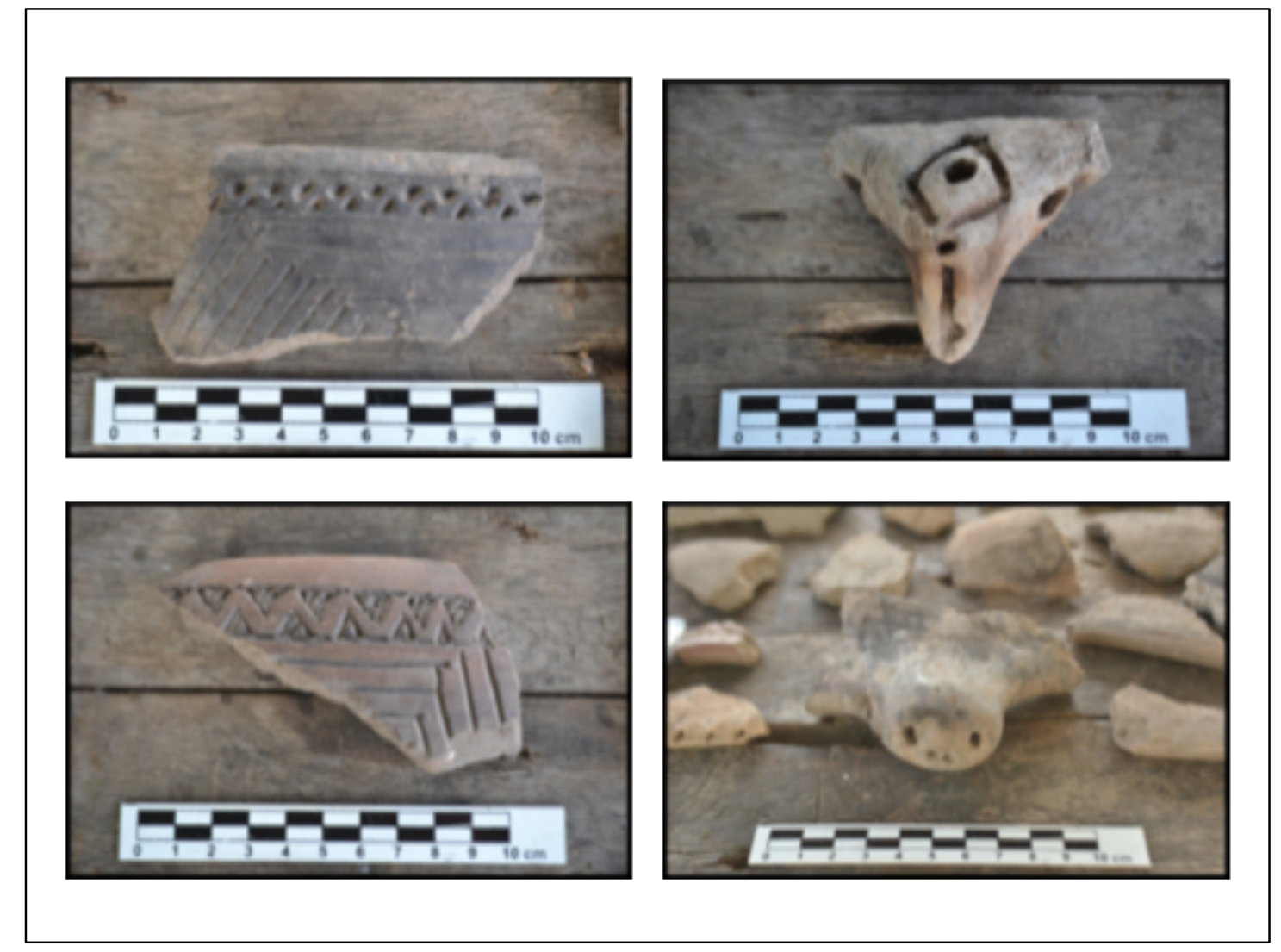

Imagem 55: Cerâmicas típicas da fase Bacabal recuperadas no ano de 2014.

A fase Bacabal ocorre principalmente entre as camadas A-D de Monte castelo. $\mathrm{Na}$ etapa de campo de 2016 foi escavada uma unidade de 1m2 (N1012E1009) onde realizou-se um registro cuidadoso dos materiais arqueológicos e suas relações com as camadas estratigráficas identificadas no sítio. 


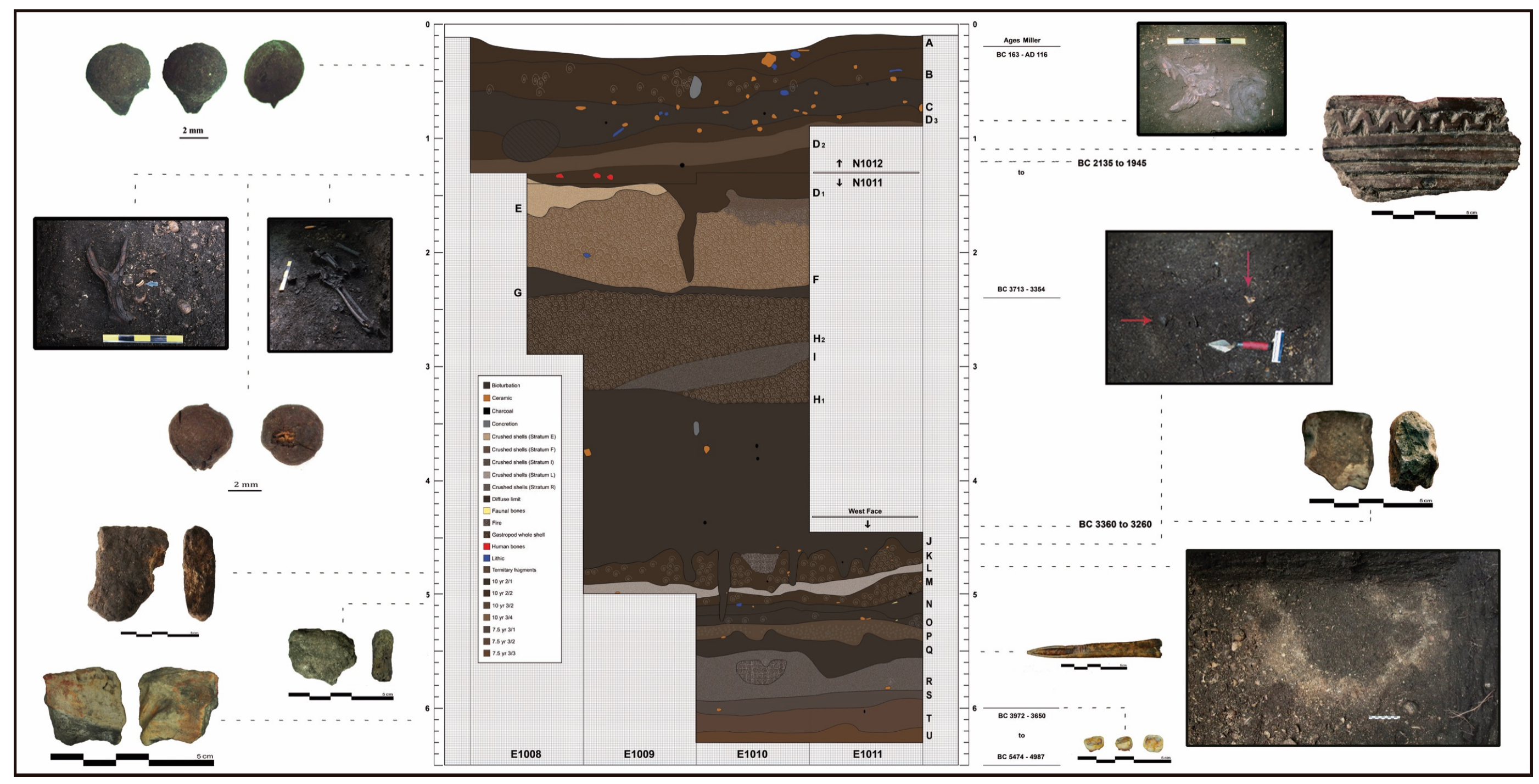

Imagem 56: Perfil norte - resultados parciais da escavação. Etapa de 2014 (460cm), Etapa 2016(630 (Pugliese 2017) 
Segundo Pugliese (2017), as Camadas estratigráficas associadas a fase Bacabal podem ser assim descritas:

A. Camada superficial perturbada, com profundidade oscilando entre 10 e $20 \mathrm{~cm}$ de espessura, dos quais os $5 \mathrm{~cm}$ iniciais são compostos predominantemente por uma camada húmica e serapilheira. Presença de fragmentos cerâmicos e algum material lítico e pouca malacofauna. Coloração 10yr 2/2 (very dark brown).

B. Matriz silto-argilo-arenosa de mesma coloração da camada anterior, mas com alta densidade de malacofauna. Alta densidade de fragmentos cerâmicos decorados, inclusive, com apêndices zoomórficos (Fase Bacabal). Aproximadamente $30 \mathrm{~cm}$ de profundidade.

C. Camada de terra preta argilo-siltosa, com sensível diminuição da quantidade de conchas (inteiras e fragmentadas) e alta densidade cerâmica (Fase Bacabal). Aproximadamente $30 \mathrm{~cm}$ de espessura. Presença de um sepultamento primário infantil (F1), depositado no sentido E-W e estendido em uma cova delimitada por conchas de gastrópodes. Aparentemente, há áreas de atividade preservadas, uma vez que nessa camada foram identificadas as primeiras feições para escavação isolada e alguns buracos de estaca foram registrados na quadra N1011/E1011. Abaixo do Sepultamento 1 encontrada a Feição 4, que corresponde a uma possível estrutura de combustão localizada na base dessa camada.

D. Terra preta argilo-silto-arenosa mais clara que a camada superior, mas que se torna progressivamente mais escura em direção ao topo das camadas $\mathrm{E}$ e F, apresentando coloração muito semelhante àquela observada no preenchimento da Feição 11. Muitos grânulos e calhaus lateríticos, além de porções de solo concrecionado. A espessura oscila entre aproximadamente $30 \mathrm{~cm}(\mathrm{~W})$ e $60 \mathrm{~cm}$ (E). Menor quantidade de cerâmica (algumas com vestígios de fuligem) e maior quantidade de conchas (bastante fragmentadas) em relação à camada anterior. A decoração da cerâmica atesta que esta camada compõe a camada de ocupação Bacabal (presença de apliques de quelônios, inclusive). Presença de um crânio e chifre de veado, sobrepondo um sepultamento adulto com estruturas circulares de conchas (F2). Aparentemente, também há áreas de atividade preservadas nessa camada. No contato da camada D com a camada $\mathrm{E}$ há manchas circulares que avançam na camada inferior, cuja forma corresponde a buracos de estaca, alguns linearmente dispostos. 


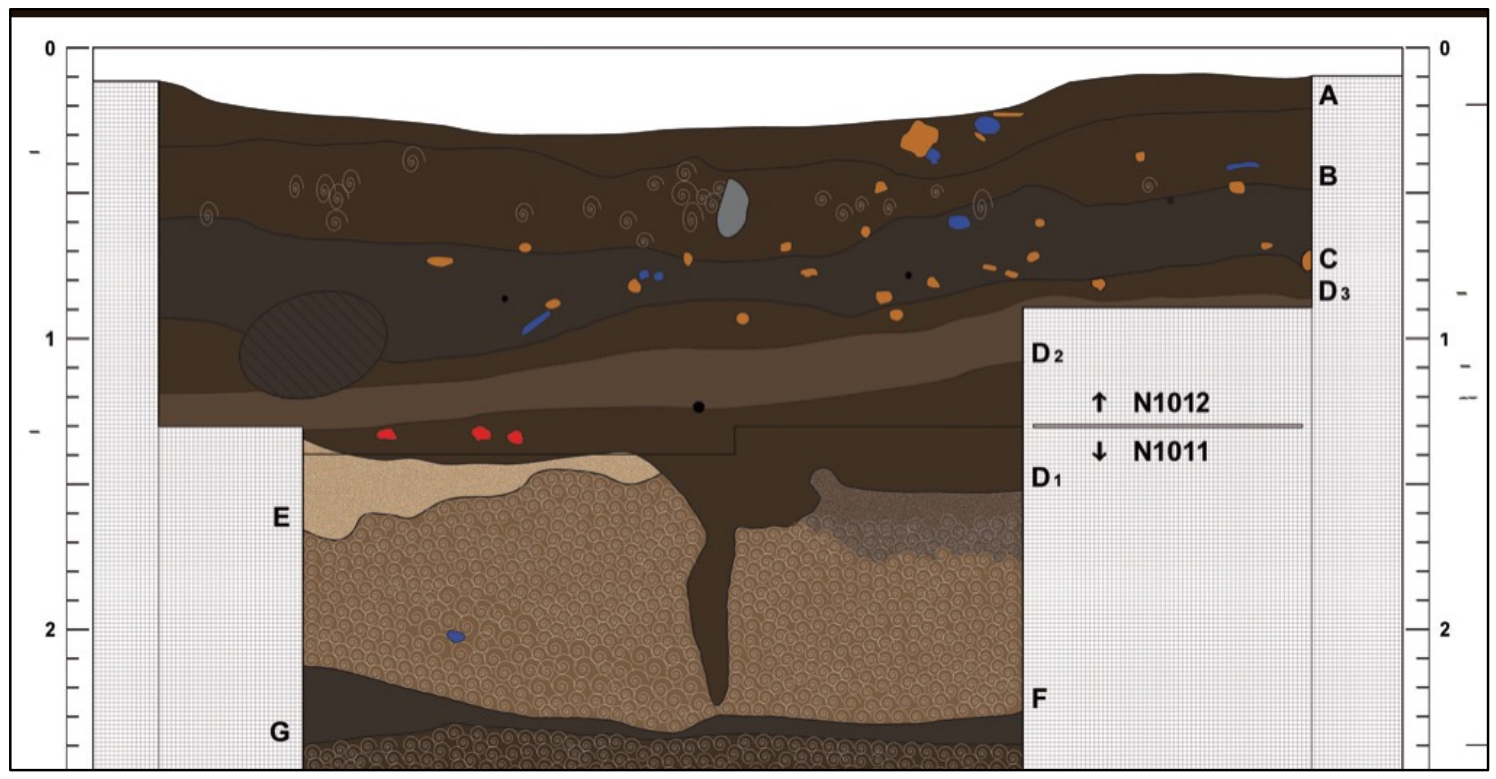

Imagem 57: detalhe do perfil norte, camadas A-G.(Pugliese 2017) 
A cerâmica Bacabal ocorre de maneira farta entre as camadas A e D do sítio. Nas camadas E e F podem ocorrer alguns cacos, mas provavelmente associados a eventos construtivos das camadas superiores. Até o momento se tem disponíveis as seguintes datações - radiocarbônicas e termoluminescência - relacionadas as camadas da fase Bacabal:

\begin{tabular}{|c|c|c|c|c|c|c|c|}
\hline Sigla & ${ }^{14} \mathrm{C}$ & 1 - Sigma & 2 - Sigma & Profundidade & Camada & Unidade & Fonte \\
\hline B10318 & & & & & & & \\
\hline $\begin{array}{c}5 \\
\text { B10628 }\end{array}$ & $810 \pm 70$ & cal AD $1147-1326 p=0,8930$ & cal AD $1341-1390 \mathrm{p}=0,0936$ & $10-15$ & $?$ & $\mathrm{C} 3$ & Miller(2009) \\
\hline $\begin{array}{c}5 \\
\mathrm{~B} 10318\end{array}$ & $1540 \pm 80$ & $\begin{array}{c}\text { cal AD } 405-675 p=0,9924 \\
\text { cal BC } 115-\text { AD } 249\end{array}$ & cal AD $390-400 p=0,0075$ & $10-15$ & $?$ & $\mathrm{C} 2$ & Miller(2009) \\
\hline $\begin{array}{c}4 \\
\text { B } 10628\end{array}$ & $1970 \pm 80$ & $\begin{array}{c}\mathrm{p}=0,9896 \\
\text { cal BC } 163-\text { AD } 116\end{array}$ & cal BC $135-118 p=0,009$ & $20-25$ & $?$ & $\mathrm{C} 2$ & Miller(2009) \\
\hline 6 & $2060 \pm 60$ & $\mathrm{p}=0,9717$ & cal BC $198-174 p=0,0282$ & $120-130$ & $\mathrm{D}$ & $\mathrm{C} 4$ & Miller(2009) \\
\hline SI6844 & $2270 \pm 105$ & cal BC $543-42 p=0,97$ & cal BC $20-A D 18 p=0,0142$ & $100-110$ & $\mathrm{D}$ & $\mathrm{C} 4$ & Miller(2009) \\
\hline SI6843 & $2475 \pm 105$ & $\mathrm{cal}$ BC $806-356 \mathrm{p}=0,9888$ & cal BC $283-257 \mathrm{p}=0,0111$ & $20-30$ & $\mathrm{~B}$ & $\mathrm{C} 4$ & Miller(2009) \\
\hline B66308 & $2760 \pm 100$ & cal BC $1131-745 p=0,9356$ & cal BC $644-551 p=0,0383$ & $20-25$ & B & $\mathrm{C} 4$ & Miller(2009) \\
\hline B66309 & $3160 \pm 70$ & cal BC $1532-1192 \mathrm{p}=0,9856$ & cal BC $1143-1131 p=0,0064$ & $110-120$ & $\mathrm{D}$ & $\mathrm{C} 4$ & Miller(2009) \\
\hline $\begin{array}{r}\text { SI6846 } \\
\text { B40841 }\end{array}$ & $3580 \pm 105$ & cal BC $2146-1615 \mathrm{p}=0,9885$ & cal BC $2196-2171 p=0,0114$ & $170-180$ & $?$ & $\begin{array}{c}\mathrm{C} 1 \\
\mathrm{~N} 1011 / \mathrm{E} 1\end{array}$ & Miller(2009) \\
\hline 3 & $3700 \pm 30$ & cal BC 2120 - 1975 & cal BC $2135-1945$ & 122 & $\mathrm{D}$ & 009 & ArqueoTrop \\
\hline SI6847 & $3920 \pm 85$ & cal BC $2576-2129 \mathrm{p}=0,9786$ & cal BC $2087-2048 p=0,0213$ & $210-220$ & $\mathrm{~F}$ & $\mathrm{C} 4$ & $\begin{array}{l}\text { Miller(2009) } \\
\text { Miller (2009) }\end{array}$ \\
\hline SI6845 & $3945 \pm 110$ & cal BC $2679-2033 p=0,9844$ & cal BC $2692-2689 p=0,0006$ & $160-170$ & $\mathrm{D}$ & $\mathrm{C} 4$ & \\
\hline
\end{tabular}

Tabela 1: datações radiocarbônicas para a fase Bacabal.

\begin{tabular}{|l|c|c|c|c|c|}
\hline no.LAB & N & E & Profundidade & Datação & Camada \\
\hline CSQCA-76 & 1012 & 1009 & $30-40 \mathrm{~cm}$ & $2048 \pm 378$ & B \\
\hline CSQCA-84 & 1012 & 1009 & $100-110 \mathrm{~cm}$ & $3220 \pm 238$ & D2 \\
\hline
\end{tabular}

Tabela 2: datações por termoluminescência feitas com cerâmicas da fase Bacabal.

Na Camada D, que está associada a um pacote cerâmico de ca. de 3.500 - 4.000 anos AP., foram exumados dois sepultamentos humanos, um adulto e um infantil. O indivíduo adulto não foi ainda completamente recuperado, mas, a partir da sua porção já escavada, foi identificado o sexo masculino, em um enterramento direto de um indivíduo completamente articulado. Um crânio de veado com boa parte da galhada ainda preservada estava colocado sobre o braço esquerdo e muitos outros artefatos foram encontrados em associação ao esqueleto - como um instrumento de dente de roedor e arranjos circulares de conchas indicando a realização de um ritual para o enterramento daquele indivíduo. A criança foi, da mesma maneira, encontrada em um sepultamento primário, mas em posição distinta e com outros tipos de artefatos associados. Ambos os sepultamentos primários estavam associados a bolsões preenchidos por matriz onde predominavam conchas encontradas inteiras ou em fragmentos (Pugliese 2017). 

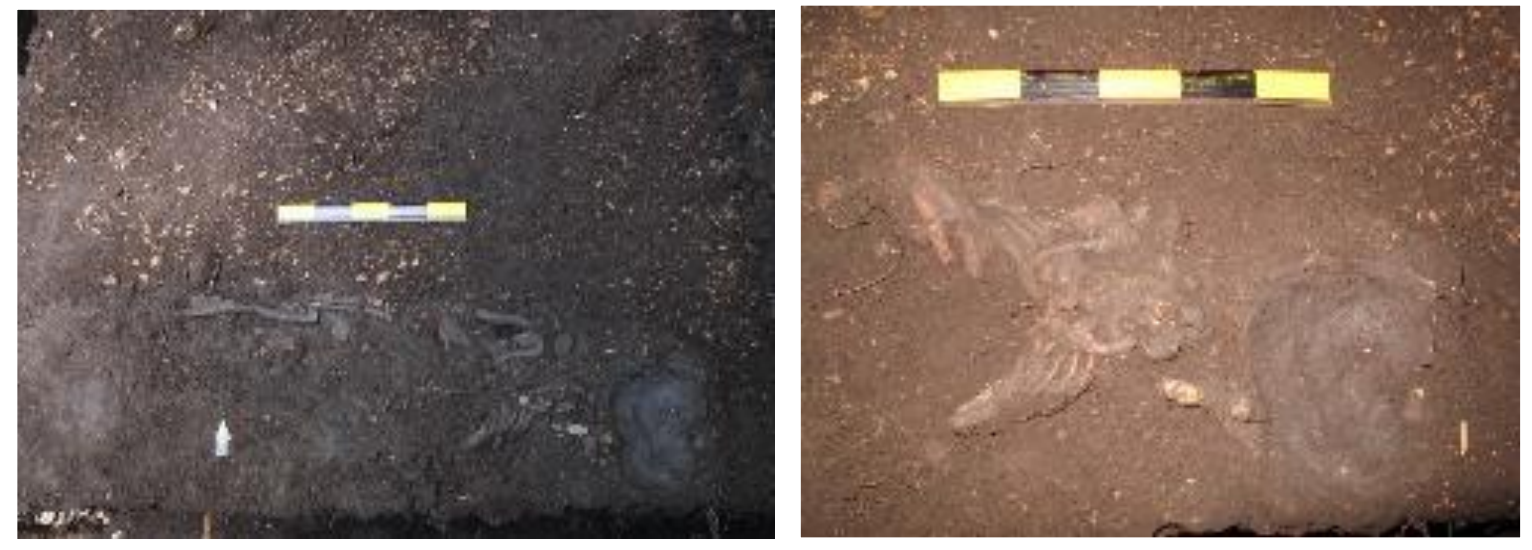

Imagem 58: Sepultamento 1 (Foto: Eduardo Neves).
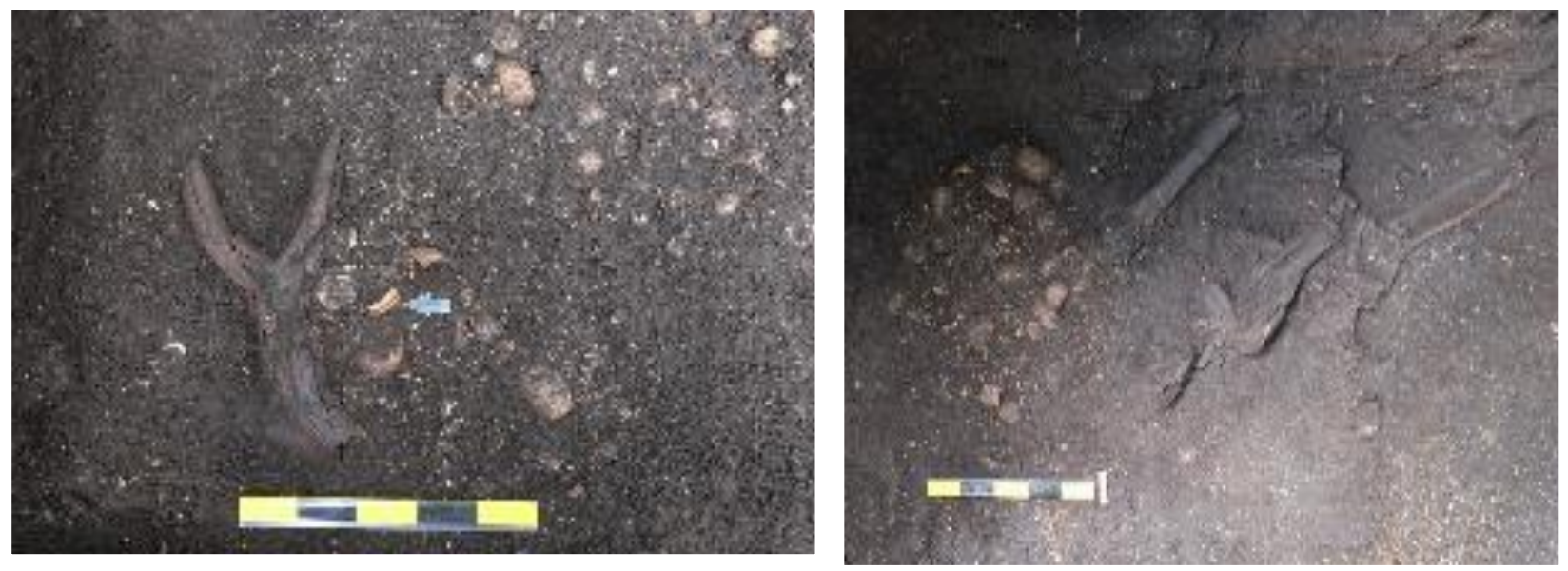

Imagem 59: Sepultamento 2 (Foto: Eduardo Neves). 


\section{Procedimentos de análise da cerâmica}

\section{Análise tipológica}

Com o método estabelecido para adquirir informações sobre a cerâmica procuramos criar categorias a partir de atributos que pudessem refletir escolhas realizadas nas diferentes etapas do processo de manufatura de utensílios cerâmico. Foram elencados atributos descritivos, tecnológicos, morfológicos e decorativos baseados naqueles definidos anteriormente por Shepard (1956), Meggers (1970), Chmyz et al. (1976), Rye (1987), Rice (1987) e Orton et al. (2003), além de recentes trabalhos na área, como Almeida (2013), Suze (2014), Betancourt (2011), Miller (2009) e Barreto et al. (2016).

O objetivo da escolha dos atributos foi fazer uma descrição da cerâmica detalhada da cerâmica na busca de compreender a sua e variabilidade formal e artefactual (Schiffer e Skibo 1997). A variabilidade formal está relacionada as propriedades físicas de um artefato, como composição, dimensões, peso, texturas e cor (Silva, 2007). Já a variabilidade artefactual está ligada a análise de atributos pertinentes a explicação das diferenças e similaridades entre os tipos de artefatos no tempo e no espaço (cf. Schiffer e Skibo, 1997).

Também se teve como preocupação a produção de informação suficiente para permitir a possibilidade de comparação com outros contextos arqueológicos adjacentes, como os sítios do trecho encachoeirado do rio Madeira e as culturas arqueológicas dos Llanos de Mojos.

Descrição dos atributos:

\section{Localização e medidas}

Primeiramente são descritos os metadados das cerâmicas escavadas. São informações relacionados a proveniência do material, contexto encontrado, quantidade e medida iniciais.

\begin{tabular}{|c|c|c|c|c|c|c|c|}
\hline $\begin{array}{c}\text { Número de } \\
\text { proveniência }\end{array}$ & $\begin{array}{c}\text { Número } \\
\text { individual }\end{array}$ & Norte & Leste & Profundidade & Camada & $\begin{array}{c}\text { Espessura } \\
\text { máxima }\end{array}$ & $\begin{array}{c}\text { Espessura } \\
\text { mínima }\end{array}$ \\
\hline
\end{tabular}

$\mathrm{Na}$ amostra analisada percebe-se destarte uma variação na medida da espessura da maioria dos fragmentos, portanto decidiu-se fazer a aquisição destas duas informações. A partir dela foi gerado um terceiro dado, que é resultado do desvio da diferença entre estas duas 
medidas. Além destas medidas iniciais foi gerada uma tabela auxiliar onde o total de fragmentos dos diferentes números de proveniência tiveram sua massa mensurada expressada em gramas.

\section{Dados referentes a classe}

Categoria: série de tipos que indicam aspectos da morfologia e/ou funcionalidade do possível artefato representado no fragmento.

\begin{tabular}{|l|l|}
\hline CATEGORIA & Tipo de Artefato \\
\hline 1.Pote & 7. Cachimbo \\
2. Trempe & 8. Argila construção (marcada) \\
3. Adorno/conta & 9.Peso \\
4. Bolota de Argila & 10. argila amorfa \\
5. Tortual de fuso & \\
6. Figura & \\
\hline
\end{tabular}

1. Pote: todo artefato que possa conter algo. Relacionado ao consumo. Neste tipo são considerados potes vasilhas, pratos, tigelas, etc;

2. Trempe: aqueles artefatos que sugerem uma semelhança morfológica com aquilo descrito na etnografia e arqueologia como suportes de formato cilíndrico utilizados para estabilizar potes sob o fogo;

3. Adorno/Conta: Objetos cerâmicos usados como adorno corporal, às vezes amarrados ou presos em cordões;

4. Bolota de argila: objetos esferoidais, por vezes amorfos, feitos em argila cozida;

5. Tortual de fuso: Disco de cerâmica com perfuração central, podendo servir de peso na fiação de fibras.

6. Figura: esculturas em cerâmica que representam pessoas, animais ou plantas;

7. Cachimbo: utilizados para fumar, podem ser do tipo com fornilho ou tubulares;

8. Argila marcada: argila com impressão de galhos;

9. Peso: Objeto esférico com orifício.

O fragmento quando identificado como pote é classificado quanto a sua natureza a partir dos atributos: 


\begin{tabular}{|l|l|}
\hline $\mathbf{P P}$ & Parte do pote \\
1. Parede & 7. Base \\
2. Borda & 8. Aplique \\
3. Gargalo & 9. Flange \\
4. Bojo & 10. Asa \\
5. Carena & 11. Alça \\
6. Inflexão & 12. pescoço \\
00. Não identificado & \\
\hline
\end{tabular}

\section{Aspectos tecnológicos}

\section{Técnicas de confecção}

Os tipos de técnica de manufatura foram divididos em Acordelado, Modelado, Placas e Moldado. O Acordelado é identificado pelo tipo de fratura (conxoidal, convexa), pela longitude da quebra, ou por rachadura, marcas ou ondulações que indiquem tal técnica.

\begin{tabular}{|l|}
\hline Técnica de produção \\
1. Acordelado \\
2. Modelado \\
3. Placas \\
4. Moldado \\
00. Não identificado \\
\hline
\end{tabular}

\section{Cor da argila}

Diferentes cores de argila podem indicar diferentes matrizes de matérias-primas. Aquelas esbranquiçadas e bege podem indicar alto teor de alumínio. Aquelas vermelhas/marrom podem indicar presença de óxido de ferro (Peacock 1973).

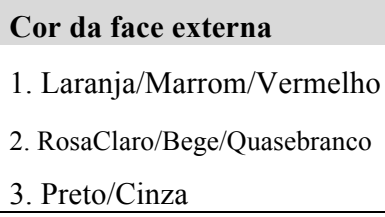




\section{Tecnologia da pasta}

A construção dos atributos relativos a tecnologia da pasta buscou trazer um conjunto de conhecimentos e princípios que poderiam ter sido escolhas que se aplicaram ao planejamento e a construção de artefatos para determinado(s) tipo(s) de atividade(s). Sendo assim, buscou-se elaborar atributos para no intuito de estabelecer o(s) tipo(s) de pasta escolhidos pelas artesãs e suas preferências.

\begin{tabular}{|l|l|}
\hline Tipo de antiplástico & Tipo de Mineral \\
\hline 1. Mineral & 1. Quartzo \\
2. Cauixí & 2. Mica \\
3.Vazios muito peq. agrupados & 3. Oxido de ferro \\
4. Concha & maior antiplástico mineral \\
5. Carvão & 1. Areia fina - $0.1-0.25 \mathrm{~mm}$ \\
6. Chamote (caco moído) & 2. Areia média $-0.25-1.0 \mathrm{~mm}$ \\
7. Vegetal & 3. Areia grossa $-1.0-3.0 \mathrm{~mm}$ \\
8. vazios varias formas muito freq & 4. Areia muito grossa $->3 \mathrm{~mm}$ \\
9. Branco, friavel, calcário? & Aspecto da areia \\
a.Cariapé & 1. Anguloso \\
& 2. Sub-anguloso \\
& 3. Esférico \\
& 99. Não se aplica \\
\end{tabular}




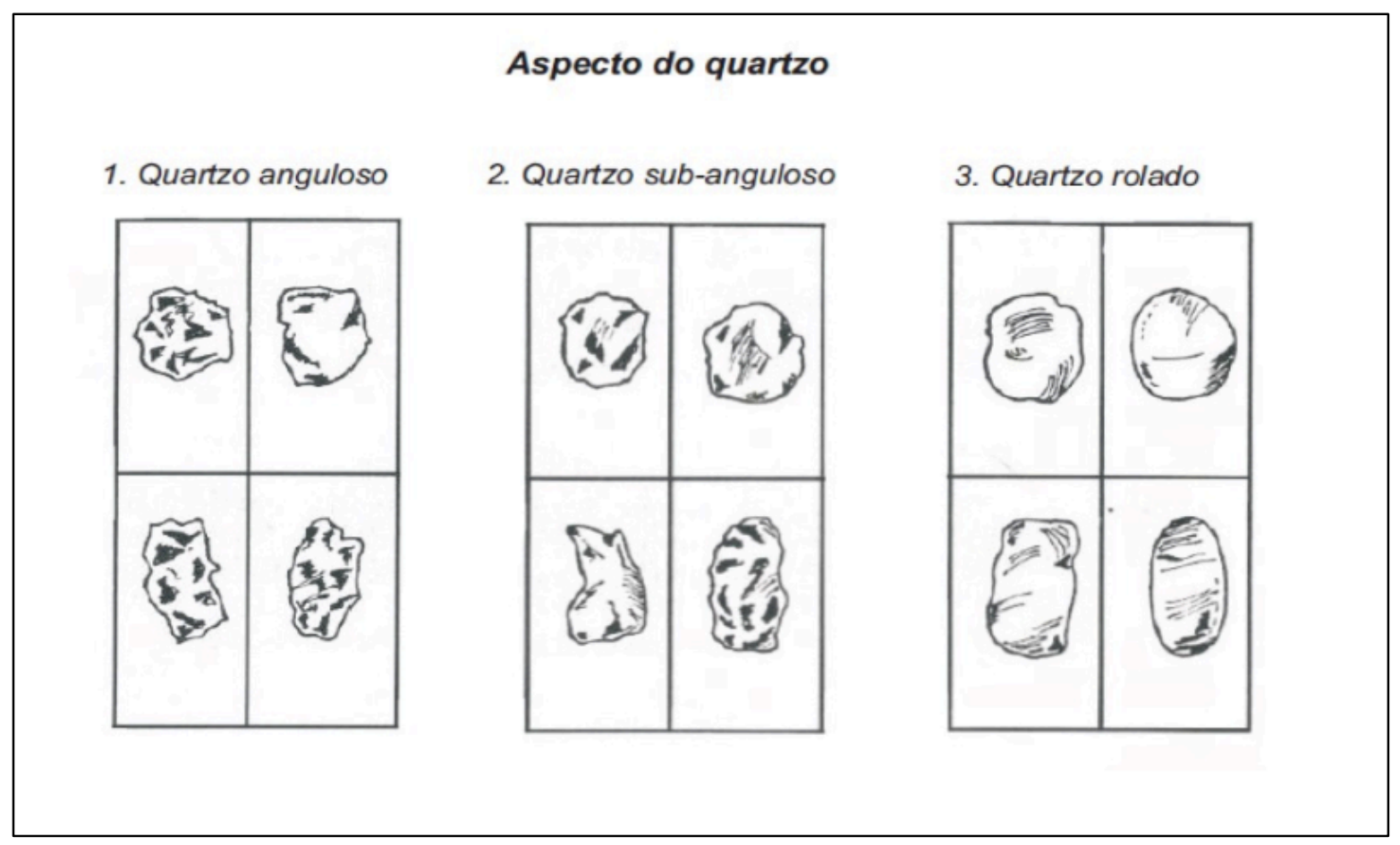

Imagem 57: tipos de aspecto da areia.

O tipo de pasta é definido pela coleta de informações sobre a variedade de inclusões não plásticas, da matriz da argila, da cor da argila e da queima. Sabe-se que para as cerâmicas da Amazônia antiga, normalmente há uma variabilidade dentro da pasta de um único pote (Lima 1986), mas em muitos casos tendências podem ser observadas. Um tipo de pasta procura observar aspectos desde a matriz da argila até inclusões visíveis com um auxílio de um microscópio binocular.

Primeiramente são identificados os tipos de antiplástico como por exemplo o cauixí, cariapé, minerais, chamote. Etc. Segundo Orton et al. (2003) a fabricação de um utensílio cerâmico (preparação da argila, forma, espessura das paredes, decoração, a relação entre o tempo de secagem do pote antes da queima e as técnicas de cocção possíveis) e as propriedades tecnológicas de um pote pronto (Porosidade, resistência física e térmica) dependem em grande parte do caráter da mistura da argila original com outros componentes antiplásticos - ou a própria eliminação destes componentes que podem estar naturalmente na matéria-prima. Quase toda a argila requer algum tipo de preparação antes de ser empregada na fabricação da cerâmica. A preparação da argila entra em duas categorias. A primeira se relaciona a limpeza, a extração de materiais não desejados, como raízes por exemplo. Em segundo lugar pode ser necessária a modificação das propriedades do material. Sendo que o objetivo é obter um produto - com propriedades previsíveis, controladas e adequadas - a partir das matériasprimas que podem variar. As propriedades desejadas para o produto final já cozido, como por 
exemplo as características térmicas (efetividade e resistência), dureza, porosidade, podem exigir certas preparações específicas (Rye 1986).

Dentro da análise do antiplástico se pretende utilizar parâmetros que possam dar informações, além do tipo de antiplástico presente, sobre a sua proporção e homogeneidade, buscando identificar se houveram determinadas escolhas feitas pela artesã durante a produção dos artefatos cerâmicos. Para tanto, serão utilizados os atributos frequência, e a forma (esfericidade) do antiplástico. Portanto pretendemos com o atributo Frequência do antiplástico estimar a proporção de antiplásticos no fragmento. Isto se dá a partir do estabelecimento de uma referência gráfica que estima uma porcentagem visual de antiplásticos na pasta. Um gabarito, a partir de Mathew et. al. (1991) serviu de base para as variáveis de análise:

\section{Frequencia}

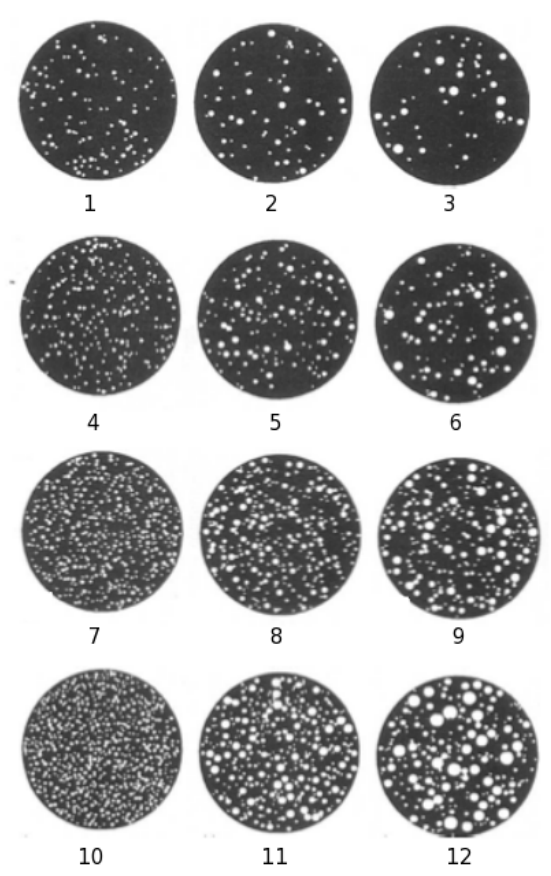

Imagem 58: 1) $5 \%, 0,5-1 \mathrm{~mm}$; 2) $5 \%, 0,5-2 \mathrm{~mm}$; 3) $5 \%, 0,5-3 \mathrm{~mm}$;) $10 \%, 0,5-1 \mathrm{~mm}$; 5) $10 \%, 0,5-2 \mathrm{~mm}$; 6) $10 \%, 0,5-3 \mathrm{~mm}$; 7) $20 \%, 0,5-1 \mathrm{~mm}$; 8) $20 \%, 0,5-2 \mathrm{~mm}$; 9) $20 \%, 0,5-3 \mathrm{~mm}$; 10) $30 \%, 0,5-1 \mathrm{~mm}$; 11) $30 \%$, 0,5-2mm; 12) 30\%, 0,5-3mm. Mathew et al. (1991)

As linhas indicam a proporção de elementos, enquanto as colunas a variação de suas dimensões (1mm, 2mm, 3mm). Os dados deste atributo de análise não buscam compreender as dimensões exatas dos componentes antiplásticos, mas sim ter uma aproximação visual de sua proporção na pasta. Nota-se que existem diferenças entre os tipos dos extremos do gabarito (1 e 12). Esta diferença, se observável, pretende contribuir com a caracterização da 
variabilidade das pastas cerâmicas utilizadas. Buscamos observar, por exemplo, se ocorreu a padronização no uso de determinadas características da argila, pois isto poderia indicar escolhas culturais. Tais escolhas podem ser entendidas como decisões feitas durante a manufatura dos produtos que determinam as propriedades formais, a partir dos recursos disponíveis acrescidos dos conhecimentos de seu produtor (Schiffer e Skibo 1997).

Por outro lado, se percebermos a existência de diferenças qualitativas no uso de diferentes antiplásticos, através do mapeamento tanto de seus usos quanto de sua disponibilidade, podemos mapear as propriedades de escolhas relacionadas a certas características de performance valorizadas por cada grupo ao longo do tempo (cf. Schiffer e Skibo, 1997). Através das escolhas técnicas, estas poderiam constituir um jogo de interações das capacidades específicas que o artefato possui, ou seja, aptidões de comportamento que o artefato deve possuir para cumprir sua função em atividade específica, como observado por Machado $(2005,2007)$ ao avaliar a importância caracterização do antiplástico como indicador de uma série de escolhas tecnológicas decorrentes de etapas da elaboração de um utensílio, ao invés de ser utilizado como uma espécie de fóssil guia de tradições cerâmicas.

\section{Tratamentos de superfície}

\section{Tipo de tratamento}

Primeiro são analisadas aquelas alterações feitas na superfície com intuito de aplicar motivos decorativos nos artefatos, divididos entre plásticos (incisões, acanalados, ponteados, apliques, filetes, etc.) e pintados, que podem ocorrer isolados ou associados.

\begin{tabular}{|ll|}
\hline Tipo de tratamento PLÁSTICO & \\
FE= Face externa & FI=face interna \\
1. Alisamento & 11. Escovado espiga \\
2. Inciso fino & 12. Estampado \\
3. Inciso Largo (fundo) & 13. Representação figurativa \\
4. Inciso Largo (raso) & 14. Não identificado \\
5. Ungulado & 15. Esgrafiato \\
6. Acanalado & 16. Digitado \\
7. Exciso & 17. cestaria \\
8. Impressão de corda & 18. Ponteado \\
9. Impressão de tecido & 19. Ponteado arrastado \\
10. escovado sabugo & 00. Não identificado \\
\hline
\end{tabular}




\begin{tabular}{|l|}
\hline Tipo de decoração CRÔMICA \\
1. Engobo vermelho \\
2. Engobo branco \\
3. Engobo preto \\
4. Banho branco \\
5. Banho vermelho \\
6. Banho preto \\
7. Pintura branca \\
8. Pintura vermelha \\
9. Pintura preta \\
00. NI \\
\hline
\end{tabular}

Os incisos foram separados a partir de sua espessura e profundidade em inciso fino, largo e raso, largo e profundo. Os tipos escovados foram denominados assim após experimentação feita em argila no intuito te identificar este tratamento de superfície e seu provável instrumento de aplicação. Diferentes instrumentos foram testados como: cascas, folhas, tecidos, cestaria, pentes e o sabugo de milho (Zea mays) foi aquele que se aproximou mais do tipo arqueológico denominado então de Escovado Sabugo. Os milhos utilizados para o experimento foram gentilmente doados por Joaquim Tupari, e são denominados de milho mole tendo sua utilização voltada principalmente para o preparo de mingau e bebidas fermentadas.

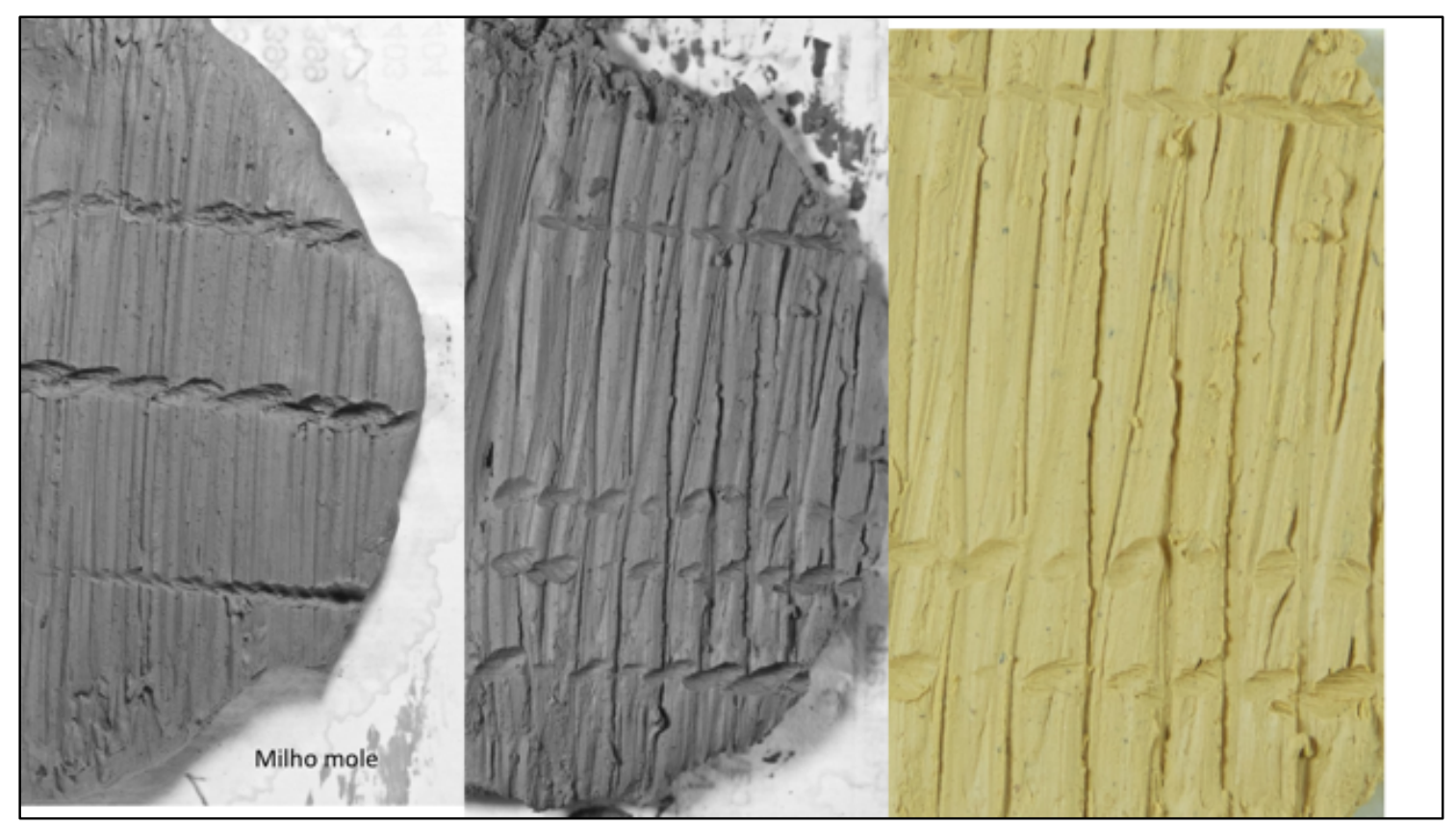

Imagem 59: resultado do experimento. 


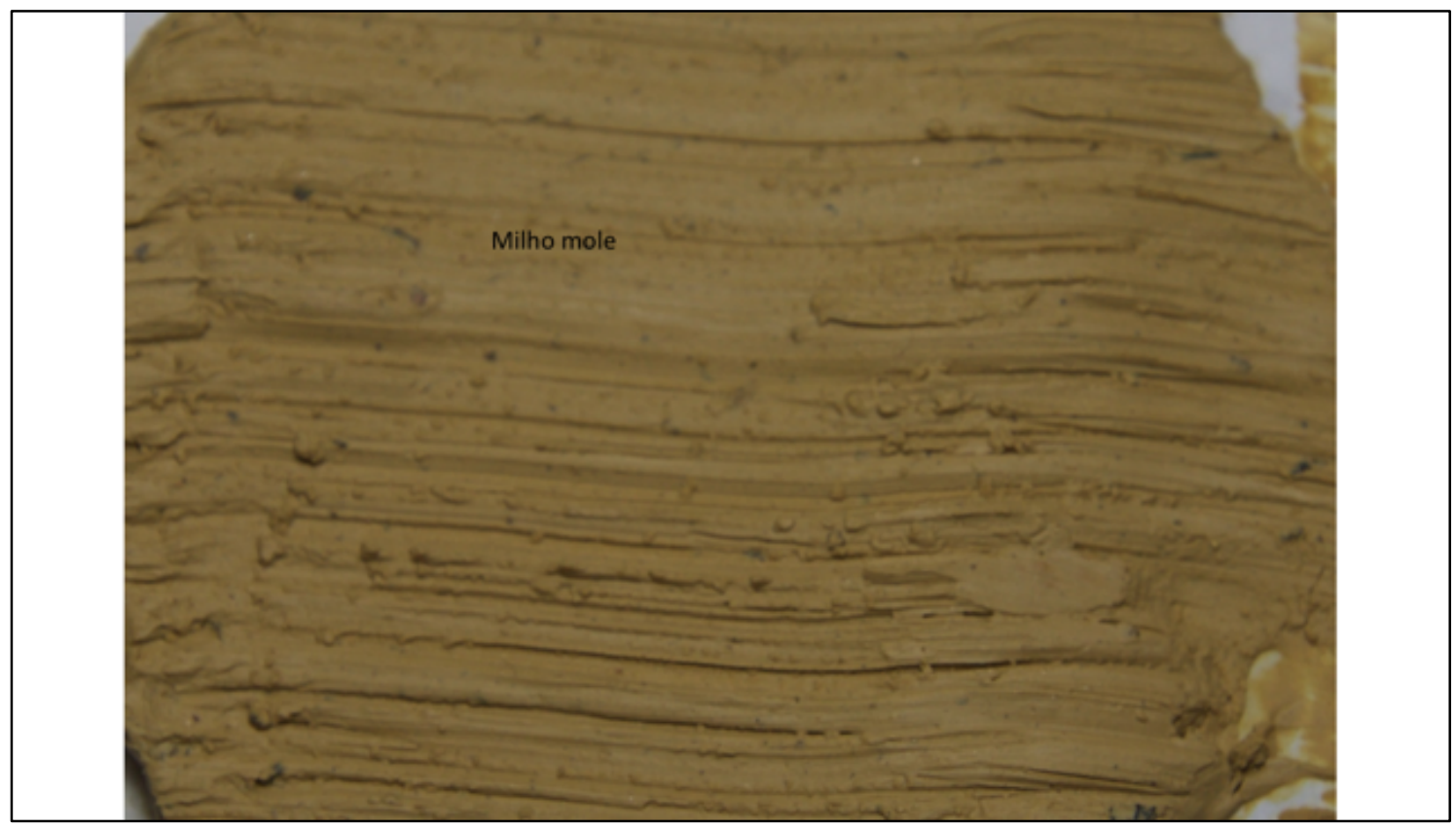

Imagem 60: resultado do experimento.

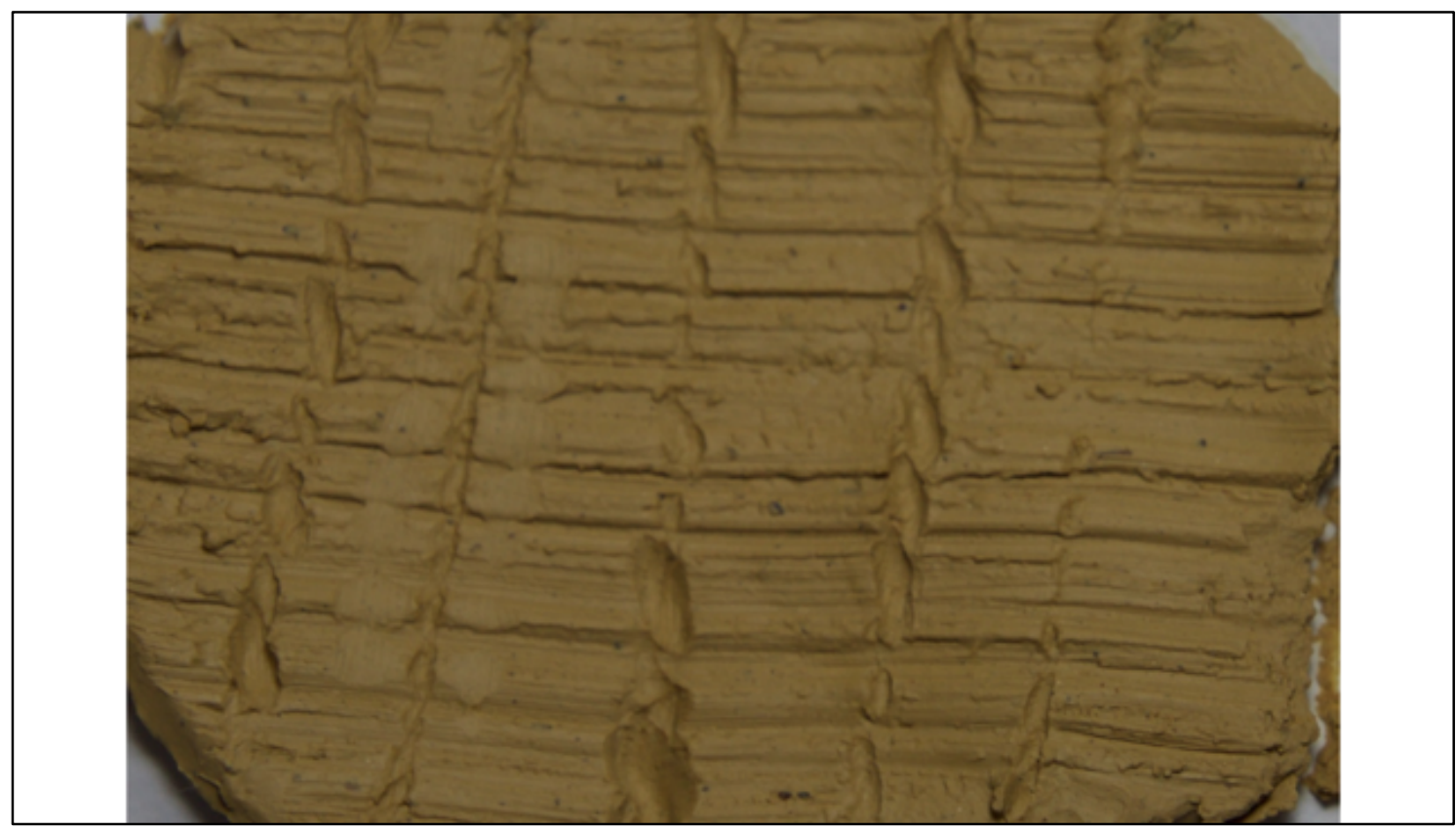

Imagem 61: detalhe do resultado do experimento com o sabugo, sem os grãos.

Outro tipo de instrumento que provavelmente pode ter sido utilizado foi denominado de Escovado espiga, dada a semelhança do resultado do experimento e dos tipos detectados arqueologicamente. Novamente o milho utilizado foi o milho mole e chama atenção que tanto 
no tipo arqueológico como o tipo criado no experimento, podem ser percebidos o posicionamento dos grãos entrelaçados ${ }^{3}$.

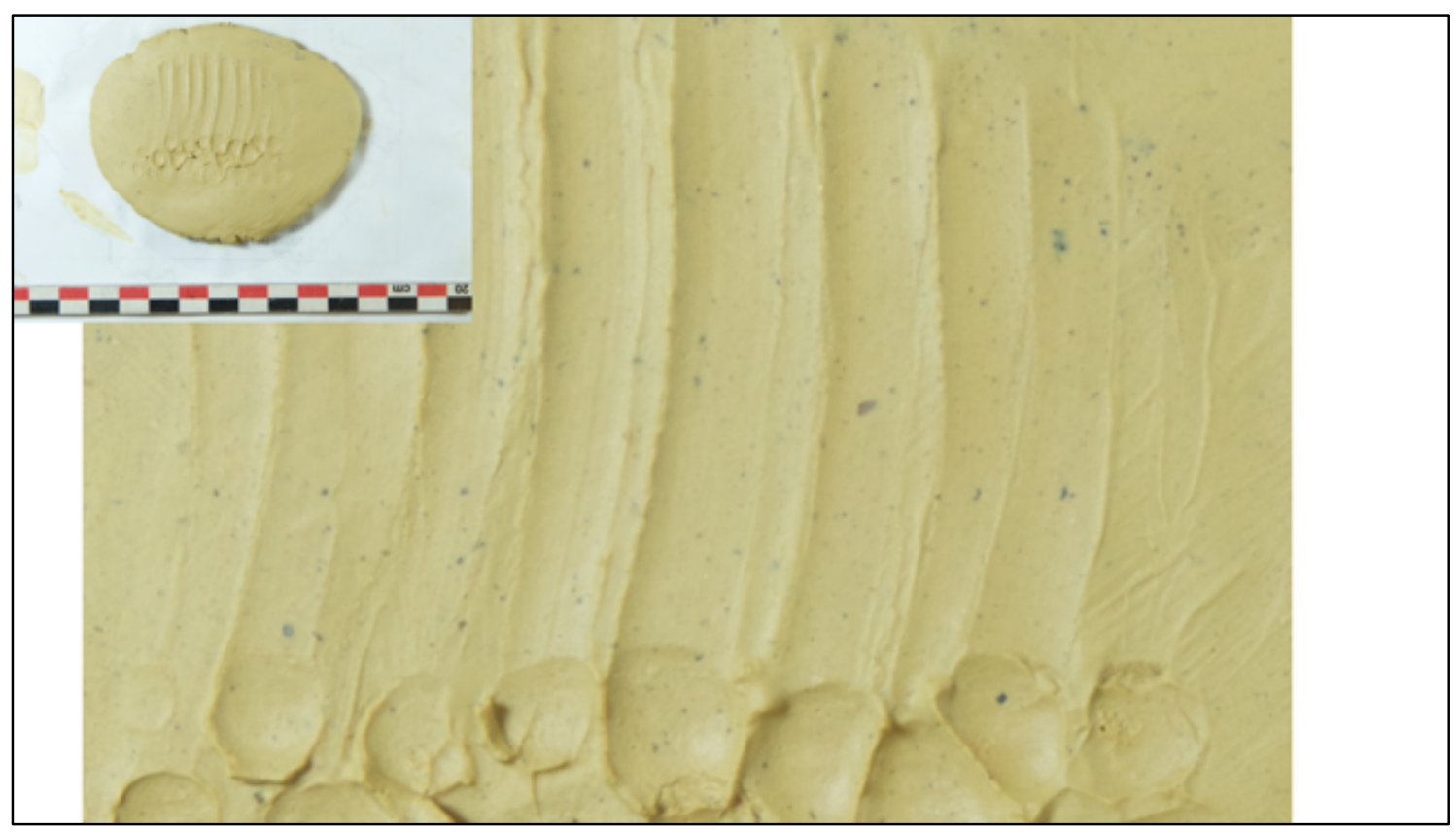

Imagem 62: detalhe do experimento feito com a espiga de milho mole.

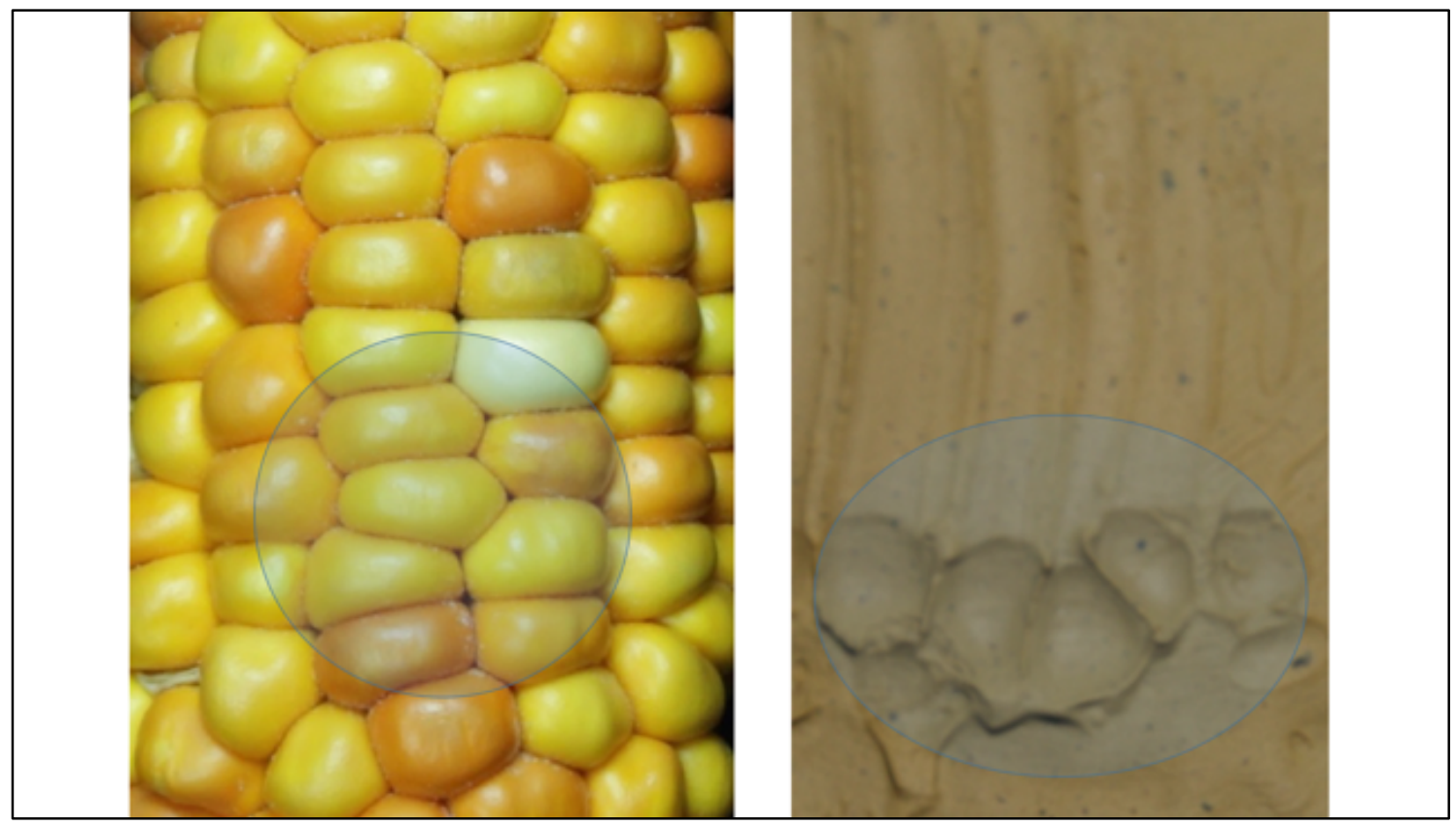

Imagem 63: a esquerda detalhe do milho mole, e à direita detalhe do resultado do experimento.

\footnotetext{
${ }^{3}$ Grão entrelaçados é uma caraterística que os milhos encontrados no comércio hoje em dia não possuem mais, dada a simetria e alinhamento dos grãos.
} 
Foi realizada a classificação dos tratamentos de superfície buscando entender os processos de acabamento dos potes, que podem ocorrem tanto antes quanto após a cocção, e podem ser diretamente influenciados pela proposta da função do artefato. Processos como alisamentos, polimento, barbotina, brunidura podem ser aplicados tanto na face interna como externa dos fragmentos, tanto em fragmentos decorados quanto alisados, e foram tipificados nesta categoria de análise.

\begin{tabular}{|l|}
\hline Tratamento dado à superfície do fragmento \\
1.Barbotina \\
2. Polido \\
3. Brunidura \\
4. Reboco \\
5. Simples \\
6. Esgrafiado \\
\hline
\end{tabular}

Para esta classificação, entendemos a barbotina como uma mistura fluída de pasta de argila, com a mesma coloração do fragmento, diferente do que foi classificado como engobo, um banho com uma mistura fluída de pasta cerâmica, com pigmentação, de cor diferente do fragmento. Rye (1987) sugere que tais processos técnicos teriam a função impermeabilizante, mas a atribui também uma função decorativa, como uma camada que se superpõe à superfície de uma peça a fim de modificar, depois da queima, a cor e o aspecto da superfície.

O Esgrafiado (imagem 67) é entendido como uma técnica que consiste em fazer incisões ou excisões em um suporte de maneira que seja descoberta uma camada inferior de cor diferente. Pode ser aplicado sobre engobo. O resultado é acentuar o motivo aplicado a peça (Bellido, 2008). É normalmente associada a potes com queima oxidante com núcleo reduzido, onde se aplicava uma queima com manutenção de altas temperaturas, sendo resfriadas de maneira rápida ao ser expostas a uma atmosfera oxidante, tendo como resultado a camada externa dos potes fosse clareada, adquirindo um tom semelhante da argila antes da queima (Rye 1981). 


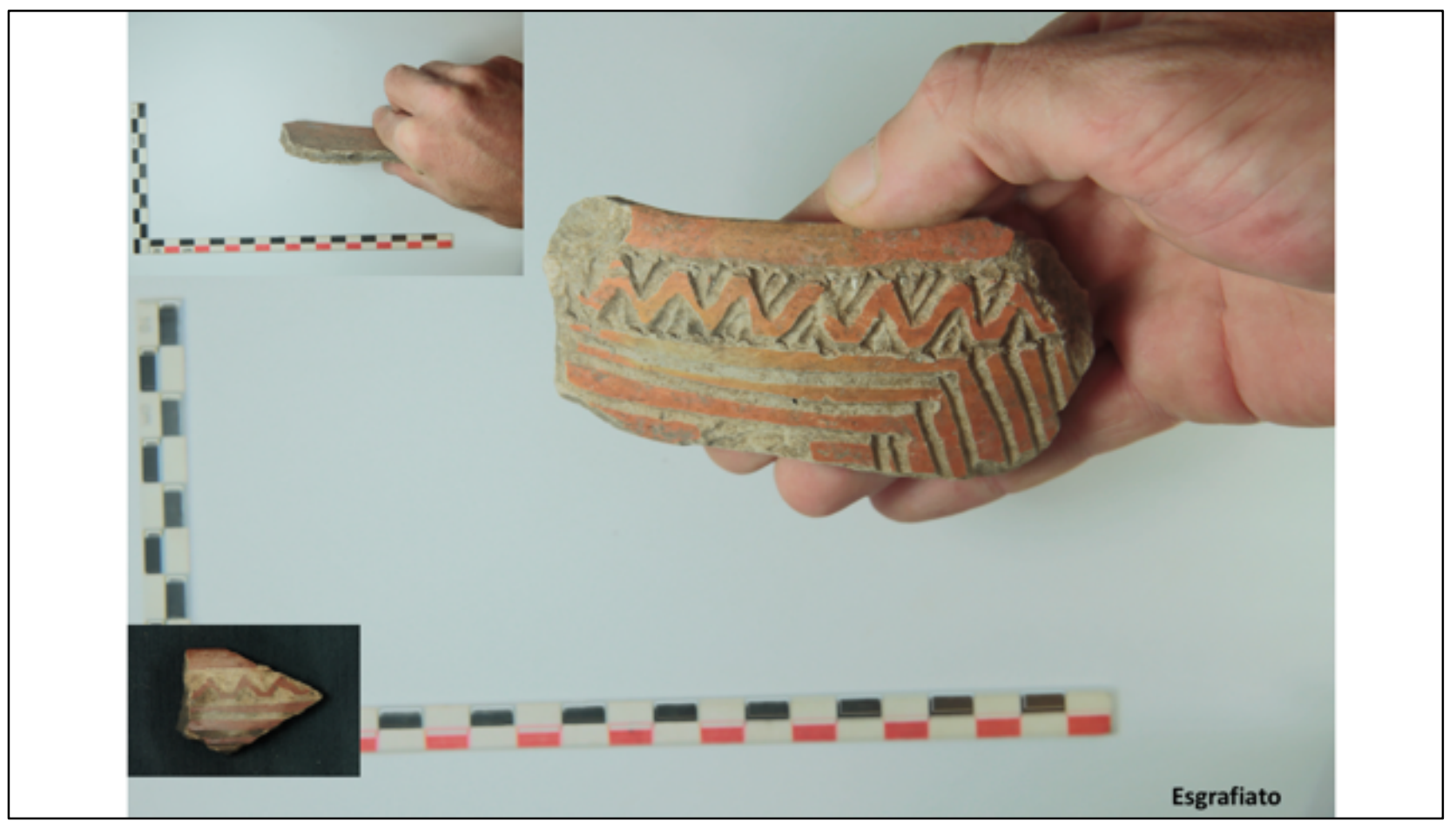

Imagem 64: fragmento com tratamento de esgrafiado, que envolve técnicas de excisão, incisão, aplicação de engobo, e controle da temperatura de queima e resfriamento da peça.

\section{Motivos decorativos}

Os tipos decorados que já foram descritos para a fase Bacabal foram elaborados mais em decorrência da técnica de produção e acabamento do que em relação ao motivo decorativo em si. Nestas descrições são identificados 12 tipos, dos quais somente o Bacabal tem-se certeza do motivo. Segundo Miller (2013 p.106), os tipos decorados da fase seriam:

- Bacabal Exciso - Faixas horizontais em ziguezague criando áreas triangulares rebaixadas por incisões finas paralelas; superfície vermelha, retoque preto.

- Bacabal Inciso Incisões largas, retas e paralelas; superfície simples.

- Branco Inciso Inciso hachurado, superfície simples.

- Capivara Inciso reticulado, superfície com banho vermelho

- Castelo Exciso Características iguais ao tipo Bacabal Exciso; superfície com banho vermelho

- Castelo Inciso - Inciso reticulado, superfície simples.

- Castelo Vermelho - Superfície com banho vermelho.

- Monte Exciso Características iguais ao tipo Bacabal Exciso; superfície simples. 
- Monte Inciso Incisões largas, retas e paralelas; superfície com banho vermelho.

- União Inciso e Ponteado Inciso e ponteado, superfície simples.

- Valão Inciso Inciso hachurado, superfície com banho vermelho.

- Valão Ponteado Ponteado estampado dentado, superfície simples.

Por haverem na nossa análise atributos relacionados ao tratamento de superfície e o tipo de técnica para aplicar a decoração, não utilizamos para a nossa classificação os mesmos atributos para compor o tipo decorativo que foram empregados por Miller (2009). É verificado durante a análise a repetição de motivos no intuito de se estabelecer tipos quem podemos separar e comparar. De maneira inicial partiu-se dos seguintes motivos:

\begin{tabular}{|c|c|c|c|}
\hline \multicolumn{4}{|l|}{ Motivos } \\
\hline 1. Bacabal & 4. Bacabal repetido & 7. Escovado - sabugo & $\begin{array}{l}\text { 10. Representação } \\
\text { Antropomorfa }\end{array}$ \\
\hline 2. Bacabal espelhado & 5. Bacabal Inciso paralelo & 8. Escovado - espiga & 11. Representação Zoomorfa \\
\hline 3. Bacabal 2 - não preenchido & 6. Inciso cruzado (losangular) & 9. impressão de cestaria & 12. Quadriculado \\
\hline & & & 13. Inciso não cruzado \\
\hline
\end{tabular}

\section{Queima e Vestígios de produção e utilização}

Para elaboração dos atributos da queima, levou-se em consideração que a queima tradicional indígena registrada (Silva 2007, Wüst 1984) provavelmente é algo muito semelhante ao que seus antepassados da Amazônia antiga praticaram, e sendo assim sabe-se que podem haver variações de queima dentro de um mesmo pote dado aos vários fatores que a influenciam - como a quantidade de oxigênio e a manutenção da temperatura - resultando em potes com tonalidades de cores resultado de ambientes ora redutores, ora oxidantes.

$\mathrm{Na}$ busca de identificar estes diferentes tipos de queima utilizamos um gabarito visual elaborado a partir da proposta de Rye (1981) que busca reconhecer a possível atmosfera da queima dos potes quando produzidos. Além dos atributos relacionados a queima em ambiente redutor e oxidantes, e suas variações, foi incluído o tipo incompleta, referindo-se quando o fragmento apresenta uma porção reduzida e outra ainda parcialmente crua no interior do fragmento, dissolvendo-se facilmente em água. 


\section{Aspecto da queima}

1. Oxidante

2. Oxidante, núcleo reduzido

3. Reduzida, núcleo oxidante

4. Reduzida

5. Oxidante interna/reduz externa

6. Oxidante externa/reduz interna

7. Queima incompleta(crua)

99. Não se aplica

00. Não identificado

Tipo de queima (adaptado de Rye, 1981)

1. Oxidante

2. Oxidante, núcleo reduzido
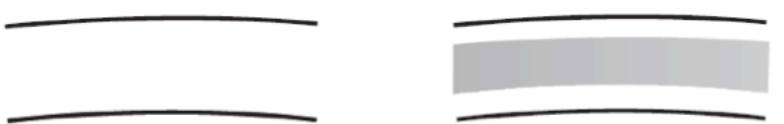

3. Reduzida, núcleo reverso

4. Reduzida
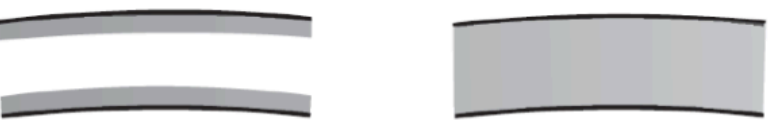

5. Oxidante interna,

Também procuramos observar se vestígios relacionados a técnicas de produção pudessem ser identificados nos fragmentos. Para tal os atributos foram divididos em:

\begin{tabular}{|ll|}
\hline Vestígio de produção e gestos & \\
1. Folha & 5.bolhas de ar superfície \\
2. Queima de confecção & 6. alteração serrilhado \\
3. Impressão de galhos & 7. ondulação eixo vertical \\
4. Impressão de folha & 00. Não identificado \\
\hline
\end{tabular}

Os vestígios de uso dos vasilhames procuraram identificar rastros relacionados a utilização dos utensílios que podem estar presentes tanto na superfície interna quanto externa 
dos fragmentos. O uso pode estar relacionado ao uso junto ao fogo, como depósitos de fuligem na parte externa, e depósitos de carbono na parte interna, por exemplo. Outras alterações como furo posterior a queima e reciclagem também são considerados. Os fragmentos foram classificados a partir da presença de:

\begin{tabular}{|ll|}
\hline Vestígio de utilização & \\
1. Fuligem & 5. Vestígio orgânico \\
2. Desgaste por 'colher' ou outro objeto & 6. Furo posterior a queima \\
3. Oxidação & 00. Não identificado \\
4. Fermentação & \\
\hline
\end{tabular}

\section{Grau de Conservação}

A elaboração deste atributo teve como objetivo auxiliar na compreensão da preservação da amostra e ao mesmo tempo auxiliar na explicação dos processos que levaram a construção do sambaqui Monte Castelo. Miller (2009) observa que devido a alcalinidade da matriz do sambaqui, os fragmentos ali encontrados apresentam um estado de conservação mais preservado em relação à aqueles situados em sítios do entorno do monumento e das ilhas de terra firme.

O autor não chega a entrar em detalhes, mas a presença de fragmentos oxidados no registro das camadas do Monte Castelo pode sugerir indícios de utilização destas como componente do material construtivo do sítio.

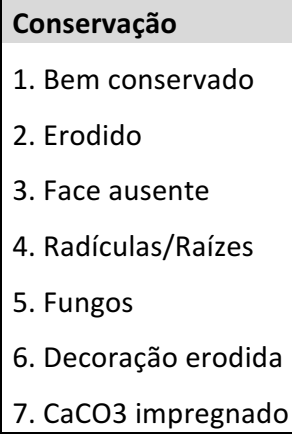




\section{Classificação de Bordas e Bases}

Bordas

As bordas são classificadas a partir de sua morfologia, inclinação e espessura. Os atributos adotados são os mesmos indicados pela TERMINOLOGIA (Chmyz 1976). Quanto à morfologia, a borda pode ser classificada como: direta, extrovertida, introvertida. A inclinação é irrestrita inclinada, irrestrita, direta e restrita. Adotamos na classificação a elaboração de um dado em relação à morfologia e outro em relação à inclinação da borda, pois um mesma morfologia de borda pode indicar diferentes funções de um pote, dependendo de sua inclinação(Imagem 68). O espessamento é classificado como direto, expandido, reforçado internamente, reforçado externamente, dobrada ou contraída. 


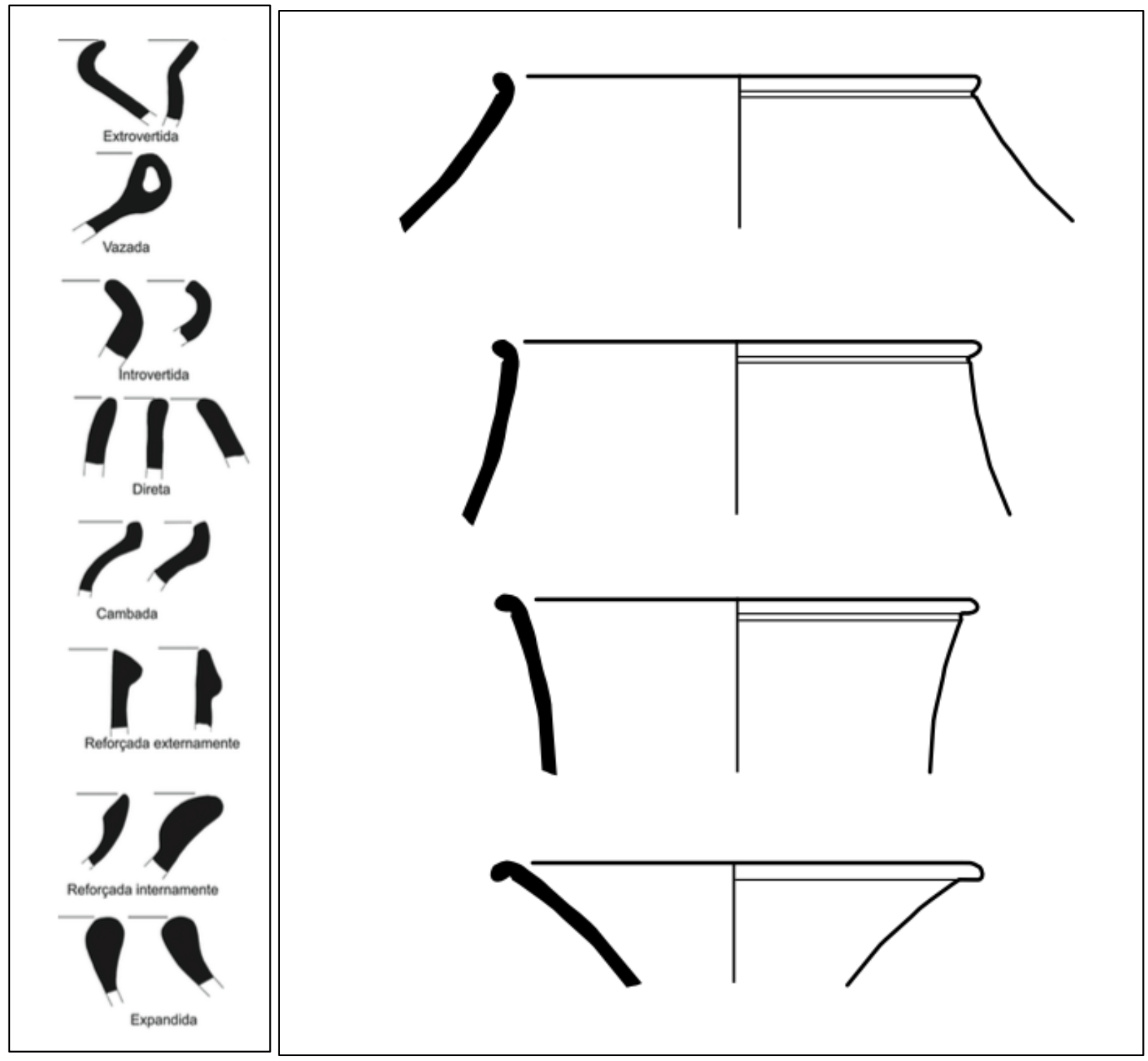

Imagem 65: a esquerda tipos morfológicos e de espessamento de borda (Barreto et al. 2016). A direita a mesma borda e suas possiveis diferentes inclinações. De cima para baixo: restrita, direta, irrestrita e irrestrita inclinada.

Junto a verificação da morfologia e inclinação da borda é analisado o tipo de lábio (imagem 69), classificados como: arredondado, plano, apontado ou biselado, e tendo a sua espessura mensurada em milímetros. Quando possível obtemos dados sobre o diâmetro aproximado de abertura de boca do pote e sua representatividade expressada em por cento, em relação ao que seria o diâmetro de um pote completo. 


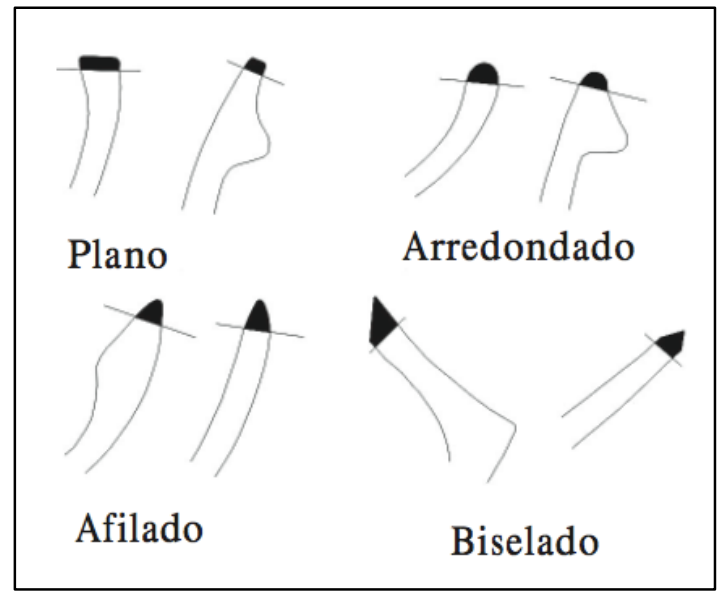

Imagem 66: tipos de lábio (Barreto et al. 2016)

\section{Bases}

As bases foram classificadas em relação a sua morfologia (imagem 71), e quando possível foi registrado o ângulo referente a sua inclinação (imagem 70).

\begin{tabular}{|ll|}
\hline Tipo de base & \\
1. Biplana & 8. Côncava-plana \\
2. Plano-côncava & 9. Bi-côncava \\
3. Plano-convexa & 10. Anelar \\
4. Convexa-plana & 11. Pedestal \\
5. Convexa-côncava & 12. Trípode \\
6. Bi-convexa & 99. Não se aplica \\
7. Côncava-convexa & 00. Não identificado \\
\hline \multicolumn{2}{|c}{ Tabela 3: atributos para classificação de base } \\
\hline
\end{tabular}

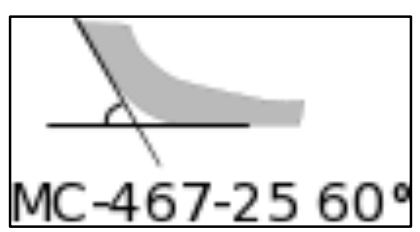

Imagem 67: exemplo de coleta de informação da inclinação de uma base. 


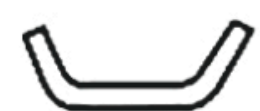

1. Biplana

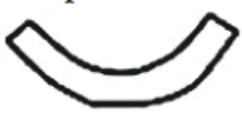

2. Plano-côncava

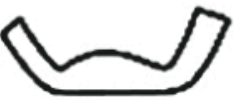

3. Plano-convexa

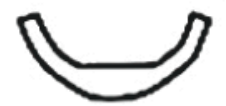

7. Côncavaconvexa

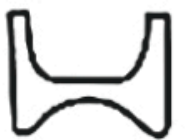

8. Côncava-plana

4. Convexa-plana
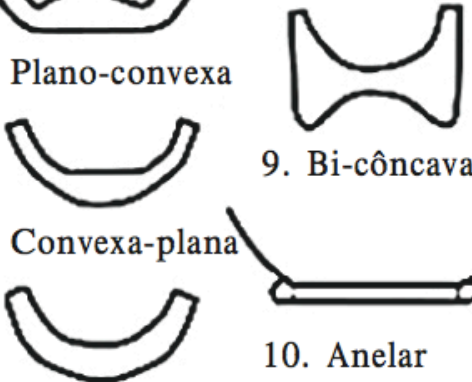

9. Bi-côncava

9. Bi-concava

5. Convexacôncava



6. Bi-convexa

\section{Anelar}

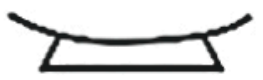

11. Pedestal

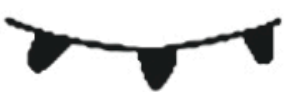

12. Trípode

Imagem 68: tipos de base (Barreto et al. 2016)

O processo de apreciação da amostra ainda incluiu o registro gráfico, que consiste no desenho dos perfis de bordas em 2D, indicando a inclinação, espessura, tratamento de superfície e o possível diâmetro de abertura. Havendo a ocorrência de fragmentos (ou conjunto de fragmentos agrupados) como bordas, bojos e bases, que fornecessem dados quanto a morfologia dos potes, serão realizadas reconstruções de forma. Também são desenhados os perfis das bases, indicando a inclinação. O processo de registro concluiu-se com a fotografia dos tipos selecionados e a ilustração da borda, sua projeção de diâmetro junto a foto do fragmento. 


\section{Capítulo 4 - Descrição da fase Bacabal}

\section{Amostra analisada}

A amostra analisada provém de dois contextos recuperados durante as duas etapas de escavação do sítio Monte Castelo. O primeiro trata-se das porções escavadas relacionadas ao colapso da escavação feita nos anos 80 por Eurico Miller. Nesta matriz era abundante a presença de vestígios diagnósticos relacionados a fase Bacabal que por vezes eram encontrados em meio a vestígios ligados às duas últimas ocupações do sítio arqueológico, que remetem a presença de uma fazenda, e da utilização do local por indígenas moradores da T.I. Rio Branco, vizinha da REBIO do Guaporé.

Portanto, dada a natureza diversa das amostras e o objetivo de descrever ao máximo os atributos relativos a fase Bacabal procedemos a avaliação de duas maneiras. A primeira amostra analisada buscou obter a variabilidade formal dos atributos, levando em conta todos os vestígios cerâmicos recuperada das duas etapas de escavação $(\mathrm{n}=1351)$. A variabilidade está relacionada as propriedades físicas de um artefato, como composição, dimensões, peso, texturas e cor (Silva, 2007).

Para este contexto foram analisados fragmentos cerâmicos provenientes da etapa de escavação de $2014(\mathrm{n}=1720)$. Após a lavagem, numeração e triagem, 919 fragmentos cerâmicos foram classificados como diagnóstico $(53,46 \%)$. 


\begin{tabular}{|c|c|c|c|c|c|c|}
\hline NP & Unidade & Nível $(\mathrm{cm})$ & Diagnóstico & Peso(g) & $\begin{array}{c}\text { Não- } \\
\text { diagnóstico }\end{array}$ & Peso(g) \\
\hline 16 & N1010 E1009-10 & $200-250$ & 12 & 470 & 6 & 140 \\
\hline 31 & N1011 E1011 & $0-80$ & 10 & 340 & 2 & 30 \\
\hline 22 & N1010 E1009-10 & $250-300$ & 12 & 342 & 0 & 0 \\
\hline 90 & N1009 E1010 & $330-350$ & 22 & 344 & 40 & 644 \\
\hline 36 & N1011 E1011 & $0-100$ & 116 & 3492 & 252 & 4426 \\
\hline 8 & N1010 E1008,5 & $0-20$ & 67 & 1850 & 101 & 1936 \\
\hline 40 & N1011 E1011 & $0-80$ & 6 & 80 & 9 & 98 \\
\hline 82 & N1010 E1008,5 & $140-150$ & 2 & 10 & 4 & 30 \\
\hline 87 & N1009 E1010 & $320-330$ & 17 & 210 & 14 & 190 \\
\hline 14 & N1010 E1009-10 & $140-200$ & 88 & 2598 & 12 & 150 \\
\hline 38 & N1010 E1011 & $0-80$ & 113 & 2336 & 38 & 666 \\
\hline 13 & N1011 E1009-10 & $20-90$ & 154 & 3018 & 134 & 2210 \\
\hline 3 & Corte 4 & superfície & 28 & 376 & 9 & 216 \\
\hline 1 & Corte 4 & superfície & 21 & 438 & 0 & 0 \\
\hline 18 & N1011 E1009-10 & $90-100$ & 52 & 998 & 0 & 0 \\
\hline 204 & N1009 E1008,5 & $130-140$ & 3 & 48 & 0 & 0 \\
\hline 63 & N1009 E1008,5 & $120-130$ & 1 & 12 & 0 & 0 \\
\hline 68 & N1009 E1008,5 & $140-150$ & 1 & 20 & 0 & 0 \\
\hline 1001.3 & N1009 E1008,5 & $140-150$ & 1 & 22 & 0 & 0 \\
\hline 207 & For a do sítio & superfície & 33 & 650 & 23 & 340 \\
\hline 73 & N1010 E1008,5 & $130-140$ & 10 & 290 & 0 & 0 \\
\hline 105 & N1010 E1008,5 & $190-200$ & 1 & 8 & 0 & 0 \\
\hline 20 & N1011 E1009-10 & $100-110$ & 45 & 878 & 39 & 580 \\
\hline 35 & N1011 E1009-10 & $90-100$ & 38 & 926 & 89 & 716 \\
\hline 62 & N1009 E1008,5 & $90-100$ & 30 & 522 & 24 & 458 \\
\hline 205 & N1011 E1009-10 & $100-110$ & 6 & 58 & 0 & 0 \\
\hline 69 & N1011 E1011 & $90-100$ & 11 & 220 & 0 & 0 \\
\hline 70 & N1010 E1011 & $90-100$ & 9 & 150 & 0 & 0 \\
\hline 204 & N1009 E1008,5 & $130-140$ & 3 & 58 & 5 & 26 \\
\hline 57 & N1011 E1008 & $90-100$ & 7 & 92 & 0 & 0 \\
\hline \multicolumn{3}{|c|}{ Total } & 919 & 20856 & 801 & 12856 \\
\hline
\end{tabular}

Tabela 4: Resultado da triagem de materiais cerâmicos da etapa de 2014

A segunda amostra analisada é proveniente especificamente da segunda etapa de escavação, onde com um contexto bem preservado e com um registro rigoroso da proveniência do material buscamos obter dados relativos a variabilidade dos artefatos (cf. Schiffer e Skibo, 1997). Nesse sentido procuramos analisar aqueles atributos pertinentes a explicação das diferenças e similaridades entre os tipos de artefatos no tempo e no espaço. A amostragem feita no ano de 2016 atingiu 1208 fragmentos, dos quais 485 foram elencados como diagnóstico. 


\begin{tabular}{|c|c|c|c|c|c|c|}
\hline NP & $\begin{array}{c}\text { Nivel } \\
(\mathrm{cm})\end{array}$ & Camada & Diagnóstico & $\begin{array}{c}\text { peso } \\
(\mathrm{g})\end{array}$ & $\begin{array}{c}\text { Não } \\
\text { diagnóstico }\end{array}$ & $\begin{array}{c}\text { peso ND } \\
(\mathrm{g})\end{array}$ \\
\hline 280 & $10-20 \mathrm{~cm}$ & $\mathrm{~A}$ & 5 & 78 & 10 & 102 \\
\hline 282 & $20-30$ & A & 18 & 385 & 15 & 90 \\
\hline 317 & $30-40$ & A & 29 & 364 & 24 & 128 \\
\hline 321 & $30-40$ & A-B & 15 & 210 & 15 & 120 \\
\hline 322 & $40-50$ & B & 57 & 1210 & 39 & 650 \\
\hline 264 & $50-60$ & B & 12 & 270 & 29 & 140 \\
\hline 364 & $60-70$ & B & 26 & 320 & 42 & 430 \\
\hline 382 & $60-70$ & C & 9 & 100 & 26 & 180 \\
\hline 410 & $70-80$ & C & 23 & 300 & 36 & 324 \\
\hline 413 & $70-80$ & D3 & 39 & 566 & 51 & 520 \\
\hline 418 & $80-90$ & D3 & 91 & 1630 & 188 & 1466 \\
\hline 435 & $80-90$ & D2 & 29 & 690 & 59 & 814 \\
\hline 437 & $90-100$ & D3 & 19 & 405 & 23 & 312 \\
\hline 438 & $90-100$ & D2 & 64 & 1740 & 100 & 1050 \\
\hline 467 & $100-110$ & D2 & 49 & 760 & 66 & 890 \\
\hline & TOTAL & & 485 & 9028 & 723 & 7216 \\
\hline
\end{tabular}

Tabela 5: Resultado da triagem do material cerâmico de 2016

\section{Resultados da análise cerâmica}

Os dados utilizados para caracterizar a variabilidade formal da cerâmica da fase Bacabal são provenientes da soma das duas amostragens realizadas. Entre as etapas de 2014 e 2016 somou-se um montante de 2928 fragmentos cerâmicos, dos quais 1318 (45\%) foram considerados diagnósticos.

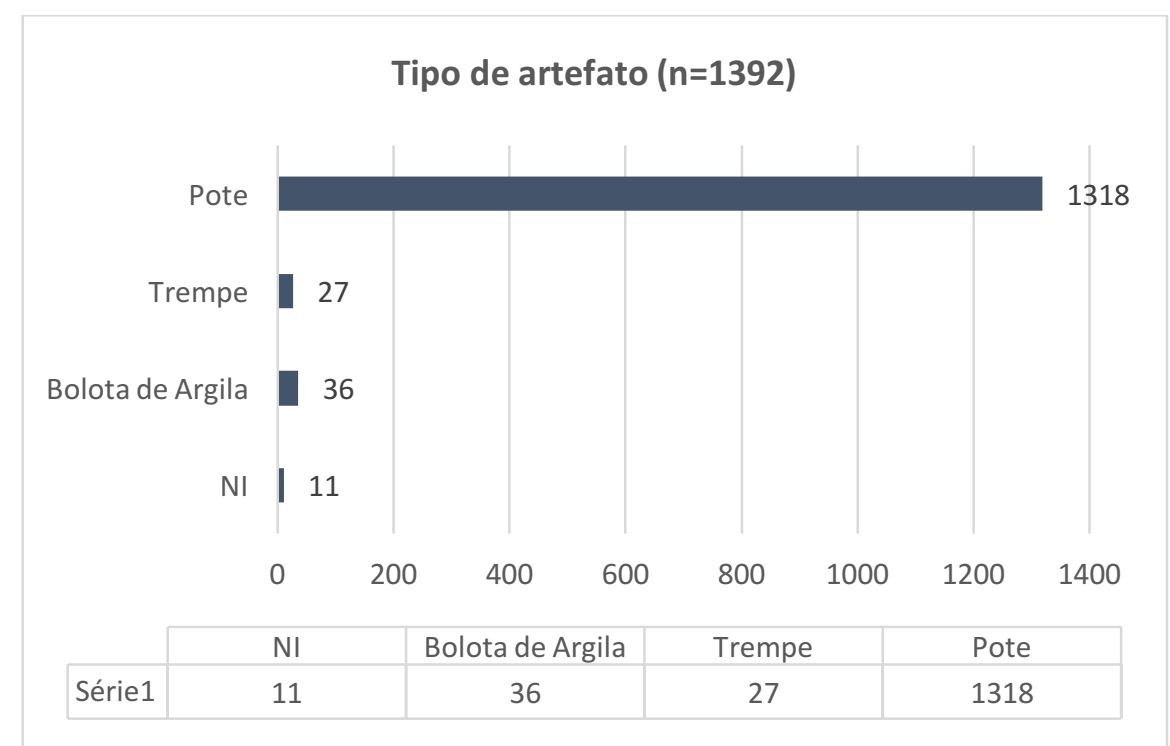

Gráfico 1: tipos de artefatos identificados 
A maioria das evidências foram classificadas como potes (94.68\%), ocorrendo também outros tipos de artefatos (4,52\%), que foram distribuídos entre trempes $(n=27)$, bolotas de argila (n=36) (gráfico 1, tabela 6)

\begin{tabular}{|l|c|c|}
\hline Tipo de artefato & Quantidade & $\mathbf{\%}$ \\
\hline NI & 11 & 0,79 \\
\hline Bolota de Argila & 36 & 2,59 \\
\hline Trempe & 27 & 1,94 \\
\hline Pote & 1318 & 94,68 \\
\hline $\mathrm{n}=$ & 1392 & \\
\hline \multicolumn{2}{|c|}{ Tabela 6: tipos de artefatos identificados }
\end{tabular}

Potes

Os fragmentos de potes por sua vez foram divididos em relação a sua posição no artefato e divididos em: paredes, bordas, bases, apliques, asas, alças e gargalo. As paredes $(n=869 / 65,93 \%)$, bordas $(n=303 / 22,99 \%)$ e bases $(n=108 / 8,19 \%)$ foram os tipos mais recorrentes, enquanto que asas $(1,19 \%)$ e alças $(0,91 \%)$ ocorrem de maneira discreta, e gargalos $(0,38 \%)$ e apliques $(0,15 \%)$ são raros (Gráfico 2).

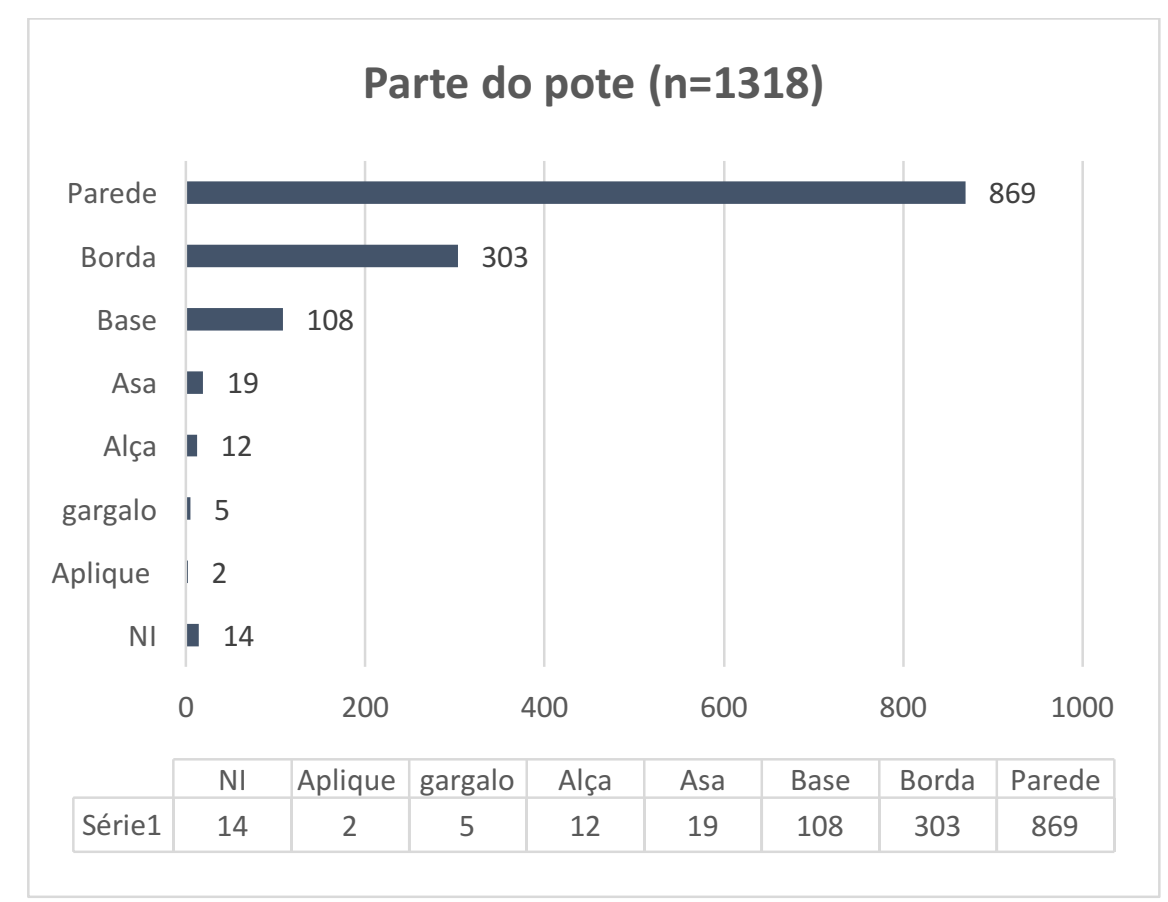

Gráfico 2: partes identificados dos potes 


\begin{tabular}{|l|c|c|}
\hline Parte & Quantidade & $\mathbf{\%}$ \\
\hline NI & 14 & 1,06 \\
\hline Aplique & 2 & 0,15 \\
\hline gargalo & 5 & 0,38 \\
\hline Alça & 12 & 0,91 \\
\hline Asa & 19 & 1,44 \\
\hline Base & 108 & 8,19 \\
\hline Borda & 303 & 22,99 \\
\hline Parede & 869 & 65,93 \\
\hline $\mathrm{n}=$ & 1318 & \\
\hline \multicolumn{2}{|c|}{ Tabela 7: partes identificados dos potes } \\
\hline
\end{tabular}

\section{Espessura dos fragmentos}

A espessura dos fragmentos variou entre 2 e $32 \mathrm{~mm}(\mathrm{n}=1281)$, tendo a maior ocorrência entre uma espessura de 5 e 8mm (n=935/72,98\%) (Gráfico 3 e 4). As bodas e bases, quando comparadas com paredes, parecem ter uma menor simetria na composição de cada fragmento, ou seja, uma distancia maior entre a menor medida obtida e a menor. No gráfico 4 temos a tendência linear para a espessura de paredes, bases e bordas. A partir da plotagem e dos dados da previsão linear (r2) percebe-se estatisticamente as tendências para os casos onde existe uma variação mais significativa entre a medida maior e menor da espessura estariam mais relacionados a bordas e bases do que paredes. Ao mesmo tempo que o baixo valor de $\mathrm{r} 2$ para as paredes também demonstra uma assimetria aparente para estes indivíduos. 
Espessura dos fragmentos $n=1281$

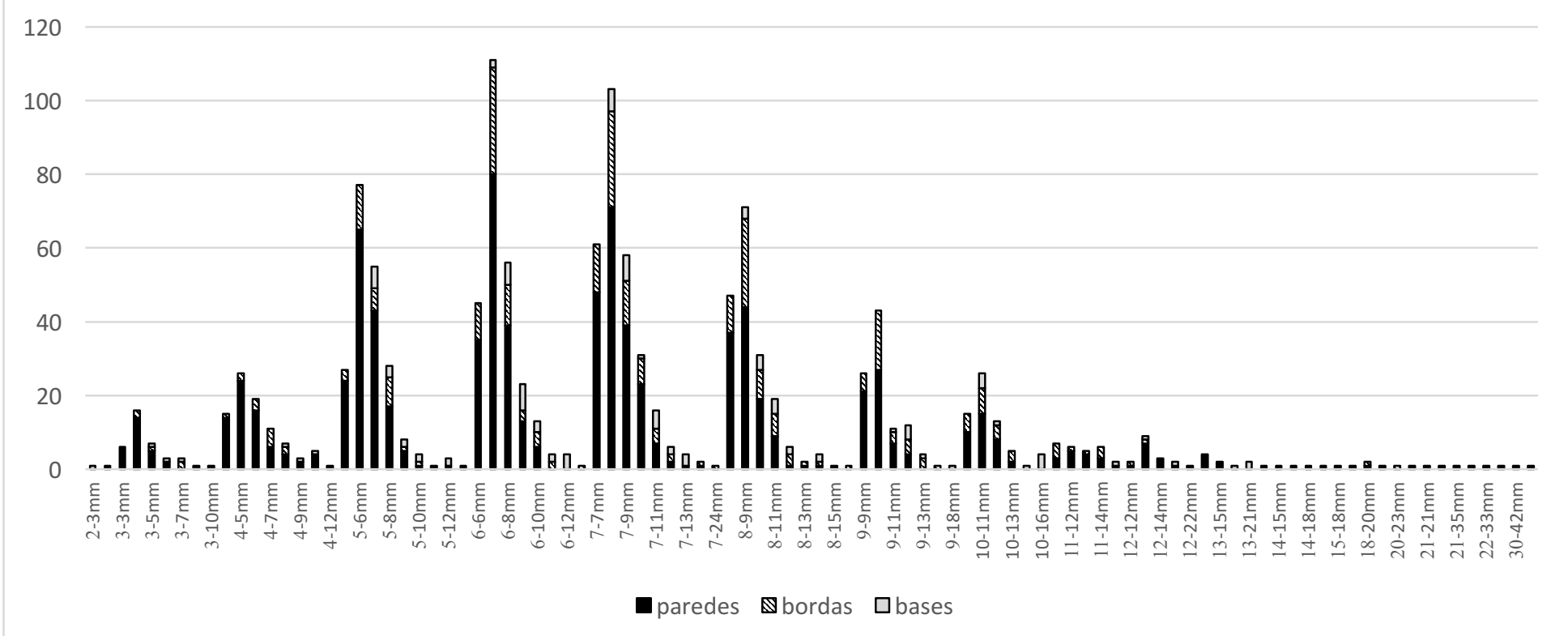

Gráfico 3: Espessura dos fragmentos 


\begin{tabular}{|c|c|c|c|c|c|c|c|c|c|c|c|c|c|c|}
\hline espessura & paredes & bordas & bases & total & espessura & paredes & bordas & bases & total & espessura & paredes & bordas & bases & total \\
\hline $2-3 \mathrm{~mm}$ & 0 & & 1 & 1 & $6-16 \mathrm{~mm}$ & 0 & 1 & 0 & 1 & $11-12 \mathrm{~mm}$ & 5 & 1 & 0 & 6 \\
\hline $2-11 \mathrm{~mm}$ & 1 & 0 & 0 & 1 & $7-7 \mathrm{~mm}$ & 48 & 13 & 0 & 61 & $11-13 \mathrm{~mm}$ & 4 & 1 & 0 & 5 \\
\hline $3-3 \mathrm{~mm}$ & 6 & 0 & 0 & 6 & $7-8 \mathrm{~mm}$ & 71 & 26 & 6 & 103 & $11-14 \mathrm{~mm}$ & 3 & 3 & 0 & 6 \\
\hline $3-4 \mathrm{~mm}$ & 14 & 2 & 0 & 16 & $7-9 \mathrm{~mm}$ & 39 & 12 & 7 & 58 & $11-15 \mathrm{~mm}$ & 1 & 0 & 1 & 2 \\
\hline $3-5 \mathrm{~mm}$ & 5 & 1 & 1 & 7 & $7-10 \mathrm{~mm}$ & 23 & 7 & 1 & 31 & $12-12 \mathrm{~mm}$ & 1 & 1 & 0 & 2 \\
\hline $3-6 \mathrm{~mm}$ & 2 & 0 & 1 & 3 & $7-11 \mathrm{~mm}$ & 7 & 4 & 5 & 16 & $12-13 \mathrm{~mm}$ & 7 & 1 & 1 & 9 \\
\hline $3-7 \mathrm{~mm}$ & 0 & 2 & 1 & 3 & $7-12 \mathrm{~mm}$ & 2 & 2 & 2 & 6 & $12-14 \mathrm{~mm}$ & 3 & 0 & 0 & 3 \\
\hline $3-8 \mathrm{~mm}$ & 1 & 0 & 0 & 1 & $7-13 \mathrm{~mm}$ & 1 & 0 & 3 & 4 & $12-15 \mathrm{~mm}$ & 1 & 0 & 1 & 2 \\
\hline $3-10 \mathrm{~mm}$ & 1 & 0 & 0 & 1 & $7-14 \mathrm{~mm}$ & 1 & 1 & 0 & 2 & $12-22 \mathrm{~mm}$ & 1 & 0 & 0 & 1 \\
\hline $4-4 \mathrm{~mm}$ & 14 & 1 & 0 & 15 & $7-24 \mathrm{~mm}$ & 0 & 1 & 0 & 1 & $13-14 \mathrm{~mm}$ & 4 & 0 & 0 & 4 \\
\hline $4-5 \mathrm{~mm}$ & 24 & 2 & 0 & 26 & $8-8 \mathrm{~mm}$ & 37 & 10 & 0 & 47 & $13-15 \mathrm{~mm}$ & 2 & 0 & 0 & 2 \\
\hline $4-6 \mathrm{~mm}$ & 16 & 3 & 0 & 19 & $8-9 \mathrm{~mm}$ & 44 & 24 & 3 & 71 & $13-20 \mathrm{~mm}$ & 0 & 0 & 1 & 1 \\
\hline $4-7 \mathrm{~mm}$ & 6 & 5 & 0 & 11 & $8-10 \mathrm{~mm}$ & 19 & 8 & 4 & 31 & $13-21 \mathrm{~mm}$ & 0 & 0 & 2 & 2 \\
\hline $4-8 \mathrm{~mm}$ & 4 & 2 & 1 & 7 & $8-11 \mathrm{~mm}$ & 9 & 6 & 4 & 19 & $13-22 \mathrm{~mm}$ & 1 & 0 & 0 & 1 \\
\hline $4-9 \mathrm{~mm}$ & 2 & 0 & 1 & 3 & $8-12 \mathrm{~mm}$ & 1 & 3 & 2 & 6 & $14-15 \mathrm{~mm}$ & 1 & 0 & 0 & 1 \\
\hline $4-10 \mathrm{~mm}$ & 4 & 0 & 1 & 5 & $8-13 \mathrm{~mm}$ & 1 & 1 & 0 & 2 & $14-17 \mathrm{~mm}$ & 1 & 0 & 0 & 1 \\
\hline $4-12 \mathrm{~mm}$ & 1 & 0 & 0 & 1 & $8-14 \mathrm{~mm}$ & 1 & 1 & 2 & 4 & $14-18 \mathrm{~mm}$ & 1 & 0 & 0 & 1 \\
\hline $5-5 \mathrm{~mm}$ & 24 & 3 & 0 & 27 & $8-15 \mathrm{~mm}$ & 1 & 0 & 0 & 1 & $15-16 \mathrm{~mm}$ & 1 & 0 & 0 & 1 \\
\hline $5-6 \mathrm{~mm}$ & 65 & 12 & 0 & 77 & $8-18 \mathrm{~mm}$ & 0 & 1 & 0 & 1 & $15-18 \mathrm{~mm}$ & 1 & 0 & 0 & 1 \\
\hline $5-7 \mathrm{~mm}$ & 43 & 6 & 6 & 55 & $9-9 \mathrm{~mm}$ & 21 & 5 & 0 & 26 & $15-23 \mathrm{~mm}$ & 1 & 0 & 0 & 1 \\
\hline $5-8 \mathrm{~mm}$ & 17 & 8 & 3 & 28 & 9-10mm & 27 & 16 & 0 & 43 & $18-20 \mathrm{~mm}$ & 1 & 1 & 0 & 2 \\
\hline $5-9 \mathrm{~mm}$ & 5 & 1 & 2 & 8 & $9-11 \mathrm{~mm}$ & 7 & 3 & 1 & 11 & $19-21 \mathrm{~mm}$ & 1 & 0 & 0 & 1 \\
\hline $5-10 \mathrm{~mm}$ & 1 & 1 & 2 & 4 & $9-12 \mathrm{~mm}$ & 4 & 4 & 4 & 12 & $20-23 \mathrm{~mm}$ & 0 & 1 & 0 & 1 \\
\hline $5-11 \mathrm{~mm}$ & 1 & 0 & 0 & 1 & $9-13 \mathrm{~mm}$ & 0 & 3 & 1 & 4 & $20-35 \mathrm{~mm}$ & 1 & 0 & 0 & 1 \\
\hline $5-12 \mathrm{~mm}$ & 1 & 0 & 2 & 3 & $9-15 \mathrm{~mm}$ & 0 & 1 & 0 & 1 & $21-21 \mathrm{~mm}$ & 1 & 0 & 0 & 1 \\
\hline $5-24 \mathrm{~mm}$ & 1 & 0 & 0 & 1 & $9-18 \mathrm{~mm}$ & 0 & & 1 & 1 & $21-30 \mathrm{~mm}$ & 1 & 0 & 0 & 1 \\
\hline $6-6 \mathrm{~mm}$ & 35 & 10 & 0 & 45 & $10-10 \mathrm{~mm}$ & 10 & 5 & 0 & 15 & $21-35 \mathrm{~mm}$ & 1 & 0 & 0 & 1 \\
\hline $6-7 \mathrm{~mm}$ & 80 & 29 & 2 & 111 & $10-11 \mathrm{~mm}$ & 15 & 7 & 4 & 26 & $22-26 \mathrm{~mm}$ & 1 & 0 & 0 & 1 \\
\hline $6-8 \mathrm{~mm}$ & 39 & 11 & 6 & 56 & $10-12 \mathrm{~mm}$ & 8 & 4 & 1 & 13 & $22-33 \mathrm{~mm}$ & 1 & 0 & 0 & 1 \\
\hline $6-9 \mathrm{~mm}$ & 13 & 3 & 7 & 23 & $10-13 \mathrm{~mm}$ & 2 & 3 & 0 & 5 & $30-35 \mathrm{~mm}$ & 1 & 0 & 0 & 1 \\
\hline $6-10 \mathrm{~mm}$ & 6 & 4 & 3 & 13 & $10-14 \mathrm{~mm}$ & 0 & 0 & 1 & 1 & $30-42 \mathrm{~mm}$ & 1 & 0 & 0 & 1 \\
\hline $6-11 \mathrm{~mm}$ & 0 & 2 & 2 & 4 & $10-16 \mathrm{~mm}$ & 0 & 0 & 4 & 4 & \multirow[t]{2}{*}{$32-34 \mathrm{~mm}$} & 1 & \multirow[t]{2}{*}{0} & \multirow[t]{2}{*}{0} & \multirow[t]{2}{*}{1} \\
\hline $6-12 \mathrm{~mm}$ & 0 & 0 & 4 & 4 & $11-11 \mathrm{~mm}$ & 3 & 4 & 0 & 7 & & & & & \\
\hline
\end{tabular}

Tabela 8: espessura mínima e máxima dos fragmentos 


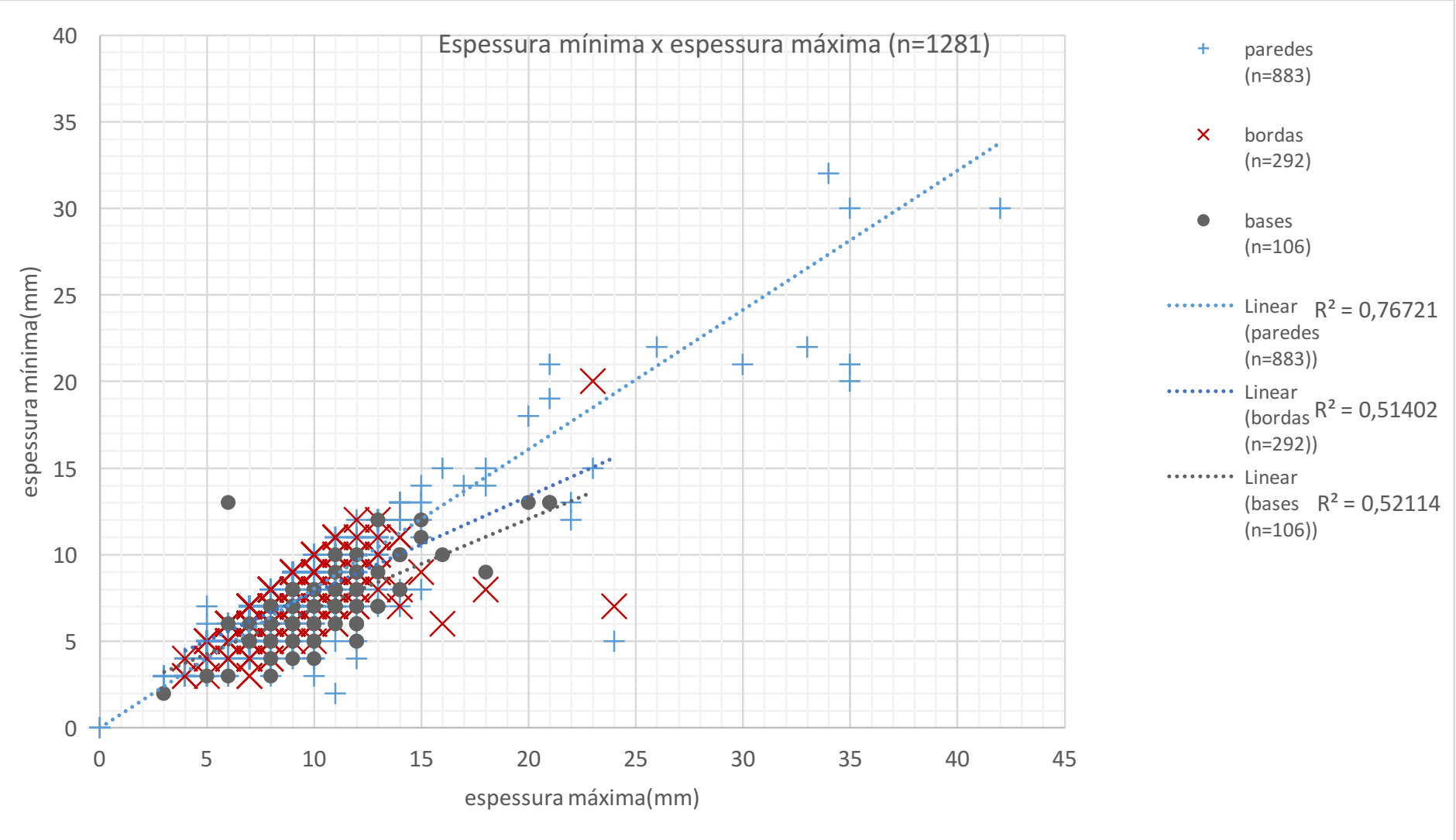

Gráfico 4: Espessura mínima e máxima dos fragmentos

Tipos de antiplástico

Os elementos identificados como inclusões não plásticas na pasta dos fragmentos dos potes foram: areia (quartzo, óxido de ferro, calcário), cauxí, vestígios de vegetais, concha e carvão. Também foram considerados para a classificação do antiplástico os vazios que ocorrem de maneira muito frequente e que se diferem de bolhas causadas pelo amassado da preparação da argila para pastas. (cf. Peacock 1973). Os vazios foram classificados em dois tipos: 1) rombos grandes, irregulares e esparsos denominados de vazios irregulares; e 2) denominado de vazios agrupados são proporcionalmente muito menores a categoria anterior e semelhantes a borbulhas, ocorrendo sempre em grupo.

Em 97,66\%(n=1353) dos casos a areia, o cauxí e os vazios agrupados estão presentes na composição da pasta. Em muitos casos ocorre uma combinação que junta os vazios agrupados, o calcário e as conchas. A partir da presença e ausência destes atributos foram percebidas tendências divididas em três grupos: Grupo 1 (a) n=565;(b) n=294; Grupo 2 (a) $n=135$; (b) n=184; e Grupo 3 (a) n=99; (b) n=43 e (c) n=33. As tendências do grupo 1 e 2 foram criadas a partir da presença e ausência dos vazios agrupados e do calcário, já o grupo 3 foi a partir da presença de conchas, como se pode ver resumidamente no quadro abaixo: 


\begin{tabular}{|c|c|c|c|c|c|}
\hline Tipo & Descrição do antiplástico na pasta & $n=$ & $\%$ & n total : & $\%$ \\
\hline \multirow[t]{2}{*}{ Grupo 1} & a) mineral/cauxí/vazios agrupados/vazios irregulares/calcário & 565 & 40,79 & 859 & 62,02 \\
\hline & b) mineral/cauxí/vazios agrupados/vazios irregulares & 294 & 21,23 & & \\
\hline \multirow[t]{2}{*}{ Grupo 2} & a) mineral/cauxí/vazios agrupados/calcário & 135 & 9,74 & 319 & 23,02 \\
\hline & b) mineral/cauxí/vazios agrupados & 184 & 13,28 & & \\
\hline \multirow[t]{3}{*}{ Grupo 3} & a) mineral/cauxí/vazios agrupados/concha/vazios irregulares/calcário & 99 & 7,14 & 175 & 12,62 \\
\hline & b) mineral/cauxí/concha/vazios irregulares/ calcário & 43 & 3,1 & & \\
\hline & c) mineral/cauxí/vazios irregulares/concha/vazios agrupados & 33 & 2,38 & & \\
\hline \multicolumn{2}{|c|}{ Outras associações } & 32 & 2,34 & 32 & 2,34 \\
\hline \multicolumn{2}{|l|}{ total } & & & 1385 & 100 \\
\hline
\end{tabular}

Tabela 9: Tipos de antiplástico e agrupamentos 


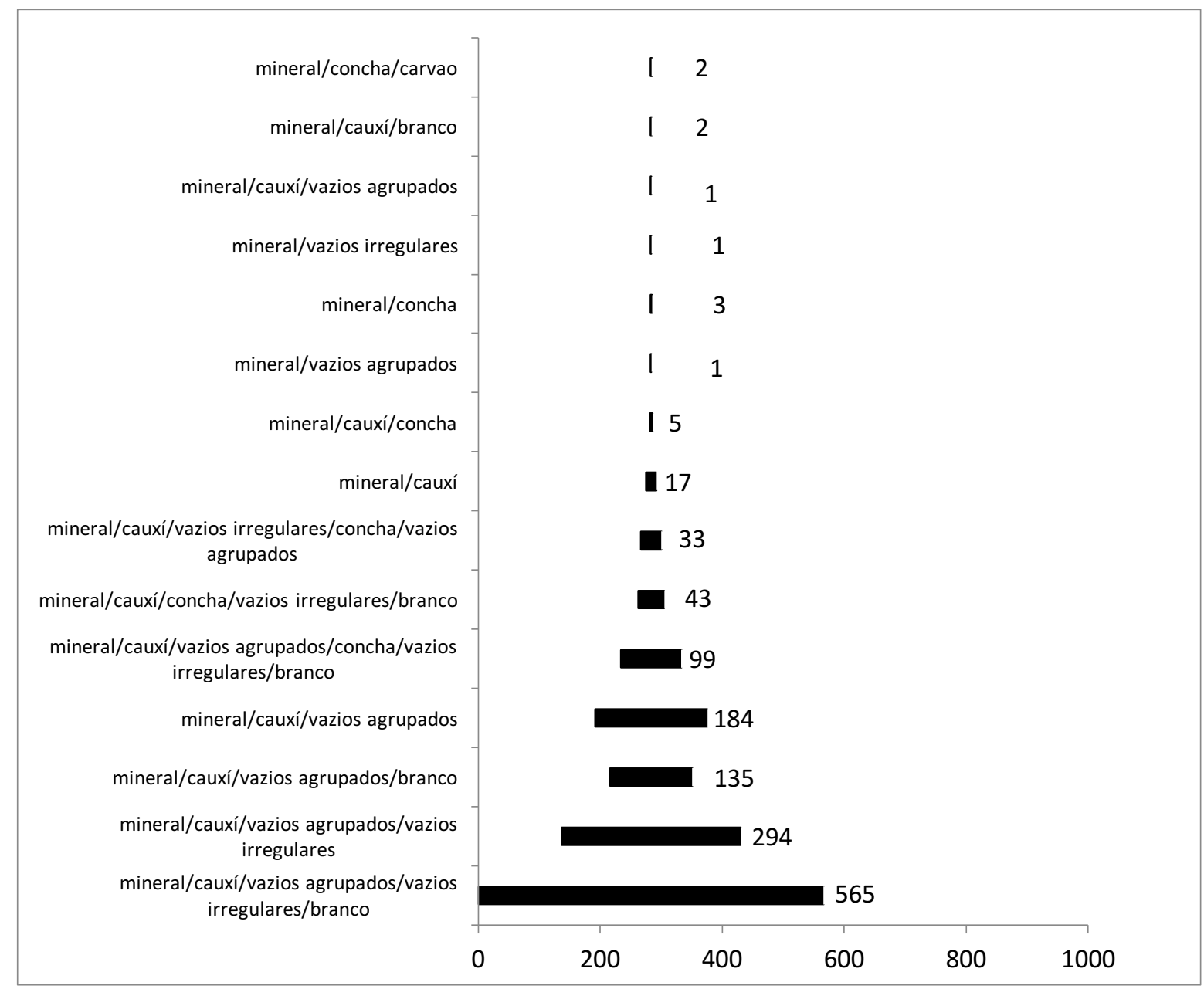

Gráfico 5: quantidade de fragmentos por tipo de antiplástico

Houve associado a estes tipos uma ocorrência muito discreta de materiais como: carvão e vestígios de vegetal combinados a estes tipos e compõem uma quantia pequena dentro da amostra $(4,04 \% ; n=56)$ e que podem ser resultado do uso ocasional ou desproposital destes elementos como antiplástico. 


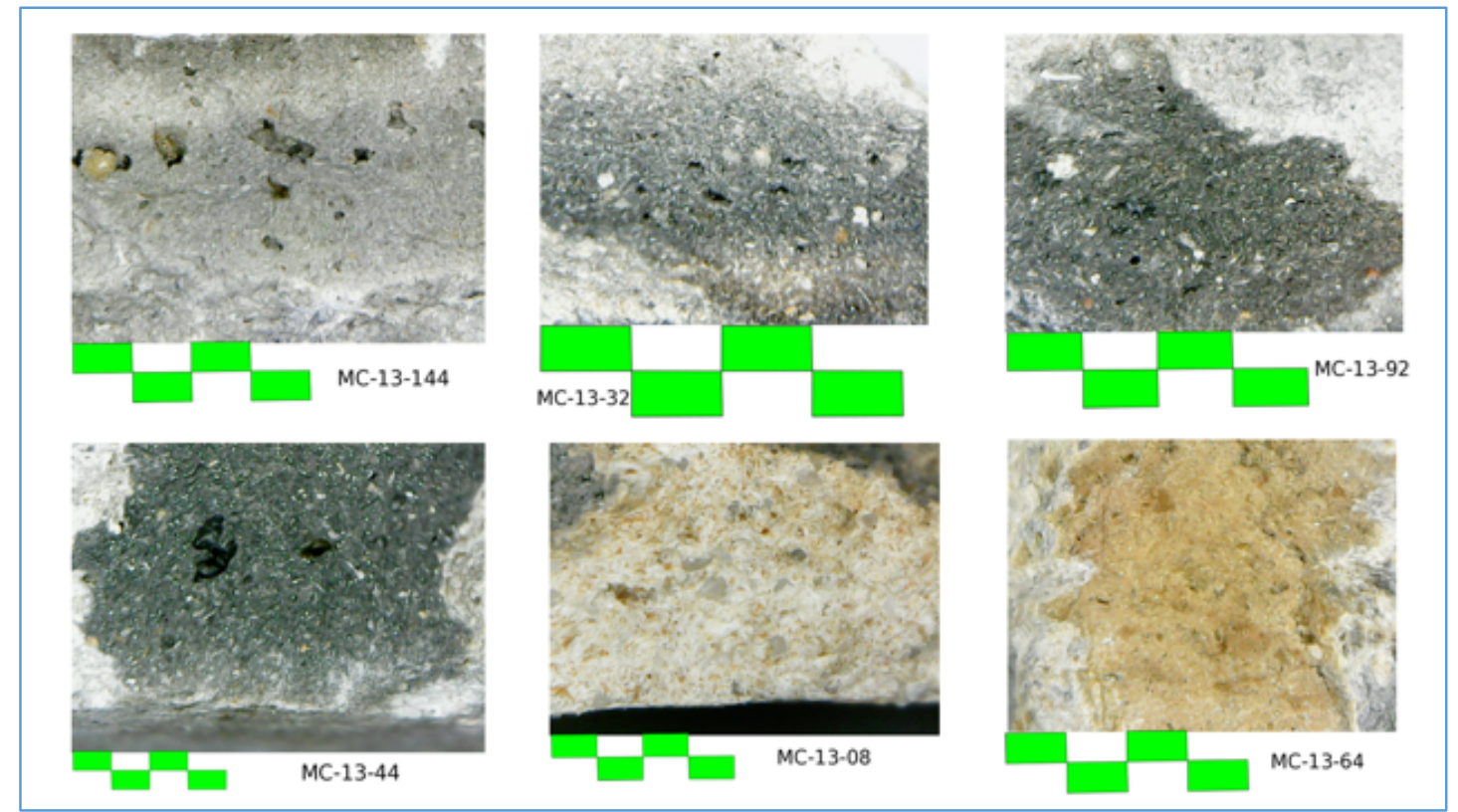

Imagem 69: perfil de fragmentos cerâmicos onde é percebido as partículas brancas (calcário) e os vazios irregulares e agrupados, escala em milímetros.
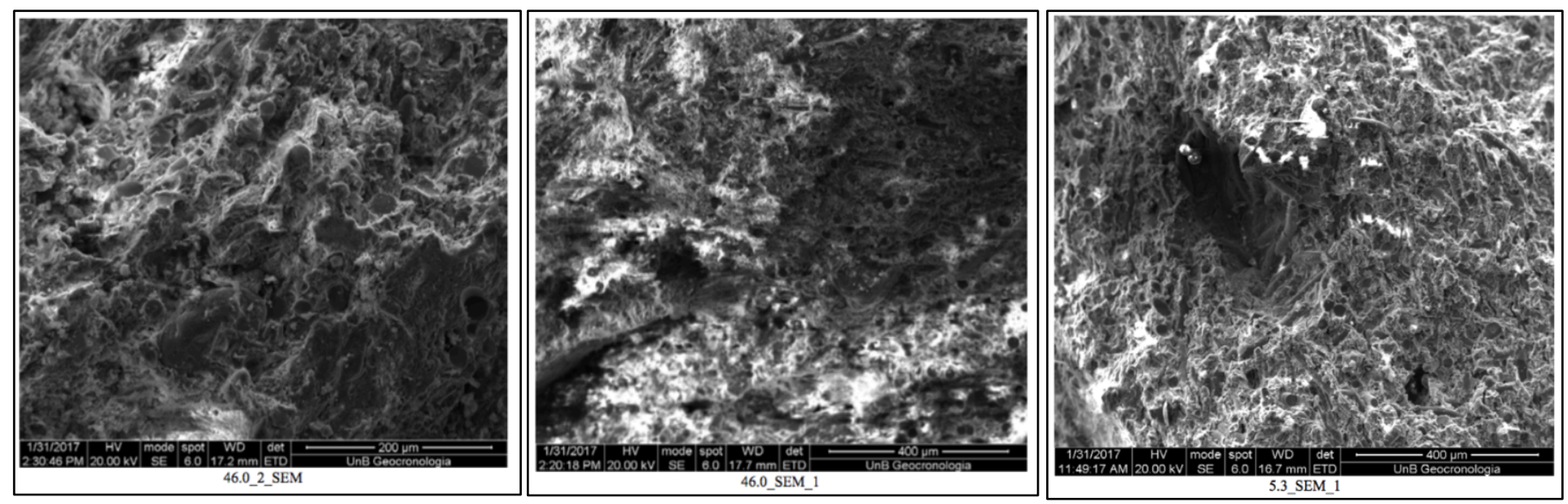

Imagem 70: vazios agrupados registrados a partir de microscopia eletrônica, do SEM, onde a topografia e o arranjo dos minerais são registrados e os agrupamentos de vazios podem ser visualizados. Da esquerda para a direita: Camada D3, camada D2, camada C. Fonte: Pugliese (2017).

Frequência do antiplástico e dimensão da areia

Uma característica que se percebe ao avaliar a granulometria das inclusões minerais na cerâmica da fase Bacabal é a ocorrência de pequenos grãos que variam entre areia fina até areia média (0.1-1mm). A frequência é marcante nos grupos $1(82,31 \%)$, grupo $2(81,5 \%)$ e grupo 3 (74,86\%). Contudo, neste último grupo 3 ocorrem casos de maneira significativa que apontam para uma granulometria mais grossa chegando a alguns casos com dimensões maiores que $3 \mathrm{~mm}$.

Mesmo assim, o alto grau de incidência de pequenas inclusões nos três grupos de antiplástico pode ter sido resultado da preferência na escolha de determinado tipo (s) de 
matéria-prima ou resultado de uma maneira de preparação da argila. Somente no grupo 3 se percebe uma pequena diferença na proporção de grãos grossos a muito grossos. Esta é uma hipótese de caráter especulativo, já que este grupo que está relacionado a presença de conchas na pasta tem uma representatividade pouco representativa na amostra $(12,62 \%)$ e esta diferença poderia estar ligada mais à pouca amostragem do que a uma escolha tecnológica.

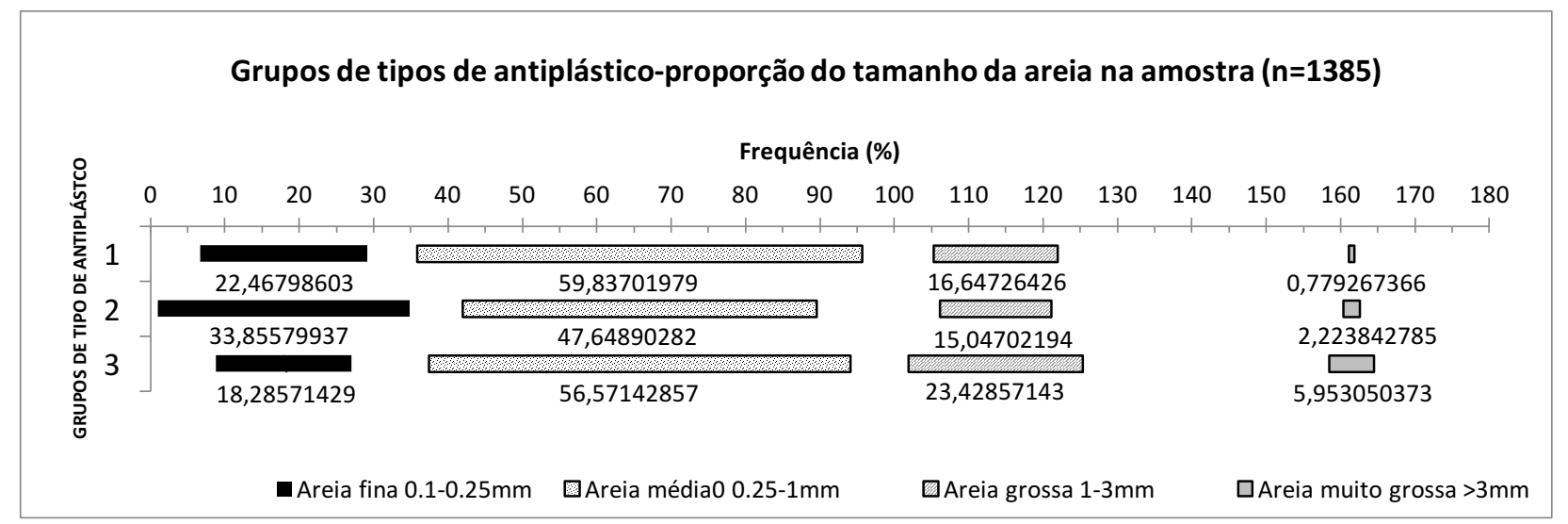

Gráfico 6: sequencia seriada do tamanho da partícula de areia entre os grupos de tipo de antiplástico.

\begin{tabular}{|c|c|c|c|c|c|c|c|c|}
\hline \multirow[b]{2}{*}{ Tipo } & \multicolumn{2}{|c|}{ Areia fina $0.1-0.25 \mathrm{~mm}$} & \multicolumn{2}{|c|}{ Areia média0 $0.25-1 \mathrm{~mm}$} & \multicolumn{2}{|c|}{ Areia grossa 1-3mm } & \multicolumn{2}{|c|}{ Areia muito grossa $>3 \mathrm{~mm}$} \\
\hline & Quantidade & $\%$ & Quantidade & $\%$ & Quantidade & $\%$ & Quantidade & $\%$ \\
\hline Grupo1 & 193 & 22,47 & 514 & 59,84 & 143 & 16,64 & 9 & 0,77 \\
\hline Grupo 2 & 108 & 33,86 & 152 & 47,65 & 48 & 15,04 & 10 & 2,22 \\
\hline Grupo 3 & 32 & 18,29 & 99 & 56,57 & 41 & 23,42 & 3 & 5,95 \\
\hline
\end{tabular}

Tabela 10: quantidade e porcentagem dos tipos de tamanho de partículas de areia entre os grupos de antiplástico.

Na pasta dos fragmentos de potes a inclusão de elementos não plásticos é alta. Nos três grupos avaliados parece haver uma tendência semelhante na distribuição dos indivíduos entres os tipos relacionados ao grau de frequência do antiplástico, onde aqueles que indicam menos incidência (5\% de antiplástico na pasta) variam a sua presença entre $11-13,48 \%$, enquanto os de incidência média (10\%) ocorrem entre $22,86-30 \%$ e aqueles de incidência alta $(20-30 \%)$ aparecem entre $57-65,14 \%$ dos casos. Novamente existe uma discreta disparidade entre os grupos 1 e 2 comparados ao grupo 3, que possui menos indivíduos relacionados aos tipos com pouco antiplástico que também pode estar relacionada a diferença na quantidade de fragmentos da amostra de cada grupo, do que uma escolha tecnológica. 


\section{Grupo de antiplástico e grau de frequência na pasta ( $n=1385)$}

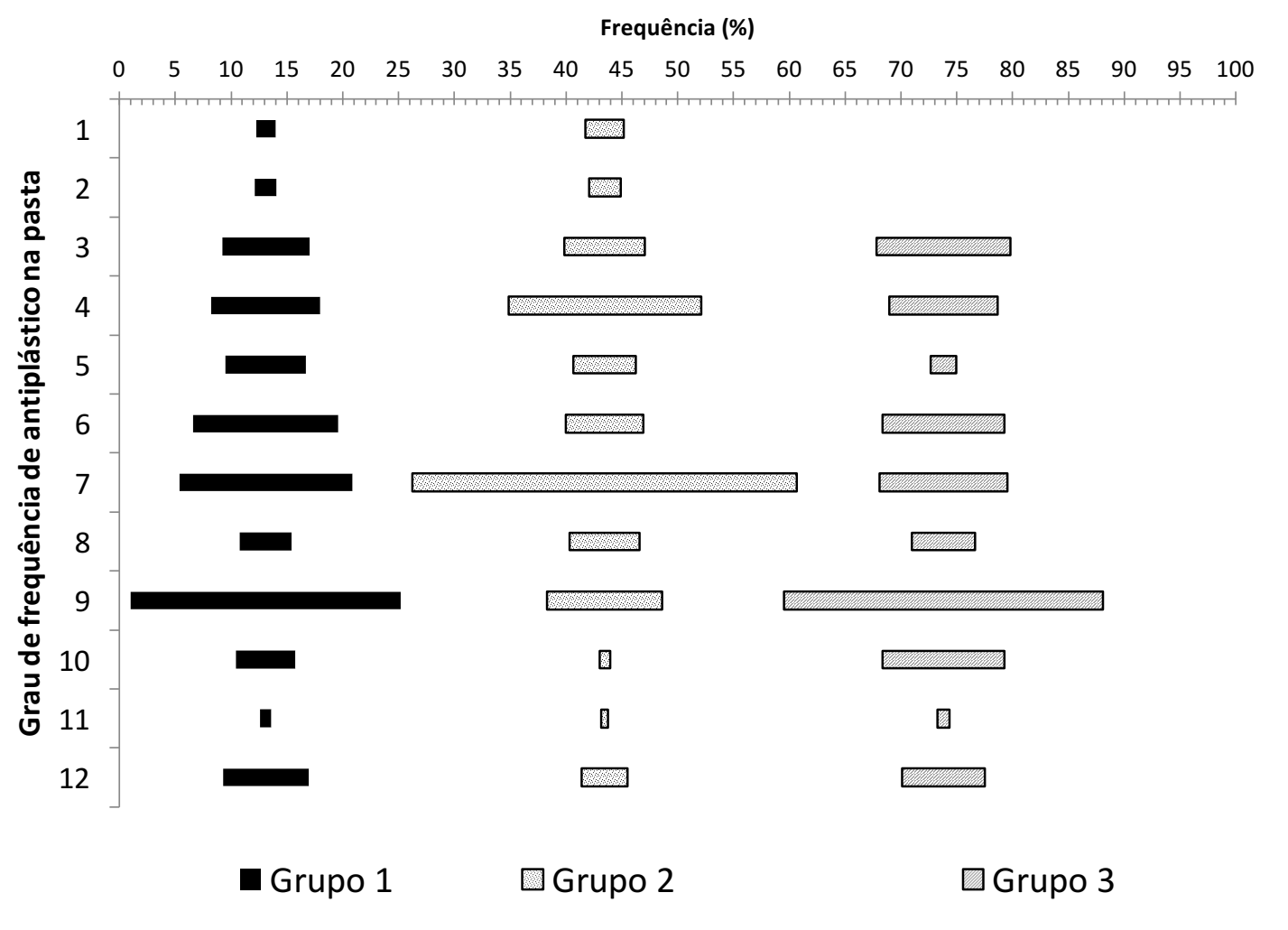

Gráfico 7: Sequencia seriada do grau de incidencia de antiplástico por tipo de pasta. 1) 5\%, 0,5-1mm;2) $5 \%, 0,5-2 \mathrm{~mm}$; 3) $5 \%, 0,5-3 \mathrm{~mm}$; 4) $10 \%, 0,5-1 \mathrm{~mm}$; 5) $10 \%, 0,5-2 \mathrm{~mm}$; 6) $10 \%, 0,5-3 \mathrm{~mm}$; 7) $20 \%, 0,5-$ $1 \mathrm{~mm}$; 8) $20 \%, 0,5-2 \mathrm{~mm}$; 9) $20 \%, 0,5-3 \mathrm{~mm}$; 10) $30 \%, 0,5-1 \mathrm{~mm}$; 11) $30 \%, 0,5-2 \mathrm{~mm}$; 12) $30 \%, 0,5-3 \mathrm{~mm}$.

\begin{tabular}{|c|c|c|}
\hline Grupo $1 \mathrm{n}=859$ & & \\
\hline Frequência & Quant & $\%$ \\
\hline 1 & 15 & 1,75 \\
\hline 2 & 17 & 1,98 \\
\hline 3 & 67 & 7,80 \\
\hline 4 & 84 & 9,78 \\
\hline 5 & 62 & 7,22 \\
\hline 6 & 112 & 13,04 \\
\hline 7 & 133 & 15,48 \\
\hline 8 & 40 & 4,66 \\
\hline 9 & 208 & 24,21 \\
\hline 10 & 46 & 5,36 \\
\hline 11 & 9 & 1,05 \\
\hline 12 & 66 & 7,68 \\
\hline
\end{tabular}

\begin{tabular}{|c|c|c|}
\hline Grupo $2 n=319$ & & \\
\hline Frequência & Quant & $\%$ \\
\hline 1 & 11 & 3,45 \\
\hline 2 & 9 & 2,82 \\
\hline 3 & 23 & 7,21 \\
\hline 4 & 55 & 17,24 \\
\hline 5 & 18 & 5,64 \\
\hline 6 & 22 & 6,90 \\
\hline 7 & 110 & 34,48 \\
\hline 8 & 20 & 6,27 \\
\hline 9 & 33 & 10,34 \\
\hline 10 & 3 & 0,94 \\
\hline 11 & 2 & 0,63 \\
\hline 12 & 13 & 4,08 \\
\hline
\end{tabular}

\begin{tabular}{|c|c|c|}
\hline Grupo $3 \mathrm{n}=175$ & & \\
\hline Frequência & Quant & $\%$ \\
\hline 1 & 0 & 0,00 \\
\hline 2 & 0 & 0,00 \\
\hline 3 & 21 & 12,00 \\
\hline 4 & 17 & 9,71 \\
\hline 5 & 4 & 2,29 \\
\hline 6 & 19 & 10,86 \\
\hline 7 & 20 & 11,43 \\
\hline 8 & 10 & 5,71 \\
\hline 9 & 50 & 28,57 \\
\hline 10 & 19 & 10,86 \\
\hline 11 & 2 & 1,14 \\
\hline 12 & 13 & 7,43 \\
\hline
\end{tabular}

Tabela 11: quantidade e porcentagem do grau de incidência de antiplástico por tipo de pasta. 1) 5\%, 0,5-1mm; 2) $5 \%, 0,5-2 \mathrm{~mm}$; 3) $5 \%, 0,5-3 \mathrm{~mm}$; 4) $10 \%, 0,5-1 \mathrm{~mm}$; 5) $10 \%, 0,5-2 \mathrm{~mm}$; 6) $10 \%, 0,5-3 \mathrm{~mm}$; 7) $20 \%, 0,5-1 \mathrm{~mm}$; 8) $20 \%, 0,5-2 \mathrm{~mm}$; 9) $20 \%, 0,5-3 \mathrm{~mm}$; 10) $30 \%, 0,5-1 \mathrm{~mm}$; 11) $30 \%, 12) 30 \%, 0,5-3 \mathrm{~mm}$.

Pode-se dizer que o estabelecimento de gabaritos visuais para avaliar a quantidade de antiplástico pode ser válido na medida em que algumas tendências puderam ser verificas. Um problema adicional é que a cerâmica antiga é notória por sua chance de apresentar extrema variabilidade dentro da pasta de um único pote. 
A relação entre a dimensão das inclusões e o seu grau de incidência de componentes no fragmento demonstrou também situações de ocorrência semelhante entre os tipos de pasta separados pelo tipo antiplástico. Aqui novamente os grupos 1 e 2 possuem maior semelhança se comparados ao grupo 3.

Tipos com pouco antiplásticos (carga entre 5-10\%) e antiplástico muito fino (até $0.5 \mathrm{~mm})$ foram mais recorrentes nos grupos $1(11 \%)$ e $2(19 \%)$ do que no grupo $3(5 \%)$. O mesmo parece acontecer com aqueles tipos com alta incidência de antiplástico e com componentes maiores que $3 \mathrm{~mm}$ onde nos grupos 1 e 2 - 12,22\% e 11,29\% - demonstram ser menos frequentes que no grupo $3(25,71 \%)$

Os tipos de pasta mais frequentes na coleção analisada foram aqueles que contém mineral, abundante cauxí, vazios irregulares, vazios agrupados e calcário, apresenta inclusões minerais entre 0.1 e $1 \mathrm{~mm}$ de tamanho e carga entre $20-30 \%$ na pasta $(n=314,23,2 \%)$. Em seguida ocorre este mesmo tipo, porém com inclusões não plásticas variando entre $1-3 \mathrm{~mm}$ $(n=311,22,98 \%)$. Em seguida ocorrem os tipos semelhantes relacionados com o grupo 2, onde as mesmas inclusões ocorrem, com exceção dos vazios agrupados. Aqueles com antiplástico de até $1 \mathrm{~mm}$ representam $9,53 \%(\mathrm{n}=129)$ e aqueles entre $1-3 \mathrm{~mm}$ correspondem $8,2 \%(\mathrm{n}=111)$ da amostra analisada.

Miller também observa a alta inclusão de cauxí na pasta e a presença de areia fina como antiplástico. Nas amostras de argila coletadas no entorno do sítio Monte Castelo não são encontradas conchas e a presença de cauxí é inferior ao que é encontrado na pasta (Miller 2009; Pugliese 2017). Isto poderia significar que o antiplástico de cauxí e conchas são inclusões encontradas na pasta e não originárias da fonte de matéria-prima. A areia fina encontrada na pasta pode ser relacionada a escolha por este tipo mineral presente na argila, já que o local de sua produção está inserida geomorfologicamente na formação Guaporé (Adamy 2010), que por sua vez possui duas subunidades inter-digitadas: a de nível inferior não inundável constituídos por depósitos arenosos e constituído de areias grossas a médias e lentes de argila, e outra superior, sujeita a inundação do banhado que é composta de areia muito fina a fina e lentes de argila. Seria plausível pensar que as indígenas responsáveis pela cerâmica tivessem preferência na escolha da argila de depósitos mais recentes, com areia mais fina. 


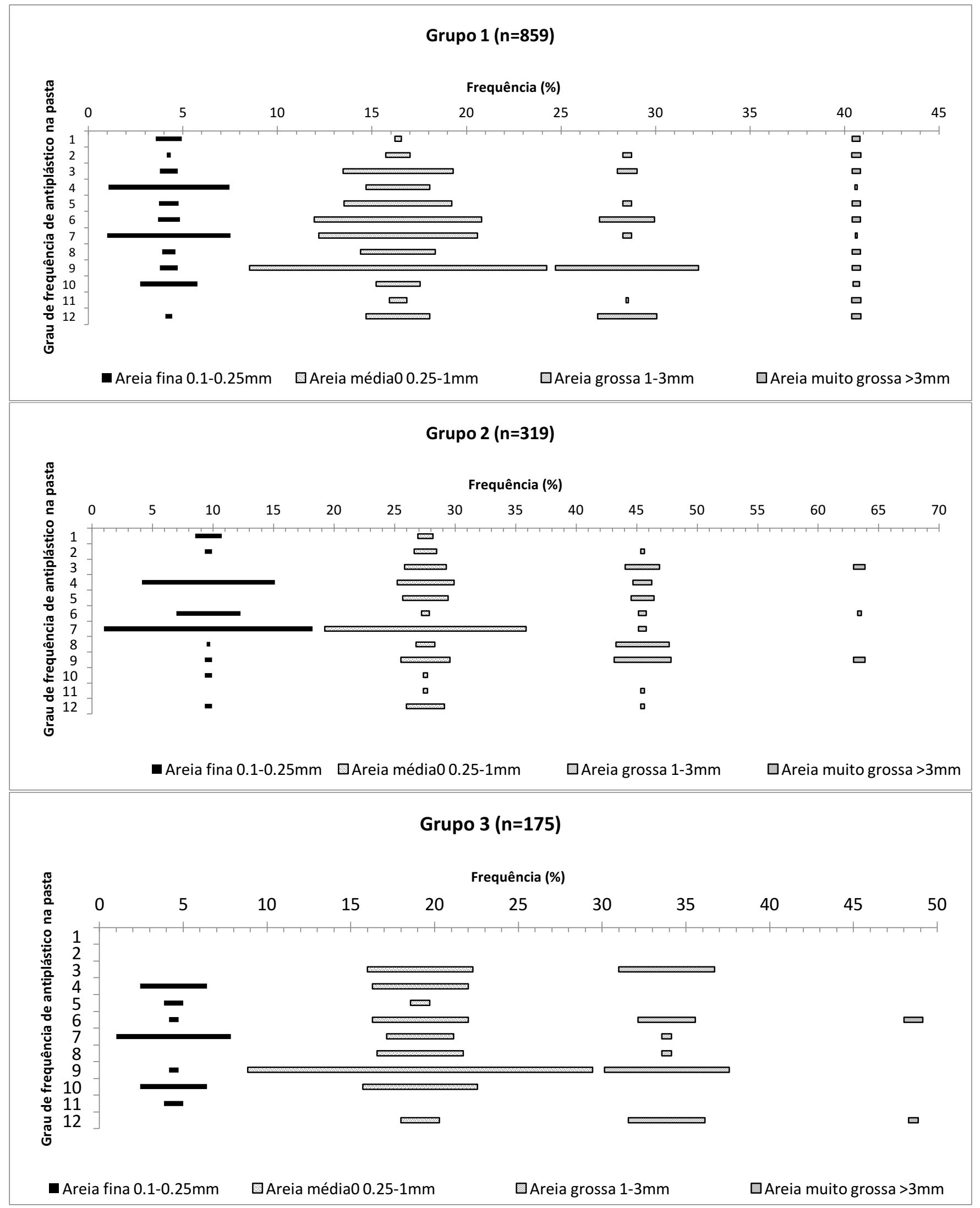

Gráfico 8: sequencia seriada dos tipos de tamanho das partículas de areia entre os tipos de frequência de antiplásticos dos grupos 1, 2 e 3. 


\begin{tabular}{|c|c|c|c|c|c|c|c|c|c|}
\hline \multirow{2}{*}{$\begin{array}{l}\text { Grupo } 1 \text { n=859 } \\
\text { Freq/dimensão }\end{array}$} & \multicolumn{2}{|c|}{ Areia fina $0.1-0.25 \mathrm{~mm}$} & \multicolumn{2}{|c|}{ Areia média0 $0.25-1 \mathrm{~mm}$} & \multicolumn{2}{|c|}{ Areia grossa $1-3 \mathrm{~mm}$} & \multicolumn{2}{|c|}{ Areia muito grossa $>3 \mathrm{~mm}$} & \multirow[b]{2}{*}{ total } \\
\hline & Quantidade & $\%$ & Quantidade & $\%$ & Quantidade & $\%$ & Quantidade & $\%$ & \\
\hline 1 & 12 & 1,40 & 3 & 0,35 & 0 & 0 & 0 & 0,00 & 15 \\
\hline 2 & 2 & 0,23 & 11 & 1,28 & 4 & 0,46 & 0 & 0,00 & 17 \\
\hline 3 & 8 & 0,93 & 50 & 5,82 & 9 & 1,04 & 0 & 0,00 & 67 \\
\hline 4 & 55 & 6,40 & 29 & 3,38 & 0 & 0 & 0 & 0,00 & 84 \\
\hline 5 & 9 & 1,05 & 49 & 5,70 & 4 & 0,46 & 0 & 0,00 & 62 \\
\hline 6 & 10 & 1,16 & 76 & 8,85 & 25 & 2,91 & 1 & 0,12 & 112 \\
\hline 7 & 56 & 6,52 & 72 & 8,38 & 4 & 0,46 & 1 & 0,12 & 133 \\
\hline 8 & 6 & 0,70 & 34 & 3,96 & 0 & 0 & 0 & 0,00 & 40 \\
\hline 9 & 8 & 0,93 & 135 & 15,72 & 65 & 7,56 & 0 & 0,00 & 208 \\
\hline 10 & 26 & 3,03 & 20 & 2,33 & 0 & 0 & 0 & 0,00 & 46 \\
\hline 11 & 0 & 0,00 & 8 & 0,93 & 1 & 0,11 & 0 & 0,00 & 9 \\
\hline 12 & 3 & 0,35 & 29 & 3,38 & 27 & 3,14 & 7 & 0,81 & 66 \\
\hline Grupo 2 n=319 & \multicolumn{2}{|c|}{ Areia fina $0.1-0.25 \mathrm{~mm}$} & \multicolumn{2}{|c|}{ Areia média0 $0.25-1 \mathrm{~mm}$} & \multicolumn{2}{|c|}{ Areia grossa 1-3mm } & \multicolumn{2}{|c|}{ Areia muito grossa $>3 \mathrm{~mm}$} & \\
\hline Freq/dimensão & Quantidade & $\%$ & Quantidade & $\%$ & Quantidade & $\%$ & Quantidade & $\%$ & total \\
\hline 1 & 7 & 2,19 & 4 & 1,25 & 0 & 0,00 & 0 & 0,00 & 11 \\
\hline 2 & 2 & 0,63 & 6 & 1,88 & 1 & 0,31 & 0 & 0,00 & 9 \\
\hline 3 & 0 & 0,00 & 11 & 3,45 & 9 & 2,82 & 3 & 0,94 & 23 \\
\hline 4 & 35 & 10,97 & 15 & 4,70 & 5 & 1,57 & 0 & 0,00 & 55 \\
\hline 5 & 0 & 0,00 & 12 & 3,76 & 6 & 1,88 & 0 & 0,00 & 18 \\
\hline 6 & 17 & 5,33 & 2 & 0,63 & 2 & 0,63 & 1 & 0,31 & 22 \\
\hline 7 & 55 & 17,24 & 53 & 16,61 & 2 & 0,63 & 0 & 0,00 & 110 \\
\hline 8 & 1 & 0,31 & 5 & 1,57 & 14 & 4,39 & 0 & 0,00 & 20 \\
\hline 9 & 2 & 0,63 & 13 & 4,08 & 15 & 4,70 & 3 & 0,94 & 33 \\
\hline 10 & 2 & 0,63 & 1 & 0,31 & 0 & 0,00 & 0 & 0,00 & 3 \\
\hline 11 & 0 & 0,00 & 1 & 0,31 & 1 & 0,31 & 0 & 0,00 & 2 \\
\hline 12 & 2 & 0,63 & 10 & 3,13 & 1 & 0,31 & 0 & 0,00 & 13 \\
\hline Grupo 3 n=175 & \multicolumn{2}{|c|}{ Areia fina $0.1-0.25 \mathrm{~mm}$} & \multicolumn{2}{|c|}{ Areia média0 $0.25-1 \mathrm{~mm}$} & \multicolumn{2}{|c|}{ Areia grossa $1-3 \mathrm{~mm}$} & \multicolumn{2}{|c|}{ Areia muito grossa $>3 \mathrm{~mm}$} & \\
\hline Freq/dimensão & Quantidade & $\%$ & Quantidade & $\%$ & Quantidade & $\%$ & Quantidade & $\%$ & total \\
\hline 1 & 0 & 0,00 & 0 & 0,00 & 0 & 0,00 & 0 & 0,00 & 0 \\
\hline 2 & 0 & 0,00 & 0 & 0,00 & 0 & 0,00 & 0 & 0,00 & 0 \\
\hline 3 & 0 & 0,00 & 11 & 6,29 & 10 & 5,71 & 0 & 0,00 & 21 \\
\hline 4 & 7 & 4,00 & 10 & 5,71 & 0 & 0,00 & 0 & 4,00 & 17 \\
\hline 5 & 2 & 1,14 & 2 & 1,14 & 0 & 0,00 & 0 & 1,14 & 4 \\
\hline 6 & 1 & 0,57 & 10 & 5,71 & 6 & 3,43 & 2 & 0,57 & 19 \\
\hline 7 & 12 & 6,86 & 7 & 4,00 & 1 & 0,57 & 0 & 6,86 & 20 \\
\hline 8 & 0 & 0,00 & 9 & 5,14 & 1 & 0,57 & 0 & 0,00 & 10 \\
\hline 9 & 1 & 0,57 & 36 & 20,57 & 13 & 7,43 & 0 & 0,57 & 50 \\
\hline 10 & 7 & 4,00 & 12 & 6,86 & 0 & 0,00 & 0 & 4,00 & 19 \\
\hline 11 & 2 & 1,14 & 0 & 0,00 & 0 & 0,00 & 0 & 1,14 & 2 \\
\hline 12 & 0 & 0,00 & 4 & 2,29 & 8 & 4,57 & 1 & 0,00 & 13 \\
\hline
\end{tabular}

Tabela 12: quantidade e porcentagem dos tipos de tamanho das partículas de areia entre os tipos de frequência de antiplásticos dos grupos 1, 2 e 3. 


\section{Cor da pasta}

Houve pouca variação na cor da pasta nos fragmentos analisados. Os tons marrom/laranja/vermelho predominaram na amostra, seguido por aqueles pretos $(5,76 \%)$ e os de tons claros, rosados, beges e esbranquiçados $(3,88 \%)$.

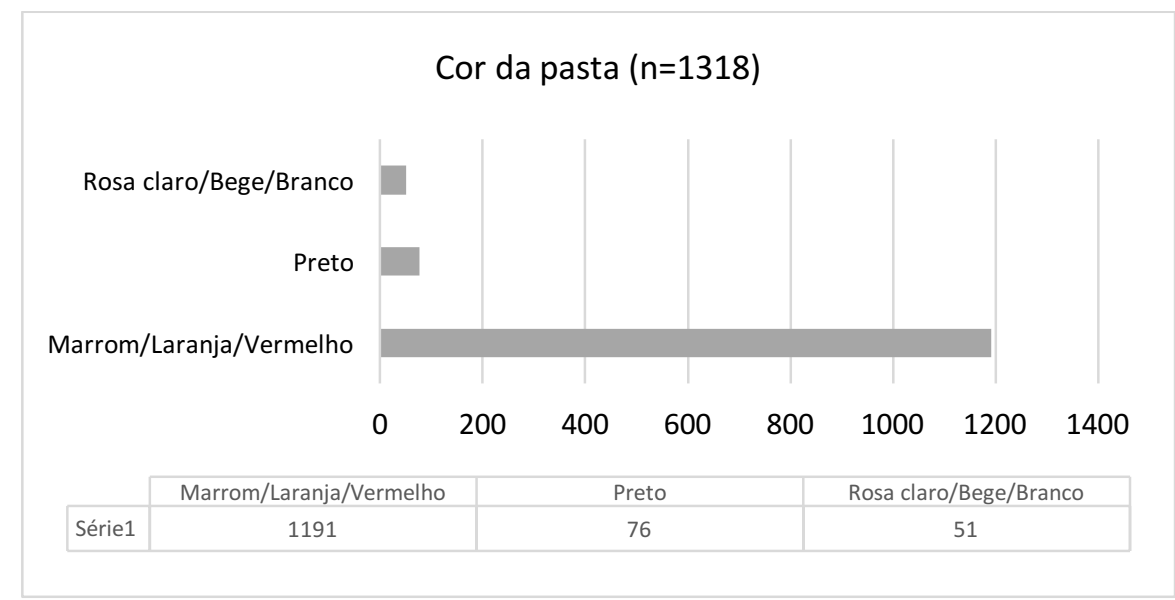

Gráfico 9: quantidade de fragmentos por cor

\begin{tabular}{lll}
\hline Cor $\mathbf{n}=\mathbf{1 3 1 8}$ & quantidade & $\mathbf{\%}$ \\
\hline Marrom/Laranja/Vermelho & 1191 & 90,36 \\
\hline Preto & 76 & 5,76 \\
\hline Rosa claro/Bege/Branco & 51 & 3,88
\end{tabular}

Tabela 13: quantidade e porcentagem dos fragmentos separados pelo tipo cor.

\section{Confecção e queima}

A técnica de manufatura dos potes que pode ser identificada foi o acordelado, que foi percebido a partir de fraturas características que esta técnica de pode apresentar. $\mathrm{O}$ acordelado foi identificado em 763 fragmentos $(n=763)$

Téc. Manufatura dos potes $(n=1318)$

Acordelado

Não identificado

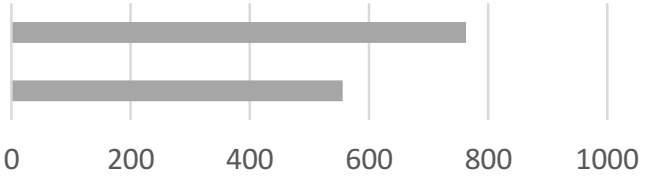

Gráfico 10: quantidade de fragmentos com a técnica de manufatura identificada. 


\begin{tabular}{lcc}
\hline Téc. Manufatura $\mathbf{n = 1 3 1 8}$ & quantidade & $\%$ \\
\hline Não identificado & 555 & 42,11 \\
\hline Acordelado & 763 & 57,89 \\
\hline
\end{tabular}

Tabela 14: quantidade e porcentagem de fragmentos com a técnica de manufatura identificada

Recentemente Pugliese (2017) a partir da análise de perfis das cerâmicas por microscopia eletrônica de varredura (MEV), percebeu que a queima dos artefatos foi realizada em um ambiente de queima redutora, que poderia ter alcançado $1000{ }^{\circ} \mathrm{C}$, e valores resultados de análises de perda ao fogo (LOI) também indicam uma baixa quantidade água estrutural e carbonatos nas amostras da fase Bacabal que seria decorrência da utilização de uma técnica de queima que garantiria a manutenção das altas temperaturas ao longo do período de queima dos artefatos.

$\mathrm{Na}$ análise dos fragmentos verificamos uma alta incidência de queima em ambientes redutores onde o tipo redutora $(n=484)$, oxidante com núcleo reduzido $(n=319)$ representam $61 \%$ da amostra.

A queima oxidante atinge $22,7 \%(n=299)$ e oxidante representam $12,83 \%(n=169)$ da amostra. Outros tipos de queima compõem 3,49\% do analisado.

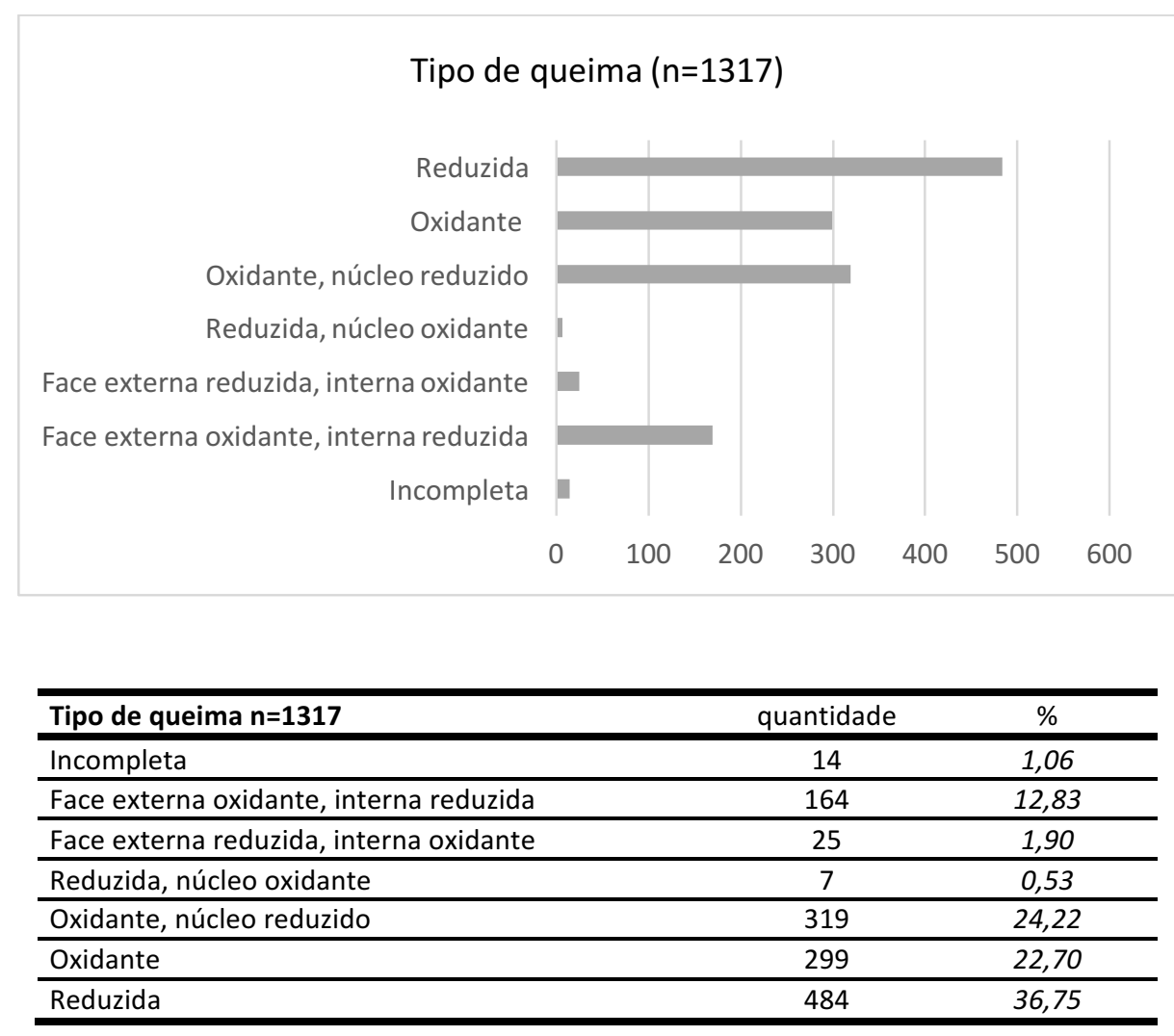


Ao avaliarmos o tipo de queima e seu comportamento em relação a porção do pote se percebe que a queima que corresponde ao tipo face externa oxidante e interna reduzida $(n=164)$ possui uma proporção significativamente maior de ocorrência de bases, e significativamente menor em relação as bordas ao compararmos aos outros tipos de queima comparação aos outros tipos de queima.

\section{Localização dos tipos de queima nas diferentes partes dos potes}

Frequência (\%)

$0 \quad 10 \quad 20 \quad 30 \quad 40 \quad 50 \quad 60 \quad 70 \quad 8090100110120130140150160$
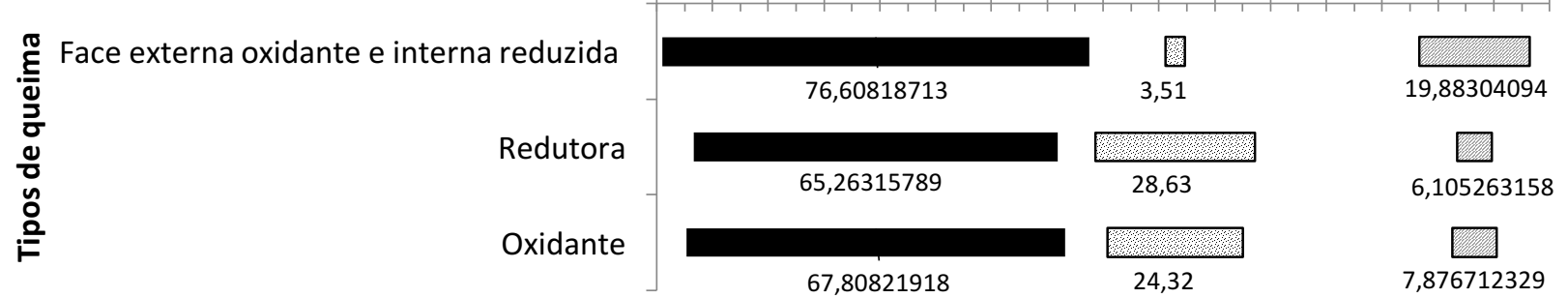

parede

$\square$ borda

\begin{tabular}{|l|c|c|c|c|c|c|}
\hline Tipo de queima/porção do pote & parede & $\%$ & Borda & $\%$ & Base & $\%$ \\
\hline Face externa oxidante e interna reduzida & 129 & 76,61 & 6 & 3,51 & 34 & 19,88 \\
\hline Redutora & 310 & 65,26 & 136 & 28,63 & 29 & 6,11 \\
\hline Oxidante & 198 & 67,81 & 71 & 24,32 & 23 & 7,88 \\
\hline
\end{tabular}

Já em relação a distribuição de tratamento de superfície entre os tipos de queimas percebemos que a queima tipo face externa oxidante e interna reduzida possui novamente uma diferença em relação as tendências observadas entre os outros tipos de queima. Aqui as superfícies alisadas são menos frequentes $(22,9 \%)$ e é muito alto o índice do tratamento escovado sabugo $(63,8 \%)$. Percebe-se também que neste tipo de queima ocorrem também todos os tipos de incisões e impressões.

Percebe-se também que o tipo exciso ocorre principalmente entre as queimas redutoras $(31,43 \%)$ e oxidante com o núcleo reduzido $(54,29 \%)$, indicando que talvez os potes onde encontramos os motivos excisos tivessem uma queima em alta temperatura e controlada. 


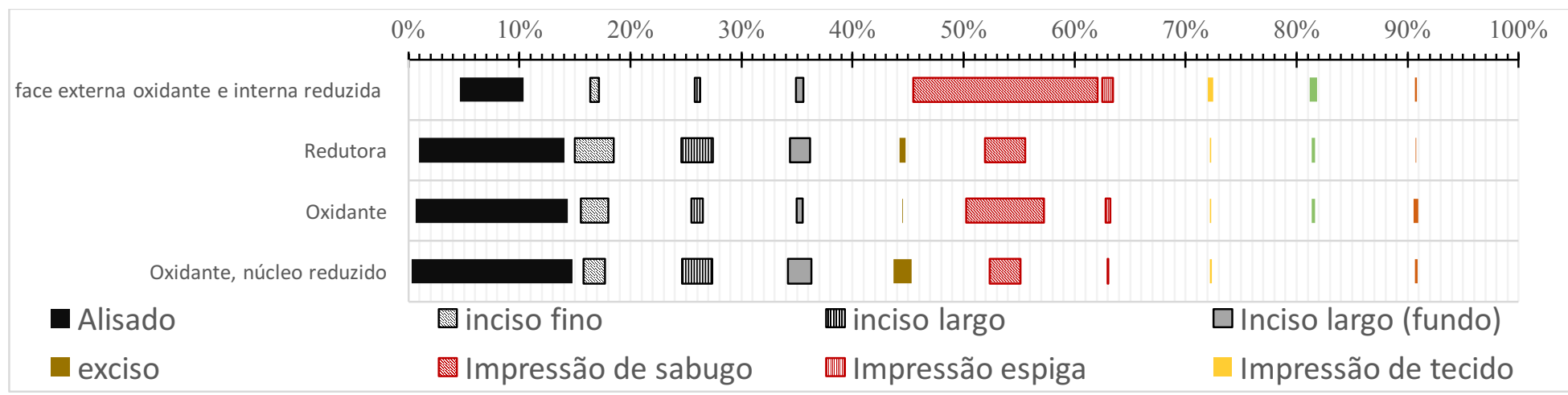

\begin{tabular}{|c|c|c|c|c|c|c|c|c|c|c|c|c|c|c|c|c|c|c|c|c|c|}
\hline & $n=$ & Alisado & $\%$ & $\begin{array}{l}\text { inciso } \\
\text { fino }\end{array}$ & $\%$ & $\begin{array}{l}\text { inciso } \\
\text { largo }\end{array}$ & $\%$ & $\begin{array}{c}\text { Inciso largo } \\
\text { (fundo) }\end{array}$ & $\%$ & exciso & $\%$ & $\begin{array}{l}\text { Impressão } \\
\text { de sabugo }\end{array}$ & $\%$ & $\begin{array}{l}\text { Impressão } \\
\text { espiga }\end{array}$ & $\%$ & $\begin{array}{l}\text { Impressão } \\
\text { de tecido }\end{array}$ & $\%$ & $\begin{array}{l}\text { Impressão } \\
\text { de cestaria }\end{array}$ & $\%$ & $\begin{array}{c}\text { Pontead } \\
0\end{array}$ & $\%$ \\
\hline $\begin{array}{c}\text { face externa } \\
\text { oxidante e } \\
\text { interna } \\
\text { reduzida }\end{array}$ & 164 & 36 & 22,09 & 5 & 3,07 & 3 & 1,84 & 4 & 2,45 & 0 & 0,00 & 104 & 63,80 & 6 & 3,68 & 3 & 1,84 & 4 & 2,45 & 1 & 0,61 \\
\hline Redutora & 478 & 241 & 50,42 & 64 & 13,39 & 52 & 10,88 & 33 & 6,90 & 11 & 2,30 & 66 & 13,81 & 0 & 0,00 & 2 & 0,42 & 5 & 1,05 & 1 & 0,21 \\
\hline Oxidante & 295 & 155 & 52,54 & 28 & 9,49 & 12 & 4,07 & 6 & 2,03 & 1 & 0,34 & 79 & 26,78 & 5 & 1,69 & 1 & 0,34 & 3 & 1,02 & 5 & 1,69 \\
\hline $\begin{array}{l}\text { Oxidante, } \\
\text { núcleo } \\
\text { reduzido }\end{array}$ & 311 & 173 & 55,63 & 23 & 7,40 & 32 & 10,29 & 25 & 8,04 & 19 & 6,11 & 33 & 10,61 & 1 & 0,32 & 2 & 0,64 & 0 & 0,00 & 3 & 0,96 \\
\hline
\end{tabular}

\section{Tratamento de superficie}

O acabamento de superfície da cerâmica da fase Bacabal é marcado por uma variedade de técnicas e pela presença marcante de tipos com alteração plástica de superfície como excisões, incisões, escovados e impressões.

Praticamente metade da amostra apresentou tipos alisados enquanto a outra metade apresentou elementos decorativos na face externa. As superfícies externas em mais da metade dos casos foram preparadas com barbotina, polimentos, banhos e engobos para ser suporte para a aplicação de motivos decorativos que ocorreram alterando plasticamente da superfície. A decoração exclusivamente crômica com motivos pintados não ocorre, as cores incidem sempre junto ao retoque de decorações plásticas.

O tipo alisado foi o mais popular entre os tratamentos de superfície (48,24\%). Já entre os decorados o escovado sabugo foi o mais popular entre os tipos $(22,89 \%)$, seguido das incisões finas $(9,8 \%)$, largas fundas $(8,69 \%)$ e rasas $(4,13 \%)$, excisões $(2,68 \%)$. Tipos relacionados a impressão, como: espiga, cestaria e tecido, juntos somam $(3,61 \%)$, e o ponteado representa $(0,77 \%)$ dos casos da amostra analisada. Já a face interna dos fragmentos foi alisada em $99,71 \%$ dos casos. 


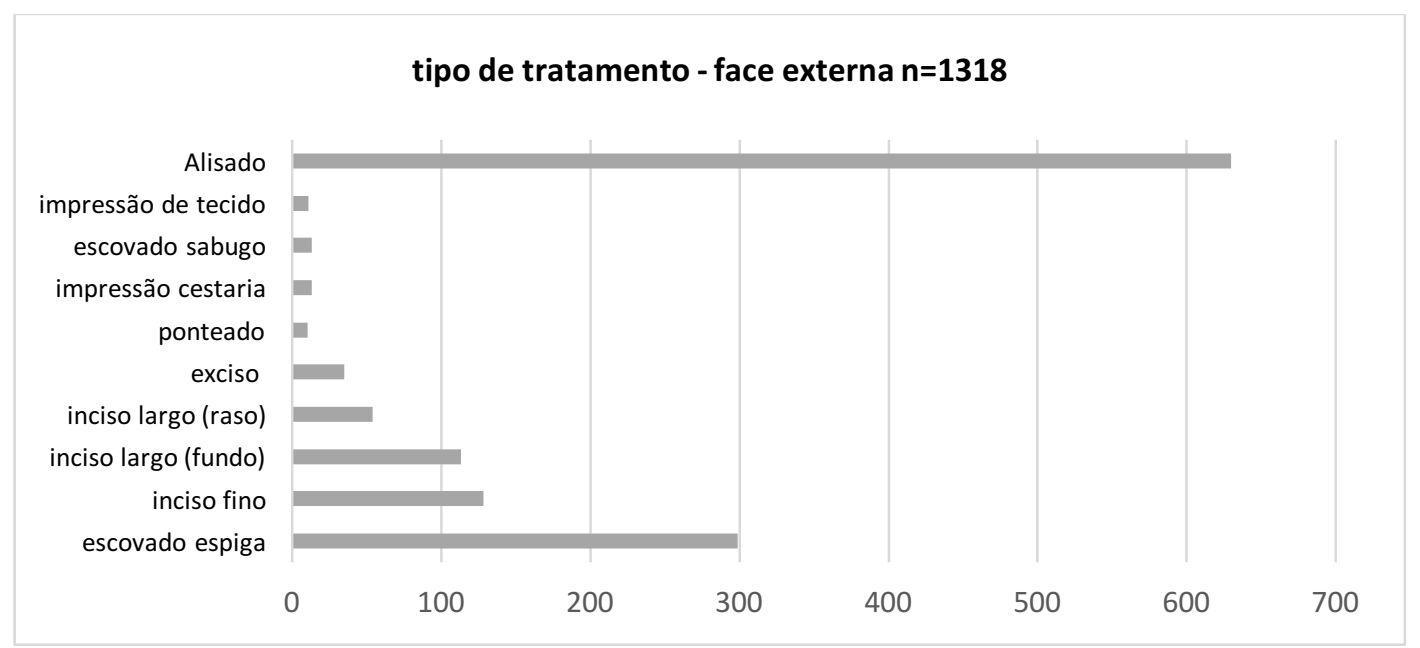

Gráfico 11: tipo de tratamento dado a face externa dos fragmentos $(n=1318)$

\begin{tabular}{lcc}
\hline Tipo de tratamento dado FE $\mathbf{n}=\mathbf{1 3 0 6}$ & quantidade & $\%$ \\
\hline escovado sabugo & $\mathbf{2 9 9}$ & $\mathbf{2 2 , 8 9}$ \\
\hline inciso fino & 128 & 9,80 \\
\hline inciso largo (fundo) & 113 & 8,65 \\
\hline inciso largo (raso) & 54 & 4,13 \\
\hline exciso & 35 & 2,68 \\
\hline ponteado & 10 & 0,77 \\
\hline impressão cestaria & 13 & 1,00 \\
\hline escovado espiga & 13 & 1,00 \\
\hline impressão de tecido & 11 & 0,84 \\
\hline Alisado & 630 & 48,24 \\
\hline
\end{tabular}

Tabela 15: quantidade e proporção na amostra do tipo de tratamento de superfície aplicado a face externa dos fragmentos $(n=1318)$

Já o tratamento aplicado às superfícies em praticamente todos casos foi a barbotina $(82,77 \%)$, seguido do polimento $(9,25 \%)$, esgrafiado $(1,91 \%)$, brunidura $(0,61 \%)$ e simples $(2,3 \%)$.

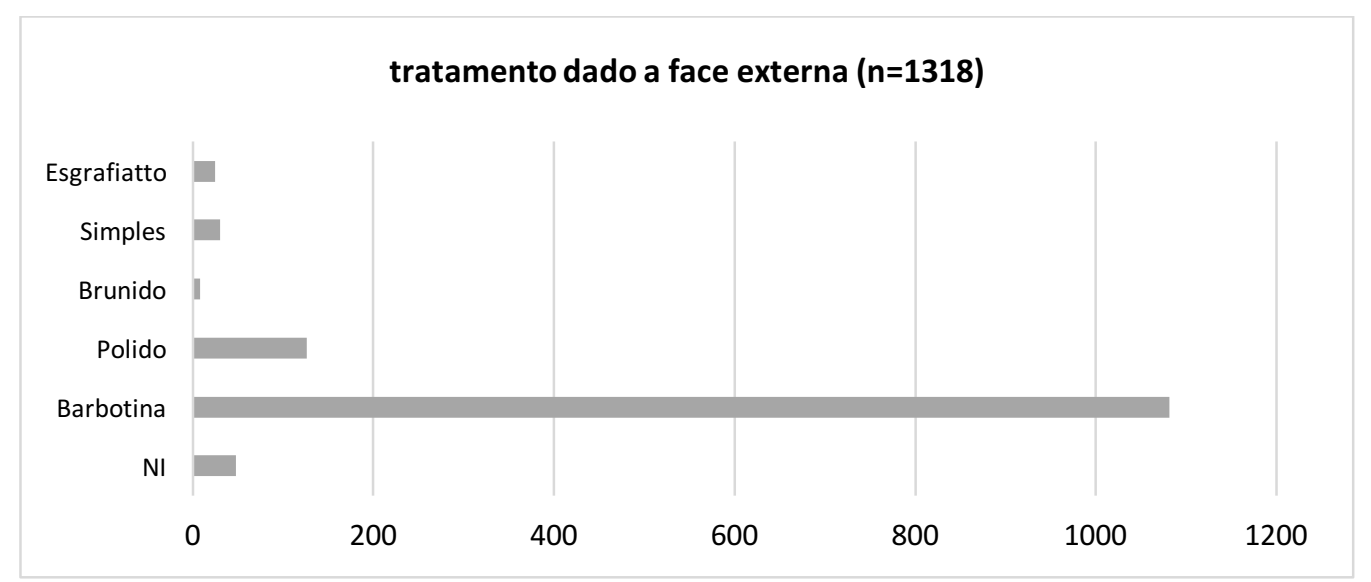

Gráfico 12: tratamento dado a face externa dos fragmentos 


\begin{tabular}{lcc}
\hline $\begin{array}{l}\text { tratamento dado a face externa } \\
(\mathbf{n = 1 3 1 8})\end{array}$ & quantidade & $\%$ \\
\hline $\mathrm{NI}$ & 48 & 3,68 \\
\hline Barbotina & 1081 & 82,77 \\
\hline Polido & 126 & 9,65 \\
\hline Brunido & 8 & 0,61 \\
\hline Simples & 30 & 2,30 \\
\hline Esgrafiato & 25 & 1,91 \\
\hline
\end{tabular}

Tabela 16: quantidade e proporção dos tipos de tratamento dado a face externa dos fragmentos

\section{Tipos alisados}

Nos tipos alisados $(48,63 \%, n=630)$ percebe-se a utilização de variados instrumentos e técnicas em diferentes momentos de secagem do pote, identificadas a partir de vestígios deixados no processo de alisamento. Tais técnicas foram classificadas como: barbotina, polido e brunidura e a pintura em vermelho (engobo e banho). Dentre as superfícies alisadas sem decoração $(n=420)$ em um quarto da amostra $(27,15 \%)$ houve alguma modificação na superfície externa do pote como: polimento, brunidura e/ou aplicação de coloração vermelha a partir de banho ou barbotina.

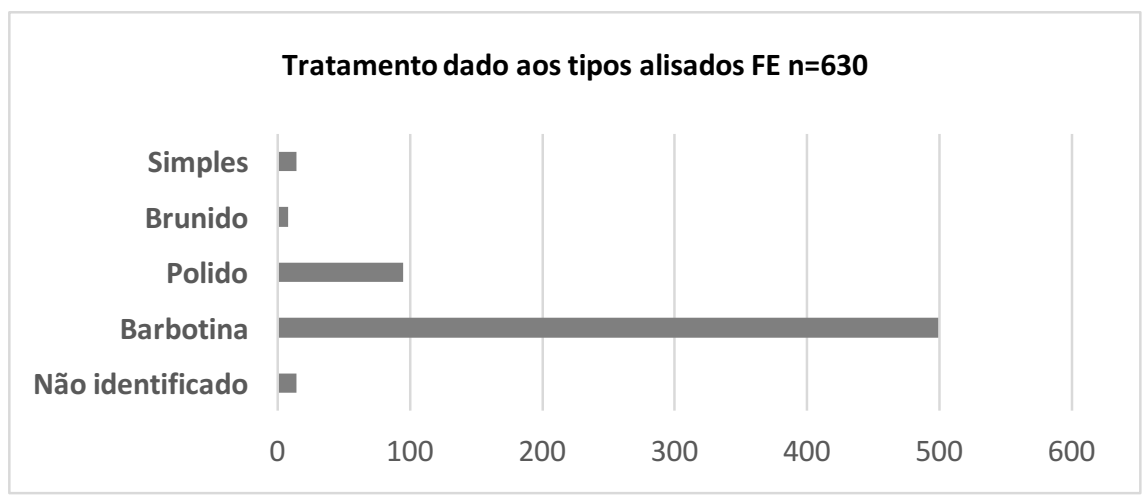

Gráfico 13: tratamento dado a face externa dos tipos alisados

\begin{tabular}{lcc}
\hline Tratamento dado aos tipos alisados FE $\mathbf{n}=\mathbf{6 3 0}$ & quantidade & $\%$ \\
\hline Não identificado & 14 & 2,22 \\
\hline Barbotina & 499 & 79,21 \\
\hline Polido & 95 & 15,08 \\
\hline Brunido & 8 & 1,27 \\
\hline Simples & 14 & 2,22 \\
\hline
\end{tabular}

Tabela 17: quantidade e proporção do tratamento dado a face externa dos tipos alisados 
O Engobo vermelho 8,9\% $(n=56)$ na face externa e em $66,07 \%(n=37)$ destes casos a pintura ocorre também na face interna. Banho vermelho foi encontrado em 4,29\%(n=27) em $62,96 \%(n=14)$ destes ocorreu o banho na face interna também.

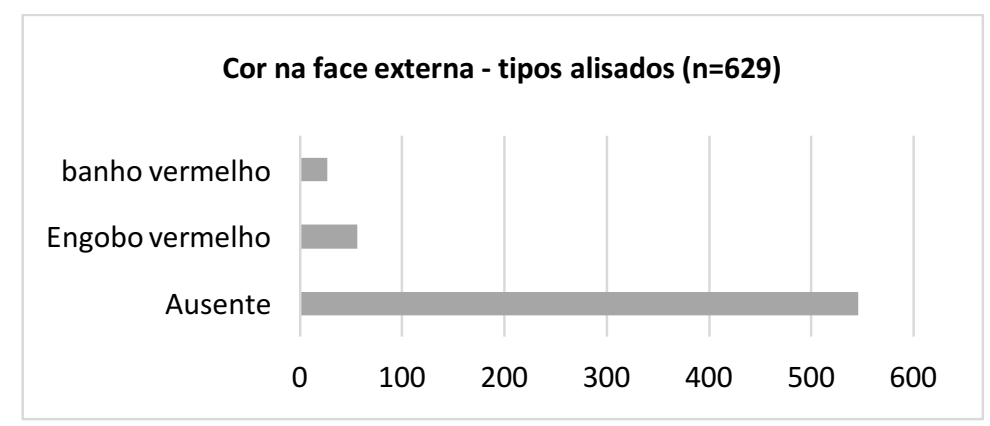

Gráfico 14: cor na face externa

\begin{tabular}{lcc}
\hline cor FE tipos alisados $(\mathbf{n = 6 2 9 )}$ & quantidade & \% \\
\hline Ausente & 546 & 86,80 \\
\hline Engobo vermelho & 56 & 8,90 \\
\hline banho vermelho & 27 & 4,29 \\
\hline
\end{tabular}

Tabela 18: quantidade e porcentagem dos tipos com aplicação de pigmentação na face externa

Vestígios de alisamento

Em 25\% da amostra analisada foi possível perceber quatro tipos de vestígios associados ao alisamento de potes. Destes, três foram aplicados com a superfície antes do ponto de couro - quando durante a secagem ainda se pode dar acabamento, aparar, adicionar elementos na peça com facilidade. O outro está associado a aplicação em outro momento da secagem, entre o ponto de couro e o ponto de osso - quando argila já está mais seca.

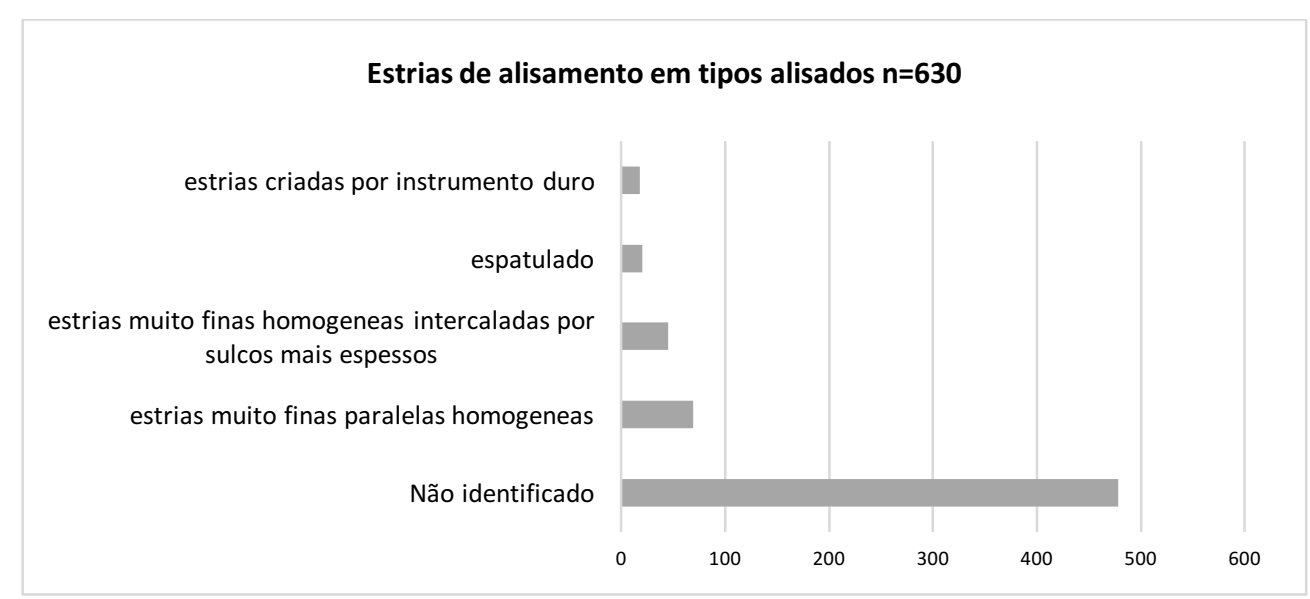

Gráfico 15: quantidade de tipos de estrias de alisamento em tipos alisados $n=630$ 


\begin{tabular}{lcc}
\hline Estrias de alisamento em tipos alisados $\mathbf{n = 6 3 0}$ & quantidade & $\%$ \\
\hline Não identificado & 478 & 75,87 \\
\hline estrias muito finas paralelas homogêneas & 69 & 10,95 \\
\hline estrias muito finas homogêneas intercaladas por sulcos mais espessos & 45 & 7,14 \\
\hline espatulado & 20 & 3,17 \\
\hline estriada criadas por instrumento duro & 18 & 2,86 \\
\hline
\end{tabular}

Gráfico 16: quantidade e proporção de tipos de estrias de alisamento em tipos alisados $n=630$

Tipos decorados

Os tipos decorados foram elaborados a partir de diferentes técnicas, a maioria delas plásticas e que foram aplicadas em superfícies tratadas de diferentes maneiras, recebendo muitas vezes algum tratamento posterior, como polimento e/ou engobo. Os atributos relativos as alterações plásticas de superfície foram divididos em incisões: finas, largas aprofundadas e largas e rasas; exciso; escovados: espiga e sabugo; impressão de: cestaria e de tecido (imagem 74). Na classificação destes tipos decorados também forma considerados outros tratamentos que não alteram plasticamente a superfície como o engobo e o banho, além do polimento e da brunidura. 


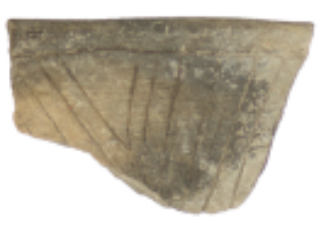

a)

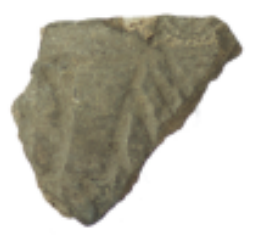

e)

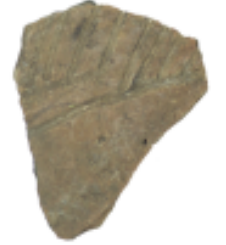

b)

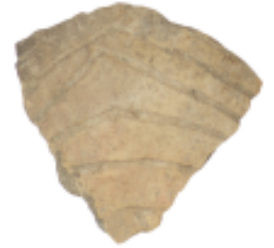

f)

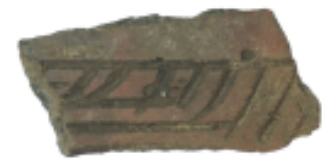

c)

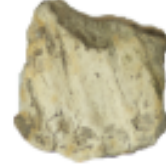

g)

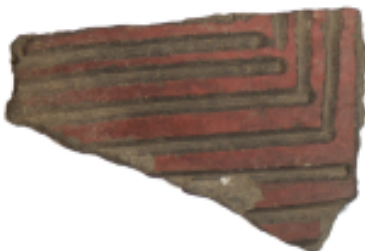

d)

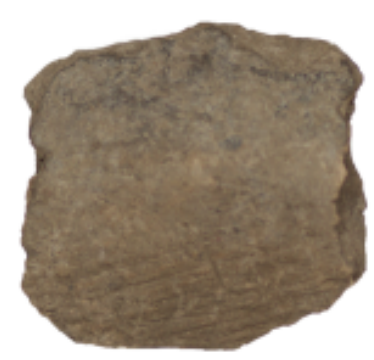

k)

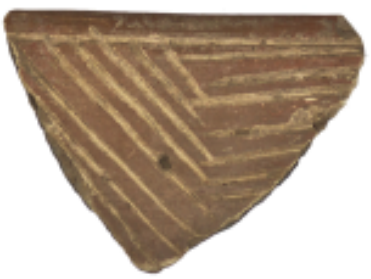

o)

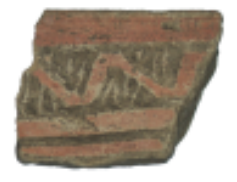

s)

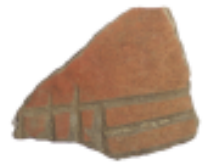

p)

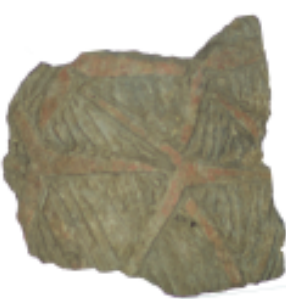

m)

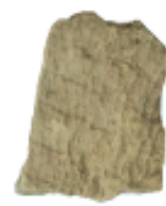

i)

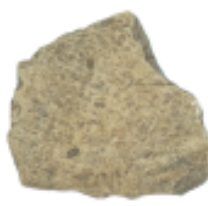

j)
I)

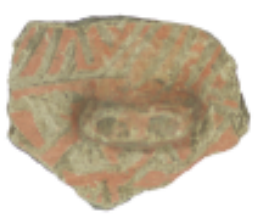

q)

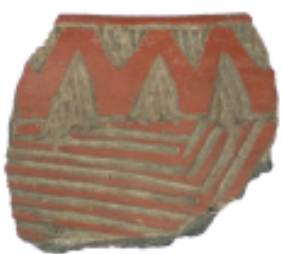

n)

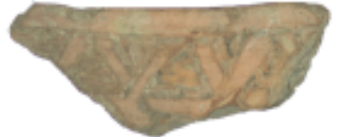

r)

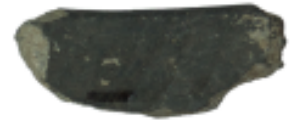

v)

u)

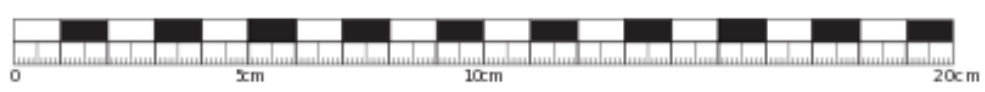

Imagem 71:a-b) inciso fino; $c$-d) inciso largo fundo; e-f) inciso largo raso; $g$-h) escovado espiga; i) impressão de cestaria; j) impressão de tecido; $k$-l) escovado sabugo; $m$ - $n$ ) exciso; $n$ - $p$ ) engobo vermelho; $q-s)$ banho vermelho; $t$-u) polido; v) brunido; $n-q)$ esgrafiado. 
Entre os tipos decorados o escovado sabugo foi o mais popular (22,89\%), seguido das incisões finas $(9,8 \%)$, largas fundas $(8,69 \%)$ e rasas $(4,13 \%)$; excisões $(2,68 \%)$. Os diferentes tipos de impressão, como: espiga, cestaria e tecido somam $(3,61 \%)$ e o ponteado representa $(0,77 \%)$ dos casos analisados. Os tipos impressos e o escovado espiga foram aplicados em superfície com barbotina em todos os casos, já o tipo escovado sabugo por vezes sofreu polimento posterior. No tratamento esgrafiado ocorrem somente os tipos inciso largo e fundo e exciso.

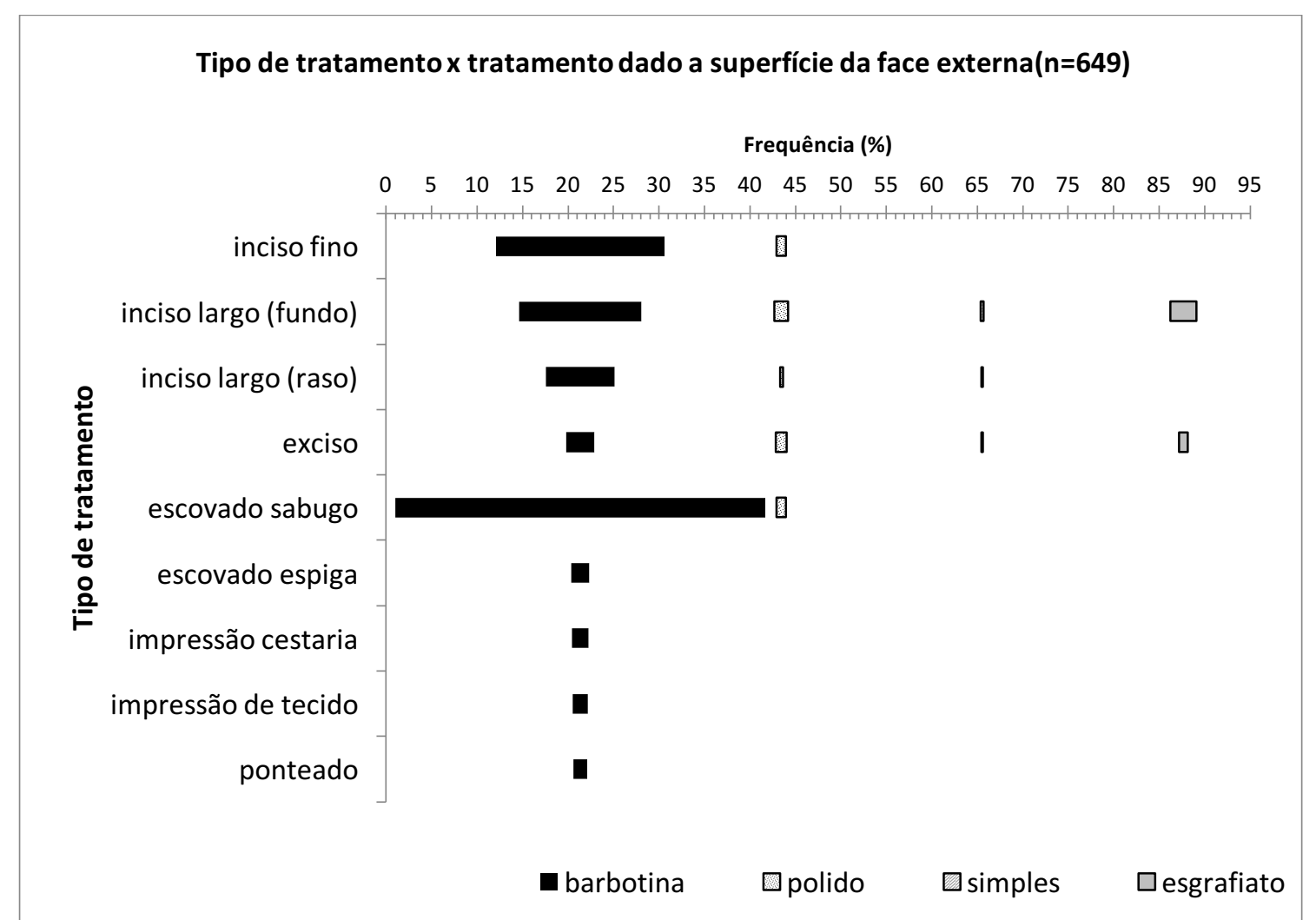

Gráfico 17: sequencia seriada da frequência do tipo de tratamento e o tratamento dado a superfície da face externa $(n=649)$,

\begin{tabular}{|l|c|c|c|c|c|c|c|c|}
\hline Tipo/tratamento dado & Barbotina & $\%$ & Polido & $\%$ & Simples & $\%$ & Esgrafiado & $\%$ \\
\hline inciso fino & 120 & 18,49 & 7 & 1,08 & 0 & 0 & 0 & 0 \\
\hline inciso largo (fundo) & 87 & 13,41 & 10 & 1,54 & 2 & 0,31 & 19 & 2,93 \\
\hline inciso largo (raso) & 49 & 7,55 & 2 & 0,31 & 1 & 0,15 & 0 & 0 \\
\hline exciso & 20 & 3,08 & 8 & 1,23 & 1 & 0,15 & 6 & 0,92 \\
\hline escovado sabugo & 264 & 40,68 & 7 & 1,08 & 0 & 0 & 0 & 0 \\
\hline escovado espiga & 13 & 2,00 & 0 & 0,00 & 0 & 0 & 0 & 0 \\
\hline impressão cestaria & 12 & 1,85 & 0 & 0,00 & 0 & 0 & 0 & 0 \\
\hline impressão de tecido & 11 & 1,69 & 0 & 0,00 & 0 & 0 & 0 & 0 \\
\hline ponteado & 10 & 1,54 & 0 & 0,00 & 0 & 0 & 0 & 0 \\
\hline
\end{tabular}

Tabela 19: Tipo de tratamento $x$ tratamento dado a superficie da face externa $(n=649)$ 
Os tipos Inciso largo e o exciso são característicos também por ocorrer de maneira mais frequente em superfícies com aplicação de algum pigmento (engobo ou banho) do que nas superfícies com ausência de cor. Também é possível notar que os tipos escovados e as impressões ocorrem somente em superfície sem aplicação de cor.

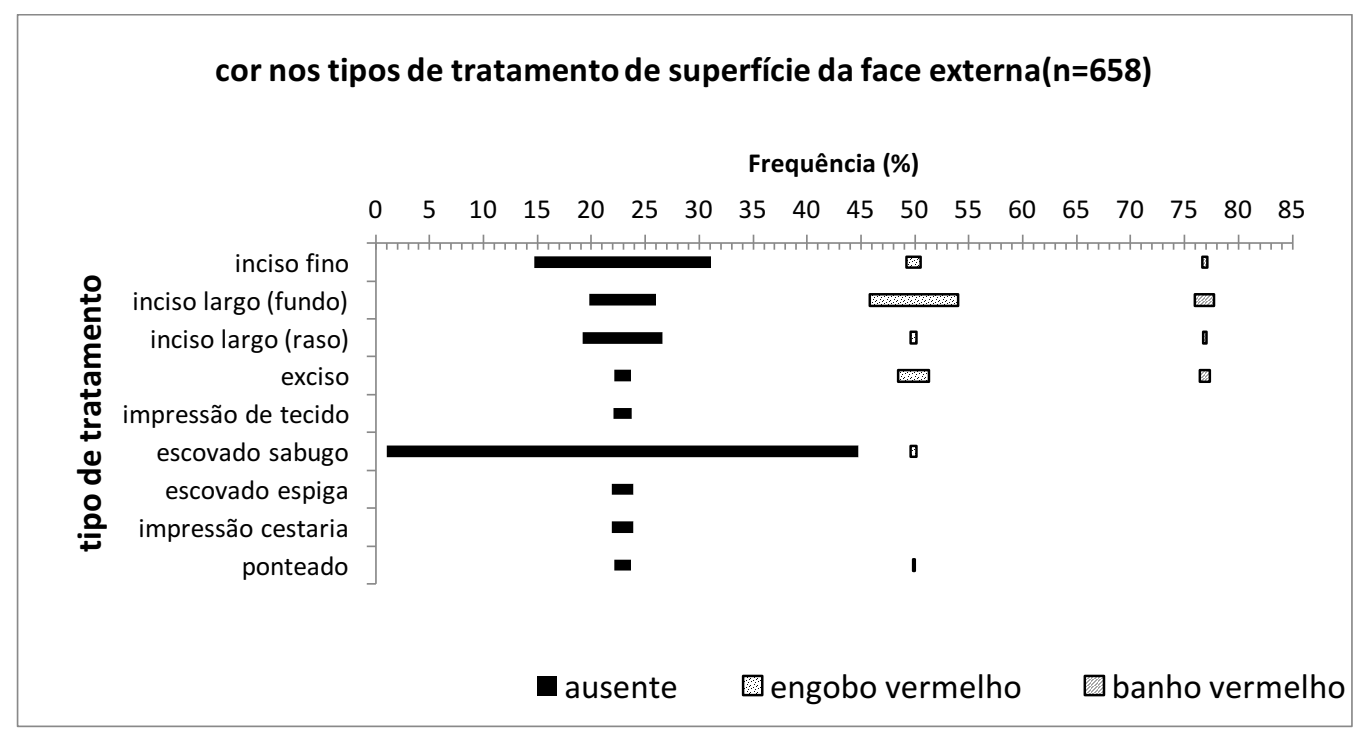

\begin{tabular}{|l|c|c|c|c|c|c|}
\hline cor nos tipos decorados $\mathbf{n}=\mathbf{6 6 0}$ & Ausente & $\mathbf{\%}$ & Engobo vermelho & $\%$ & Banho vermelho & $\%$ \\
\hline inciso fino & 108 & 16,36 & 9 & 1,36 & 3 & 0,45 \\
\hline inciso largo (fundo) & 41 & 6,21 & 54 & 8,18 & 12 & 1,82 \\
\hline inciso largo (raso) & 49 & 7,42 & 4 & 0,61 & 2 & 0,30 \\
\hline exciso & 10 & 1,52 & 19 & 2,88 & 6 & 0,91 \\
\hline impressão de tecido & 11 & 1,67 & 0 & 0 & 0 & 0 \\
\hline escovado sabugo & 289 & 43,79 & 4 & 0,61 & 0 & 0,00 \\
\hline escovado espiga & 13 & 1,97 & 0 & 0 & 0 & 0 \\
\hline impressão cestaria & 13 & 1,97 & 0 & 0 & 0 & 0 \\
\hline ponteado & 10 & 1,52 & 1 & 0,15 & 0 & 0 \\
\hline
\end{tabular}

Motivos decorativos

A partir da recorrência de padrões decorativos na cerâmica elencamos 14 tipos em busca de contextualizar a ocorrência e variação. Os motivos decorativos identificados foram: 1) bacabal; 2) bacabal espelhado; 3) bacabal 2 - não preenchido; 4) bacabal repetido; 5) bacabal paralelo; 6) inciso losangular; 7) inciso cruzado; 8) inciso não cruzado; 9) escovado sabugo; 10) escovado espiga); 11) impressão de tecido; 12) impressão de cestaria; 13) representação zoomorfa e 14) representação antropomorfa (imagem 75). 
Os tipos mais recorrentes são o escovado sabugo (41,76\%), seguido pelo Bacabal paralelo (22,8\%\%). O tipo Bacabal e suas idiossincrasias - Bacabal 2, Bacabal espelhado e Bacabal repetido - juntos somam 9,86\% dos tipos decorados. O escovado espiga e as impressões de tecido e cestaria somam 8,32\%. Representações zoomorfas e antropomorfas $(0,64 \%)$, e o quadriculado representam $0,64 \%$ e completam os motivos reconhecidos (gráfico $18)$.

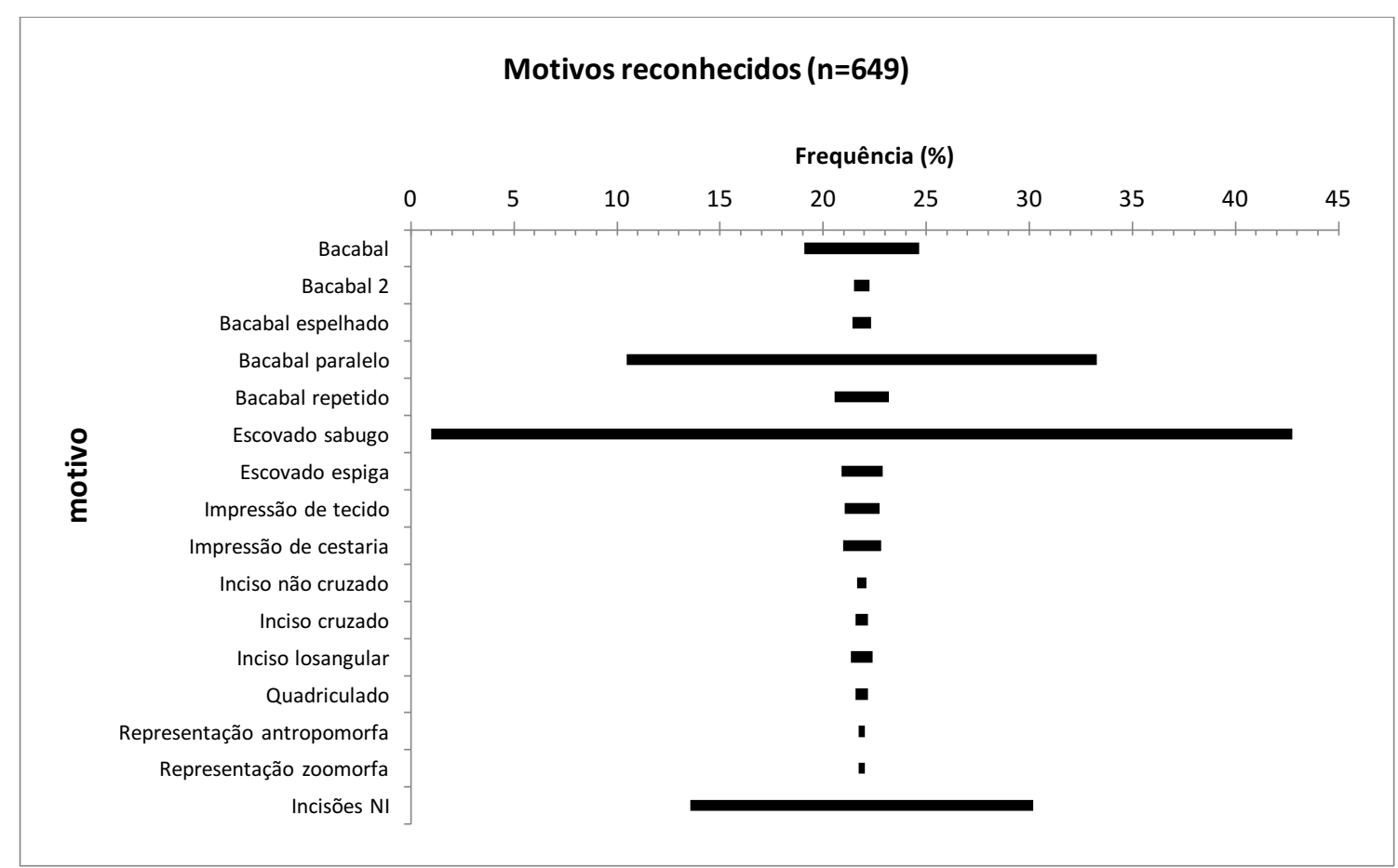

Gráfico 18: motivos reconhecidos na fase Bacabal

\begin{tabular}{lcc}
\hline motivo decorativo $(\mathbf{n}=\mathbf{6 4 9})$ & quantidade & $\%$ \\
\hline Bacabal & 36 & 5,55 \\
\hline Bacabal 2 & 5 & 0,77 \\
\hline Bacabal espelhado & 6 & 0,92 \\
\hline Bacabal paralelo & 148 & 22,80 \\
\hline Bacabal repetido & 17 & 2,62 \\
\hline Escovado sabugo & 271 & 41,76 \\
\hline Escovado espiga & 13 & 2,00 \\
\hline Impressão de tecido & 11 & 1,69 \\
\hline Impressão de cestaria & 12 & 1,85 \\
\hline Inciso não cruzado & 3 & 0,46 \\
\hline Inciso cruzado & 4 & 0,62 \\
\hline Inciso losangular & 7 & 1,08 \\
\hline Quadriculado & 4 & 0,62 \\
\hline Representação antropomorfa & 2 & 0,31 \\
\hline Representação zoomorfa & 2 & 0,31 \\
\hline Incisões NI & 108 & 16,64 \\
\hline
\end{tabular}

Tabela 20: quantidade e proporção dos motivos identificados $(n=649)$ 


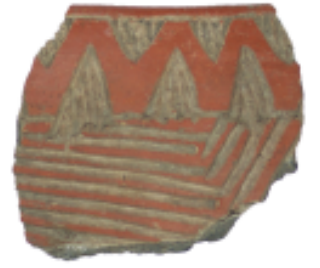

a)

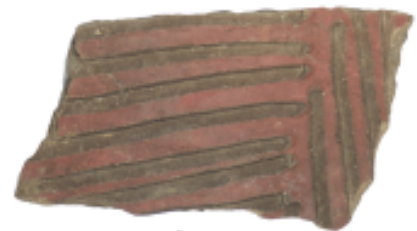

e)

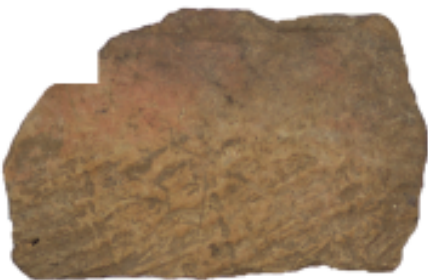

i)

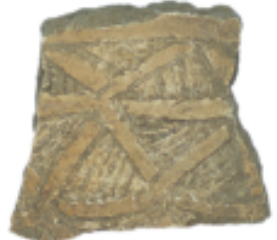

b)

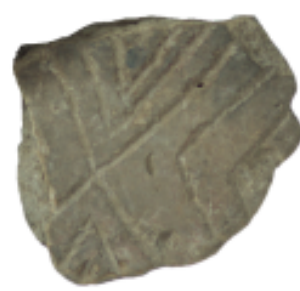

f)

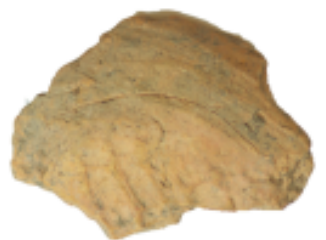

j)

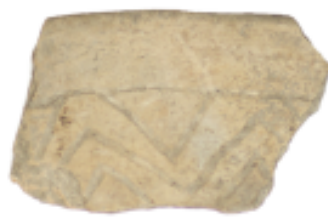

c)

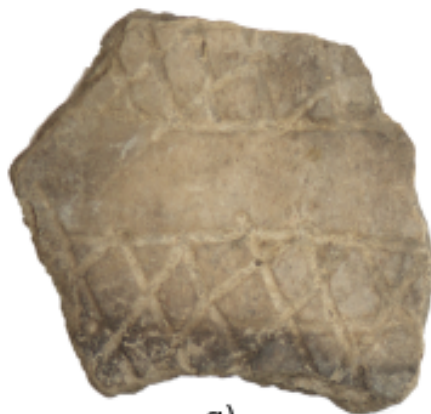

g)

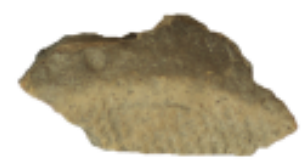

k)

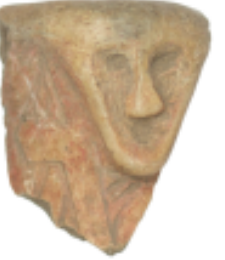

o)

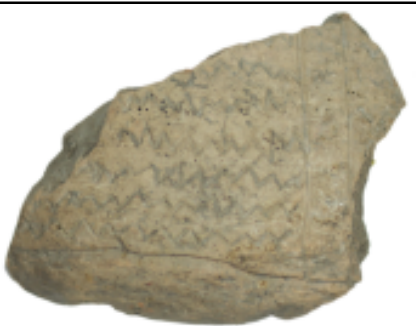

d)

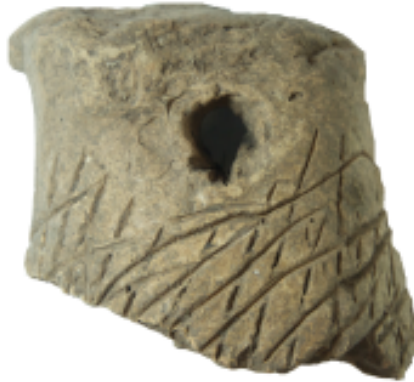

h)
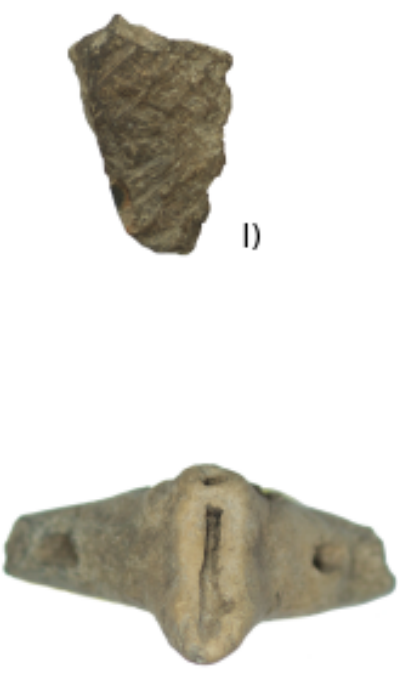

p)

m)

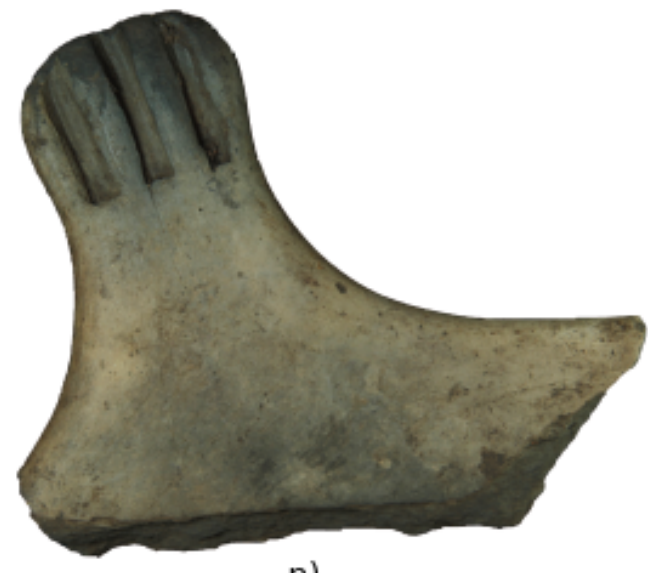

n)

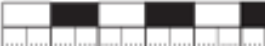

Imagem 72: Motivos decorativos identificados: a) bacabal; b) bacabal espelhado; c) bacabal 2; d) bacabal repetido; e) bacabal inciso paralelo; f) inciso losangular; g) inciso cruzado; $h$ ) inciso não cruzado; i) escovado sabugo; j) escovado espiga); $k$ ) impressão de de tecido; l) impressão de cestaria;

m) quadriculado; n) representação zoomorfa; n-o) representação antropomorfa n) rosto; o) vulva.

$\mathrm{Na}$ avaliação do tratamento dado as superfícies com motivos reconhecido verificamos que o escovado sabugo predomina entre os tipos aplicados sob barbotina (46,59\%), seguido por Bacabal paralelo $(15,26 \%)$ e o motivo Bacabal e suas idiossincrasias $(6,02 \%)$. Alguns tipos decorativos receberam polimento em sua finalização, como é o caso do bacabal paralelo $(0,8 \%)$ e das representações antropomorfa $(0,2 \%)$ e zoomorfa $(0,2 \%)$, assim como o escovado 
sabugo (1,61\%). Entre aqueles que receberam banho, engobo ou esgrafiado, o bacabal paralelo predominou (12\%), e este tipo também ocorreu associado ao polimento $(2,01 \%)$. Os motivos Bacabal, Bacabal espelhado e paralelo são os únicos que ocorrem em todos os tipos de suporte, sejam eles simples, com barbotina, polidos, engobado, engobado e polido ou com banho.

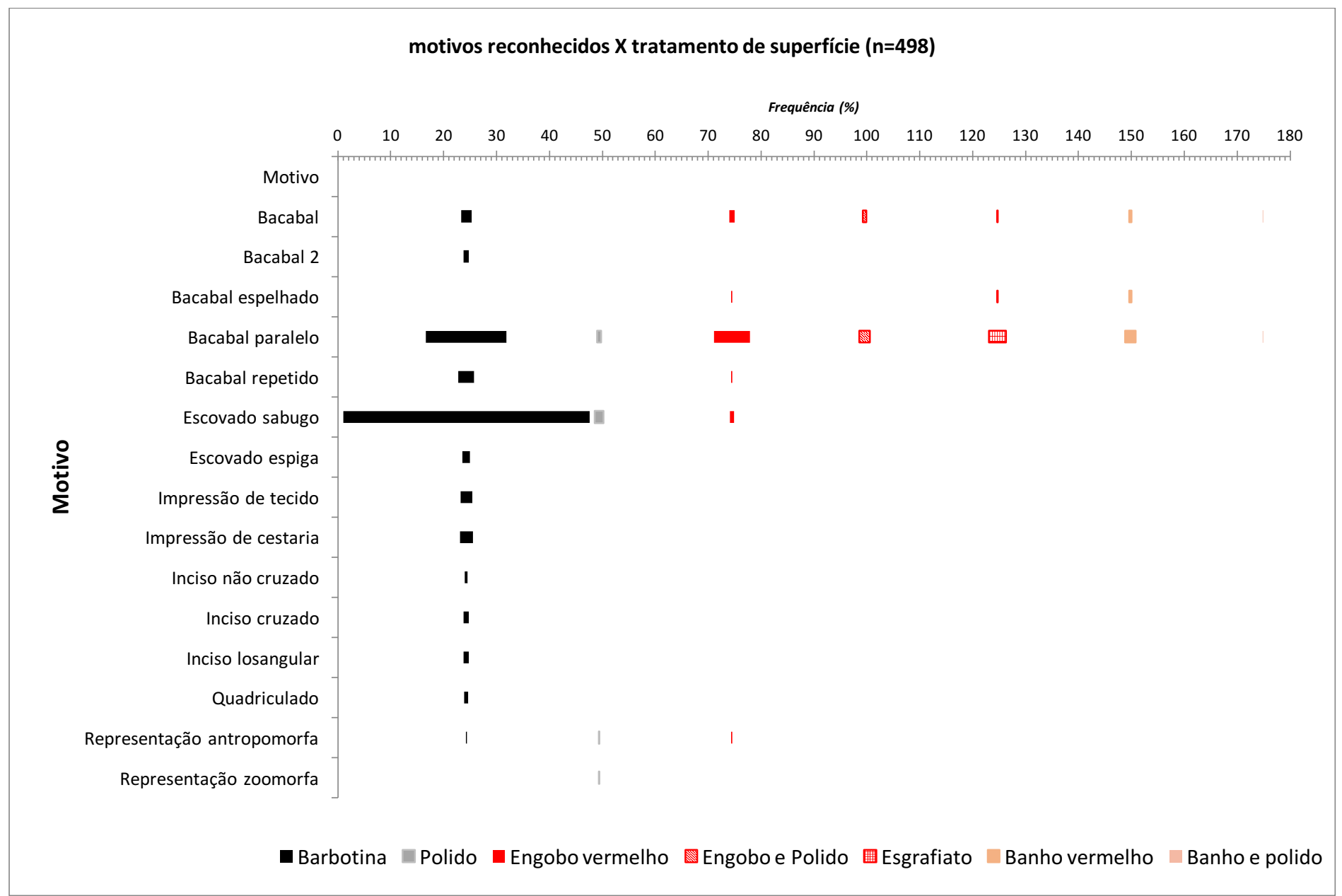

Gráfico 19: sequência seriada dos tipos de tratamento de superfície entre os motivos decorativos reconhecidos na fase Bacabal

\begin{tabular}{|c|c|c|c|c|c|c|c|c|c|c|c|c|c|c|c|c|}
\hline Motivos reconhecidos ( $n=498$ ) & \multicolumn{4}{|c|}{ ausente } & \multicolumn{6}{|c|}{ engobo vermelho } & \multicolumn{6}{|c|}{ banho vermelho } \\
\hline tratamento dado FE & barbotina & $\%$ & polido & $\%$ & engobo & $\%$ & polido & $\%$ & esgrafiado & $\%$ & banho & $\%$ & polido & $\%$ & esgrafiado & $\%$ \\
\hline Bacabal & 10 & 2,01 & 0 & 0 & 5 & 1,00 & 3 & 0,60 & 1 & 0,20 & 2 & 0,40 & 1 & 0,20 & 0 & 0 \\
\hline Bacabal 2 & 5 & 1,00 & 0 & 0 & 0 & 0,00 & 0 & 0,00 & 0 & 0,00 & 0 & 0,00 & 0 & 0,00 & 0 & 0 \\
\hline Bacabal espelhado & 0 & 0,00 & 0 & 0 & 1 & 0,20 & 0 & 0,00 & 1 & 0,20 & 2 & 0,40 & 0 & 0,00 & 0 & 0 \\
\hline Bacabal paralelo & 76 & 15,26 & 4 & 0,80 & 34 & 6,83 & 10 & 2,01 & 16 & 3,21 & 10 & 2,01 & 1 & 0,20 & 0 & 0 \\
\hline Bacabal repetido & 15 & 3,01 & 0 & 0 & 1 & 0,20 & 0 & 0,00 & 0 & 0,00 & 0 & 0,00 & 0 & 0,00 & 0 & 0 \\
\hline Escovado sabugo & 232 & 46,59 & 8 & 1,61 & 4 & 0,80 & 0 & 0,00 & 0 & 0,00 & 2 & 0,40 & 0 & 0,00 & 0 & 0 \\
\hline Escovado espiga & 7 & 1,41 & 0 & 0 & 0 & 0,00 & 0 & 0,00 & 0 & 0,00 & 0 & 0,00 & 0 & 0,00 & 0 & 0 \\
\hline Impressão de tecido & 11 & 2,21 & 0 & 0 & 0 & 0,00 & 0 & 0,00 & 0 & 0,00 & 0 & 0,00 & 0 & 0,00 & 0 & 0 \\
\hline Impressão de cestaria & 12 & 2,41 & 0 & 0 & 0 & 0,00 & 0 & 0,00 & 0 & 0,00 & 1 & 0,20 & 0 & 0,00 & 0 & 0 \\
\hline Inciso não cruzado & 3 & 0,60 & 0 & 0 & 0 & 0,00 & 0 & 0,00 & 0 & 0,00 & 0 & 0,00 & 0 & 0,00 & 0 & 0 \\
\hline Inciso cruzado & 5 & 1,00 & 0 & 0 & 0 & 0,00 & 0 & 0,00 & 0 & 0,00 & 0 & 0,00 & 0 & 0,00 & 0 & 0 \\
\hline Inciso losangular & 5 & 1,00 & 0 & 0 & 0 & 0,00 & 0 & 0,00 & 0 & 0,00 & 0 & 0,00 & 0 & 0,00 & 0 & 0 \\
\hline Quadriculado & 4 & 0,80 & 0 & 0 & 0 & 0,00 & 0 & 0,00 & 0 & 0,00 & 0 & 0,00 & 0 & 0,00 & 0 & 0 \\
\hline Representação antropomorfa & 1 & 0,20 & 1 & 0,20 & 1 & 0,20 & 0 & 0,00 & 0 & 0,00 & 0 & 0,00 & 0 & 0,00 & 0 & 0 \\
\hline Representação zoomorfa & 0 & 0,00 & 1 & 0,20 & 0 & 0,00 & 0 & 0,00 & 0 & 0,00 & 0 & 0,00 & 0 & 0,00 & 0 & 0 \\
\hline
\end{tabular}


Imagem 73: $a-j)$ motivo Bacabal, excisos,

associado a

Bacabal paralelo,

com tratamento

tipo esgrafiado;

k-l) motivo

Bacabal

associado a

Bacabal paralelo

e engobo

vermelho $m, n, q, s$ )

polidos; o, $r, s$ )

com barbotina;

p) em superficie

simples; $t$ )

Bacabal em

serrilhado

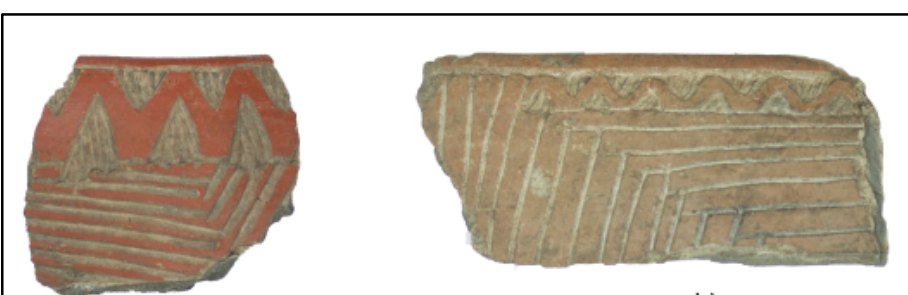

a)

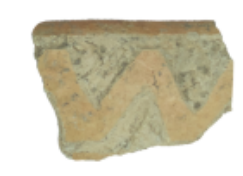

e)

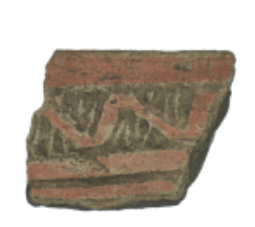

i)

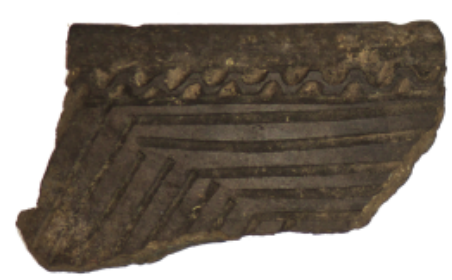

m)

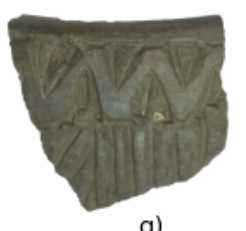

q)

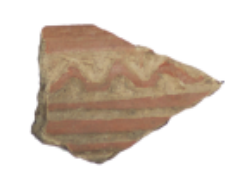

f)

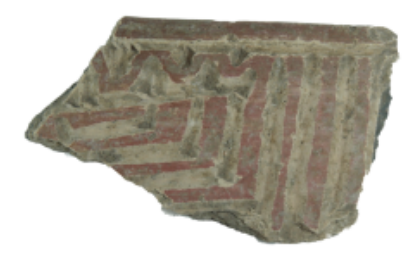

j)
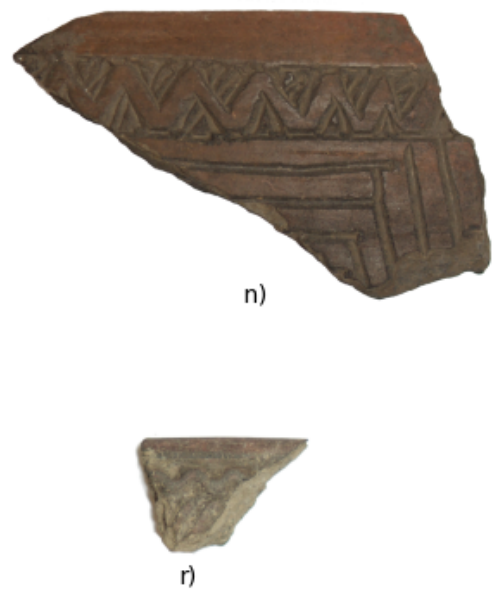

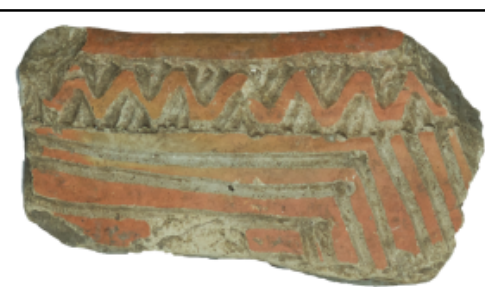

c)

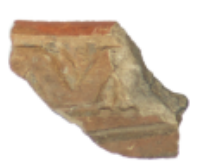

g)

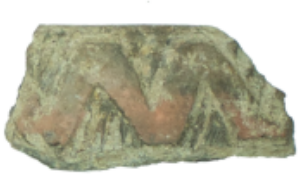

k)
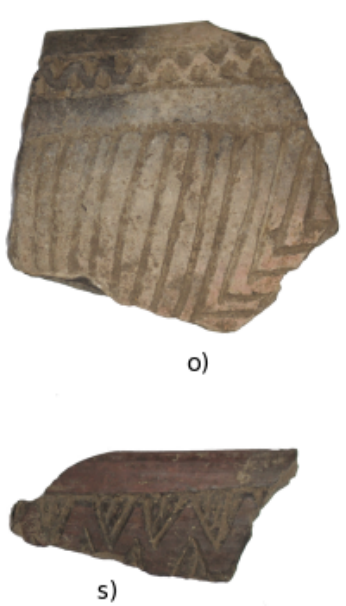

s)
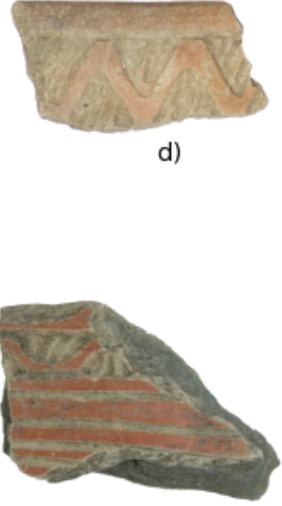

h)

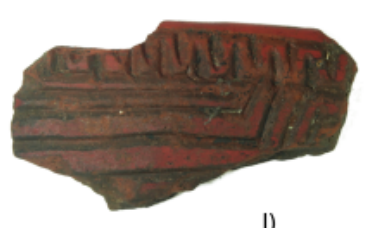

l)

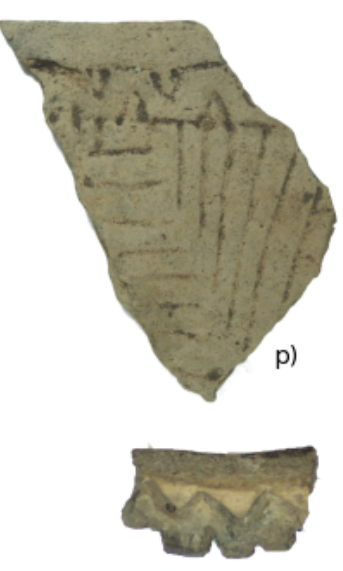

t)

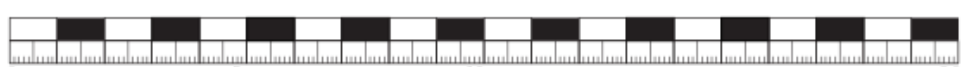




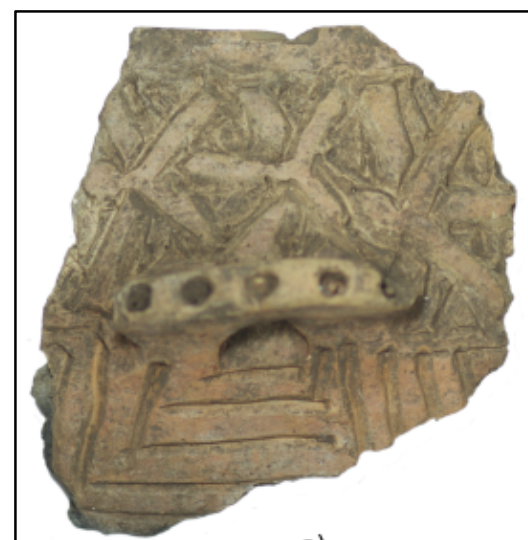

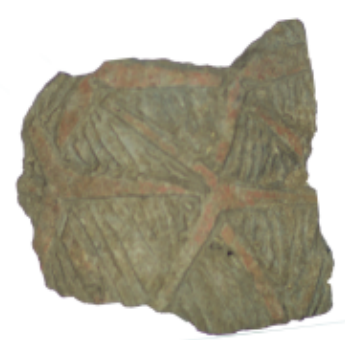

b)

a)

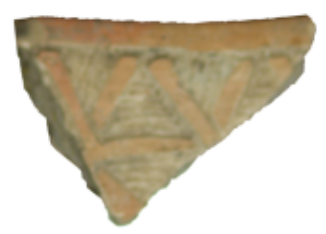

e)

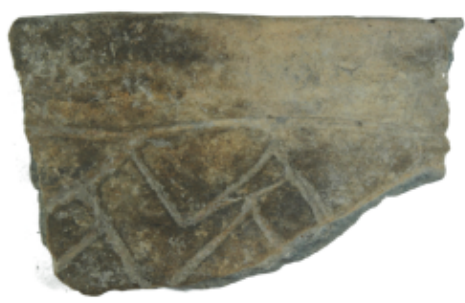

i)

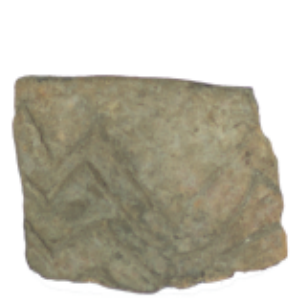

I) f)

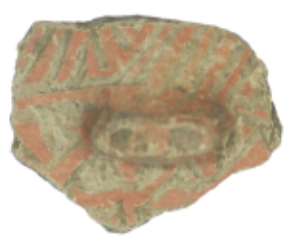

j)

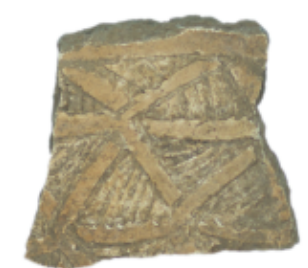

c)

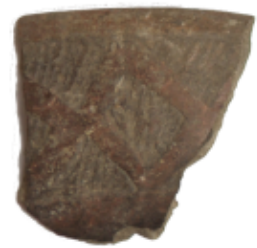

g)

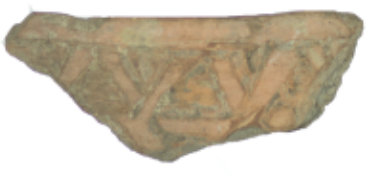

d)

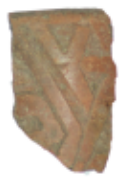

h)
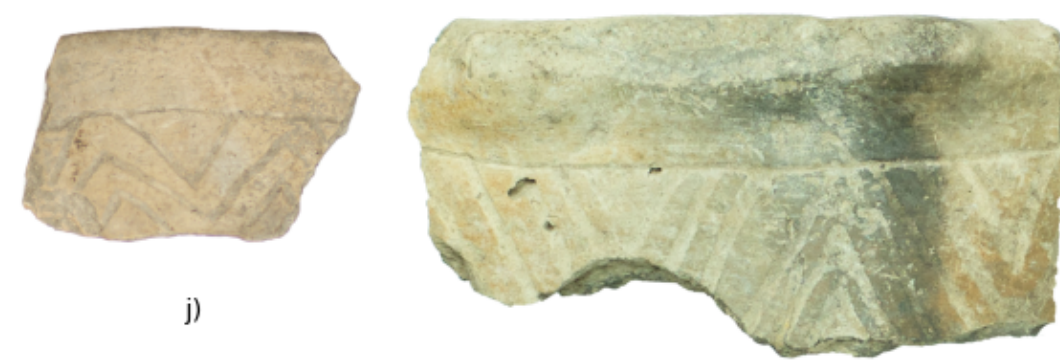

k)
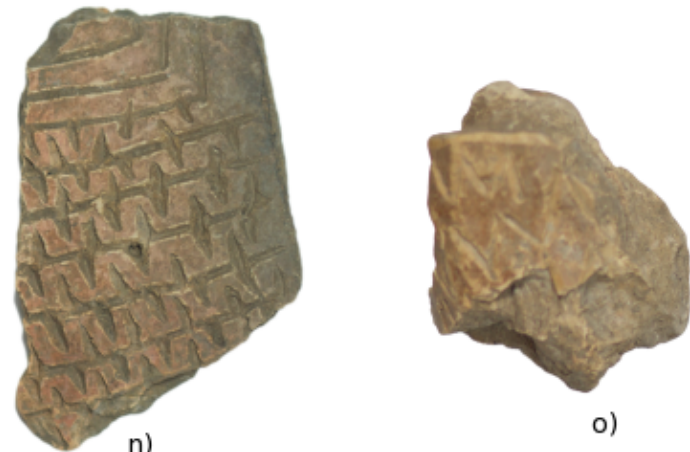

o)

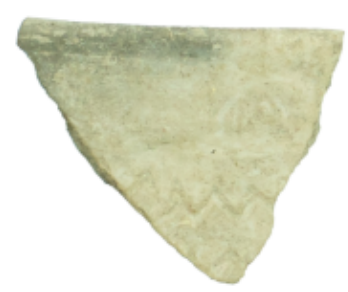

p)

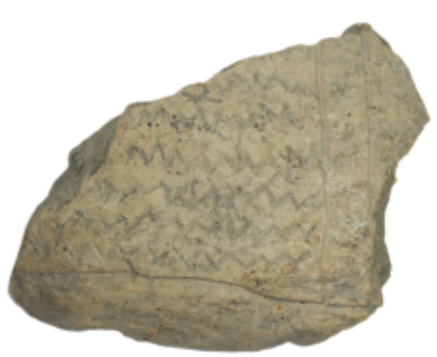

m)

n)

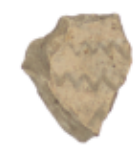

q)

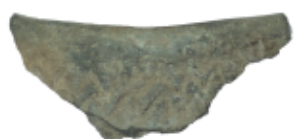

r)

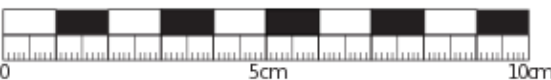

Imagem 74: a-h) Bacabal espelhado, excisos - esgrafiado(e,f); banho vermelho (a.c.d); engobo vermelho (b,c); engobo vermelho e polimento $(g, h) i$-l) Bacabal 2 - inciso fino, superficie com barbotina; m-r) Bacabal repetido - barbotina (m,p,q,r); exciso, polido e engobo vermelho (n); inciso polido e engobo vermelho (o). 


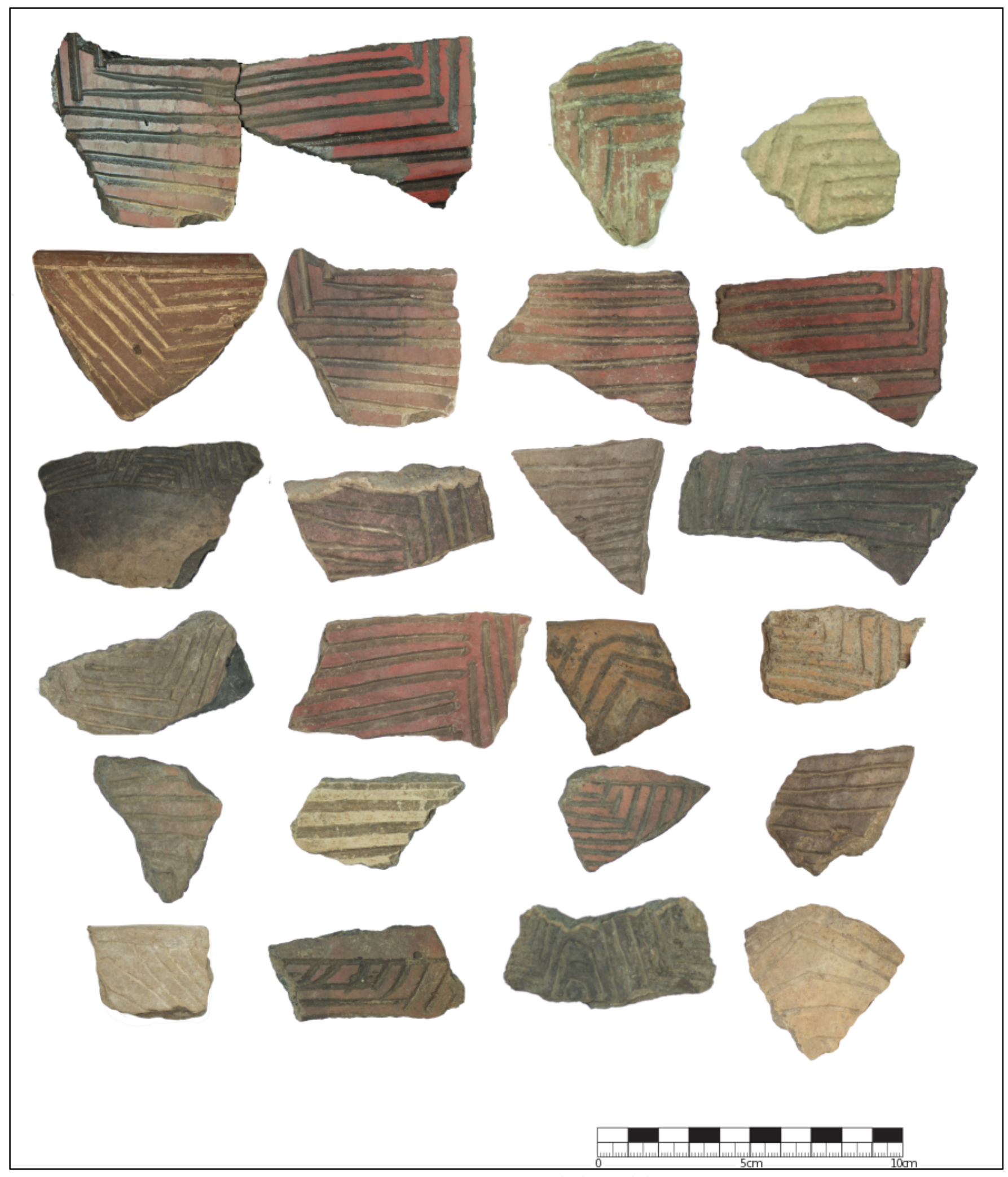

Imagem 75: motivo Bacabal paralelo. 


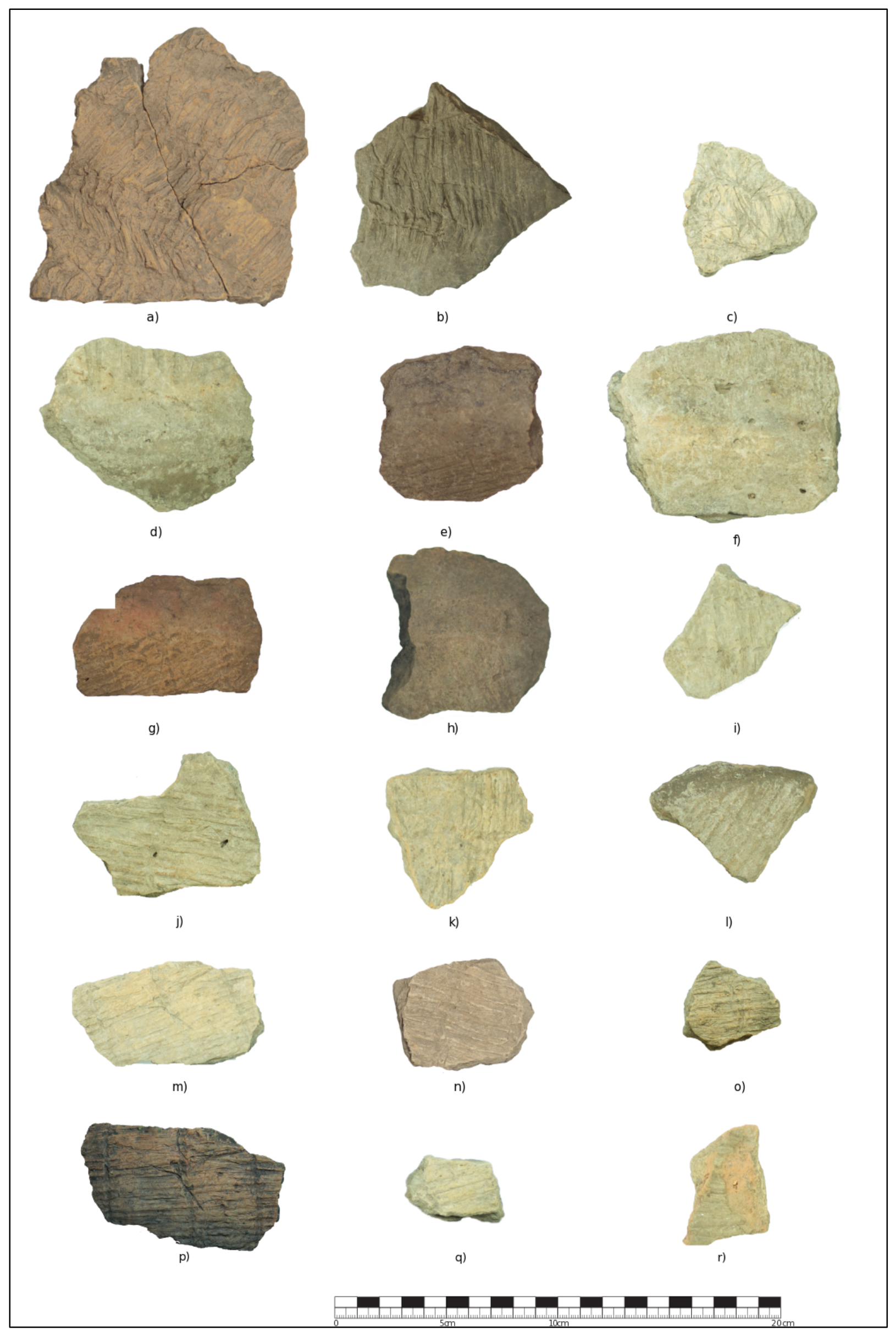

Imagem 76: a-c) Escovados indefinidos; d-q) escovados sabugo; r) escovado sabugo com barbotina erodindo. 


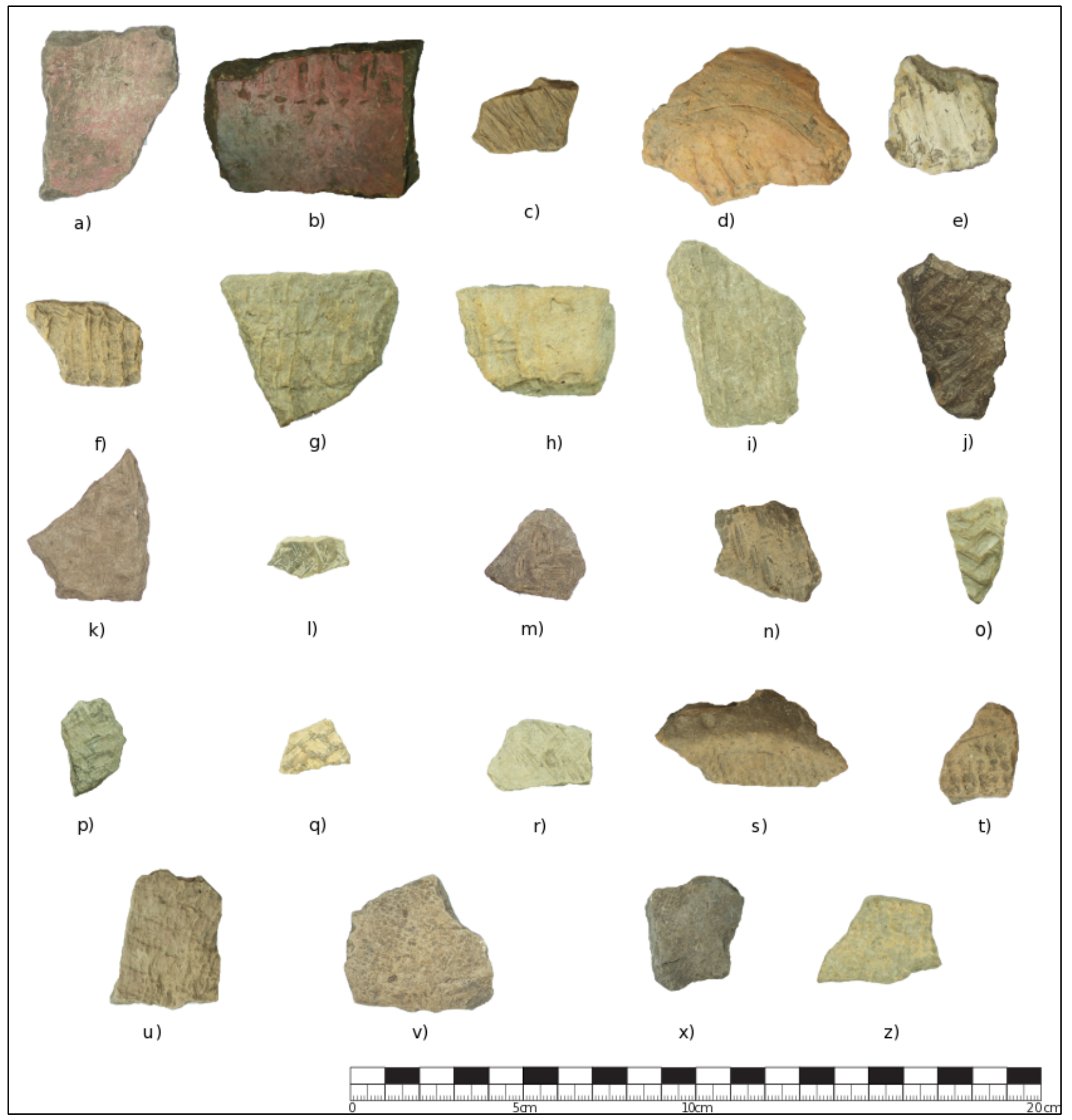

Imagem 77: a-b) Escovado sabugo com polimento e banho vermelho; c) escovado sabugo; d-f) escovado espiga; $g$-i) impressão de tecido; $j$-r) impressão de cestaria; $s$-z) impressão de tecido. 


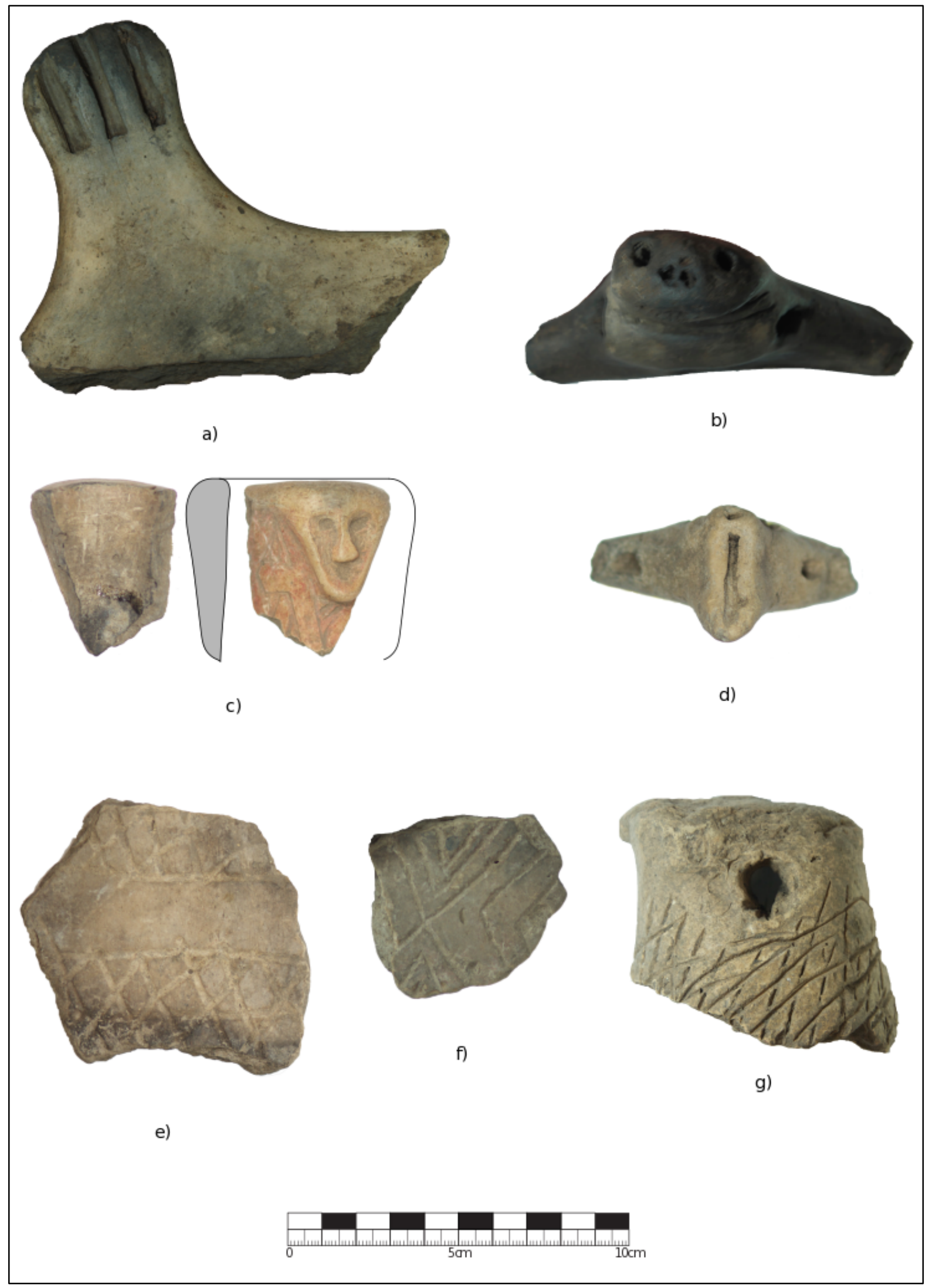

Imagem 78:motivos decorativos, a-b) representação zoomorfa; $c$-d) representação antropomorfa, face (a); vulva(b); e)inciso cruzado; f) inciso losangular; g) inciso não cruzado 


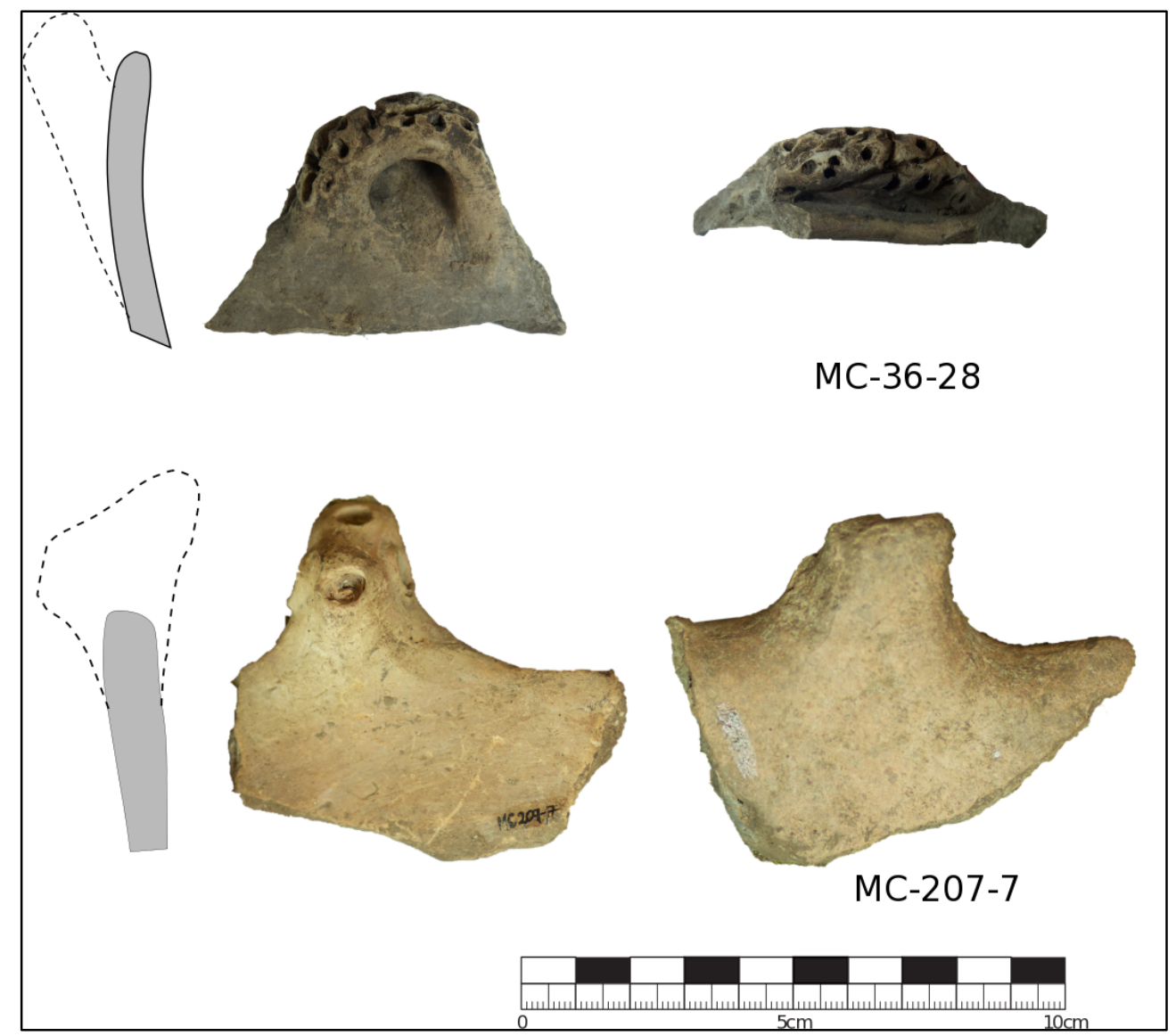

Imagem 79: fragmentos de bordas com alça (acima) e asa (abaixo) ponteadas.

\section{Vestígios de uso e reciclagem}

Em 34,59\% $(\mathrm{n}=456)$ foram observadas alterações por uso, sendo a maioria dos casos identificados como fuligem, na parte interna, externa ou em ambas as faces dos fragmentos. Também foram identificados seis casos onde um furo foi confeccionado após a queima do artefato. Este tipo de furo ocorreu especificamente em bordas. Alguns fragmentos foram alterados após a quebra do pode, como é o caso dos serrilhados encontrados em alguns fragmentos.

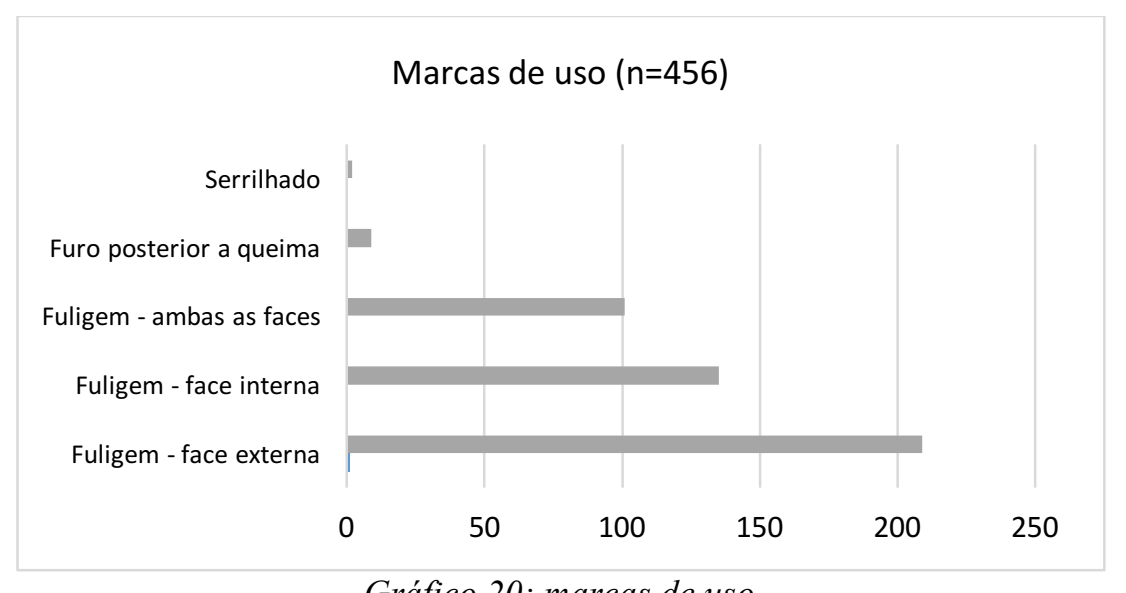

Gráfico 20: marcas de uso. 


\begin{tabular}{lcc}
\hline Marcas de uso ( $\mathbf{n}=\mathbf{4 5 6})$ & quantidade & $\%$ \\
\hline Fuligem - face externa & 209 & 45,83 \\
\hline Fuligem - face interna & 135 & 29,61 \\
\hline Fuligem - ambas as faces & 101 & 22,15 \\
\hline Furo posterior a queima & 9 & 1,97 \\
\hline Serrilhado & 2 & 0,44 \\
\hline
\end{tabular}

Tabela 21: quantidade e proporção dos tipos com marcas de uso.

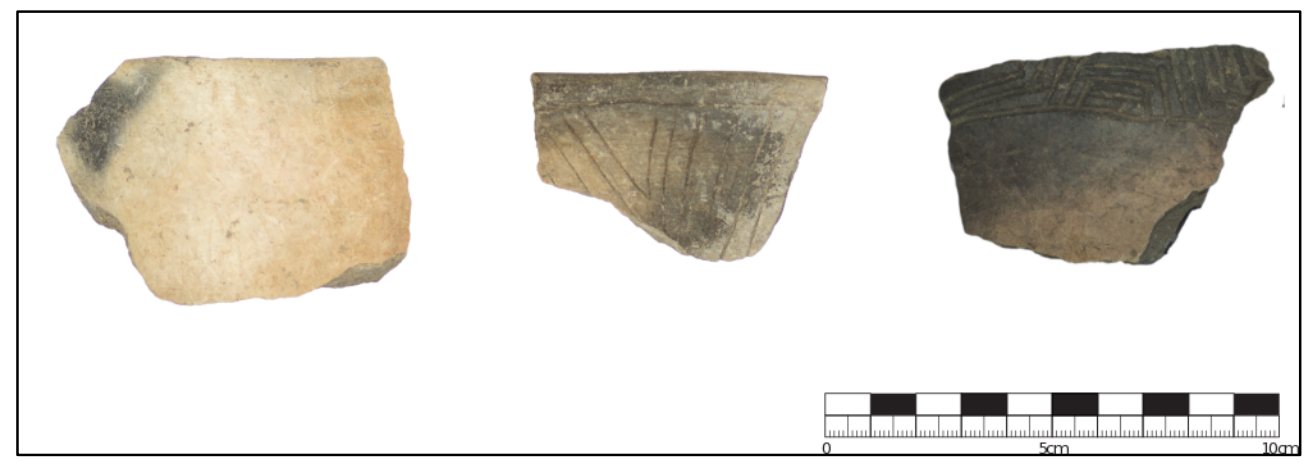

Imagem 80: Vestígios de queima de confecção

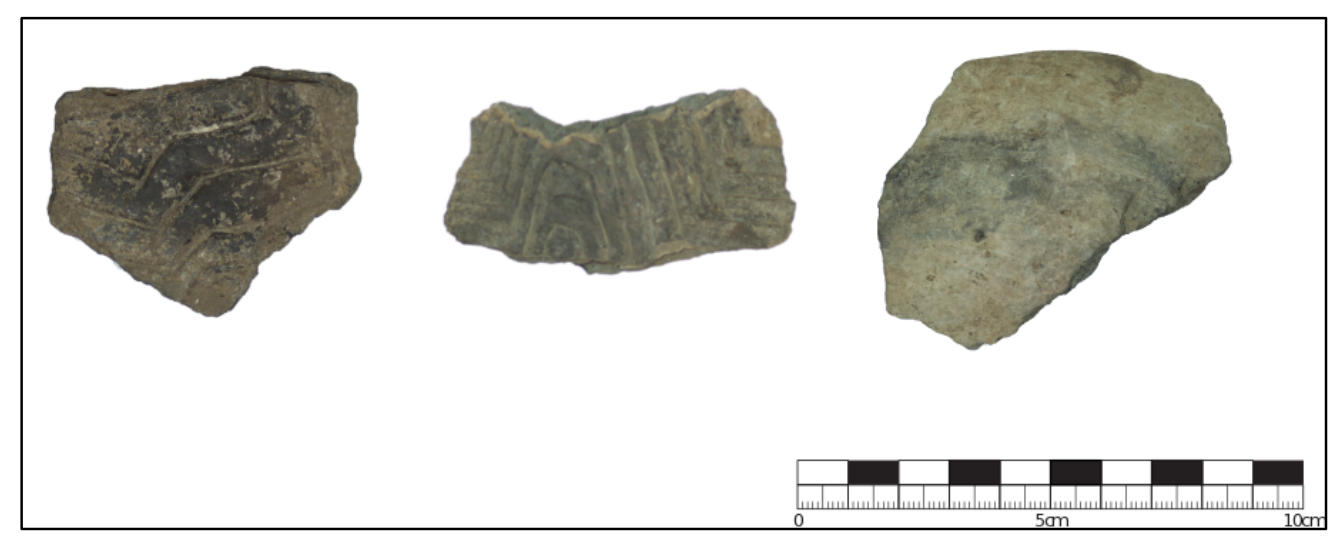

Imagem 81: depósitos de fuligem na face externa

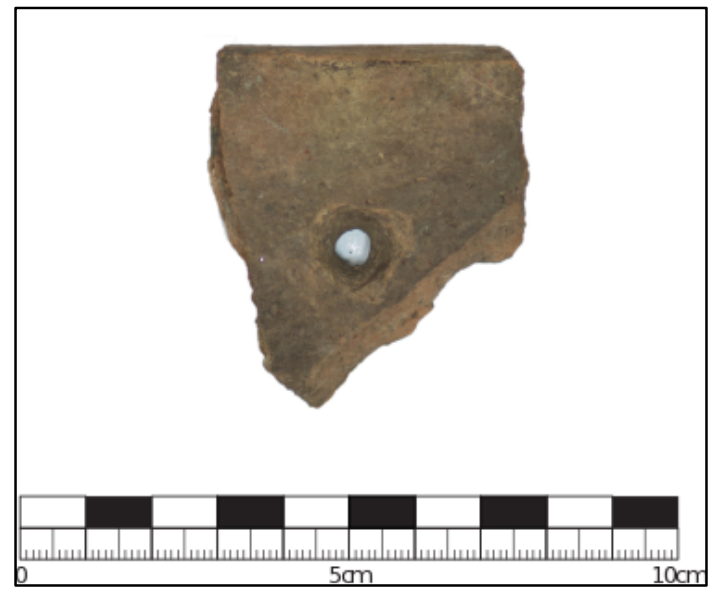

Imagem 82: Borda direta com furo posterior a queima 


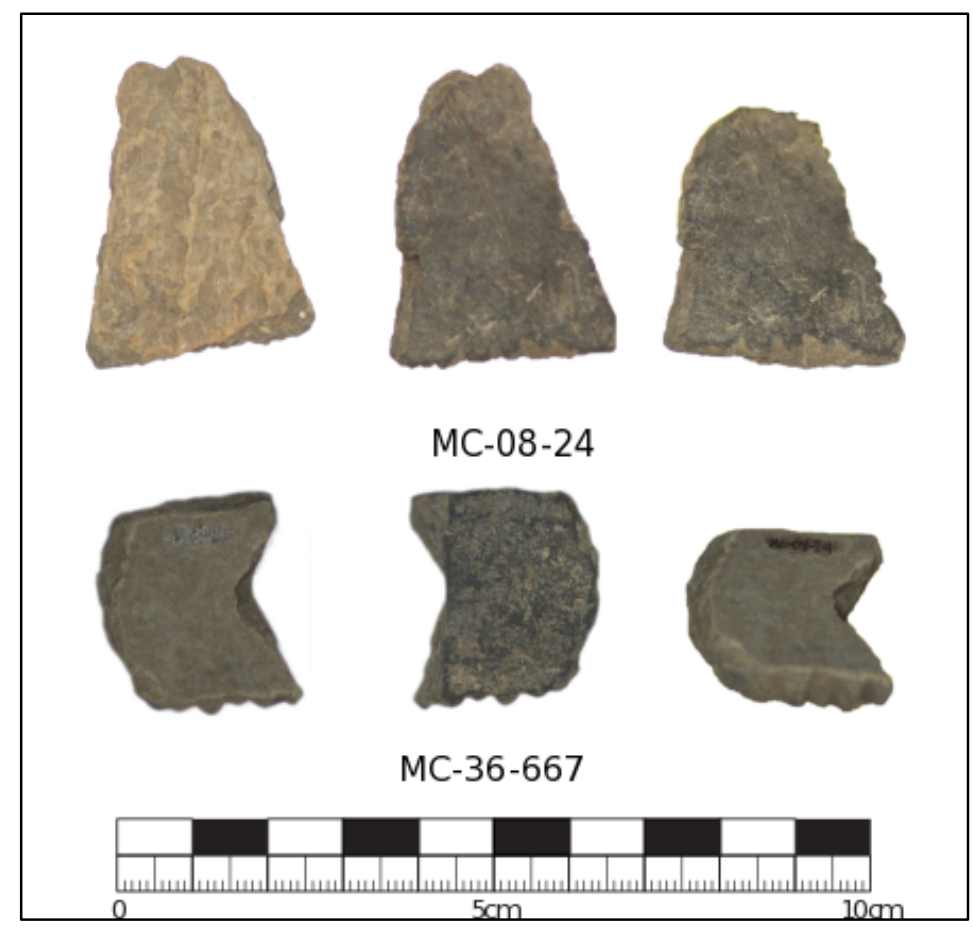

Imagem 83: Fragmentos de potes com alterações em serrilhado.

Tipos de borda

Entre os fragmentos classificados como bordas (n=294) em 226 indivíduos $(76,87 \%)$ todos os atributos da análise foram classificados como positivos, não havendo nenhum dos atributos avaliados para compor o tipo morfológico como não identificado. Os tipos morfológicos foram elaborados a partir de uma relação de atributos referentes a morfologia, inclinação, espessamento, morfologia do lábio e diâmetro de boca.

A partir do atributo morfologia da borda, podemos separar as bordas em diretas $n=149$ $(65,64 \%)$, introvertidas $n=46(20,27 \%)$ e extrovertidas $n=32(14,09 \%)$. Levando em consideração o atributo inclinação, podemos agrupar as bordas a partir dos três tipos morfológicos que se subdividem em 12 variações. As bordas diretas são aquelas com maior variação, seguido pelas introvertidas e extrovertidas.

Mesmo havendo tal variação tipológica a diferença morfológica entre os potes não aparenta ser tão diversa e a maior parte das evidências possuem inclinação de borda semelhantes, sendo pouco frequentes as formas muito abertas ou muito restritas. 


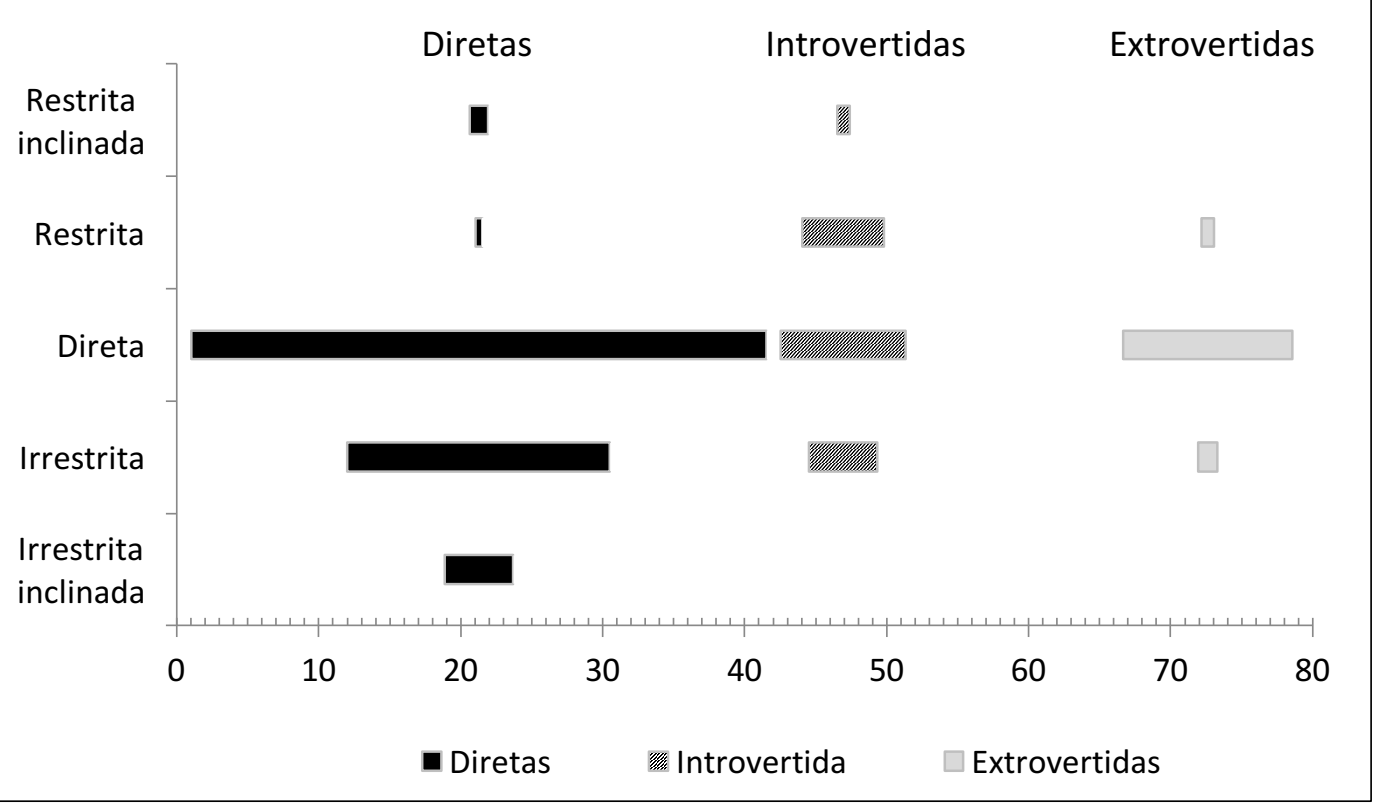

Gráfico 21: sequência seriada dos tipos de morfologia de borda entre os tipos de inclinação

\begin{tabular}{|l|c|c|c|c|c|c|}
\hline $\mathrm{n}=227$ & & & & & & \\
\hline Inclinação/Morfologia & Diretas & $\%$ & Introvertidas & $\%$ & Extrovertidas & $\%$ \\
\hline Irrestrita inclinada & 11 & 4,85 & 0 & 0 & 0 & 0 \\
\hline Irrestrita & 42 & 18,50 & 11 & 4,85 & 3 & 1,32 \\
\hline Direta & 92 & 40,53 & 20 & 8,81 & 27 & 11,89 \\
\hline Restrita & 1 & 0,44 & 13 & 5,73 & 2 & 0,88 \\
\hline Restrita inclinada & 3 & 1,32 & 2 & 0,88 & 0 & 0 \\
\hline
\end{tabular}

Tabela 22: Quantidade e proporção dos tipos de morfologia de borda em relação aos tipos de inclinação.

Bordas Diretas (n=149)

Entre os tipos de morfologia de borda, as bordas Diretas compõem o grupo mais numeroso e apresenta a maior variabilidade interna. $\mathrm{O}$ diâmetro de boca variou entre 5 e $76 \mathrm{~cm}$. A inclinação dos fragmentos foi classificada entre Irrestrita inclinada até restrita inclinada, sugerindo que tais fragmentos tenham grande possibilidade de ser provenientes da quebra de pratos, tigelas, copos e panelas de diferentes formas e tamanhos. Neste tipo furos posteriores a queima e também apliques de asas e alças.

O tipo de inclinação mais frequente foi o direto, encontrado em $61,07 \%$ dos casos $(n=91)$. O espessamento destas bordas com inclinação direta foi em sua maioria linear $(68,13 \% n=62)$ havendo também uma porção considerável de bordas expandidas $(30,76 \% n=28)$ e um único caso com reforço externo. As bordas com inclinação direta e lineares possuíam na grande maioria dos 
casos o lábio plano $(23,31 \%)$ ou arredondado (68,25\%), mas ocorre também o tipo afilado (7,93\%). Naquelas com espessamento expandido os lábios possuem uma tendência semelhante, sendo os planos representando $24,13 \%$ e os arredondados chegando a 68,96\%. (gráfico 22 e 23, tabela 23 e 24).

O segundo grupo mais numeroso é de bordas irrestritas, representando $25,5 \%$ da amostra de bordas diretas, onde os lábios planos e arredondados ocorrem de maneira proporcional, e ocorrem também lábios afilados e biselados. Outro grupo semelhante seria o das bordas diretas irrestritas e inclinadas (7,39\%), onde ocorrem lábios arredondados em espessamento linear em $75 \%$ dos casos. O grupo menos frequente é representado pelos potes restritos $(n=4)$, todos com espessamento linear, mas com uma ampla variação do lábio, ocorrendo os tipos plano, arredondado e afilado.

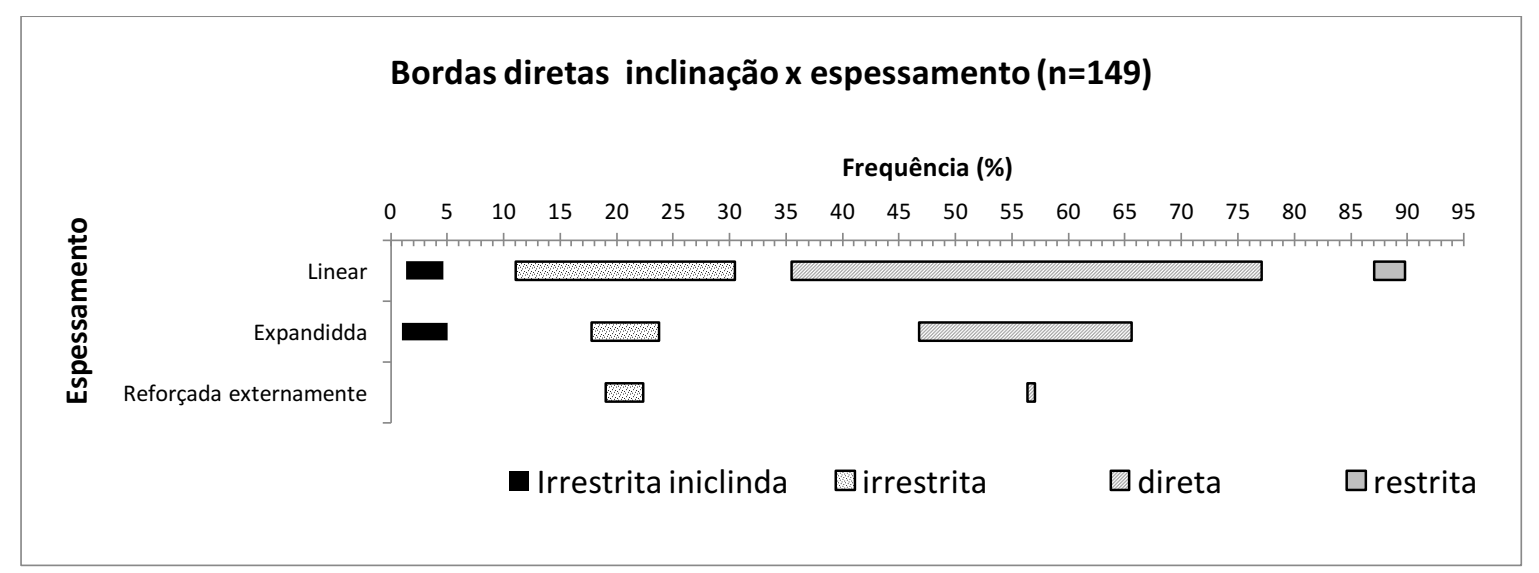

Gráfico 22: sequência seriada dos tipos de inclinação entre os tipos de espessamento das bordas diretas.

$\mathrm{n}=149$
\begin{tabular}{|l|c|c|c|c|c|c|c|c|}
\hline Espessamento/Inclinação & $\begin{array}{c}\text { Irrestrita } \\
\text { inclinada }\end{array}$ & $\%$ & irrestrita & $\%$ & direta & $\%$ & restrita & $\%$ \\
\hline Linear & 5 & 3,36 & 29 & 19,46 & 62 & 41,61 & 4 & 2,68 \\
\hline Expandida & 6 & 4,03 & 9 & 6,04 & 28 & 18,79 & 0 & 0,00 \\
\hline Reforçada externamente & 0 & 0,00 & 5 & 3,36 & 1 & 0,67 & 0 & 0,00 \\
\hline
\end{tabular}

Tabela 23: quantidade e proporção dos tipos de inclinação entre os tipos de espessamento das bordas diretas. 


\section{Tipos de lábios entre os tipos de espessamento de bordas diretas e suas inclinações \\ $(n=146)$}

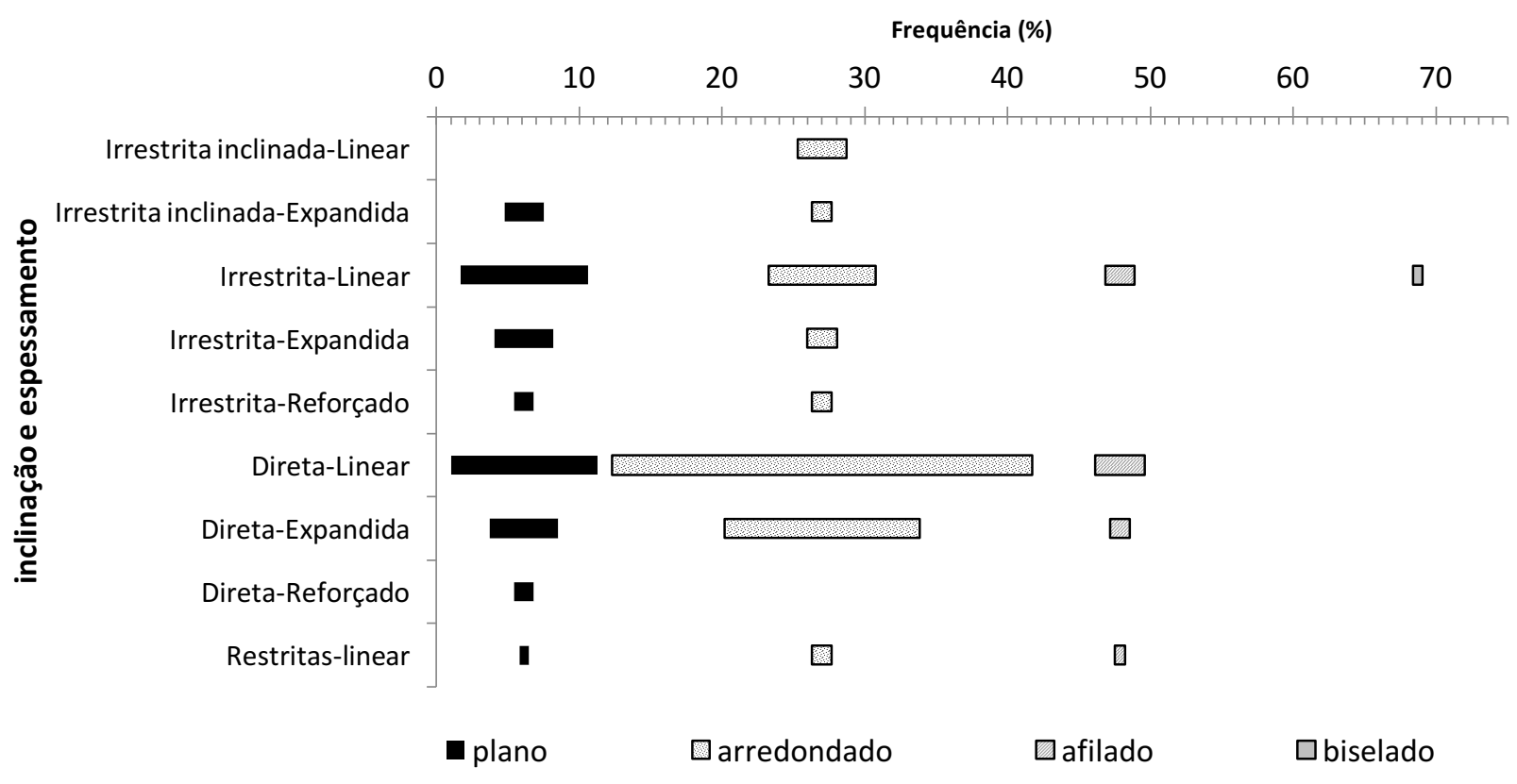

Gráfico 23:sequência seriada da frequência dos tipos de lábios entre os tipos de espessamento de bordas diretas e suas inclinações $(n=146)$

\begin{tabular}{|l|r|l|r|r|r|l|r|l|}
\hline Inclinaçao/espessamento/lábio & plano & $\%$ & arredondado & $\%$ & afilado & $\%$ & Biselado & $\%$ \\
\hline Irrestrita inclinada-Linear & 0 & 0,00 & 5 & 3,42 & 0 & 0,00 & 0 & 0,00 \\
\hline Irrestrita inclinada-Expandida & 4 & 2,74 & 2 & 1,37 & 0 & 0,00 & 0 & 0,00 \\
\hline Irrestrita-Linear & 13 & 8,90 & 11 & 7,53 & 3 & 2,05 & 1 & 0,68 \\
\hline Irrestrita-Expandida & 6 & 4,11 & 3 & 2,05 & 0 & 0,00 & 0 & 0,00 \\
\hline Irrestrita-Reforçado & 2 & 1,37 & 2 & 1,37 & 0 & 0,00 & 0 & 0,00 \\
\hline Direta-Linear & 15 & 10,27 & 43 & 29,45 & 5 & 3,42 & 0 & 0,00 \\
\hline Direta-Expandida & 7 & 4,79 & 20 & 13,70 & 2 & 1,37 & 0 & 0,00 \\
\hline Direta-Reforçado & 2 & 1,37 & 0 & 0,00 & 0 & 0,00 & 0 & 0,00 \\
\hline Restritas-linear & 1 & 0,68 & 2 & 1,37 & 1 & 0,68 & 0 & 0,00 \\
\hline
\end{tabular}

Tabela 24:quantidade e frequência dos tipos de lábios entre os tipos de espessamento de bordas diretas e suas inclinações $(n=146)$

A espessura das bordas diretas variou desde as mais entre finas 4-5 $\mathrm{mm}$ até casos com mais de $23 \mathrm{~mm}$ de espessura. Na grande maioria dos casos a espessura dos não é simétrica em todo o fragmento. Observa-se isto a partir da avaliação das medidas de espessura mínima e máxima. O gráfico 24 indica os valores do coeficiente de determinação (r2) para as diferentes inclinações de borda. Esse valor pode nos indicar que quanto maior o valor de mais semelhantes as medidas máximas e mínimas. A bordas com inclinação restrita são aquelas mais simétricas ( $\mathrm{r} 2=0,92)$, já as outras inclinações têm valores menores devido a incidência maior de tipos com espessamento expandido entre eles. 


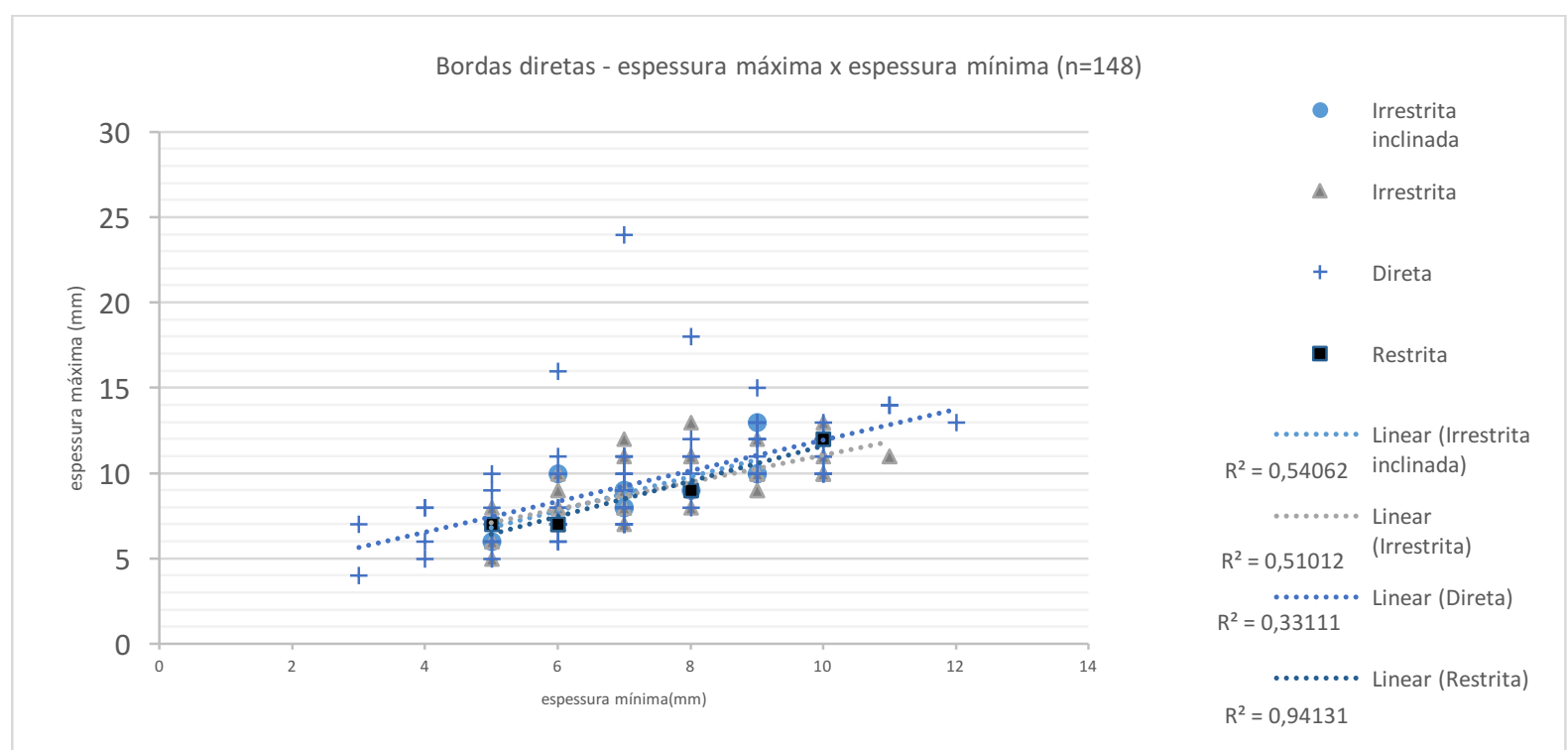

Gráfico 24:previsão linear das medidas de espessura máxima e mínima entre as bordas diretas.

Entre os tipos mais populares, as bordas entre 7-9mm de espessura são as mais recorrentes neste tipo de borda (46,31\%) seguido por aquelas entre 10-12mm (35,57\%). Os mais finos, entre 4-6mm ocorrem em $8,72 \%$ dos casos, e aqueles maiores que $13 \mathrm{~mm}$ de espessura representam $9,4 \%$ da amostra de bordas diretas (Gráfico 25 e tabela 25). O dado de r2 $(0,26)$ na previsão linear entre a espessura e o diâmetro de boca aponta que nas bordas diretas a espessura não parece indicar o tamanho da abertura de boca, ou seja, os tipos mais finos não estão necessariamente associados aos menores diâmetros e nem os tipos mais espessos ocorrem somente em diâmetros maiores (Gráfico 26).

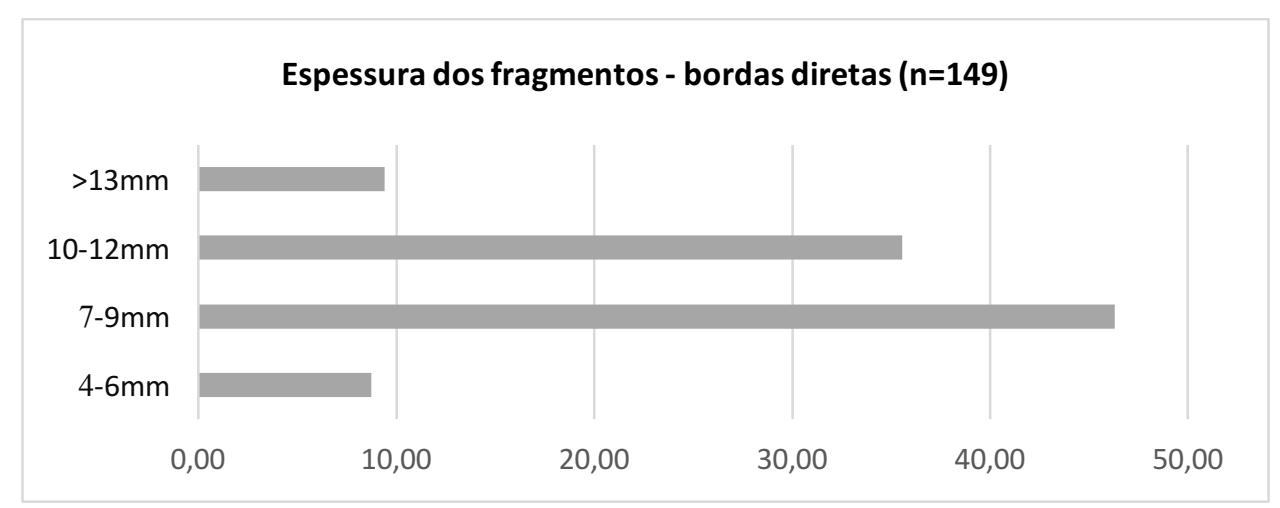

Gráfico 25: espessura do fragmentos - bordas diretas $(n=149)$

\begin{tabular}{lcc}
\hline Espessura & quantidade & $\%$ \\
\hline $4-6 \mathrm{~mm}$ & 13 & 8,72 \\
$7-9 \mathrm{~mm}$ & 69 & 46,31 \\
$10-12 \mathrm{~mm}$ & 53 & 35,57 \\
$>13 \mathrm{~mm}$ & 14 & 9,40 \\
\hline
\end{tabular}

Tabela 25: quantidade de fragmentos e proporção entre os tipos de espessura máxima e mínima. 


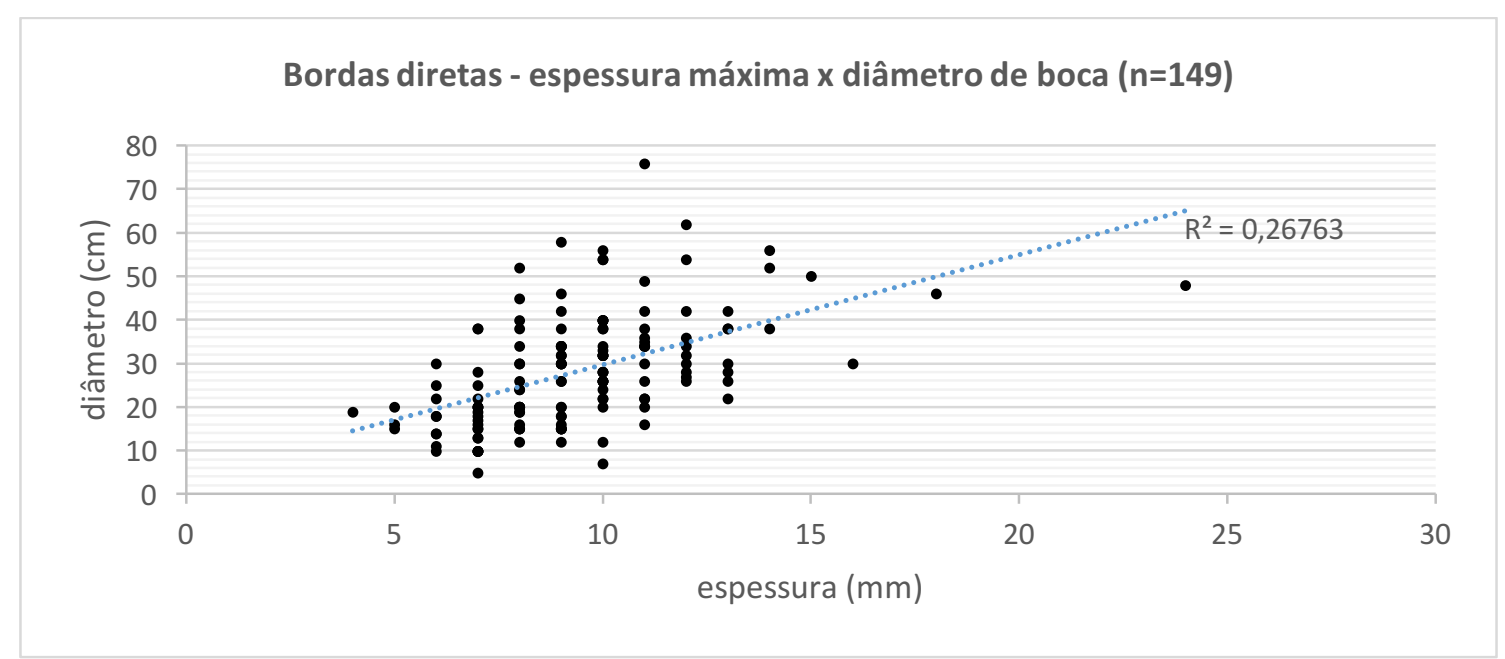

Gráfico 26: previsão linear entre as medidas de espessura e diâmetro de boca

O diâmetro de boca entre as bordas irrestritas inclinadas varia entre $15-38 \mathrm{~cm}$. Os tipos entre18-26cm $(81,07 \%, n=8)$ são os mais frequentes, outros diâmetros são pouco frequentes nos diâmetros $(\mathrm{n}=3,15 \mathrm{~cm}, 30 \mathrm{~cm}$ e $38 \mathrm{~cm})$. Entre as bordas irrestritas a variação é ampla, e o diâmetro fica entre 10 e $62 \mathrm{~cm}$. Os tipos mais recorrentes são aqueles entre 30 e $38 \mathrm{~cm}(37,1 \%, \mathrm{n}=15)$ e 10 $15 \mathrm{~cm}(14,28 \%, \mathrm{n}=6)$. As bordas com inclinação direta tiveram uma ampla diferença entre os tipos de diâmetros, com valores entre 5 e $72 \mathrm{~cm}$. Os diâmetros entre 20-22cm (17,39\%) e 30-34cm $(18,47 \%)$ foram os mais populares enquanto a incidência de tipos menores é mais baixa: 10$12 \mathrm{~cm}(7,6 \%)$ e $13-16 \mathrm{~cm}(13,04 \%)$. Os tipos de diâmetros maiores e mais frequentes têm valores entre $38-42 \mathrm{~cm}(10,86 \%)$ e $52-56 \mathrm{~cm}(6,52 \%)$. Os valores para as bordas restritas ficaram entre 19$38 \mathrm{~cm}$ (gráfico 27). 


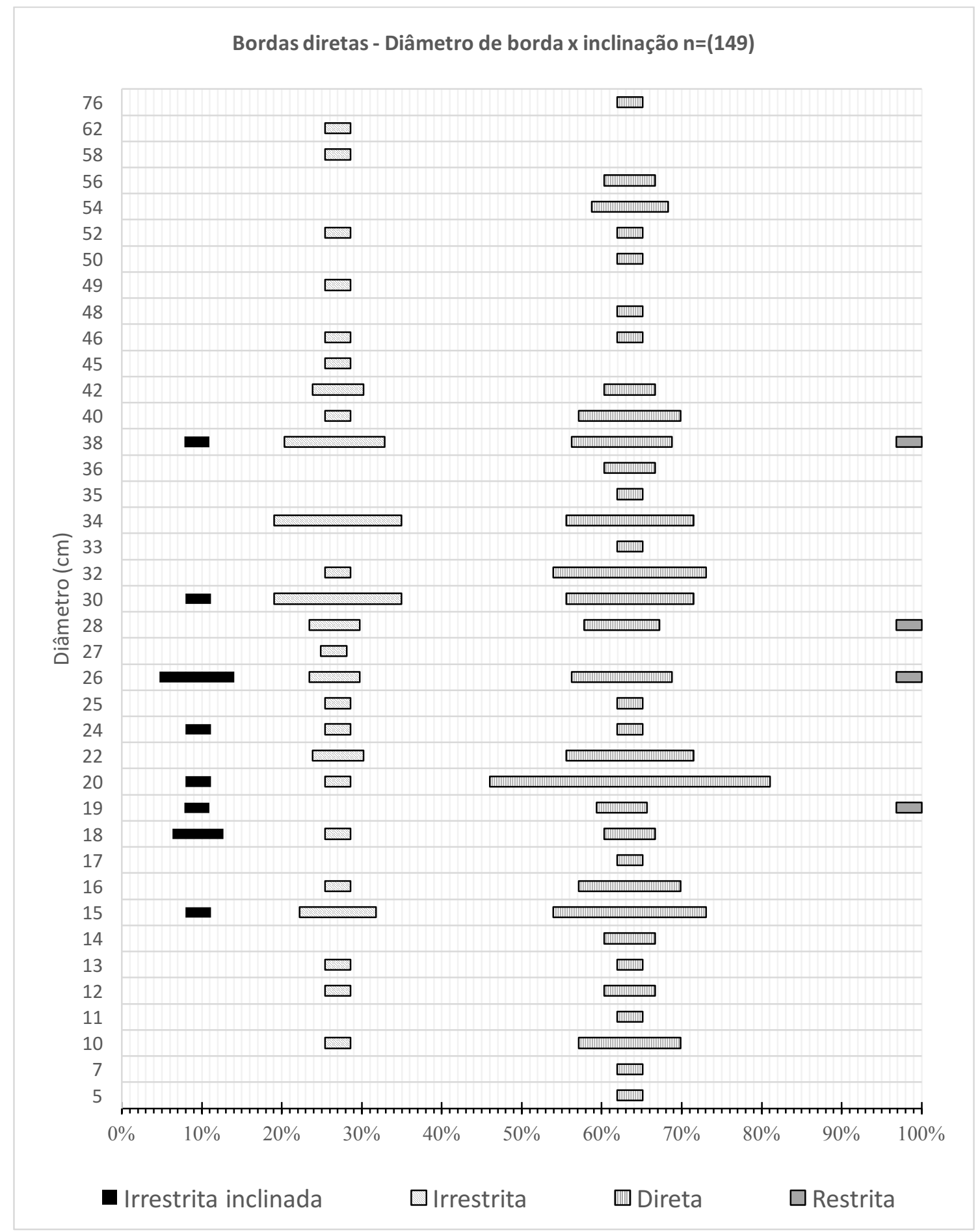

Gráfico 27: sequência seriada dos tipos de inclinação da bordas diretas entre os tipos de diâmetro de abertura de boca. 


\begin{tabular}{|c|c|c|c|c|c|c|c|c|}
\hline diâmetro/inclinação & $\begin{array}{l}\text { Irrestrita } \\
\text { inclinada }\end{array}$ & $\%$ & irrestrita & $\%$ & direta & $\%$ & restrita & $\%$ \\
\hline 5 & 0 & 0,00 & 0 & 0,00 & 1 & 0,67 & 0 & 0 \\
\hline 7 & 0 & 0,00 & 0 & 0,00 & 1 & 0,67 & 0 & 0,00 \\
\hline 10 & 0 & 0,00 & 1 & 0,67 & 4 & 2,68 & 0 & 0,00 \\
\hline 11 & 0 & 0,00 & 0 & 0,00 & 1 & 0,67 & 0 & 0,00 \\
\hline 12 & 0 & 0,00 & 1 & 0,67 & 2 & 1,34 & 0 & 0,00 \\
\hline 13 & 0 & 0,00 & 1 & 0,67 & 1 & 0,67 & 0 & 0,00 \\
\hline 14 & 0 & 0,00 & 0 & 0,00 & 2 & 1,34 & 0 & 0,00 \\
\hline 15 & 1 & 0,67 & 3 & 2,01 & 6 & 4,03 & 0 & 0,00 \\
\hline 16 & 0 & 0,00 & 1 & 0,67 & 4 & 2,68 & 0 & 0,00 \\
\hline 17 & 0 & 0,00 & 0 & 0,00 & 1 & 0,67 & 0 & 0,00 \\
\hline 18 & 2 & 1,34 & 1 & 0,67 & 2 & 1,34 & 0 & 0,00 \\
\hline 19 & 1 & 0,67 & 0 & 0,00 & 2 & 1,34 & 1 & 0,67 \\
\hline 20 & 1 & 0,67 & 1 & 0,67 & 11 & 7,38 & 0 & 0,00 \\
\hline 22 & 0 & 0,00 & 2 & 1,34 & 5 & 3,36 & 0 & 0,00 \\
\hline 24 & 1 & 0,67 & 1 & 0,67 & 1 & 0,67 & 0 & 0,00 \\
\hline 25 & 0 & 0,00 & 1 & 0,67 & 1 & 0,67 & 0 & 0,00 \\
\hline 26 & 3 & 2,01 & 2 & 1,34 & 4 & 2,68 & 1 & 0,67 \\
\hline 27 & 0 & 0,00 & 1 & 0,67 & 0 & 0,00 & 0 & 0,00 \\
\hline 28 & 0 & 0,00 & 2 & 1,34 & 3 & 2,01 & 1 & 0,67 \\
\hline 30 & 1 & 0,67 & 5 & 3,36 & 5 & 3,36 & 0 & 0,00 \\
\hline 32 & 0 & 0,00 & 1 & 0,67 & 6 & 4,03 & 0 & 0,00 \\
\hline 33 & 0 & 0,00 & 0 & 0,00 & 1 & 0,67 & 0 & 0,00 \\
\hline 34 & 0 & 0,00 & 5 & 3,36 & 5 & 3,36 & 0 & 0,00 \\
\hline 35 & 0 & 0,00 & 0 & 0,00 & 1 & 0,67 & 0 & 0,00 \\
\hline 36 & 0 & 0,00 & 0 & 0,00 & 2 & 1,34 & 0 & 0,00 \\
\hline 38 & 1 & 0,67 & 4 & 2,68 & 4 & 2,68 & 1 & 0,67 \\
\hline 40 & 0 & 0,00 & 1 & 0,67 & 4 & 2,68 & 0 & 0,00 \\
\hline 42 & 0 & 0,00 & 2 & 1,34 & 2 & 1,34 & 0 & 0,00 \\
\hline 45 & 0 & 0,00 & 1 & 0,67 & 0 & 0,00 & 0 & 0,00 \\
\hline 46 & 0 & 0,00 & 1 & 0,67 & 1 & 0,67 & 0 & 0,00 \\
\hline 48 & 0 & 0,00 & 0 & 0,00 & 1 & 0,67 & 0 & 0,00 \\
\hline 49 & 0 & 0,00 & 1 & 0,67 & 0 & 0,00 & 0 & 0,00 \\
\hline 50 & 0 & 0,00 & 0 & 0,00 & 1 & 0,67 & 0 & 0,00 \\
\hline 52 & 0 & 0,00 & 1 & 0,67 & 1 & 0,67 & 0 & 0,00 \\
\hline 54 & 0 & 0,00 & 0 & 0,00 & 3 & 2,01 & 0 & 0,00 \\
\hline 56 & 0 & 0,00 & 0 & 0,00 & 2 & 1,34 & 0 & 0,00 \\
\hline 58 & 0 & 0,00 & 1 & 0,67 & 0 & 0,00 & 0 & 0,00 \\
\hline 62 & 0 & 0,00 & 1 & 0,67 & 0 & 0,00 & 0 & 0,00 \\
\hline 76 & 0 & 0,00 & 0 & 0,00 & 1 & 0,67 & 0 & 0,00 \\
\hline
\end{tabular}

Tabela 26: quantidade e frequência dos tipos de inclinação das bordas diretas entre os tipos de diâmetro.

\section{Decoração}

Os tipos decorados foram encontrados na maioria dos diâmetros de abertura de boca (5$56 \mathrm{~cm}$ ) e entre todos os tipos de inclinação de borda, representado 29,53\% das bordas. Estes tipos com decoração ocorrem com uma frequência discreta entre os tipos mais inclinados: como os irrestritos inclinados e os restritos, onde ocorrem os motivos Bacabal e Bacabal 2, e incisão não identificada. Os tipos irrestritos apresentaram decoração nos diâmetros entre 12-20cm e entre 30- 
$38 \mathrm{~cm}$. Foi verificado a presença dos tipos Bacabal, Bacabal 2, Bacabal paralelo, quadriculado e motivo não identificado. Os maiores diâmetros deste tipo morfológico não apresentaram decorações. Entre as bordas com inclinação direta as medidas de abertura de boca ficaram entre $12-56 \mathrm{~cm}$, sendo proporcionalmente distribuída entre os diferentes tipos de diâmetro. Neste tipo ocorrem todos os motivos mencionados anteriormente além da representação zoomorfa e antropomorfa. O motivo Bacabal ocorre na maioria dos diâmetros de abertura. 


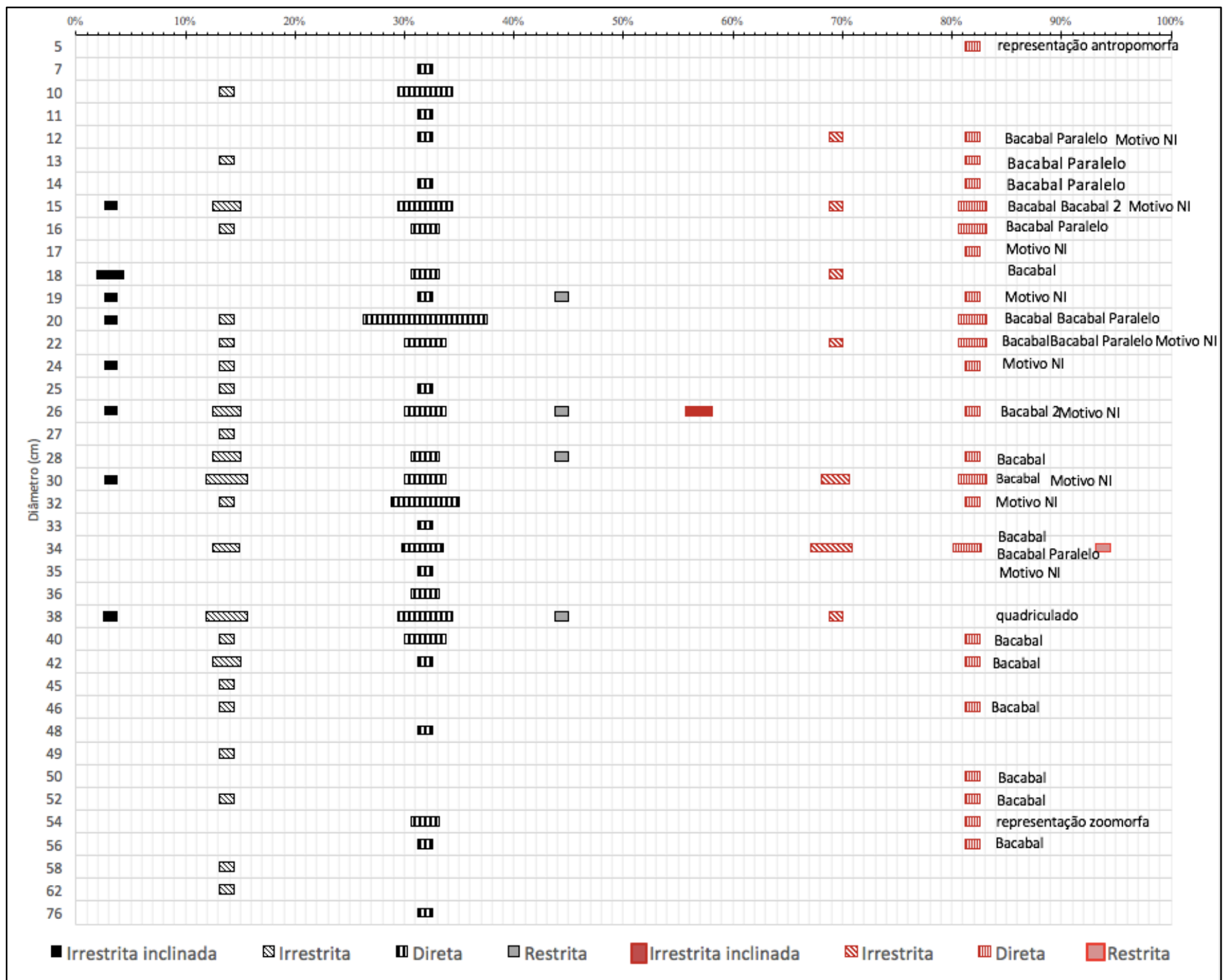

Gráfico 28: sequencia seriada das bordas diretas simples e decoradas entre os diâmetros de boca. 
Tabela 27: quantidade e porcentagem das bordas diretas entre os diâmetros de abertura de boca.

\begin{tabular}{|c|c|c|c|c|c|c|c|c|c|c|c|c|c|c|c|c|c|}
\hline \multicolumn{17}{|c|}{ Decoração (n=149) } & \multirow[b]{3}{*}{$\begin{array}{r}\text { Motivo } \\
\end{array}$} \\
\hline & \multicolumn{8}{|c|}{ Ausente } & \multicolumn{8}{|c|}{ Presente } & \\
\hline & $\begin{array}{c}\text { Irrestrita } \\
\text { Incl. }\end{array}$ & $\%$ & Irrestrita & $\%$ & Direta & $\%$ & Restrita & $\%$ & $\begin{array}{l}\text { Irrestrita } \\
\text { Incl. }\end{array}$ & $\%$ & Irrestrita & $\%$ & Direta & $\%$ & Restrita & $\%$ & \\
\hline 5 & 0 & 0 & 0 & 0,00 & 0 & 0 & 0 & 0,00 & 0 & 0,00 & 0 & 0,00 & 1 & 0,67 & 0 & 0 & Representação antropomorfa \\
\hline 7 & 0 & 0 & 0 & 0,00 & 1 & 0,67 & 0 & 0,00 & 0 & 0,00 & 0 & 0,00 & 0 & 0,00 & 0 & 0 & \\
\hline 10 & 0 & 0 & 1 & 0,67 & 4 & 2,68 & 0 & 0,00 & 0 & 0,00 & 0 & 0,00 & 0 & 0,00 & 0 & 0 & \\
\hline 11 & 0 & 0 & 0 & 0,00 & 1 & 0,67 & 0 & 0,00 & 0 & 0,00 & 0 & 0,00 & 0 & 0,00 & 0 & 0 & \\
\hline 12 & 0 & 0 & 0 & 0,00 & 1 & 0,67 & 0 & 0,00 & 0 & 0,00 & 1 & 0,67 & 1 & 0,67 & 0 & 0 & Bacabal paralelo / Motivo NI \\
\hline 13 & 0 & 0 & 1 & 0,67 & 0 & 0,00 & 0 & 0,00 & 0 & 0,00 & 0 & 0,00 & 1 & 0,67 & 0 & 0 & Bacabal paralelo \\
\hline 14 & 0 & 0 & 0 & 0,00 & 1 & 0,67 & 0 & 0,00 & 0 & 0,00 & 0 & 0,00 & 1 & 0,67 & 0 & 0 & Bacabal paralelo \\
\hline 15 & 1 & 0,67 & 2 & 1,34 & 4 & 2,68 & 0 & 0,00 & 0 & 0,00 & 1 & 0,67 & 2 & 1,34 & 0 & 0 & Bacabal / Bacabal 2 / Motivo NI \\
\hline 16 & 0 & 0,00 & 1 & 0,67 & 2 & 1,34 & 0 & 0,00 & 0 & 0,00 & 0 & 0,00 & 2 & 1,34 & 0 & 0 & Bacabal paralelo \\
\hline 17 & 0 & 0,00 & 0 & 0,00 & 0 & 0,00 & 0 & 0,00 & 0 & 0,00 & 0 & 0,00 & 1 & 0,67 & 0 & 0 & Motivo NI \\
\hline 18 & 2 & 1,34 & 0 & 0,00 & 2 & 1,34 & 0 & 0,00 & 0 & 0,00 & 1 & 0,67 & 0 & 0,00 & 0 & 0 & Bacabal \\
\hline 19 & 1 & 0,67 & 0 & 0,00 & 1 & 0,67 & 1 & 0,67 & 0 & 0,00 & 0 & 0,00 & 1 & 0,67 & 0 & 0 & Motivo NI \\
\hline 20 & 1 & 0,67 & 1 & 0,67 & 9 & 6,04 & 0 & 0,00 & 0 & 0,00 & 0 & 0,00 & 2 & 1,34 & 0 & 0 & Bacabal / Bacabal paralelo \\
\hline 22 & 0 & 0,00 & 1 & 0,67 & 3 & 2,01 & 0 & 0,00 & 0 & 0,00 & 1 & 0,67 & 2 & 1,34 & 0 & 0 & Bacabal / Bacabal paralelo / Motivo NI \\
\hline 24 & 1 & 0,67 & 1 & 0,67 & 0 & 0,00 & 0 & 0,00 & 0 & 0,00 & 0 & 0,00 & 1 & 0,67 & 0 & 0 & Motivo NI \\
\hline 25 & 0 & 0,00 & 1 & 0,67 & 1 & 0,67 & 0 & 0,00 & 0 & 0,00 & 0 & 0,00 & 0 & 0,00 & 0 & 0 & \\
\hline 26 & 1 & 0,67 & 2 & 1,34 & 3 & 2,01 & 1 & 0,67 & 2 & 1,34 & 0 & 0,00 & 1 & 0,67 & 0 & 0 & Bacabal 2 / Motivo NI \\
\hline 27 & 0 & 0,00 & 1 & 0,67 & 0 & 0,00 & 0 & 0,00 & 0 & 0,00 & 0 & 0,00 & 0 & 0,00 & 0 & 0 & \\
\hline 28 & 0 & 0,00 & 2 & 1,34 & 2 & 1,34 & 1 & 0,67 & 0 & 0,00 & 0 & 0,00 & 1 & 0,67 & 0 & 0 & Bacabal \\
\hline 30 & 1 & 0,67 & 3 & 2,01 & 3 & 2,01 & 0 & 0,00 & 0 & 0,00 & 2 & 1,34 & 2 & 1,34 & 0 & 0 & Bacabal / Motivo NI \\
\hline 32 & 0 & 0,00 & 1 & 0,67 & 5 & 3,36 & 0 & 0,00 & 0 & 0,00 & 0 & 0,00 & 1 & 0,67 & 0 & 0 & Motivo NI \\
\hline 33 & 0 & 0,00 & 0 & 0,00 & 1 & 0,67 & 0 & 0,00 & 0 & 0,00 & 0 & 0,00 & 0 & 0,00 & 0 & 0 & \\
\hline 34 & 0 & 0,00 & 2 & 1,34 & 3 & 2,01 & 0 & 0,00 & 0 & 0,00 & 3 & 2,01 & 2 & 1,34 & 1 & 0,67 & Bacabal / Bacabal paralelo /Motivo NI \\
\hline 35 & 0 & 0,00 & 0 & 0,00 & 1 & 0,67 & 0 & 0,00 & 0 & 0,00 & 0 & 0,00 & 0 & 0,00 & 0 & 0 & \\
\hline 36 & 0 & 0,00 & 0 & 0,00 & 2 & 1,34 & 0 & 0,00 & 0 & 0,00 & 0 & 0,00 & 0 & 0,00 & 0 & 0 & \\
\hline 38 & 1 & 0,67 & 3 & 2,01 & 4 & 2,68 & 1 & 0,67 & 0 & 0,00 & 1 & 0,67 & 0 & 0,00 & 0 & 0 & Quadriculado \\
\hline 40 & 0 & 0,00 & 1 & 0,67 & 3 & 2,01 & 0 & 0,00 & 0 & 0,00 & 0 & 0,00 & 1 & 0,67 & 0 & 0 & Bacabal \\
\hline 42 & 0 & 0,00 & 2 & 1,34 & 1 & 0,67 & 0 & 0,00 & 0 & 0,00 & 0 & 0,00 & 1 & 0,67 & 0 & 0 & Bacabal \\
\hline 45 & 0 & 0,00 & 1 & 0,67 & 0 & 0,00 & 0 & 0,00 & 0 & 0,00 & 0 & 0,00 & 0 & 0,00 & 0 & 0 & \\
\hline 46 & 0 & 0,00 & 1 & 0,67 & 0 & 0,00 & 0 & 0,00 & 0 & 0,00 & 0 & 0,00 & 1 & 0,67 & 0 & 0 & Bacabal \\
\hline 48 & 0 & 0,00 & 0 & 0,00 & 1 & 0,67 & 0 & 0,00 & 0 & 0,00 & 0 & 0,00 & 0 & 0,00 & 0 & 0 & \\
\hline 49 & 0 & 0,00 & 1 & 0,67 & 0 & 0,00 & 0 & 0,00 & 0 & 0,00 & 0 & 0,00 & 0 & 0,00 & 0 & 0 & \\
\hline 50 & 0 & 0,00 & 0 & 0,00 & 0 & 0,00 & 0 & 0,00 & 0 & 0,00 & 0 & 0,00 & 1 & 0,67 & 0 & 0 & Bacabal \\
\hline 52 & 0 & 0,00 & 1 & 0,67 & 0 & 0,00 & 0 & 0,00 & 0 & 0,00 & 0 & 0,00 & 1 & 0,67 & 0 & 0 & Bacabal \\
\hline 54 & 0 & 0,00 & 0 & 0,00 & 2 & 1,34 & 0 & 0,00 & 0 & 0,00 & 0 & 0,00 & 1 & 0,67 & 0 & 0 & Representação zoomorfa \\
\hline 56 & 0 & 0,00 & 0 & 0,00 & 1 & 0,67 & 0 & 0,00 & 0 & 0,00 & 0 & 0,00 & 1 & 0,67 & 0 & 0 & Bacabal \\
\hline 58 & 0 & 0,00 & 1 & 0,67 & 0 & 0,00 & 0 & 0,00 & 0 & 0,00 & 0 & 0,00 & 0 & 0,00 & 0 & 0 & \\
\hline 62 & 0 & 0,00 & 1 & 0,67 & 0 & 0,00 & 0 & 0,00 & 0 & 0,00 & 0 & 0,00 & 0 & 0,00 & 0 & 0 & \\
\hline 76 & 0 & 0,00 & 0 & 0,00 & 1 & 0,67 & 0 & 0,00 & 0 & 0,00 & 0 & 0,00 & 0 & 0,00 & 0 & 0 & \\
\hline
\end{tabular}




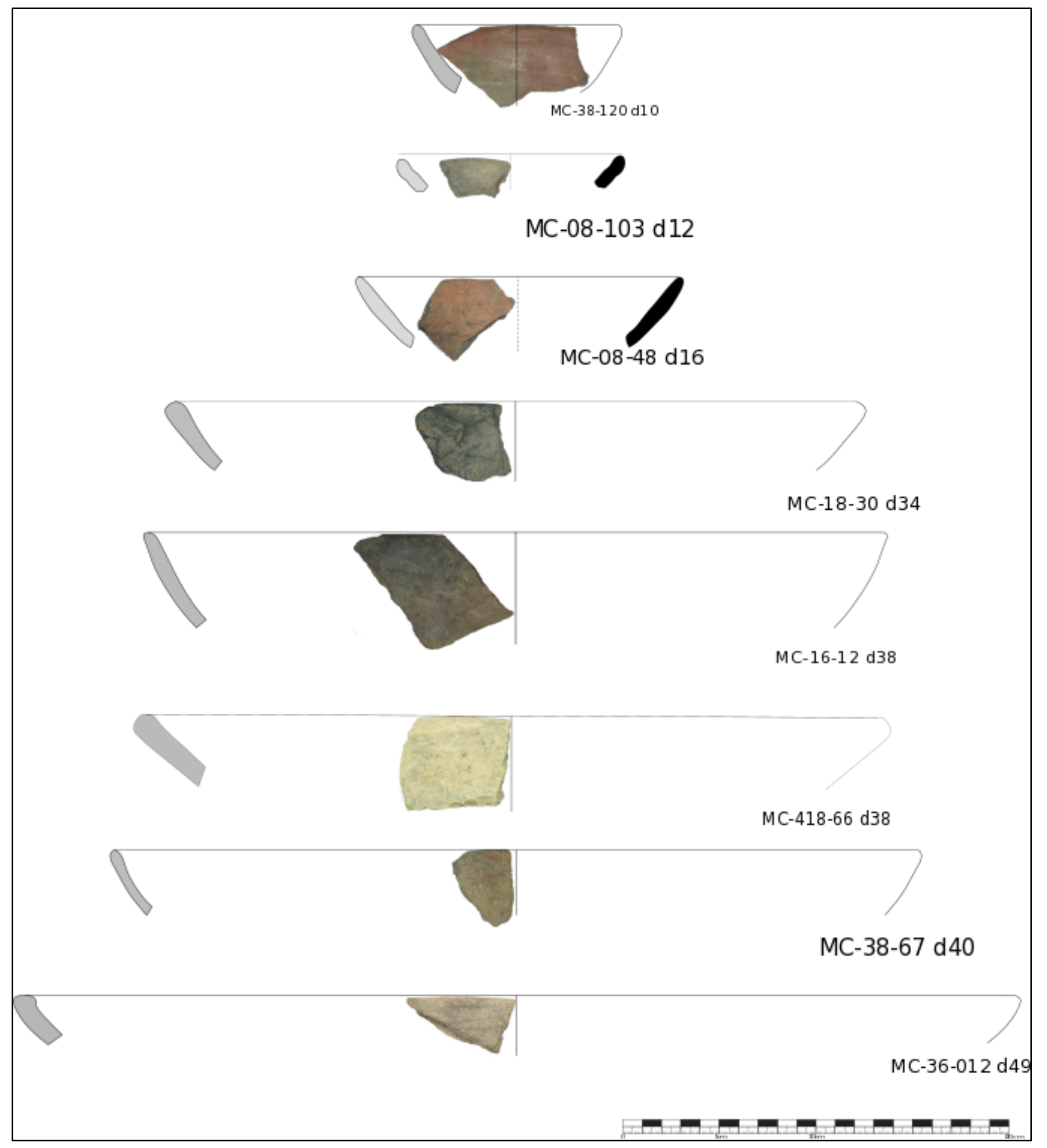

Imagem 84: Morfologia direta, inclinação irrestrita inclinada. 


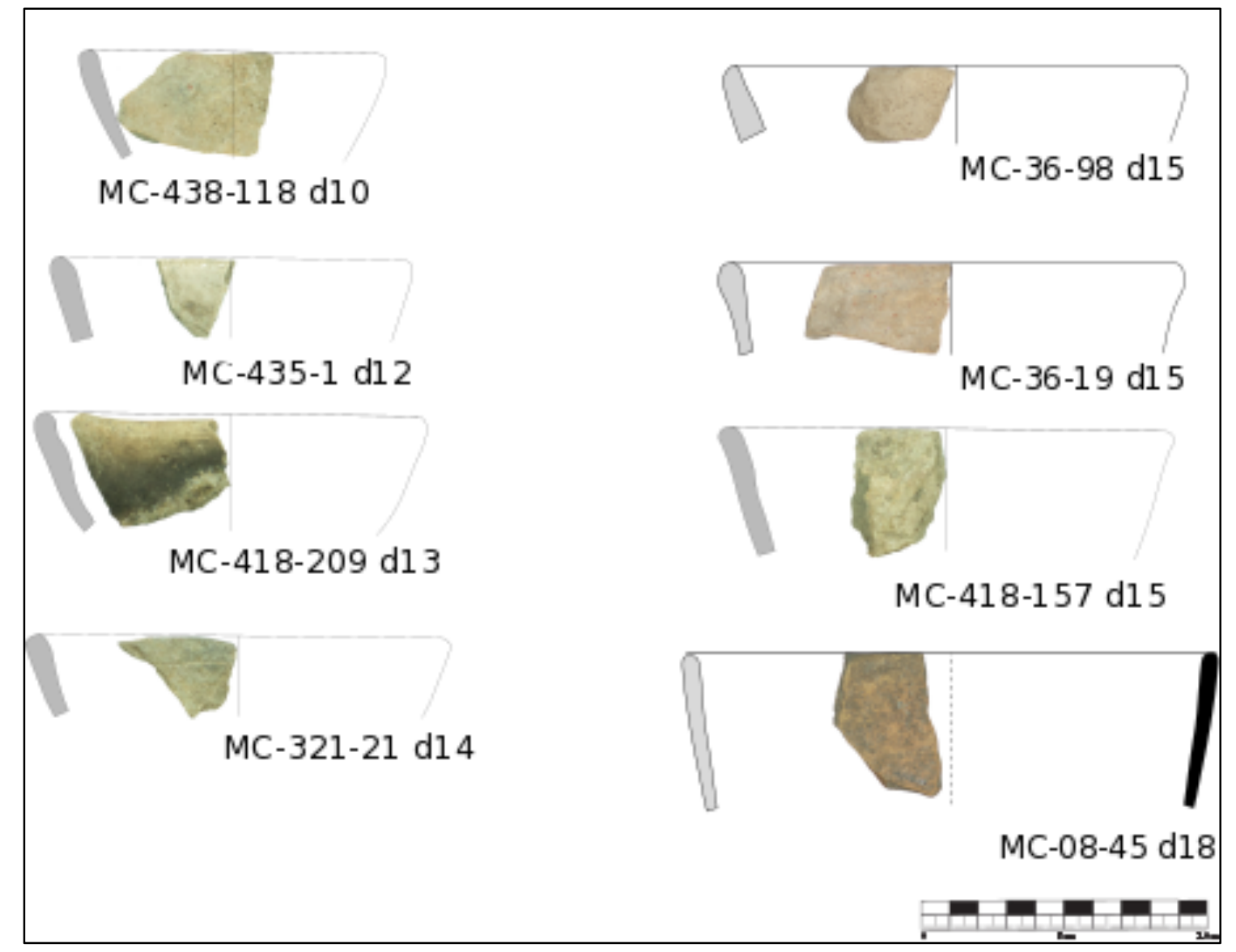

Imagem 85: Morfologia Direta, inclinação Irrestrita.

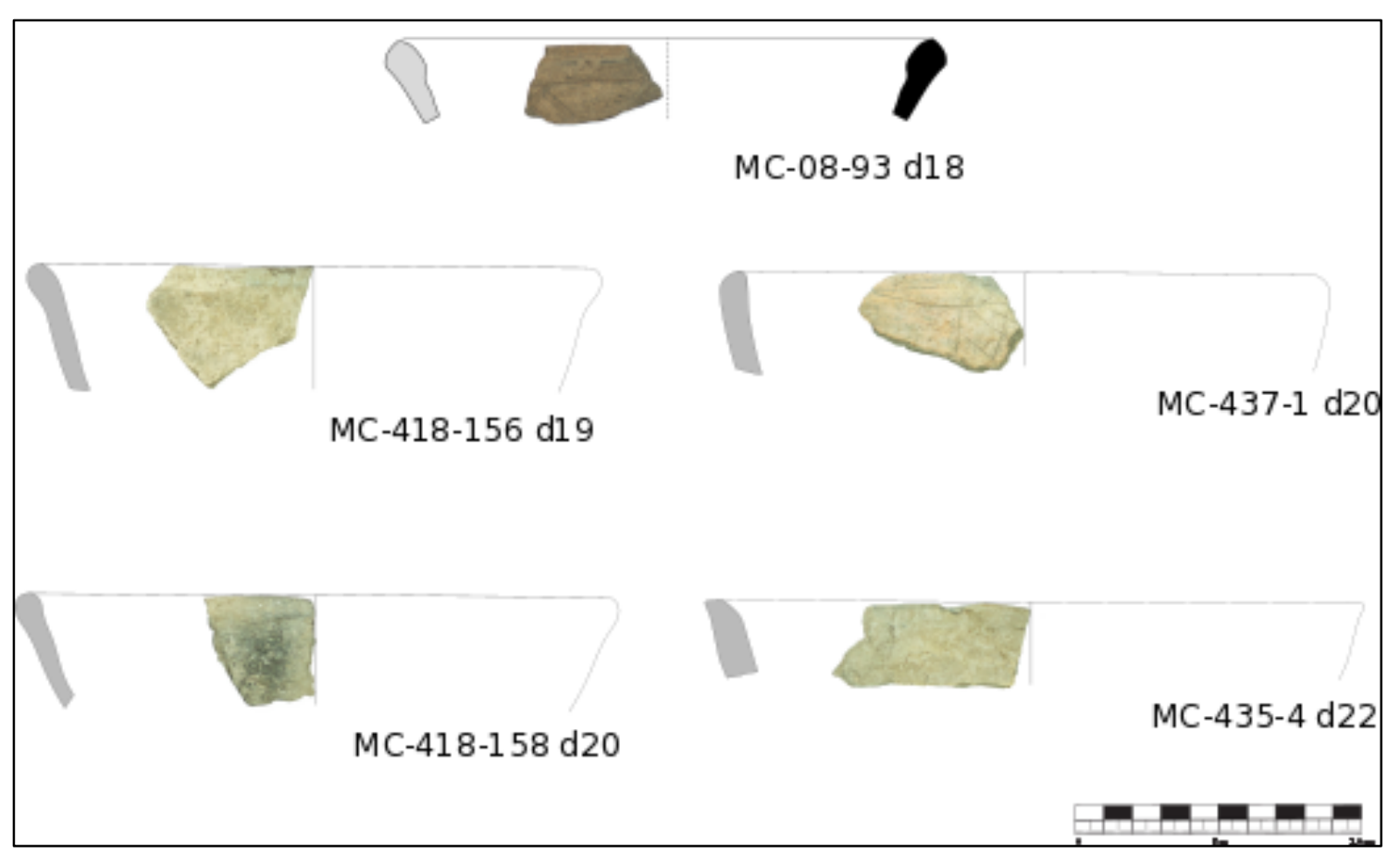

Imagem 86:Morfologia Direta, inclinação Irrestrita 


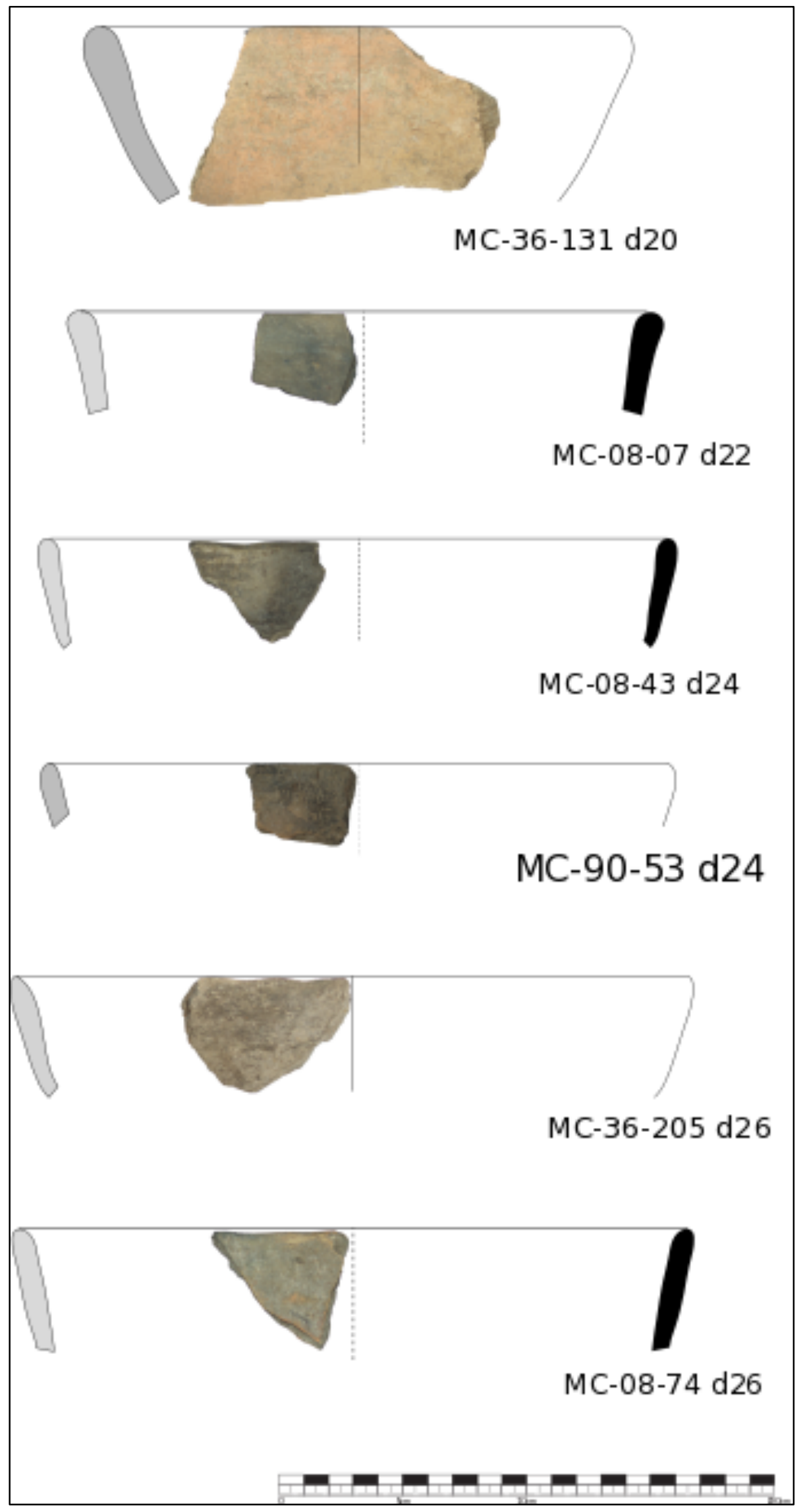

Imagem 87: Morfologia Direta, inclinação Irrestrita 


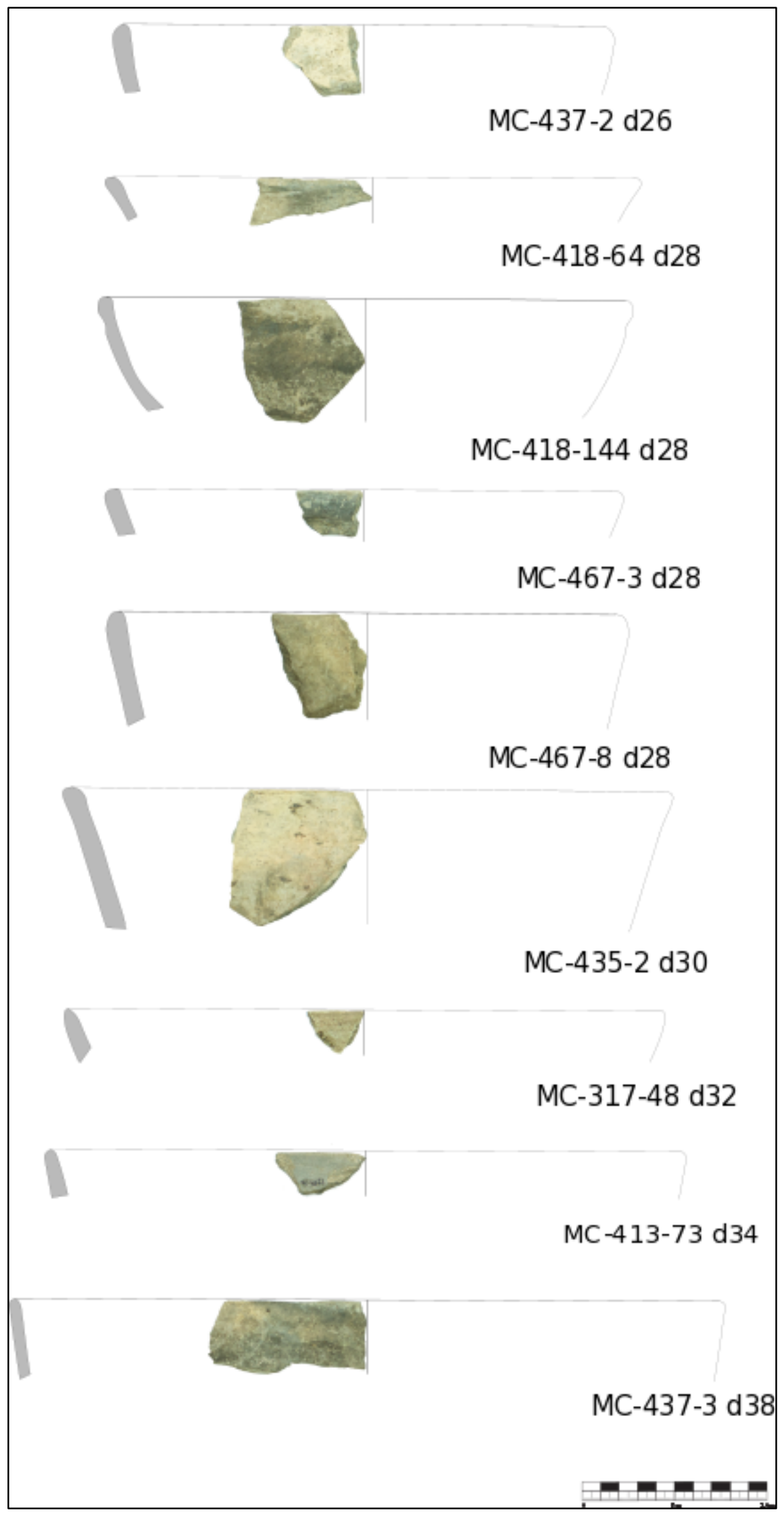

Imagem 88: Morfologia Direta, inclinação Irrestrita. 


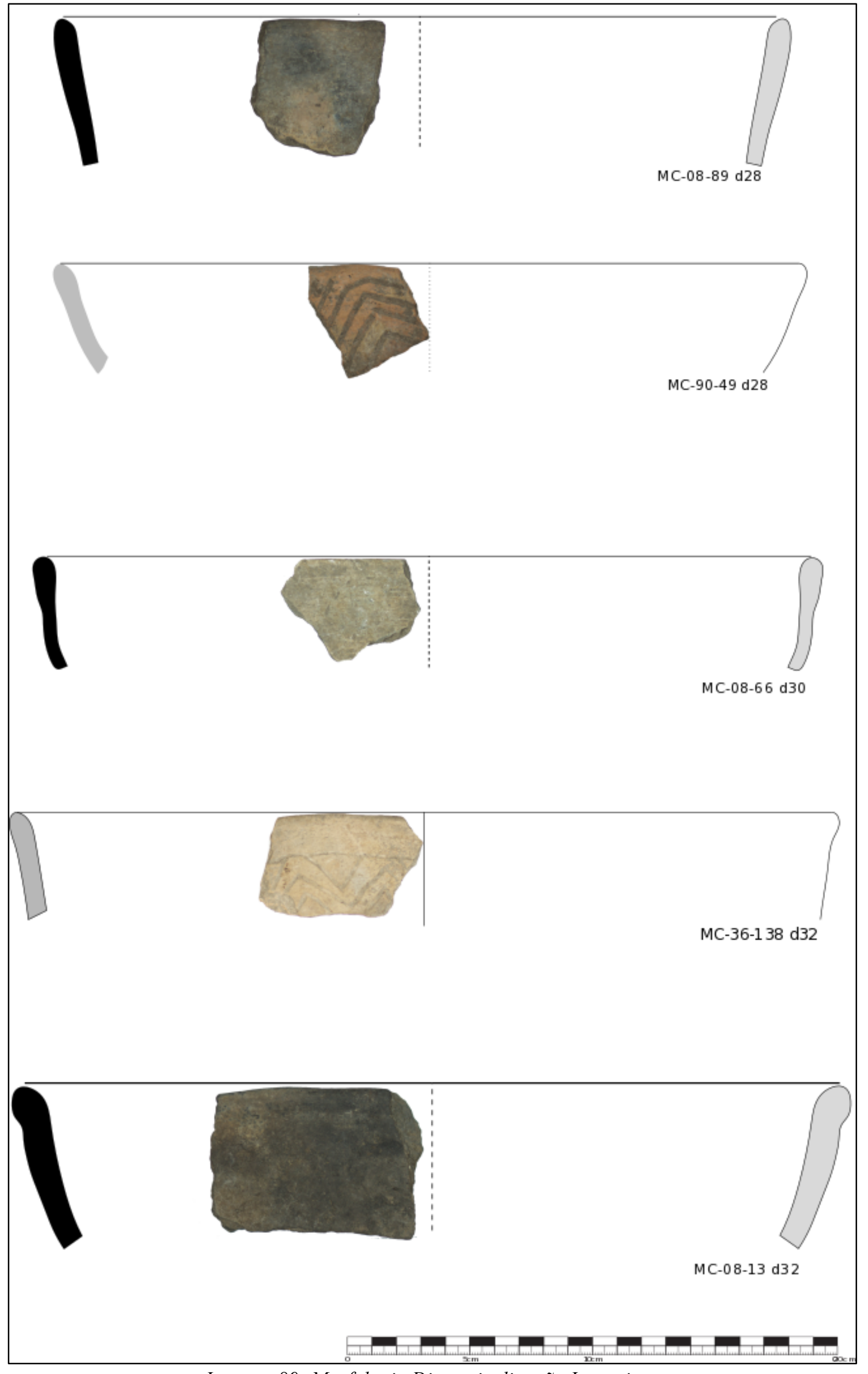

Imagem 89: Morfologia Direta, inclinação Irrestrita. 


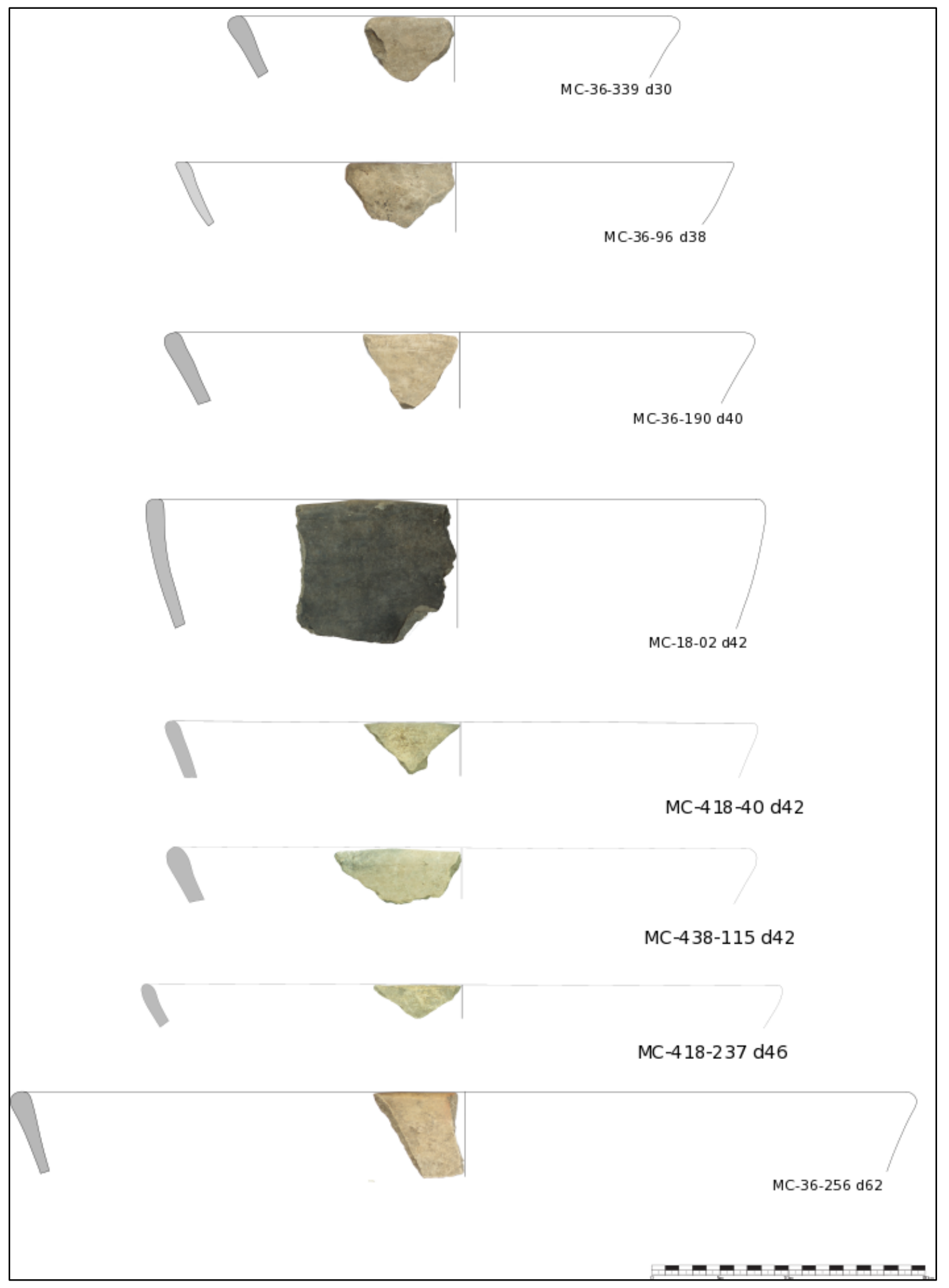

Imagem 90: Morfologia Direta, inclinação Irrestrita. 


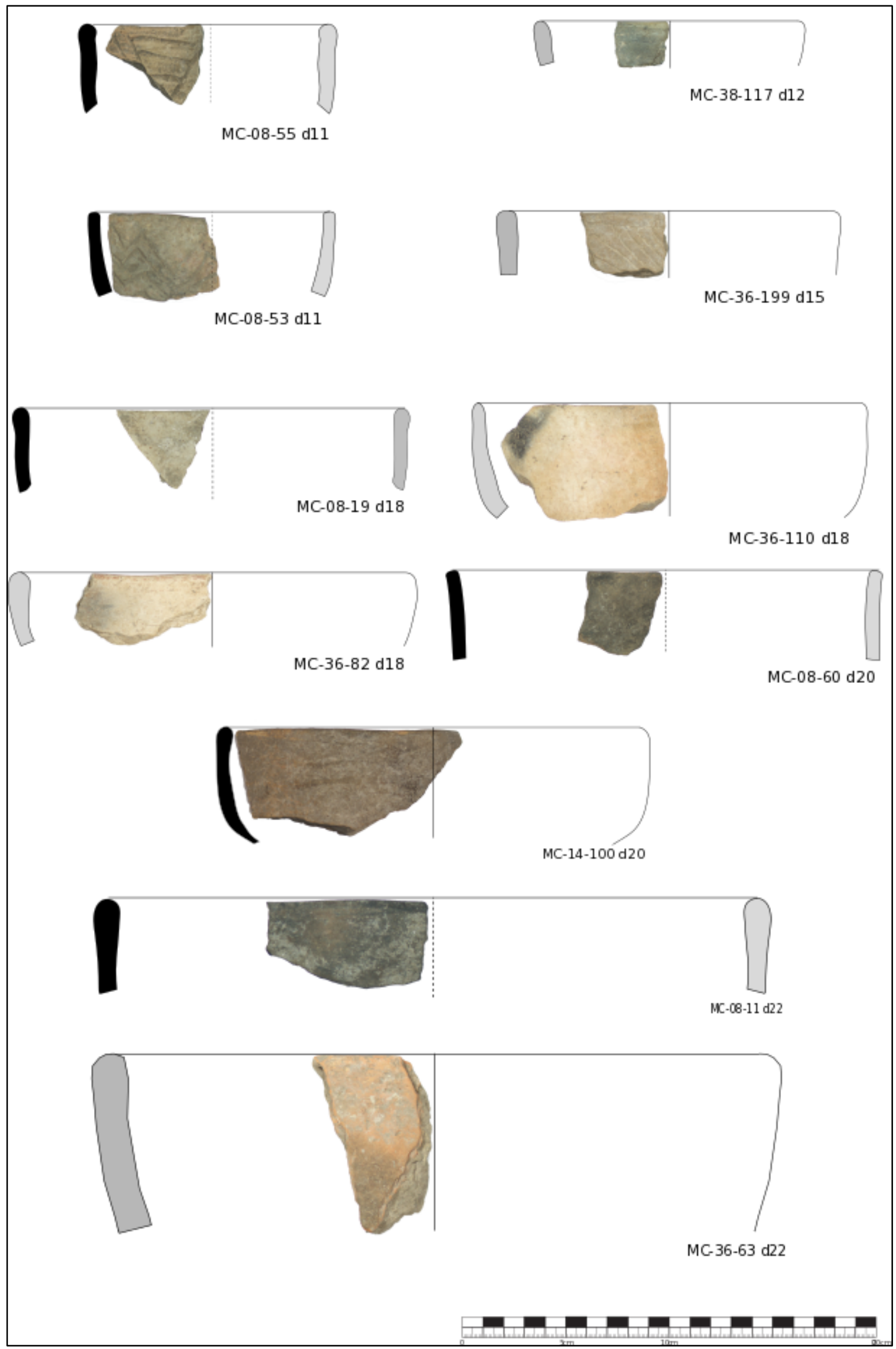

Imagem 91: Morfologia Direta, inclinação Direta. 
MC-418-257 d12

MC-364-55 d16
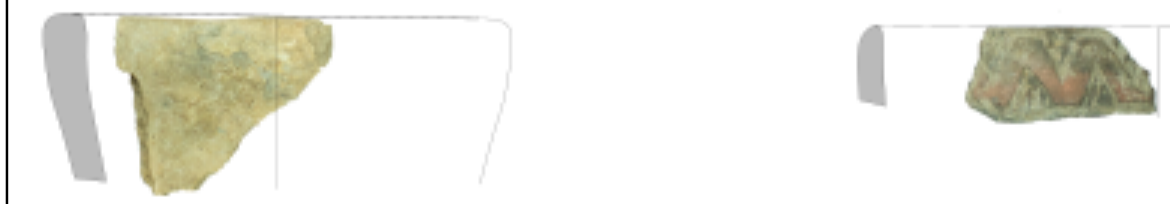

MC-413-72 d18

MC-467-6 d13

MC-282-2 d15

MC-317-45 d19
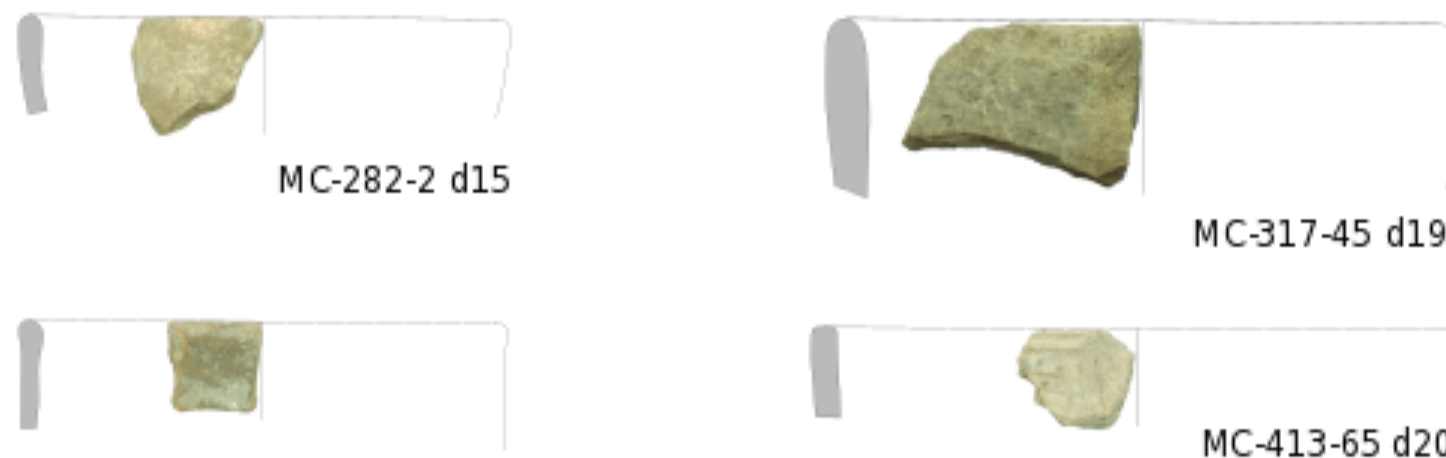

MC- $413-65$ d20

MC-418-220 d15

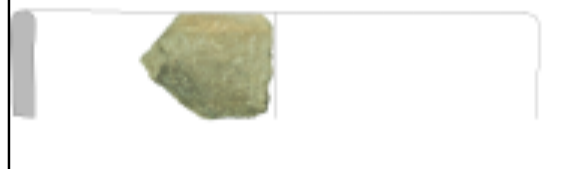

MC-418-66x d15
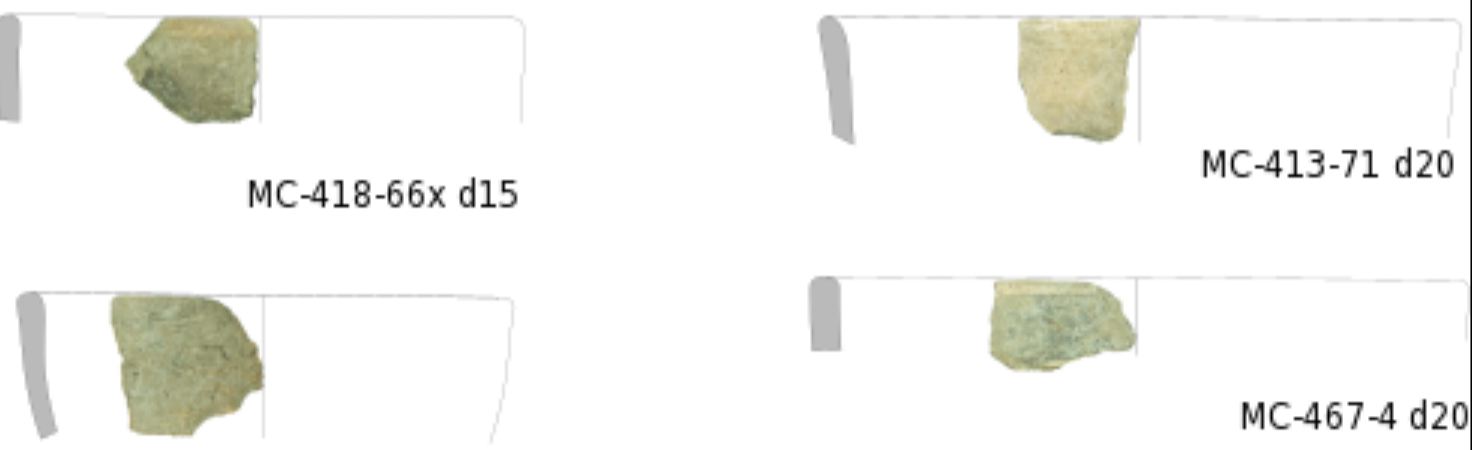

MC-467-4 d20

MC-418-50 d15
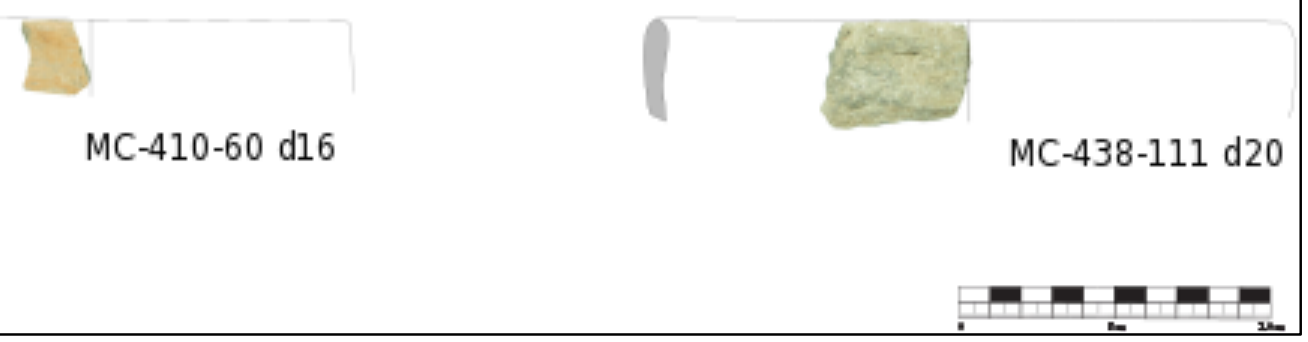

Imagem 92: Morfologia Direta, inclinação Direta. 


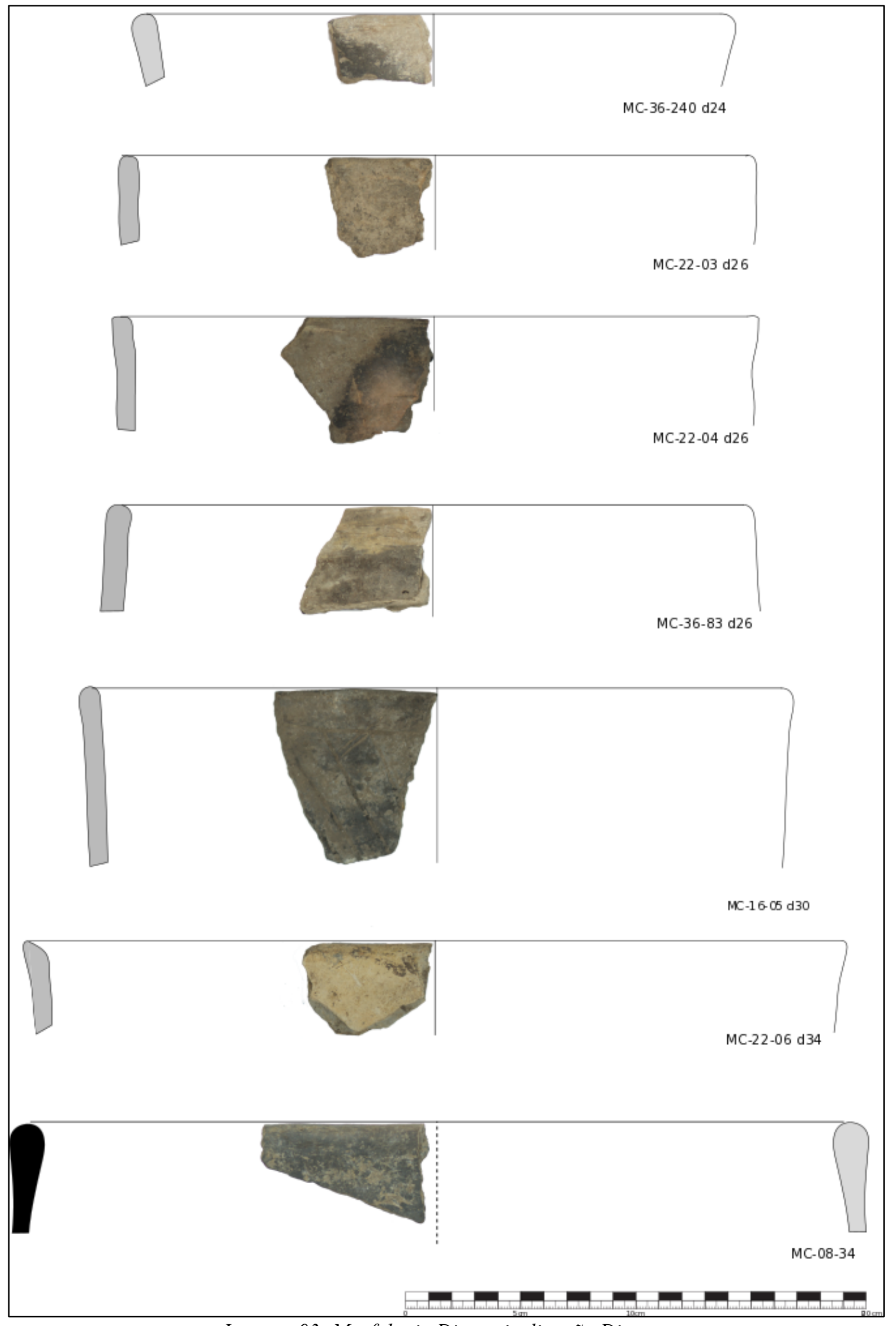

Imagem 93: Morfologia Direta, inclinação Direta. 


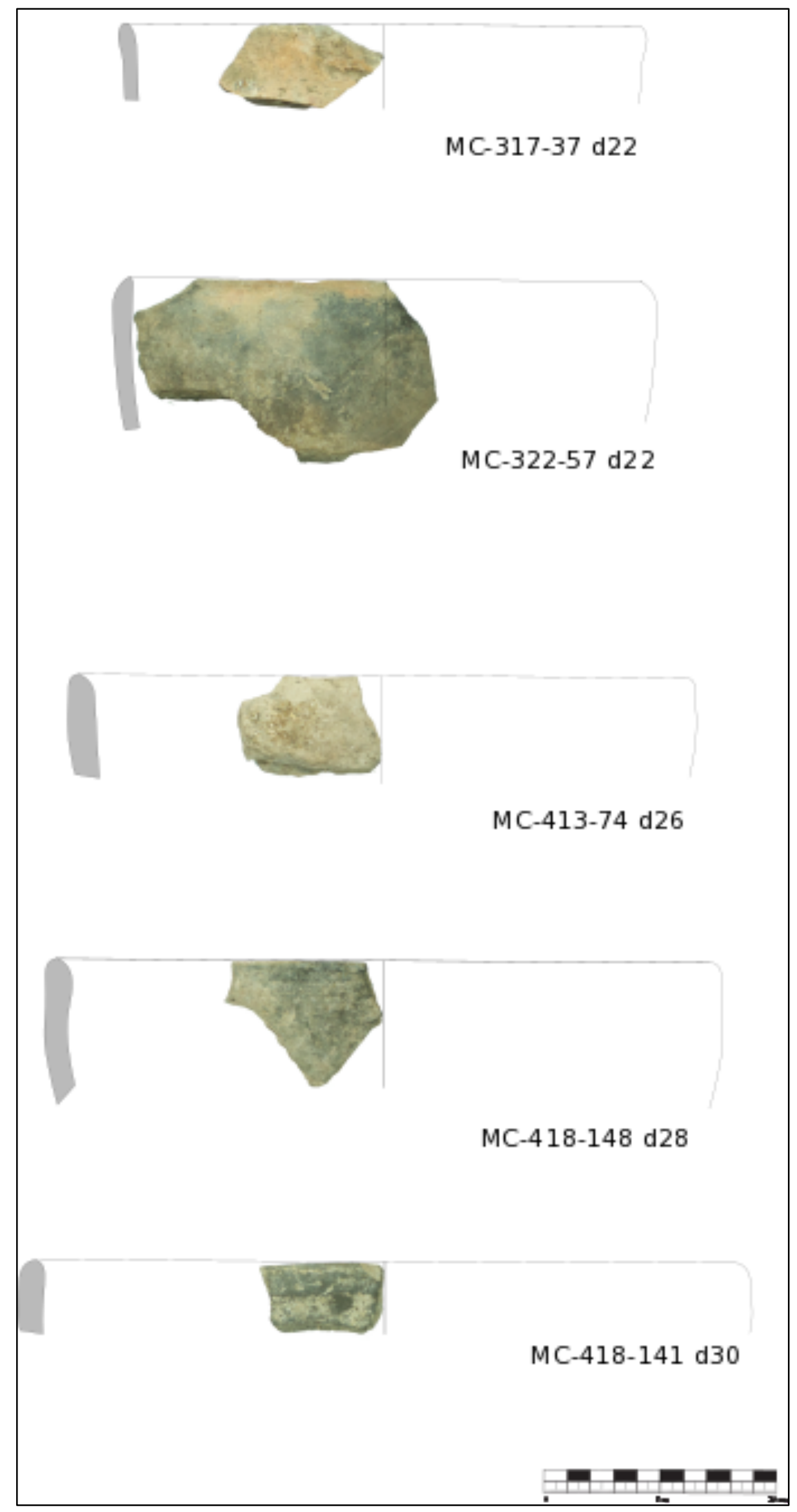




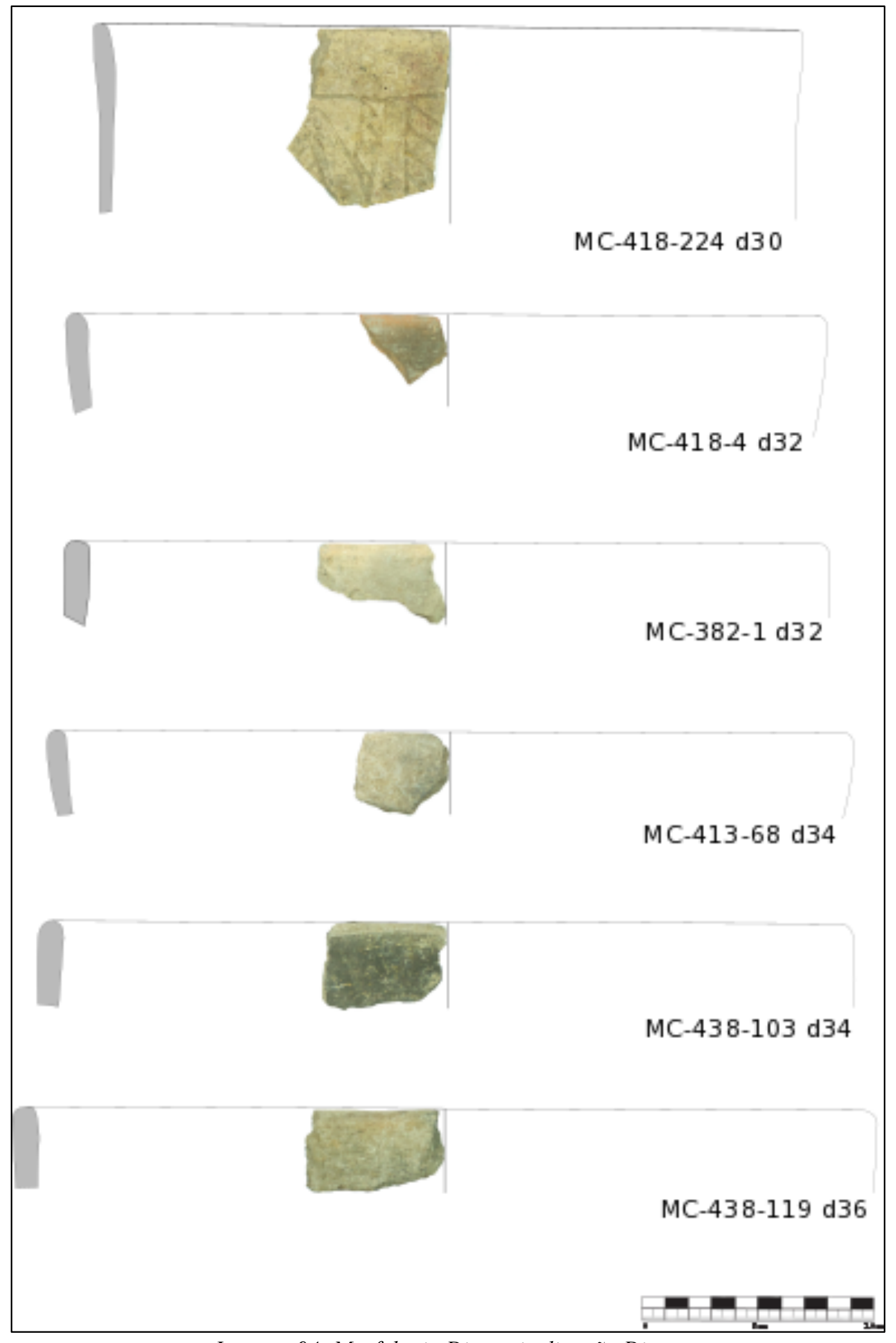

Imagem 94: Morfologia Direta, inclinação Direta 


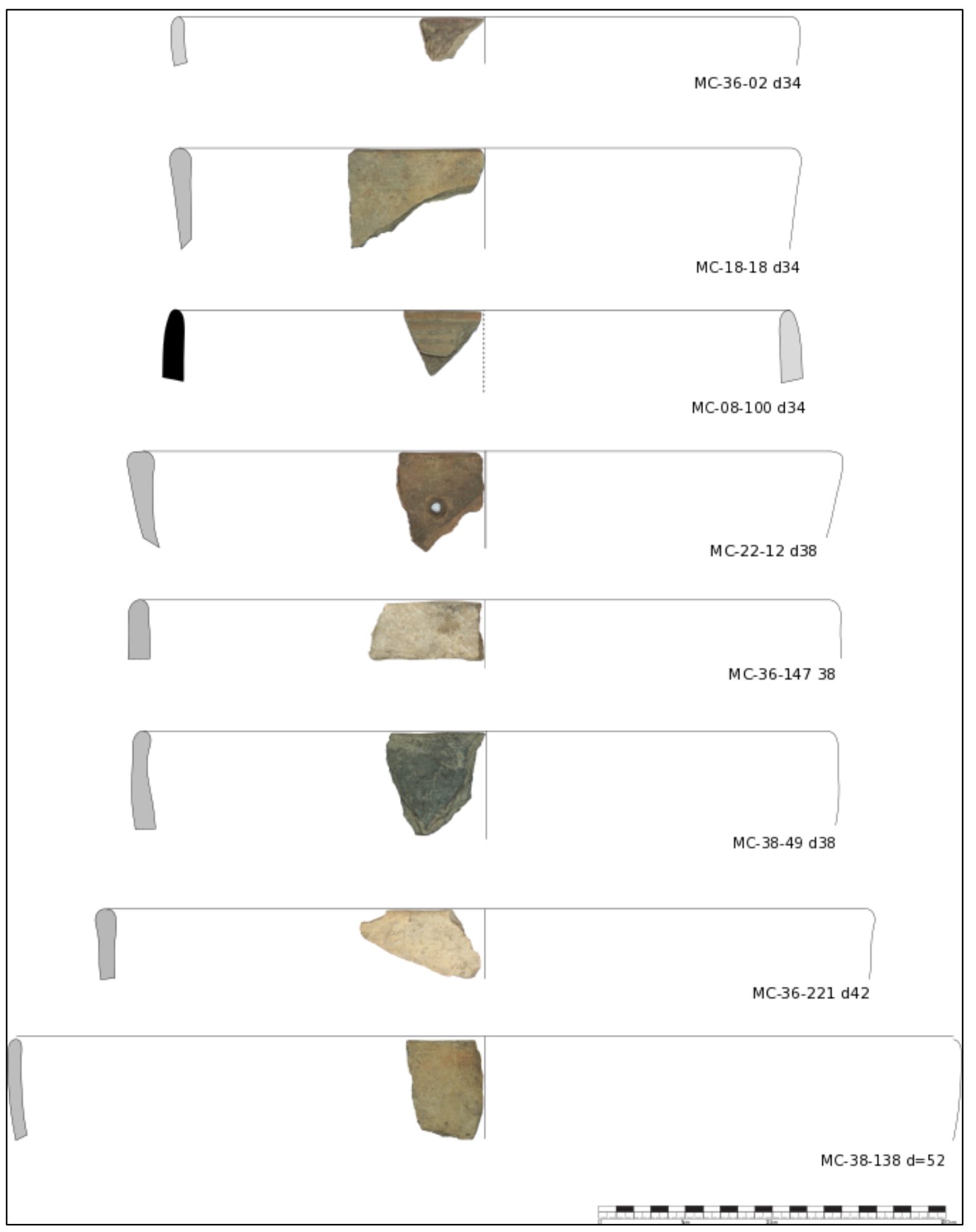

Imagem 95: Morfologia Direta, inclinação Direta 


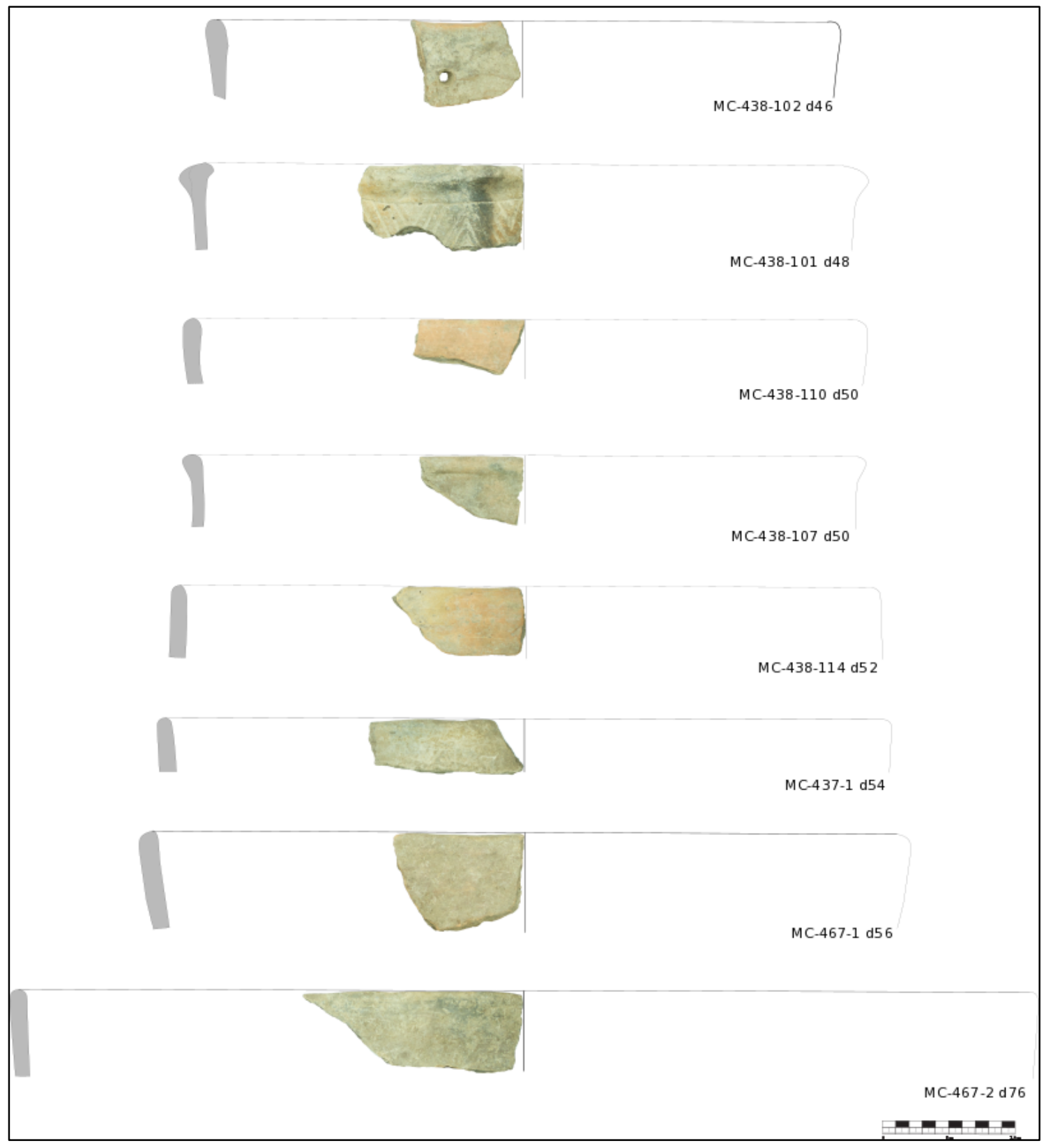

Imagem 96: Morfologia Direta, inclinação Direta. 


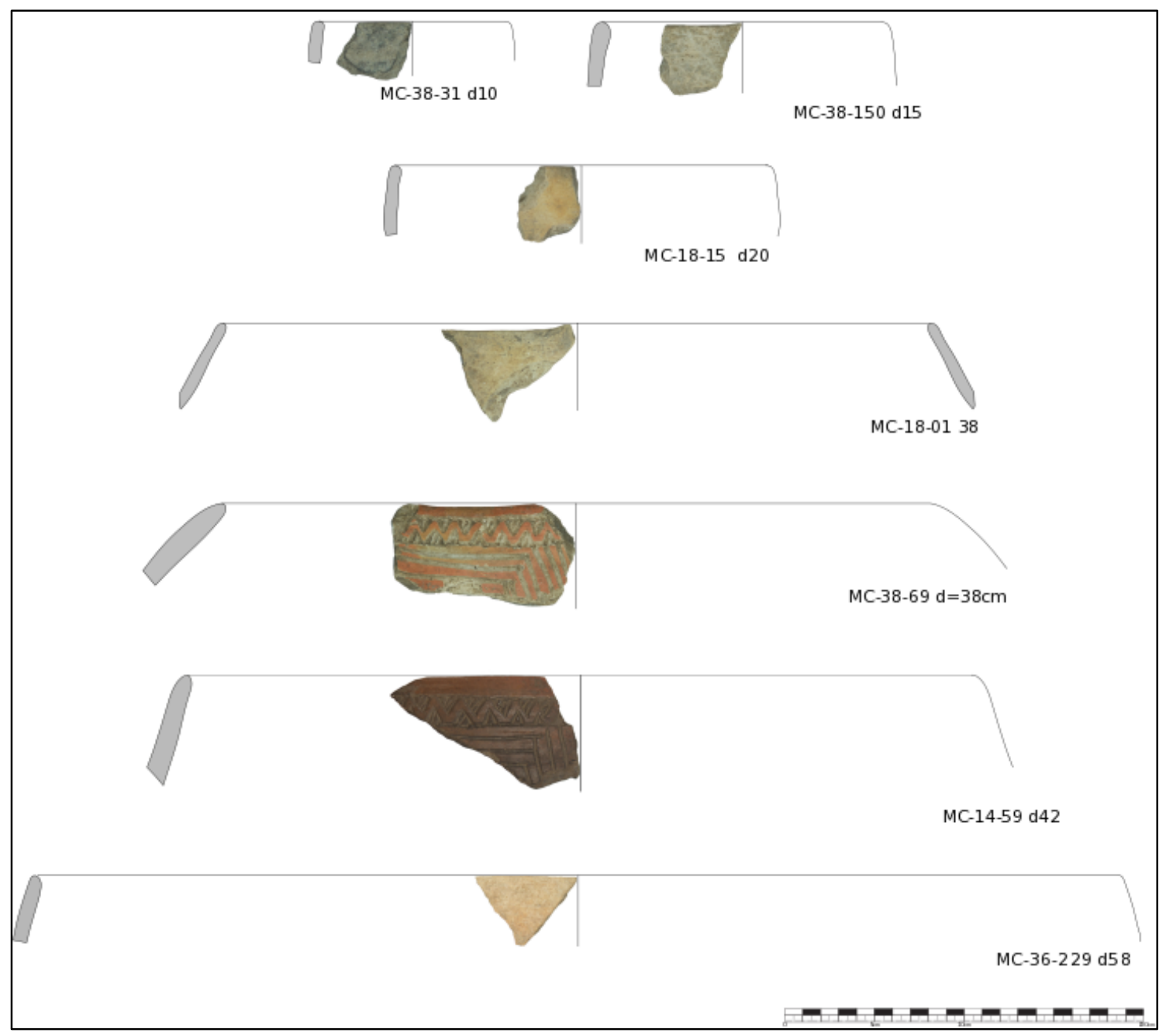

Imagem 97: Morfologia Direta, inclinação restrita.

\section{Introvertidas}

As bordas introvertidas possuem diâmetros iniciando em $12 \mathrm{~cm}$ e indo até $38 \mathrm{~cm}$. Esta morfologia de borda está ligado ao consumo, armazenamento e preparação de recursos. A inclinação varia entre irrestrita até restrita inclinada. $\mathrm{O}$ espessamento dessas bordas também varia pouco e são raros os espessamentos que não são lineares, que estão exclusivamente ligados às formas mais restritas do tipo.

As bordas introvertidas diretas são as mais frequentes as com inclinação restrita $(28,26 \%)$. Bordas irrestritas $(23,91 \%)$ e restritas inclinadas $(4,34 \%)$ compõem o restante das amostras deste tipo (Gráfico 29 e tabela 30). 


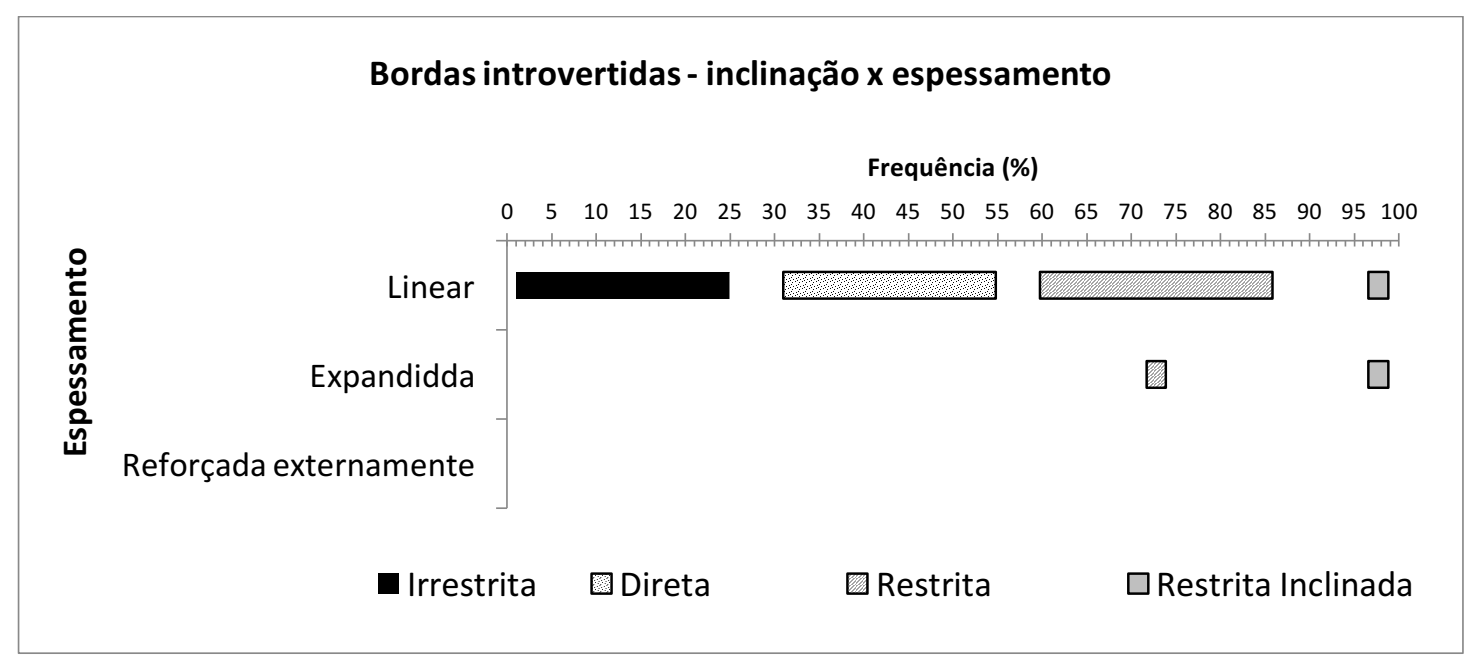

Gráfico 29: sequência seriada dos tipos de inclinação entre os tipos de espessamento de bordas introvertidas $(n=46)$.

\begin{tabular}{|l|c|c|c|c|c|c|c|c|}
\hline Introvertidas $(\mathrm{n}=46)$ & Irrestrita & $\%$ & Direta & $\%$ & Restrita & $\%$ & Restrita Inclinada & $\%$ \\
\hline Linear & 11 & 23,91 & 18 & 39,13 & 12 & 26,08 & 1 & 2,17 \\
\hline Expandida & 0 & 0 & 1 & 2,17 & 1 & 2,17 & 1 & 2,17 \\
\hline Reforçada externamente & 0 & 0 & 1 & 2,17 & 0 & 0 & 0 & 0,00 \\
\hline
\end{tabular}

Gráfico 30: quantidade e proporção dos tipos de inclinação entre os tipos de espessamento de bordas introvertidas $(n=46)$,

Nas bordas irrestritas são muito raros os lábios planos $(6,52 \%)$, sendo mais comuns os arredondados (50\%) e é muito marcante a presença dos afilados $(43,47 \%)$, em relação as bordas com morfologia direta e introvertida. Os tipos mais comuns entre as bordas introvertidas são as de inclinação irrestritas com espessamento linear e lábio arredondado (19,57\%), diretas, lineares e com lábio arredondados (19,57\%) e afilados(19,57\%), seguido de restritas, lineares com lábio afilado(17,39\%).(Gráfico 30 e tabela 28) 
Tipos de lábios entre os tipos de espessasmento de bordas introvertidas e suas inclinações

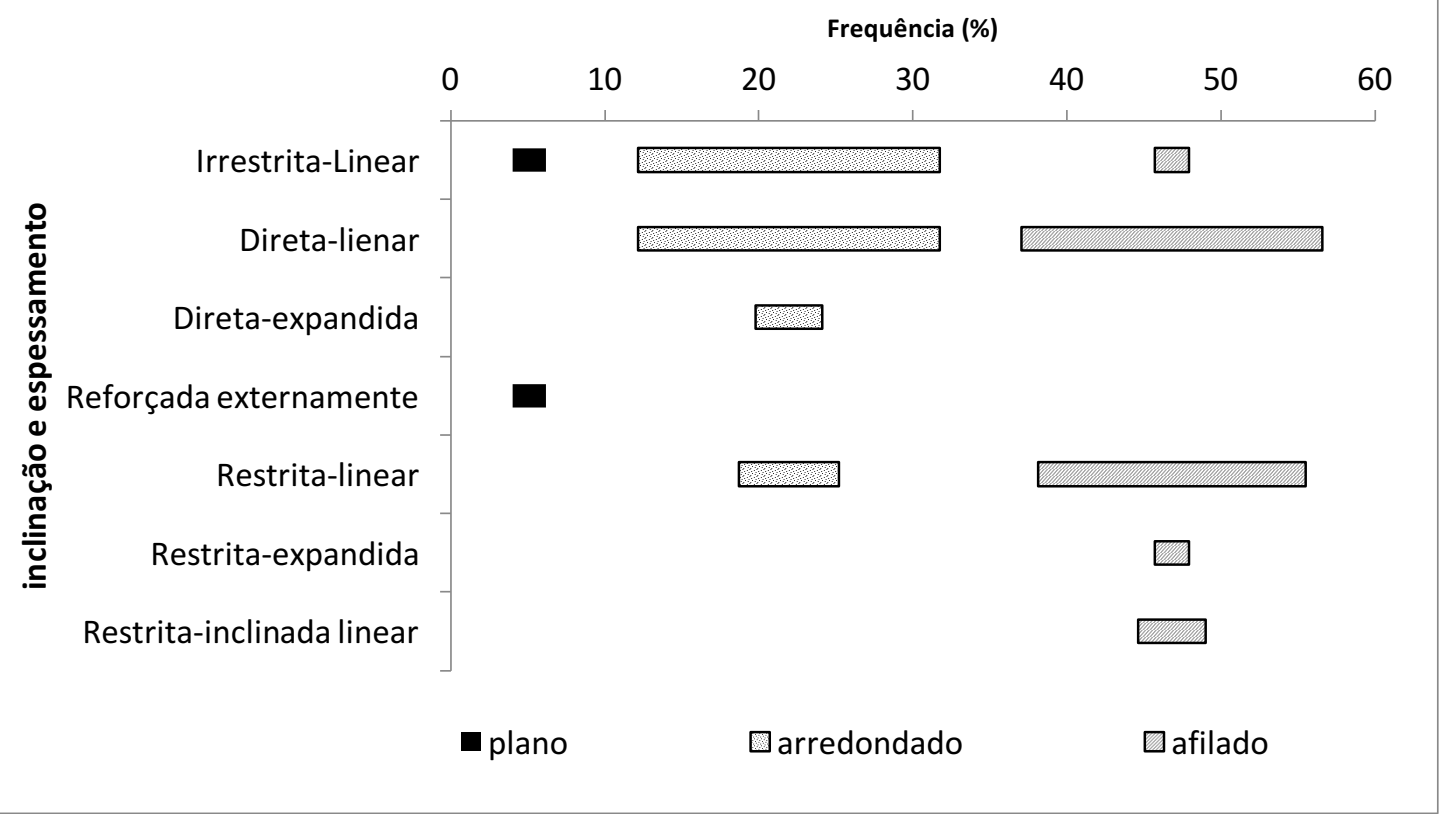

Gráfico 31: sequência seriada dos tipos de lábios entre os tipos de espessamento de bordas introvertidas e suas inclinações

\begin{tabular}{|l|c|c|c|c|c|c|}
\hline $\mathrm{n}=46$ & plano & $\%$ & arredondado & $\%$ & afilado & $\%$ \\
\hline Irrestrita-Linear & 1 & 2,17 & 9 & 19,57 & 1 & 2,17 \\
\hline Direta-linear & 0 & 0,00 & 9 & 19,57 & 9 & 19,57 \\
\hline Direta-expandida & 0 & 0,00 & 2 & 4,35 & 0 & 0,00 \\
\hline Reforçada externamente & 1 & 2,17 & 0 & 0,00 & 0 & 0,00 \\
\hline Restrita-linear & 0 & 0,00 & 3 & 6,52 & 8 & 17,39 \\
\hline Restrita-expandida & 0 & 0,00 & 0 & 0,00 & 1 & 2,17 \\
\hline Restrita-inclinada linear & 0 & 0,00 & 0 & 0,00 & 2 & 4,35 \\
\hline
\end{tabular}

Tabela 28: quantidade e frequência dos tipos de lábios entre os tipos de espessamento de bordas introvertidas e suas inclinações

A espessura das bordas introvertida variou entre os tipos mais finos com 3-4mm de espessura, até os mais espessos, com 12-13mm. A previsão linear da espessura mínima e máxima dos fragmentos resulta um valor de $\mathrm{r} 2$ mais próximo de 1 (gráfico 22), indicando que a variação na simetria entre a espessura mínima e máxima não é tão grande se comparada aos índices obtidos na previsão linear das bordas diretas. 


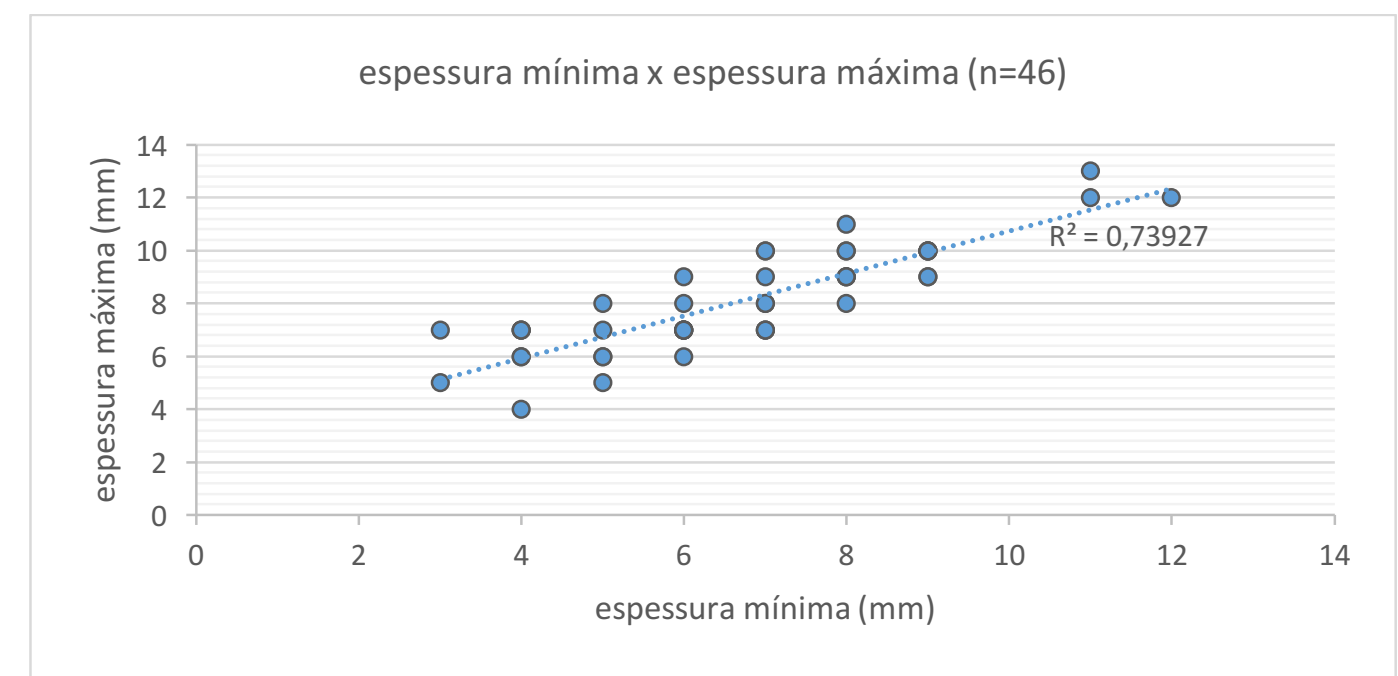

Gráfico 32: previsão linear da espessura mínima e máxima das bordas introvertidas.

A grande maioria das bordas introvertidas tem entre 6-9 $\mathrm{mm}$ de espessura $(65,22 \%)$, os tipos mais espessos, entre $10-13 \mathrm{~mm}$ representam $28,26 \%$, enquanto os mais finos (3-5mm) atingem $6,52 \%$. Uma projeção linear feita entre a espessura máxima do fragmento e o diâmetro de abertura de boca, assim como nas bordas diretas, obteve um valor de $\mathrm{r} 2$ baixo $(0,15)$, onde não é possível estabelecer uma relação direta na proporção da espessura do fragmento e o diâmetro de boca (Gráficos 33 e 34, tabela 29).

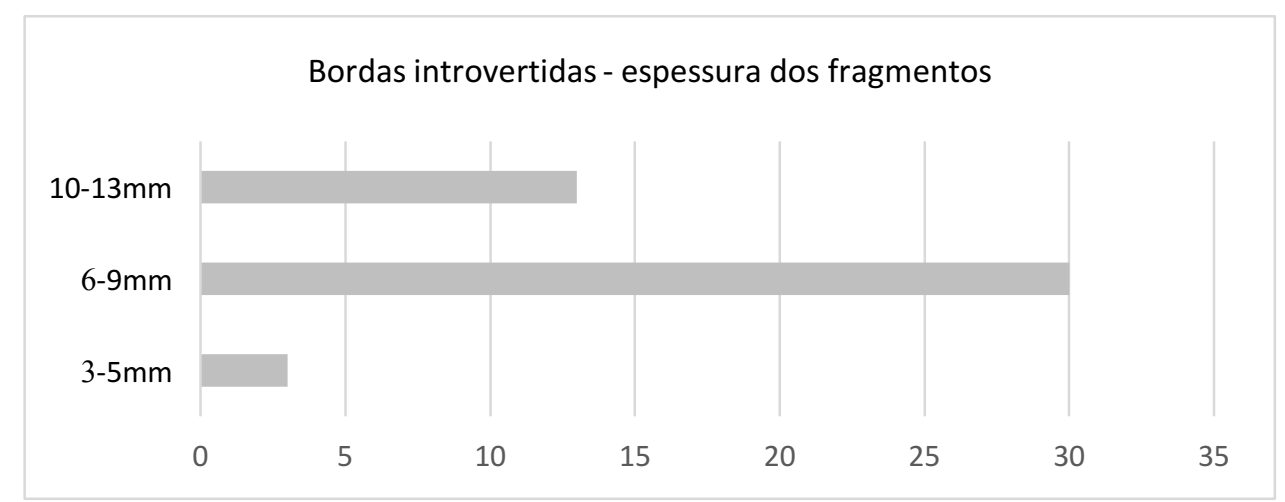

Gráfico 33: espessura dos fragmentos das bordas introvertidas.

\begin{tabular}{lcc}
\hline Espessura & quantidade & $\%$ \\
\hline $3-5 \mathrm{~mm}$ & 3 & 6,52 \\
$6-9 \mathrm{~mm}$ & 30 & 65,22 \\
$10-13 \mathrm{~mm}$ & 13 & 28,26 \\
\hline
\end{tabular}

Tabela 29: quantidade e proporção dos tipos de espessura dos fragmentos das bordas introvertidas 


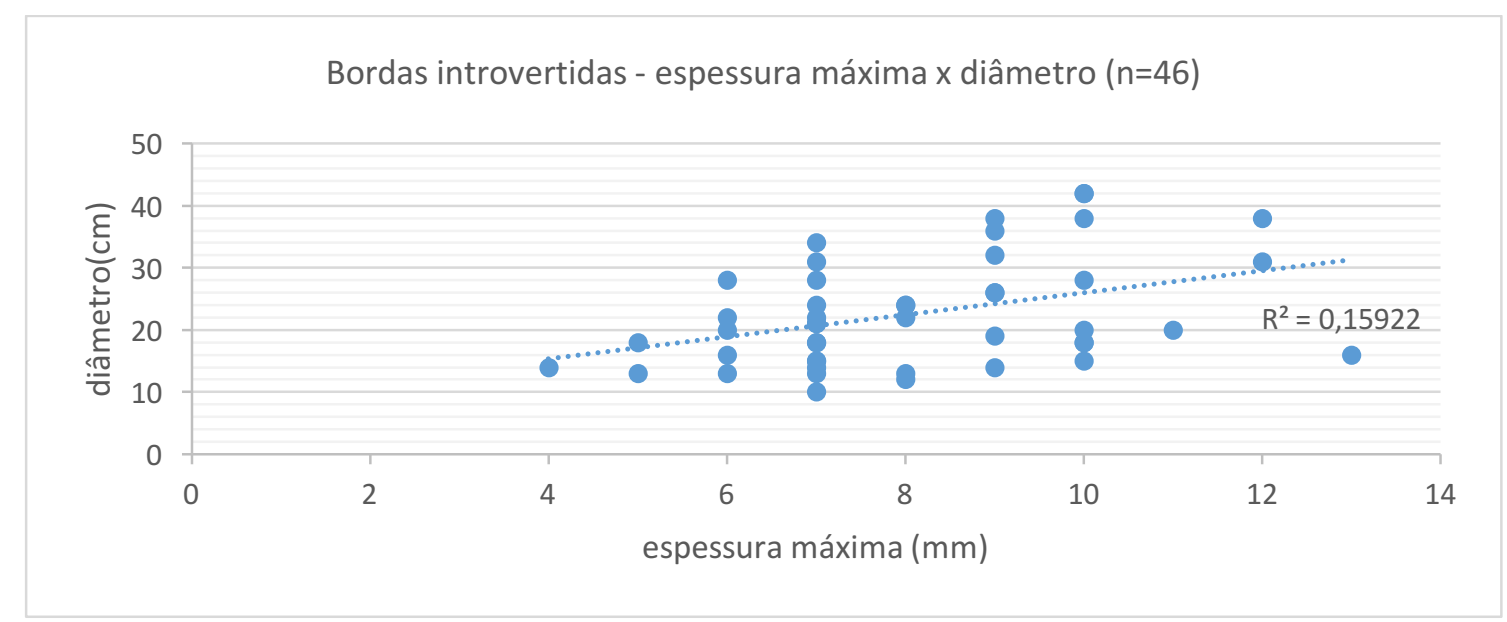

Gráfico 34: previsão linear entre a espessura máxima e o diâmetro de boca das bordas introvertidas.

O diâmetro das bordas introvertidas variou entre e $10-38 \mathrm{~cm}$. Os intervalos mais frequentes entre os indivíduos ficaram entre 18-22cm (30,43\%), 13-16 cm (26,08\%), seguidos por e $24-28 \mathrm{~cm}$ e $31-38 \mathrm{~cm}$, ambos representando $17,39 \%$ das bordas introvertidas. Os tipos mais populares estão relacionados a inclinação direta $(43,47 \%)$ onde são encontrados indivíduos entre $18-38 \mathrm{~cm}$ de diâmetro de boca. Bordas com inclinação restritas $(28,26 \%)$ variam entre $14-38 \mathrm{~cm}$, enquanto as bordas com inclinação irrestritas $(23,91 \%)$ variam entre $10-38 \mathrm{~cm}$. 


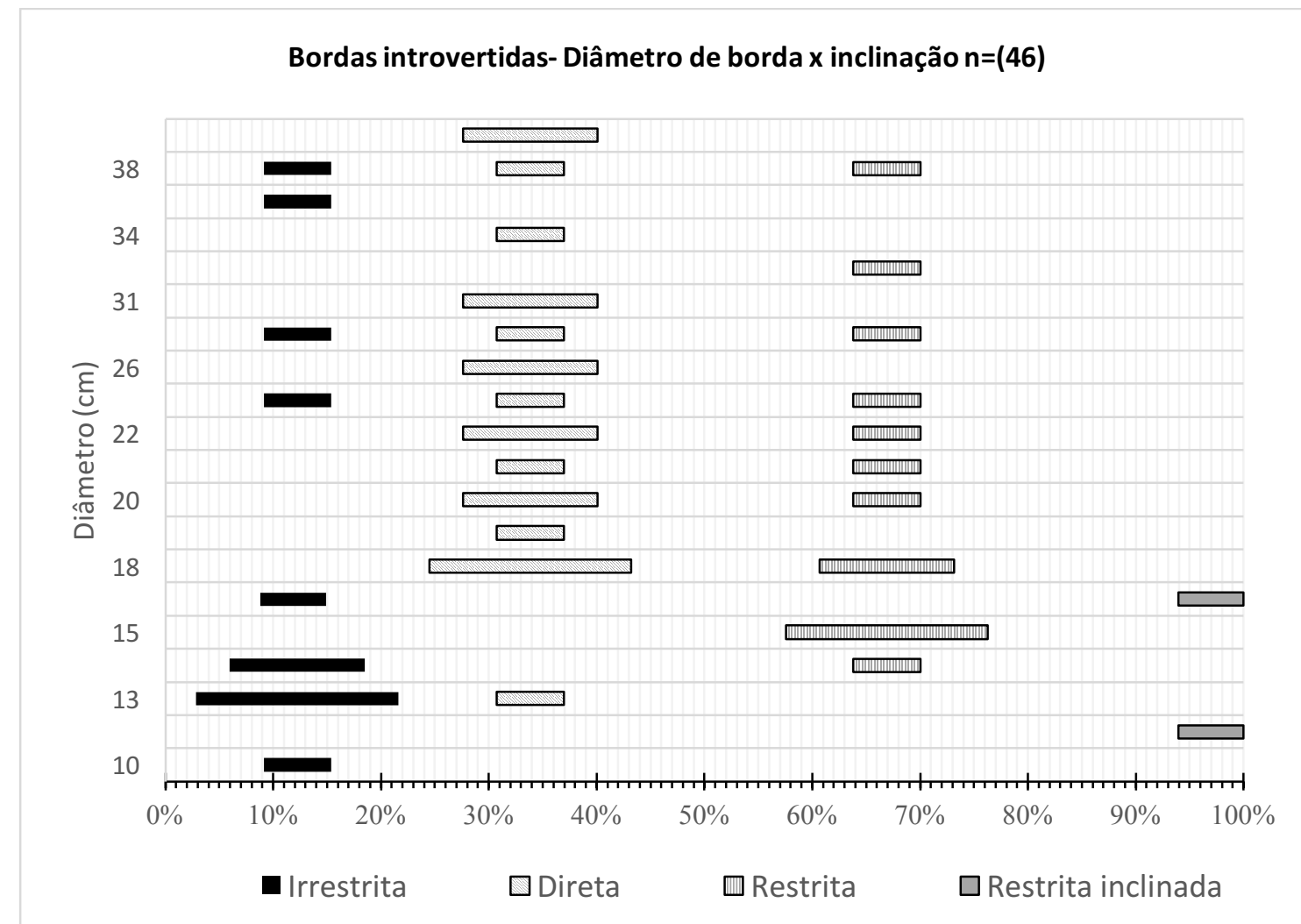

Gráfico 35: sequência seriada dos tipos de inclinação das bordas introvertidas entre os valores de diâmetro de abertura de boca.

\begin{tabular}{|c|c|c|c|c|c|c|c|c|}
\hline diâmetro/inclinação & irrestrita & $\%$ & direta & $\%$ & restrita & $\%$ & restrita inclinada & $\%$ \\
\hline 10 & 1 & 2,17 & 0 & 0,00 & 0 & 0,00 & 0 & 0,00 \\
\hline 12 & 0 & 0,00 & 0 & 0,00 & 0 & 0,00 & 1 & 2,17 \\
\hline 13 & 3 & 6,52 & 1 & 2,17 & 0 & 0,00 & 0 & 0,00 \\
\hline 14 & 2 & 4,35 & 0 & 0,00 & 1 & 2,17 & 0 & 0,00 \\
\hline 15 & 0 & 0,00 & 0 & 0,00 & 3 & 6,52 & 0 & 0,00 \\
\hline 16 & 1 & 2,17 & 0 & 0,00 & 0 & 0,00 & 1 & 2,17 \\
\hline 18 & 0 & 0,00 & 3 & 6,52 & 2 & 4,35 & 0 & 0,00 \\
\hline 19 & 0 & 0,00 & 1 & 2,17 & 0 & 0,00 & 0 & 0,00 \\
\hline 20 & 0 & 0,00 & 2 & 4,35 & 1 & 2,17 & 0 & 0,00 \\
\hline 21 & 0 & 0,00 & 1 & 2,17 & 1 & 2,17 & 0 & 0,00 \\
\hline 22 & 0 & 0,00 & 2 & 4,35 & 1 & 2,17 & 0 & 0,00 \\
\hline 24 & 1 & 2,17 & 1 & 2,17 & 1 & 2,17 & 0 & 0,00 \\
\hline 26 & 0 & 0,00 & 2 & 4,35 & 0 & 0,00 & 0 & 0,00 \\
\hline 28 & 1 & 2,17 & 1 & 2,17 & 1 & 2,17 & 0 & 0,00 \\
\hline 31 & 0 & 0,00 & 2 & 4,35 & 0 & 0,00 & 0 & 0,00 \\
\hline 32 & 0 & 0,00 & 0 & 0,00 & 1 & 2,17 & 0 & 0,00 \\
\hline 34 & 0 & 0,00 & 1 & 2,17 & 0 & 0,00 & 0 & 0,00 \\
\hline 36 & 1 & 2,17 & 0 & 0,00 & 0 & 0,00 & 0 & 0,00 \\
\hline 38 & 1 & 2,17 & 1 & 2,17 & 1 & 2,17 & 0 & 0,00 \\
\hline 42 & 0 & 0,00 & 2 & 4,35 & 0 & 0,00 & 0 & 0,00 \\
\hline
\end{tabular}

Tabela 30: quantidade e percentual dos dos tipos de inclinação das bordas introvertidas entre os valores de diâmetro de abertura de boca. 


\section{Decorados}

Os indivíduos do tipo alisado representam $73,91 \%$ da amostra, enquanto os tipos decorados são encontrados em 26,08\% dos casos. Mesmo havendo esta diferença, os tipos decorados, assim como os tipos alisados, podem ser encontrados na grande maioria dos diâmetros de abertura de boca identificados (10-42cm). Somente no caso das bordas Irrestritas e inclinadas com diâmetros entre $10-16 \mathrm{~cm}$ que não são encontrados entre os tipos decorados. As bordas irrestritas, mais frequentes entre $18-26 \mathrm{~cm}$ possuem proporção semelhante na ocorrência entre os tipos simples e decorados. É entre as bordas com inclinação direta que encontramos a maior diversidade de ocorrência entre os valores dos diâmetros (10-38cm), maior inclusive que os alisados. Os motivos Bacabal, Bacabal paralelo, Bacabal espelhado e Bacabal repetido foram os mais frequentes e ocorrem entre todos os diâmetros observados (Gráfico 36, tabela 31).

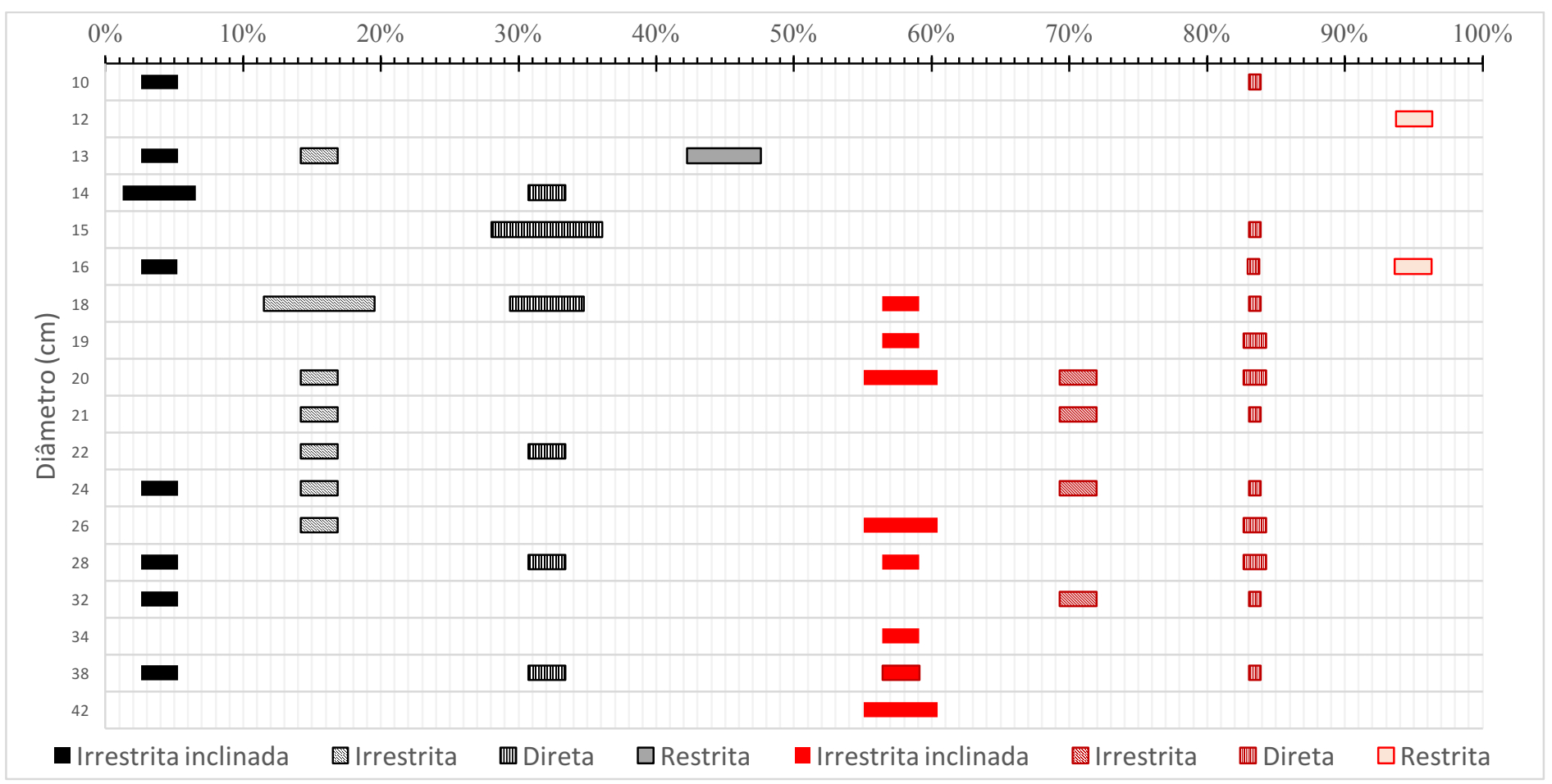

Gráfico 36: sequência seriada do tipos de borda introvertidas alisadas e decoradas entre os diâmetros de abertura de boca identificados. 


\begin{tabular}{|c|c|c|c|c|c|c|c|c|c|c|c|c|c|c|c|}
\hline \multicolumn{7}{|c|}{ Alisadas } & \multicolumn{8}{|c|}{ Decoradas } & \multirow{3}{*}{ motivo } \\
\hline & Irrestrita & $\%$ & Direta & $\%$ & Restrita & $\%$ & Irrestrita & $\%$ & Direta & $\%$ & Restrita & $\%$ & Restrita inclinada & $\%$ & \\
\hline 10 & 1 & 2,17 & 0 & 0,00 & 0 & 0,00 & 0 & 0,00 & 0 & 0,00 & 0 & 0,00 & 0 & 0,00 & \\
\hline 12 & 0 & 0,00 & 0 & 0,00 & 0 & 0,00 & 0 & 0,00 & 0 & 0,00 & 0 & 0,00 & 1 & 2,17 & Bacabal paralelo \\
\hline 13 & 1 & 2,17 & 1 & 2,17 & 0 & 0,00 & 2 & 4,35 & 0 & 0,00 & 0 & 0,00 & 0 & 0,00 & Bacabal / Quadriculado \\
\hline 14 & 2 & 4,35 & 0 & 0,00 & 1 & 2,17 & 0 & 0,00 & 0 & 0,00 & 0 & 0,00 & 0 & 0,00 & \\
\hline 15 & 0 & 0,00 & 0 & 0,00 & 3 & 6,52 & 0 & 0,00 & 0 & 0,00 & 0 & 0,00 & 0 & 0,00 & \\
\hline 16 & 1 & 2,17 & 0 & 0,00 & 0 & 0,00 & 0 & 0,00 & 0 & 0,00 & 0 & 0,00 & 1 & 2,17 & Bacabal paralelo \\
\hline 18 & 0 & 0,00 & 3 & 6,52 & 2 & 4,35 & 0 & 0,00 & 1 & 2,17 & 0 & 0,00 & 0 & 0,00 & Motivo $\mathrm{NI}$ \\
\hline 19 & 0 & 0,00 & 0 & 0,00 & 0 & 0,00 & 0 & 0,00 & 1 & 2,17 & 0 & 0,00 & 0 & 0,00 & Bacabal \\
\hline 20 & 0 & 0,00 & 1 & 2,17 & 0 & 0,00 & 0 & 0,00 & 2 & 4,35 & 1 & 2,17 & 0 & 0,00 & Bacabal / Bacabal espelhado \\
\hline 21 & 0 & 0,00 & 1 & 2,17 & 0 & 0,00 & 0 & 0,00 & 0 & 0,00 & 1 & 2,17 & 0 & 0,00 & Bacabal espelhado \\
\hline 22 & 0 & 0,00 & 1 & 2,17 & 1 & 2,17 & 0 & 0,00 & 0 & 0,00 & 0 & 0,00 & 0 & 0,00 & \\
\hline 24 & 1 & 2,17 & 1 & 2,17 & 0 & 0,00 & 0 & 0,00 & 0 & 0,00 & 1 & 2,17 & 0 & 0,00 & Bacabal paralelo \\
\hline 26 & & 0,00 & 1 & 2,17 & 0 & 0,00 & 0 & 0,00 & 2 & 4,35 & 0 & 0,00 & 0 & 0,00 & Bacabal \\
\hline 28 & 1 & 2,17 & 0 & 0,00 & 1 & 2,17 & 0 & 0,00 & 1 & 2,17 & 0 & 0,00 & 0 & 0,00 & Motivo NI \\
\hline 32 & 1 & 2,17 & 0 & 0,00 & 0 & 0,00 & 0 & 0,00 & 0 & 0,00 & 1 & 2,17 & 0 & 0,00 & Bacabal \\
\hline 34 & & 0,00 & 0 & 0,00 & 0 & 0,00 & 0 & 0,00 & 1 & 2,17 & 0 & 0,00 & 0 & 0,00 & Bacabal paralelo \\
\hline 38 & 1 & 2,17 & 0 & 0,00 & 1 & 2,17 & 0 & 0,00 & 1 & 2,17 & 0 & 0,00 & 0 & 0,00 & Bacabal paralelo \\
\hline 42 & & 0,00 & 0 & 0,00 & 0 & 0,00 & 0 & 0,00 & 2 & 4,35 & 0 & 0,00 & 0 & 0,00 & Bacabal \\
\hline
\end{tabular}

Tabela 31: quantidade e porcentagem dos tipos de borda introvertidas alisadas e decoradas entre os diâmetros de abertura de boca identificados.

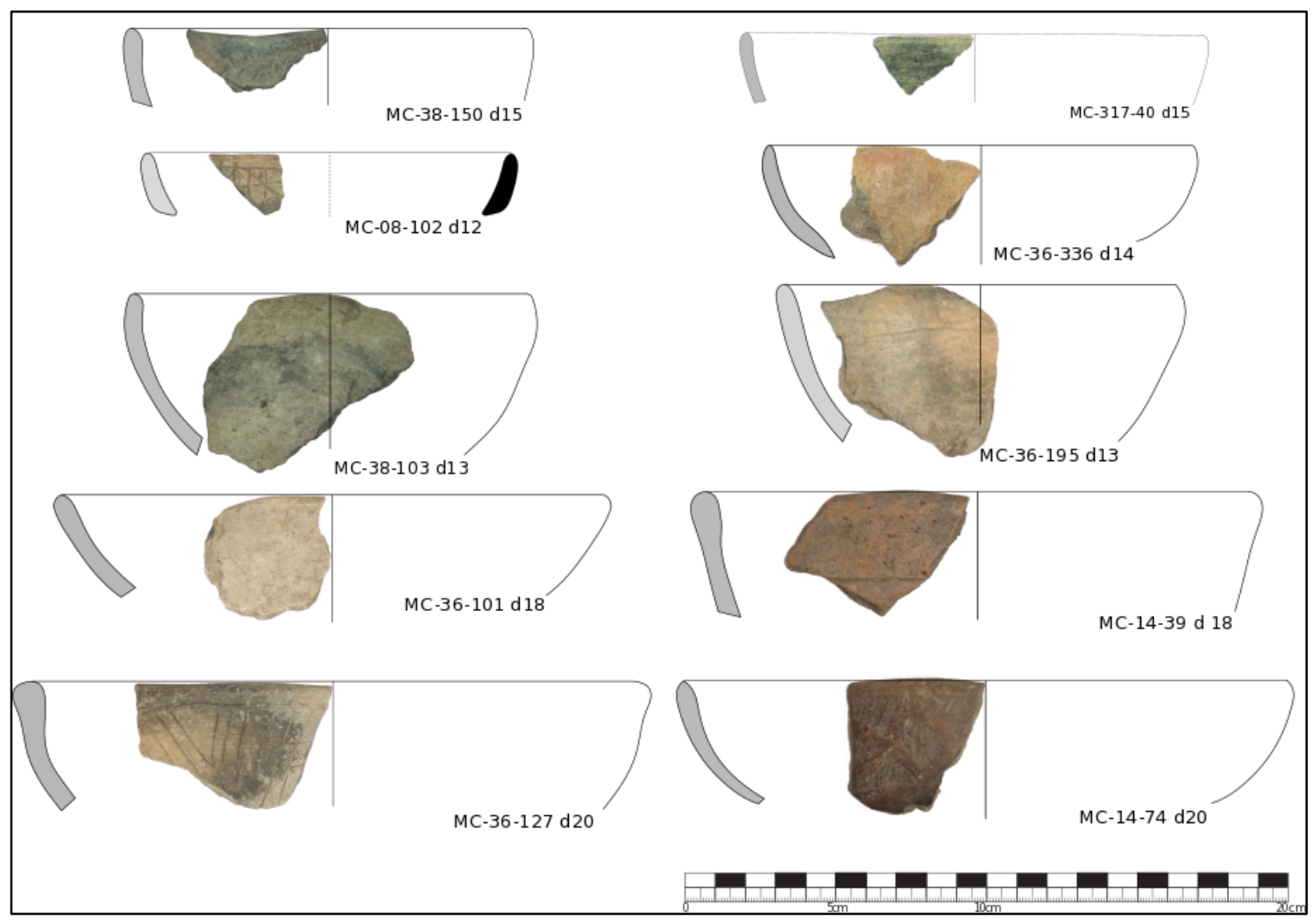

Imagem 98: Introvertidas irrestritas inclinadas 


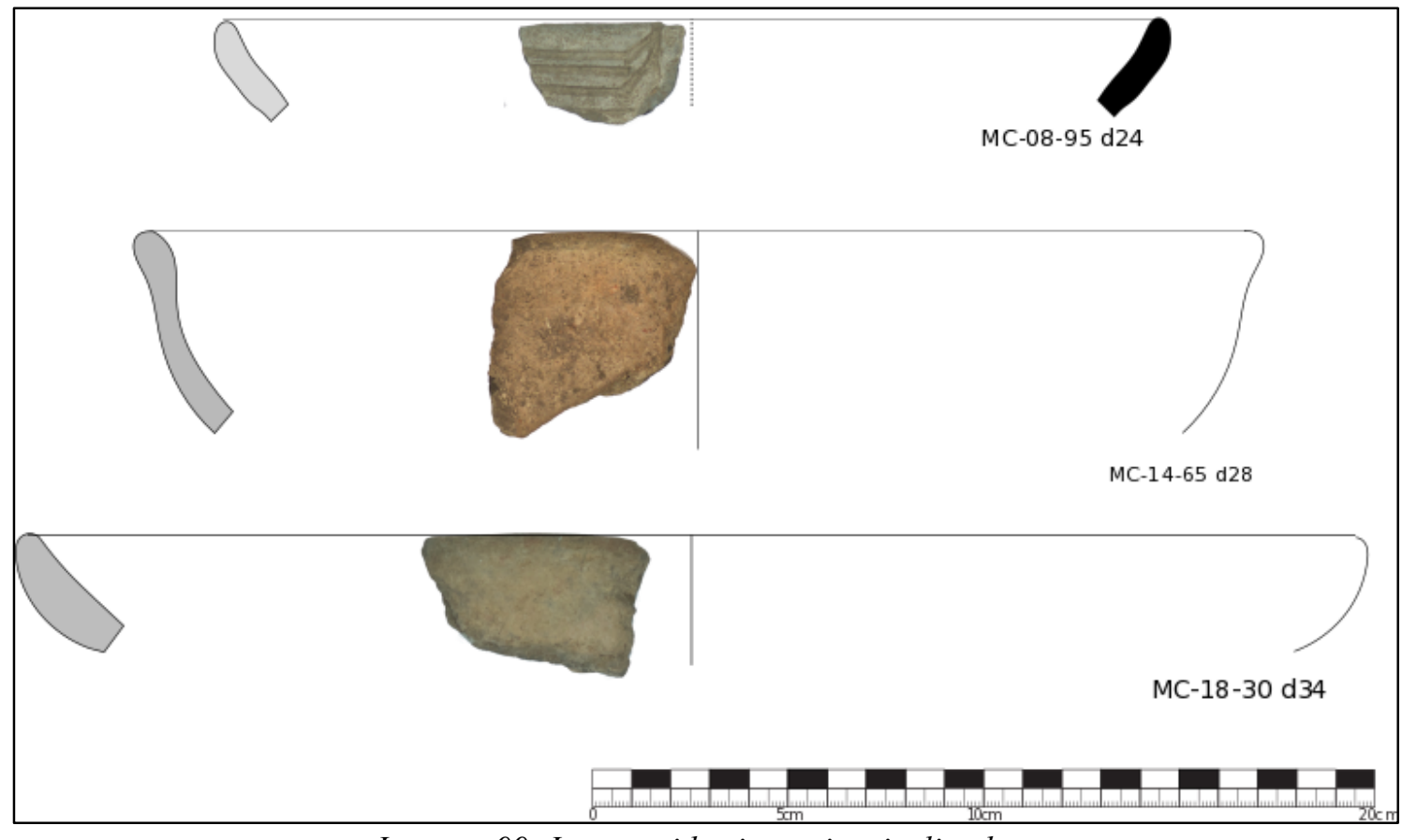

Imagem 99: Introvertidas irrestritas inclinadas 


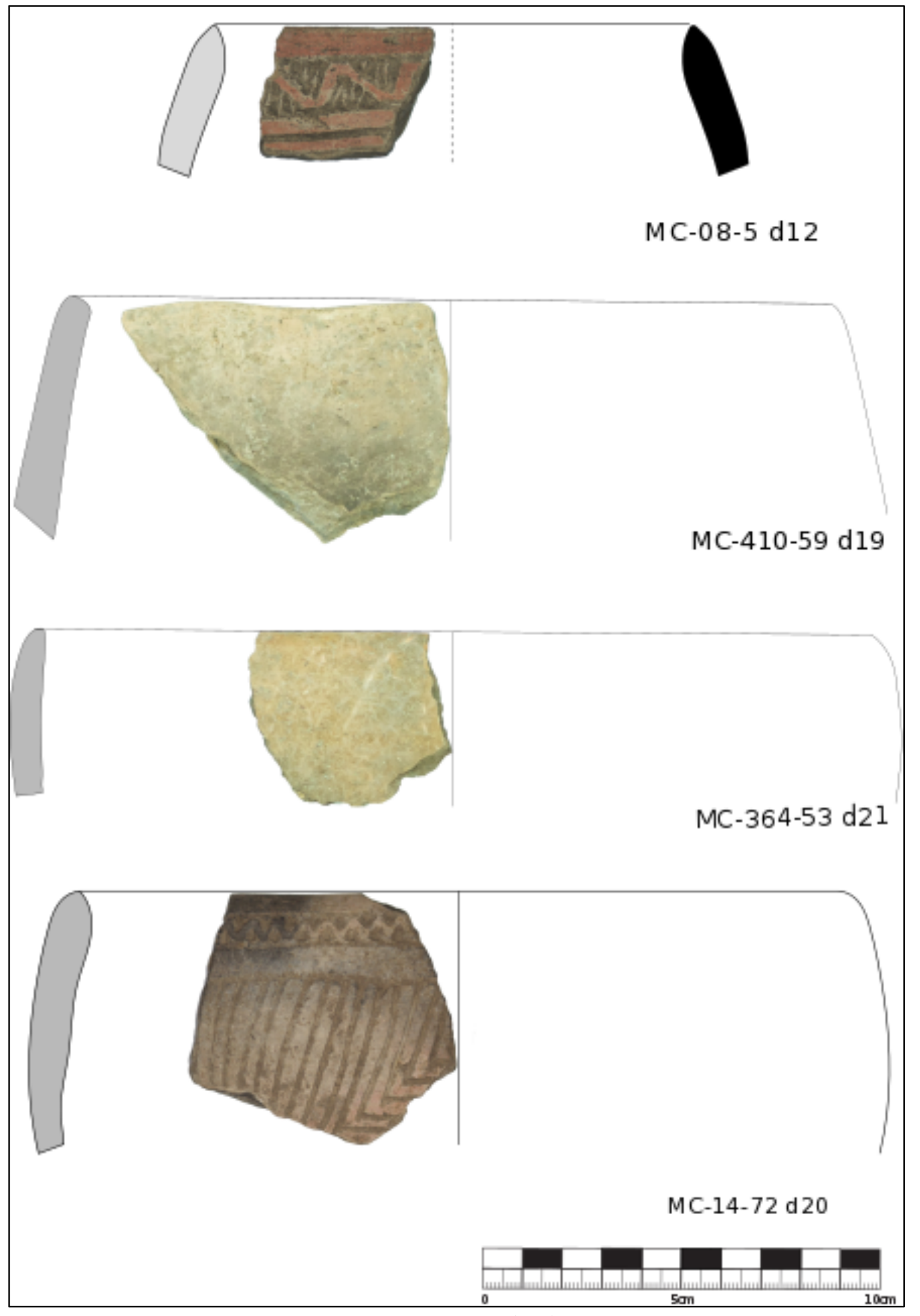

Imagem 100: Introvertidas diretas. 


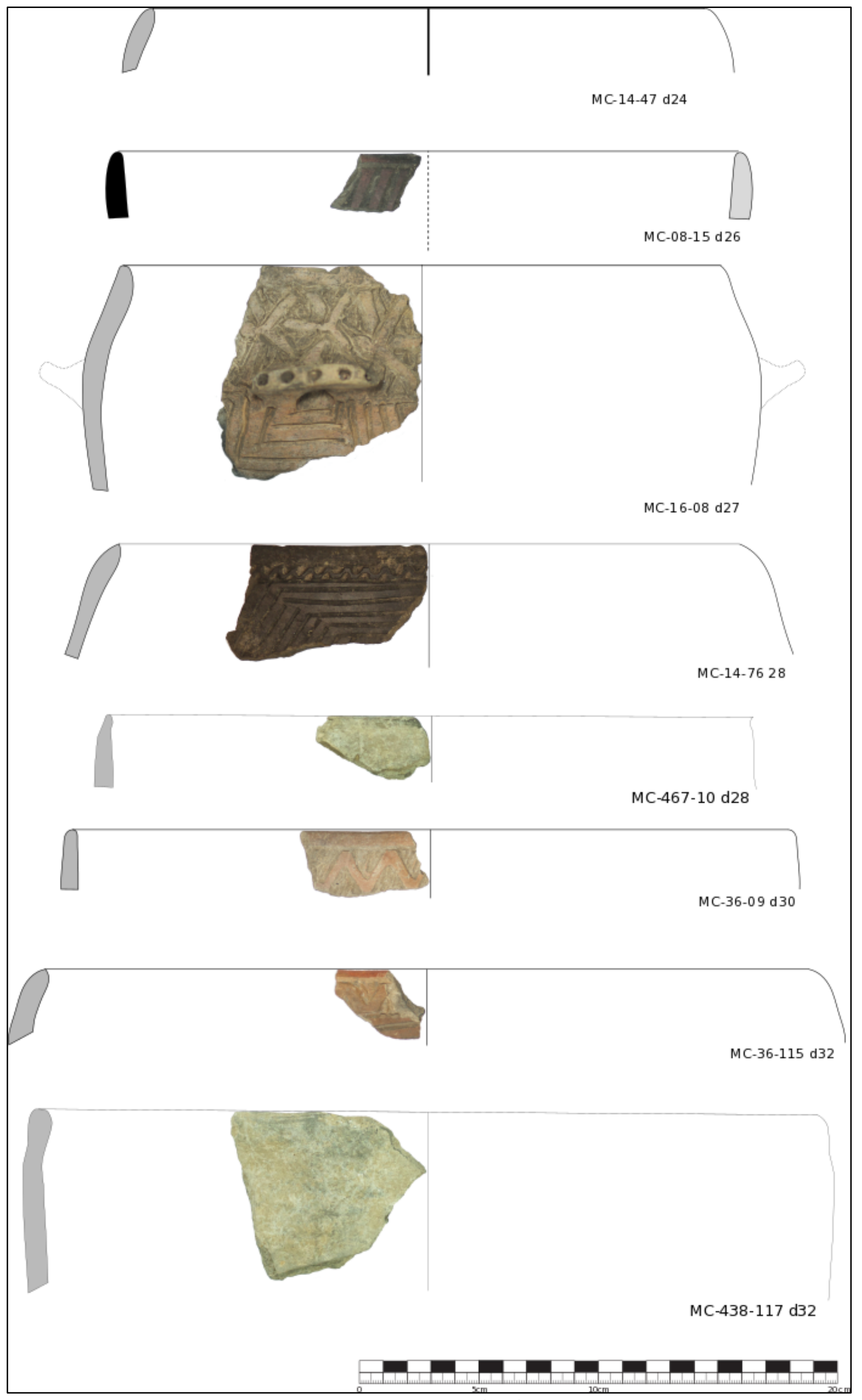




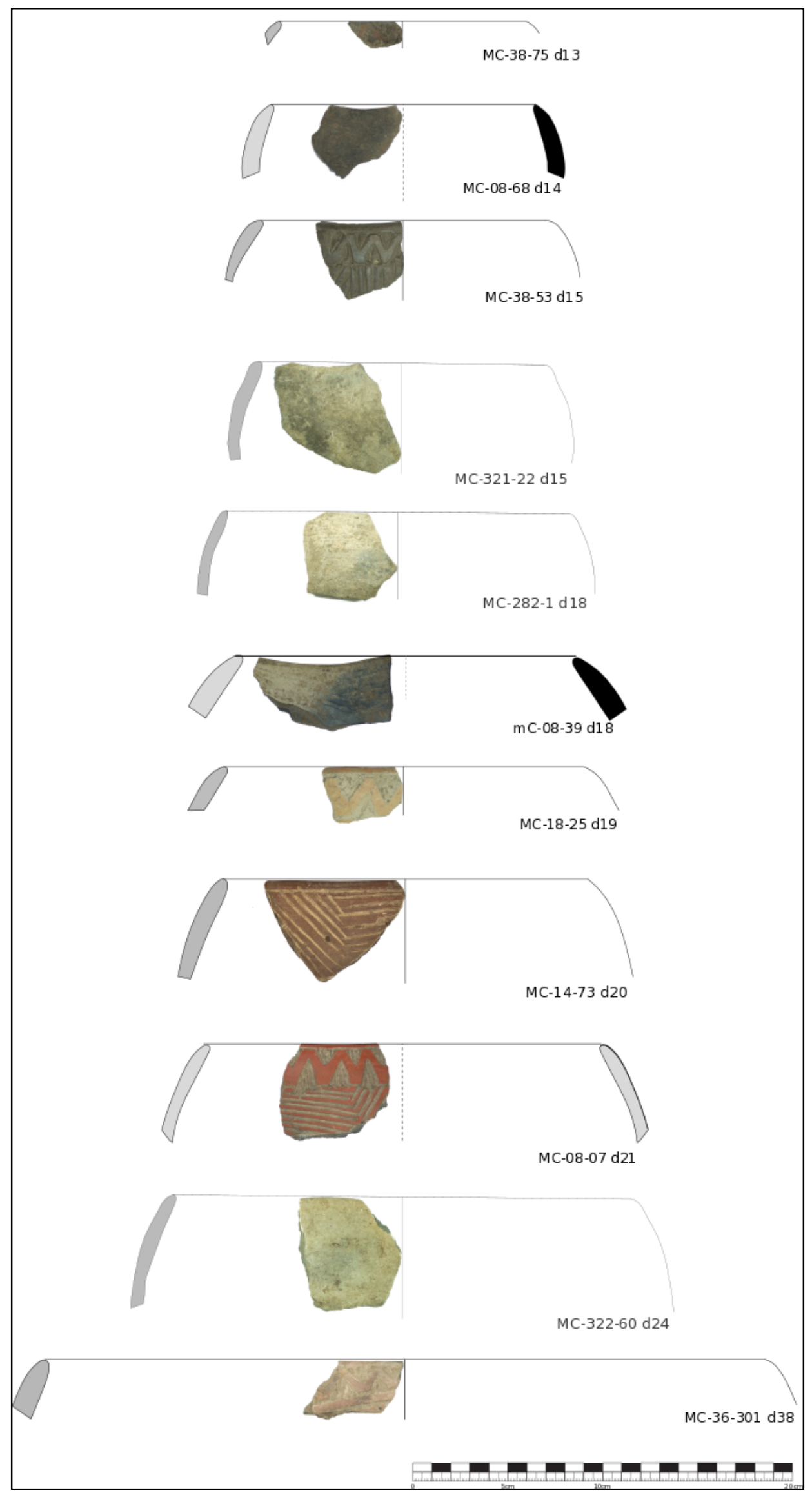

Imagem 102: Introvertidas restritas. 
Extrovertidas $n=27$

As bordas extrovertidas têm uma menor representação na amostra e são encontradas em 14,09\% $(n=32)$ das bordas. Tem o diâmetro de boca uma variação entre 6 e 42 centímetros. A inclinação restrita é rara $(6,06 \%)$ e é muito frequente a inclinação direta $(81,81 \%)$. Ocorrem também casos com inclinação restrita (9.09\%). As bordas extrovertidas possuem espessamento do tipo linear na maioria dos casos, e em 12,28\% dos indivíduos foi encontrado algum reforço e as dos tipo expandidas. O lábio em metade das ocorrências é arredondado (50\%), e em bordas com inclinação restrita ocorrem os do tipo plano (9,37\%). Esta variação indica a presença de potes de diferentes tamanhos, que poderiam estar ligados ao preparo e ao estoque de recursos. Neste tipo não foram encontrados indivíduos com alças, asas ou qualquer outro tipo de aplique (gráfico 27, tabela 32).

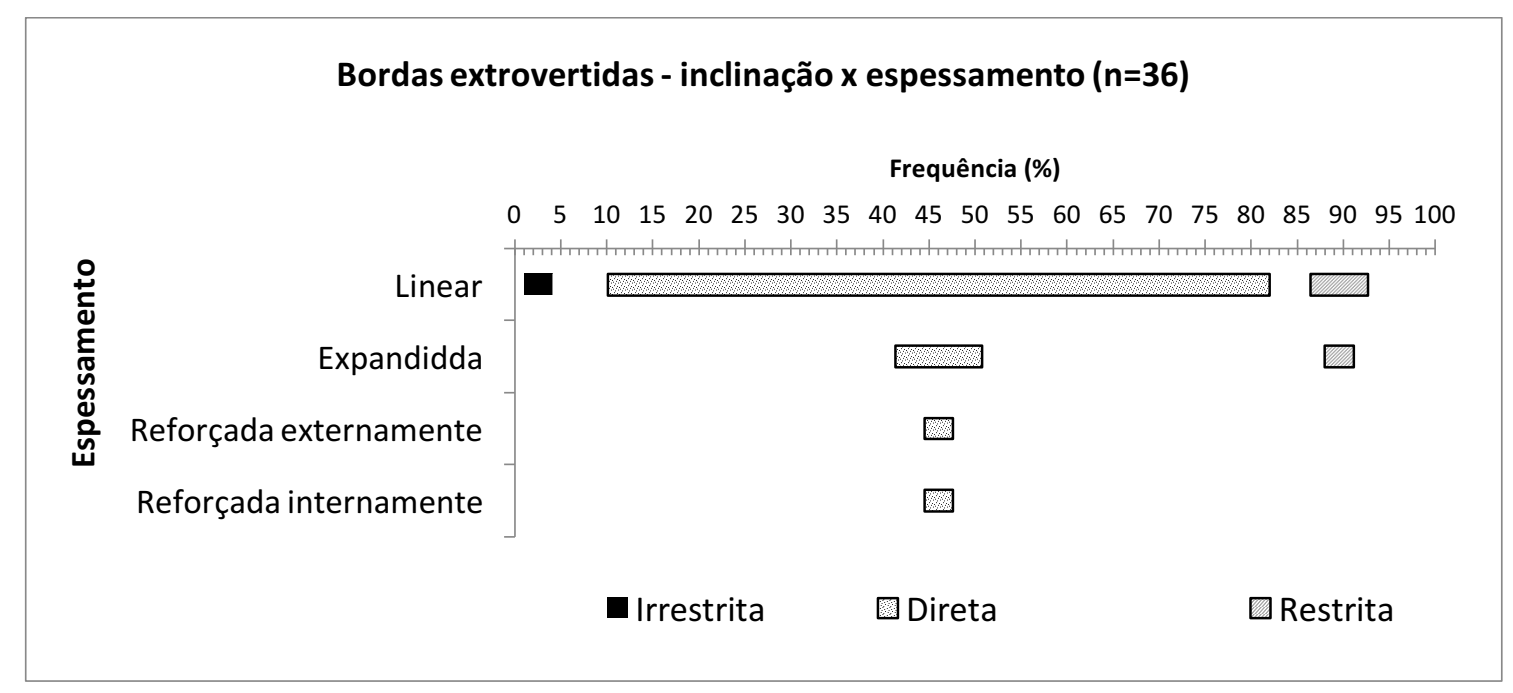

Gráfico 37: sequência seriada dos tipos de inclinação das bordas extrovertidas entre os tipos de espessamento.

Bordas extrovertidas
$\mathrm{n}=32$

Tabela 32: : quantidade e percentual dos tipos de inclinação das bordas extrovertidas entre os tipos de espessamento. 
A espessura dos fragmentos das bordas extrovertidas variou entre 4 e $14 \mathrm{~mm}$. Valores da progressão linear da espessura mínima e máxima dos fragmentos indicam um valor de r2 baixo $(0,45)$ que representa uma variação considerável na espessura das bordas extrovertidas, onde pouco ocorre o espessamento tipo expandido e os tipos reforçados (Gráfico 38).

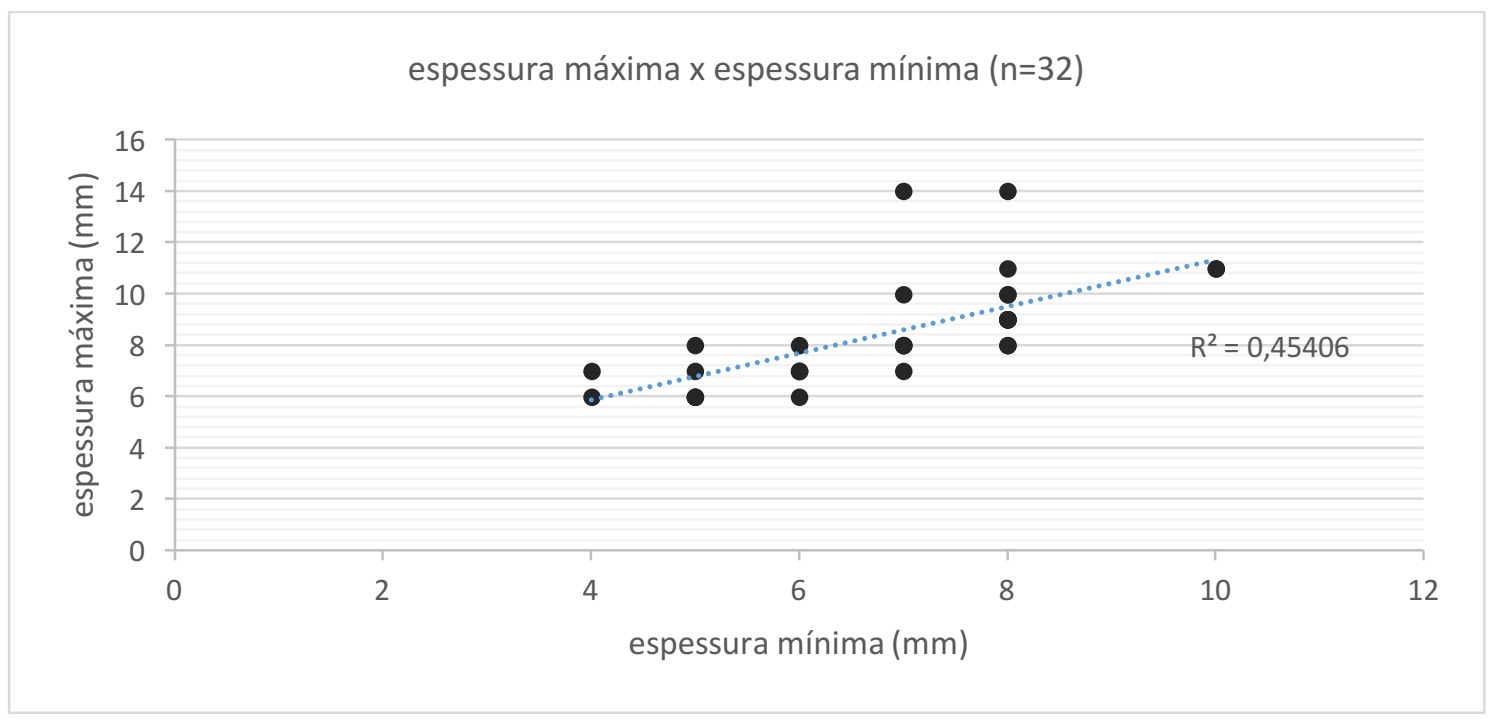

Gráfico 38: previsão linear da espessura mínima e máxima das bordas extrovertidas.

A maioria dos fragmentos de bordas extrovertidas ficou entre 7-9mm, ocorrendo em $62,5 \%$ dos casos. Os tipos mais finos ocorrem em $15,63 \%$ das evidências, à medida que os mais espessos são registrados em 21,88\% da amostra (Gráfico 39, tabela 33).

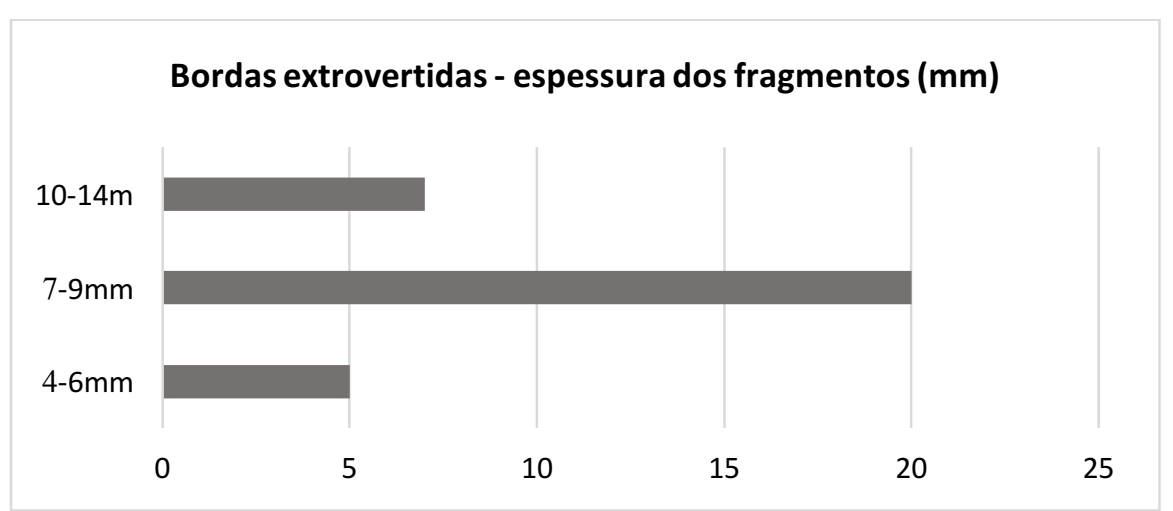

Gráfico 39: distribuição das bordas extrovertidas entre as espessuras mais frequentes

\begin{tabular}{lcc}
\hline Espessura & Quantidade & $\%$ \\
\hline $4-6 \mathrm{~mm}$ & 5 & 15,63 \\
$7-9 \mathrm{~mm}$ & 20 & 62,50 \\
$10-14 \mathrm{~m}$ & 7 & 21,88
\end{tabular}

Tabela 33: quantidade e porcentagem dos tipos de espessura das bordas extrovertidas. 
Os potes com inclinação irrestrita $(6,25 \%)$ ficaram entre os maiores diâmetros (50-56cm), enquanto os de inclinação restrita $(9,38 \%)$ ocorreram entre diâmetros menores (13-20cm). A grande maioria dos casos (84,37\%) ocorreu com a inclinação direta, entre $6-42 \mathrm{~cm}$ de diâmetro, mais frequentes entre $14-19 \mathrm{~cm}$ e entre $28-32 \mathrm{~cm}$. (Gráfico 40, tabela 34).

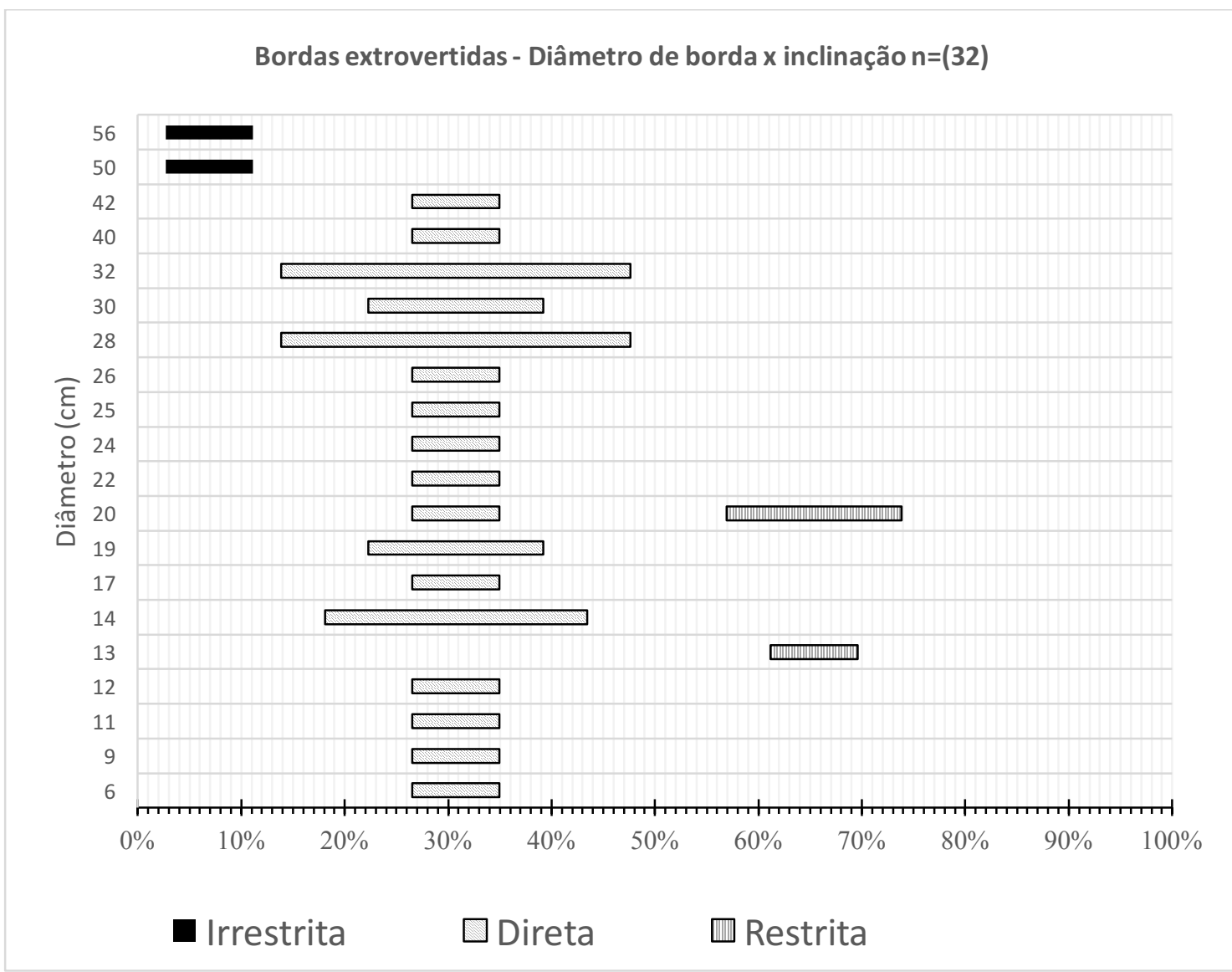

Gráfico 40: sequência seriada dos tipos de inclinação das bordas extrovertidas entre os diâmetros diagnosticados.

\begin{tabular}{|l|c|c|c|c|c|c|}
\hline diâmetro & Irrestrita & $\%$ & Direta & $\%$ & Restrita & $\%$ \\
\hline 6 & 0 & 0 & 1 & 3,125 & 0 & 0 \\
\hline 9 & 0 & 0 & 1 & 3,125 & 0 & 0 \\
\hline 11 & 0 & 0 & 1 & 3,125 & 0 & 0 \\
\hline 12 & 0 & 0 & 1 & 3,125 & 0 & 0 \\
\hline 13 & 0 & 0 & & 0 & 1 & 3,125 \\
\hline 14 & 0 & 0 & 3 & 9,375 & 0 & 0 \\
\hline 17 & 0 & 0 & 1 & 3,125 & 0 & 0 \\
\hline 19 & 0 & 0 & 2 & 6,25 & 0 & 0 \\
\hline 20 & 0 & 0 & 1 & 3,125 & 2 & 6,25 \\
\hline 22 & 0 & 0 & 1 & 3,125 & 0 & 0 \\
\hline 24 & 0 & 0 & 1 & 3,125 & 0 & 0 \\
\hline 25 & 0 & 0 & 1 & 3,125 & 0 & 0 \\
\hline 26 & 0 & 0 & 1 & 3,125 & 0 & 0 \\
\hline 28 & 0 & 0 & 4 & 12,5 & 0 & 0 \\
\hline
\end{tabular}




\begin{tabular}{|l|c|c|c|c|c|c|}
\hline 30 & 0 & 0 & 2 & 6,25 & 0 & 0 \\
\hline 32 & 0 & 0 & 4 & 12,5 & 0 & 0 \\
\hline 40 & 0 & 0 & 1 & 3,125 & 0 & 0 \\
\hline 42 & 0 & 0 & 1 & 3,125 & 0 & 0 \\
\hline 50 & 1 & 3,125 & 0 & 0 & 0 & 0 \\
\hline 56 & 1 & 3,125 & 0 & 0 & 0 & 0 \\
\hline
\end{tabular}

Tabela 34: : quantidade e porcentagem dos tipos de inclinação das bordas extrovertidas entre os diâmetros diagnosticados.

Apesar da baixa representatividade em relação a amostra de bordas, os tipos decorados das bordas extrovertidas $(n=14)$ aparecem entre praticamente todas as proporções de diâmetro, dos pequenos aos grandes, e são compostos de diferentes motivos, sendo o mais recorrente o Bacabal (42,85\%); seguido do Bacabal repetido (14,28\%); Bacabal espelhado (7,14\%); Bacabal 2 (\%7,14); Bacabal paralelo $(\% 7,14)$ e Incisões sem motivo reconhecido (21,42\%). Tipos de inclinação irrestritos não apresentaram decoração, enquanto tipos restritos sim (Gráfico 41, tabela 35).

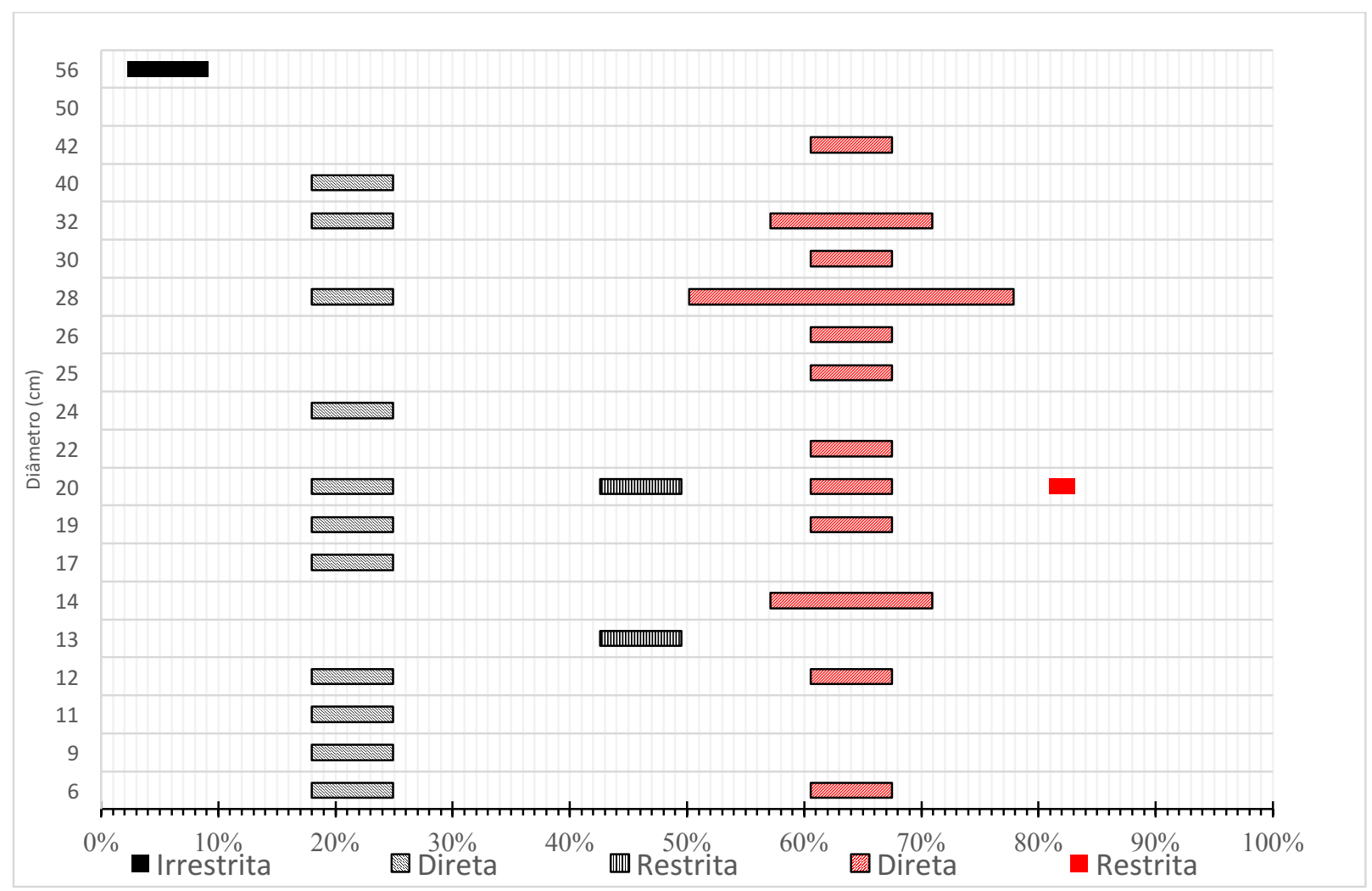

Gráfico 41: sequência seriada dos tipos de inclinação das bordas extrovertidas alisadas (em preto) e decoradas (em vermelho) entre os tipos de diâmetro reconhecidos. 
Extrovertidas $(n=32)$

\begin{tabular}{|c|c|c|c|c|c|c|c|c|c|c|c|}
\hline diâmetro & Irrestrita & $\%$ & Direta & $\%$ & Restrita & $\%$ & Direta & $\%$ & Restrita & $\%$ & Motivo \\
\hline 6 & 0 & 0,00 & 1 & 3,13 & 0 & 0,00 & 1 & 3,13 & 0 & 0 & Motivo NI \\
\hline 9 & 0 & 0,00 & 1 & 3,13 & 0 & 0,00 & 0 & 0,00 & 0 & 0 & \\
\hline 11 & 0 & 0,00 & 1 & 3,13 & 0 & 0,00 & 0 & 0,00 & 0 & 0 & \\
\hline 12 & 0 & 0,00 & 1 & 3,13 & 0 & 0,00 & 1 & 3,13 & 0 & 0 & Motivo NI \\
\hline 13 & 0 & 0,00 & 0 & 0,00 & 1 & 3,13 & 0 & 0,00 & 0 & 0 & \\
\hline 14 & 0 & 0,00 & 0 & 0,00 & 0 & 0,00 & 2 & 6,25 & 0 & 0 & Bacabal/Bacabal repetido \\
\hline 17 & 0 & 0,00 & 1 & 3,13 & 0 & 0,00 & 0 & 0,00 & 0 & 0 & \\
\hline 19 & 0 & 0,00 & 1 & 3,13 & & 0,00 & 1 & 3,13 & 0 & 0 & Bacabal \\
\hline 20 & 0 & 0,00 & 1 & 3,13 & 1 & 3,13 & 1 & 3,13 & 1 & 3,13 & Bacabal/Motivo NI \\
\hline 22 & 0 & 0,00 & 0 & 0,00 & 0 & 0,00 & 1 & 3,13 & 0 & 0 & Bacabal 2 \\
\hline 24 & 0 & 0,00 & 1 & 3,13 & 0 & 0,00 & 0 & 0,00 & 0 & 0 & \\
\hline 25 & 0 & 0,00 & 0 & 0,00 & 0 & 0,00 & 1 & 3,13 & 0 & 0 & Bacabal \\
\hline 26 & 0 & 0,00 & 0 & 0,00 & 0 & 0,00 & 1 & 3,13 & 0 & 0 & Bacabal \\
\hline 28 & 0 & 0,00 & 1 & 3,13 & 0 & 0,00 & 4 & 12,50 & 0 & 0 & $\begin{array}{l}\text { Bacabal/Bacabal espelhado/Bacabal } \\
\text { repetido }\end{array}$ \\
\hline 30 & 0 & 0,00 & 0 & 0,00 & 0 & 0,00 & 1 & 3,13 & 0 & 0 & Bacabal \\
\hline 32 & 0 & 0,00 & 1 & 3,13 & 0 & 0,00 & 2 & 6,25 & 0 & 0 & Bacabal paralelo/Bacabal repetido \\
\hline 40 & 0 & 0,00 & 1 & 3,13 & 0 & 0,00 & 0 & 0,00 & 0 & 0 & \\
\hline 42 & 0 & 0,00 & 0 & 0,00 & 0 & 0,00 & 1 & 3,13 & 0 & 0 & Bacabal \\
\hline 50 & 0 & 0,00 & 0 & 0,00 & 0 & 0,00 & 0 & 0,00 & 0 & 0 & \\
\hline 56 & 1 & 3,13 & 0 & 0,00 & 0 & 0,00 & 0 & 0,00 & 0 & 0 & \\
\hline
\end{tabular}

Tabela 35: quantidade e porcentagem dos tipos de inclinação das bordas extrovertidas alisadas e decoradas entre os tipos de diametro reconhecidos 


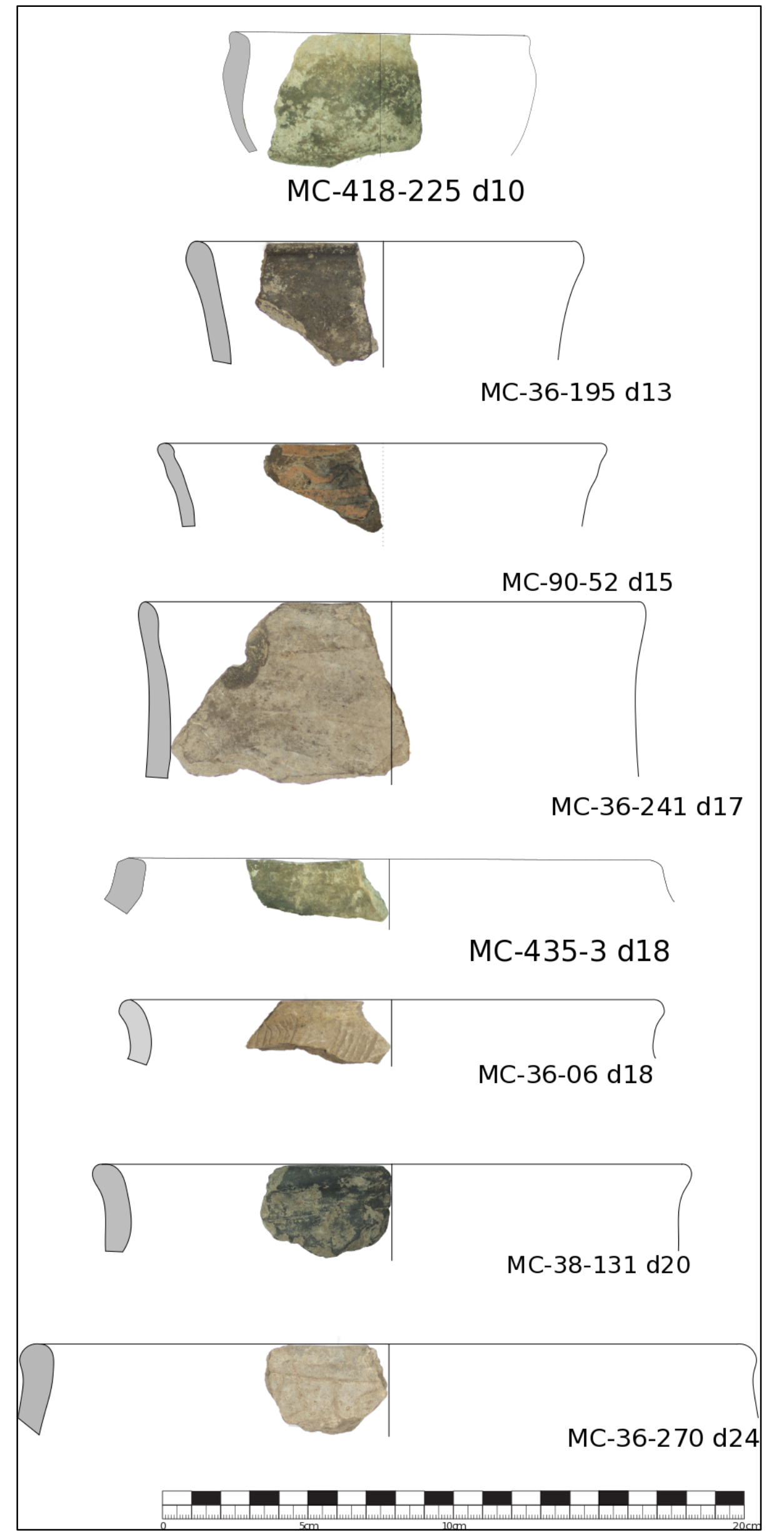

Imagem 103: bordas extrovertidas. 


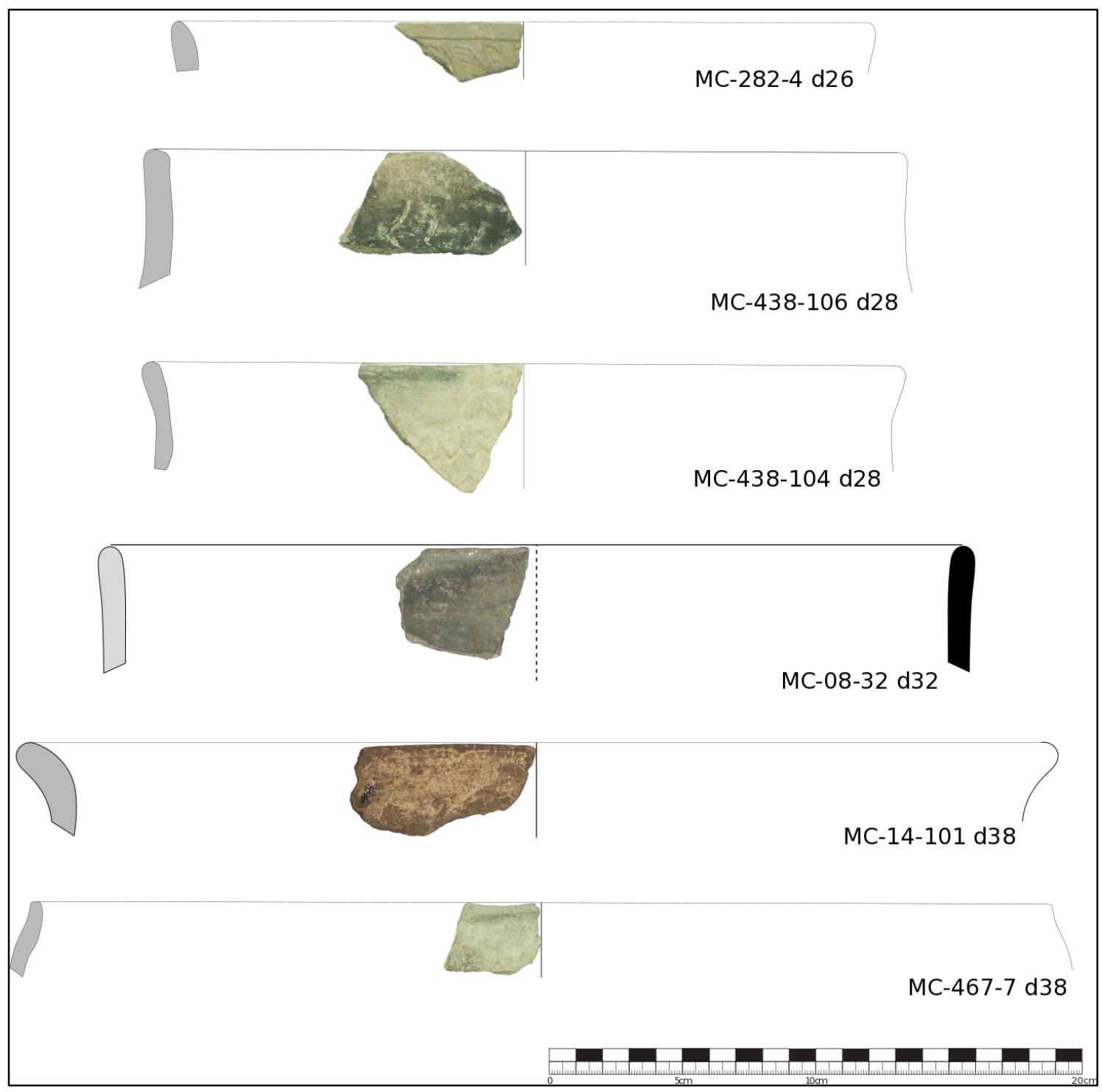

Imagem 104: bordas extrovertidas.

Asas e alças

Asas e alças são recorrentes no contexto da fase bacabal. As alças possuem decoração incisa e ponteada em muitos casos, enquanto as asas ocorrem desde as simples até casos ponteados, incisos, zoomórficos e antropomórficos (imagens 80-83). 


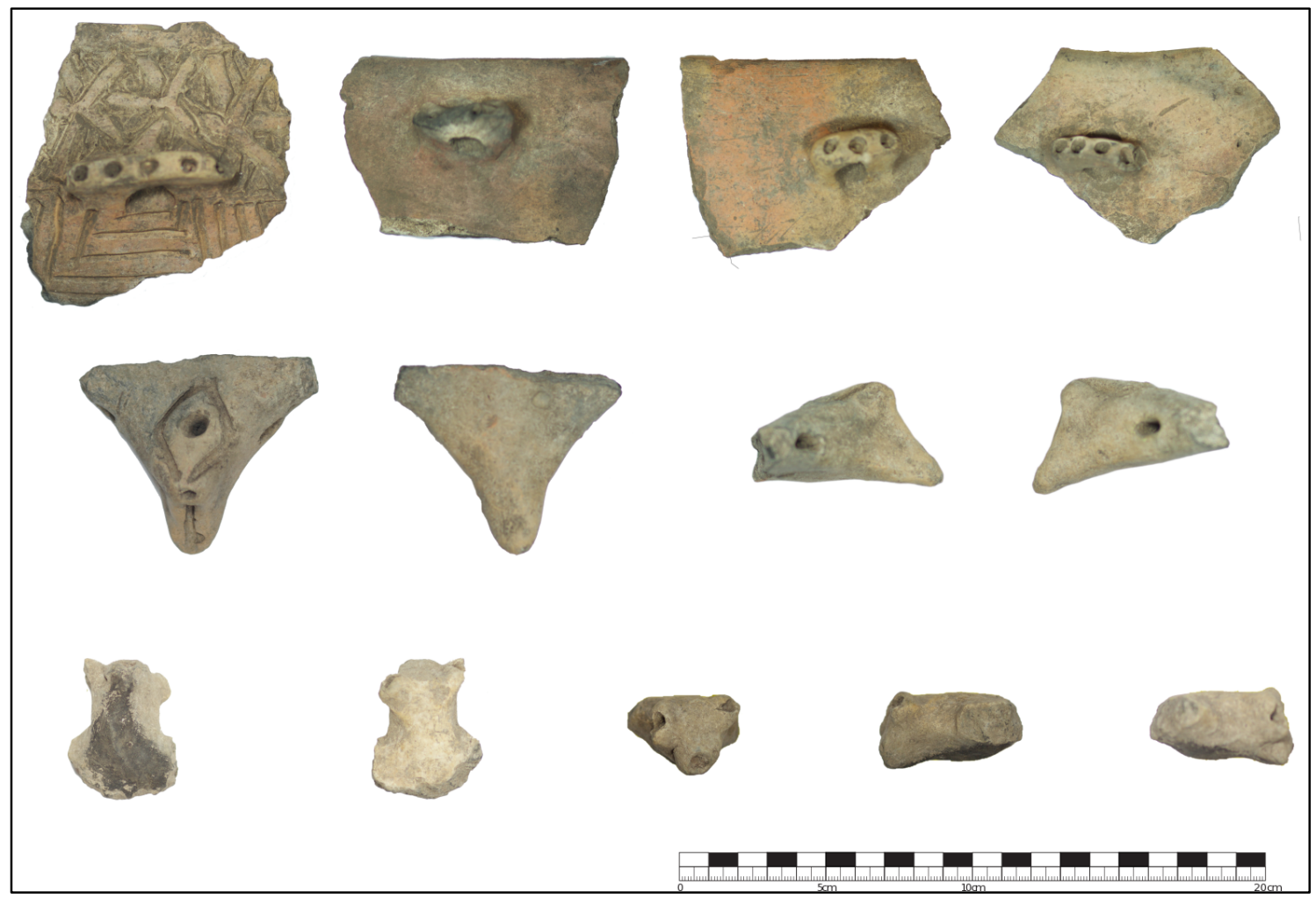

Imagem 105: acima asas ponteadas e incisas, ao centro asa antropomorfa, abaixo asa ponteada. 


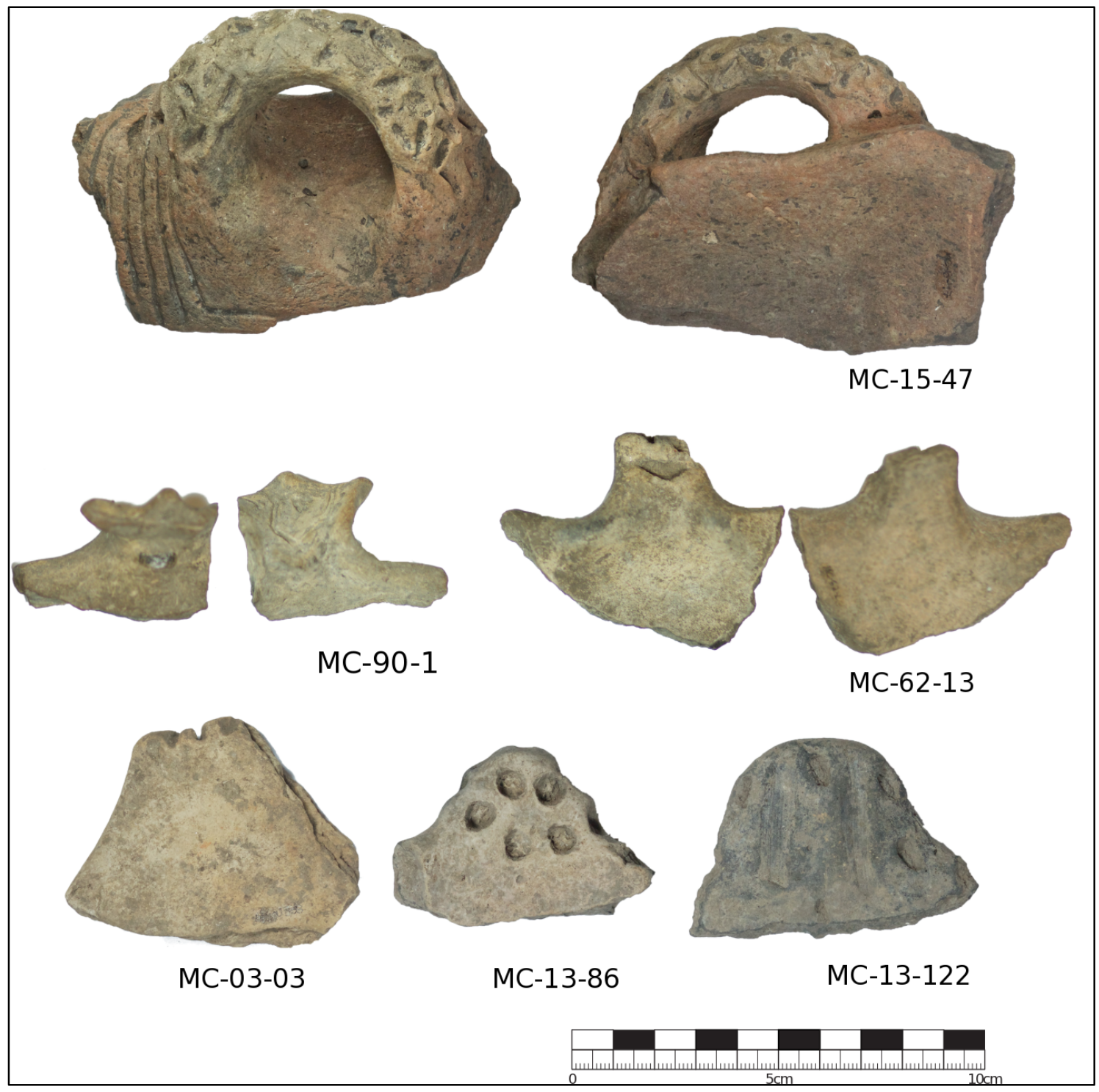

Imagem 106: acima asa inciso e ponteada, abaixo asas incisas e ponteadas. 

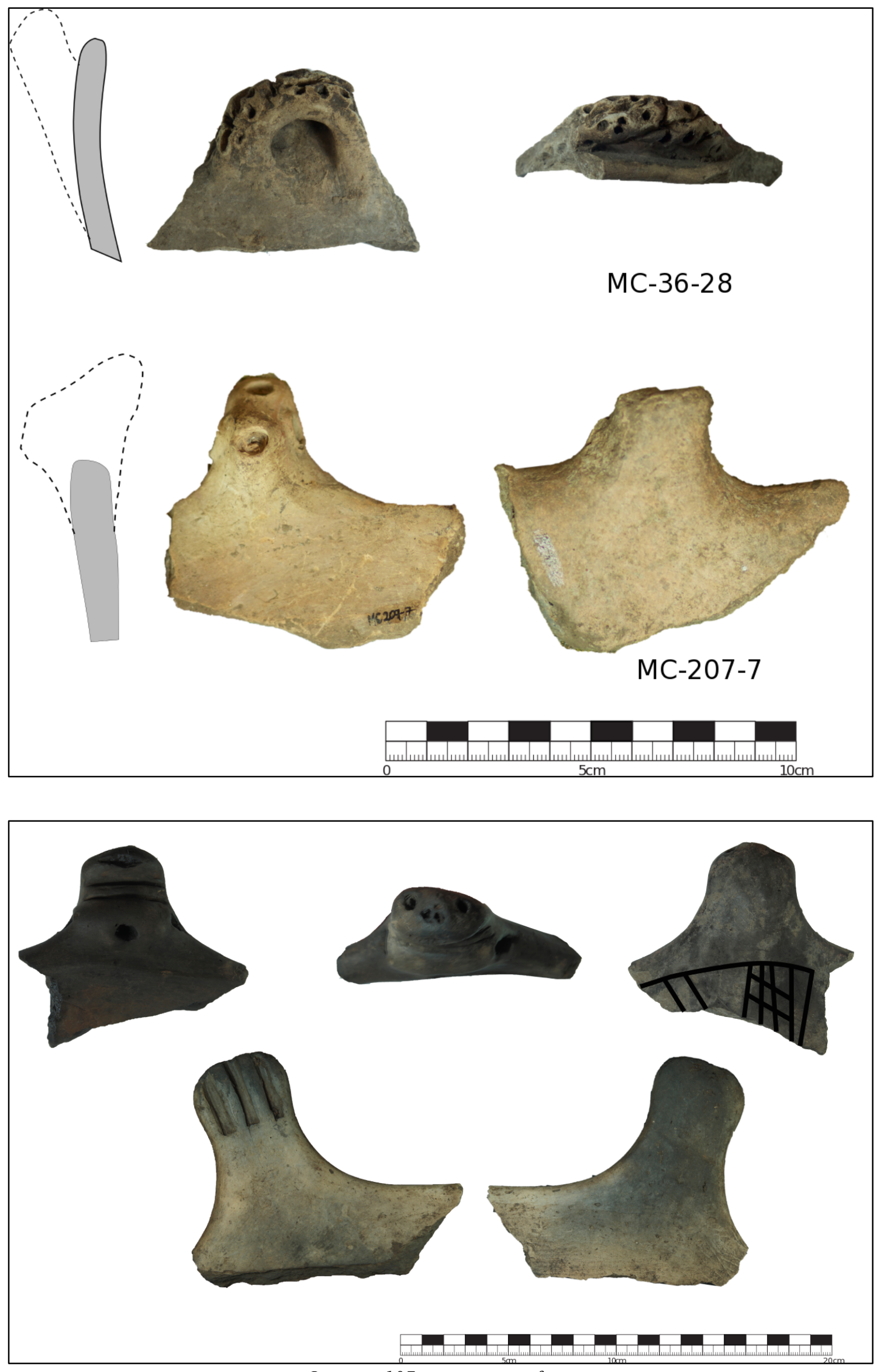

Imagem 107: asas zoomorfas. 


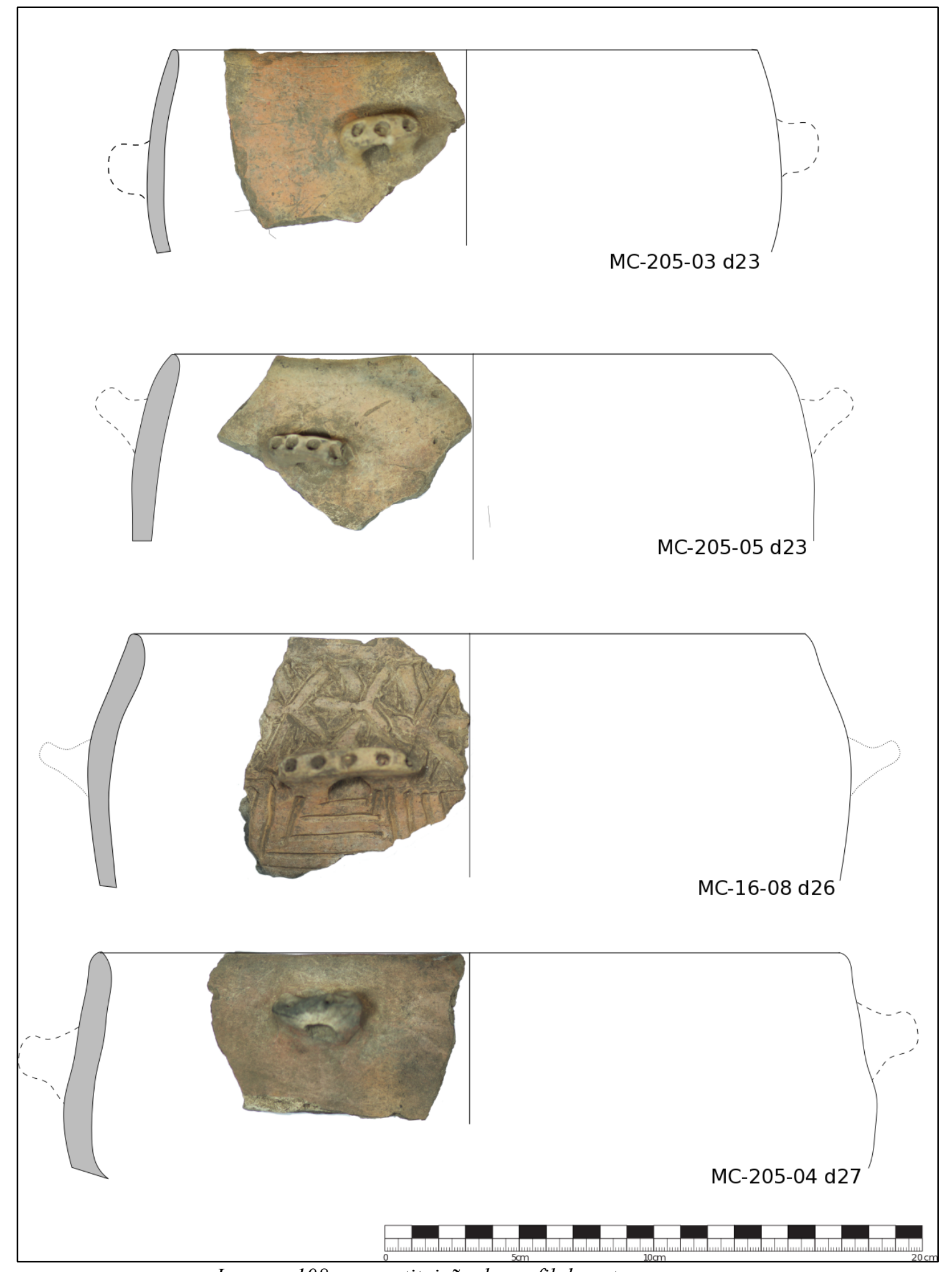

Imagem 108: reconstituição do perfil de potes com asas. 
Bases

Na classificação feita por Miller as bases dos potes seriam simples, em sua maioria biplanas, ocorrendo casos com bases levemente convexas. Nas nossas análises não houve nenhuma variação identificada entre os tipos de bases. Em todos os casos, quando identificadas, foram todas classificadas como biplanas e com ângulos de junção a parede variando entre $10^{\circ}$ e $88^{\circ}$. Talvez o problema possa se classificatório, contudo como ocorrem outros tipos, estes devem ocorrer de maneira mais discreta no registro e infelizmente não foram localizados em nossas amostragens.

Miller alerta ao fato de que os potes teriam sido erguidos sobre esteiras, com vários tipos de urdiduras de fibras como o periperiaçu e a taboa. Em nossa discussão sugerimos que tais impressões poderiam apresentar variabilidade e além dos suportes propostos por Miller, poderia também apresentar outros tipos de impressão como sabugo e espiga de milho, cestaria e tecidos.

\begin{tabular}{lcc}
\hline & Quantidade & $\%$ \\
\hline alisado & 29 & 27,10 \\
\hline polido & 4 & 3,74 \\
\hline brunido & 1 & 0,93 \\
\hline impressão tecido & 4 & 3,74 \\
\hline escovado sabugo & 66 & 61,68 \\
\hline escovado espiga & 3 & 2,80 \\
\hline
\end{tabular}

Tabela 36: tipos de tratamento de superficie das bases.

Além de apresentar este índice relacionado a variabilidade do tratamento de superfície e o alto índice de tipos decoradas, as bases tem como característica a variação da espessura máxima e mínima $(\mathrm{r} 2=0,52)$ e uma frequência considerável de queima com redução da face interna $(25,23 \%)$. 


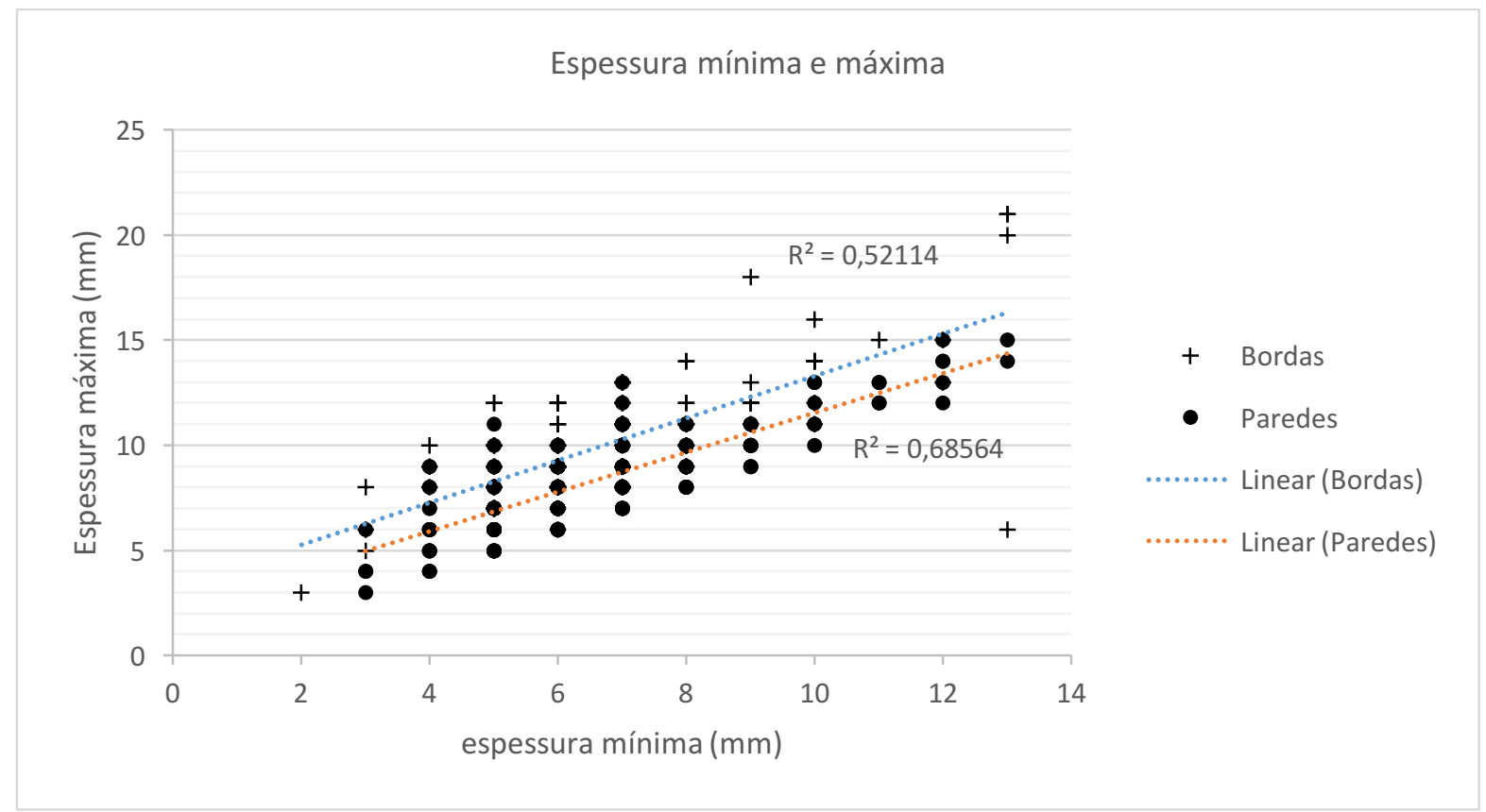

Gráfico 42: espessura mínima e máxima de bordas e paredes com impressões

\begin{tabular}{|c|c|c|c|c|c|}
\hline Bordas $n=107$ & Quant. & $\%$ & Paredes com impressão $(n=235)$ & Quant & $\%$ \\
\hline Oxidante & 27 & 25,23 & Oxidante & 67 & 28,51 \\
\hline Núcleo reduzido & 19 & 17,76 & Núcleo reduzido & 24 & 10,21 \\
\hline Reduzida & 30 & 28,04 & Reduzida & 48 & 20,43 \\
\hline Reduzida face interna, oxidante face externa & 4 & 3,74 & Reduzida face interna, oxidante face externa & 8 & 3,40 \\
\hline Oxidante face interna, reduzida face externa & 27 & 25,23 & Oxidante face interna, reduzida face externa & 90 & 38,30 \\
\hline
\end{tabular}

Tabela 37: tipo de queima entre as bordas e as paredes com impressão

Ao remetermos aos fragmentos não que foram classificados como base, mas que apresentam marcas de impressão, estes trazem características muito semelhantes as bordas, como a diferença na espessura $(\mathrm{r} 2=0,68)$ e queima, que apresenta alto índice de oxidação na parte interna.

Quem sabe as bases planas encontradas em grande quantidade no sítio poderiam estar relacionadas a alta incidência de trempes no contexto arqueológico da fase Bacabal.

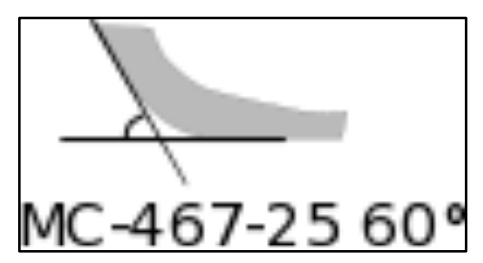

Imagem 109: procedimento para a coleta do ângulo de saida da parede na bases. 


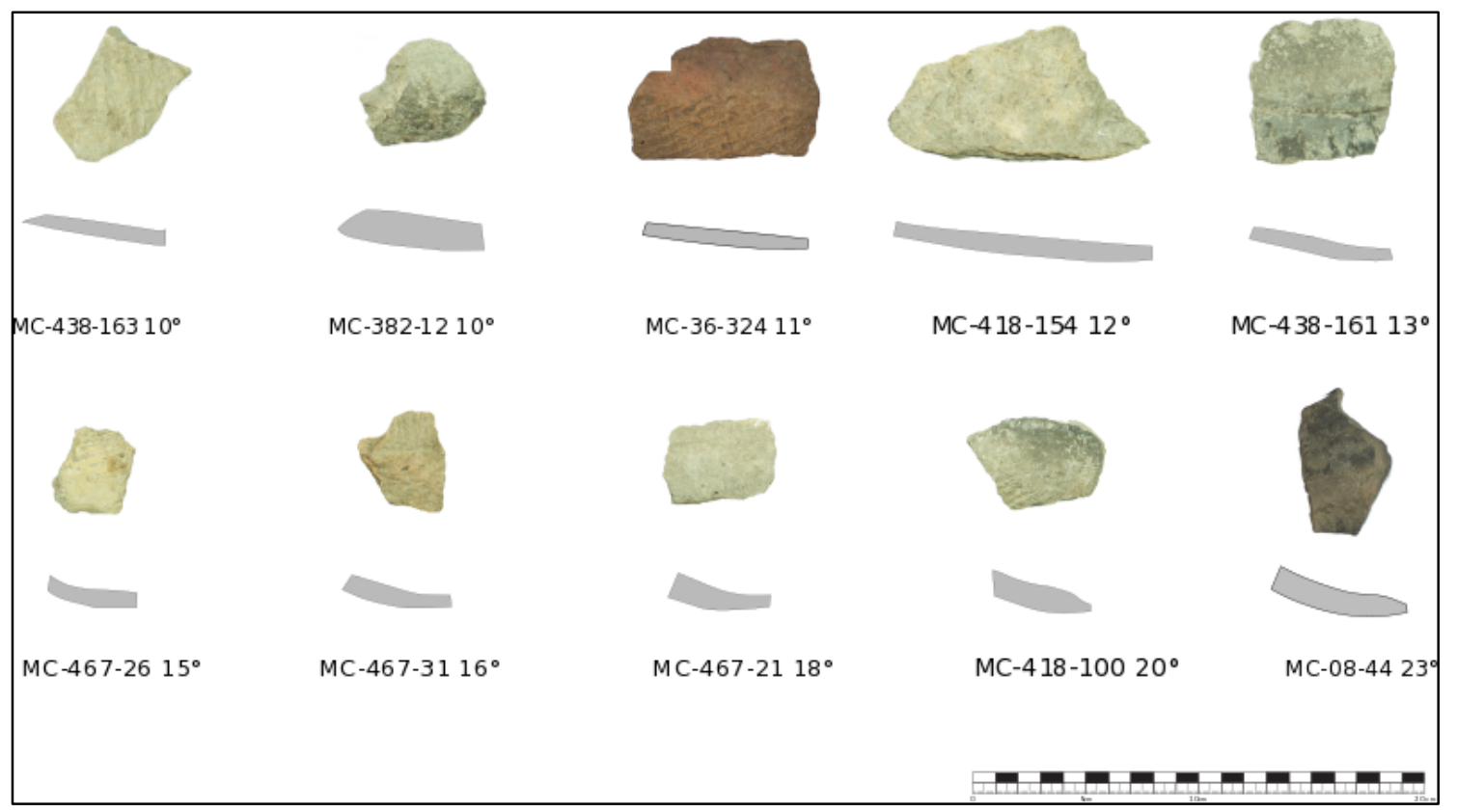

Imagem 110: bordas $10^{\circ}-23^{\circ}$ 


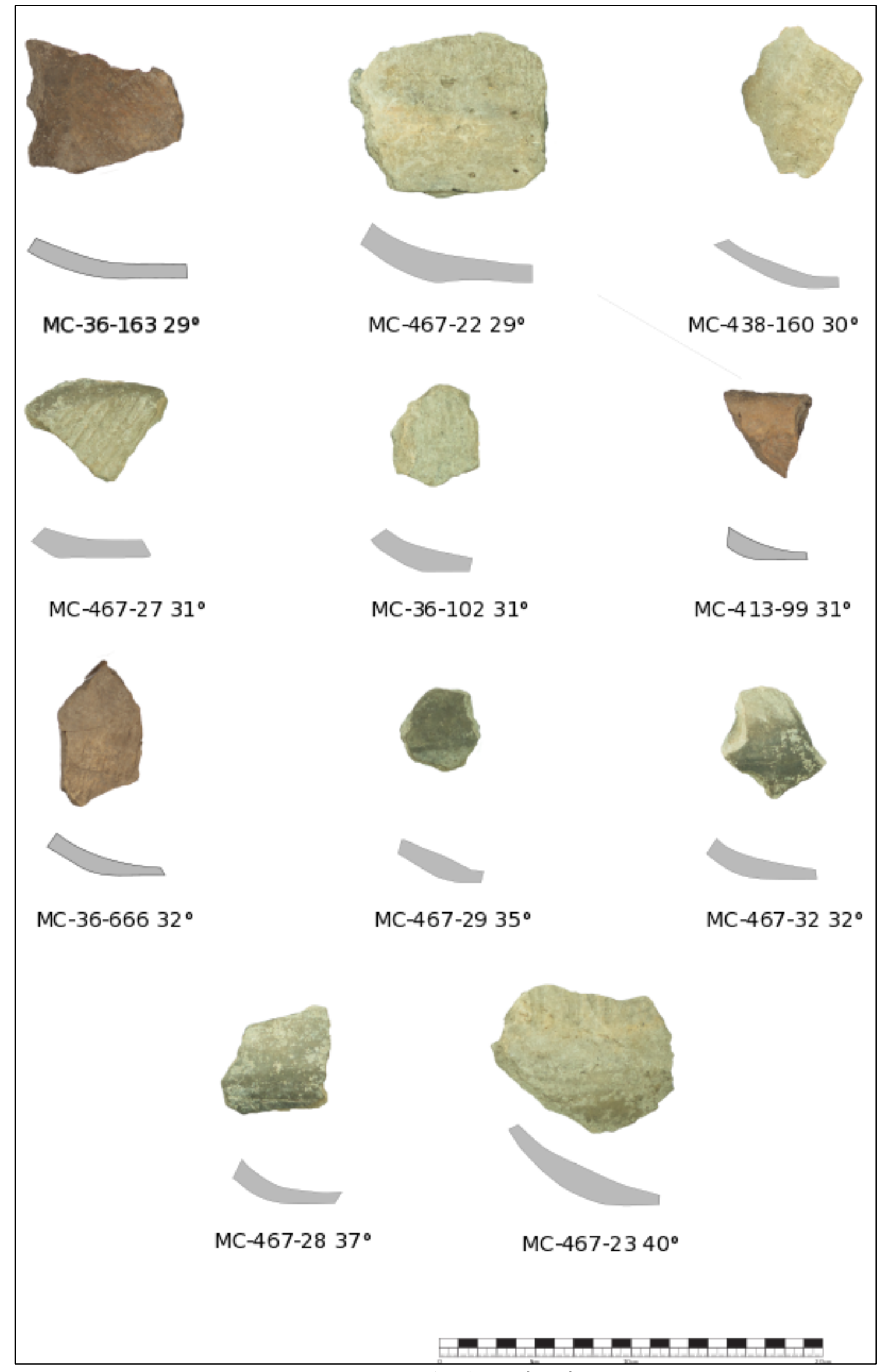

Imagem 111: bordas, $29^{\circ}-40^{\circ}$ 


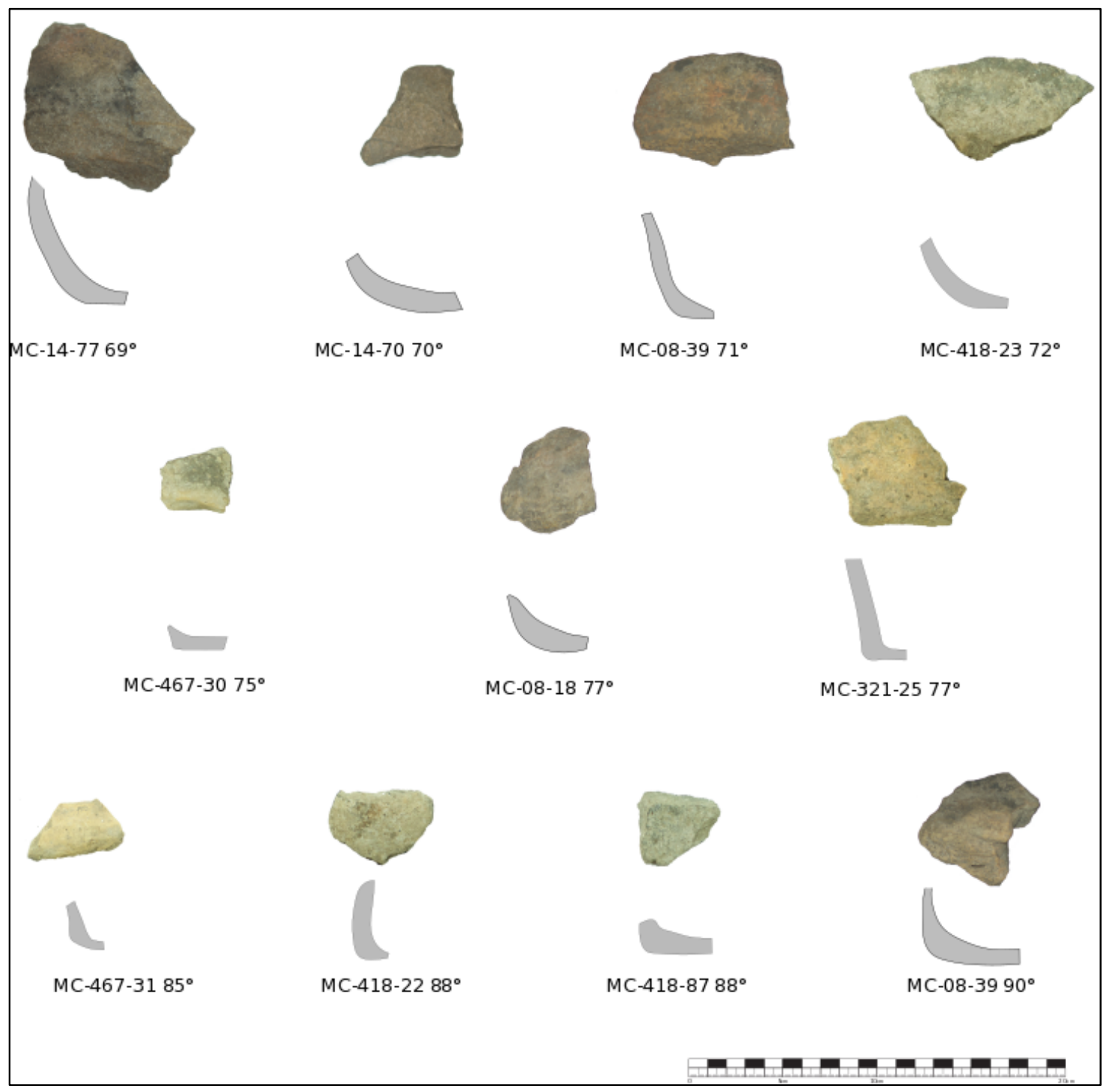

Imagem 112: bordas, $69^{\circ}-90^{\circ}$. 


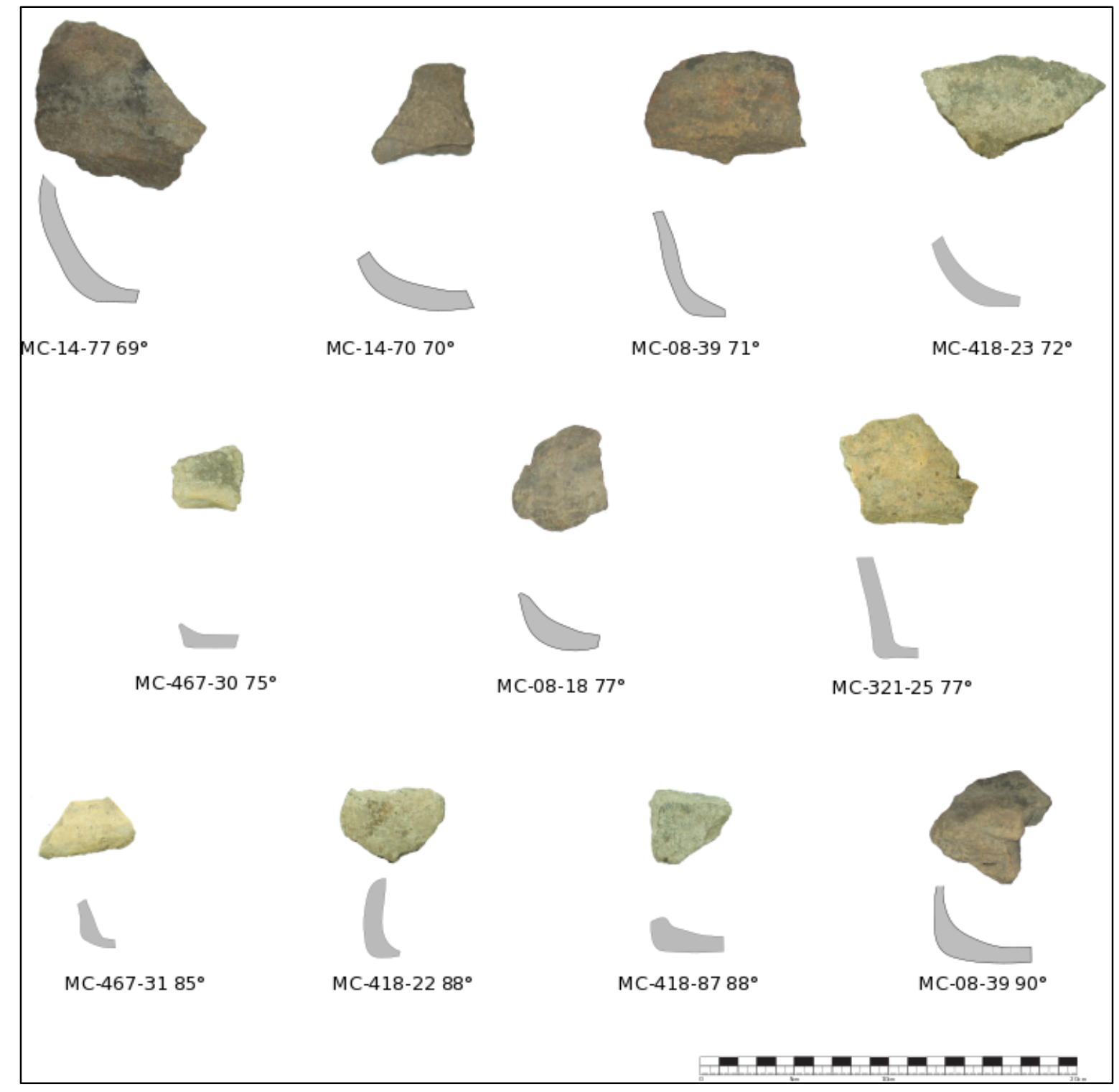

Imagem 113: bordas com angulo reto. 


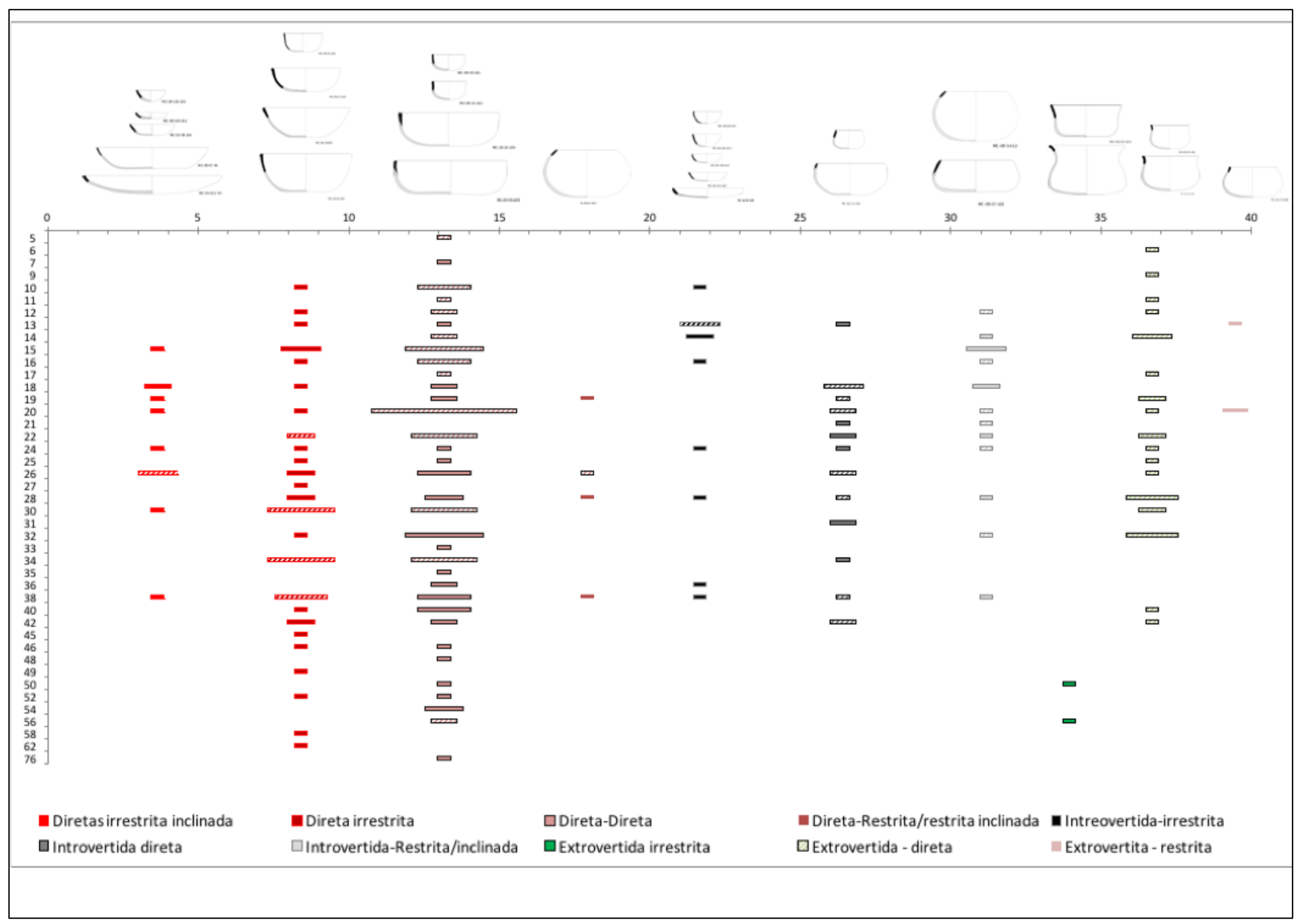

Imagem 114: Sequência seriada dos tipos morfológicos inspirados nas bordas divididas por tipo e inclinação, distribuidas pelo diâmetro de boca. As séries hachuradas indicam que ocorrem tipos decorados. 


\section{Trempes}

Trempes fragmentadas são recorrentes durante a análise de $90 \%$ dos números de proveniência registrados nas escavações e classificados como fase Bacabal. Trempes são entendidas como suportes para estabilizar panelas acima do fogo. Até hoje trempes são usadas por povos indígenas, um exemplo próximo ao rio Guaporé está entre os Enawene nawe, nação falante de língua do tronco Arawak (Imagem 118).

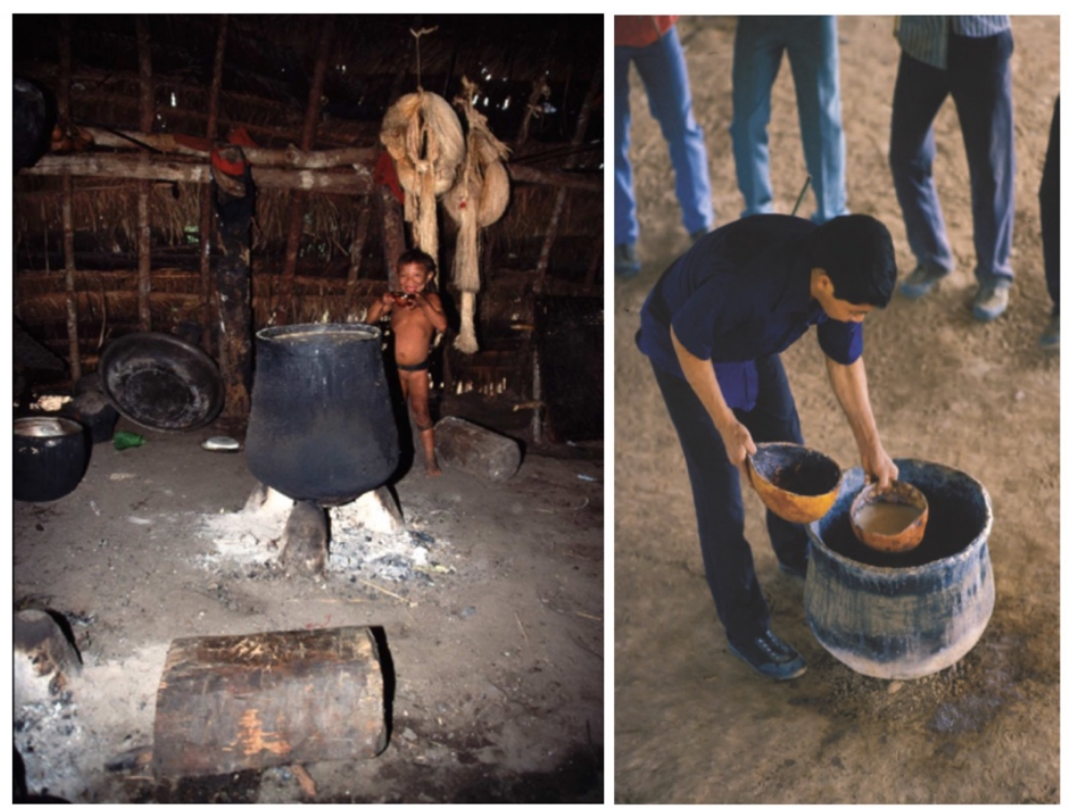

Figura 1. Recipiente (paiti) en el centro de la casa de reunión; colección Ph. Erikson, 1993

Imagem 115: Panelas grandes para cozer bebidas fermentadas registradas entre Enawenenawe (Gerard,s.d.), a direita, entre indígenas falantes de língua do troco Pano na fronteira do Brasil com o Acre (Erikson, 1993). Em ambos os casos os potes estão escorados por trempes.

Ao compararmos o contexto de ocorrência de deste tipo de artefato durante a fase Bacabal com o cenário observado no alto rio Madeira (Almeida 2013; Zuse 2014) e nos Llanos de Mojos (Betancourt 2011, 2016), no rio Guaporé é muito alta a incidência de trempes $(\mathrm{N}=32)$. Para se ter uma ideia, em meio a mais de 500,000 fragmentos cerâmicos escavados em diferentes sítios arqueológicos no alto rio Madeira, um pouco mais de meia dúzia de fragmentos são relacionadas do tipo trempe (Scientia 2013, Zuse 2014). 
De maneira especulativa, poderíamos supor que este alto índice de trempes estaria associado ao grande número de bases biplanas e pela escassez de rochas ao entorno do território ocupado pela gente responsável pela formação do registro arqueológico classificado como fase Bacabal.

As trempes foram confeccionadas com uma pasta diferente dos potes. Aqui o cauxí ocorre em menos abundância e vazios irregulares e agrupados não foram encontrados. Os vestígios ocorrem em diferentes tamanhos, desde aquelas mais fragmentadas até as mais conservadas. Em $72 \%$ dos casos o antiplástico das trempes é diferente daquele dos potes, com menos ocorrência de cauxí e ausência de vazios, irregulares e agrupados. A queima também é diferenciada. Grande parte dos indivíduos $(n=22)$ teve uma queima incompleta, com a parte interna dos fragmentos ainda crua. Uma pequena porção $(n=5)$ apresentou queima redutora e estas trempes teriam indícios de serem ocas, tendo outro processo de manufatura diferente das mais comuns no registro. Em poucos casos ocorreu tratamento de superfície como polimento $(\mathrm{n}=2)$, incisões largas $(n=3)$ e incisões finas $(n=2)$.

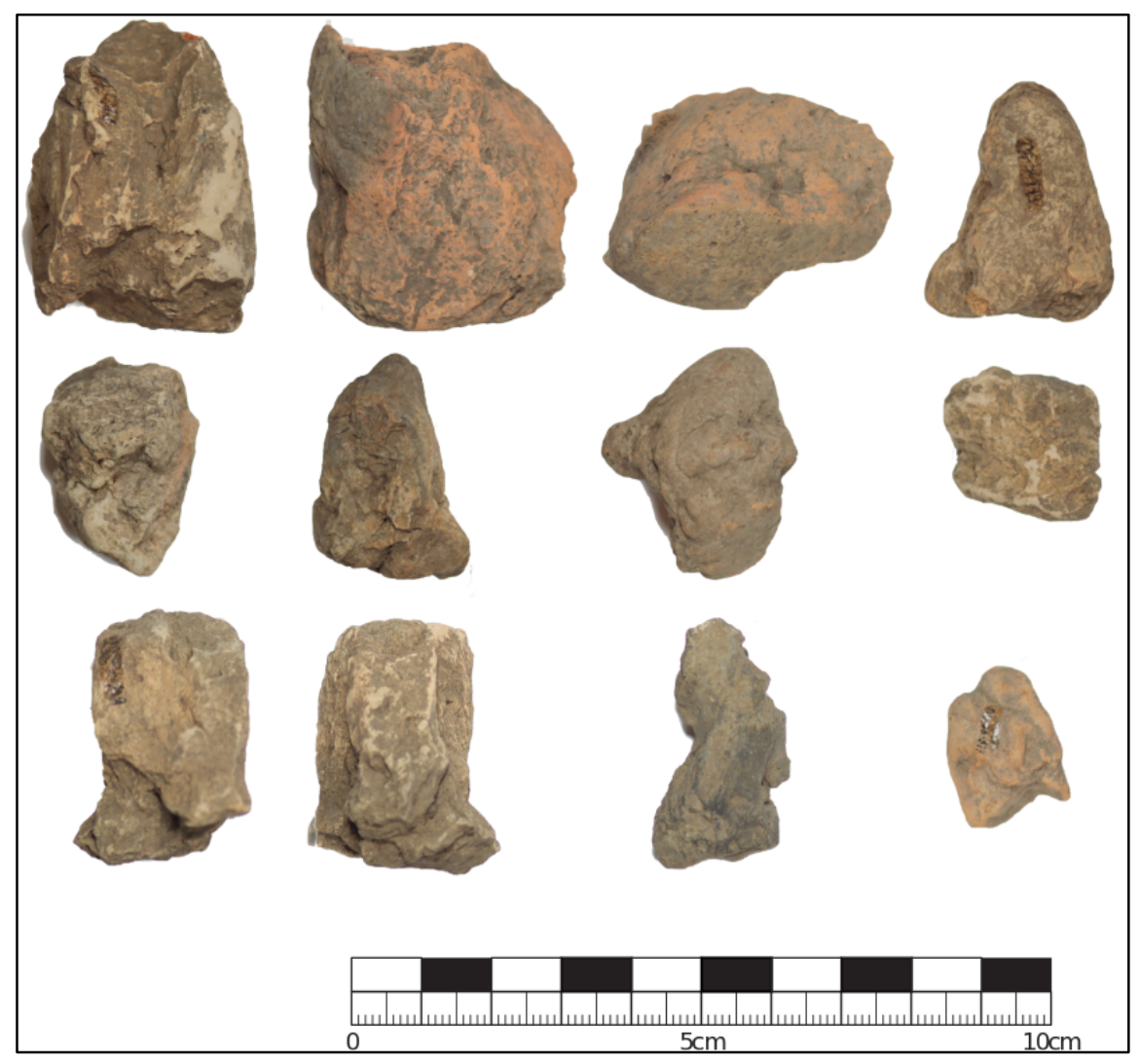

Imagem 116: trempes bem fragmentadas 


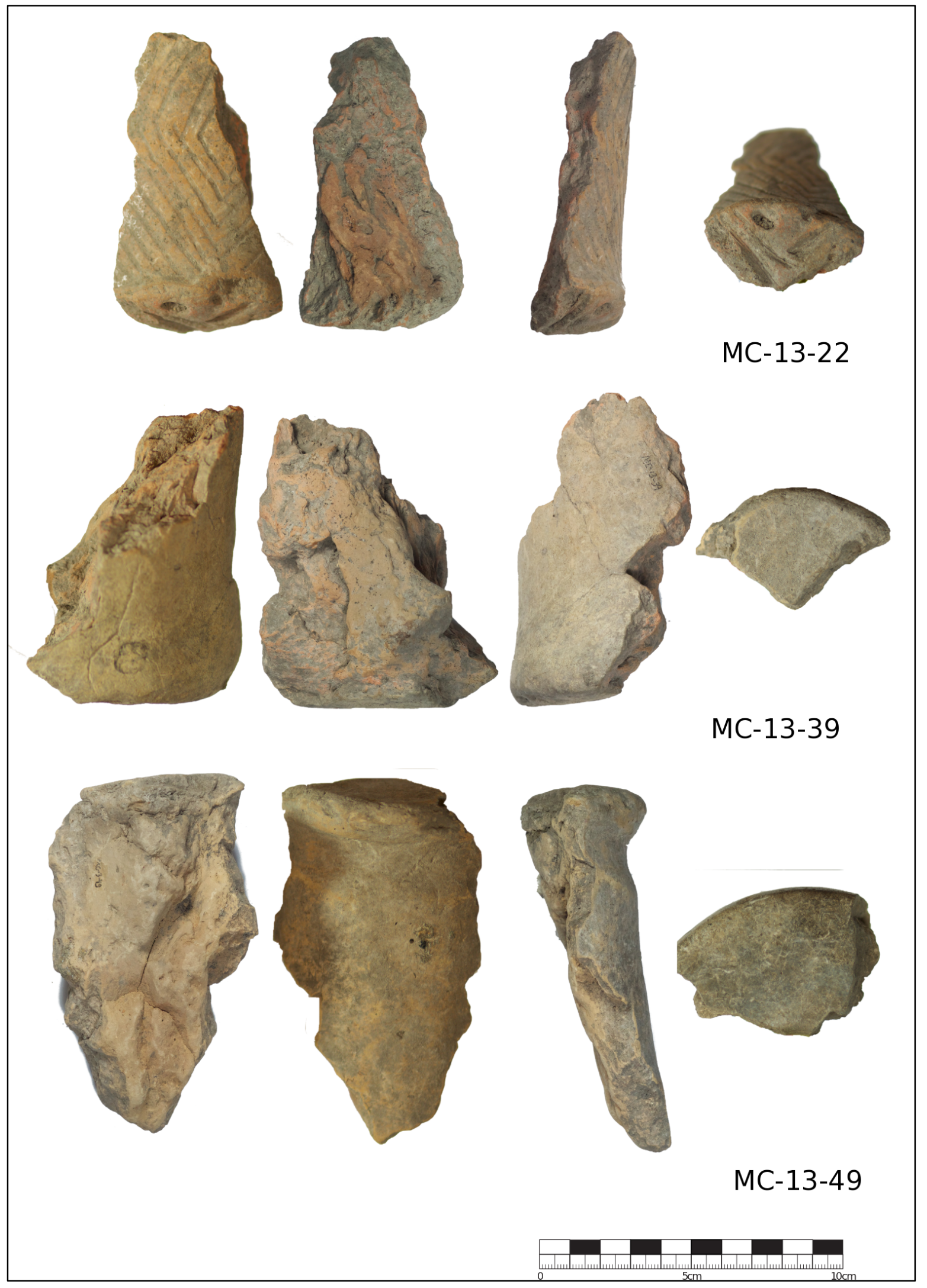

Imagem 117: acima trempe decorada com motivo Bacabal Losangular, ao centro com superfície alisada e abaixo polida. Nota-se a queima identificada como incompleta nestes exemplares. 


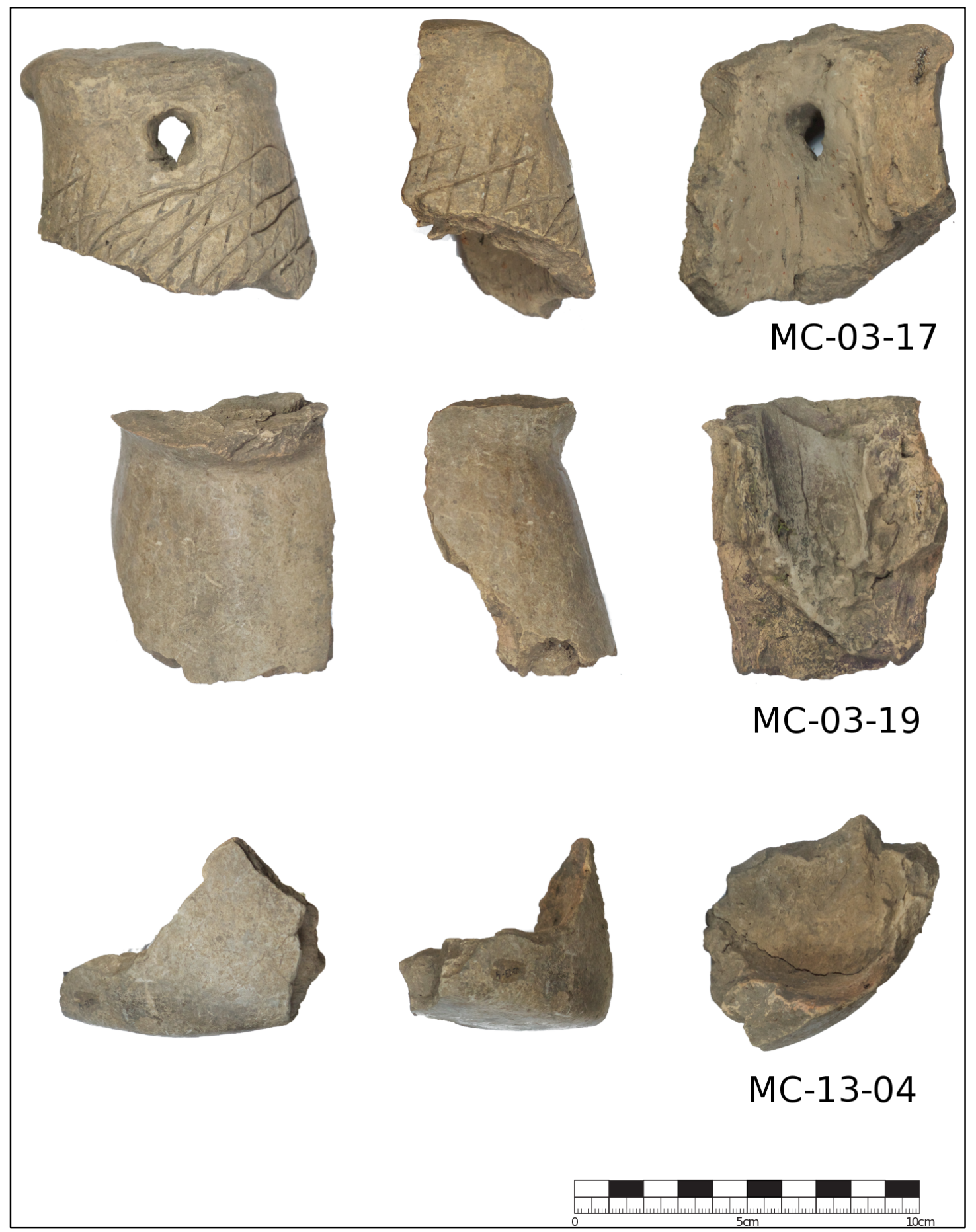

Imagem 118: acima trempe decorada com o motivo Inciso não-cruzado, ao centro e abaixo trempes com a queima reduzida completa, percebe-se que estes exemplos tem seu interior oco. 

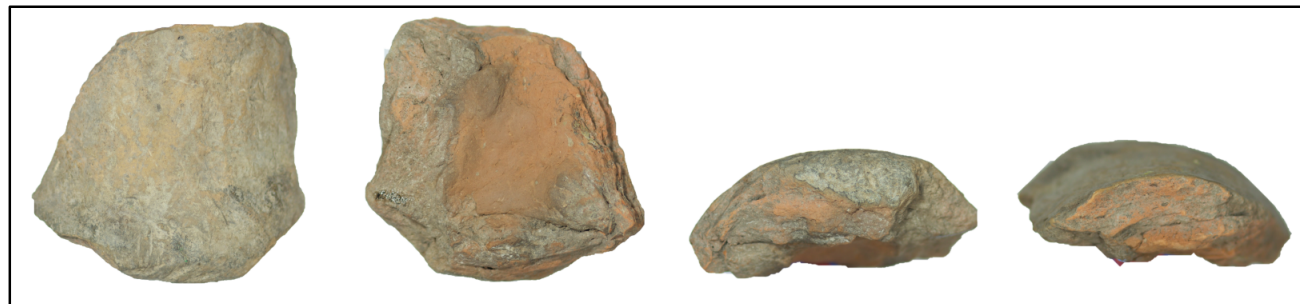

MC-18-36
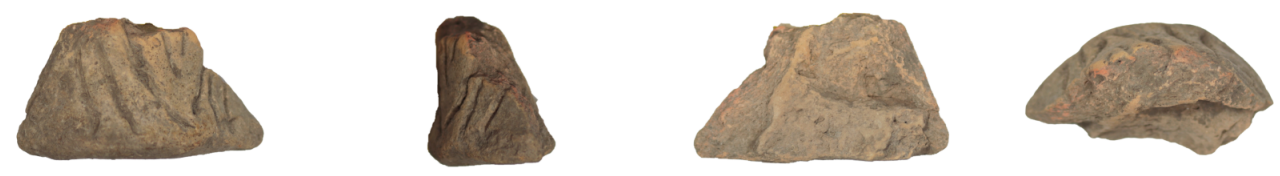

MC-36-05
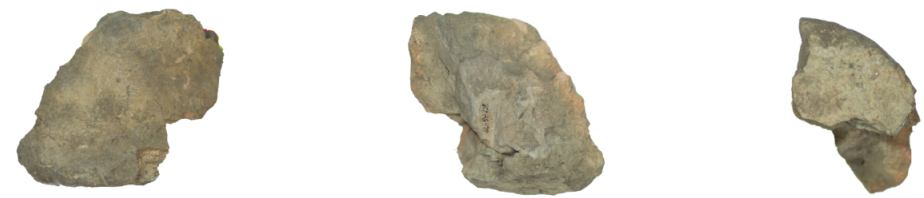

MC-16-09

ma

Imagem 119: trempes com queima incompleta

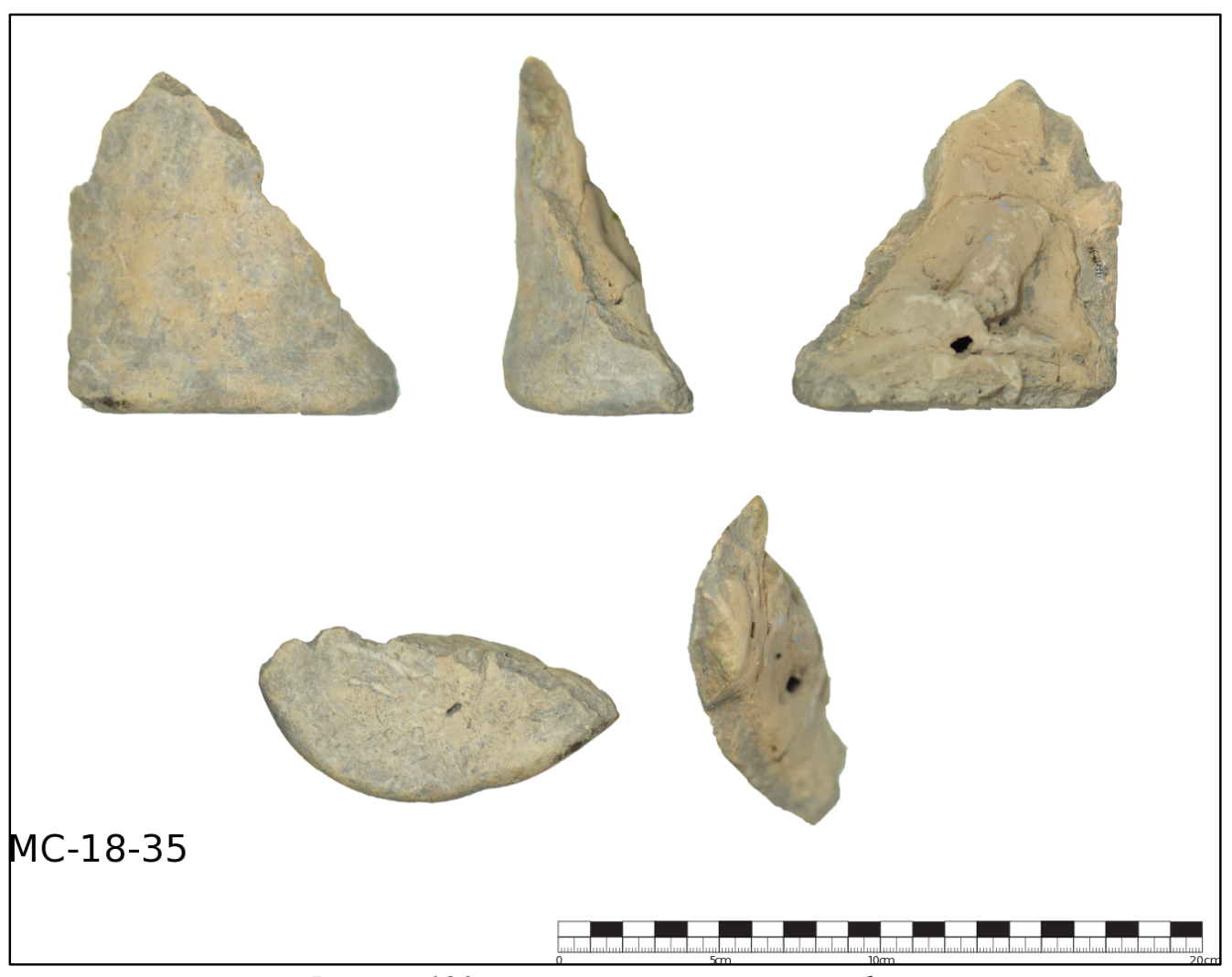

Imagem 120: trempe com queima incompleta. 
Bolotas de argila

As bolotas de argila são recorrentes em todo o registro arqueológico encontrado no Monte Castelo, extrapolam a fase bacabal e são muito comuns em meio a toda a sequência da fase Sinimbu e abundantes durante a fase Cupim (ca. 8000-5000) (Pugliese 2017).

Assim como na fase Sinimbu e Cupim, as bolotas variam em sua forma e tamanho, e por vezes são encontradas impressões de vegetais na superfície.

Durante a fase Bacanal trempes fragmentadas em diferentes tamanhos, e alguns fragmentos classificados como bolota de argila, talvez poderiam ser entendidos como fragmentos de trempes, pois a pasta identificada nestes vestígios é muito semelhante aquelas encontradas nas trempes, onde não ocorrem os vazios agrupados e irregulares.

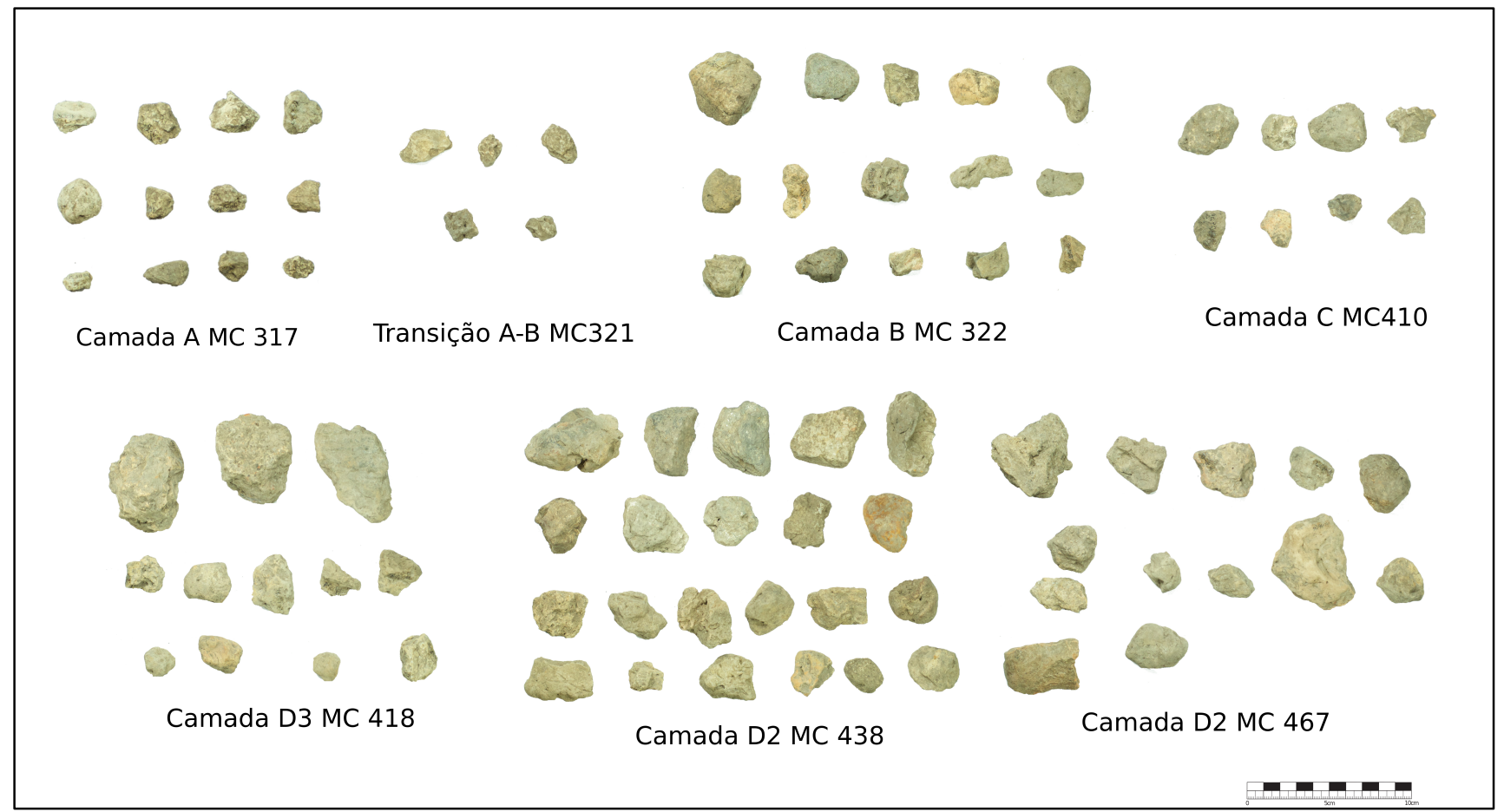

Imagem 121: bolotas de argila da fase Bacabal.

\section{Variabilidade}

Uma parcela da amostra pode ser coletada com controle estratigráfico $(n=437)$ a partir da amostragem da unidade de $1 \mathrm{~m} 2$ denominada N1012E1009. Ocorreram além de fauna e esparsos materiais líticos, fragmentos de trempes, bolotas de argila e potes, estes 
contendo 105 bordas das quais 75 delas foi possível mensurar e classificar todos os atributos.

Os níveis iniciais $(0-70 \mathrm{~cm})$ estavam comprometidas em sua porção sul dado o colapso decorrente de agentes perturbativos, principalmente entre $0-40 \mathrm{~cm}$, comprometendo em certo grau a amostragem por camadas.

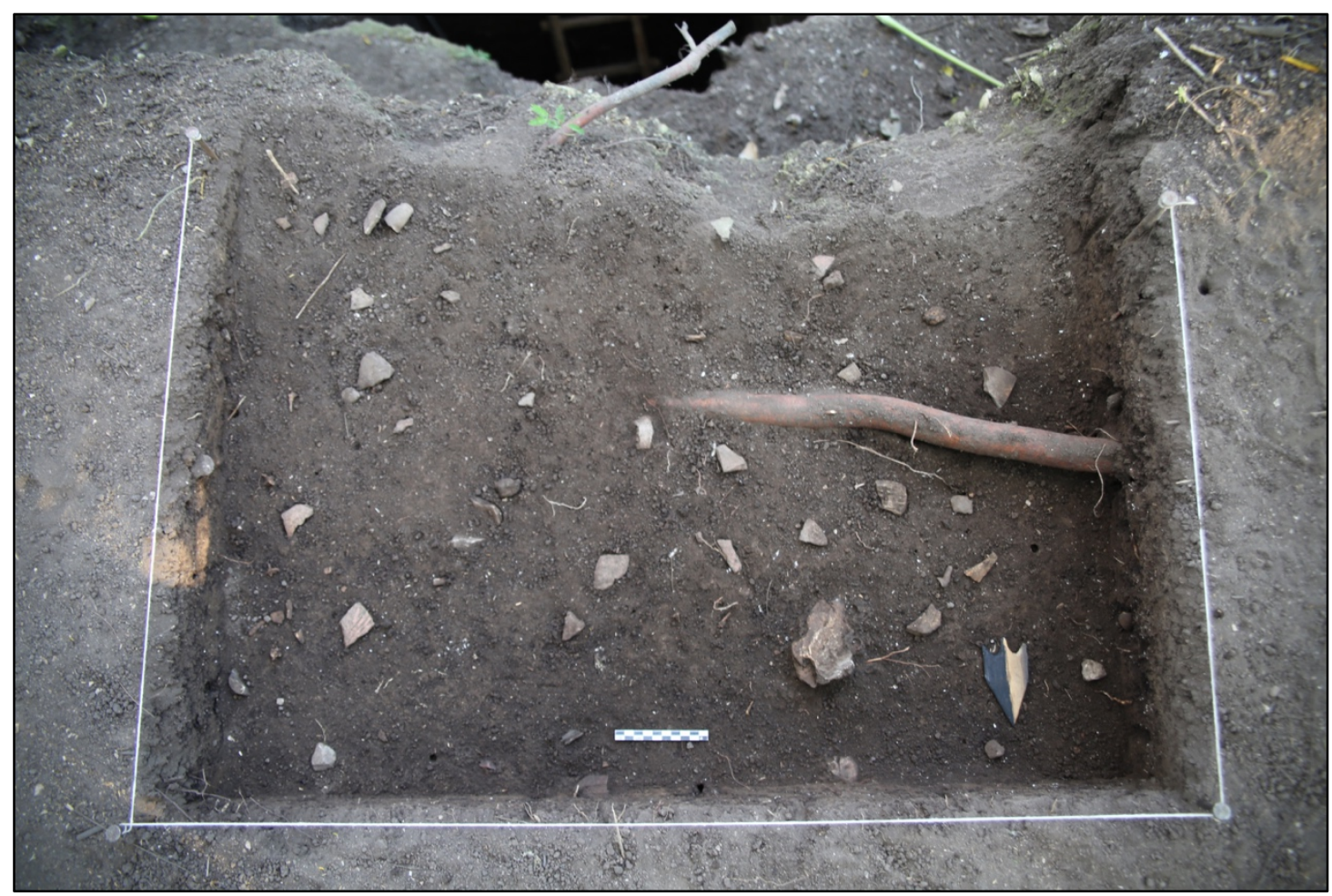

Imagem 122: N1012E1009, nivel 20-30cm, camada A. 


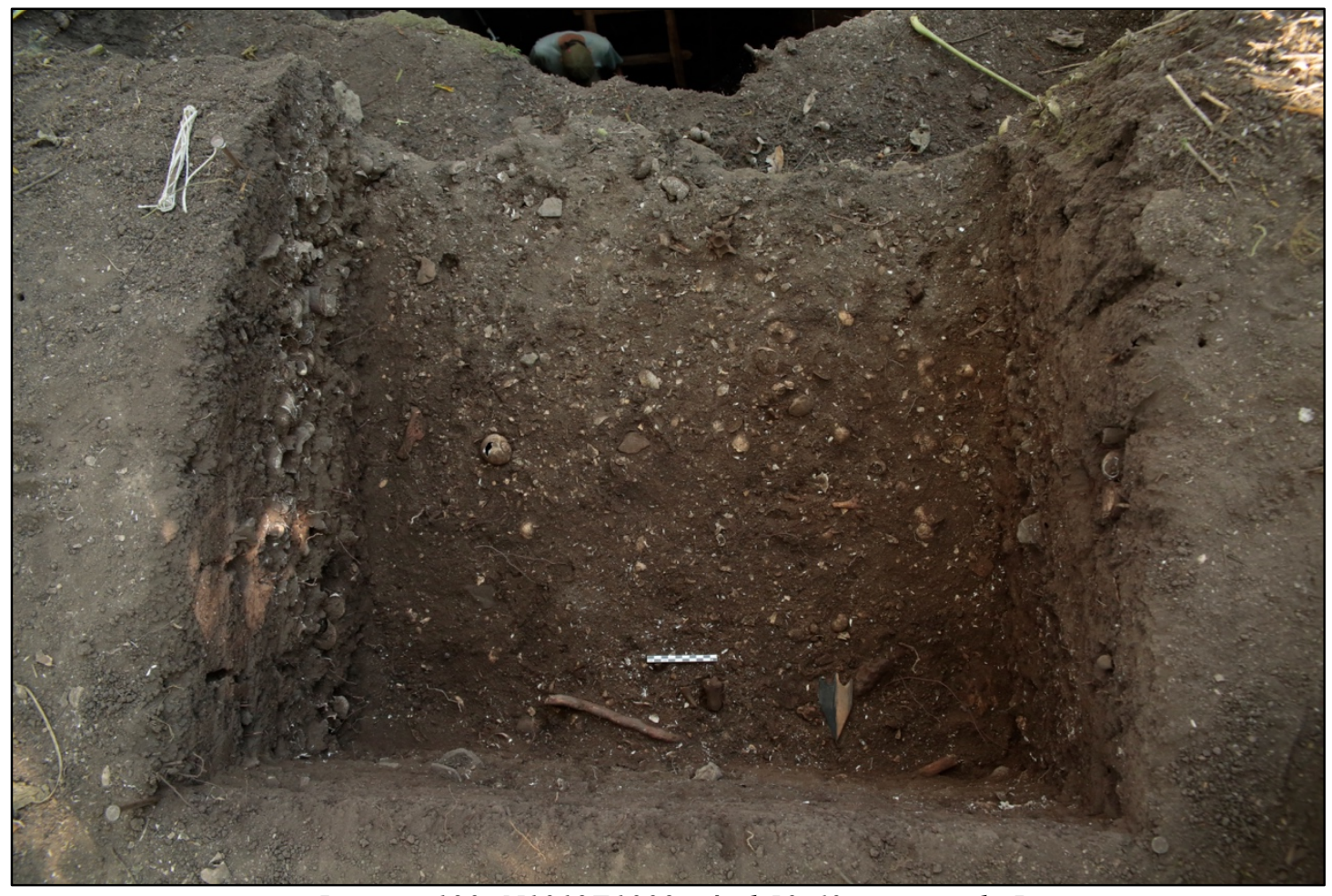

Imagem 123: N1012E1009, nivel 50-60cm, camada B.

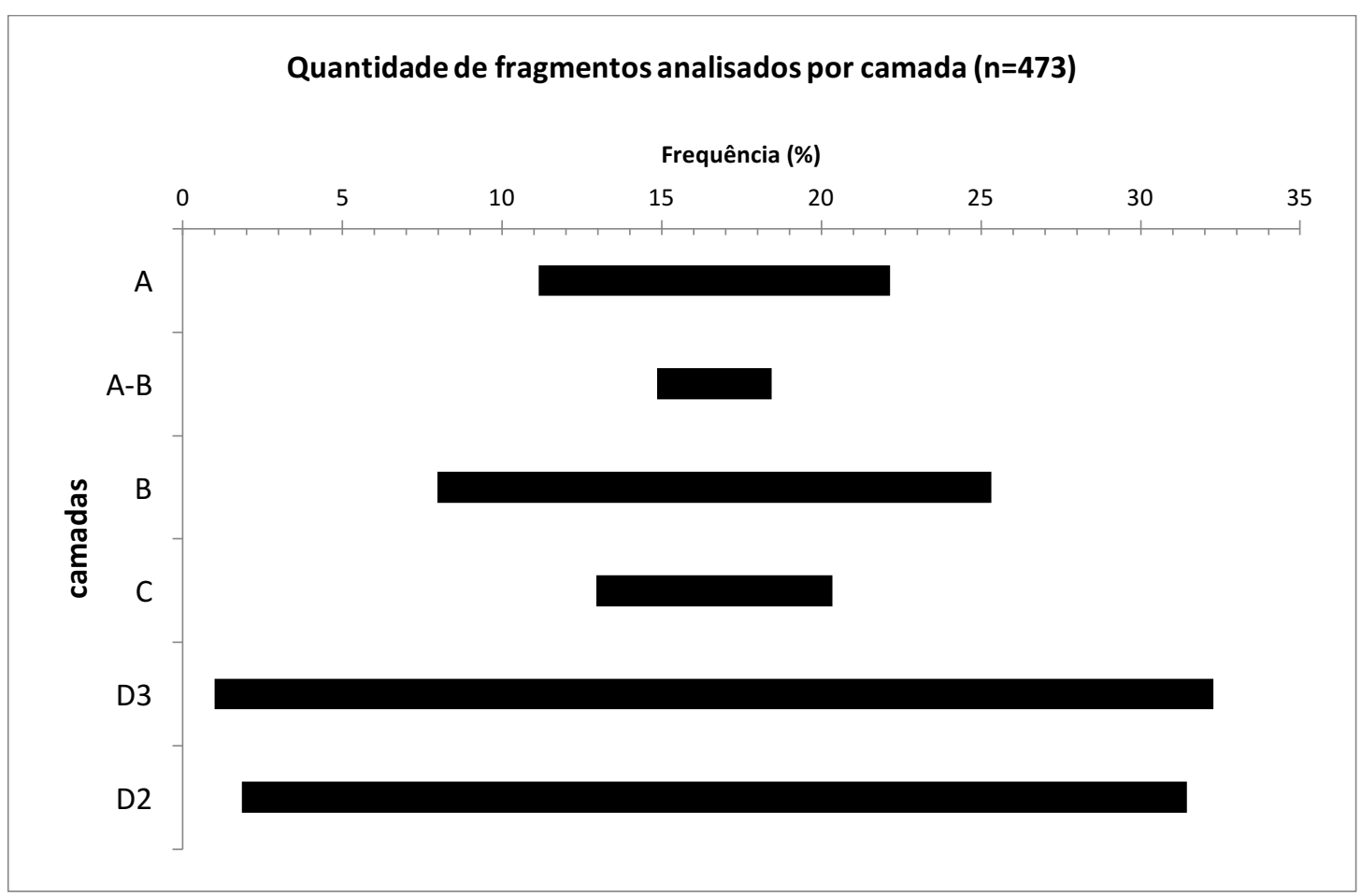

Gráfico 43: quantidade de fragmentos por camada. 


\begin{tabular}{lcc}
\hline A & 52 & 10,99 \\
\hline A-B & 17 & 3,59 \\
\hline$B$ & 82 & 17,34 \\
\hline C & 35 & 7,40 \\
\hline D3 & 148 & 31,29 \\
\hline D2 & 140 & 29,60 \\
\hline
\end{tabular}

Tabela 38: quantidade e porcentagem de fragmentos cerâmicos por camada.

A camada D parece remeter a um contexto de enterramentos dada a ocorrência de dois indivíduos associados a uma série de feições encontradas associadas a rituais e uma farta série de fragmentos decorados. $\mathrm{Na}$ camada $\mathrm{C}$ foram encontrados fragmentos cerâmicos extremamente erodidos, com alto grau de oxidação (n=4, 11,42\%), característica que remete a fragmentos que são encontrados em sítios na planície inundável e que sofrem com a sazonalidade do regime das águas (Miller 2009). As amostras que coletamos na superfície no entorno do sambaqui, também apresentaram um alto grau de oxidação. A presença de fragmentos com estas características de erosão na camada $\mathrm{C}$, uma camada com pouca concentração cerâmica se comparada as demais, e ao mesmo tempo espessa, poderíamos supor esta como uma camada mais próxima de um evento construtivo, onde houve a utilização de materiais do entorno, do que a um evento doméstico. Para as camadas A e B, devido a pouca amostragem, ainda é frágil supor se estas teriam sido formadas por eventos construtivos ou domésticos.

Com os dados relacionados a cerâmica podemos perceber algumas mudanças que ocorreram durante o tempo de produção cerâmica da fase bacabal, que atinge 3200 anos de ocorrência.

Um dos elementos percebidos é a composição da pasta, onde percebe-se que nos períodos iniciais de formação da camada Bacabal no Monte Castelo (camada D) uma maior popularidade dos tipos de antiplástico com concha se compararmos com outras camadas. Tal fato já fora citado por Miller (2009) onde também é atribuído a presença marcante de fragmentos cerâmicos com antiplástico de concha nas camadas mais antigas da fase Bacabal.

Também pode-se observar que nas camadas mais antigas há uma maior frequência na presença de areia grossa e muito grossa na pasta, enquanto que nas camadas mais recentes percebe-se uma incidência maior de grãos finos a médios. 
Tipos de antiplástico por camada $n=473$

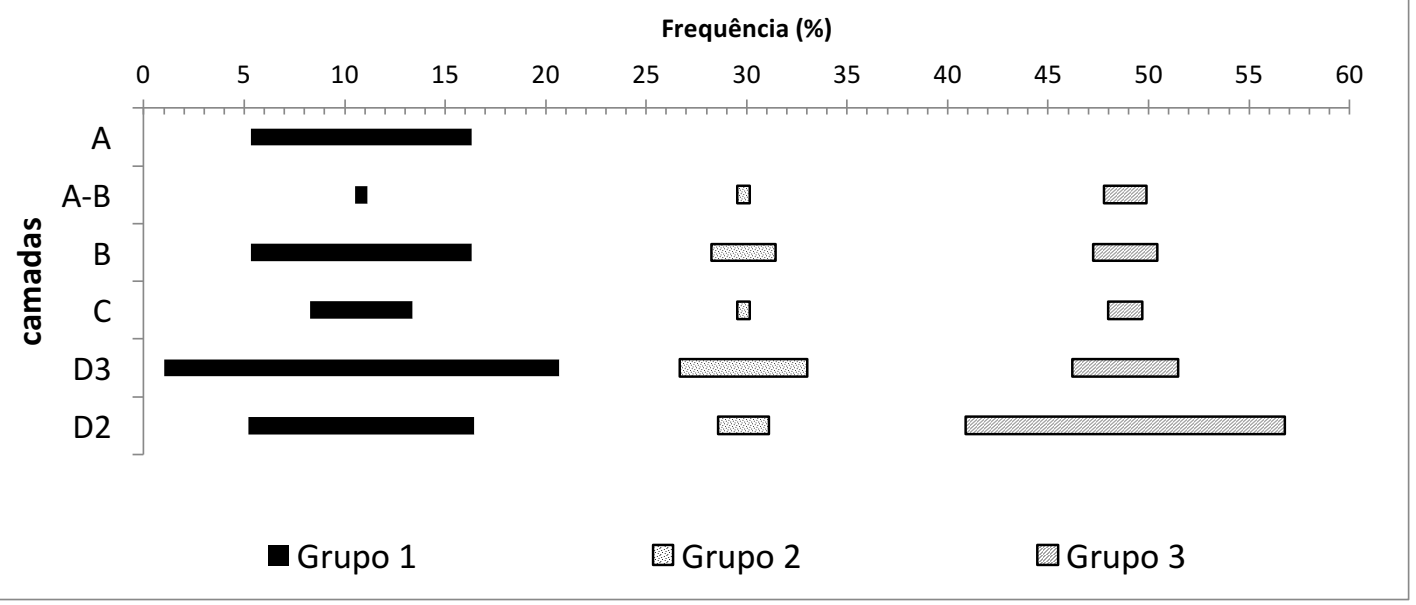

Gráfico 44: tipo de antiplástico por camada.

\begin{tabular}{lcccccc}
\hline & Grupo & & Grupo & \multicolumn{3}{c}{ Grupo } \\
& 1 & $\%$ & 2 & $\%$ & 3 & $\%$ \\
\hline A & 52 & 10,99 & 0 & 0 & 0 & 0 \\
\hline A-B & 3 & 0,63 & 3 & 0,63 & 10 & 2,11 \\
\hline B & 52 & 10,99 & 15 & 3,17 & 15 & 3,17 \\
\hline C & 24 & 5,07 & 3 & 0,63 & 8 & 1,69 \\
\hline D3 & 93 & 19,66 & 30 & 6,34 & 25 & 5,29 \\
\hline D2 & 53 & 11,21 & 12 & 2,54 & 75 & 15,86 \\
\hline
\end{tabular}

Tabela 39: quantidade e porcentagem dos tipos de antiplástico por camada.

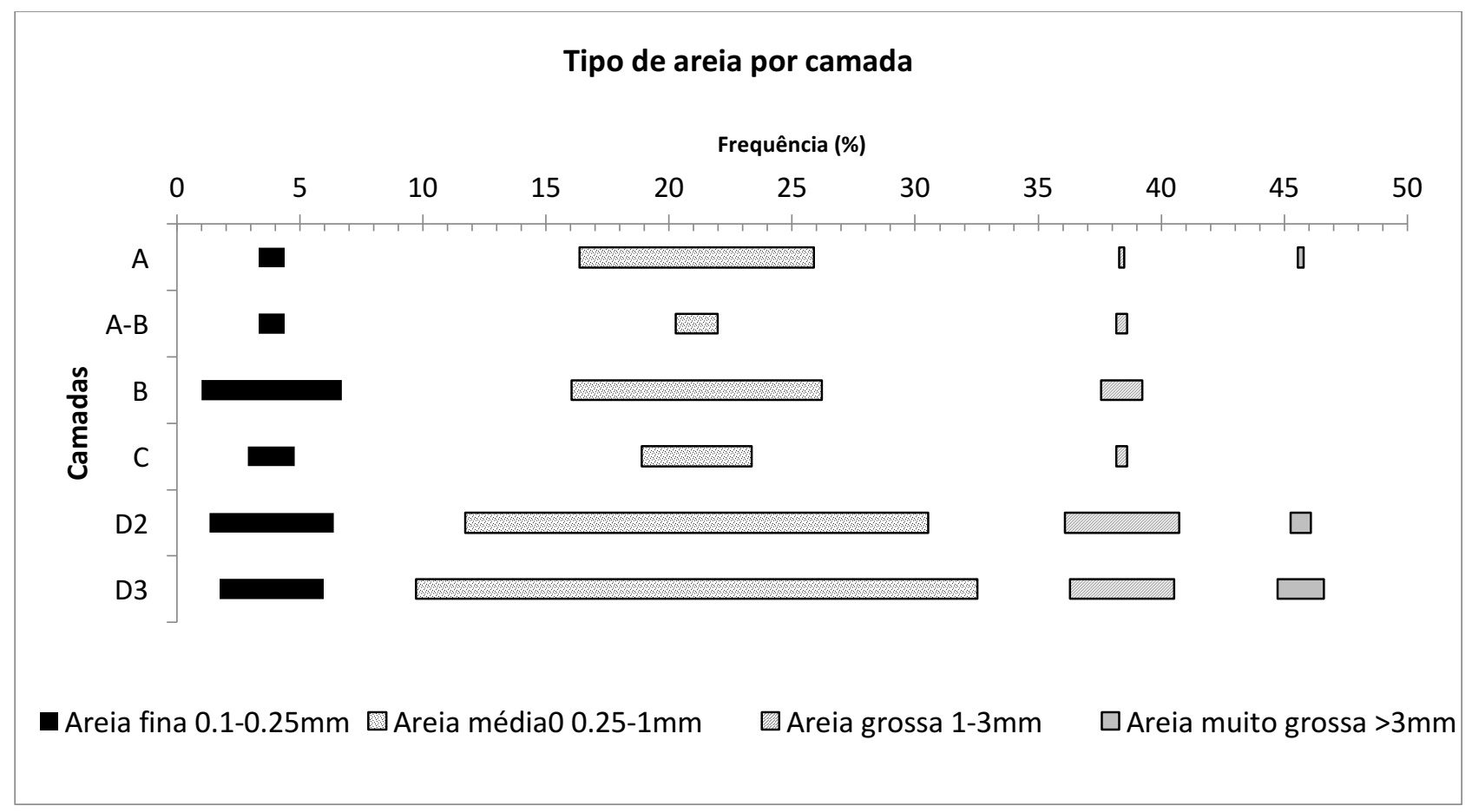

Gráfico 45: sequência seriada dos tipos de areia na pasta por camada. 


\begin{tabular}{lcccccccc} 
n=473 & \multicolumn{1}{c}{ Areia } & $\begin{array}{c}\text { Areia } \\
\text { fina }\end{array}$ & $\%$ & média & $\%$ & greia & \multicolumn{3}{c}{ Areia muito } \\
Camada & grosa & $\%$ & grossa & $\%$ \\
\hline A & 5 & 1,06 & 45 & 9,51 & 1 & 0,21 & 1 & 0,21 \\
\hline A-B & 5 & 1,06 & 8 & 1,69 & 2 & 0,42 & 0 & 0,00 \\
\hline B & 27 & 5,71 & 48 & 10,15 & 8 & 1,69 & 0 & 0,00 \\
\hline C & 9 & 1,90 & 21 & 4,44 & 2 & 0,42 & 0 & 0,00 \\
\hline D2 & 24 & 5,07 & 89 & 18,82 & 22 & 4,65 & 4 & 0,85 \\
\hline D3 & 20 & 4,23 & 108 & 22,83 & 20 & 4,23 & 9 & 1,90 \\
\hline \multicolumn{7}{c}{ Tabela } & $40:$ quantidade e porcentagem dos tipos de areia na pasta por camada.
\end{tabular}

As interpretações de Pugliese (2017) podem sustentar a hipótese de uma tendência de mudança e possível especialização no fazer cerâmico durante o tempo. Os resultados das análises isotópicas feitas pelo arqueólogo sugerem que no período inicial da fase Bacabal foram exploradas matérias-primas dispersas por uma área em diferentes pontos. Com o decorrer do tempo há uma tendência na especialização em fontes específicas de matérias-primas. Diferenças marcadas no Epsilon Niomídio indicam que as ceramistas Bacabal buscavam argilas com concentração alta de cauixí provenientes de depósitos holocênicos disponíveis localmente nos pantanais do baixo rio Branco e da confluência com o rio Guaporé (Pugliese 2017).

Tal fato não ocorreria somente em Monte Castelo, mas também é percebida em outros sítios como a Ilha do Antelo e a Ilha Pau d'Óleo onde as análises preliminares indicam que após a instalação dessa tecnologia cerâmica na região - e ao longo dos 3600 anos de produção de cerâmicas Bacabal - houve uma intensificação em fontes de matérias específicas, todas elas apresentando sinais isotópicos muito próximos (idem).

\section{Decoração}

Percebe-se que a ocorrência dos tipos decorados com motivo reconhecidos foi semelhante nos níveis da camada $\mathrm{D}$ - onde todos os tipos ocorrem - e teve menos recorrência de indivíduos e tipos decorados nas camadas A, B e C. Contudo tipos de motivo como o Escovado sabugo, Bacabal e Bacabal paralelo ocorrem em todas as camadas estratigráficas. 
Tipos de decorção por camada $n=473$

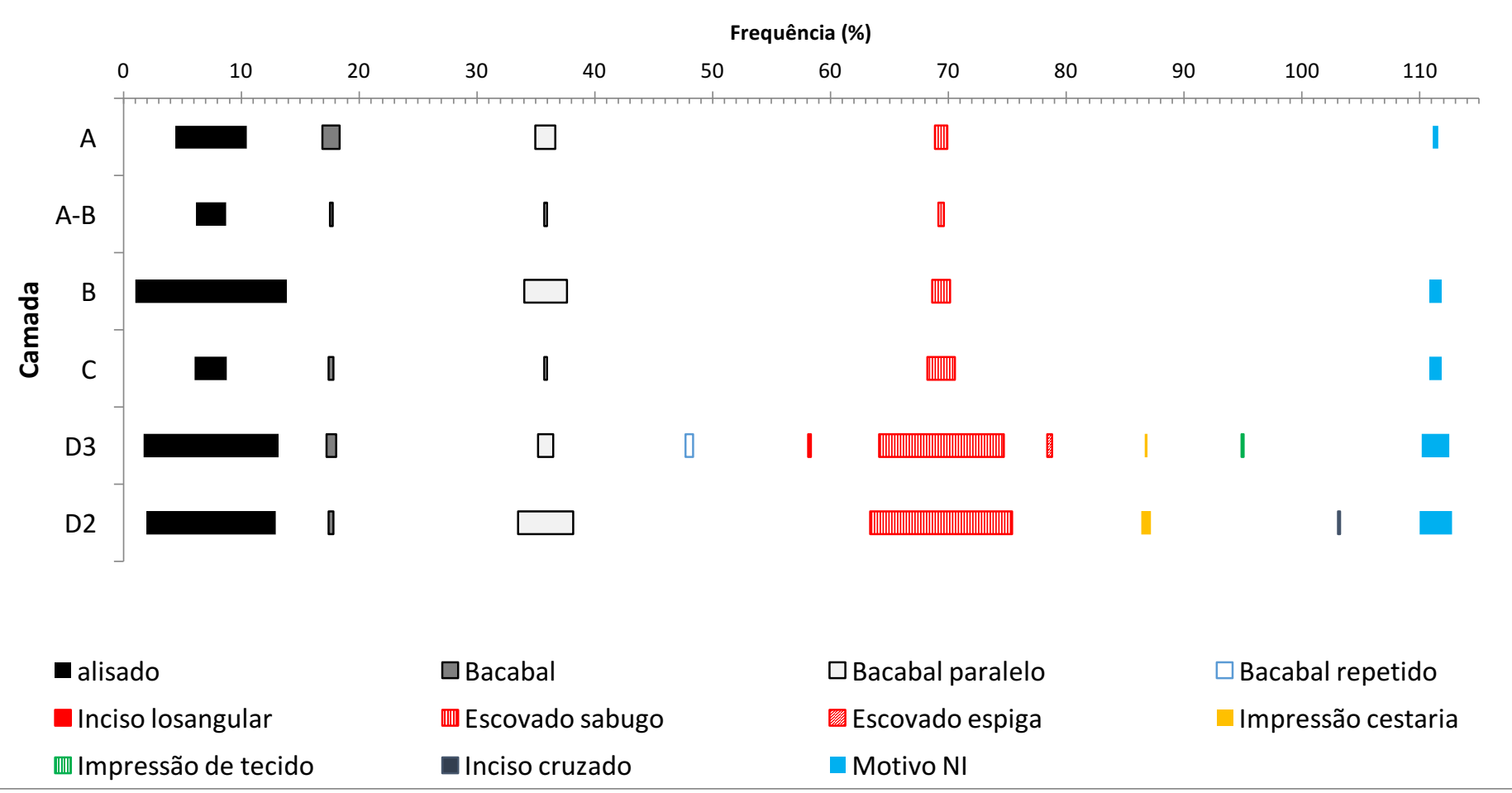

Gráfico 46: sequencia seriada dos motivos reconhecidos entre as camadas.

\begin{tabular}{|c|c|c|c|c|c|c|c|c|c|c|c|c|c|c|c|c|c|c|c|c|c|c|}
\hline & \multicolumn{22}{|c|}{ Decoração por camada ( $n=473$ ) } \\
\hline & alisado & $\%$ & Bacabal & $\%$ & $\begin{array}{c}\text { Bacabal } \\
\text { parale } \\
\text { lo } \\
\end{array}$ & $\%$ & $\begin{array}{c}\text { Inciso } \\
\text { losang } \\
\text { ular }\end{array}$ & $\%$ & $\begin{array}{c}\text { Escovado } \\
\text { sabug } \\
0 \\
\end{array}$ & $\%$ & $\begin{array}{c}\begin{array}{c}\text { Escovado } \\
\text { espig } \\
\text { a }\end{array} \\
\end{array}$ & $\%$ & $\begin{array}{r}\text { Impressão } \\
\text { cestaria }\end{array}$ & $\%$ & $\begin{array}{c}\text { Bacabal } \\
\text { repeti } \\
\text { do }\end{array}$ & $\%$ & $\begin{array}{c}\text { Impressão } \\
\text { de } \\
\text { tecido }\end{array}$ & $\%$ & $\begin{array}{c}\text { Inciso } \\
\text { cruza } \\
\text { do }\end{array}$ & $\%$ & $\begin{array}{c}\text { Motivo } \\
\mathrm{NI}\end{array}$ & $\%$ \\
\hline A & 29 & 6,13 & 7 & 1,48 & 8 & 1,69 & 0 & 0 & 5 & 1,06 & 0 & 0 & 0 & 0 & 0 & 0 & 0 & 0 & 0 & 0 & 2 & 0,42 \\
\hline$A-B$ & 12 & 2,54 & 1 & 0,21 & 1 & 0,21 & 0 & 0 & 2 & 0,42 & 0 & 0 & 0 & 0 & 0 & 0 & 0 & 0 & 0 & 0 & 0 & 0,00 \\
\hline B & 61 & 12,90 & & 0,00 & 17 & 3,59 & 0 & 0 & 7 & 1,48 & 0 & 0 & 0 & 0 & 0 & 0 & 0 & 0 & 0 & 0 & 5 & 1,06 \\
\hline C & 13 & 2,75 & 2 & 0,42 & 1 & 0,21 & 0 & 0 & 11 & 2,33 & 0 & 0 & 0 & 0 & 0 & 0 & 0 & 0 & 0 & 0 & 5 & 1,06 \\
\hline D3 & 54 & 11,42 & 4 & 0,85 & 6 & 1,27 & 1 & 0,21 & 50 & 10,57 & 2 & 0,42 & 1 & 0,21 & 3 & 0,63 & 1 & 0,21 & 0 & 0 & 11 & 2,33 \\
\hline D2 & 52 & 10,99 & 2 & 0,42 & 22 & 4,65 & 0 & 0 & 57 & 12,05 & 0 & 0 & 4 & 0,85 & 0 & 0 & 0 & 0 & 1 & 0,21 & 13 & 2,75 \\
\hline
\end{tabular}

Tabela 41: : quantidade e porcentagem dos motivos reconhecidos entre as camadas

\section{Morfologia}

As Camadas A e D possuem maior variabilidade de tipos morfológicos em relação a B-C. A camada D tem uma amostra maior que as demais e por isso chama a atenção os diferentes tipos encontrados na camada A. 
Tipos de borda por camada $\mathrm{n}=75$

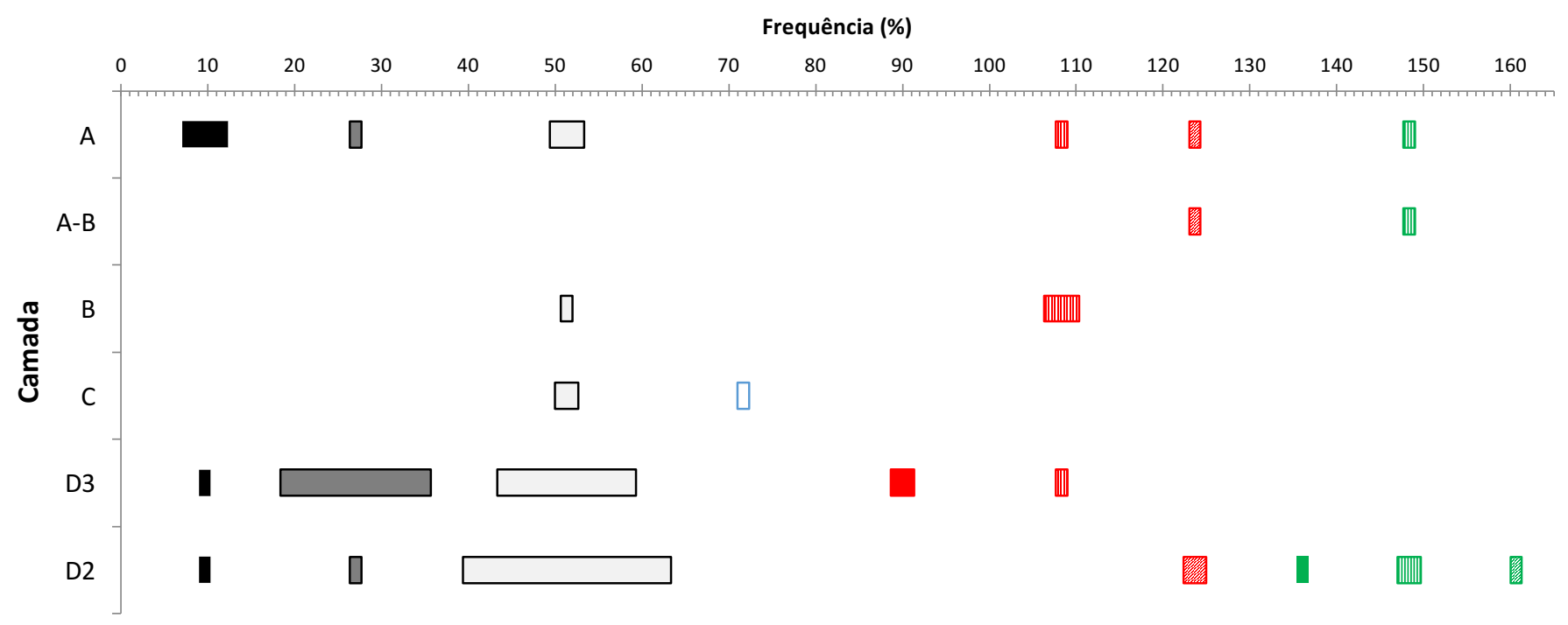

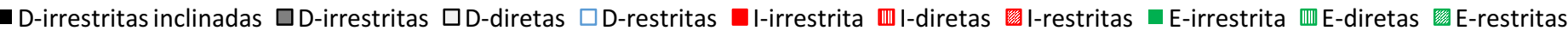
Gráfico 47: sequência seriada dos tipos de borda entre as camadas arqueológicas.

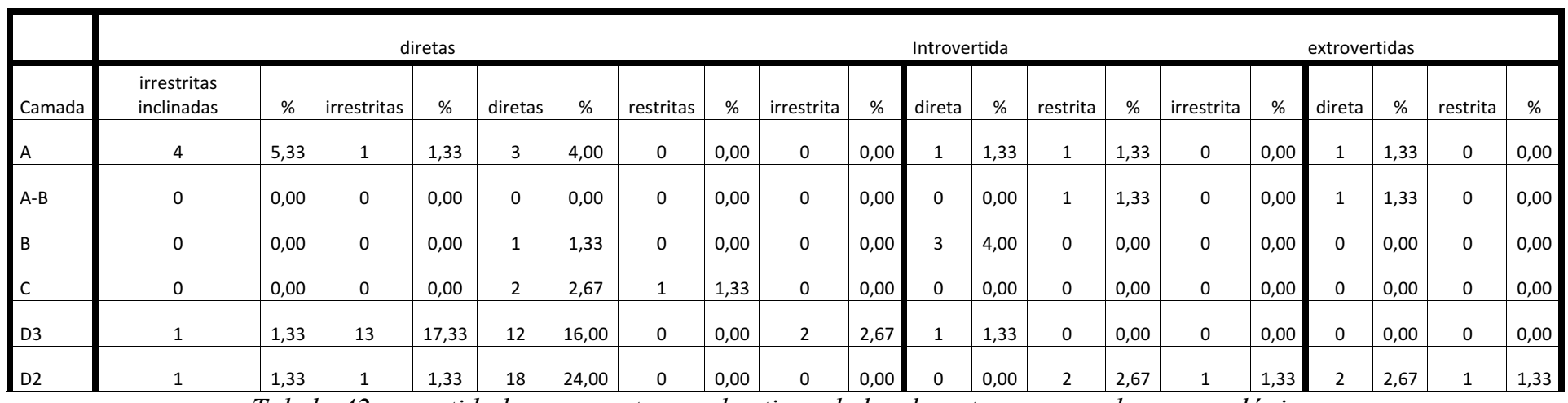

Tabela 42: quantidade e porcentagem dos tipos de borda entre as camadas arqueológicas.

\section{Análises arqueobotânicas em fragmentos}

Tendo como hipótese a utilização de milho (Zea mays) para imprimir motivos escovados nas bases de potes da fase Bacabal, buscamos evidências de tais vestígios no registro arqueológico ${ }^{4}$.

Para tanto, oito fragmentos cerâmicos de Monte Castelo foram submetidos à análise de grãos de amido e fitólitos e em apenas um deles não houve a presença de grãos de amido ou fitólitos.

\footnotetext{
${ }^{4}$ Analise gentilmente realizada pela Dra. Jennifer Watling.
} 


\begin{tabular}{|l|c|c|c|c|c|c|}
\hline Lab code & PN & x & y & z & Camada & tipo \\
\hline MC 1 & 319 & 73 & 90 & 0.34 & A & parede \\
\hline MC 2 & 340 & 41 & 57 & 0.54 & B & parede \\
\hline MC 3 & 355 & 73 & 12 & 0.53 & B & base \\
\hline MC 4 & 431 & 86 & 91 & 0.91 & d3 & base \\
\hline MC 5 & 432 & 43 & 50 & 0.87 & d3 & base \\
\hline MC 6 & 441 & 21 & 26 & 0.9 & d3 & base \\
\hline MC 7 & 477 & 13.3 & 42.5 & 1.11 & d2 & parede \\
\hline MC 8 & 1046.2 & 61 & 94 & 1.13 & f46 & base \\
\hline
\end{tabular}

Tabela 43: amostras analisadas.

\begin{tabular}{|l|l|l|l|l|l|l|l|l|}
\hline & MC 1 & MC 2 & MC 3 & MC 4 & MC 5 & MC 6 & MC 7 & MC 8 \\
\hline Zea mays & & & & & & & & \\
\hline undamaged & & & & & 1 & & & \\
\hline milled & & & & 2 * & & & & \\
\hline milled and toasted & & & & & & $(1)$ & & \\
\hline other damage & & & & & $(1)$ & & & \\
\hline & & & & & & & & \\
\hline Cucurbita sp. & & & 1 & & & & & \\
\hline & & & & & & & & \\
\hline Dioscorea sp. & & & & & 1 & & & \\
\hline & & & & & & & & \\
\hline Dioscorea trifida & & & & 1 & & & & \\
\hline & & & & & & & & \\
\hline Ipomea batatas & & & & & $1 *$ & & & \\
\hline & & & & & & & & \\
\hline Unidentified & & & & & & & & \\
\hline undamaged & & & $1 *$ & & & 1 & group & 1 \\
\hline milled & & 1 & & 1 & & 1 & & 1 \\
\hline gelatinised & & & & & & & & 1 \\
\hline tuber & & & & & & & & 1 \\
\hline Total & 0 & 1 & 2 & 4 & 4 & 3 & group & 4 \\
\hline
\end{tabular}

Tabela 44: Tabela mostrando frequências e identificações taxonômicas de grãos de amido encontrados nas cerâmicas de Monte Castelo. $X^{*}=$ encontrado na amostra de raspagem; $X=$ encontrado na amostra de pincel molhado; $(X)=$ caso em que a espécie é uma tentativa. 


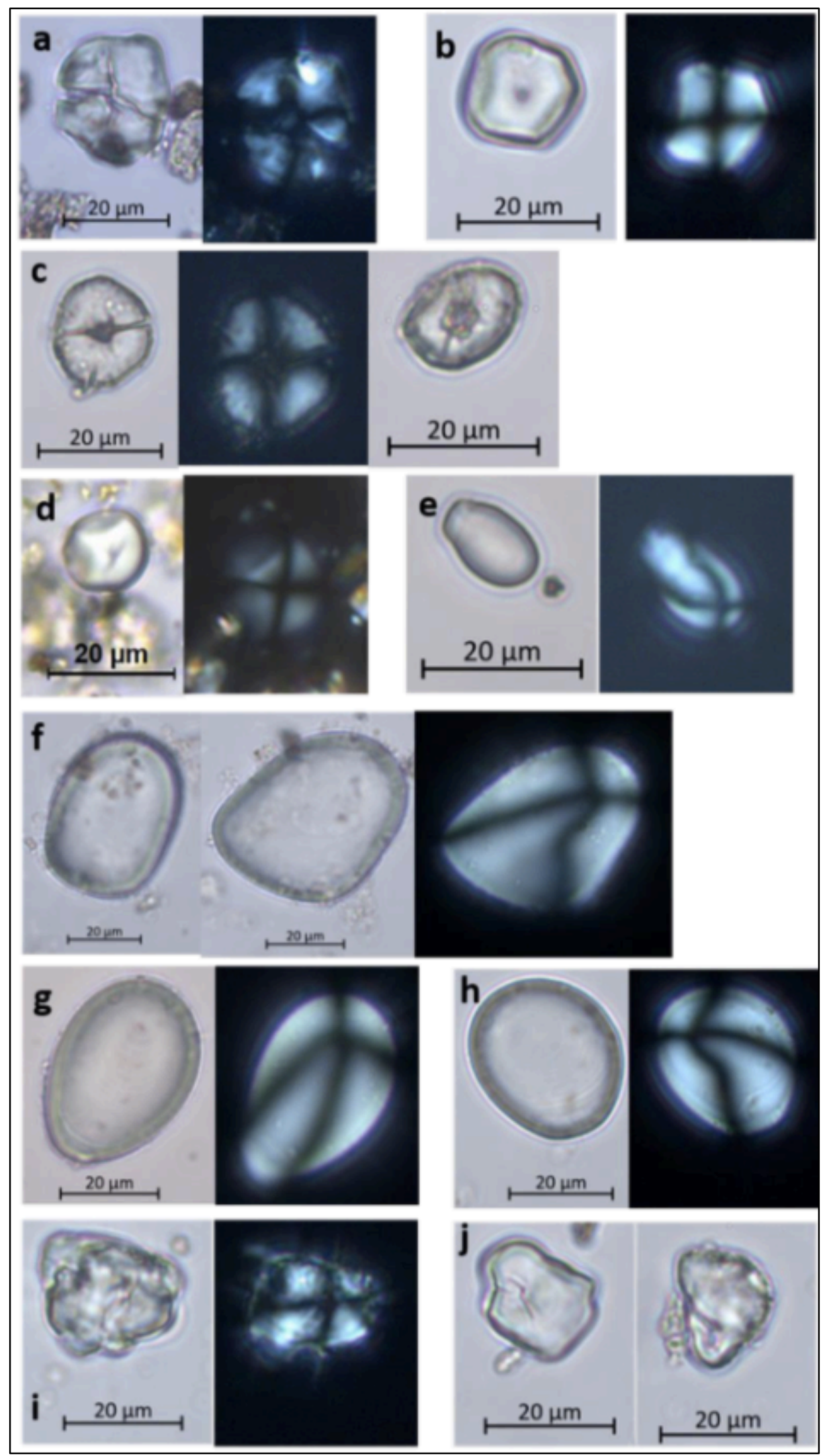

Imagem 124: grãos de amido encontrados a) milho moído, b) milho não danificado, c) milho moído e tostado, d) batata doce, e) abóbora, f) Dioscorea trifida (g), Dioscorea sp., H) amido de tubérculo não identificado (MC 8), i) amido gelatinizado por aquecimento, $j$ ) um dos grupos de amido irregular de $M C 7$ 


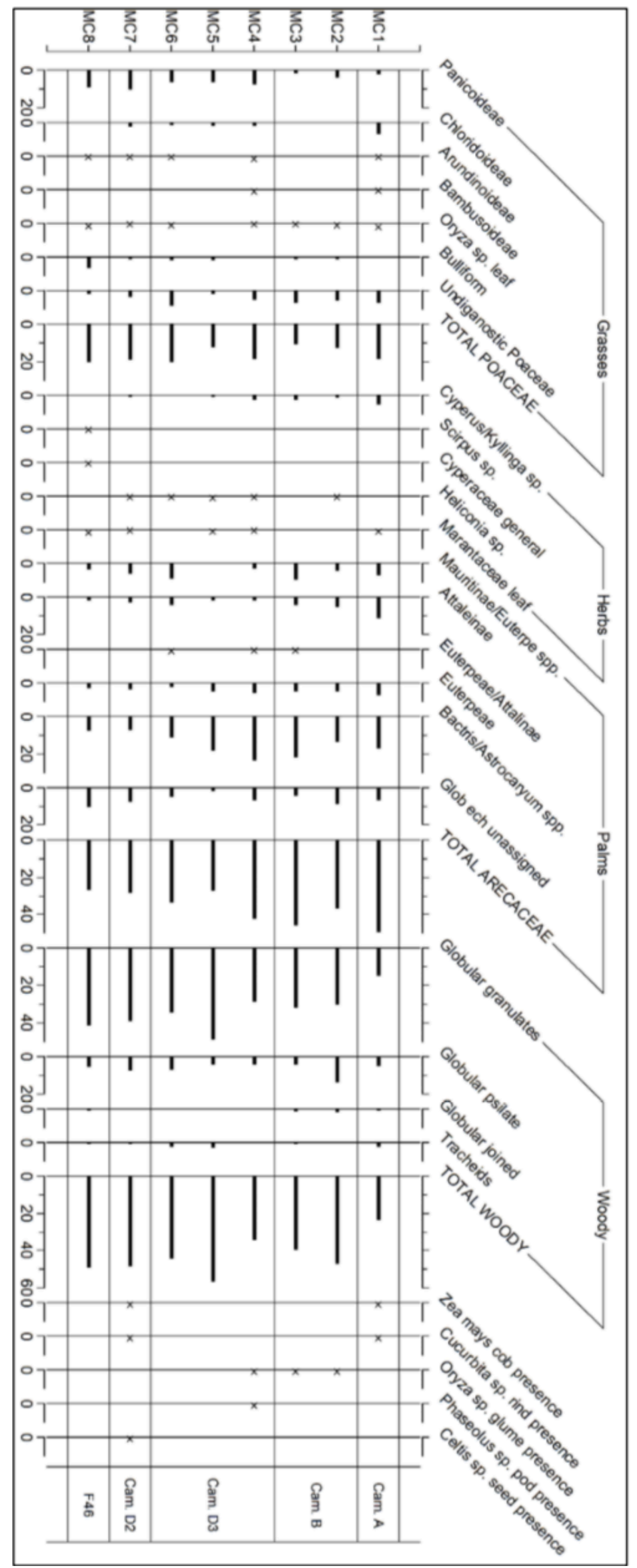

Gráfico 48: diagrama de frequência de fitólitos. 
A análise de fitólitos de sedimentos das camadas do Monte Castelo feita por L. Hilbert (Hilbert et al. 2017) já confirmou a presença de milho, abóbora e arroz em toda a estratigrafia do sítio, nas fases Sinimbu e Bacabal.

Uma análise de oito fragmentos cerâmicos de Bacabal ampliou essa lista de cultivares para incluir Phaseolus sp. (feijão), Dioscorea trifida (domesticado cará), Dioscorea sp. (cará / yam) e Ipomea batatas (batata-doce). Foi somente incluindo a análise de grãos de amido que essas culturas de tubérculos puderam ser identificadas no registro arqueológico, uma vez que nenhuma dessas espécies produz fitólitos diagnósticos.

$\mathrm{O}$ fragmento MC 4 foi utilizado para conter um alimento à base de farinha de milho (estes amidos foram encontrados apenas na amostra de raspagem) e por lógica semelhante, MC 5 também pode ter sido utilizado para processar batata-doce. Todos os outros grãos de amido foram encontrados apenas na amostra de pincel molhado, tornando mais difícil associá-los definitivamente ao uso de artefatos específicos. Por outro lado, como os fragmentos de bases MC 3, 4, 5, 8 produziram mais grãos de amido do que as bordas e paredes (MC 1, 2 e 7), isso pode ser um argumento de que esses amidos realmente se originaram dos artefatos, pois é mais comum que existam evidências de utilização de preparos de alimentos em abundância nestas seções do pote, como é observado por Skibo (1995, 1999).

A análise de grãos de amido também permitiu identificar várias técnicas de processamento de alimentos que foram empregadas pelos habitantes de Monte Castelo. A evidência de milho e milho moído mostra que esta cultura foi processada e usada na forma de farinha, e uma tentativa de identificação (MC 6, escova molhada) indica que esta farinha é torrada em algumas ocasiões. $\mathrm{O}$ grão de amido gelatinizado na amostra MC 8 foi provavelmente produzido por cozimento ou fervura. Dano de moagem também foi registrado em vários grãos de amido não identificados, sugerindo que outras plantas também foram processadas dessa maneira.

Portanto além de confirmar a presença de milho em toda a sequência da fase Bacabal, diferentes maneiras de processamento também puderam ser sugeridas. A presença de diferentes cultivares presentes no registro arqueológico relacionado ao Holoceno médio é importante na medida em que pode ajudar a entender a dispersão destes cultivares ao longo do tempo na Amazônia. 


\section{Conclusão}

A fase Bacabal ocorreu entre 2576 a.C e 1350 d. C. em sítios que ocuparam ilhas de terra firme e aterros construídos em meio a planície de inundação do Pantanal do Guaporé. O testemunho mais significativo até agora encontrado é o sambaqui Monte Castelo. Tanto no sambaqui quanto nos sítios em ilha, a cerâmica Bacabal ocorre após camadas da fase Sinimbu (8000-5000 anos AP.)

O tempero da pasta da fase Bacabal é composto por abundante cauixi, em meio a vazios agrupados e rombos irregulares com a presença de minerais - como areia fina, que pode ocorrer concomitante a concha moída e em poucos casos o cariapé. Na sequência seriada percebe-se que a presença das pastas com concha moída é mais notada em camadas relacionadas ao início da fase, e que existe uma tendência à diminuição com o tempo, assim como a seleção de areia, onde nas camadas antigas são encontrados tipos de areia com a granulometria mais grosseira do que em relação as camadas mais recentes.

A técnica de confecção predominante é o acordelado e ocorrem apliques modelados. A morfologia dos utensílios é descrita a partir das bases dos vasilhames (que raramente são côncavas e na maioria das vezes são planas e das bordas (direta, introvertida e extrovertida). É comumente encontrada a ocorrência de asas modeladas aplicadas junto ao lábio, das mais simples às mais estilizadas, por vezes zoomorfas e antropomorfas. Alças são colocadas junto a borda e podem ser simples ou decoradas com incisões e ponteados. Ocorrem nas bases biplanas em muitos casos diferentes impressões como: rede, tecido, cestaria, fibras e escovados feitos com a espiga e o sabugo do milho. Miller (2009) identifica 16 formas de pote dos quais todos ocorrem em nosso registro, com exceção do assador. Algumas formas tornam-se mais comuns nos últimos períodos, mas aparentemente não sofrem grandes mudanças na morfologia do decorrer do tempo (Miller 2009)

Ocorrem casos em que as superfícies dos fragmentos possuem sinais de polimento, mas os tipos de tratamento de superfície mais recorrentes são a aplicação da barbotina e o engobo vermelho. Ao analisar a sequência seriada ainda se nota que, ao contrário do que ocorre com o comportamento dos atributos relacionados aos tipos de pasta, na decoração plástica praticamente não se encontram tendências de surgimento e decadência de tipos, pois existem tipos decorativos que ocorrem em toda a sequência arqueológica registrada. 
1

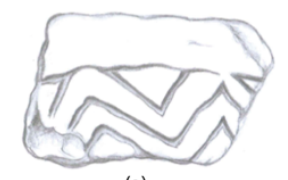

(a)

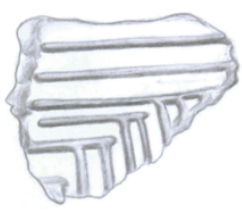

(c)

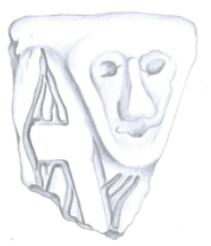

(e)
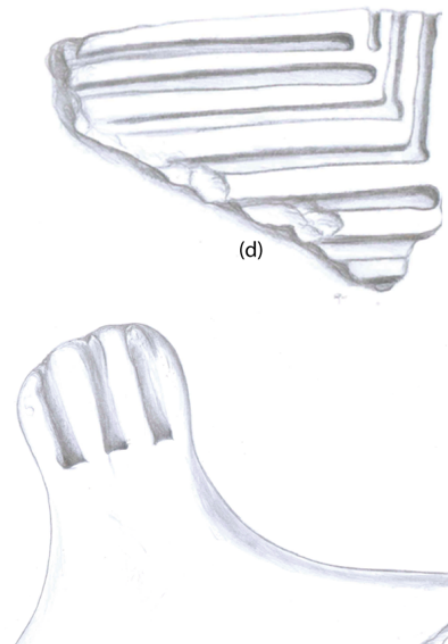

(b)
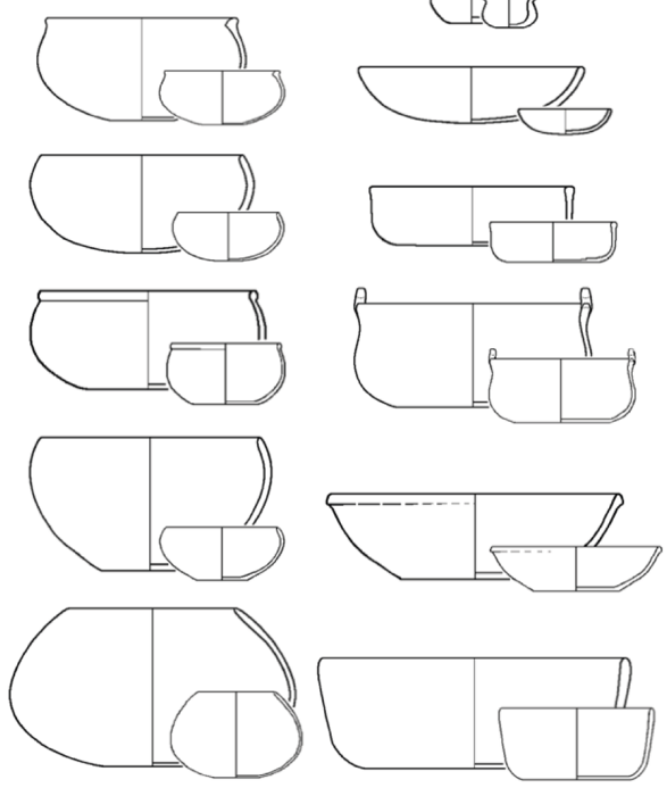

(f)
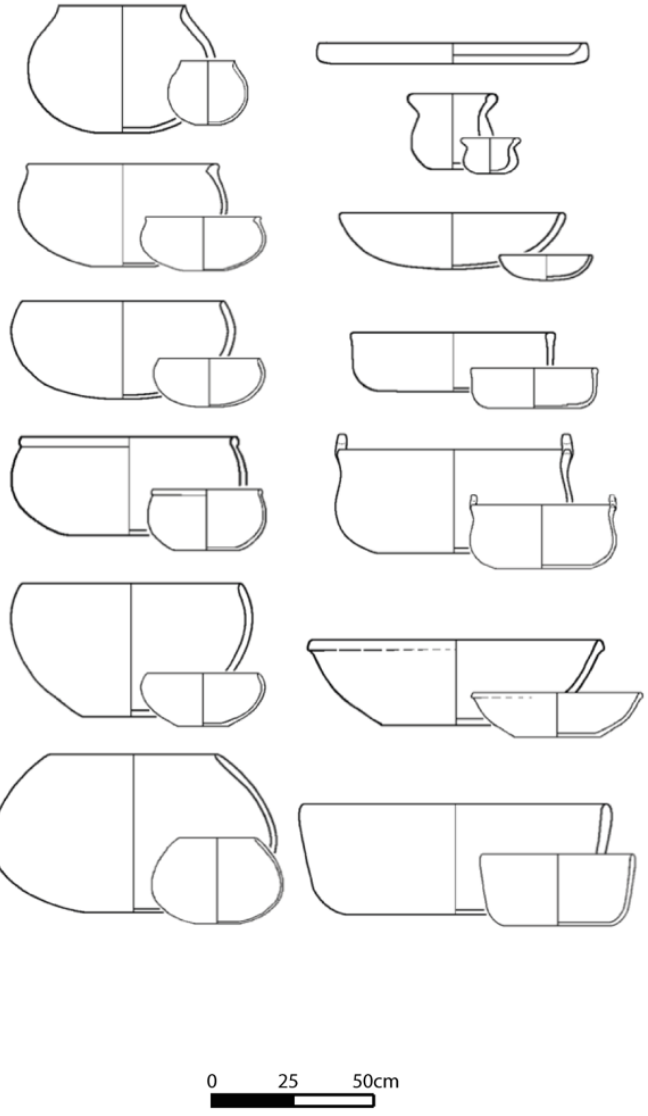

Imagem 125: 1- Cerâmica da fase Bacabal: (a) Bacabal inciso (b) Bacabal exciso-inciso-hachurado (c, d) Inciso (e) Representação antropomorfa (f) Representação zoomorfa. Desenhos de Ubirajara Mello, 2 - Morfologia dos potes segundo Miller (2009b) (Zimpel e Pugliese

Entre as decorações, o engobo vermelho, o exciso e o inciso foram os mais recorrentes e não ocorrem tipos com motivos pintados, apenas decorações plásticas associadas a engobo vermelho ou retoques em preto. As decorações plásticas típicas descritas são fartamente encontradas, com tipos caracterizados pela presença de motivos com excisões formando um motivo em ziguezague, criando áreas triangulares onde há incisões finas paralelas - esse mesmo motivo pode ser encontrado também feito a partir de linhas incisas complementadas com o ponteado. Também são comuns as incisões largas, retas e paralelas; e diferentes tipos de incisões (largas, finas, escalonadas) e ponteados.

$\mathrm{Na}$ fase Bacabal puderam ser encontrados vestígios botânicos de milho (cozido, torrado e em forma de farinha), cará, inhame, batata-doce, feijão e arroz, e vestígios indiretos de uso de algodão (pelas impressões em bases cerâmicas) e tabaco (presença de 
um cachimbo), podendo ser considerado um importante centro produtor de recursos vegetais já no Holoceno médio, corroborando com ideias recentes de que Rondônia teria um papel para a explicação sobre a origem de diferentes cultivares que se tornariam populares no registro arqueológico na Amazônia (Clement 2010; Neves 2013; Clement et al. 2015; Neves 2016; Hilbert et al. 2017; Levis et al. 2017; Watling et al. 2018).

A fase Bacabal compartilha traços no padrão de assentamento e no modo de vida com os primeiros complexos cerâmicos conhecidos, notadamente em relação ao padrão de assentamento vinculado à exploração de recursos aquáticos descrito tanto para a fase Mina, quanto para o baixo Xingu e para o sítio Taperinha.

Entretanto as cerâmicas destes complexos iniciais apresentam diferenças, como o antiplástico. Ao norte, em Taperinha, temos areia e saibro, na tradição Mina e fase Alaka a concha triturada, e ao sul, em Monte Castelo tem-se areia fina e cauxí. Os tratamentos de superfície e decorações são praticamente ausentes na fase Mina e muito elaborados na fase Bacabal.

Nesse sentido, a cerâmica da fase Bacabal estaria mais relacionada a aspectos tecnológicos do Horizonte Zonado-Hachurado do que em relação a tecnologia encontras nos complexos cerâmicos iniciais. O horizonte Zonado-Hachurado é diversificado e ocorre em diferentes locais no norte da América do Sul, e em diferentes épocas. Possui variações regionais, contudo determinadas características se tornam recorrentes como a pasta composta de cauxí e areia, quantidade alta de vasilhas que possuem bordas com o contorno simples, algumas formas complexas, além de estatuetas, cachimbos e assadores. A decoração é feita com padrões geométricos a partir de incisões e excisões na parede e junto as bordas. Ocorrem alças e asas inciso-modeladas com motivos zoomórficos e também engobo vermelho e branco.

Assim como no sambaqui do Jauarí (Hilbert 1968), em Monte Castelo também são encontrados dois contextos cerâmicos bem distintos, contudo para o baixo amazonas este evento histórico não é datado, e no Guaporé sabe-se de uma continuidade cronológica entre as cerâmicas mais antigas e aquelas mais elaboradas que ocorrem na fase Bacabal.

Contudo, a aproximação da fase Bacabal com o horizonte Zonado-Hachurado não é novidade, o padrão zonado-hachurado dos elementos decorativos da fase Bacabal sendo utilizado por Miller $(2009,2013)$ para interpretar essas cerâmicas em relação a um processo de difusão cultural a partir dos sítios da fase Valdívia, no Equador, Existem argumentos positivos como: os detalhes empregados na elaboração de motivos ziguezague, e os estarem locados sob contextos antecedentes semelhantes e surgem com 
padrão de assentamento também parecidos, e o contato entre a cultura Valdívia e a floreta Amazônica comprovado a partir de vestígios botânicos. Contudo estes dados ainda são esparsos em relação a quantidade de informação necessária para sustentar a hipótese e ainda faltam dados arqueológicos para sua comprovação.

Motivos iconográficos, como o Bacabal e o Bacabal repetido, parecem acontecer também em outras culturas cerâmicas que ocorrem a partir de 500 a.C. e são reconhecidas pela arquitetura em terra, como a fase Jasiaquiri na Bolívia, as fases Galera, Poaia, Aguapé e Descalvados no Mato Grosso e as fases Pimenteiras/Corumbiara no médio rio Guaporé. Além disso as impressões de diferentes suportes nas bases planas de potes é algo popular entre as cerâmicas conhecidas no Llanos de Mojos.

A distribuição dos conjuntos cerâmicos estudados pode representar um caso em que as fronteiras entre culturas arqueológicas não são resultado de situações de conflito no passado, e acredito que a ideia de que as zanjas, ou geoglifos tenham função defensiva pode ser reavaliada em alguns casos. Interações milenares podem ter ocorrido, e situações de conflito/união/neutralidade podem ter variado diversas vezes.

Se por um lado as fronteiras bem demarcadas na tecnologia e na morfologia da cerâmica sustentam a possibilidade da presença de uma unidade cultural marcada na história antiga dos povos que habitaram o médio Guaporé, situações de interação social parecem ter ocorrido, gerando os correlatos de intercâmbio cultural que são encontrados na forma de elementos em comum, presentes em sítios dispersos em uma ampla região arqueológica.

Os dados apresentados em Zimpel e Pugliese (2016) e outros mencionados vão na mesma direção que aqueles apresentados por Betancourt $(2011,2014)$, em relação a hipótese que explica o processo de revolvimento de terra no sudoeste amazônico como produto de uma gênese multicultural. Mas devemos destacar que o período em que o fenômeno ocorre na região considerando-se as datações produzidas no sambaqui Monte Castelo, e sendo assim, o início da história de construções em terra e de interações culturais pode estar vinculado ao Holoceno médio, ou a um período de ocupação até mesmo mais antigo, e a história relacionada ao registro arqueológico dessas frequentes num período relativamente bem mais recente (> 300 a.C.) podem ser ainda mais complexas, já que existem diferentes contextos situados neste horizonte inicial de construção de aterros encontrados em outros pontos do sudoeste amazônico e áreas adjacentes, os sambaquis na Bolívia (Lombardo, 2013) e os aterros nos estados do Mato Grosso (Migliaccio, 2006) e do Mato Grosso do Sul (Schmitz et al. 1998). 


\section{Bibliografia}

Almeida, F. O. 2013. A Tradição Policroma na Bacia do Alto rio Madeira. Tese de Doutorado, Programa de Pós-Graduação em Arqueologia, Museu de Arqueologia e Etnologia, Universidade de São Paulo.

Arroyo-Kalin, M. 2014. Amazonian Dark Earths: Geoarchaeology. In: Smith C. (eds.) Encyclopedia of Global Archaeology. Springer, New York, NY.

Bandeira, A. M. 2008. Ocupações humanas pré-históricas no litoral maranhense: um estudo arqueológico sobre o sambaqui do Bacanga na Ilha de São Luís-Maranhão. 2008. Unpublished Master's thesis, Museu de Arqueologia e Etnologia, Universidade de São Paulo, São Paulo.

Bandeira, A. M. 2009. Arqueologia no sambaqui do Bacanga, São Luís, Maranhão: Reflexões sobre a ocorrência de cerâmica em sambaquis do litoral equatorial amazônico. Revista Amazônica 1 (2): 484-511.

Bandeira, A. M. 2012. Ocupações humanas pré-coloniais na Ilha de São Luís-MA: inserção dos sítios arqueológicos na paisagem, cronologia e cultura material cerâmica. Unpublished PhD thesis, Museu de Arqueologia e Etnologia, Universidade de São Paulo, São Paulo.

Bandeira, A. M. 2016. A cerâmica Mina do Maranhão. In C. Barreto, H. P. Lima, C. J. Betancourt, (Ed.) Cerâmicas arqueológicas da Amazônia: rumo a uma nova síntese: $147-$ 157 Belém: IPHAN : Ministério da Cultura.

Becker-Donner, Etta. Archäologische Funde am mittleren Guaporé (Brasilien). In: Archiv für Völkerkunde, Band XI: 202-249. Viena. 1956.

Bellido, Antonio (2008). Diccionario de términos cerámicos y de alfarería. Cádiz: Agrija Ediciones. ISBN 84-96191-07-9.

Bel, van den, M. 2012. Archaeological investigations at the Saint-Louis on the lower Maroni river: the Early Ceramic series. Archaeology and Anthropology, Journal of the Walter Roth Museum of Anthropology v. 17, n. 2, p. 1-52.

Betancourt, C.J. La cerámica de la Loma Salvatierra. Ph.D. dissertation, Universität Bonn. (http://hss.ulb. uni-bonn.de/2010/2354/2354.htm). 2010.

La cerámica de los afluentes del Guaporé en la colección de Erland von Nordenskiöld. In: Zeitschrift für Archäologie Außereuropäischer Kulturen 4, p. 311-340, 
Unidad en la Diversidad. Implicaciones de la variabilidad cerámica de la región del Iténez, Bolivia. In: Rostain, S. (Ed.), Antes de Orellana Actas del 3er Encuentro Internacional de Arqueología Amazónica, p. 281-290 Quito, 2014.

Brochado, J.J.J.P., Lathrap, D. Amazonian Archaeology. Manuscrito, 1982.

Clement, C. R; Cristo-Araújo, M.; Coppens d'Eeckenbrugge, G.; Reis. V. M.; Lehnebach, R. e Picanço-Rodrigues, D. 2017. Origin and Dispersal of Domesticated Peach Palm. Frontiers in Ecology and Evolution 5: 148. doi: 10.3389/fevo.2017.00148

Crevels, M.; Van Der Voort, H. 2008. The Guaporé-Mamoré region as a linguistic area. In P. Muysken (Ed.). From linguistic areas to areal linguistics: 151-179. Amsterdam/Philadelphia: J. Benjamins.

Cruxent, J.M., Rouse, I. 1961. Arqueología cronológica de Venezuela. Unión Panamericana, Washington.

Damp, J.; Vargas L. P. S. 1995. The many faces of Early Valdivia ceramics. In: Barnett, W. K.; Hoopes, J.W. (eds.). The Emergence of Pottery. Technology and Innovation in Ancient Societies. Washington, DC: Smithsonian Institution Press. p. 157-168.

Denevan, W. M. 1966. The aboriginal cultural geography of the Llanos de Mojos of Bolivia. Berkeley: University of California Press.

Dougherty, B.; Calandra, H. 1984-1985. Ambiente y arqueología en el oriente boliviano: La Provincia Itenez del Departamento del Beni. Relaciones de la Sociedad Argentina de Antropología, t. XVI.

Dougherty, B.; Calandra, H. 1984. Prehispanic human settlement in the Llanos de Moxos, Bolivia. Quaternary of South America and Antarctic Peninsula 2: 163-199.

Eriksen, L. 2011. Nature and Culture in Prehistoric Amazonia: Using G.I.S. to reconstruct ancient ethnogenetic processes from archaeology, linguistics, geography, and ethnohistory. Unpublished PhD Dissertation, Lund University, Suécia.

Erickson, C. 2006. The domesticated landscapes of the Bolivian Amazon. In W. Ballé; C. Erickson (Ed.). Time and complexity in historical ecology: studies in the neotropical lowlands: 235-278. New York: Columbia University Press.

Evans, C.; Meggers, B. J. 1960. Archeological investigations in British Guiana. Smithsonian Institution Bureau of American Ethnology Bulletin, 177. Washington D.C.: U.S. Govt. Print. Off. 
Evans, C. Estrada, E. 1965, Early Formative Period of Coastal Ecuador: The Valdivia and Machalilla Phases. Smithsonian Contributions to Anthropology, No. 1. Washington, D.C.

Eremites De Oliveira, J. 2003. Da pré-história à história indígena: (re) pensando a arqueologia e os povos canoeiros do Pantanal. Revista de Arqueologia (Sociedade de Arqueologia Brasileira. Impresso), São Paulo, v. 16, p. 71-86.

Faure, G.; Mensing, T. M. 2005. Isotope Principle and Applications. 3rd Edition, John forest-savanna gradient in the Brazilian Pantanal. Anais da Academia Brasileira de

Fonseca, J. G. 1748 [1874]. Primeira Exploração dos Rios Madeira e Guaporé feita por José Gonçalves da Fonseca em 1749 por Ordem do Governo. In C.M. de Almeida (Ed.) Memorias para a historia do extincto estado do Maranhão cujo territorio comprehende hoje as províncias do Maranhão, Piauhy, Grão-Pará e Amazonas, Tomo Segundo, Rio de Janeiro: Nova Typographia de J. Paulo Hildebrand.

Ford, J. A; Webb, C. H. 1956. Poverty Point, a Late Archaic Site in Louisiana. Anthropological Papers Vol. 46, Pt. 1. American Museum of Natural History, New York.

Hill, Betsy D., 1972-1974, A new chronology of the Valdivia ceramic complex from the coastal zone of Guayas province, Ecuador. Nawpa Pacha 10-12: 1-32.

Hilbert, P. P. 1959. Achados arqueológicos num sambaqui do baixo Amazonas. Publicação do Instituto de Antropologia e Etnologia do Pará, Belém, v. 10, p. 1-22.

Hilbert, P. P. 1968. Archäologische Untersuchungen am mittleren Amazonas: Beiträge zur Vorgeschichte des südamerikanischen Tieflandes. Berlin: Reimer.

Hirtz, Alexander, 2001, Valdivia: Cultura Madre de América. Fundación Wilson Hallo, Ediciones del Sol, Quito, Ecuador.

Hoopes, John W., 1994, Ford revisited: a critical review of the chronology and relationships of the earliest ceramic complexes in the New World, 6000-1500 B.C. Journal of World Prehistory 8 (1): 1-49. 
Jaimes Betancourt, C. 2013. Diversidad cultural en los Llanos de Mojos. In: Valdez, F. (ed). Arqueología Amazónica. Las civilizaciones ocultas del bosque tropical. Quito: Instituto Francés de Estudios Andinos; Institut de Recherche pour le Dévelopement; Abya-Yala.

Jaimes Betancourt, C. 2011. La cerámica de los afluentes del Guaporé en la colección de Erland von Nordenskiöld. Zeitschrift für Archäologie Außereuropäischer Kulturen, Deustchland, v. 4, p. 311-340, 2011.

Jaimes Betancourt, C.; Prümers, H. 2015. Los Llanos de Mojos. In: Medinacelli, X. (Coord.). Bolivia. Su historia. Tomo I. De los orígenes a los Estados prehispánicos $10.000 a C-1540 d C$. La Paz: Coordinadora de Historia y La Razón.

Lathrap, D. 1977, Our Father the Cayman, Our Mother the Gourd: Spinden revisited, or a unitary model for the emergence of agriculture in the New World. In Origins of Agriculture, edited by Charles A. Reed, pp. 713-751. Mouton, The Hague.

Lathrap, D. W.; Marcos, J. G.; Zeidler, J. E. 1977. Real Alto: An ancient ceremonial center. Archaeology 30 (1): 2-13

Lima, L. F. E. A ocupação pré-colonial na fronteira ocidental: adaptabilidade humana, territorialidade e aspectos geomorfológicos na microrregião do Alto Guaporé, Mato Grosso. Tese de Doutorado, MAE-USP, 2010.

Latrubesse, E. M. 2003. The Late-Quaternary Palaeohydrology of Large South American Lombardo, U.; Prümers, H. 2010. Pre-Columbian human occupation patterns in the eastern plains of the Llanos de Moxos, Bolivian Amazonia. Journal of Archaeological Science 37: 1875-1885.

Lombardo, U.; Szabo, K.; Capriles, J. M.; May, J.; Amelung, W.; Hutterer, R.; Lehndorff, E.; Plotzki, A.; Veit, H. 2013. Early and Middle Holocene Hunter-Gatherer Occupations in Western Amazonia: The Hidden Shell Middens. PLOS ONE, v. 8, n. 8:.e72746. Doi: 10.1371/journal.pone.0072746

Lombardo, U.; Veit, H. 2013. The origin of oriented lakes: Evidence from the Bolivian Amazon, Geomorphology, doi:10.1016/j.geomorph.2013.08.029

Marcos, Jorge G., 1988, Real Alto: La Historia de Un Centro Ceremonial. Biblioteca Ecuatoriana de Arqueología 4 y 5. Escuela Superior Politécnica del Litoral, Guayaquil/Corporación Editora Nacional, Quito.

Meggers, B. J. 1997. La cerámica temprana en América del Sur: ¿invención independiente o difusión? Revista de Arqueología Americana, México, n.13, p. 7-40, 
1997.

Meggers, B.J, Evans, C, Estrada, E. 1965. Early Formative Period of Coastal Ecuador: The Valdivia and Machalilla Phases. Smithsonian Contributions to Anthropology p.1234. Doi: $10.5479 /$ si.00810223.1.1

Migliacio, M. C. 2006. O doméstico e o ritual: cotidiano Xaray no Alto Paraguai até o século XVI. Unpublished $\mathrm{PhD}$ dissertation. Museu de Arqueologia e Etnologia, Universidade de São Paulo: São Paulo.

Miller, E. T. 2013. Algumas culturas ceramistas, do noroeste do Pantanal do Guaporé à Encosta e Altiplano Sudoeste do Chapadão dos Parecis. Origem, Difusão/Migração e Adaptação - do Noroeste da América do Sul ao Brasil. Revista Brasileira de Linguística Antropológica (5) 2: 335- 386.

Miller, E. T. 2009. Pesquisas arqueológicas no Pantanal do Guaporé-RO, Brasil: a sequência seriada da cerâmica da Fase Bacabal. In B. Meggers (Ed.). Arqueologia interpretativa. $O$ método quantitativo para estabelecimento de sequências cerâmicas: estudos de caso: 103-117, Porto Nacional: Unitins.

Miller, E. T. 1992. Arqueologia nos Empreendimentos Hidrelétricos da Eletronorte. Brasília-DF: Eletronorte.

Miller, E. T. 1987. Pesquisas arqueológicas paleoindígenas no Brasil Ocidental. Estudios Atacameños 8: 37-61.

Miller, E. T. 1983. História da cultura indígena do Alto-Médio Guaporé (Rondônia e Mato Grosso). Dissertação de Mestrado, Pontifícia Universidade Católica do Rio Grande do Sul, Porto Alegre, 317p.

Miller, E. T. 1977. Relatório das Pesquisas Arqueológicas no Território Federal de Rondônia (Alto Rio Madeira, do Yata ao Cuniã). Resultados Preliminares. Programa Nacional Pesquisas Arqueológicas na Bacia Amazônica-PRONAPABA. Taquara: MARSUL.

Miller, R.G.; O'Nions, R.K. 1984. The provenance and crustal residence ages of British sediments in relation to palaeogeographic reconstruction. Earth and Planetary Science Letters 68: 459-470.

Meggers, B. J.; Miller, E. T. 2003. Hunter-Gatherers in Amazonia during the PleistoceneHolocene Transition. In: Julio Mercader (Org.). Under the Canopy. The Archaeology of Tropical Rain Forests. New Brunswick, New Jersey: Rutgers University Press, p. 291316. 
Mongeló, G. Z. 2015. O Formativo e os Modos de Produção: Ocupações Pré-ceramistas no Alto Rio Madeira - RO. Dissertação de Mestrado, Museu de Arqueologia e Etnologia da Universidade de São Paulo.

Neves, E. G. 2016. Não Existe Neolítico ao Sul do Equador: as Primeiras Cerâmicas Amazônicas e Sua Falta de Relação com a Agricultura. In C. Barreto, H. P. Lima, C. J. Betancourt, (Ed.) Cerâmicas arqueológicas da Amazônia: rumo a uma nova síntese: 3239. Belém: IPHAN : Ministério da Cultura.

Neves, E. G. 2013. Sob os Tempos Do Equinócio: Oito Mil Anos de História na Amazônia Central (6.500 AC - 1.500 DC). Tese apresentada para Concurso de Título de LivreDocente, Museu de Arqueologia e Etnologia Universidade de São Paulo.

Neves, E. G. 2011. Archaeological cultures and past identities in Precolonial Central Amazon. In Hornborg, A.; Hill, J. (Org.) Ethnicity in Ancient Amazonia: reconstructing past identities from archaeology, linguistics, and ethnohistory. Boulder: University of Colorado Press, p.31-56.

Neves, E.G. Pugliese, F.A Projeto Geoglifos e Sambaquis na Bacia do Médio Guaporé: uma proposta de levantamento arqueológico no sudoeste amazônico. ArqueoTrop, 2014

Nordenskiöld, E. 1912. Urnengräber und Mounds im bolivianischen Flachlande. Baessler-Archiv 3: 205-255.

Olsen K. M.; Schaal, B. A.1999. Evidence on the origin of cassava: phylogeography of Manihot esculenta. Proceedings of the National Academy of Sciences (USA) 96:55865591.

Olsen K. M.; Schaal, B. A. 2001. Microsatellite variation in cassava (Manihot esculenta, Euphorbiaceae) and its wildrelatives: further evidence for a southern Amazonian origin of domestication. American Journal of Botany 88:131-142.

Oyuela-Caycedo, A. 1996. The study of collector variability in the transition to sedentary food producers in northern Colombia. Journal of World Prehistory 10:49-93. doi: $10.1007 / \mathrm{bf} 02226071$

Oyuela-Caycedo A, Bonzani, R. M. 2014. San Jacinto, Ecología histórica, orígenes de la cerámica e inicios de la vida sedentaria en el Caribe colombiano. Universidad del Norte Editorial, Barranquilla.

Oyuela-Caycedo A, Bonzani, R. M. 2005. San Jacinto I a historical ecological aproach to an archaic site in Colombia. University of Alabama Press, Tuscaloosa. doi: 10.1017/s0003598x0009428x 
Pagán-Jiménez, J. R. Rodríguez-Ramos, R. Reid, B. A. van den Bel, M. Hofman, C. L. 2015. Early dispersals of maize and other food plants into the Southern Caribbean and Northeastern South America, Quaternary Science Reviews v. 123, p. 231-246, doi: 10.1016/j.quascirev.2015.07.005.

Pearsall, D.; Piperno, D. 1990. Antiquity of Maize Cultivation in Ecuador: Summary and Reevaluation of the Evidence. American Antiquity 55(2): 324.

Pearsall, Deborah M., 1988a, La Producción de Alimentos en Real Alto. Biblioteca Ecuatoriana de Arqueología, No. 2. Escuela Superior Politécnica del Litoral, Guayaquil/Corporación Editora Nacional, Quito.

1988b, An overview of Formative period subsistence in Ecuador: paleoethnobotanical data and perspectives. Diet and Subsistence: Current Archaeological Perspectives, edited by Brenda V. Kennedy and Genevieve M. LeMoine, pp. 149-164. University of Calgary, Canada.

2003, Plant food resources of the Ecuadorian Formative: an overview and comparison to the Central Andes. In Archaeology of Formative Ecuador, edited by J. Scott Raymond and Richard L. Burger, pp. 213-257. Dumbarton Oaks Research Library and Collection, Washington, D.C.

Peixoto, J. L. dos S. 2003. A ocupação dos povos indígenas pré-coloniais nos grandes lagos do Pantanal Sul-mato-grossense. Tese de Doutorado- PUCRS, Porto Alegre.

Perota, C.; Botelho, W. C. 1994. Os sambaquis do Guará e as variações climáticas no Holoceno. Revista do Departamento de Geografia (7) 1: 49-59. São Paulo: Universidade de São Paulo.

Perota C.; Cassiano, W. C. 1992. Les "Sambaquis" de Guara et des variations climatiques pendant l'Holocène. In PROST, M-T. (Ed.). Evolution des littoraux de Guyane et de la zone caraïbe méridionale pendant le quaternaire. Paris: ORSTOM, p. 379-395.

Piperno, D. R. 2011. The Origins of Plant Cultivation and Domestication in the New World Tropics: Patterns, Process, and New Developments. Current Anthropology 52: 453-470.

Piperno, D. R.; Ranere, A. J.; Dickau, R.; Aceituno, F. 2017. Niche construction and optimal foraging theory in Neotropical agricultural origins: A reevaluation in consideration of the empirical evidence. Journal of Archaeological Science, http://dx.doi.org/10.1016/j.jas.2017.01.001

Plotkin, R. L. 2011. Biogeography of the Llanos de Moxos: Natural and anthropogenic 
Prümers, H. 2017 Los monticulos artificiales de la Amazonia In: Stéphen Rostain; Carla James Betancourt. (Org.). Las Siete Maravillas de la Amazonia Precolombina. 1ed.La Paz: IV Encuentro Internacional de Arqueología Amazónica / Colección y Estudios Americanistas de Bonn 53, p. 47-72.

Prümers. H.; Jaimes Betancourt, C. Die Phase Equijebe in Jasiaquiri und Urnengräber am Guaporé. Zeitschrift für Archäologie Außereuropäischer Kulturen 7 (2017): 357 - 372.

Pugliese Jr., F. A.; Zimpel, C. A.; Neves, E. G. 2017. Los concheros de la Amazonia y la historia indígena profunda de América del Sur. In: Stéphen Rostain; Carla James Betancourt. (Org.). Las Siete Maravillas de la Amazonia Precolombina. 1ed.La Paz: IV Encuentro Internacional de Arqueología Amazónica / Colección y Estudios Americanistas de Bonn 53, p. 27-46.

Rice, P. 1987. Pottery Analysis. A Sourcebook. Chicago: The University of Chicago Press. Rice, P. 1999.

. On the Origins of Pottery. Journal of Archaeological Method and Theory 6(1): $1-54$.

Reichell-Domaltoff, G. 1985. Monsú, un sitio arqueológico. Bogotá, Colombia : Biblioteca Banco Popular.

Roddaz, M.; Viers, J.; Brusset, S.; Baby, P.; Hérail, G. 2005. Sediment provenances and drainage evolution of the Neogene Amazonian foreland basin. Earth and Planetary Science Letters 239 (1): 57-78.

Roosevelt, A. C. 2009. A historical memoir of archaeological research in Brazil (19812007). Boletim do Museu Paraense Emílio Goeldi. Ciências Humanas, 4(1), 155-170. doi: 10.1590/s1981- 81222009000100013

Roosevelt, A. C. 1999. The Maritime, Highland, Forest Dynamic and the Origins Of Complex Culture', in Salomon, F. and Schwartz, S.B. (eds.) The Cambridge History of the Native Peoples of the Americas. Cambridge: Cambridge University Press, p. 264-349.

Roosevelt, A. 1997. Amazonian Indians from Prehistory to the Present. Tucson and London: University of Arizona Press.

Roosevelt, A. C. 1995. Early pottery in the Amazon: twenty years of scholarly obscurity. In Barnett, W. K.; Hoopes, J. (Eds.). The emergence of pottery. Technology and innovation in ancient societies. Washington, D.C.: Smithsonian Institution Press, p. 115131.

Roosevelt, A. C. 1992. Arqueologia amazônica. In Carneiro Da Cunha, M. (Org.). 
História dos índios no Brasil. São Paulo: Companhia das Letras; Secretaria Municipal de Cultura; FAPESP, p. 53-86.

Roosevelt, A. C.; Housley, R. A.; Silveira, M. I.; Maranca, S.; Johnson, R. 1991. Eighth Millennium Pottery from a Prehistoric Shell Midden in the Brazilian Amazon, Science, v. 254, n. 5038 , p. $1621-1624$.

Sassaman, K. E. 2005 Poverty Point as Structure, Event, Process. Journal of Archaeological Method and Theory 12:335-364.

Saunaluoma, S. Pre-Columbian Earthworks in the Riberalta Region of the Bolivian Amazon. Amazonica 2(1), Universidade Federal do Pará, Belém, p. 86-115, 2010.

Scheel-Ybert, R.; Caromano, C. F.; Waisman, L. A. 2016. Of Forests and Gardens: Landscape, environment, and cultural choices in Amazonia, Southeastern and Southern Brazil from c. 3000 to 300 cal yrs BP. Cadernos do LEPAARQ 13: 425-458.

Schiffer, M. B.; Skibo, J. 1997. The Explanation of Artifact Variability. American Antiquity 62 (1):. 27-50.

Schmitz, P. I.; Rogge, J. H.; Rosa, A. O.; Beber, M. V.; Freitas, E. A. V. 2009. Aterros da Tradição Pantanal nas fazendas Sagrado Coração de Jesus e Bodoquena, Corumbá, MS. Pesquisas. Antropologia, (8)1:321-374.

Schmitz, P. I.; Rogge, J. H.; Rosa, A. O.; Beber, M. V. 1998. Aterros Indígenas no Pantanal do Mato Grosso do Sul. Pesquisas. Antropologia, v. 54, p. 1-271.

Silva, F. A. 2009. A organização da produção cerâmica dos Asurini do Xingu: uma reflexão etnoarqueológica sobre variabilidade e padronização artefatual. Arqueologia Sul-americana 5 (2): 121-137.

Simões, M. F. 1983. Pesquisa e Cadastro de Sítios Arqueológicos na Amazônia Legal Brasileira (1978-1982). Publicações Avulsas do Museu Paraense Emílio Goeldi 38 (89): $1-98$.

Simões, M. F. 1981. Coletores-pescadores ceramistas do litoral do Salgado (Pará). Boletim do Museu Paraense Emílio Goeldi, Nova Série: Antropologia, Belém, v. 78, p. $1-26$.

Simões, M. F.; Lopes, D. 1987. Pesquisas arqueológicas no Baixo/Médio Rio Madeira (Amazonas). Revista de Arqueologia 4 (1): 117-133.

Silveira, M. I.; Schann, D. P. 2005. Onde a Amazônia encontra o mar: estudando os sambaquis do Pará. Revista de Arqueologia, São Paulo, v. 18, p. 67-79. 
Silveira, M. I., Oliveira, E. Kern, D. C., Costa, M., Rodrigues, S. 2011. O sítio Jabuti, em Bragança, Pará, no cenário arqueológico do litoral amazônico. Boletim do Museu Paraense Emílio Goeldi. Ciências Humanas, v. 6, n. 2, 335-345.

Silveira, M. I. Rodrigues, M. C. L.; Oliveira, E; Losier, L. M. 2008. Sequência cronológica de ocupação na área do Salobo (Pará). Revista de Arqueologia, Belém, v. 21, n. 1, p. 61-84.

Trindade, T. B. 2015. Geoglifos, zanjas ou earthworks? Levantamento geral dos sítios arqueológicos com estruturas de terra em vala no médio rio Guaporé (RO) e análise comparada com os demais sítios no Sudoeste da Bacia Amazônica. Dissertação de Mestrado, Museu de Arqueologia e Etnologia da Universidade de São Paulo.

Williams, D. 1997. Early pottery in the Amazon: a correction. American Antiquity, v. 62, n. 2 , p. $342-352$.

Williams, D. 1981. Excavation of the Barambina shell mound northwest district: an interim report. Archaeology and Anthropology, Georgetown, v. 4, n. 1-2, p. 13-38.

Wüst, I. Resgate dos sítios arqueológicos Guapé 1 e 2 na área das obras construtivas da UHE-Guaporé, MT. Primeira etapa. Relatório Final. Vol. 1. Goiânia, Grupo Rede Tangará, 2001.

Zedeño, M. N.; Bowser, B.J. 2009. The archaeology of meaningful places. In Zedeño, M. N.; Bowser, B.J. (Eds.). The archaeology of meaningful places. Salt Lake City. The University of Utah Press. p. 1-14.

Zimpel Nt, C. A. 2009. Na direção das periferias extremas da Amazônia: arqueologia na bacia do rio Ji-Paraná, Rondônia. Dissertação de mestrado apresentada ao Programa de Pós-graduação em Arqueologia da Universidade de São Paulo.

Zimpel Nt, C. A.; Pugliese Jr, F. A. 2016. A fase bacabal e suas implicações para a Interpretação do Registro Arqueológico no Médio Rio Guaporé, Rondônia. In Barreto, M.C. Lima, H. Betancourt, C.J. (org.), Cerâmicas arqueológicas da Amazônia: rumo a uma nova síntese. IPHAN/MPEG. 